\title{
National Register of Historic Places (NHRP) Eligibility Determinations for Previously Recorded Archaeological Sites at Wright Patman Lake, Bowie and Cass Counties, Texas
}

Bryan C. Harrell

Search

Chris Sypniewski

Search

Alex DeCaro

Search

Nick Linville

Search

Follow this and additional works at: https://scholarworks.sfasu.edu/ita

Part of the American Material Culture Commons, Archaeological Anthropology Commons, Environmental Studies Commons, Other American Studies Commons, Other Arts and Humanities Commons, Other History of Art, Architecture, and Archaeology Commons, and the United States History Commons

Tell us how this article helped you.

This Article is brought to you for free and open access by the Center for Regional Heritage Research at SFA ScholarWorks. It has been accepted for inclusion in Index of Texas Archaeology: Open Access Gray Literature from the Lone Star State by an authorized editor of SFA ScholarWorks. For more information, please contact cdsscholarworks@sfasu.edu. 
National Register of Historic Places (NHRP) Eligibility Determinations for Previously Recorded Archaeological Sites at Wright Patman Lake, Bowie and Cass Counties, Texas

Creative Commons License

(c) $(1) \Theta$

This work is licensed under a Creative Commons Attribution-NonCommercial-No Derivative Works 4.0 International License. 


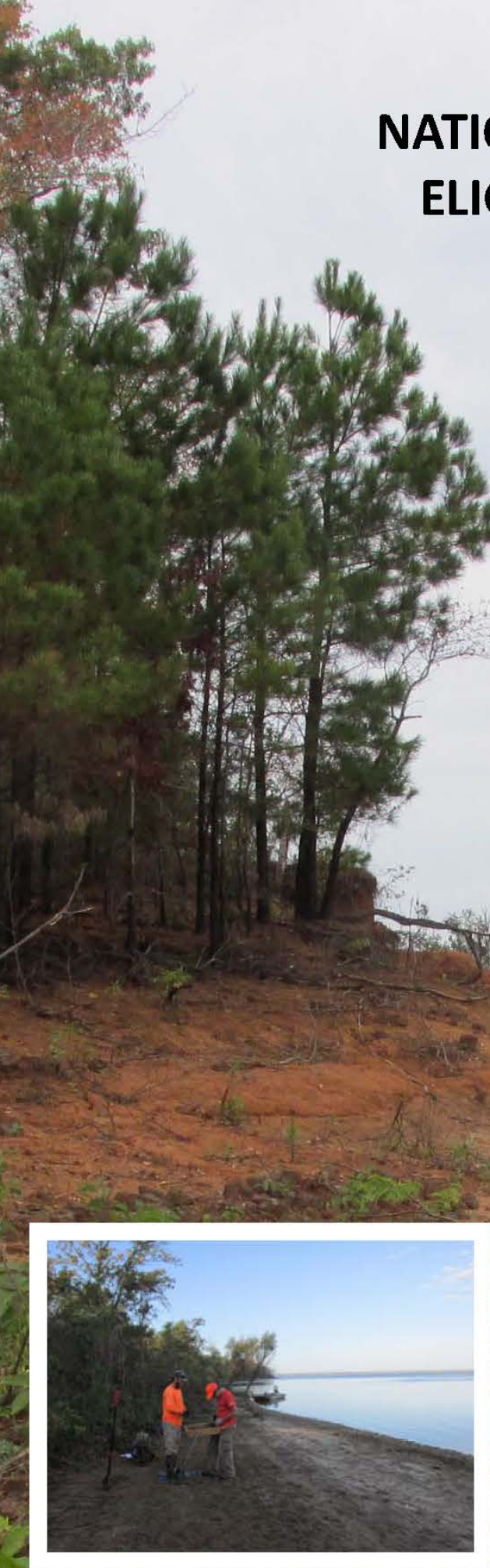

ELIGIBILITY DETERMINATIONS FOR PREVIOUSLY RECORDED ARCHAEOLOGICAL SITES AT WRIGHT PATMAN LAKE, BOWIE AND CASS COUNTIES, TEXAS

US ARMY CORPS OF ENGINEERS, FORT WORTH DISTRICT CONTRACT \#W912HY-11-D-0002, TASK ORDER \#0006
DRAFT REPORT
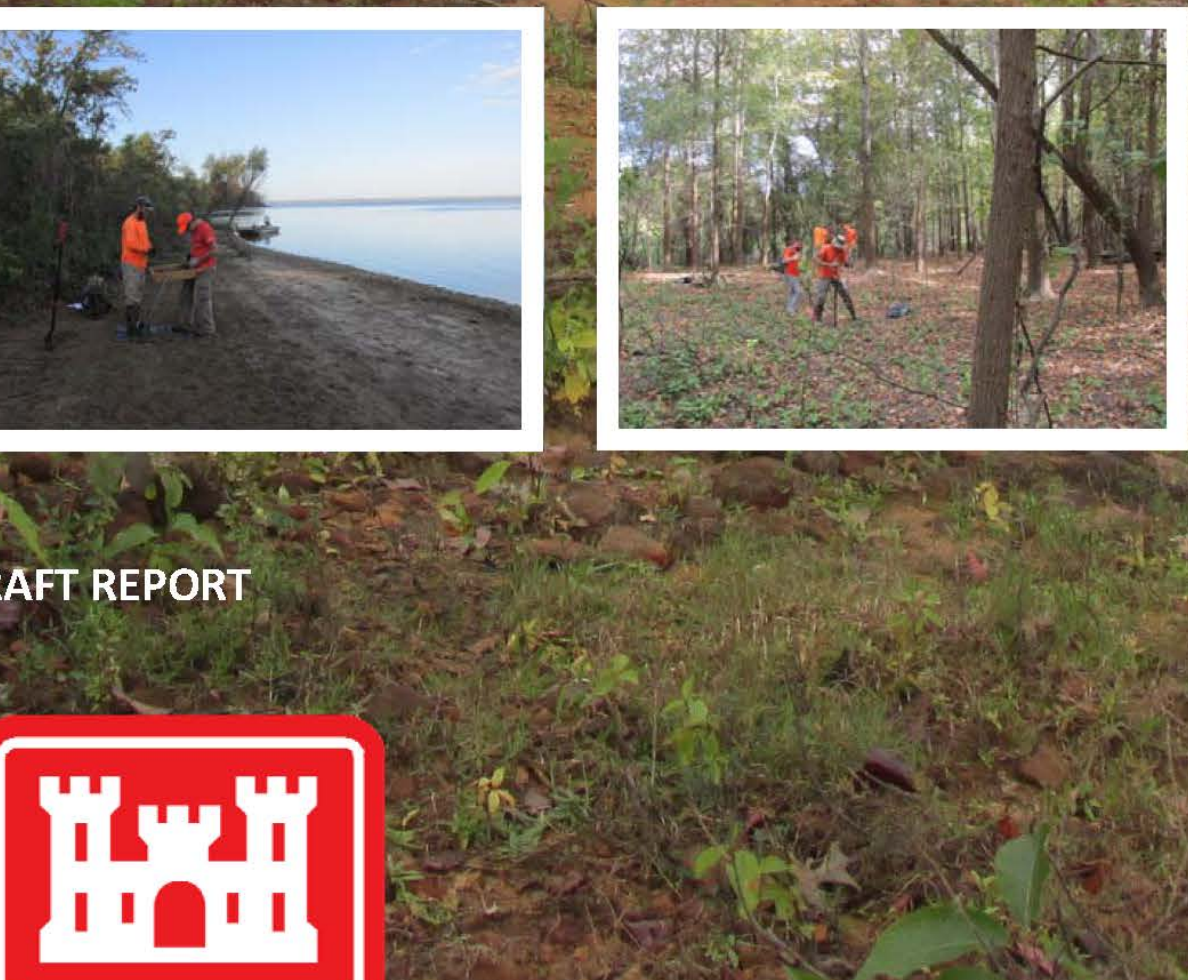

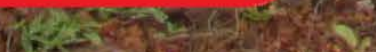

JUNE 2016

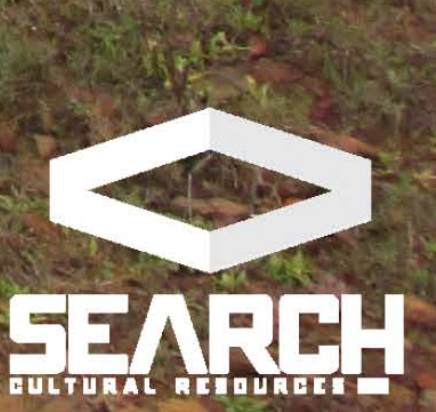





\title{
National Register Of Historic Places (NRHP) Eligibility Determinations for Previously Recorded Archaeological Sites at Wright Patman Lake, BOWIE AND CASS COUNTIES, TEXAS
}

\author{
DRAFT REPORT \\ Contract Number \\ W912HY-11-D-0002, Task Order 0006 \\ Prepared for \\ US Army Corps of Engineers \\ Fort Worth District

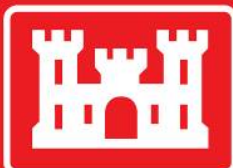

Report authored by

Bryan C. Harrell, Chris Sypniewski, Alex DeCaro, and Nick Linville

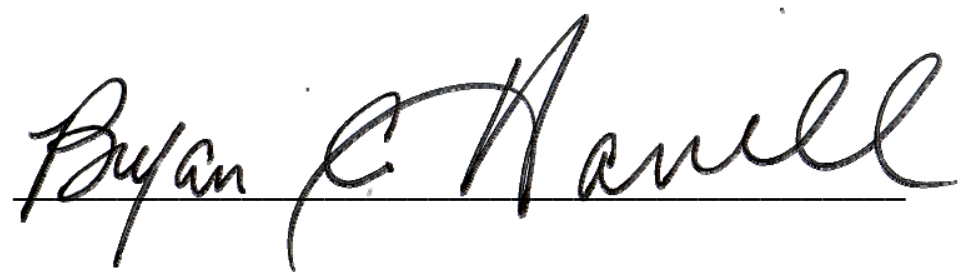

Bryan C. Harrell, MS, RPA

Principal Investigator

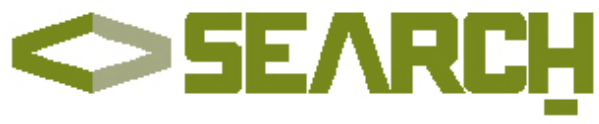

June 2016

SEARCH Project No. 3505-15167F 



\section{EXECUTIVE SUMMARY}

Between 19 October and 11 November 2015, SEARCH conducted National Register of Historic Places (NRHP) eligibility determinations at previously recorded archaeological sites at Wright Patman Lake in Bowie and Cass Counties, Texas. This project was conducted under Contract W912HY-11-D-0002, Task Order 0006 between the US Army Corps of Engineers (USACE), Fort Worth District, and SEARCH.

The USACE, Fort Worth District, is proposing to raise and operate the current pool level at Wright Patman Lake to 228.64 feet ( $\mathrm{ft}$ ) above mean sea level (amsl), thereby meeting the Ultimate Rule Curve for the provision of water to the local area. The purpose of this project was to provide systematic testing through pedestrian survey and the excavation of shovel tests and $50-x-50$-centimeter $(\mathrm{cm})$ test units at a minimum of 15 previously recorded archaeological sites within the areas of potential effect of the Ultimate Rule Curve. The goal of this project was to determine if these unassessed (NRHP-eligibility undetermined) archaeological resources were ineligible for listing in the NRHP, required additional testing to determine NRHP status, or could not be evaluated because of inundation or inability to relocate the resource.

During fieldwork, SEARCH archaeologists visited 20 archaeological sites. Four sites (41BW42, 41CS55, 41CS78, and 41CS109) are recommended for additional work to evaluate each resource's National Register of Historic Places (NRHP) status and mitigate adverse effects of the proposed pool rise for meeting the Ultimate Rule Curve, while two sites (41CS73 and 41CS79) do not meet the Secretary of the Interior's criteria for listing in the NRHP and no further work is recommended. Twelve (41BW69, 41BW77, 41CS48, 41CS58, 41CS76, 41CS95/96, 41CS108, $41 \mathrm{CS} 110,41 \mathrm{CS} 117,41 \mathrm{CS} 118,41 \mathrm{CS} 122$, and 41CS123) of the remaining 14 sites could not be full examined based on complete or partial inundation by current and rising pool levels at Wright Patman Lake. As a result, the NRHP status of these sites remains undetermined until such time as the submerged deposits can be evaluated. The remaining two sites (41BW26 and 41CS16) were not evaluated as it was determined based on site elevation that these resources are outside of the proposed Ultimate Rule Curve Area of Potential Effect.

Site 41BW42 is a small multicomponent site on an easterly projecting peninsula near the area that serves as Elliot Bluff boat landing today. The historic component consists of a small collection of glass fragments, ceramic sherds, and other miscellaneous items. The Native American component is much more robust and shows evidence of horizontal clustering. The assemblage is dominated by lithic artifacts that include a relatively large amount of lithic debitage along with formal and expedient tools. A very small quantity of Native American pottery sherds was also recovered from the exposed shoreline; however, the artifact collection is more likely the result of a preceramic occupation in the area. The quantity of artifacts in such discrete area could be the result of multiple small-scale occupations (e.g., camp sites or resources extraction locations) through time or a larger logistics station aimed at providing access to lower reaches of the Sulphur River prior to inundation. The artifact assemblage, examined in tandem with absolute dating methods (radiocarbon or thermoluminescence), has 
the potential to offer insight into the lithic economy of Native American inhabitants of the site. Furthermore, the contextual integrity of the soils across the upper terrace, though slightly deflated from erosional processes during high water episodes at the lake, are relatively intact.

Site 41CS55 is a large Native American site on a low sandbar/island surrounded by Wright Patman Lake. The large quantity of lithic debitage along with grog-tempered pottery sherds, lithic tools, and faunal and botanical remains suggest that site 41CS55 was a sizable Caddo occupation overlooking the Sulphur River prior to the inundation of the lake. The discernible concentrations of artifacts in the northern and central portions of the site suggest differential use of space, a typical hallmark of larger occupations such as villages or hamlets. The artifact assemblage, examined in tandem with absolute dating methods (radiocarbon or thermoluminescence), has the potential to offer insight into the daily lifestyle of Native American inhabitants of the site.

Site 41CS78 is a large Native American site on a low a low terrace on the south shore of Wright Patman Lake. The artifact assemblage includes a relatively large collection of lithic debitage with a smaller quantity of formal lithic tools, fire-cracked rock, Native American pottery sherds, and faunal remains. The discernible concentrations of artifacts in the eastern and western portions of the site suggest differential use of space, and in this case, the homogeneity of both assemblages may represent a series of smaller occupations along the landform edge. The artifact assemblage, examined in tandem with absolute dating methods (radiocarbon or thermoluminescence), has the potential to offer insight into the lithic economy of Native American inhabitants of the site. It is the recommendation of SEARCH that additional work be performed to mitigate adverse effects of the proposed pool rise for meeting the Ultimate Rule Curve.

A relatively large portion of site 41CS109 was inundated by rising lake levels at Wright Patman Lake. Exposed portions of the site and the adjacent uplands were tested to determine if intact cultural deposits existed within and adjacent to the defined boundary. One flake was recovered from subsurface context. The remaining large collection of debitage and lithic tools were encountered on the surface and mostly along the exposed beach. The assemblage is dominated by lithic artifacts that include a large amount of lithic debitage along with formal and expedient tools. The Kent and Gary projectile points indicate a potential Middle Archaic to Early Woodland cultural affiliation for the site. The artifact assemblage, examined in tandem with absolute dating methods (radiocarbon or thermoluminescence), has the potential to offer insight into the lithic economy of Native American inhabitants of the site. It is the recommendation of SEARCH that additional work be performed to mitigate adverse effects of the proposed pool rise for meeting the Ultimate Rule Curve. 


\section{ACKNOWLEDGMENTS}

This project was completed with the assistance and dedication of many institutions and individuals. Wright Patman Lake personnel Mike Bransford (Lake Manager), Raymon Hedges (Natural Resources), Dean Attaway (Ranger), Michael Garrett (Forester), and Matt Seavey (Forester) were instrumental in providing local knowledge of the area to include environment, boat access locations, and insight into site conditions. USACE archaeologists Rebekah Sease and Brian Cockrell provided extensive background information and contractual support that continues to be greatly appreciated. A special thanks goes to Dr. Robert Z. Selden at Stephen F. Austin State University. Dr. Selden was instrumental in overseeing lithic and Native American pottery sherd analysis and identification. SEARCH would also thank personnel at the Texas Archeological Research Lab and Texas Historical Commission for their support and continued dedication to the preservation of Texas heritage. 


\section{This PAge INTENTIONALLY Left BLANK}




\section{TABLE OF CONTENTS}

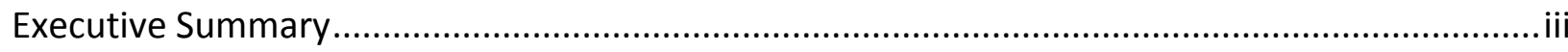

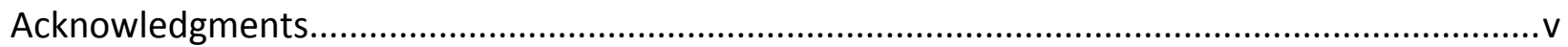

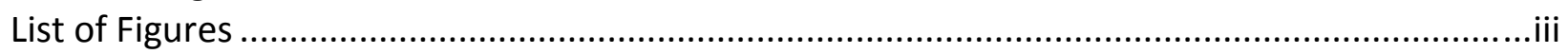

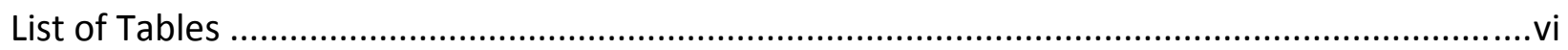

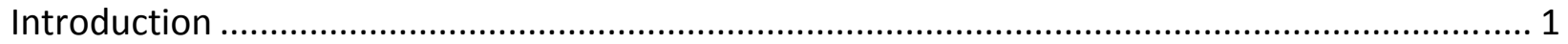

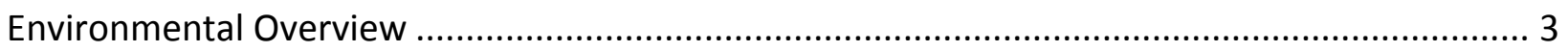

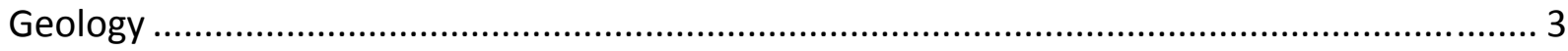

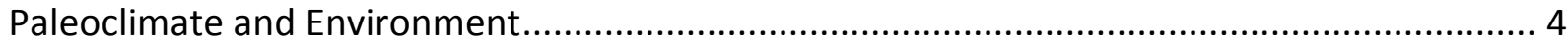

Current Climate and Environment ........................................................................... 5

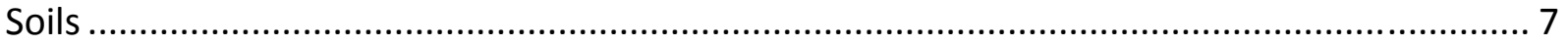

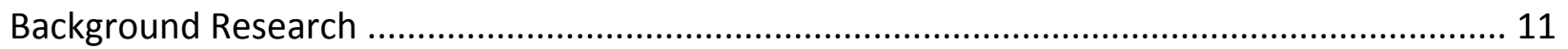

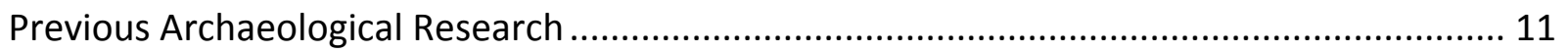

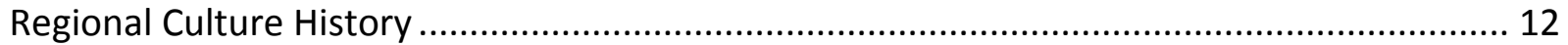

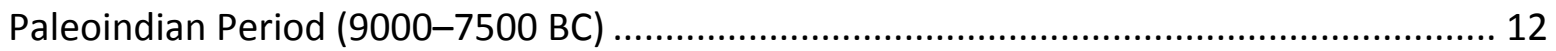

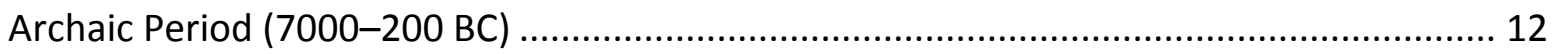

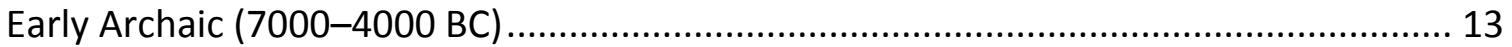

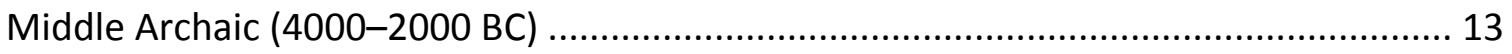

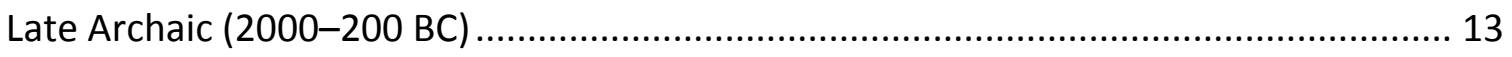

Woodland/Early Ceramic Period (200 BC-AD 800) ........................................................ 13

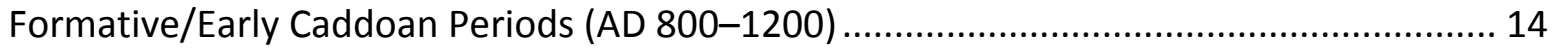

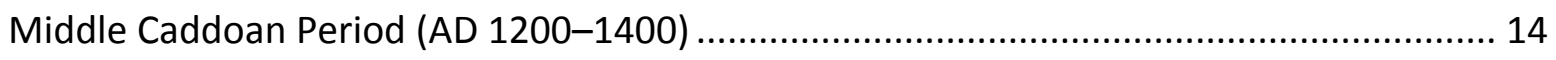

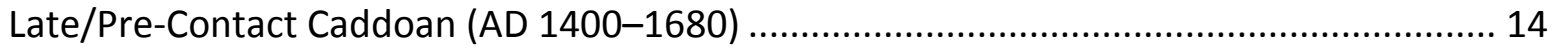

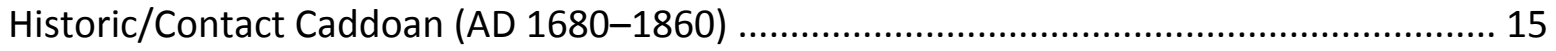

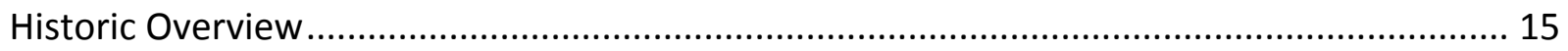

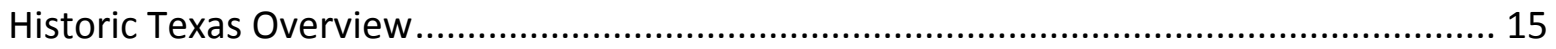

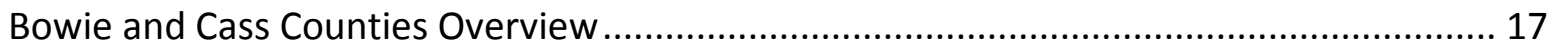

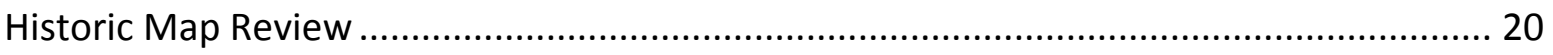

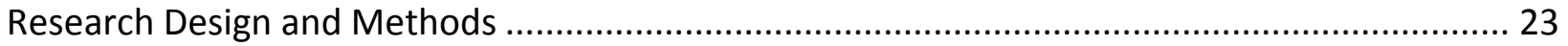

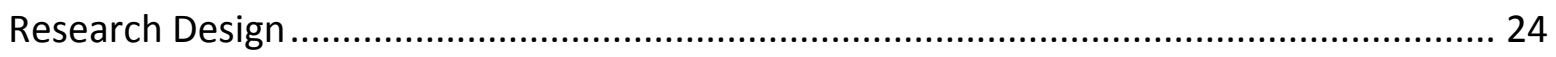

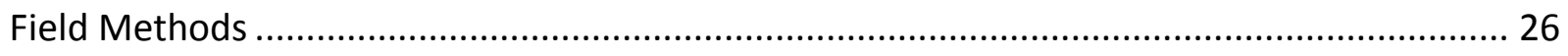

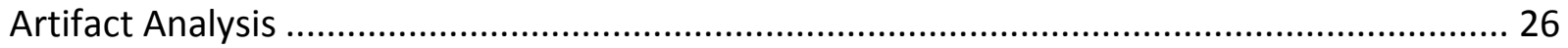

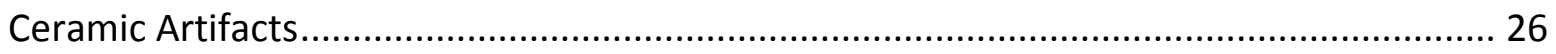

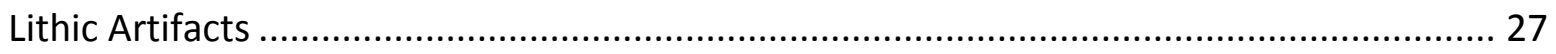

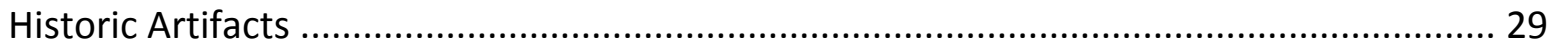

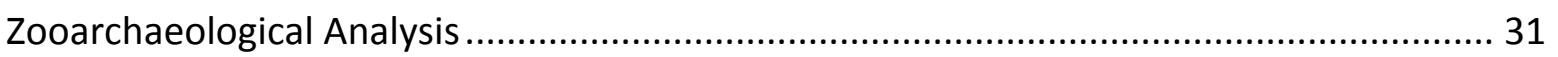

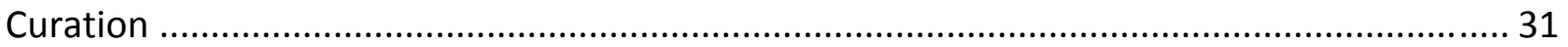

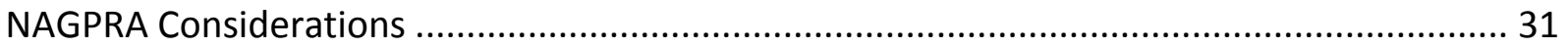

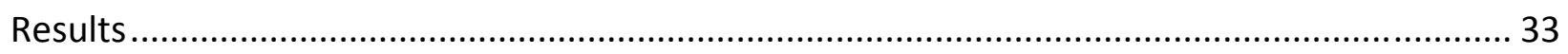

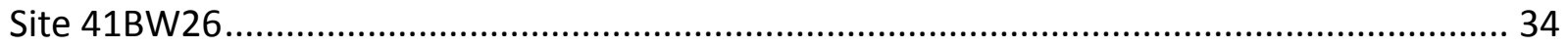

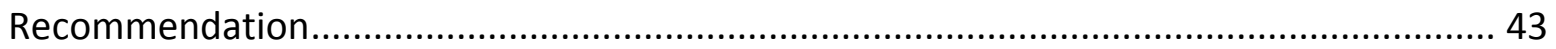

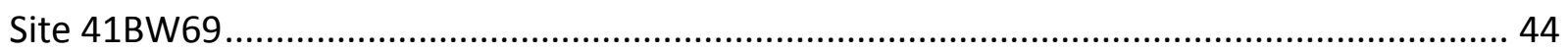




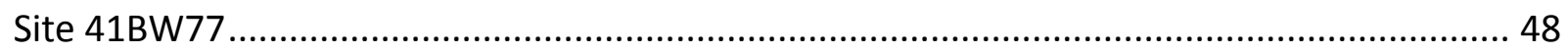

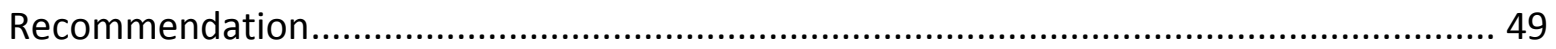

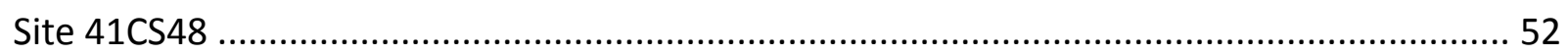

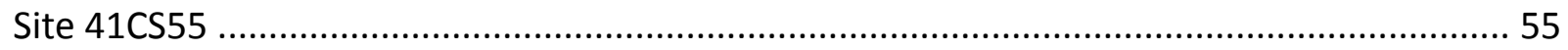

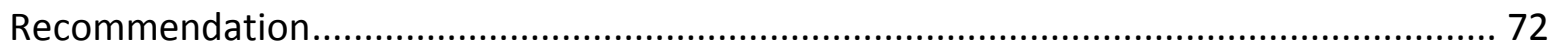

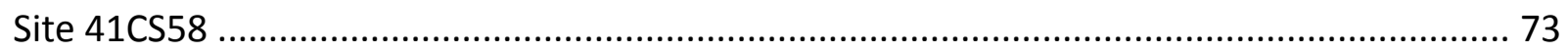

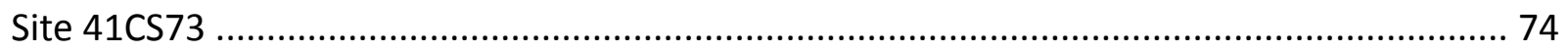

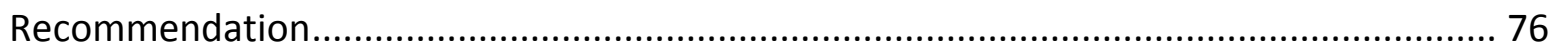

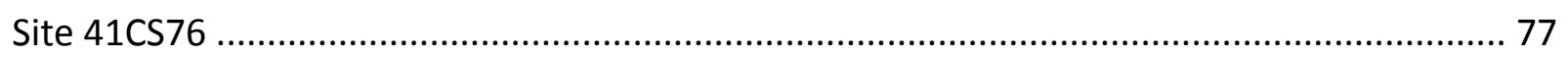

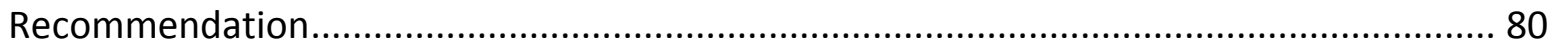

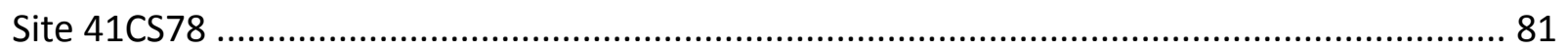

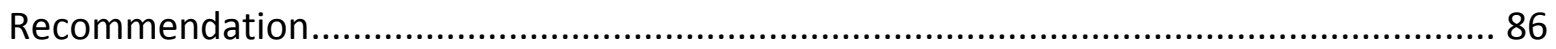

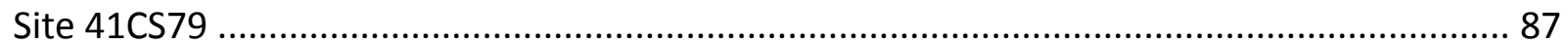

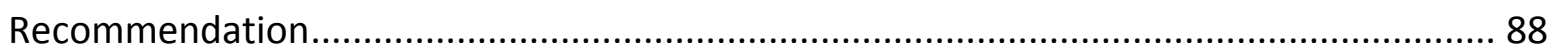

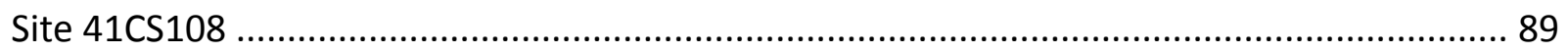

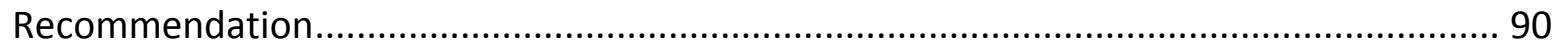

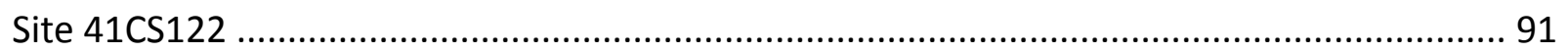

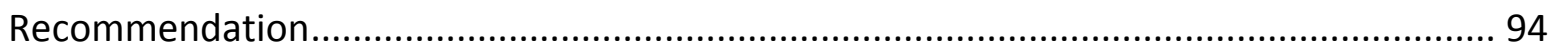

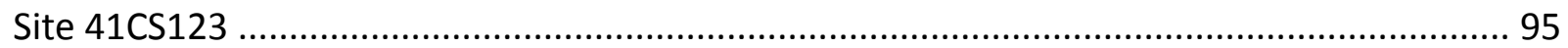

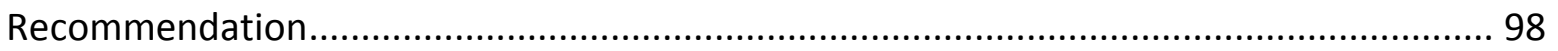

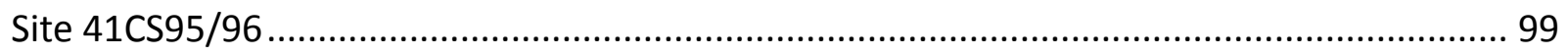

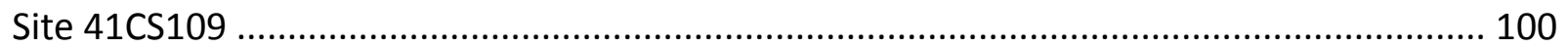

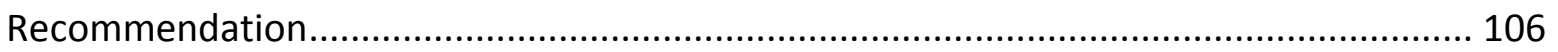

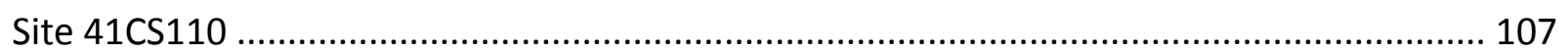

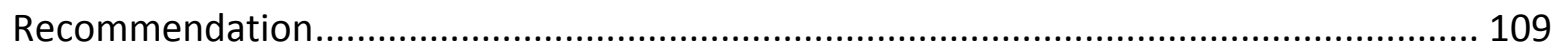

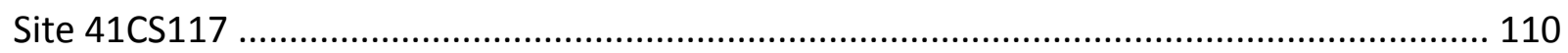

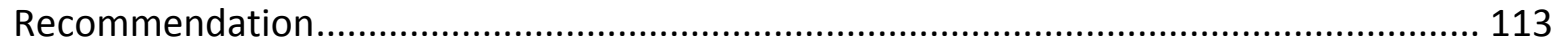

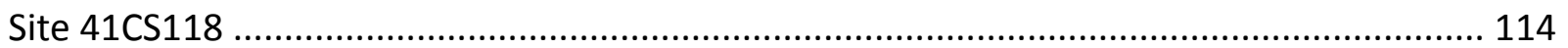

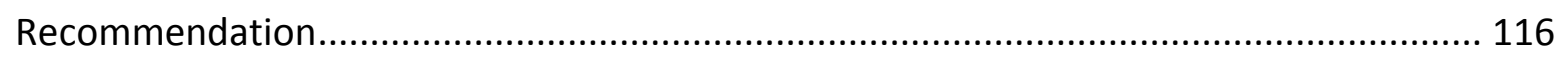

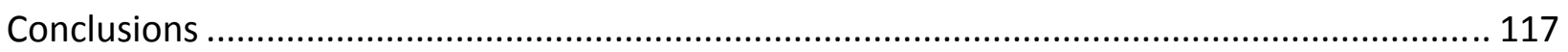

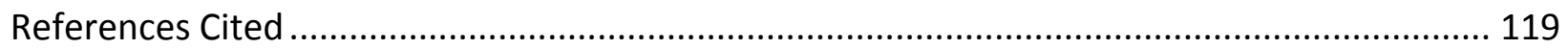

Appendix A: Artifact Inventory 


\section{LIST OF FIGURES}

Figure 1.1 Location of sites for NRHP eligibility testing at Wright Patman Lake, Bowie and Cass Counties, Texas

Figure 2.1 Geologic formations at Wright Patman Lake, Texas........................................ 4

Figure 2.2 Level 4 Ecoregions at Wright Patman Lake, Texas.......................................... 6

Figure $3.1 \quad$ Historic USGS Quadrangle Maps for Wright Patman Lake, Texas ..................... 21

Figure 5.1 1949 georeferenced aerial photograph with the location of site 41BW26 and

Wright Patman Lake fee boundary .............................................................. 34

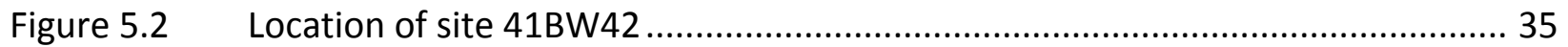

Figure $5.3 \quad$ Exposed shoreline at site 41BW42 ............................................................... 36

Figure 5.4 Typical vegetation along the upland terrace adjacent to site 41BW42 ….......... 36

Figure 5.5 SEARCH 2015 fieldwork plan map for site 41BW42 ….................................. 37

Figure 5.6 Select Native American artifacts collected from site 41BW42 .......................... 38

Figure 5.7 Select historic artifacts collected from site 41BW42 ...................................... 39

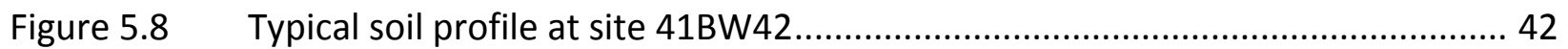

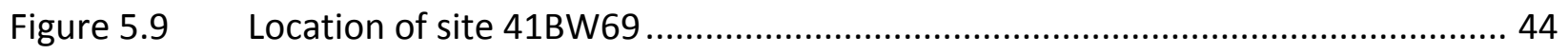

Figure 5.10 Typical vegetation along the northern edge of site 41BW69, facing south ........ 45

Figure 5.11 Typical vegetation across uplands adjacent to site 41BW69, facing north......... 46

Figure 5.12 SEARCH 2015 fieldwork plan map for site 41BW69 ......................................... 46

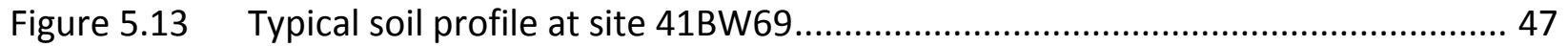

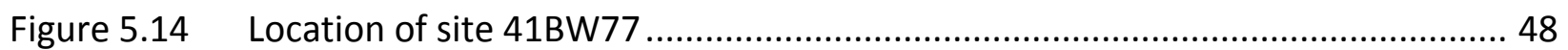

Figure 5.15 Typical vegetation in the northern portion of site 41BW77, facing north .......... 50

Figure 5.16 Typical vegetation in the northern portion of site 41BW77, facing south .......... 50

Figure 5.17 SEARCH 2015 fieldwork plan map for site 41BW77 ..................................... 51

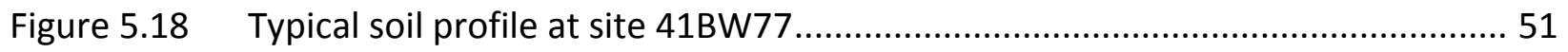

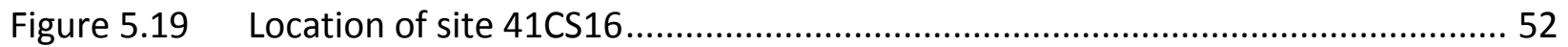

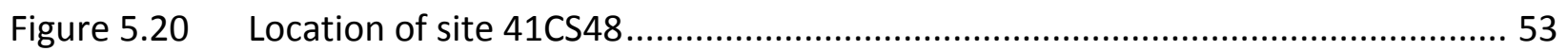

Figure 5.21 Typical vegetation at site 41CS48 from ST 3 facing south .................................. 54

Figure 5.22 SEARCH 2015 fieldwork plan map for site 41CS48 ........................................ 54

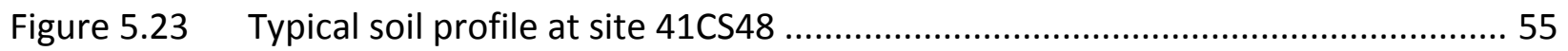

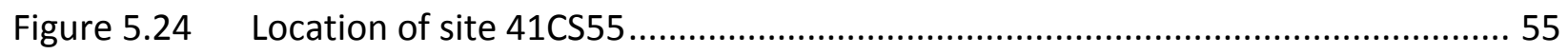

Figure 5.25 Typical vegetation at site 41CS55 ........................................................ 56

Figure 5.26 Select Native American pottery sherds collected from site 41CS55 (1 of 3)....... 67

Figure 5.27 Select Native American pottery sherds collected from site 41CS55 (2 of 3)....... 68

Figure 5.28 Select Native American pottery sherds collected from site 41CS55 (3 of 3)....... 69

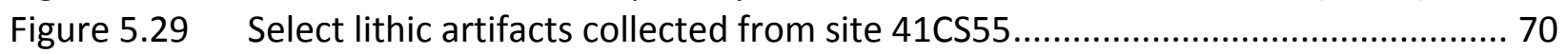

Figure 5.30 SEARCH 2015 fieldwork plan map for site 41CS55 ....................................... 71

Figure 5.31 Typical soil profile at site 41CS55 ............................................................ 72

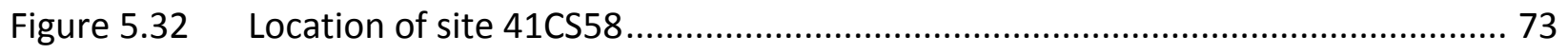


Figure 5.33 Photo from the plotted location of site 41CS58, facing south ........................ 73

Figure 5.34

Figure 5.35

Location of site 41 CS73. 74

Figure 5.36

Typical upland vegetation at site 41CS73, facing northeast. 75 Lowland/wetland vegetation along the northwest periphery of site 41CS73,

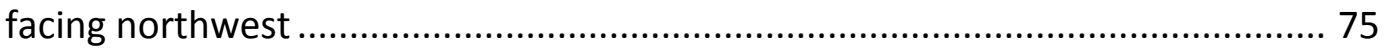

Figure 5.37 SEARCH 2015 fieldwork plan map for site 41CS73 ....................................... 76

Figure 5.38

Typical soil profile at site $41 \mathrm{CS} 73$ 76

Figure 5.39 Location of site 41 CS76. 77

Figure 5.40 Typical vegetation along the shoreline at site 41CS76, facing northwest........... 78

Figure 5.41

Figure 5.42

Figure 5.43 Typical vegetation along uplands west of site 41CS76, facing southwest ........... 78 SEARCH 2015 fieldwork plan map for site 41CS76 ….......................................... 79

Figure 5.44

SEARCH 2015 fieldwork plan map for site 41CS76 ......................................... 79

Figure 5.45

Figure 5.46

Location of site 41CS78. 81

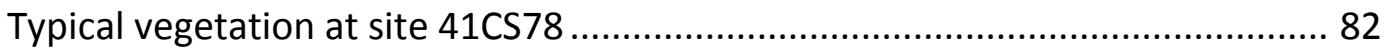

Figure 5.47

Figure 5.48

SEARCH 2015 fieldwork plan map for site 41CS78 ......................................... 85

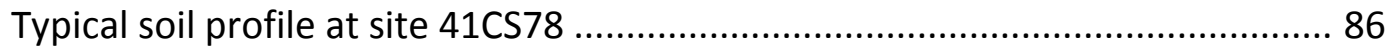

Figure 5.49

Location map and SEARCH 2015 fieldwork plan map for site 41CS79 ............... 87

Figure 5.50

Figure 5.51

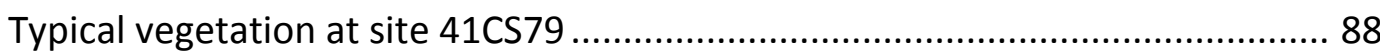

Typical soil profile at site $41 \mathrm{CS79}$............................................................... 88

Figure 5.52

Location map and SEARCH 2015 fieldwork plan map for site 41CS108 .............. 89

Figure 5.53

Figure 5.54

Typical vegetation north of site $41 \mathrm{CS} 108$, facing east...................................... 90

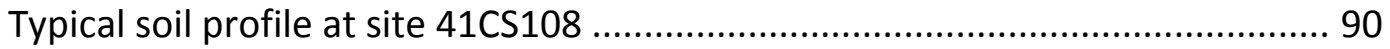

Figure 5.55

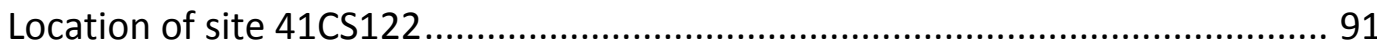

Figure 5.56

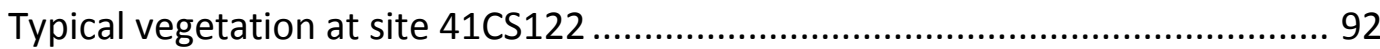

Figure 5.57

SEARCH 2015 fieldwork plan map for site 41CS122 …................................... 92

Figure 5.58

Typical soil profile at site $41 \mathrm{CS} 122$................................................................... 93

Figure 5.59

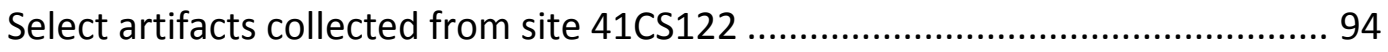

Figure 5.60

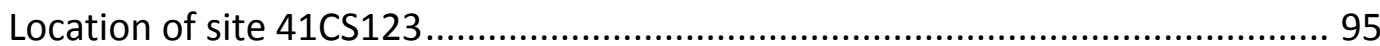

Figure 5.61

Figure 5.62

Figure 5.63

Typical vegetation on the inland areas east of site 41CS123 ........................... 96

Exposed beach along the north portion of site 41CS123, facing southwest....... 96

SEARCH 2015 fieldwork plan map for site 41CS123 ........................................ 98

Figure 5.64

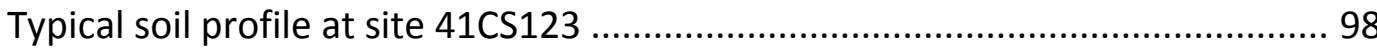

Figure 5.65

Figure 5.66

Location of site 41CS95/96

Photo south of plotted location of site 41CS95/96, facing north....................... 99

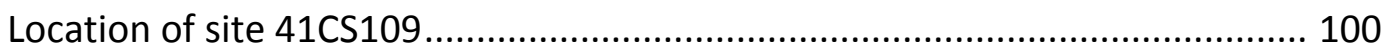

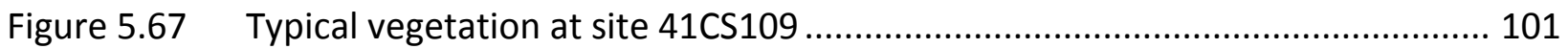

Figure 5.68 Bench and exposed beach along the east portion of site 41CS109 ................. 101

Figure 5.69 Select artifacts collected from site 41CS109 (1 of 2) ..................................... 104

Figure 5.70 Select artifacts collected from site 41CS109 (2 of 2) ..................................... 105

Figure 5.71 SEARCH 2015 fieldwork plan map for site 41CS109 ...................................... 106

Figure 5.72 Typical soil profile at 41CS109 ............................................................... 106

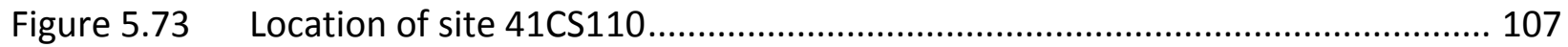

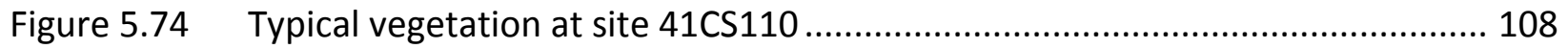

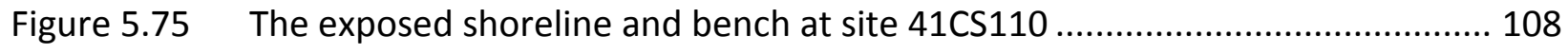


Figure 5.76 SEARH 2015 fieldwork plan map for site 41CS110 ...................................... 109

Figure 5.77 Typical soil profile at site 41CS110 ............................................................ 109

Figure $5.78 \quad$ Location of site 41CS117 ........................................................................ 110

Figure 5.79 Typical vegetation at site 41CS117 .......................................................... 111

Figure 5.80 Submerged trees and lack of exposed beach along the south portion of site

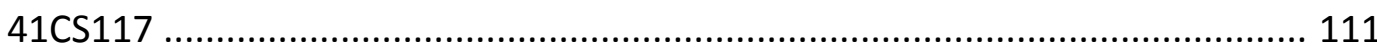

Figure 5.81 SEARCH 2015 fieldwork plan map for site 41CS117 ................................... 112

Figure 5.82 Typical soil profile from site 41CS117 ......................................................... 113

Figure 5.83 Location and SEARCH 2015 fieldwork plan map for site 41CS118 ................... 114

Figure 5.84 Typical vegetation immediately north of site 41CS118 ................................. 115

Figure 5.85 Submerged trees and lack of exposed beach along the northern edge of site

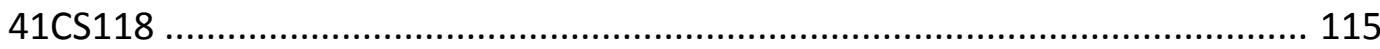

Figure 5.86 Typical shovel test profile at site 41CS118 ............................................ 116 


\section{LIST OF TABLES}

Table 1.1 List of Archaeological Sites to be Evaluated at Wright Patman Lake, Texas .......... 1

Table 4.1 Historic Contexts and Associated Study Units for the Northeast Texas

Archaeological Region................................................................................ 25

Table 5.1 Fieldwork Summary and Recommendations for Previously Recorded Sites at

Wright Patman Lake, Bowie and Cass Counties, Texas .................................... 33

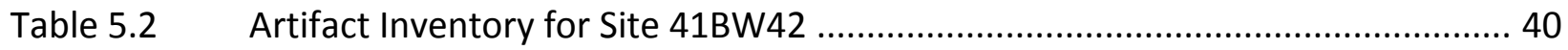

Table 5.3 Artifact Inventory for Site 41BW69 .......................................................... 47

Table 5.4 Artifact Inventory for Site 41CS55 .................................................................. 57

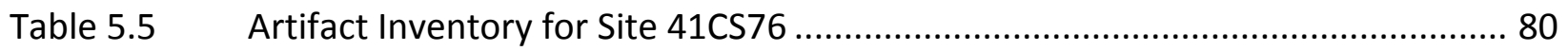

Table 5.6 Artifact Inventory for Site 41CS78 ............................................................... 83

Table 5.7 Artifact Inventory for Site 41CS122 _............................................................. 93

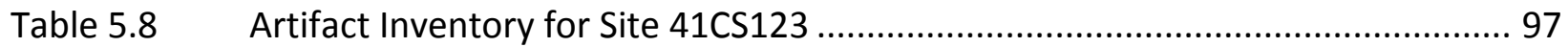

Table 5.9 Artifact Inventory for Site 41CS109 ....................................................... 102 


\section{CHAPTER 1 INTRODUCTION}

Between 19 October and 11 November 2015, SEARCH conducted National Register of Historic Places (NRHP) eligibility determinations at previously recorded archaeological sites at Wright Patman Lake in Bowie and Cass Counties, Texas (Figure 1.1). This project was conducted under Contract W912HY-11-D-0002, Task Order 0006 between the US Army Corps of Engineers (USACE), Fort Worth District, and SEARCH.

The USACE, Fort Worth District, is proposing to raise and operate the current pool level at Wright Patman Lake to 228.64 feet ( $\mathrm{ft}$ ) above mean sea level (amsl), thereby meeting the Ultimate Rule Curve for the provision of water to the local area. The purpose of this project was to provide systematic testing through pedestrian survey and the excavation of shovel tests and $50-x-50$-centimeter $(\mathrm{cm})$ test units at a minimum of 15 previously recorded archaeological sites within the areas of potential effect of the Ultimate Rule Curve. The goal of this project was to determine if these unassessed (NRHP-eligibility undetermined) archaeological resources were ineligible for listing in the NRHP, required additional testing to determine NRHP status, or could not be evaluated because of inundation or inability to relocate the resource.

Table 1.1 presents a list of 15 Primary Sites and 5 Contingency Sites for evaluation. If a site on the Primary Sites list could not be evaluated because of an inability to relocate the resource through testing or if the resource was fully inundated or submerged, then a site from the Contingency Sites list was substituted in order as presented so that at least 15 sites were evaluated.

Table 1.1. List of Archaeological Sites to be Evaluated at Wright Patman Lake, Texas.

\begin{tabular}{|l|l|l|l|}
\hline \multicolumn{2}{|c|}{ Primary Sites } & \multicolumn{1}{c|}{ Contingency Sites } \\
\hline 41BW26 & $41 C S 48$ & $41 C S 78$ & $41 C S 95 / 96$ \\
\hline 41BW42 & $41 C S 55$ & $41 C S 79$ & $41 C S 109$ \\
\hline 41BW69 & $41 C S 58$ & $41 C S 108$ & $41 C S 110$ \\
\hline 41BW77 & $41 C S 73$ & $41 C S 122$ & $41 C S 117$ \\
\hline 41CS16 & $41 C S 76$ & $41 C S 123$ & $41 C S 118$ \\
\hline
\end{tabular}

This investigation was conducted to comply with 54 U.S.C. $\S 306108$ (Effect of undertaking on historic property) and guidelines established under 36 CFR Part 800 (Protection of Historic Properties). This report conforms to standards provided in the Guidelines for Cultural Resource Management Reports issued by the Council of Texas Archeologists. Bryan C. Harrell is the Principal Investigator for this project. He meets the Secretary of the Interior's Standards and Guidelines for Archaeology and Historic Preservation (48 FR 44716-42) and is listed on the Register of Professional Archaeologists (RPA). Fieldwork was conducted by Bryan C. Harrell, Chris Sypniewski, Alex DeCaro, Matt Hanks, Michael Offord, Mark Miragliotta, Marianne McGlinn, Sean Farrell, Jena Sadd, Joey Stahl, Shelby Ellis, Blue Nelson, Ray Tubby, Eden Andes, Kathryn Parker, and Ivor Mollema. 


\section{Figure Redacted}

Figure 1.1. Location of sites for NRHP eligibility testing at Wright Patman Lake, Bowie and Cass Counties, Texas. 


\section{CHAPTER 2 \\ ENVIRONMENTAL OVERVIEW}

\section{GEOLOGY}

Wright Patman Lake and associated lands within the existing USACE fee boundary are underlain by five geologic formations. Three of the formations (Wilcox Group undivided, Reklaw Formation, and Queen City Formation) are of Eocene age (ca. 56-33.9 million years ago), two (Fluviatile terrace deposits undivided) are of Pleistocene age (ca. 2.6 million to 12,000 years ago), and the Recent Alluvium Floodplain deposits are of Holocene age and are less than 12,000 years old (Figure 2.1).

The Wilcox Group (undivided) is found primarily in upland areas adjacent to the lower floodplain throughout the Wright Patman Lake fee boundary. It consists of gray thinly bedded to massive, locally cross-bedded silty and sandy clay with calcareous siltstone and ironstone concretions (Barnes 1979). Local beds of clay, lignite, silt, and quartz sand are also present. White et al. (1995:5) note that the Wilcox Group possesses lithic resources (sandstone, ferruginous sandstone, petrified wood, and chert) that are suitable for stone tool manufacture.

The Reklaw Formation occurs along the southeastern and south-central edges of the Wright Patman Lake fee boundary at higher elevations beyond the Wilcox Group and is composed of quartz sand and clay. The upper part is a brownish-black to brownish-gray, carbonaceous, laminated, silty muscovitic clay that weathers light brown to light reddish-brown. Ironstone concretions commonly occur in this zone. The lower part consists of a cross-bedded grayishgreen, fine to very fine grained, argillaceous quartz sand that weathers moderate brown to dark yellowish-orange with clay ironstone ledges and rubble (Barnes 1979).

The Queen City Formation also occurs along the southeastern and south-central edges of the Wright Patman Lake fee boundary but at higher elevations beyond the Reklaw Formation. This formation consists of fine-grained to medium-grained (locally) quartz sand with thin beds of clay and sandy clay with ironstone concretions. The clay and sandy clay are locally carbonaceous and weather very light gray to white (Barnes 1979).

Fluviatile terrace deposits (undivided) occur in relatively isolated pockets (small and large) between the lower floodplain and Wilcox Group throughout the Wright Patman Lake fee boundary. These deposits are composed primarily of sand, silt, and some clay (Barnes 1979).

Recent Alluvium Floodplain deposits are the dominant formation in the western portion of the Wright Patman Lake fee boundary. These deposits consist of unconsolidated sedimentary deposits that are subject to periodic inundation (Barnes 1979). 


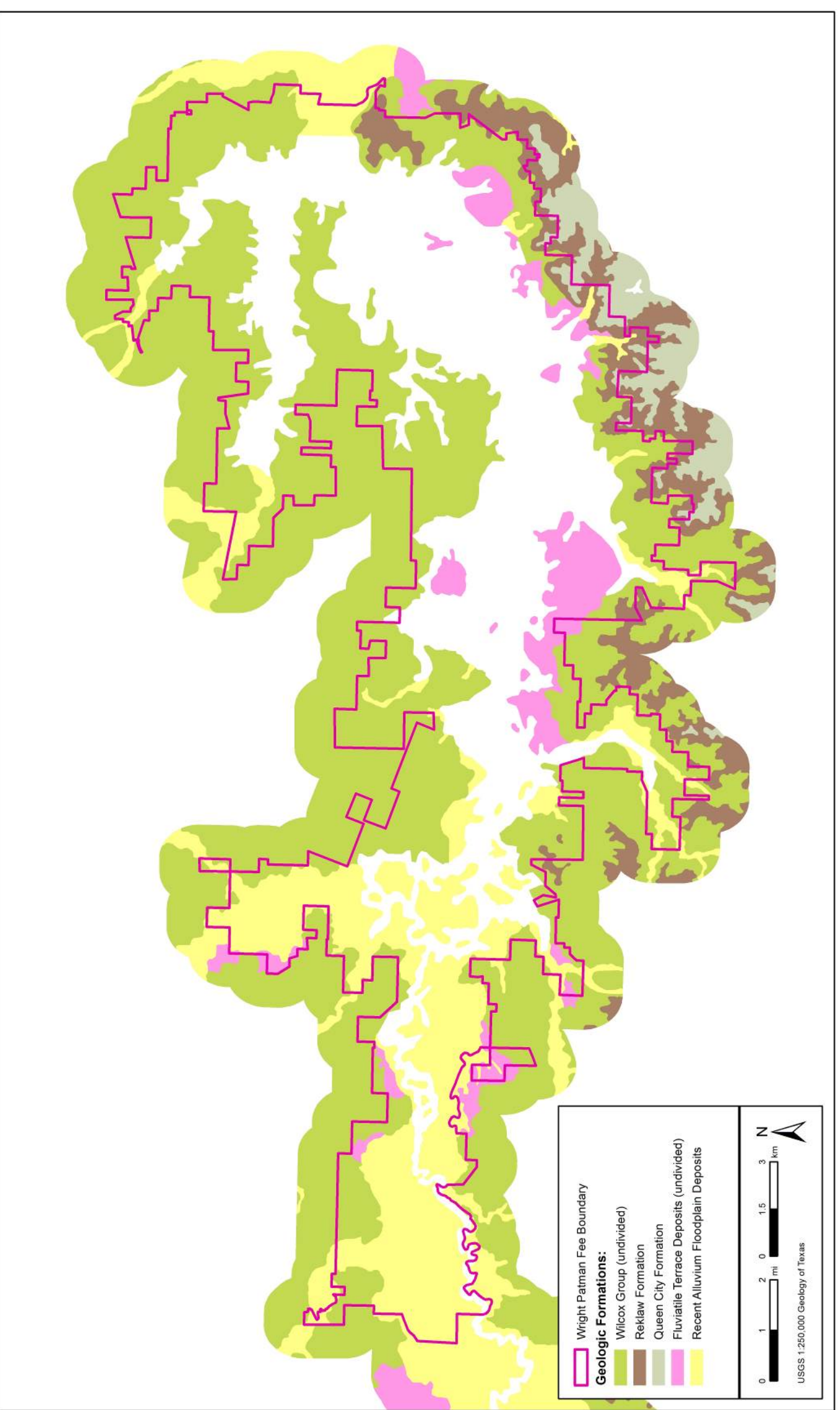

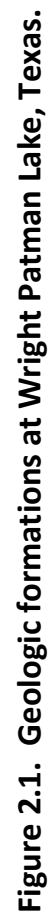




\section{PALEOCLIMATE AND ENVIRONMENT}

Archaeologists generally agree that human migration into North America occurred during the late Pleistocene epoch as the landscape was slowly transitioning out of the full Wisconsin glacial period 18,000 to 12,000 years Before Present (BP). The environmental landscape that these people encountered was much different than the environmental landscape of today. During the full Wisconsin glacial period, most of the Southeast (to include eastern Texas) was much cooler and drier with an average sea level approximately 120 meters lower than current sealevel stands (Bense 1994:18, Rohling et al. 1998:162). Vegetation included cold-weather species like spruce and jack pine (Delcourt and Delcourt 1981). As humans slowly trickled into North America, temperatures were increasing. Interglacial conditions began to prevail.

By $12,500 \mathrm{BP}$, glacial conditions ceased, marking the beginning of the Holocene. The Early Holocene (12,500-8500 BP) was a period of warmer, drier summers and rapid sea level rise, though temperatures remained cool compared to today. The large dominant forest belts that had existed for millennia began breaking into smaller biotic communities (Bense 1994:22). Also, the megafauna that had characterized the Pleistocene epoch were becoming extinct. The Middle Holocene (8500-4000 BP), known as the Altithermal or Hypsithermal, was much drier and hotter than previous periods, as the tropical air mass moving out of the Caribbean and Gulf of Mexico influenced summer weather patterns (Bense 1994:22). Within Texas, prairies expanded at the expense of forests, which were transitioning from predominately oak and hickory species to southern pine species (Delcourt and Delcourt 1985).

During the Late Holocene (4000 BP-present), the climate, water levels, and plant communities of eastern Texas attained essentially modern conditions by 3000 BP and have been fairly stable through all phases of habitation by ceramic-using cultures. This, however, does not mean climatic variability did not exist. Peter and Jurney (1988) note a dry-moist-dry trend between 3,200 and 150 years ago. Even during this episodic cycling, White et al. (1995:13) suggest that vegetation borders did not necessarily shift but rather "the mosaic of habitat patches changed in character and size."

\section{Current Climate ANd EnVironment}

Wright Patman Lake occupies the Tertiary Uplands and Floodplains and Low Terraces of the South Central Plains ecoregion (also known as the Piney Woods Region) (Figure 2.2). The Tertiary Uplands are rolling, gently to moderately sloping uplands that cover a large portion of east Texas, southern Arkansas, and northern Louisiana. The vegetation main canopy typically consists of shortleaf pine, loblolly pines southern red oak, post oak, white oak, hickory, and sweetgum. The understory consists of American beautyberry, sumac, hawthorn, and greenbriar along with grasses such as yellow Indiangrass, pinehill bluestem, narrowleaf woodoats, and panicums. bluejack oak, post oak, and stunted pines are typically found on 


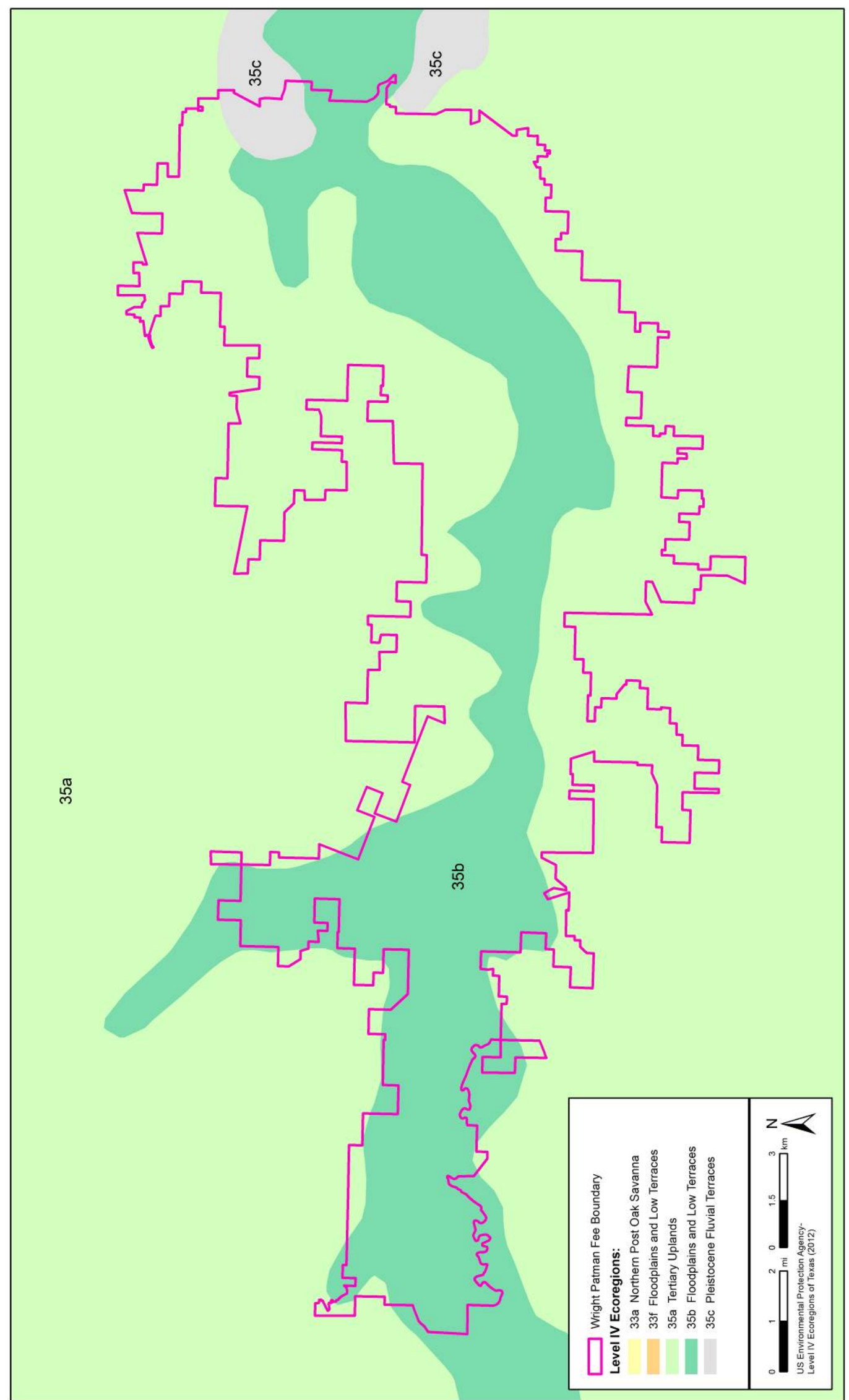

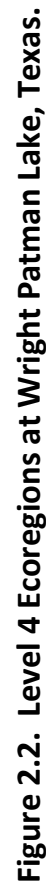


sandier formations. The western portion of the area is typically drier and exhibits an increase in pasture, oak-pine, and oak-hickory forest occurrence (Griffith et al. 2004).

The Floodplains and Low Terraces of the South Central Plains ecoregion are the western extent of a broad southern bottomland community that extends from Virginia to Texas. These areas are true bottomlands with distinctive biota of oaks and gum as opposed to smaller swamp and wetland communities of the uplands that maintain vegetation similar to other upland environments. The Floodplains and Low Terraces vegetation typically consist of water oak, willow oak, sweetgum, blackgum, elm, red maple, southern red oak, swamp chestnut oak, and loblolly pine. Within flooded areas, water tupelo and bald cypress are prominent (Griffith et al. 2004).

\section{SOILS}

Soil types are variable across the project area and consist of eight soil map units associated with archaeological sites examined during this project. These include Adaton-Muskogee complex, 0 to 2 percent slopes (41BW77); Cuthbert fine sandy loam, 5 to 15 percent slopes (41CS76); Eastwood very fine sandy loam, 1 to 5 percent slopes (41CS48, 41CS73, 41CS79, 41CS109, 41CS110, 41CS117, and 41CS118); Hainesville fine sand, 0 to 2 percent slopes (41CS78); Metcalf silt loam, 0 to 2 percent slopes (41CS73, 41CS108, 41CS109, 41CS122, and 41CS123); Woodtell very fine sandy loam, 5 to 12 percent slopes (41BW69); Wrightsville silt loam, 0 to 1 percent slopes (41CS55); and Udorthents, loamy and clayey, 0 to 1 percent slopes (41BW42).

Adaton soils are poorly drained and located on broad uplands and stream terraces of low relief of the Southern Coastal Plains Major Land Resource Area. Parent material consists is loamy alluvium. A typical pedon displays:

- 0 to 6 inches - dark grayish-brown (10YR 4/2) silty loam,

- 6 to 19 inches - light brownish-gray (10YR 6/2) silty clay loam mottled with yellowishbrown (10YR 5/6) and pale brown (10YR 6/3),

- 19 to 41 inches - light brownish-gray (10YR 6/2) silty clay loam mottled with yellowishbrown (10YR 5/6), and

- 41 to 66 inches - light brownish-gray (2.5YR 6/2) silty clay loam mottled with yellowishbrown (10YR 5/6) and pale brown (10YR 6/3).

Cuthbert soils are well drained soils located on moderately sloping to steep uplands, generally on long narrow side slopes above drainageways. Parent material consists of clayey marine deposits. A typical pedon displays:

- 0 to 4 inches - very dark gray (10YR 3/1) and grayish-brown (10YR5/2) dry, fine sandy loam,

- 4 to 8 inches - brown (10YR5/3) fine sandy loam, 
- 8 to 20 inches - dark red (2.5YR 3/6) clay,

- 20 to 29 inches - red (2.5YR 4/8) clay mottled with thin strata of light brownish-gray (10YR 6/2) and pale brown (10YR 6/3),

- 29 to 34 inches - stratified layers of red (2.5YR 4/8), strong brown (7.5YR 5/6) and grayish-brown (10YR5/2) sandy clay loam, and

- 34 to 60 inches - stratified layers of red (2.5YR 4/8) and strong brown (7.5YR 5/6) sandstone with fine sandy loam texture mottled with grayish-brown (10YR 5/2) and brownish-gray (10YR 6/2) shale with clay texture

Eastwood soils are well drained soils located on gently sloping interstream divides and on moderately steep side slopes adjacent to drainageways. Parent material consists of clayey marine deposits. A typical pedon displays:

- 0 to 3 inches - dark yellowish brown (10YR 4/4) very fine sandy loam,

- 3 to 8 inches - light yellowish brown (10YR 6/4) and strong brown (7.5YR 5/6) very fine sandy loam,

- 8 to 12 inches - red (2.5YR 4/6) clay,

- 12 to 17 inches - red (2.5YR 4/6) clay; few fine prominent light brownish gray (2.5Y 6/2) and (10YR 6/2) relic mottles,

- 17 to 23 inches - red (2.5YR 4/6) clay; common medium prominent light brownish gray (2.5Y 6/2) relic mottles,

- 23 to 28 inches - red ( 2.5 YR 4/8) clay; many medium prominent light gray (10YR 7/2) relic mottles,

- 28 to 37 inches -yellowish brown (10YR 5/6) silty clay; common medium prominent red (2.5YR 5/6) and light brownish gray (2.5Y 6/2) relic mottles,

- 37 to 46 inches - light yellowish brown (2.5Y 6/4) silty clay loam; common medium faint light brownish gray (2.5Y 6/2) and few fine prominent brownish yellow (10YR 6/6) relic mottles,

- 46 to 51 inches - yellowish brown (10YR 5/4) loam; common medium faint light brownish gray (2.5Y 6/2) and few medium faint yellowish brown (10YR 5/6) lithochromic mottles, and

- 51 to 72 inches - light yellowish brown (2.5Y 6/4) weakly consolidated materials of silty clay loam texture; common fine distinct brownish yellow (10YR 6/6) lithochromic mottles.

Hainesville soils are somewhat excessively drained soils located on nearly level Pleistocene Age stream terraces with slopes of 0 to 2 percent. Parent material consists of sandy alluvium. A typical pedon displays:

- 0 to 14 inches - yellowish brown (10YR 5/4) fine sand,

- 14 to 58 inches - strong brown (7.5YR 5/6) fine sand with very pale brown (10YR 8/3) spots of uncoated sand, 
- 58 to 70 inches - brownish-yellow (10YR 6/6) fine sand with very pale brown (10YR 8/3) spots of uncoated sand, and

- 70 to 80 inches - yellow (10YR 7/6) fine sand with yellowish red (5YR 4/6) iron concretions.

Metcalf soils are somewhat poorly drained soils located on broad level to nearly level marine or stream terraces. Parent material consists of loamy alluvium over clayey residuum weathered from sandstone and shale. A typical pedon displays:

- 0 to 3 inches - dark grayish-brown (10YR 4/2) silty loam,

- 3 to 8 inches - light yellowish-brown (10YR 6/4) silty loam mottled with strong brown (7.5YR 5/8),

- 8 to 16 inches - yellowish-brown (10YR 5/6) loam,

- 16 to 30 inches - yellowish brown (10YR 5/4) loam with red (2.5YR 4/8) masses of oxidized iron and light brownish-gray (10YR 6/2) iron depletion,

- 30 to 38 inches - light brownish-gray (10YR 6/2) loam with gray (10YR 6/1) silt inclusions and yellowish-brown (10YR 5/6) oxidized iron,

- 38 to 55 inches - gray (10YR 6/1) silty clay with red (10R 4/8) and yellowish-brown (10YR $5 / 6)$ masses of oxidized iron, and

- 55 to 65 inches - light brownish-gray (2.5Y 6/2) silty clay with yellowish-brown (10YR $5 / 6)$ masses of oxidized iron.

Muskogee soils are moderately well drained soils located on stream and marine terraces. Parent material consists of loamy alluvium. A typical pedon displays:

- 0 to 5 inches - brown (10YR 4/3) silty loam,

- 5 to 9 inches - yellowish-brown (10YR 5/4) silty loam,

- 9 to 14 inches - yellowish-brown (10YR 5/6) silty loam,

- 14 to 26 inches - yellowish-brown (10YR 5/6) silty clay loam mottled with grayish-brown (10YR 5/2),

- 26 to 46 inches - mottled light brownish-gray (10YR 6/2) silty clay with yellowish-red (5YR 5/6), and

- 46 to 72 inches - yellowish-red (5YR 4/6) clay mottled with light gray (10YR7/2).

Woodtell soils are well drained and are located on gently sloping stream divides and strongly to moderately steep side slopes of uplands. Parent material consists of residuum weathered from sandstone and shale in the Wilcox formations of Eocene age. A typical pedon displays:

- 0 to 6 inches - dark grayish-brown (10YR 4/2) fine sandy loam,

- 6 to 12 inches - yellowish-red (5YR 4/8) very hard and firm clay,

- 12 to 29 inches - red (2.5YR 4/8) clay with gray (10YR 6/1) redox depletions,

- 29 to 45 inches - yellowish-brown (10YR 5/8) clay loam with gray (10YR 6/1) redox depletions and red (2.5YR 4/8) redox concentrations, and 
- 45 to 72 inches - stratified layers of olive gray (5Y 6/2) and gray (10YR 5/1) shale with clay loam.

Wrightsville soils are poorly drained soils located on Coastal plains, level to depression areas on old stream terraces. Parent material consists of clayey alluvium. A typical pedon displays:

- 0 to 1 inches - black (10YR 2/1) partially decomposed leaves, twigs, and roots; extremely acid,

- 1 to 2 inches - dark grayish brown (10YR 4/2) silt loam,

- 2 to 10 inches - grayish brown (10YR 5/2) silt loam,

- 10 to 17 inches - gray (10YR 6/1) silt loam with common medium distinct yellowish brown (10YR 5/8) masses of iron accumulation in matrix,

- 17 to 23 inches - gray (10YR 5/1) silty clay loam with common medium distinct yellowish brown (10YR 5/6) masses of iron accumulation throughout; light gray (10YR 7/2) clay depletions on faces of prisms,

- 23 to 39 inches - gray (10YR 5/1) silty clay with interfingers and small pockets of light gray (10YR 7/2) silt loam clay depletions; light gray (10YR $7 / 2$ ) clay depletions on prism faces; common medium distinct strong brown (7.5YR 5/6) masses of iron accumulation in matrix,

- 39 to 49 inches - light brownish gray (2.5Y 6/2) silty clay loam with small pockets of light gray (10YR 7/2) silt loam clay depletions in matrix and on prism faces; many medium distinct strong brown (7.5YR 5/8) masses of iron accumulation in matrix,

- 49 to 62 inches - light brownish gray (2.5Y 6/2) silt loam with common medium distinct strong brown (7.5YR 5/8) masses of iron accumulation in matrix; few small dark brown iron-manganese concretions; light gray (10YR 7/2) clay depletions on prism faces and in small pockets in matrix, and

- 62 to 72 inches - gray (10YR 5/1) silt loam with light gray (10YR 7/2) silt clay depletions in small pockets in matrix; common coarse prominent strong brown (7.5YR 5/8) masses of iron accumulation in matrix. 


\section{CHAPTER 3 BACKGROUND RESEARCH}

This chapter presents a brief discussion of previous archaeological research associated with archaeological sites examined during this project along with the cultural chronology of Northeast Texas. For an in-depth discussion of the cultural chronology for this area, refer to Austin (2005), Kenmotsu and Perttula (1993), Perttula (2004), and White et al. (1995) along with any of the numerous cultural resources survey reports developed for this area.

\section{Previous ArChaeological Research}

In the Fall of 1949, Stephenson (1950) directed a preliminary archaeological survey of properties in Bowie and Cass Counties, Texas that were scheduled to be flooded by the construction of what was known at that time as Texarkana Reservoir (currently Wright Patman Lake). Field methods included surface collection, excavations of a few test pits, and consultation with local informants. The survey resulted in the identification of 50 archaeological sites that were classified as either non-pottery sites, mound sites, large village areas, or small camp areas. Two sites from Stephenson's 1949 survey, 41BW26 and 41CS16, were revisited by SEARCH archaeologists for the current NRHP-evaluation project.

In 1970, Briggs and Malone (1970) directed an extensive archaeological survey for the proposed Texarkana Reservoir Enlargement project that would extend the conservation pool to $240.5 \mathrm{ft}$ amsl. Field methods included pedestrian survey and consultation with local informants and amateur archaeologists. A total of 140 archaeological sites was identified during fieldwork efforts. Sixteen (41BW42, 41BW69, 41BW77, 41CS48, 41CS55, 41CS58, 41CS73, 41CS76, 41CS78, 41CS79, 41CS95/96, 41CS108, 41CS109, 41CS110, 41CS117, and 41CS118) of the 20 sites revisited by SEARCH archaeologists for the current NRHP-evaluation project were identified by Briggs and Malone in 1970.

In 1995, Geo-Marine conducted a cultural resource inventory of 600 acres at Wright Patman Lake in Bowie and Cass Counties, Texas (Cliff et al. 1996). During the survey, they revisited site 41CS78. Geo-Marine archaeologists conducted a pedestrian survey and excavated 10 shovel tests within the site boundary, identifying a large number of lithics and pottery sherds across the surface, but only collecting two artifacts from subsurface contexts. Cliff et al. (1996:47) noted that the site had been severely eroded, but suggested that the site retained research potential based on the presence of subsurface archaeological deposits. As a result, they recommended that the site's NRHP status remain undetermined until further work could complete the evaluation process.

In 2004, Ecological Communication Corporation (ECC) conducted a cultural resources inventory of 1,414 acres at Wright Patman Lake and Lake $O^{\prime}$ the Pines in Bowie, Upshur, and Marion 
Counties, Texas. During the survey, they visited site 41BW69 as part of a cultural resources inventory for timber-harvesting parcels at Wright Patman Lake (Trierweiler and Jones 2005). ECC archaeologists conducted a pedestrian survey and excavated 10 shovel tests within the site boundary, but encountered no artifacts. Trierweiler and Jones (2005:75), however, noted that lake levels were approximately four feet higher $(\sim 225 \mathrm{ft})$ than when the site was first identified by Briggs and Malone in 1970, and suggested that cultural deposits were likely submerged. As a result, they recommended that the NRHP status of site 41BW69 remain undetermined until such time as the submerged deposits could be evaluated.

\section{Regional CUlture History}

\section{Paleoindian Period (9000-7500 BC)}

The most widely accepted model for the peopling of North America argues that Asian populations migrated to the western hemisphere over the Bering land bridge that linked Siberia and Alaska some 12,000 years ago. However, data are mounting in support of migrations that date to before 12,000 years ago. Excavations at the Debra L. Friedkin site in central Texas produced a large assemblage of lithic artifacts, known as the Buttermilk Creek Complex, that lies beneath a Clovis assemblage and dates to approximately 13,200 to 15,500 years ago (Waters et al. 2011)

This early period of human history in North America is identified primarily by its remarkable projectile points (Clovis, Folsom, Dalton, San Patrice, Scottsbluff). Unfortunately, these items are often found in isolation, leaving few opportunities to date these components (Perttula 1988:17). Despite the limited number of well-stratified and datable Paleoindian sites in Northeast Texas, data from surrounding regions suggest that people of this period were highly dispersed and organized into mobile hunter-gatherer groups with a generalized adaptation strategy and diverse tool kit (scrapers, denticulates, burins, and adzes) rather than having a specialized hunting strategy focused solely on megafauna (Fields and Tomka 1993:82; Perttula 2004:373-374). Regional distribution data of Paleoindian projectile points suggests the use of major river valleys and streams (Anderson 1996; Thurmond 1990).

\section{Archaic Period (7000-200 BC)}

By about 10,000 years ago the Pleistocene megafauna that contributed to the diet of the first peoples to enter the Americas were extinct. In addition, the environment continued to change, albeit more slowly than in the preceding Paleoindian period. As the climate warmed, the initially widespread oak-hickory forests were gradually replaced with fine-grained and patchy pine-oak forests, a process that may have intensified during the mid-Holocene Hypsithermal interval (Delcourt and Delcourt 1981). In general, these dynamics initially fostered highly mobile forager economies similar to those of their Paleoindian forebears, followed during the Hypsithermal interval by a more condensed settlement strategy characterized by decreasing 
mobility and greater reliance on local resources. The inhabitants still likely had a foraging economy. The Archaic period in Northeast Texas was a time of slow gradual changes in subsistence patterns, increasing population size and density, increasing sedentism, and the creation of group territories (Perttula 2004:374-376; White et al. 1995:18-19).

\section{Early Archaic (7000-4000 BC)}

The Early Archaic is characterized by small, dispersed occupations, suggesting highly mobile hunter-gather groups (Perttula 2004). Recent paleoenviromental studies (Ferring 1995) suggest that the drier climate, reduced biomass, and expansion of prairie habitat played a fundamental role in keeping populations on the move. Typical Early Archaic projectile points from the region include Cossatot, Dawson, Keithville, Kirk, Palmer, and Wells. These types tend to have straight or expanding stems (Story 1990; Thurmond 1990).

\section{Middle Archaic (4000-2000 BC)}

The Middle Archaic is characterized by larger and more frequent open camps. These occupations typically include a more diverse lithic tool kit that includes cutters and scrapers, groundstone tools, mortars and pestles, and mealing stones that suggest an increased use of plant foods (Neuman 1984:77, 79). Typical Middle Archaic projectile points include Big Sandy, Carrollton, Evans, Calf Creek, Johnson, Morrill, Lone Oak, Trinity, and Wesley. These types still tend to have straight or expanding stems (Story 1990; Thurmond 1990).

\section{Late Archaic (2000-200 BC)}

The Late Archaic is characterized by an increased spatial distribution of sites across broader portions of the landscape, including major streams, tributaries, springs, and upland ridges (Perttula 2004:375-376). Population is thought to have peaked during the Late Archaic, resulting in a decrease in mobility and an increase in interregional contact (White et al. 1995). Typical Late Archaic projectile points include expanding stem (Castroville, Edgewood, Ellis, Ensor, Lange, Palmillas, Yarbrough) and contracting stem (Gary, Kent) types (Story 1990; Thurmond 1990).

\section{Woodland/Early Ceramic Period (200 BC-AD 800)}

The Woodland/Early Ceramic period is characterized by the appearance of coarse pottery tempered with clay/grog or bone, Gary projectile points, the introduction of horticulture, utilization of the bow, and longer site occupations (Dockall and Fields 2006:12; Kenmotsu and Perttula 1993:45). Although data for this period are scarce, sites of this period have been identified. Middens, burials, and evidence for structures (postmolds) suggest longer periods of sedentism (Perttula 2004:377). In addition, this period is thought to be influenced by the Fourche Maline tradition north of the Red River (Perttula et al. 1993; Story 1990). 
The primary ceramic type for this period is Williams Plain, which often occurs as very thick bowls or flowerpot-shaped jars (Perttula 2004:376). Other non-local pottery types appear at Woodland sites and seem to be from the Lower Mississippi Valley. These include Tchefuncte Stamped, Churupa Punctated, Marksville Incised, and Marksville Stamped types, implying active contact and trade routes with this region (Perttula 2004:376).

\section{Formative/Early Caddoan Periods (AD 800-1200)}

The Formative and Early Caddoan Periods are poorly defined in Northeast Texas and are typically addressed together. Sites are typically located on uplands near major streams, tributaries, and springs with a proclivity towards well-drained and fertile soil for horticulture. Settlement patterns include permanent villages, hamlets, and farmsteads. The archaeological evidence for this is found in middens, pits, mounds, cemeteries, and rectangular or circular structures. Villages are more common during the Early Caddoan and extend into the Middle Caddoan Period (Perttula 2004:378-379; White et al. 1995:20).

Characteristic artifacts from this period include celts, ceramic pipes, earspools, and decorated pottery. Typical pottery types include Hickory Fine Engraved, Caramel Engraved, Crockett Curvilinear Incised, and Pennington Punctated-Incised (Thurmond 1990). These artifact types appear to be part of the Alto complex, which was likely influenced by Coles Creek culture to the east. Some differences, however, are apparent with the appearance of two new projectile points (Hayes, Homan), carinated bowls, and finely engraved pottery with red pigment filler (Neuman 1970).

\section{Middle Caddoan Period (AD 1200-1400)}

The Middle Caddoan period is defined by the Haley phase from Arkansas, which is based on shaft burials and abundant grave offerings. Settlement patterns include small farmsteads surrounding ceremonial mound centers and cemeteries adjacent to mound centers (Wyckoff 1974). Although there is continued cultivation of maize and squash, paleobotanical and stable carbon isotope data on human remains suggest that they were not fully dependent on maize and other crops until after AD 1300 (Perttula 2004:383).

\section{Late/Pre-Contact Caddoan (AD 1400-1680)}

The Late Caddoan period includes multiple regional phases of which two, Titus and Texarkana, are within Northeast Texas. Titus phase settlements include small hamlets with family cemeteries and larger villages with status-ranked community cemeteries, suggesting a complex social hierarchy and elite-controlled society (White et al. 1995:21). Conversely, the Texarkana phase demonstrates the continued utilization of mounded ceremonial centers seen during the Middle Caddoan period (Story 1990). 
These settlement and mortuary practices indicate an increased social complexity over preceding periods. Likewise, Caddoan pottery increased in variety, not only in shape and decoration, but also in function. These changes suggest that pottery served both a utilitarian and sacred function (Perttula 2004:404). Interestingly, there is a marked decrease in lithic tools and debris, which may reflect a shift to wood and bone tools (Pettula 2004:404).

The Late Caddoan period also marks the first contact with Europeans and more specifically by the De Soto/Moscoso entrada (ca AD 1540). Although there is scant archaeological evidence of Caddo/Spanish interaction, infectious diseases most likely had a heavy impact on the Caddo (Kenmotsu and Perttula 1993).

\section{Historic/Contact Caddoan (AD 1680-1860)}

The Historic Caddoan period is marked by a continued European presence that eventually displaces the Caddo and other Native American tribes out of Texas. Caddo settlements by this period are communities of small farmsteads dispersed over a larger area with household cemeteries replacing the previous mound cemeteries. Caddo pottery remained diverse, while the archaeological remains include basketry, ornaments, bone, stone, and wood based tools. By 1740, European items are found on Historic Caddo sites and include guns, lead shot, gunflints, glass beads, metal tools, and precious metal ornaments (Kenmotsu and Perttula 1993).

\section{HISTORIC OVERVIEW}

This historic overview addresses a generalized history of Texas along with an overview of the historical development of Bowie and Cass Counties. Located in northeastern Texas, these counties have many themes in common in their histories.

\section{Historic Texas Overview}

The Spanish were leaders in the European exploration of the Gulf of Mexico rim. Making landfall in present-day Florida in 1528, the expedition of Pánfilo de Narváez disintegrated in the panhandle of that state. In rustic vessels, a small group of survivors followed the Gulf Coast and sighted the modern-day Texas before reaching Mexico (Weddle 1991, 2000).

Other Spanish explorers entered the modern-day state of Texas. In 1540 an expedition from Mexico led by Francisco Vazquez de Coronado reached northern Texas. After explorer Hernando de Soto's death on the Mississippi in 1542, Luis de Moscoso Alvarado took command of the remnants of the expedition and attempted to reach Mexico over land. Though historians have struggled to certifiably document the route, there is general agreement that Moscoso reached Texas (Flint and Flint 2012). In 1554, three Spanish vessels en route from Veracruz to 
Spain wrecked along Padre Island (Weddle 1985). For years to come, the Spanish rarely ventured into Texas.

Sailing for France, Rene Robert Cavelier (Sieur de LaSalle) challenged the Spanish presence in the Gulf of Mexico. La Salle put soldiers and colonists ashore at Matagorda Bay in 1685 and explored the interior of Texas as far as the Rio Grande River, but his colony failed (Weddle 1991). France's incursion into land that Spain claimed influenced new Spanish attempts at exploration and occupation. The Rivas-Iriarte Expedition (1686-1687) skirted the Gulf coast to find signs of La Salle's failed colony and the Teran de los Rios Expedition explored inland Texas with a goal to establish missions among the native population (Weddle 1991, 2000).

As Spain gradually acquired a strong foothold along the southern Gulf of Mexico, the Spanish attempted to spread their influence. In the seventeenth and eighteenth centuries missions spread into Texas and the Spanish granted sweeping acreages to cattlemen who established the first ranches; however, the region remained thinly populated into the nineteenth century (Chipman and Joseph 2010). This frontier condition was inviting to Anglo migrants from the fledgling United States who saw opportunities to prosper in Texas. They increasingly settled in Texas and, especially, following Mexico's independence from Spain in 1821. Despite an early failure at the Battle of the Alamo (1836), Texas ultimately won independence from Mexico and formed a Republic (Campbell 1989). Less than a decade later, Texas joined the United States.

The period of Texas history between statehood and the Civil War was marked by increasing conflict with Mexico and the entrenchment of slavery. Mexico's objection to Texas statehood influenced a war between the United States and Mexico (1846-1848). The US victory forced Mexico to acknowledge Texas' place in the United States and recognized the Rio Grande as Texas' western border. With peace, settlement began to spread across Texas and many new settlers relied on slave labor to support their agricultural pursuits.

Deeply concerned about the fate of slavery and states' rights issues, Texans resoundingly voted to secede from the Union in 1861. Many thousands of Texans joined the Confederate military; however, the majority protected Texas interests in the Southwest during the conflict. Col. Rip Ford, for example, commanded Confederates in the Rio Grande region and sent troops against the Comanche, Union invaders, and Mexican invaders (Smith 1992). Meanwhile, Confederates built coastal fortifications, engaged in blockade running, and battled the Union Navy along the coast of the state (Hall 2014). The South surrendered in 1865 and Texas, like many other former Confederate states, entered a period of political and economic instability.

In the late nineteenth century, railroad development and the success of the cattle industry brought prosperity to Texas. Many new homesteads were established in this period. Unlike many other states, Texas retained the rights to its unclaimed lands and, thus, the state and not the federal government dispersed homestead acreage. By the end of the century, Texas had a distinctly agrarian identity even though urban centers such as San Antonio, Galveston, Dallas, and others grew in population and industry (Moneyhon 2004). 
Texas was one of the most populous states in the twentieth century, a period which brought numerous changes in society, economy, and culture. The petroleum industry spread like wildfire across the Texas landscape. The 426-mile Gulf Intracoastal Waterway was completed in midcentury between Sabine Pass and Brownsville. Along with this important transportation corridor came interstate development and state highway improvements. World War II brought new military and industrial development to the state. The increase of industrial jobs led to an increase in urbanization in Houston, San Antonio, Austin, Fort Worth, and Dallas that continued well into the postwar period (Martin 1969). Extensive migration as the countryside moved to the city and newcomers from other states and Mexico settled in Texas. The civil rights movement elevated the position of African Americans and Hispanics in Texas society.

The Texas coast prominently featured in the history of the state in the twentieth century. Louisianans laid the foundation in Texas for the shrimping industry, now the largest commercial fishing industry in the state (Maril 1995). The effort to protect the near-extinct whooping crane was emblematic of increased environmental awareness and resulted in the 1937 creation of what became a system of national wildlife refuges in Texas. The state also was embroiled with the federal government in a dispute over submerged lands along the Texas coast (Bartley 1953). In 1960, Texas finally affirmed title to its three-league Gulfward boundary which consisted of nearly 2.5 million acres. Texas has held a truly unique place in the history of the nation.

\section{Bowie and Cass Counties Overview}

Europeans first reached the region in the mid-sixteenth century. Permanent settlement, however, came much later in the early nineteenth century. Through the Republic period of Texas history and the annexation to the United States, settlement spread in the region and an agricultural economy developed. Into the twentieth century, agriculture continued to dominate the economy. In the present, the counties are primarily rural and agricultural.

When Europeans first entered the present-day Bowie and Cass County region of Texas in the mid-sixteenth century, they encountered the Caddo. Until the late eighteenth century, these agricultural people remained in the region. They abandoned their villages as a result of epidemic disease and conflict with the Osages. After the Caddo, several native groups, including the Shawnee, Delaware, and Kickapoo, immigrated into this area of Texas (Harper 2010a).

Following the death of Hernando de Soto on the Mississippi in 1542, Moscoso took over the Spanish expedition. Historians have developed numerous interpretations of Moscoso's route, including one that passes through Bowie County. While Moscoso and his men may have been the first Europeans to enter the region, there is a stronger likelihood that French expeditions led by Henri Joutel and Henri de Tonti between 1687 and 1690 were first. For several decades after these expeditions, the European presence in Bowie and Cass Counties was minimal. In 1719, another Frenchman, Jean Baptists Benard de la Harpe, established Le Poste des Cadodaquious in present-day Bowie County (Harper 2010a). 
In the early nineteenth century the United States sponsored numerous explorations of the West. President Thomas Jefferson sent Thomas Freeman and Dr. Peter Custis to explore the region including Bowie County in 1806. At Spanish Bluff (near today's New Boston) the Freeman-Custis Expedition encountered Spanish soldiers who forced them to leave the area. This engagement prefaced what would be many years of Spanish-American contention over Texas. Another important legacy of the expedition was white settlement along the Red River. Until the northern boundary of Texas was firmly established in the 1830s, many considered these frontier settlements to be part of Arkansas (Harper 2010a).

As American interest in the West turned into actual settlement by the 1830s, the first settlers came to what is now Cass County. Three mineral springs attracted Reece Hughes who built a cabin at what later became known as Hughes Springs. Many of the new settlers who came to Cass County were from neighboring southern states. A significant number were slaveowners as well. The economy that arose in Cass County was based on agriculture and, to a large extent, cotton and corn. In the antebellum period, the expansion of agriculture brought with it the expansion of slavery. Jefferson (Marion County) was the shipping point for much of the agricultural products that came out of Cass County (Harper 2010b).

Bowie County was established in 1840 and, six years later, the county lost land area when Cass, Titus, and Morris counties were created. The first county seat of Bowie was called Boston (and, later, Old Boston). Four decades later, the county seat transferred to the rising town of Texarkana. In the antebellum period, many Southerners settled in Bowie County, bringing with them the institution of slavery. The economic outlook of the county was heavily agricultural and focused on cotton, corn, and livestock (Harper 2010a).

When Texas became a state, Cass County was included in Bowie County, but that changed before the year 1846 ended. Cass became its own county. Lewis Cass, a US Senator from Michigan who favored Texas annexation to the United States, was the namesake. The first county seat was Jefferson; however, in less than ten years and after a local political struggle, the county chose to make Linden the county seat in 1852. Just prior to the Civil War in 1860, Cass County lost territory to a newly formed county, Marion (Harper 2010b).

Bowie County overwhelmingly voted in support of Texas' secession from the Union in 1861 . The Residents of Cass County similarly had strong, pro-Southern opinions during the secession crisis of 1860-1861. The extent of their anger at the North was symbolized in the renaming of the county Jefferson Davis in honor of the leading southern politician (the name Cass was reinstated in 1871). On the eve of the Civil War in Cass County, the slave population was larger than the free population. The free population resoundingly approved secession from the United States in 1861 (Harper 2010b).

While there were no pitched battles in Bowie or Cass Counties during the Civil War, the result of the conflict depressed the economy as it did across the South. Social instability and violence against freedmen were common in the postwar period. Unlike other areas of the South, 
Republican rule did not last long in Cass County. By 1869, the conservative Democrats had regained control of the government (Harper 2010b).

During the Reconstruction period, agriculture remained the foundation of the economy of Cass County and neighboring Bowie County. Cotton continued as a cash crop and corn was the principal food crop. Up to the 1920s, hogs were the principal livestock raised in the counties. Well into the twentieth century, farmers in Cass County continued to focus on cultivating cotton and corn; however, the number of farmers who owned their land declined as farming operations became consolidated. By 1930, 61 percent of farmers were tenants whereas in 1880 only a quarter of farmers were tenants (Harper 2010b). A similar pattern emerged in Bowie County (Harper 2010a).

Along with the increase in tenancy, another important change in Cass County in the Reconstruction period was railroad development. Railroad investors joined to sponsor the completion of the Texas and Pacific Railway through Cass County in 1873. The arrival of the railroad spurred the creation of the new towns of Atlanta and Queen City. The East Line and Red River Railroad completed their own line through southwestern Cass County in 1876 . The town of Hughes Springs emerged as a supply center along this line. Even as these new towns emerged, Cass County was considerably rural (Harper 2010b).

In comparison to neighboring Cass County, Bowie County had a larger urban population, and largely as a result of the emergence of Texarcana. By 1900, this town which was founded as the Texas and Pacific Railway reached the region, was a major market and shipping point for agricultural products from the region. By 1930, nearly half of Bowie County's population (approx. 20,000) lived in Texarcana (Harper 2010a).

The Great Depression sharply impacted Bowie and Cass Counties. The nationwide financial crisis cut farm values in Cass County in half. As a result of federal directives to restrict planting, many tenants and sharecroppers had to abandon their livelihoods, and many of them left the region. Even as the general economy improved following World War II (1941-1945), farm operations increasingly relied less on tenants and sharecroppers, and thus the rural population dwindled. Farm mechanization also decreased the need for farm labor in this period. Another trend was a transition away from cotton and corn production to livestock, and especially beef and poultry (Harper 2010a, 2010b).

New industries came to Cass County in the twentieth century. The lumber industry expanded in Cass County in the early twentieth century and, by the 1940s, the annual production of lumber in the county reached 75 million board feet (Harper 2010b). As was the case across Texas, oil prospectors came to Cass County in the 1930s. In that decade, oil companies drilled over 100 wells. Though the county never became a major oil producer, millions of barrels of black gold flowed from Cass County land through the twentieth century (Harper 2010b).

In recent years, many residents of Bowie and Cass Counties are employed in manufacturing, trade and local government occupations. The population of Bowie County is approximately 
57,000 and it is spread across Texarkana, New Boston, Wake Village, Hooks, De Kalb, Maud, Red Lick, Redwater, and Simms (Harper 2010a). The most recent census data for Cass County (2014) counted 30,361 residents spread across several communities: Linden, Atlanta, Hughes Springs, Queen City, Avinger, Bloomburg, Bivins, Marietta, Domino, and Kildare (Harper 2010b).

Wright Patman Lake, formerly known as Lake Texarkana and Texarkana Reservoir, is the result of dam construction on the Sulphur River that began in 1948, having been authorized by the Flood Control Act of 1946. Water from the Sulphur River was blocked and diverted through dam control structures in 1953, and by 1956, the flood gates were closed, beginning the impoundment process. The lake, located in Bowie and Cass Counties, is used for recreational purposes and provides water for the City of Texarkana

(USACE 2016).

\section{Historic Map Review}

Historic topographic maps provide information on the historical setting of the study area. Four of these maps provide coverage of the study area (Figure 3.1). The New Boston (1909) topographic map covers the northwestern portion of the study area while the Texarcana (1909) topographic map covers the northeastern portion. The Linden (1910) topographic map covers the southwestern portion of the study area while the Atlanta topographic map (1910) covers the southeastern portion. Each of these maps is discussed below with emphasis on features in or near the study area.

\section{New Boston (1909)}

The New Boston topographic map, which provides information on the northwestern portion of the study area, illustrates several historic features in the study area. Generally, the area appears to have been quite rural. The most prominent are the St. Louis \& Southwestern Railroad and the Northeast Texas Railroad. There are several prominent creeks including Whatley Creek and Sulphur Creek. A county bridge is noted over Sulphur Creek. Other notable locations in the study area are Paps School, Pettis Bridge, McFarland Island, Cottonwood Ford, Malden Lake, Big Lake, several structures, and unnamed roads or trails.

\section{Linden (1910)}

The southeastern potion of the study area is illustrated in the 1910 Linden topographic map. Similar to other parts of the study area, the Linden topographic map depicts a very rural area. The main features of the area are natural features, including Overcup Pond, Overcup Slough, and Bailard Creek. Signs of human activity include Panhandle School, a handful of scattered structures, and several unimproved and improved roads. 


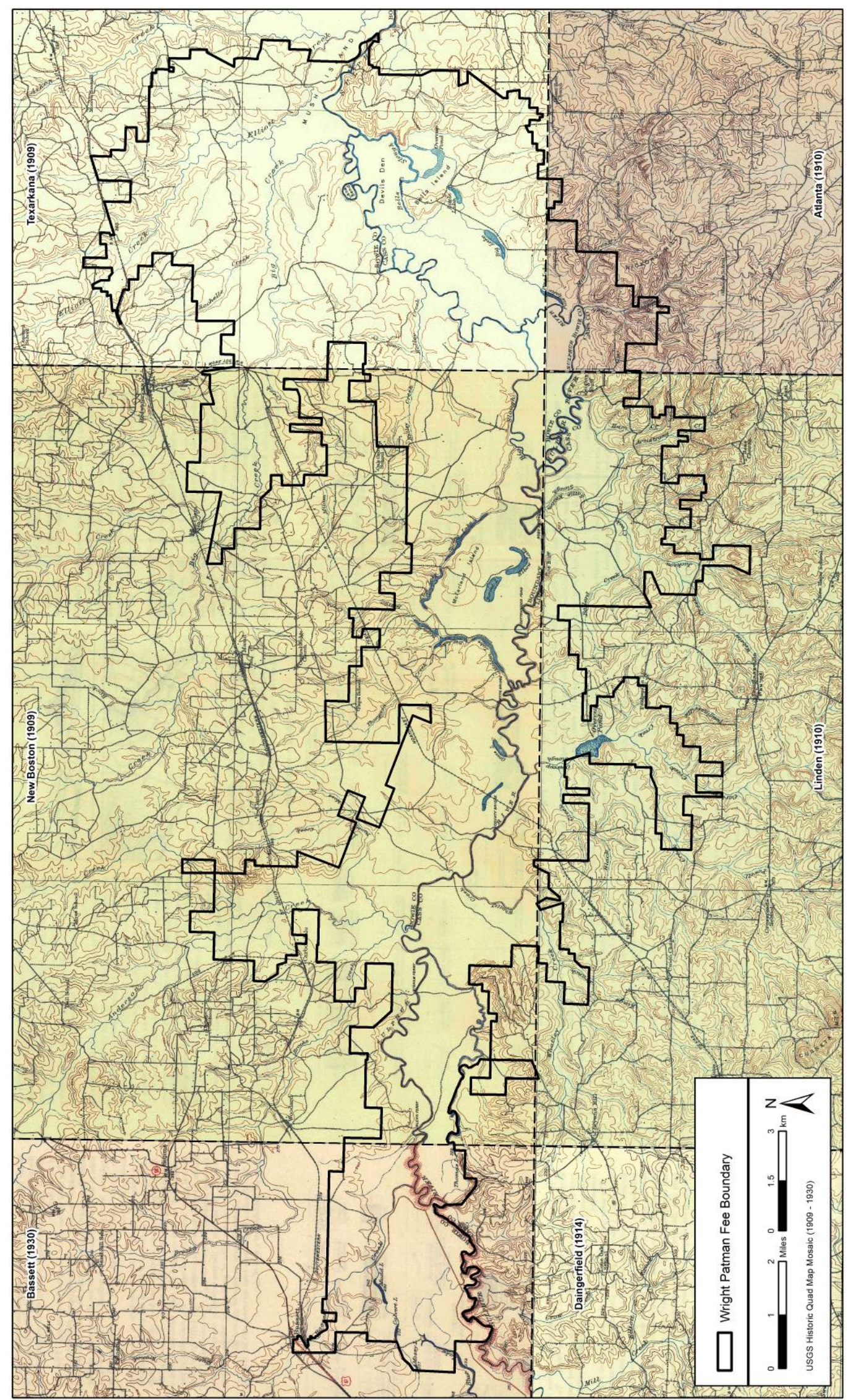




\section{Texarkana (1909)}

The Texarkana (1909) topographic map provides coverage of the northeastern portion of the study area. This map indicates the northeastern portion of the study area to be quite rural as well. The most prominent manmade feature in the map is the St. Louis \& Southwestern Railroad. Approximately half a dozen structures are indicated throughout the study area and there are several improved and unimproved roads, none of which are named on the map. Elliott Creek and Mush Island are the most prominent natural features in the map.

\section{Atlanta (1910)}

The Atlanta topographic map encompasses a small portion of the study area, primarily the southeastern shore of the present Wright Patman Lake. The 1910 map indicates two improved roads and there are several structures along these roads. 


\section{CHAPTER 4 \\ RESEARCH DESIGN AND METHODS}

The goal of this project is to characterize 15 archaeological sites, based on preliminary systematic fieldwork, as either requiring additional testing to determine National Register of Historic Places (NRHP) status or ineligible for listing in the NRHP. Archaeological site evaluations follow 36 CFR 60.4, which states that:

The quality of significance in American history, architecture, archeology, and culture is present in districts, sites, buildings, structures and objects that possess integrity of location, design, setting, materials, workmanship, feeling, and association, and,

A. that are associated with events that have made a significant contribution to the broad patterns of our history; or

B. that are associated with the lives of persons significant in our past; or

C. that embody the distinctive characteristics of a type, period or method of construction, or that represent the work of a master, or that possess high artistic values, or that represent a significant and distinguishable entity whose components may lack individual distinction; or

D. that have yielded, or may be likely to yield, information important in prehistory or history.

These criteria require a level of clarification to illuminate the issue of site importance. As such, the following attribute evaluations add a measure of specificity that can be used in assessing site significance and NRHP eligibility:

- Site Integrity: Does the site contain intact cultural deposits or is it disturbed?

- Preservation: Does the site contain material suited to in-depth analysis and/or absolute dating such as preserved features, botanical material, or faunal remains?

- Uniqueness: Is the information contained in the site redundant in comparison to that available from similar sites, or do the remains provide a unique or insightful perspective on research concerns of regional importance?

- Relevance to Current and Future Research: Would additional work at this site contribute to our knowledge of the past? Would preservation of the site protect valuable information for future studies? While this category is partly a summary of the above considerations, it also recognizes that a site may provide valuable information regardless of its integrity, preservation, or uniqueness.

The visibility of archeological deposits is limited in shovel tests and small test units $(50 \times 50 \mathrm{~cm})$; nevertheless, there are certain physical characteristics a site may possess that make it more likely to be eligible. For this project, those sites would require additional work to determine NRHP status. These site characteristics include, but are not limited to: 
a) well preserved cultural features (e.g., post holes and molds, hearths, pits, burials); however, these are rarely identified during preliminary fieldwork;

b) stratified deposits and/or identifiable cultural components that can be isolated vertically and/or horizontally;

c) artifact density within stratigraphically discrete components (note that artifact density is based on local average densities and not an arbitrary number of artifacts per cubic meter);

d) single site assemblages identifiable to a specific time period or culture, historic sites with well preserved and minimally disturbed features like wells, privies, foundations, chimneys; or

e) historic sites that can be tied to specific historic personages that, through archival research, could reconstruct historic development or cultural history in the region, or historic sites that demonstrate commercial or social focus (mills, stores, shops, manufacturing facilities).

Given both the National Register criteria as well as the attributes of specific archaeological resources, while assessing eligibility there are several criteria indicating that a site is probably not eligible to the NRHP. These include, but are not limited to:

a) isolated artifacts or low-density artifact assemblages (In some cases, a single isolated artifact or artifacts within a low-density assemblage may have significance as a unique or sacred object);

b) disturbed surface artifact scatters;

c) sites damaged to the extent that depositional integrity has been lost (unless the site contains unique or rare artifact assemblages, for example a Paleoindian cache);

d) multicomponent sites in which components have been mixed due to extensive site damage or depositional processes; or,

e) recent artifact debris (less than fifty years old).

\section{RESEARCH DESIGN}

Research designs within CRM broadly range from regional designs to methodological and technical designs to topical and theoretical designs, or some combination thereof. The research design for this project takes a broad regional approach and examines each site within the context of NRHP evaluation criteria, research orientation developed for the Northeast Texas Archaeological Region (Perttula and Kenmotsu 1993) (Table 4.1), and fieldwork necessary to achieve these goals. Thus, the specific goals of this project can be summarized as follows:

1. Identify the cultural components and examine the horizontal distribution of artifact classes represented at the archaeological site.

2. Determine if the identified cultural components occur within intact, stratified contexts. 
3. Determine if sufficient artifact classes and features exist to provide insight into general site function, subsistence patterns, and/or settlement systems in prehistoric and/or historic contexts as presented for Northeast Texas.

Table 4.1. Historic Contexts and Associated Study Units for the Northeast Texas Archaeological Region.

\begin{tabular}{|c|c|}
\hline Historic Context & Study Units \\
\hline $\begin{array}{l}\text { Quaternary Environments and Archaeology in } \\
\text { Northeast Texas (Collins and Bousman 1993) }\end{array}$ & $\begin{array}{l}\text { 1. Modern climate } \\
\text { 2. Botanical Markers of Climate Change } \\
\text { 3. Analysis of Stable Isotopes }\end{array}$ \\
\hline $\begin{array}{l}\text { Changes in Hunter-Gatherer Mobility in } \\
\text { Northeast Texas (Fields and Tomka 1993) }\end{array}$ & $\begin{array}{ll}\text { 1. } & \text { Chronology and Typology } \\
\text { 2. Settlement Systems and Site Planning } \\
\text { 3. Subsistence } \\
\text { 4. Trade and Exchange } \\
\text { 5. Technological Change/Material Culture }\end{array}$ \\
\hline $\begin{array}{l}\text { The Emergence of Sedentism in Northeast } \\
\text { Texas, ca. } 500 \text { BC to AD } 1000 \text { (Perttula et al. } \\
\text { 1993) }\end{array}$ & $\begin{array}{l}\text { 1. Paleoenvironments } \\
\text { 2. Settlement Systems } \\
\text { 3. Subsistence Systems } \\
\text { 4. Social Systems } \\
\text { 5. Demography and Health } \\
\text { 6. Mortuary Practices } \\
\text { 7. Intra- and Interregional Exchange and Interaction } \\
\text { 8. Material Culture Characterizations } \\
\text { 9. Technological Change }\end{array}$ \\
\hline $\begin{array}{l}\text { The Development of Agriculture in Northeast } \\
\text { Texas before AD } 1600 \text { (Perttula 1993a) }\end{array}$ & $\begin{array}{l}\text { 1. Chronology and Typology } \\
\text { 2. Settlement Systems } \\
\text { 3. Subsistence Systems } \\
\text { 4. Social and Political Complexity } \\
\text { 5. Demographic Change } \\
\text { 6. Mortuary Practices } \\
\text { 7. Local and Extra-local Trade and Exchange } \\
\text { 8. Technological Change } \\
\text { 9. Material Culture } \\
\end{array}$ \\
\hline $\begin{array}{l}\text { Effects of European Contact on Native and } \\
\text { Immigrant Indians in Northeast Texas (Perttula } \\
\text { 1993b) }\end{array}$ & $\begin{array}{l}\text { 1. Demography, Impacts of Disease, and Health } \\
\text { Conditions } \\
\text { 2. Language } \\
\text { 3. Religion, Ideology, and Ceremony } \\
\text { 4. Social Structure and Social Status } \\
\text { 5. Political Organization } \\
\text { 6. Settlement Systems, Site Planning, and Architecture } \\
\text { 7. Subsistence and Economic Systems } \\
\text { 8. Artifacts and Technology } \\
\text { 9. Trade and Exchange-Foreign Relations } \\
\text { 10. Ethnicity and Territoriality } \\
\text { 11. Missionization and Acculturation } \\
\end{array}$ \\
\hline
\end{tabular}




\section{FiELD METHODS}

In an effort to examine previously identified archaeological resources and recover additional artifact data, sites and/or portions of sites were subjected to pedestrian survey and systematic subsurface testing within existing archaeological site boundaries. Shovel tests (ST) excavated during this project measured $30 \mathrm{~cm}$ in diameter and were excavated at 5-, 10-, and 20-m intervals. No shovel tests were excavated within improved roadways or in areas with standing water. Negative shovel tests were flagged with pink flagging tape, while positive shovel tests were flagged with pink and blue. The cultural content, soil strata and texture, predominant Munsell color, and environmental setting were recorded on shovel test forms. All excavated sediments were screened through $1 / 4$-inch mesh hardware cloth.

Upon completion of artifact delineation, $50-x-50-\mathrm{cm}$ test units were excavated based on the results of the initial pedestrian and subsurface surveys. Test unit excavation followed standard archaeological practices. All units were excavated in $10-\mathrm{cm}$ arbitrary levels within natural soil strata. Once culturally sterile sediments were encountered, excavations terminated in upland settings where an argillic $B$ horizon is present and continued for a minimum of two additional 10-cm levels in alluvial settings. Sediments from general excavation levels were screened through 1/4-inch hardware cloth.

During fieldwork, locations of positive shovel tests and test units were recorded using a Trimble GeoExplorer XT GPS receiver. Location information was also documented on hand-sketched site maps, USGS quadrangle maps, and historic and modern aerial photographs provided by MCB Camp Lejeune. After data collection, location information was post-processed for accuracy and imported into an ArcGIS shapefile.

All artifacts recovered during the archaeological survey were returned to the laboratory facilities for cleaning and processing. Artifacts were washed clean of sand and dirt and allowed to air dry. Materials were then rebagged and organized by field specimen numbers (FS\#) and provenience (Appendix A).

\section{ARTIFACT ANALYSIS}

\section{Ceramic Artifacts}

With the exception of residual sherds (i.e., sherds smaller than $1 / 2 \mathrm{in}^{2}$ ), Native American ceramic artifacts recovered during the investigation were analyzed to determine paste, temper, surface treatment, and ware type. Paste, temper, and surface treatment were examined macroscopically with the aid of a low-magnification light or hand lens. When necessary, microscopic analysis was conducted at low magnification under white light with a 20X Leica Stereo Zoom Microscope. Small pieces of each sherd were broken to expose fresh surfaces for paste and temper characterization. Temper types generally include fiber, silt, sand, granule, 
pebble, grog/clay, crushed quartz, limestone/marl, crushed shell, and bone. Particle size is based on the Wentworth scale. The scale includes: silt $(<1 / 16 \mathrm{~mm})$, very fine sand $(1 / 16-1 / 8$ $\mathrm{mm})$, fine sand $(1 / 8-1 / 4 \mathrm{~mm})$, medium sand $(1 / 4-1 / 2 \mathrm{~mm})$, coarse sand $(1 / 2-2 \mathrm{~mm})$, granule (2-4 mm), and pebble (4-64 mm). Dr. Robert Z. Selden at Stephen F. Austin State University assisted with the analysis of Native American pottery sherds collected during this project.

\section{Lithic Artifacts}

Lithic artifacts were organized by provenience and separated into three categories: debitage, lithic-other (e.g., fire-cracked rock, thermal shatter), and tools. Categories are based on ideals that lithic specimens approximate morphologically. Lithic material was examined both macroscopically and microscopically for possible use wear. Lithics were examined macroscopically with the aid of a low-magnification light or 10X hand lens. Microscopic analysis was conducted at low magnification under white light with a 20X Leica stereo zoom microscope. Presence or absence of thermal alteration was also recorded for each specimen.

Flake form categories used in this analysis are based on morphological characteristics such as the presence or absence of platform, bulb of percussion, cortex, and dorsal flaking scars, as well as an assessment of flake portion (complete, proximal, or medial-dorsal). SEARCH lithic analysis also takes into consideration additional characteristics such size, and utilization or use-wear, as well as technological typology terms which relay staging information, such as retouch, or expedient use (informal flake tools) to create a hybrid analytical framework which combines cortical, technological typology, and aggregate analysis schemes (Ahler 1986; Andrefsky 2005; Sullivan and Rozen 1985). Cortical information and typological categories are part of an analytical scheme meant to infer core and tool reduction phase. In addition, shatter (angular or thermal) is noted in SEARCH's typology.

Flake form and size categories are useful because they can be tallied and compared to experimentally derived assemblages in order to interpret possible site activities (Austin 1999). Ideally, samples with higher percentages of larger flake size categories reflect core reduction activities. Samples exhibiting higher percentages of smaller flake size categories typically reflect debitage associated with patterned tool production. While core reduction and bifacial tool production may result in lithic assemblages with different signatures, both activities were often carried out in the same locale resulting in a "mixed" assemblage.

Specific lithic categories are described below:

- Biface fragment: a tool fragment with evidence of flaking on both surfaces that meet to form a single edge that circumscribes the tool.

- Chopper, bifacial: a pebble or cobble modified through bifacial flaking to create a strong working edge that can be used with forceful strokes.

- Core: a mass of stone that functioned as a source of flakes. 
- Cortex fragment: a fragment of the exterior surface of a pebble/cobble with evidence of percussion damage or flake scarring on the ventral surface.

- Fire cracked rock: stones fractured through exposure to heat or fire as a by-product of use in fire rings, roasting pits, or as boiling stones.

- Flake fragment: A partial or incomplete flake.

- Flake, blade: a specialized type of flake detached from a blade core. Typical characteristics include a prepared platform, at least one arris that runs the length of the flake, parallel lateral margins, and a length at least twice as long as it is wide. A microblade has a length of less than $5 \mathrm{~cm}$.

- Flake, core reduction: a percussion flake removed in the process of reducing a core in its earliest stages of reduction.

- Flake, early reduction: a percussion flake removed during the earliest stages of reduction. In coastal Carolina, early reduction flakes result from test-flaking pebbles or cobbles, cortex removal during biface fabrication, and, less commonly, from core reduction. Early reduction flakes are not necessarily large but tend to be relatively thick. Typical characteristics include an abundance of cortex on the dorsal surface, a lack of dorsal flake scars, and a large cortical or flat striking platform. The bulb of force (aka "bulb of percussion") tends to appear as a small cone of crushing on the ventral surface just beneath a cortical platform.

- Flake, pressure: a flake removed during the creation of a platform edge or regularizing and sharpening the edge of a tool by the application of pressure to the edge using an antler tine or pointed bone. Pressure flakes possess very small platforms. Though typically very small in size, pressure flakes can be larger and relatively long.

- Flake, retouched: a small flake removed from the edge of a tool, either through percussion or pressure, in order to resharpen its edge(s). The platforms and proximal ends of these flakes will possess remnants of the tool edge from which they were removed, often exhibiting edge rounding and step fractures.

- Flake, thinning: a percussion flake removed during the removal of bulk and mass to develop convexity in a biface. In coastal Carolina, thinning flakes are limited by the small size of the objective starting piece. Thinning flakes are not necessarily long but they are thin. Typical characteristics include a narrow, lipped flat or multi-faceted platform, a diffuse or flat bulb of force, a curved long-section, a feathered flake.

- Flake, thinning; late: a percussion or pressure flake removed during refinement and shaping of a biface. Platforms tend to be small, multifaceted, and lipped. Multiple overlapping flake scars tend to be present on the dorsal surface.

- Flake, unspecified: a flake that cannot be classified as a specific flake type (e.g., thinning flake, early reduction flake, etc.). Unspecified flakes are nondiagnostic flakes, meaning they cannot be placed into any of the morphological type categories relative to a lithic reduction stage. There are a number of steps involved in flintknapping to progress from an objective piece of stone to a useable tool form; not all of the flakes detached will be classifiable. Each step is affected by a number of interrelated variables.

- Flake, utilized or blade: an expedient tool that exhibits use-wear in the form of microflaking along one or more margins, but not necessarily intentional retouch. 
- Projectile point/knife Preform, Early stage: a bifacial tool possessing a hafting area at its proximal end that potentially functioned as either a projectile point or hafted knife, or both. Early stage preform (sometimes called blanks) are roughly finished past the point of late stage biface but are not completed to form a functional projectile point/knife.

- Projectile point/knife, Contracting stemmed: a bifacial tool possessing a stemmed hafting area at its proximal end that potentially functioned as either a projectile point or hafted knife, or both. Contracting stemmed PPKs possess a hafting area that is narrower at the blade end and tapers toward the proximal end.

- Projectile point/knife, Straight stemmed: a bifacial tool possessing a stemmed hafting area at its proximal end that potentially functioned as either a projectile point or hafted knife, or both. Straight stemmed PPKs possess a hafting area that is narrower than the body, and does not contract or expand along the length.

- Scraper, UID: a tool that possesses a broad working edge with a moderate to steep edge angle. The greater edge angle is deemed more effective for performing scraping tasks.

- Shatter, angular: debitage exhibiting a blocky and angular form.

- Shatter, thermal: small fragments of rock that detached from a larger rock due to direct exposure to heat or fire. A potlid is an example of thermal shatter.

- Uniface: a tool that has been intentionally flaked and shaped across one face.

- Tested pebble/cobble: natural lithic pebbles/cobbles possessing evidence of flake removals intended to determine the suitability of the stone for tool manufacture but showing no evidence to suggest that it itself was intended as a tool or core.

\section{Historic Artifacts}

SEARCH uses Architecture (A), Clothing (C), Furniture (F), Kitchen (K), Personal (P), Arms (R), Tobacco ( $T$ ), and Activities ( $\mathrm{Z}$ ) artifact categories as a framework to rebuild site function and temporal placement. These categories follow South's (1977) categorization system based on artifact function and are useful for approaching the analysis of historic artifacts.

Architecture covers a broad range of structural items such as brick, mortar, nails, and window glass, to name a few. Clothing artifacts consist of various fasteners and apparel related items. Furniture artifacts traditionally include hardware and Kitchen artifacts involve food preparation and eating. The Personal category includes items used primarily by and for an individual. Artifacts in the Arms category include all types of weapons and ammunition. Examples of the Activities category include artifacts representing leisure time, such as marbles, fish hooks, gaming pieces, and children's tea sets, as well as work-related artifacts such as axes, harness parts, horseshoes, and plow parts.

The Kitchen category contains the most comprehensive and detailed classification of artifacts. Ceramics and bottle glass constitute two of the largest artifact types within the Kitchen category. Both of these materials are very durable, survive long term exposure to soil and the natural environment, and due to the breakable nature of these vessels, enter the archaeological record regularly. Few of these artifacts are routinely adapted to other uses and 
therefore, material from both the Kitchen ceramic and glass classifications can be used to help place an archaeological site temporally.

Archaeologists often use the mean date of manufacture as a way of determining relative site age. Mean dates are achieved by calculating the mean of the median manufacturing dates for each specific type and style. The date is derived by multiplying the frequency of each type by its respective median manufacture dating, collectively adding together the product across all types, and dividing by the number of ceramic types in the sample (South 1977:217).

The formula has been extended in this case to calculate all mean dates available due to recent research in bottle glass dating techniques which allow for a clearer understanding of the temporal limits of glass manufacturing. South's (1977) classification for ceramics has been shown to work effectively on archaeological sites. Classifications are based on differences in paste texture and hardness as well as glaze color and method of decoration. Changes in these criteria can be used to date ceramic artifacts and help determine the age of the site. Changes in the pottery industry were spawned by a need to provide better, stronger, and/or fancier wares to a larger market. The driving force of this change was the desire to produce a European form of porcelain that could be produced quickly and inexpensively and therefore distributed to a mass market. New decorative techniques included the advent of transfer print which allowed popular patterns to be essentially printed or stamped directly onto unfired ceramic bodies using oiled paper stencils and engraved copper plate templates.

George Miller's (1980) studies have revealed that surface treatments such as slip/glaze color, painting method and color, and embossed designs are the best indicators of ceramic types and periods of manufacture. These elements are incorporated in the coding and analysis procedure at SEARCH's lab. Ceramic analysis also included the identification of sherds by rim, base, or body. Archaeologists noted vessel form whenever possible and if the sherd was from a hollowware or flatware vessel. Notes were made of any vessel that could be mended or cross mended between proveniences. Maker's marks on ceramics were recorded and researched using the internet and printed reference books in an attempt to identify manufacturer, location and date of manufacture. The following sources were consulted: Barber (2001), Godden (1991), Kowalsky and Kowalsky (1999), and the Florida Museum of Natural History's Digital Type Collection at http://www.flmnh.ufl.edu/histarch/gallery_types/.

Bottle glass artifacts within this group are categorized whenever possible by method of manufacture, in addition to color and function. Characteristics indicative of various manufacturing methods include the presence or absence of mold seams and basal scars, various lip finishes, and embossing. Color can be diagnostic and it can also be indicative of function and manufacturing technique and therefore was noted during analysis. Vessel shape is often a function of use and is noted to help determine site activities. Bottle function was noted when observable. The following sources were examined for information about bottle manufacturing and dating: Jones and Sullivan (1989); and the Bureau of Land Management and Society for Historical Archaeology Historic Glass Bottle Identification \& Information Website at http://www.sha.org/bottle/index.htm. 


\section{Zooarchaeological Analysis}

The fauna recovered provides a glimpse into the subsistence behavior of people in an area where few previous faunal studies have been conducted. The analysis of the faunal material followed current zooarchaeological procedures (Reitz and Wing 1999). The fauna from each sample fraction were rough sorted into broad taxonomic categories, usually to class, and then sorted further to the lowest taxon possible (e.g., family, genus, species). All remains were identified using comparative collections. Any cultural modification such as thermal alteration, polishing, and butchering was noted. Quantitative analysis included counting the number of individual specimens (NISP) and weighing identified elements. Each level of each stratum is treated as a discrete unit and quantified separately.

\section{CURATION}

The material recovered during this effort will be curated with the Texas Archeological Research Laboratory (TARL) of the University of Texas at Austin. No suspected Native American Graves Protection and Repatriation Act (NAGPRA) artifacts were processed during analysis. Maps, field notes, photographs, and other documentation are presently curated and stored at the SEARCH laboratory facility but will be curated along with the other materials recovered during this project.

All materials will be stored and curated in 4-mil polyethylene bags that best fit the size and dimension of the artifact(s) in question. Any friable or fragile materials will be placed into rigid protective containers such as clear polypropylene boxes or metal containers. All artifacts/artifact groups will have acid-free paper labels detailing provenience and analysis information printed using a laser printer, sealed inside a 4-mil tag bag, and inserted into the exterior artifact or artifact group bag. Materials will be bagged by discrete provenience groupings, and all provenience bags will have an acid-free paper label that details the project and provenience information included within the bag. Materials will be boxed in archivalquality acid-free boxes by site and provenience within the site.

\section{NAGPRA CONSIDERATIONS}

In accordance with Caddo requests, the security of identified and/or recovered human remains was evaluated. No suspected NAGPRA funerary items or human remains were encountered during fieldwork efforts associated with this project. In the lab, an individual trained in the identification of human skeletal remains was present. No human remains were identified during artifact analysis. 


\section{This PAge INTENTIONALLY Left BLANK}




\section{CHAPTER 5 \\ RESULTS}

Each site was subjected to pedestrian survey and systematic subsurface testing within its existing boundaries, and in cases of partially submerged sites, across upland terrain immediately adjacent to the site boundary. Table $\mathbf{5 . 1}$ presents a summary of fieldwork, artifact counts by provenience, and the NRHP recommendation for each site. Individual results for each archaeological site are presented below.

Table 5.1. Fieldwork Summary and Recommendations for Previously Recorded Sites at Wright Patman Lake, Bowie and Cass Counties, Texas

\begin{tabular}{|c|c|c|c|c|c|c|}
\hline \multirow{2}{*}{ Site \# } & \multicolumn{3}{|c|}{ Shovel Tests } & \multirow{2}{*}{$\begin{array}{l}\text { Test Units } \\
50-\mathrm{x}-50 \mathrm{~cm}\end{array}$} & \multirow{2}{*}{$\begin{array}{c}\text { Artifact } \\
\text { Count }\end{array}$} & \multirow{2}{*}{ Recommendation } \\
\hline & Positive & Negative & Total & & & \\
\hline 41BW26 & 0 & 0 & 0 & 0 & 0 & $\begin{array}{l}\text { Not located within fee boundary; } \\
\text { NRHP status undetermined }\end{array}$ \\
\hline 41BW42 & 15 & 7 & 22 & 3 & 141 & Additional work recommended \\
\hline 41BW69 & 3 & 40 & 43 & 3 & 10 & $\begin{array}{l}\text { Partially submerged; NRHP status } \\
\text { undetermined }\end{array}$ \\
\hline 41BW77 & 0 & 22 & 22 & 0 & 0 & $\begin{array}{l}\text { Partially submerged; NRHP status } \\
\text { undetermined }\end{array}$ \\
\hline $41 \mathrm{CS} 16$ & 0 & 0 & 0 & 0 & 0 & $\begin{array}{l}\text { Out of Ultimate Rule Curve APE; } \\
\text { NRHP status undetermined }\end{array}$ \\
\hline $41 \mathrm{CS} 48$ & 0 & 20 & 20 & 0 & 0 & $\begin{array}{l}\text { Partially submerged; NRHP status } \\
\text { undetermined }\end{array}$ \\
\hline $41 \mathrm{CS} 55$ & 14 & 13 & 27 & 5 & 794 & Additional work recommended \\
\hline $41 \mathrm{CS} 58$ & 0 & 0 & 0 & 0 & 0 & $\begin{array}{l}\text { Completely submerged; NRHP } \\
\text { status undetermined }\end{array}$ \\
\hline $41 \mathrm{CS} 73$ & 2 & 23 & 25 & 0 & 2 & Ineligible; no further work \\
\hline $41 \mathrm{CS} 76$ & 2 & 5 & 7 & 2 & 33 & $\begin{array}{l}\text { Partially submerged; NRHP status } \\
\text { undetermined }\end{array}$ \\
\hline $41 \mathrm{CS78}$ & 10 & 37 & 47 & 4 & 194 & Additional work recommended \\
\hline $41 \mathrm{CS} 79$ & 0 & 6 & 6 & 0 & 0 & Ineligible; no further work \\
\hline $41 \mathrm{CS} 108$ & 0 & 21 & 21 & 0 & 0 & $\begin{array}{l}\text { Partially submerged; NRHP status } \\
\text { undetermined }\end{array}$ \\
\hline $41 \mathrm{CS} 122$ & 1 & 16 & 17 & 3 & 29 & $\begin{array}{l}\text { Partially submerged; NRHP status } \\
\text { undetermined }\end{array}$ \\
\hline $41 \mathrm{CS} 123$ & 0 & 19 & 19 & 2 & 40 & $\begin{array}{l}\text { Completely submerged; NRHP } \\
\text { status undetermined }\end{array}$ \\
\hline $41 \mathrm{CS} 95 / 96$ & 0 & 0 & 0 & 0 & 0 & $\begin{array}{l}\text { Completely submerged; NRHP } \\
\text { status undetermined }\end{array}$ \\
\hline 41CS109 & 1 & 11 & 12 & 0 & 96 & Additional work recommended \\
\hline $41 \mathrm{CS} 110$ & 0 & 12 & 12 & 0 & 11 & $\begin{array}{l}\text { Partially submerged; NRHP status } \\
\text { undetermined }\end{array}$ \\
\hline $41 \mathrm{CS} 117$ & 2 & 16 & 18 & 2 & 2 & $\begin{array}{l}\text { Partially submerged; NRHP status } \\
\text { undetermined }\end{array}$ \\
\hline $41 \mathrm{CS} 118$ & 0 & 27 & 27 & 0 & 0 & $\begin{array}{l}\text { Partially submerged; NRHP status } \\
\text { undetermined }\end{array}$ \\
\hline Totals & 50 & 295 & 345 & 24 & 1,355 & \\
\hline
\end{tabular}




\section{SITE 41BW26}

Stephenson recorded site 41BW26 (originally identified as 41-20D4-2) between two AfricanAmerican home sites in the fall of 1949. The site was located in an active cotton field on a rolling ridge that overlooks Anderson Creek. He characterized the site as a large village area that covered 5 to 10 acres and included a large number of pottery sherds along with lithic debitage and tools (Stephenson 1950:8).

A review of 1949 aerial photography that was georeferenced to modern aerial photography shows that the location of site 41BW26 as listed on the Texas Archaeological Research Laboratory (TARL) site form (TARL 1949a) and within the USACE Fort Worth Wright Patman Lake Geographic Information System (GIS) database is plotted incorrectly (Figure 5.1). Based on Stephenson's description, the site should be plotted at least $200 \mathrm{~m}$ west of its current centerpoint location rather than within the wooded bottomlands adjacent to Anderson Creek, thus placing the site within the cultivated area shown on the 1949 aerial photograph and out of the current Wright Patman Lake fee boundary (see Figure 5.1). Elevations across the ridges in the areas cultivated in 1949 range from 240 to $250 \mathrm{ft}$ amsl, placing the site outside of the area of potential effect for the Ultimate Rule Curve at Wright Patman Lake. As a result, the site was not assessed during this project and site 41CS95/96 was chosen from the Contingency List. The NRHP status of site 41BW26 remains undetermined.

\section{Figure Redacted}

Figure 5.1. 1949 georeferenced aerial photograph with the location of site 41BW26 and Wright Patman Lake fee boundary. 


\section{SITE 41BW42}

Briggs and Malone recorded site 41BW42 (Figure 5.2) in January 1970. The site was located at an elevation between 225 and $230 \mathrm{ft}$ amsl on the eroding northwest face of an easterly projecting peninsula (TARL 1970a) near the area that serves as Elliot Bluff boat landing today. The artifact assemblage from their initial survey includes a single Native American pottery sherd and a large collection of lithic artifacts composed of flake debitage, bifacial tools, a unifacial tool, a PPK, and miscellaneous chunks (Briggs and Malone 1970:Figure 14, Table 2; Figure 15, Table 3A).

SEARCH archaeologists visited site 41BW42 on October 20 and 21, 2015, when pool elevations were between 224.22 and 224.25 feet ( $\mathrm{ft}$ ) above mean sea level (amsl). The site boundary as presented in the USACE Fort Worth Wright Patman Lake GIS database covers 825 square meters $\left(\mathrm{m}^{2}\right)$ ( 0.20 acres [ac]) along an exposed and eroding beach face backed by an elevated terrace. The beach is devoid of vegetation (Figure 5.3), while the terrace contains a mixture of hardwoods with a relatively open, but scrubby understory of small saplings and low brush (Figure 5.4).

During the initial reconnaissance at site 41BW42, SEARCH archaeologists determined that the plotted site location as listed on the TARL site form and within the USACE Fort Worth Wright Patman Lake GIS database occurred mostly across the low, sandy beach that was exposed by

Figure Redacted

Figure 5.2. Location of site 41BW42. 


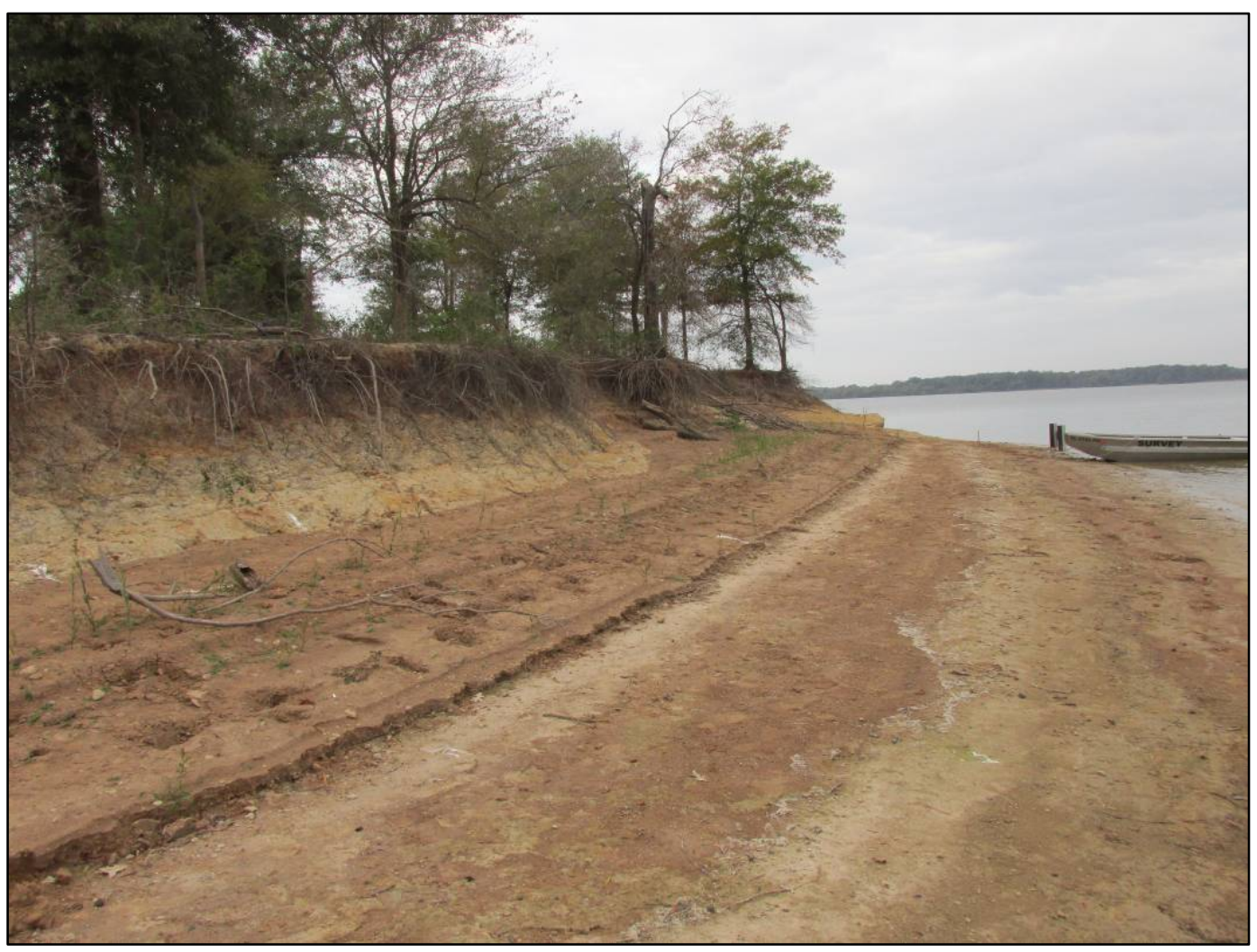

Figure 5.3. Exposed shoreline at site 41BW42.

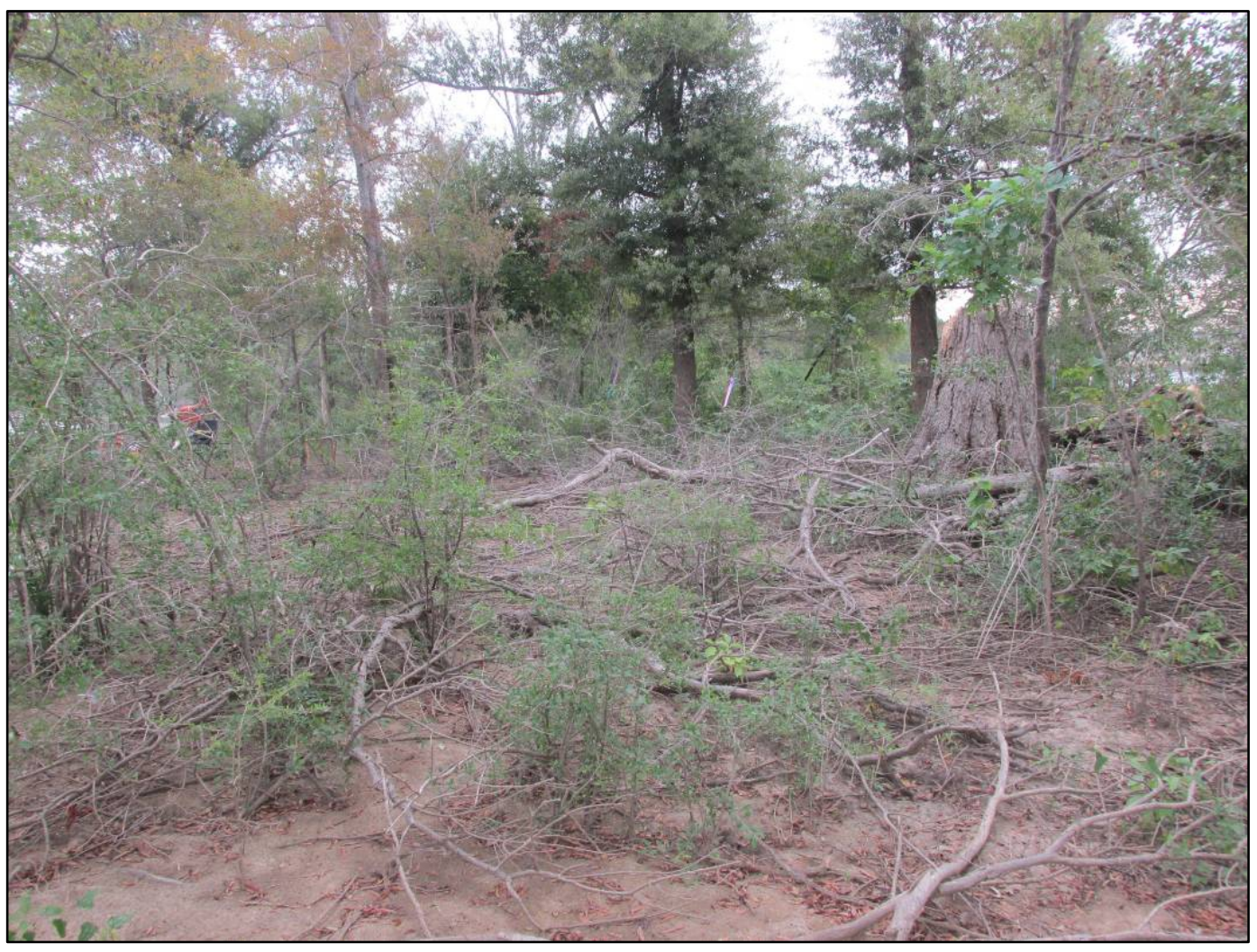

Figure 5.4. Typical vegetation along the upland terrace adjacent to site 41BW42. 
the current lake level ( $224.25 \mathrm{ft}$ amsl). As a result, investigations focused on pedestrian survey and judgmental shovel testing along the exposed beach where surface visibility was 100 percent, and systematic subsurface testing of the upland terrace adjacent to the site's southern boundary (Figure 5.5).

The pedestrian survey consisted of two sets of parallel transects that were spaced $2 \mathrm{~m}$ apart, and yielded a total of 32 artifacts (Figures 5.6 and 5.7; Table 5.2). The eastern set (Transects 15 ) occurred within the site boundary and was placed between the existing water line and eroded bench line along the upland terrace (see Figure 5.5). Transects in this area produced 26 artifacts that included an assortment of lithic debitage, two pieces of chert thermal shatter, five pieces of fire-cracked rock ( 2 basalt, 2 quartzite, 1 UID), one tested chert cobble, and two plain grog-tempered pottery sherds. Debitage $(n=16)$ includes one quartzite core reduction flake, five early reduction flakes ( 4 chert, 1 basalt), four chert thinning flakes, five chert late thinning flakes, and one piece of chert angular shatter. The western set (Transects 6-8) occurred along an exposed beach west of the site boundary. Transects in this area produced far fewer artifacts. These items include one fire-cracked rock, one piece of petrified wood, and a single historic/modern whiteware sherd.

Subsurface testing included the excavation of 22 shovel tests, of which 15 were positive for cultural material ( $n=63$ ), and three $50-x-50-\mathrm{cm}$ test units (see Figure 5.5), all of which produced artifacts $(n=49)$. A typical soil profile displayed light yellowish-brown (10YR 6/4) clayey loam

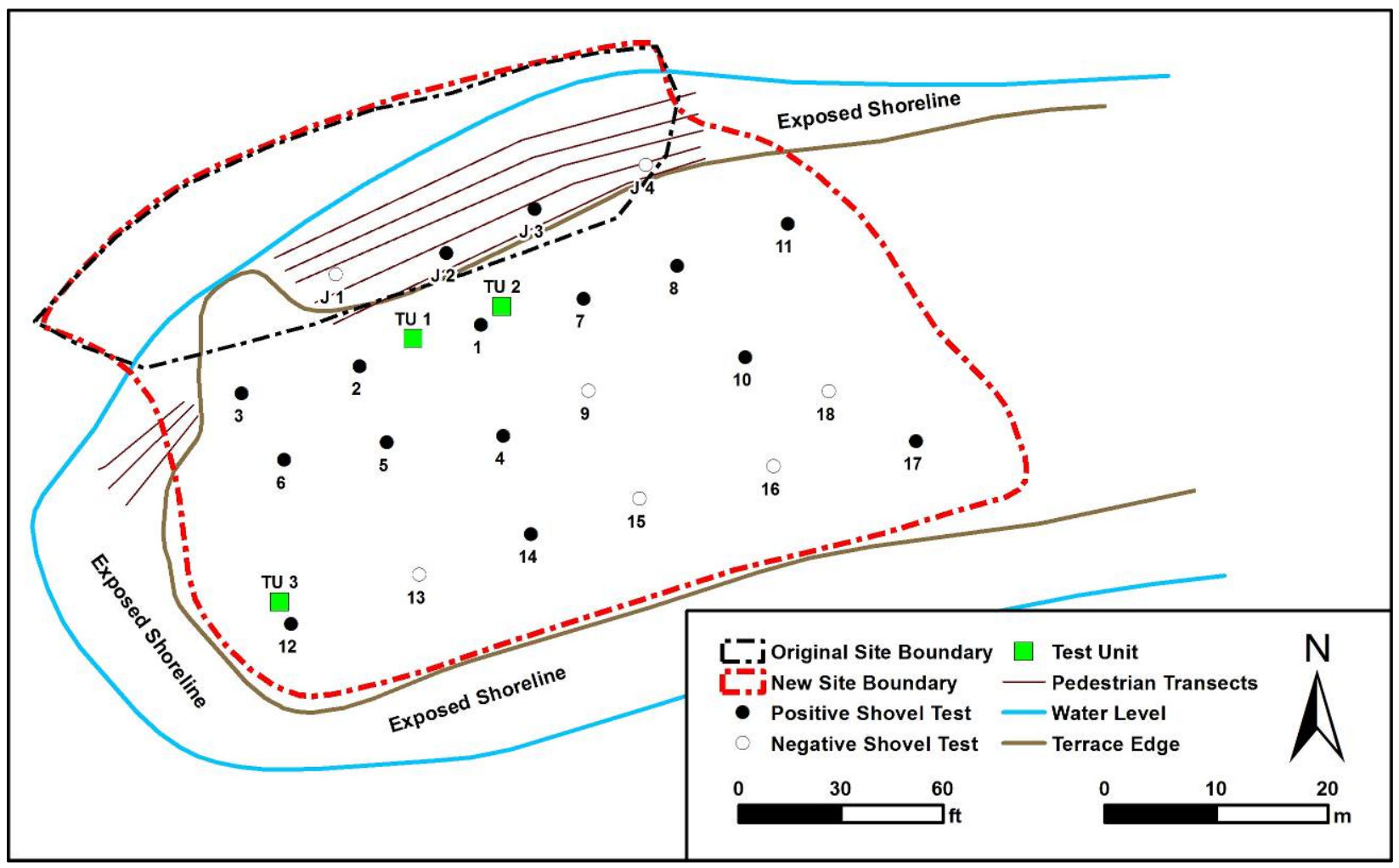

Figure 5.5. SEARCH 2015 fieldwork plan map for site 41BW42. 


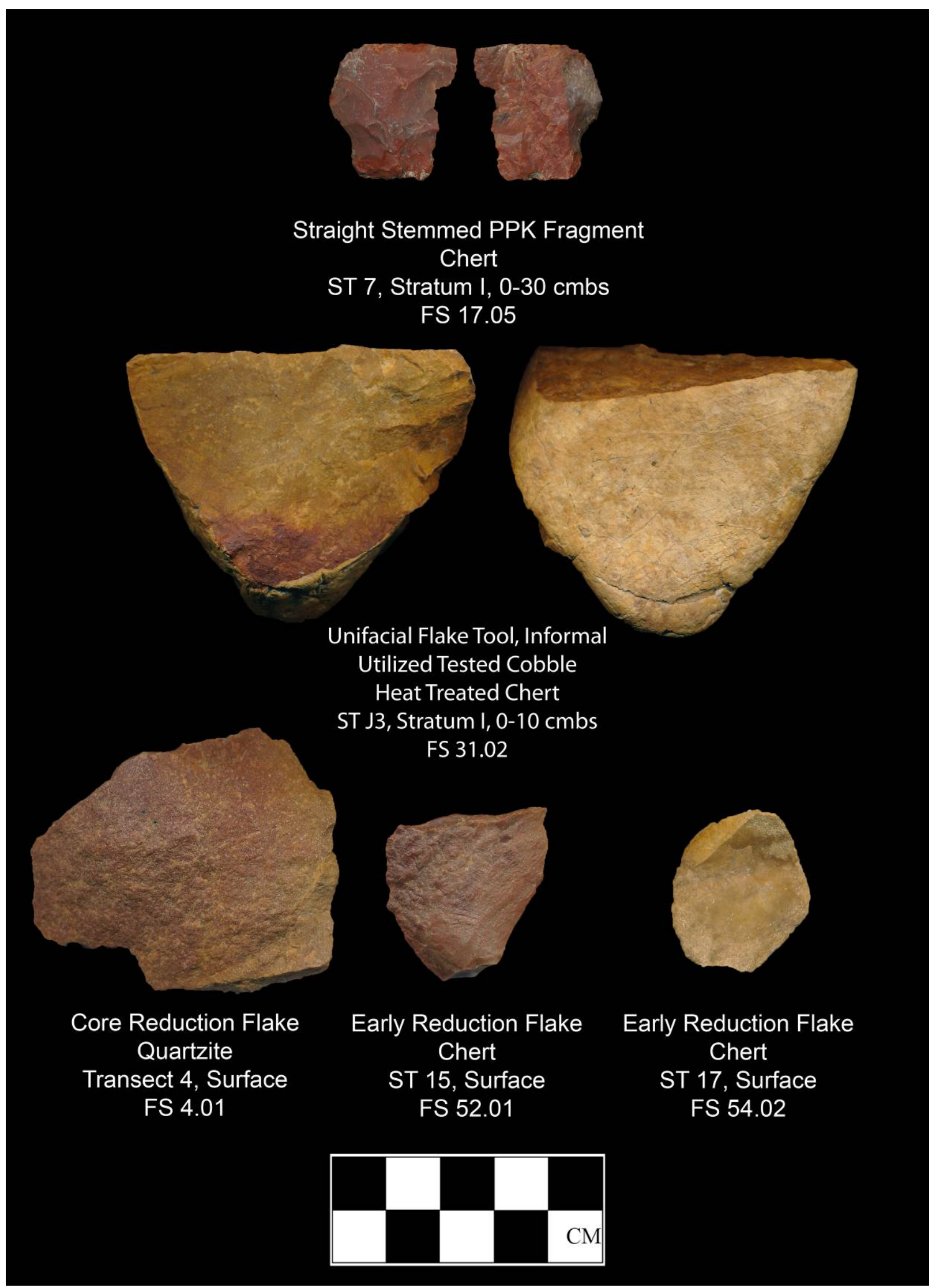

Figure 5.6. Select Native American artifacts collected from site 41BW42. 


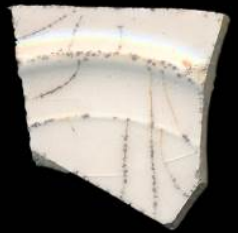

Whiteware Base Fragment Transect 7 , Surface FS 6.01

Machine Made Bottle Base Soda Green ST 12, Surface FS 22.01

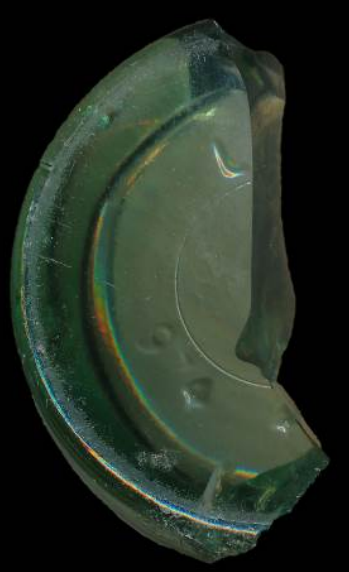

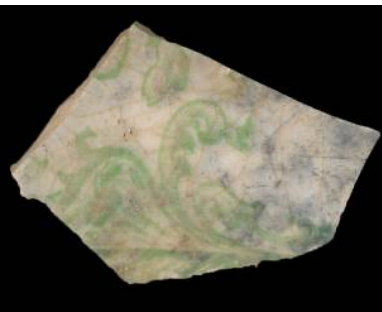

Green Transfer Printed Refined Earthenware ST 2, Stratum I, 0-10 cmbs FS 11.01
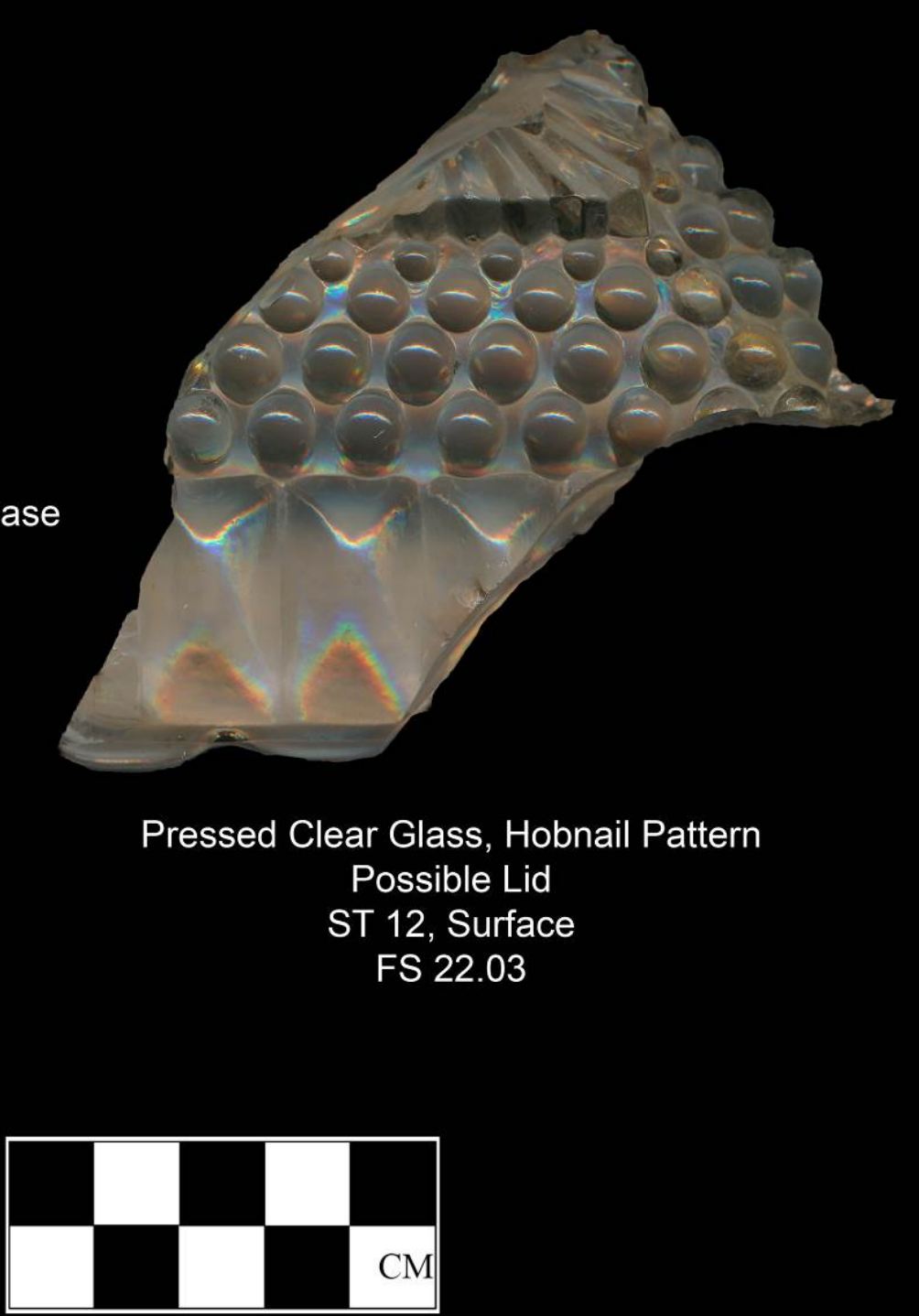

Figure 5.7. Select historic artifacts collected from site 41BW42. 
Table 5.2. Artifact Inventory for Site 41BW42.

\begin{tabular}{|c|c|c|c|c|c|}
\hline Provenience & $\begin{array}{l}\text { Depth } \\
\text { (cmbs) }\end{array}$ & Description & Count & $\begin{array}{c}\text { Weight } \\
\text { (g) }\end{array}$ & Comments \\
\hline CP 1 & Surface & Flake, early reduction & 2 & 2.74 & Chert, $>1 / 2^{\prime \prime}$, complete \\
\hline CP 1 & Surface & Flake, early reduction & 1 & 0.18 & Chert, >1/4", complete \\
\hline CP 1 & Surface & Flake, early reduction & 1 & 23.55 & Basalt, $>1 \mathrm{~cm}$, complete \\
\hline CP 1 & Surface & Flake, early reduction & 1 & 1.80 & Chert, > 1/2", medial distal \\
\hline CP 1 & Surface & Flake, thinning & 1 & 2.35 & Chert, > $1 \mathrm{~cm}$, complete \\
\hline CP 1 & Surface & Flake, thinning & 1 & 2.08 & Chert, > 1/2", proximal \\
\hline CP 1 & Surface & Flake, thinning; late & 2 & 0.77 & Chert, $>1 / 2^{\prime \prime}$, complete \\
\hline CP 1 & Surface & Flake, thinning; late & 1 & 0.68 & Chert, $>1 / 2^{\prime \prime}$, medial distal \\
\hline $\mathrm{CP} 1$ & Surface & Fire cracked rock & 2 & 111.52 & Unidentified material \\
\hline CP 1 & Surface & Fire cracked rock & 2 & 21.42 & Quartzite \\
\hline $\mathrm{CP} 2$ & Surface & Flake, thinning; late & 1 & 0.09 & Chert, >1/4", complete \\
\hline $\mathrm{CP} 2$ & Surface & Flake, thinning & 1 & 0.91 & Chert, > 1/2", proximal \\
\hline CP 2 & Surface & Fire cracked rock & 1 & 0.97 & \\
\hline CP 3 & Surface & Shatter, thermal & 2 & 10.28 & \\
\hline CP 3 & Surface & Flake, thinning; late & 1 & 0.17 & Chert, $>1 / 4^{\prime \prime}$, complete \\
\hline CP 3 & Surface & Flake, thinning & 1 & 1.30 & Chert, > 1/2", proximal \\
\hline CP 4 & Surface & Flake, core reduction & 1 & 36.80 & Quartzite, $>2 \mathrm{~cm}$, proximal \\
\hline CP 4 & Surface & Shatter, angular & 1 & 2.51 & Chert \\
\hline CP 4 & Surface & Aboriginal ceramic, plain & 2 & 12.12 & Grog/clay temper, body \\
\hline CP 5 & Surface & Unmodified stone & 3 & 77.93 & \\
\hline CP 5 & Surface & Tested cobble & 1 & 51.14 & Chert \\
\hline CP 7 & Surface & Whiteware & 1 & 2.17 & Flatware, base \\
\hline CP 8 & Surface & Fire cracked rock & 1 & 343.73 & \\
\hline CP 8 & Surface & Possible cultural lithic & 1 & 39.97 & Petrified wood \\
\hline \multicolumn{3}{|c|}{ Surface Collection Point Subtotal } & 32 & 747.18 & \\
\hline ST 1 & Surface & Flake, early reduction & 1 & 13.50 & Other, $>1 \mathrm{~cm}$, complete \\
\hline ST 1 & Surface & Fire cracked rock & 4 & 43.61 & \\
\hline ST 1 & $0-5$ & Flake, thinning & 1 & 1.02 & Chert, > 1/2", complete \\
\hline ST 2 & Surface & Flake, thinning & 1 & 1.14 & Chert, > 1/2", complete \\
\hline ST 2 & Surface & Flake, thinning & 1 & 1.30 & Chert, > 1/2", proximal \\
\hline ST 2 & Surface & Flake, thinning; late & 1 & 0.09 & Chert, > 1/4", proximal \\
\hline ST 2 & $0-10$ & Refined earthenware & 1 & 4.04 & Green transfer print, burned \\
\hline ST 2 & $10-20$ & Miscellaneous glass & 1 & 0.32 & Soda green, $>1 / 2$ inches, flat \\
\hline ST 2 & $10-20$ & Animal bone & 1 & 0.36 & \\
\hline ST 3 & $0-20$ & Flake, thinning & 1 & 0.91 & Chert, > 1/2", proximal \\
\hline ST 3 & $0-20$ & Shatter, angular & 1 & 1.80 & Chert, > 1/2" \\
\hline ST 4 & $5-10$ & Shatter, angular & 1 & 0.87 & Chert, $>1 / 2^{\prime \prime}$ \\
\hline ST 5 & $10-20$ & Flake, thinning; late & 1 & 0.41 & Chert, > 1/4", proximal \\
\hline ST 5 & $10-20$ & Flake, thinning; late & 1 & 0.17 & Chert, > 1/4", medial distal \\
\hline ST 6 & $0-20$ & Animal bone & 1 & 0.81 & \\
\hline ST 7 & $0-30$ & Shatter, angular & 1 & 1.22 & Chert, $>1 / 2^{\prime \prime}$, non-orientable \\
\hline ST 7 & $0-30$ & Flake, thinning & 1 & 0.23 & Chert, > 1/4", complete \\
\hline ST 7 & $0-30$ & Flake, thinning; late & 1 & 0.10 & Chert, > 1/4", complete \\
\hline ST 7 & $0-30$ & Flake, thinning; late & 1 & 0.02 & Chert, <1/4", proximal \\
\hline ST 7 & $0-30$ & PPK fragment & 1 & 2.61 & Chert, > 1/2" \\
\hline ST 8 & $0-10$ & Flake, thinning; late & 2 & 0.45 & Chert, > 1/4", complete \\
\hline
\end{tabular}


Table 5.2. Artifact Inventory for Site 41BW42.

\begin{tabular}{|c|c|c|c|c|c|}
\hline Provenience & $\begin{array}{l}\text { Depth } \\
\text { (cmbs) }\end{array}$ & Description & Count & $\begin{array}{l}\text { Weight } \\
\text { (g) }\end{array}$ & Comments \\
\hline ST 8 & $0-10$ & Flake, thinning; late & 1 & 0.35 & Chert, > 1/2", complete \\
\hline ST 8 & $0-10$ & Flake, thinning & 1 & 2.58 & Chert, > 1/2", non-orientable \\
\hline ST 8 & $0-10$ & Bottle glass & 1 & 0.71 & Clear \\
\hline ST 8 & $10-20$ & Flake, thinning & 1 & 0.63 & Chert, $>1 / 2^{\prime \prime}$, complete \\
\hline ST 8 & $10-20$ & Possible cultural lithic & 1 & 7.10 & Petrified wood, possible debitage \\
\hline ST 10 & $0-10$ & Flake, thinning & 1 & 0.53 & Chert, > 1/2", complete \\
\hline ST 10 & $0-10$ & Fire cracked rock & 1 & 23.79 & Chert \\
\hline ST 10 & $0-10$ & Animal bone & 1 & 0.52 & Otolith \\
\hline ST 11 & $0-10$ & Flake, thinning & 1 & 0.48 & Chert, > 1/4", complete \\
\hline ST 12 & Surface & Bottle glass & 4 & 58.59 & $\begin{array}{l}\text { Soda green, machine made, } \\
\text { Dr.Pepper }\end{array}$ \\
\hline ST 12 & Surface & Glass vessel & 1 & 94.37 & Clear, salt dish lid frag \\
\hline ST 12 & Surface & Flat glass & 1 & 55.02 & Amber, non-burned \\
\hline ST 12 & $0-10$ & Flake, thinning; late & 1 & 0.10 & Quartzite, > 1/4", complete \\
\hline ST 12 & $0-10$ & Flake, thinning; late & 1 & 0.15 & Chert, > 1/4", complete \\
\hline ST 12 & $0-10$ & Flake, thinning & 2 & 1.52 & Chert, > 1/2", complete \\
\hline ST 12 & $0-10$ & Bottle glass & 1 & 1.15 & Clear \\
\hline ST 12 & $0-10$ & Bottle glass & 1 & 3.45 & Soda green, Dr.Pepper \\
\hline ST 12 & $0-10$ & Whiteware & 1 & 0.54 & Flatware, base \\
\hline ST 12 & $0-10$ & Uid lead & 1 & 2.26 & \\
\hline ST 12 & $10-20$ & Shatter, angular & 1 & 2.10 & Chert, $>1 / 2^{\prime \prime}$ \\
\hline ST 12 & $10-20$ & Flake, early reduction & 1 & 1.71 & Chert, $>1 / 2^{\prime \prime}$, proximal \\
\hline ST 12 & $10-20$ & Shatter, angular & 1 & 0.22 & Chert, > 1/4" \\
\hline ST 12 & $10-20$ & Bottle glass & 1 & 0.93 & Soda green, neck, Dr.Pepper \\
\hline ST 12 & $10-20$ & Brass, eyelet, rivet & 1 & 0.58 & \\
\hline ST 12 & $20-30$ & Flake, thinning; late & 1 & 0.41 & Quartzite, > 1/4", proximal \\
\hline ST 14 & $0-10$ & Shatter, angular & 1 & 1.16 & Chert, > 1/2" \\
\hline ST 14 & $10-20$ & Flake, thinning & 2 & 2.37 & Chert, > 1/2", complete \\
\hline ST 17 & $10-20$ & Flake, thinning; late & 1 & 0.16 & Chert, > 1/4", complete \\
\hline ST 17 & $10-20$ & Flake, thinning; late & 1 & 0.15 & Chert, > 1/4", medial distal \\
\hline ST 17 & $20-30$ & Flake, thinning; late & 1 & 0.43 & Chert, $>1 / 2^{\prime \prime}$, medial distal \\
\hline $\mathrm{J} 2$ & $0-5$ & Flake, retouch & 1 & 0.05 & Chert, $>1 / 8^{\prime \prime}$, proximal \\
\hline J 3 & $0-10$ & Flake, thinning; late & 1 & 0.24 & Chert, >1/2", complete \\
\hline $\mathrm{J} 3$ & $0-10$ & Flake tool, unifacial & 1 & 94.99 & Utilized tested cobble fragment \\
\hline \multicolumn{3}{|c|}{ Shovel Test Subtotal } & 63 & 434.32 & \\
\hline TU 1 & $7-20$ & Flake, early reduction & 2 & 2.05 & Chert, $>1 / 2^{\prime \prime}$, complete \\
\hline TU 1 & $7-20$ & Flake, thinning & 1 & 0.41 & Chert, > 1/4", complete \\
\hline TU 1 & $7-20$ & Flake, thinning & 2 & 1.18 & Chert, $>1 / 2^{\prime \prime}$, complete \\
\hline TU 1 & $7-20$ & Flake, thinning & 1 & 0.68 & Chert, > 1/2", proximal \\
\hline TU 1 & $7-20$ & Flake, thinning & 1 & 0.36 & Chert, $>1 / 2^{\prime \prime}$ medial-distal \\
\hline TU 1 & $7-20$ & Flake, thinning; late & 2 & 0.44 & Chert, >1/4", complete \\
\hline TU 1 & $7-20$ & Flake, thinning; late & 2 & 0.49 & Chert, $>1 / 4^{\prime \prime}$, medial-distal \\
\hline TU 1 & $7-20$ & Flake, thinning; late & 3 & 0.59 & Chert, > 1/4", proximal \\
\hline TU 1 & $7-20$ & Flake, thinning; late & 1 & 0.06 & Chert, < 1/4", medial-distal \\
\hline TU 2 & $0-10$ & Flake, thinning; late & 1 & 0.39 & Chert, > 1/2", complete \\
\hline TU 2 & $0-10$ & Shatter, angular & 1 & 0.34 & Chert \\
\hline TU 3 & $0-10$ & Flake, thinning & 1 & 1.26 & Quartzite, > 1/2", complete \\
\hline
\end{tabular}


Table 5.2. Artifact Inventory for Site 41BW42.

\begin{tabular}{|c|c|c|c|c|c|}
\hline Provenience & $\begin{array}{l}\text { Depth } \\
\text { (cmbs) }\end{array}$ & Description & Count & $\begin{array}{c}\text { Weight } \\
\text { (g) }\end{array}$ & Comments \\
\hline TU 3 & $0-10$ & Flake, thinning & 1 & 0.65 & Quartzite, > 1/2", medial-distal \\
\hline TU 3 & $0-10$ & Flake, thinning & 1 & 0.27 & Chert, $>1 / 4^{\prime \prime}$, proximal \\
\hline TU 3 & $0-10$ & Flake, thinning & 1 & 0.37 & Chert, $>1 / 2^{\prime \prime}$, proximal \\
\hline TU 3 & $0-10$ & Flake, thinning & 1 & 0.59 & Chert, $>1 / 2^{\prime \prime}$, medial-distal \\
\hline TU 3 & $0-10$ & Flake, thinning; late & 2 & 0.44 & Chert, $>1 / 4^{\prime \prime}$, proximal \\
\hline TU 3 & $0-10$ & Flake, thinning; late & 2 & 0.60 & Chert, $>1 / 2 "$, complete \\
\hline TU 3 & $0-10$ & Flake, thinning; late & 1 & 0.08 & Chert, > 1/4", proximal \\
\hline TU 3 & $0-10$ & Potlid & 1 & 0.83 & Chert, $>1 / 2^{\prime \prime}$, complete \\
\hline TU 3 & $0-10$ & Shatter, thermal & 2 & 0.42 & Chert \\
\hline TU 3 & $0-10$ & Tested cobble & 1 & 54.03 & Chert \\
\hline TU 3 & $0-10$ & Uniface, fragment & 1 & 5.22 & Chert \\
\hline TU 3 & $0-10$ & Fire cracked rock & 1 & 7.75 & \\
\hline TU 3 & $0-10$ & Animal bone & 5 & 2.97 & Otoliths \\
\hline TU 3 & $0-10$ & Bottle glass & 5 & 6.67 & Amber \\
\hline TU 3 & $0-10$ & Bottle glass & 5 & 7.55 & Amethyst \\
\hline TU 3 & $0-10$ & Shotgun shell & 1 & 3.25 & "Winchester repeater No 20" \\
\hline \multicolumn{3}{|c|}{ Test Unit Subtotal } & 49 & 99.94 & \\
\hline
\end{tabular}

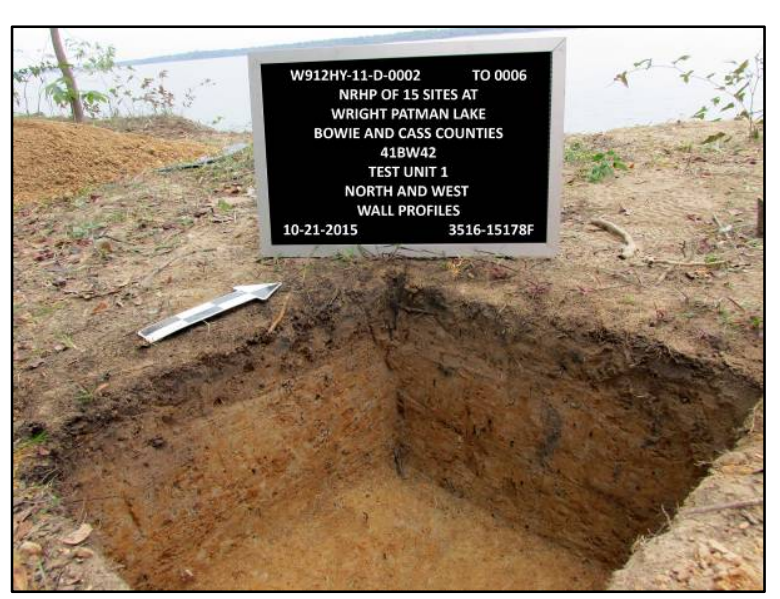

Figure 5.8. Typical soil profile at site 41BW42. from 0 to $10 \mathrm{~cm}$ below surface (cmbs), mottled light yellowish-brown (10YR 6/4) and yellowishred (5YR 4/6) loamy clay from 10 to $20 \mathrm{cmbs}$, and strong brown (7.5YR 4/6) clay from 20 to 30+ cmbs (Figure 5.8).

Artifacts from shovel tests (see Figures $\mathbf{5 . 6}$ and 5.7; Table 5.1) were concentrated within two areas. The first area, located adjacent to the southern boundary, consists of four consecutive shovel tests (ST 1, 2, 7, and 8) that yielded a combined 24 artifacts, accounting for over onethird of the shovel test artifact assemblage. The collection includes one chert PPK fragment, one early reduction flake (UID material), six chert thinning flakes, six chert late thinning flakes, one piece of angular shatter, four pieces of firecracked rock, two pieces of glass (1 clear, 1 soda green), one refined earthenware sherd (burned), one piece of petrified wood, and one animal bone fragment. All artifacts were recovered between 0 and $30 \mathrm{cmbs}$ with all but five items collected between 0 and $20 \mathrm{cmbs}$.

The second area, located in the southwestern corner of the terrace, is limited to ST 12, but includes 20 artifacts. The collection consists of one chert early reduction flake, two chert thinning flakes, three late thinning flakes (1 chert, 2 quartzite), two pieces of angular chert shatter, seven pieces of bottle glass ( 1 clear, 6 soda green), one piece of flat glass, one clear glass vessel fragment, one piece of lead, one brass eyelet/grommet, and a single whiteware 
sherd. All artifacts were collected between 0 and $20 \mathrm{cmbs}$ with the exception of a single late thinning flake encountered between 20 and $30 \mathrm{cmbs}$.

The remaining eight shovel tests in the central portion of the terrace $(S T 3,4,5,6,10,11,14$, and 17) and two judgmental shovel tests on the exposed shoreline ( 2 and J 3) yielded 19 artifacts that consist of a small collection of lithic debitage, one unifacial flake tool, one piece of fire-cracked chert, and two animal bone fragments. Debitage includes one chert retouch flake, five chert thinning flakes, six chert late thinning flakes, and three pieces of angular chert shatter. All artifacts were collected between 0 and $20 \mathrm{cmbs}$ with the exception of a single late thinning flake encountered between 20 and $30 \mathrm{cmbs}$.

Test Unit 1 was placed between ST 1 and ST 2. All artifacts from TU 1 (see Table 5.1) were collected from Level 1 (0-10 cmbs). The assemblage consists of 15 artifacts and includes two chert early reduction flakes, five chert thinning flakes, and eight chert late thinning flakes.

Test Unit 2 was placed between ST 1 and ST 7 and only produced two artifacts (see Table 5.1). The assemblage, collected between 0 and $10 \mathrm{cmbs}$, consists of one late thinning flake and one piece of angular shatter.

Test Unit 3 was placed approximately two meters north of ST 12 . The test unit yielded 32 artifacts (see Table 5.1) that include one chert uniface fragment, five thinning flakes (3 chert, 2 quartzite), five chert late thinning flakes, one chert potlid, two pieces of thermal chert shatter, one piece of fire-cracked rock, one tested chert cobble, 10 pieces of bottle glass ( 5 amber, 5 amethyst [1880-1917]), one shotgun shell stamped with "WINCHESTER REPEATER No 20" (1927-1937) (Ball 1997), and five animal bone fragments. All artifacts were collected between 0 and $10 \mathrm{cmbs}$.

\section{Recommendation}

Site 41BW42 is a small multicomponent site on an easterly projecting peninsula near the area that serves as Elliot Bluff boat landing today. The historic component consists of a small collection of glass fragments, ceramic sherds, and other miscellaneous items. The amethyst glass (1880-1917) and stamped Winchester shotgun shell (1927-1937) point to an early twentieth century presence at the site. The ephemeral nature of the historic collection suggests that the artifacts are likely the result of a previous fishing, hunting, or camping trip rather than the result of a more domestic context (e.g., historic habitation). As a result, the historic component does not contribute to the NRHP eligibility of site 41BW42.

The Native American component is much more robust and shows evidence of horizontal clustering. The assemblage is dominated by lithic artifacts that include a relatively large amount of lithic debitage along with formal and expedient tools. A very small quantity of Native American pottery sherds was also recovered from the exposed shoreline; however, the artifact collection is more likely the result of a preceramic occupation in the area. The quantity of artifacts in such discrete area could be the result of multiple small-scale occupations (e.g., 
camp sites or resources extraction locations) through time or a larger logistics station aimed at providing access to lower reaches of the Sulphur River prior to inundation. The artifact assemblage, examined in tandem with absolute dating methods (radiocarbon or thermoluminescence), has the potential to offer insight into the lithic economy of Native American inhabitants of the site. Furthermore, the contextual integrity of the soils across the upper terrace, though slightly deflated from erosional processes during high water episodes at the lake, are relatively intact. Based on these findings, it is the recommendation of SEARCH that additional work be performed to evaluate the NRHP status of site 41BW42 and mitigate adverse effects of the proposed pool rise for meeting the Ultimate Rule Curve.

\section{SITE 41BW69}

Briggs and Malone recorded site 41BW69 (Figure 5.9) in February 1970. The site was located west of Kelly Creek Landing, at an elevation of $222 \mathrm{ft}$ amsl on the edge of Lake Wright Patman Fieldwork resulted in the collection of three dart points ( 1 Gary), the base of a point, two biface fragments, cores, heavy bifaces, chunks, and flake debitage (Briggs and Malone 1970:Figure 14, Table 2; Figure 15, Table 3A). When it was first recorded, this site was described as "heavily subjected to tourist travel" and largely destroyed (TARL 1970b).

In 2004, Ecological Communication Corporation (ECC) visited site 41BW69 as part of a cultural resources inventory for timber-harvesting parcels at Wright Patman Lake (Trierweiler and Jones Figure Redacted

Figure 5.9. Location of site 41BW69. 
2005). ECC archaeologists conducted a pedestrian survey and excavated 10 shovel tests within the site boundary, but encountered no artifacts. Trierweiler and Jones (2005:75), however, noted that lake levels were approximately four feet higher $(\sim 225 \mathrm{ft}$ ) than when the site was first identified by Briggs and Malone in 1970, and suggested that cultural deposits were likely submerged. As a result, they recommended that the NRHP status of site $41 \mathrm{BW} 69$ remain undetermined until such time as the submerged deposits could be evaluated.

SEARCH archaeologists visited site 41 BW69 on November 10, 2015 . The pool elevation measured $226.59 \mathrm{ft}$ amsl. The site boundary as presented in the USACE Fort Worth Wright Patman Lake GIS database covers $5,515 \mathrm{~m}^{2}(1.36 \mathrm{ac})$ along a low terrace edge within and adjacent to Wright Patman Lake. The eastern edge of the site is approximately $155 \mathrm{~m}$ west of the Kelly Creek boat ramp. Vegetation along the northern edge of the site and across the adjacent uplands consists of mixed hardwoods and pine with sparse understory of smaller saplings and vines (Figures 5.10 and $\mathbf{5 . 1 1}$ ).

During the initial reconnaissance at site 41BW69, SEARCH archaeologists determined that the plotted site location as listed on the TARL site form and within the USACE Fort Worth Wright Patman Lake GIS database was largely submerged. As a result, nearly all of the archaeological investigation occurred across the uplands adjacent to the site's northern boundary (Figure 5.12).

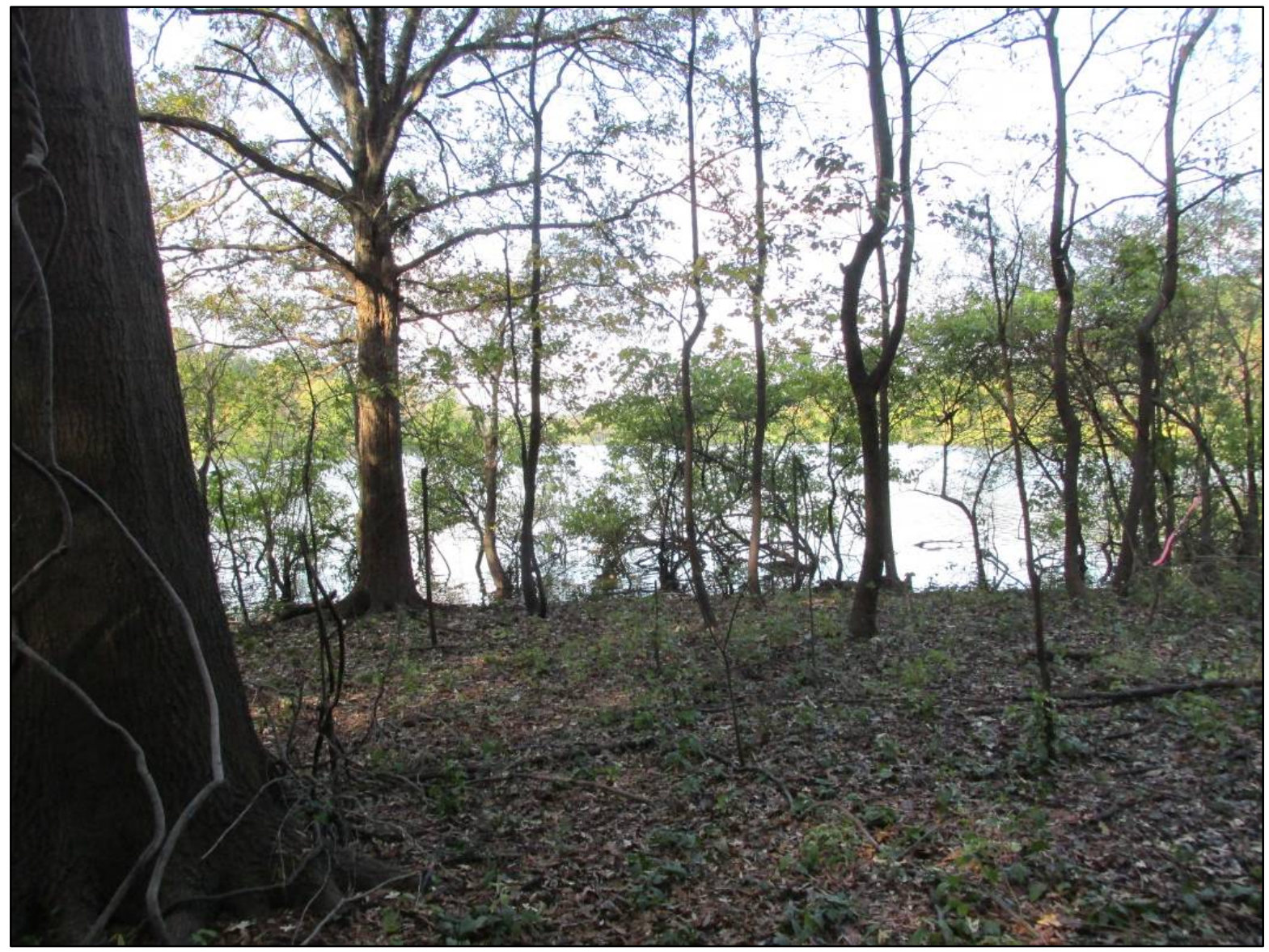

Figure 5.10. Typical vegetation along the northern edge of site 41BW69, facing south. 


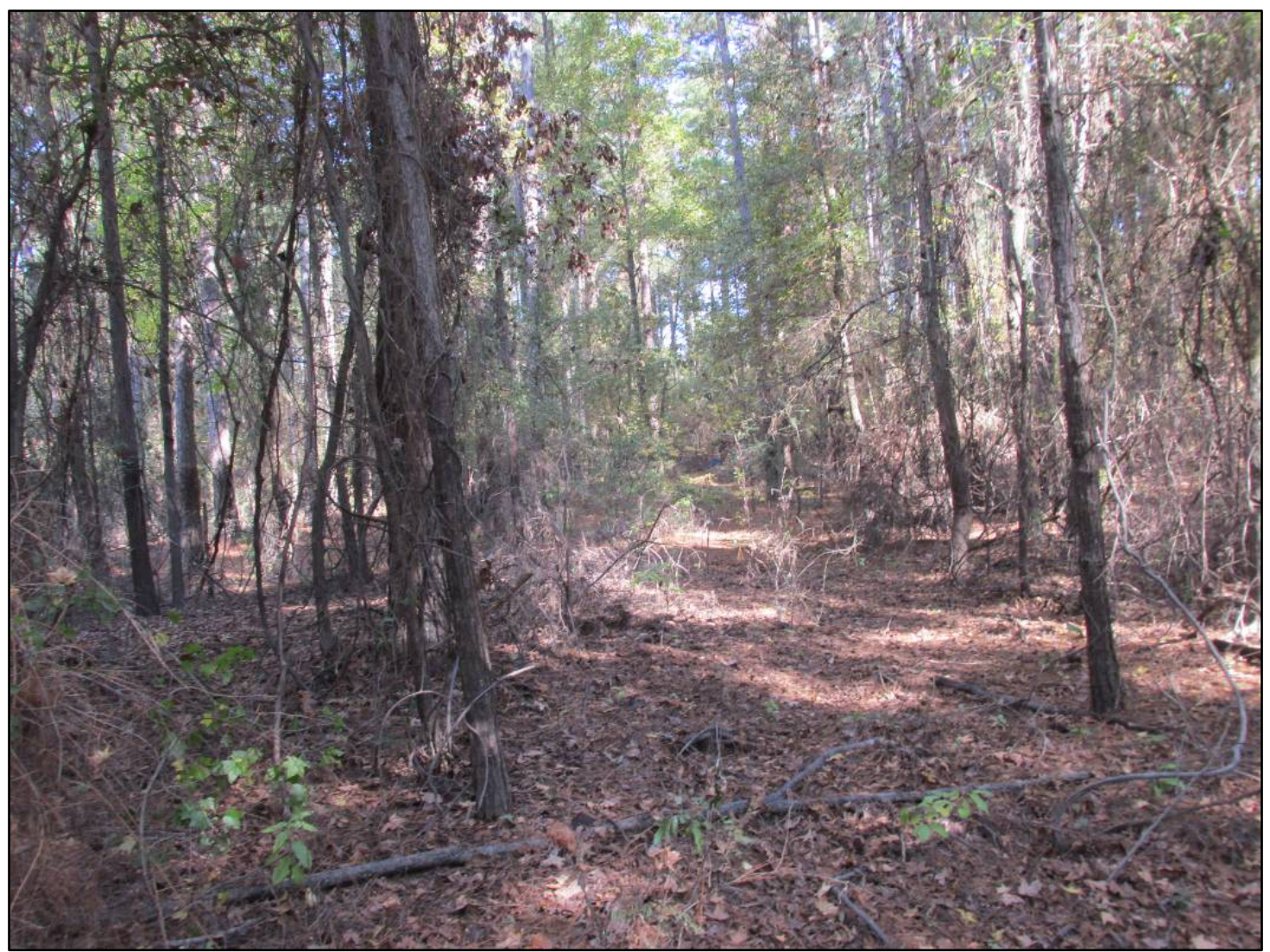

Figure 5.11. Typical vegetation across uplands adjacent to site 41BW69, facing north.

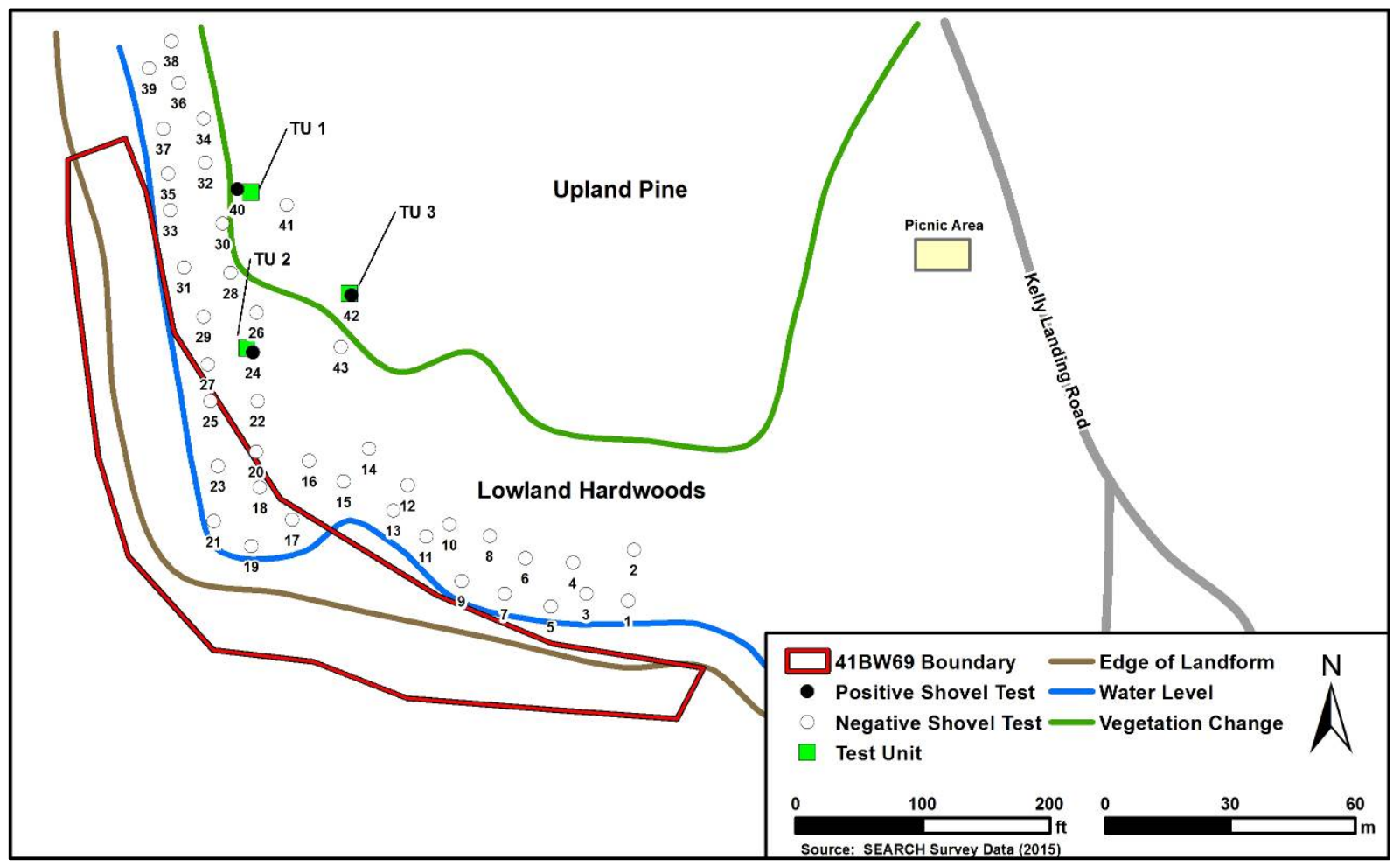

Figure 5.12. SEARCH 2015 fieldwork plan map for site 41BW69. 
Ground surface visibility ranged between 30 and 50 percent with better visibility occurring near the waterline. A pedestrian survey was conducted along transects that measured the length of the site and spaced $5 \mathrm{~m}$ apart, beginning at the water line and extending 20 to $30 \mathrm{~m}$ north and east. No exposed beach, scarps, or benches were observed. No artifacts were recovered during the pedestrian survey.

Subsurface testing included the excavation of 43 shovel tests, of which three (ST 24, 40, and 42) were positive for cultural material, and three 50 $x-50-c m$ test units, of which two (TU 2 and 3) produced artifacts. A typical soil profile displayed dark grayish-brown (10YR 3/2) to brown (10YR 5/3) sand and/or loamy sand from 0 to $10 \mathrm{cmbs}$, mottled yellowish-brown (10YR 5/6) and strong brown (7.5YR 5/6) sandy clay from 10

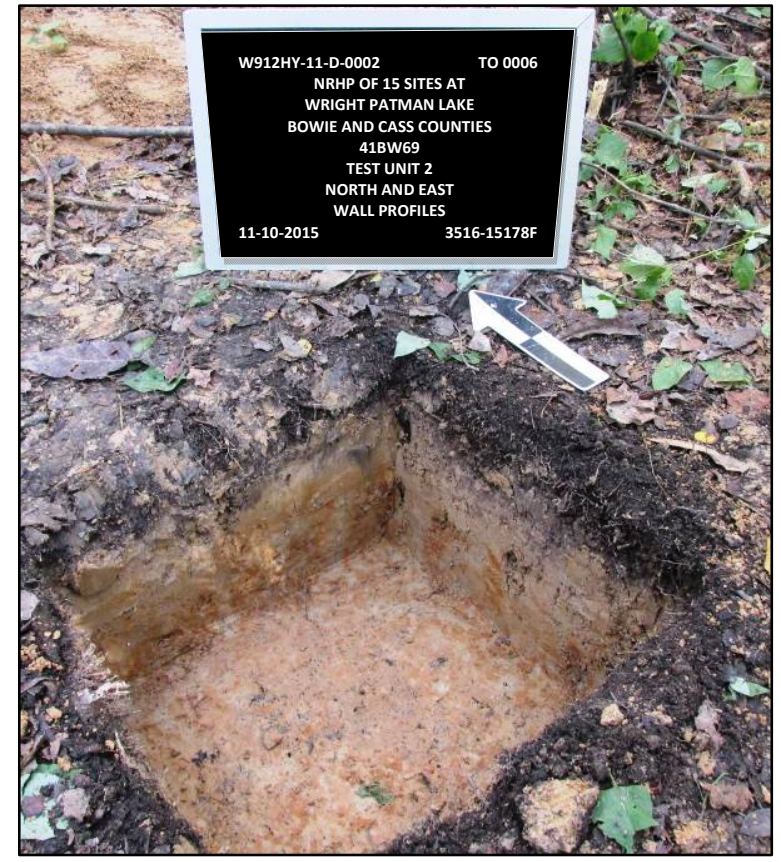

Figure 5.13. Typical soil profile at site 41BW69. to $20 \mathrm{cmbs}$, and strong brown (7.5YR 5/6) clay from 20 to $30+\mathrm{cmbs}$ (Figure 5.13).

Shovel tests yielded only five artifacts. Test Unit 1 was placed adjacent to ST 40 but produced no artifacts. Test Unit 2 was placed near ST 24 and yielded a single thinning flake. Test Unit 3 was placed adjacent to ST 42 and produced four thinning flakes. Table $\mathbf{5 . 3}$ presents a summary of artifacts collected from site 41BW69.

Table 5.3. Artifact Inventory for Site 41BW69.

\begin{tabular}{|c|c|c|c|c|c|}
\hline Provenience & $\begin{array}{l}\text { Depth } \\
\text { (cmbs) }\end{array}$ & Description & Count & $\begin{array}{l}\text { Weight } \\
\text { (g) }\end{array}$ & Comments \\
\hline ST 24 & $0-20$ & Flake, early reduction & 1 & 1.53 & Chert, $>1 / 2^{\prime \prime}$, complete \\
\hline ST 24 & $0-20$ & Flake, late thinning & 1 & 0.26 & Chert, $>1 / 4^{\prime \prime}$, medial-distal \\
\hline ST 40 & $5-20$ & Flake, thinning & 1 & 0.83 & Chert, > 1/2", complete \\
\hline ST 42 & $50-60$ & Flake, core reduction & 1 & 8.03 & Chert, > 1", complete \\
\hline ST 42 & $50-60$ & Flake, thinning & 1 & 1.26 & Chert, $>1 / 2^{\prime \prime}$, complete \\
\hline \multicolumn{3}{|c|}{ Shovel Test Subtotal } & 5 & 11.91 & \\
\hline TU 2 & $5-10$ & Flake, late thinning & 1 & 0.24 & Chert, > 1/4", complete \\
\hline TU 3 & $10-20$ & Flake, late thinning & 2 & 0.77 & Chert, > 1/2", complete \\
\hline TU 3 & $20-30$ & Flake, late thinning & 2 & 0.26 & Chert, >1/4", complete \\
\hline \multicolumn{3}{|c|}{ Test Unit Subtotal } & 5 & 1.27 & \\
\hline \multicolumn{3}{|c|}{ Site Total } & 10 & 13.18 & \\
\hline
\end{tabular}




\section{Recommendation}

In November 2015, a relatively large portion of site 41BW69 was inundated by the rising pool level at Wright Patman Lake. Exposed portions of the site and the adjacent uplands were tested to determine if intact cultural deposits existed within and adjacent to the defined boundary. The artifact assemblage collected in the vicinity of site 41BW69 is a relatively small, diffuse scatter of lithic debitage located to the east of the northwestern portion of the site (see Figure 5.12). The areas within the site boundary, and across adjacent uplands that were subjected to pedestrian survey and subsurface testing and the associated artifact assemblage are not considered significant and do not contribute to the NRHP eligibility of site 41BW69. As only a portion of the site could be tested, SEARCH recommends that the NRHP status of site 41BW69 remain undetermined until such time as the submerged deposits can be evaluated.

\section{SITE 41BW77}

Briggs and Malone recorded site 41BW77 (Figure 5.14) in March 1970. They identified the site at an elevation between 222 and $223 \mathrm{ft}$ amsl on a small oval, willow-covered projection in Wright Patman Lake. This landform was previously a terrace of the Big Creek area. The site form (TARL 1970c) denotes that pottery sherds and lithic flakes eroding from just below the root level were collected from the site; however, Briggs and Malone (1970:Figure 14, Table 2) reported that site $41 B W 77$ only produced three lithic artifacts.

\section{Figure Redacted}

Figure 5.14. Location of site 41BW77. 
The site boundary as presented in the USACE Fort Worth Wright Patman Lake GIS database covers $1,560 \mathrm{~m}^{2}(0.39 \mathrm{ac})$ along a low terrace edge within and adjacent to Wright Patman Lake. The centerpoint of the site is approximately $480 \mathrm{~m}$ east of Red River Road. Vegetation along the northern edge of the site and across the adjacent uplands consists of mixed hardwoods and pine with sparse understory of smaller saplings and vines (Figures 5.15 and 5.16).

SEARCH archaeologists visited the site on November 10, 2015, and determined that the plotted site location as listed on the TARL site form and within the USACE Fort Worth Wright Patman Lake GIS database was largely submerged (see Figure 5.14) by the existing lake level (226.59 ft amsl). As a result, nearly all of the archaeological investigation occurred across the uplands adjacent to the site's northern boundary. Ground surface visibility ranged between 20 and 40 percent with better visibility occurring near the waterline.

A pedestrian survey was conducted along transects that measured a distance equivalent to the diameter of the site boundary and spaced $5 \mathrm{~m}$ apart. Transects began at and were oriented parallel to the existing water line. No exposed beach, scarps, or benches were observed, and no artifacts were encountered during the pedestrian survey.

Subsurface testing included the excavation of 22 shovel tests (Figure 5.17), none of which produced artifacts. As a result, no test units were excavated at site 41BW77. A typical soil profile displayed very dark gray (10YR 3/1) sandy loam from 0 to $20 \mathrm{cmbs}$, yellowish-brown (10YR 5/6) loamy clay from 20 to $35 \mathrm{cmbs}$, and strong brown (7.5YR 5/6) clay from 35 to 55+ cmbs (Figure 5.18).

\section{Recommendation}

In November 2015, a relatively large portion of site 41BW77 was inundated by the rising pool level at Wright Patman Lake. Exposed portions of the site and the adjacent uplands were tested to determine if intact cultural deposits existed within and adjacent to the defined boundary. No artifacts were observed during pedestrian survey and subsurface testing. As only a small portion of the site could be tested, SEARCH recommends that the NRHP status of site 41BW77 remain undetermined until such time as the submerged deposits can be evaluated. 


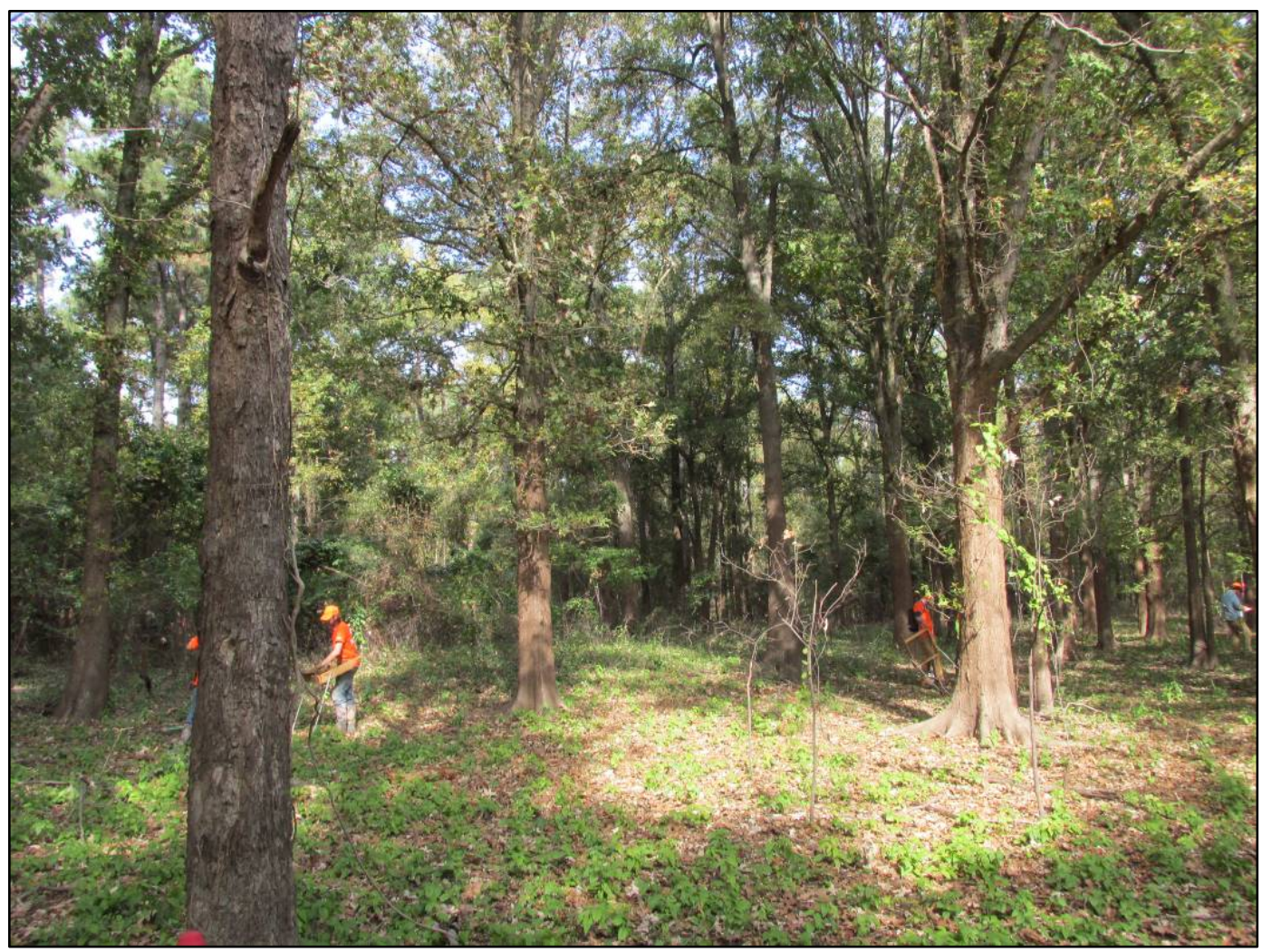

Figure 5.15. Typical vegetation in the northern portion of site 41BW77, facing north.

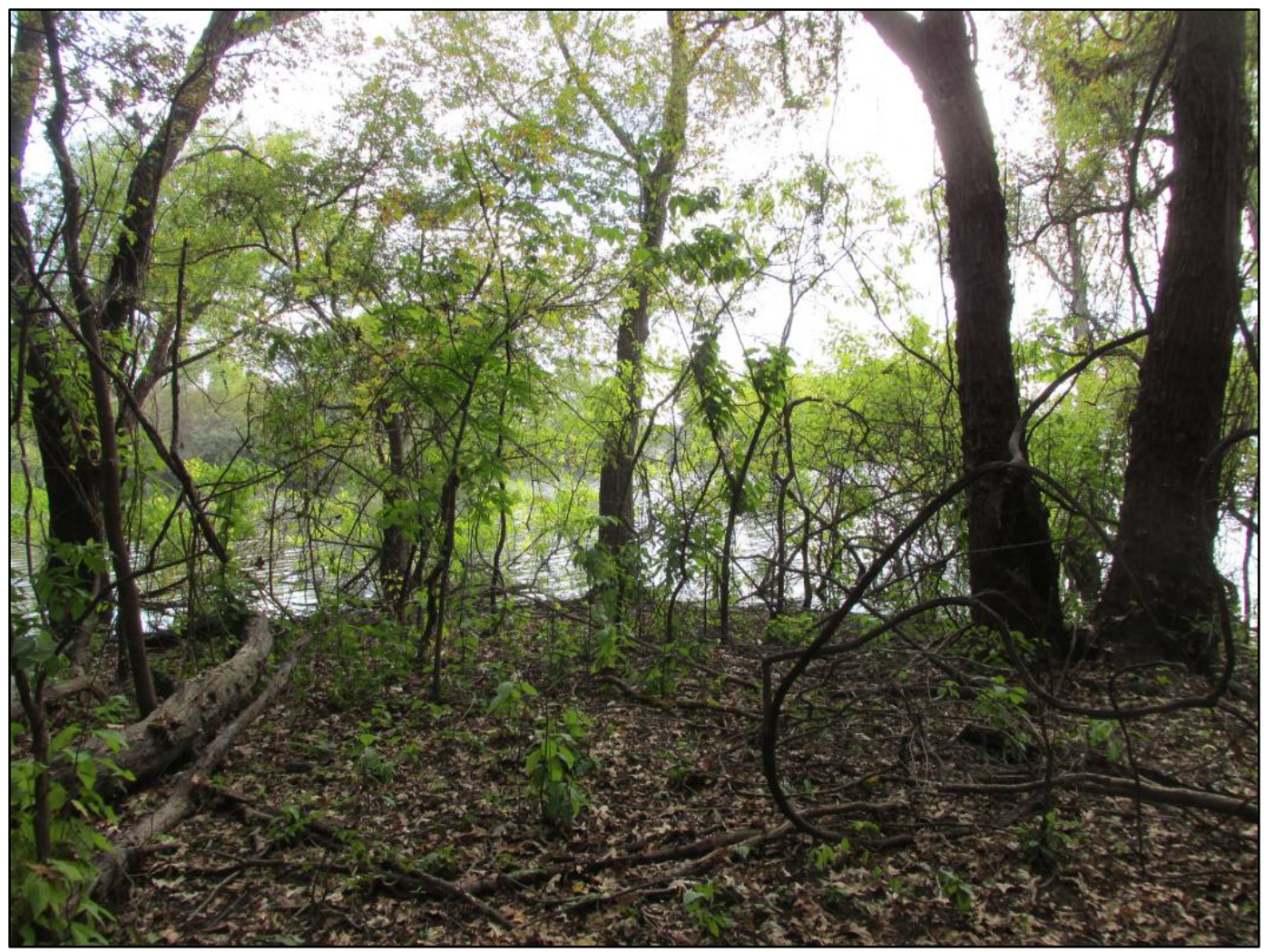

Figure 5.16. Typical vegetation in the northern portion of site 41BW77, facing south. 


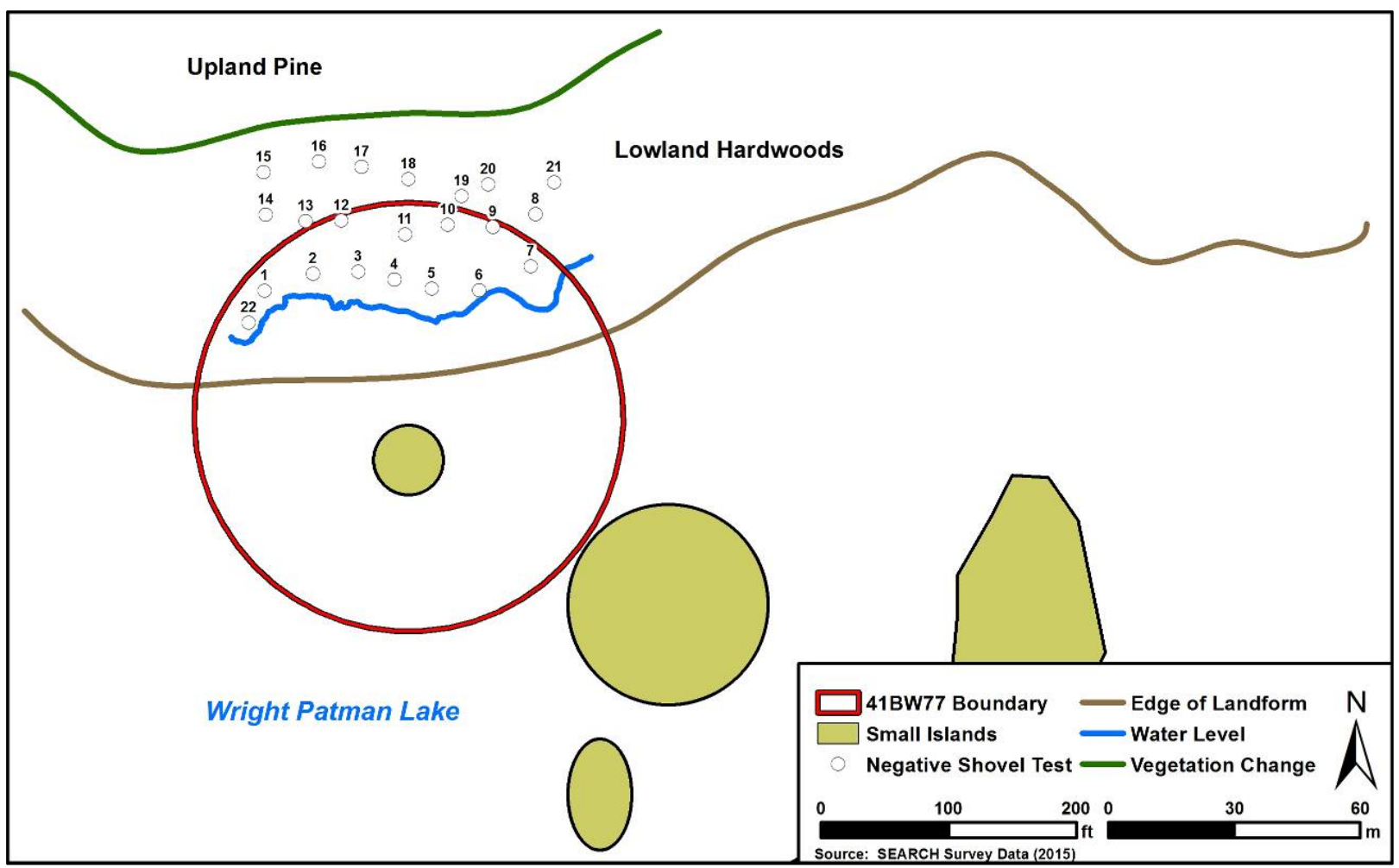

Figure 5.17. SEARCH 2015 fieldwork plan map for site 41BW77.

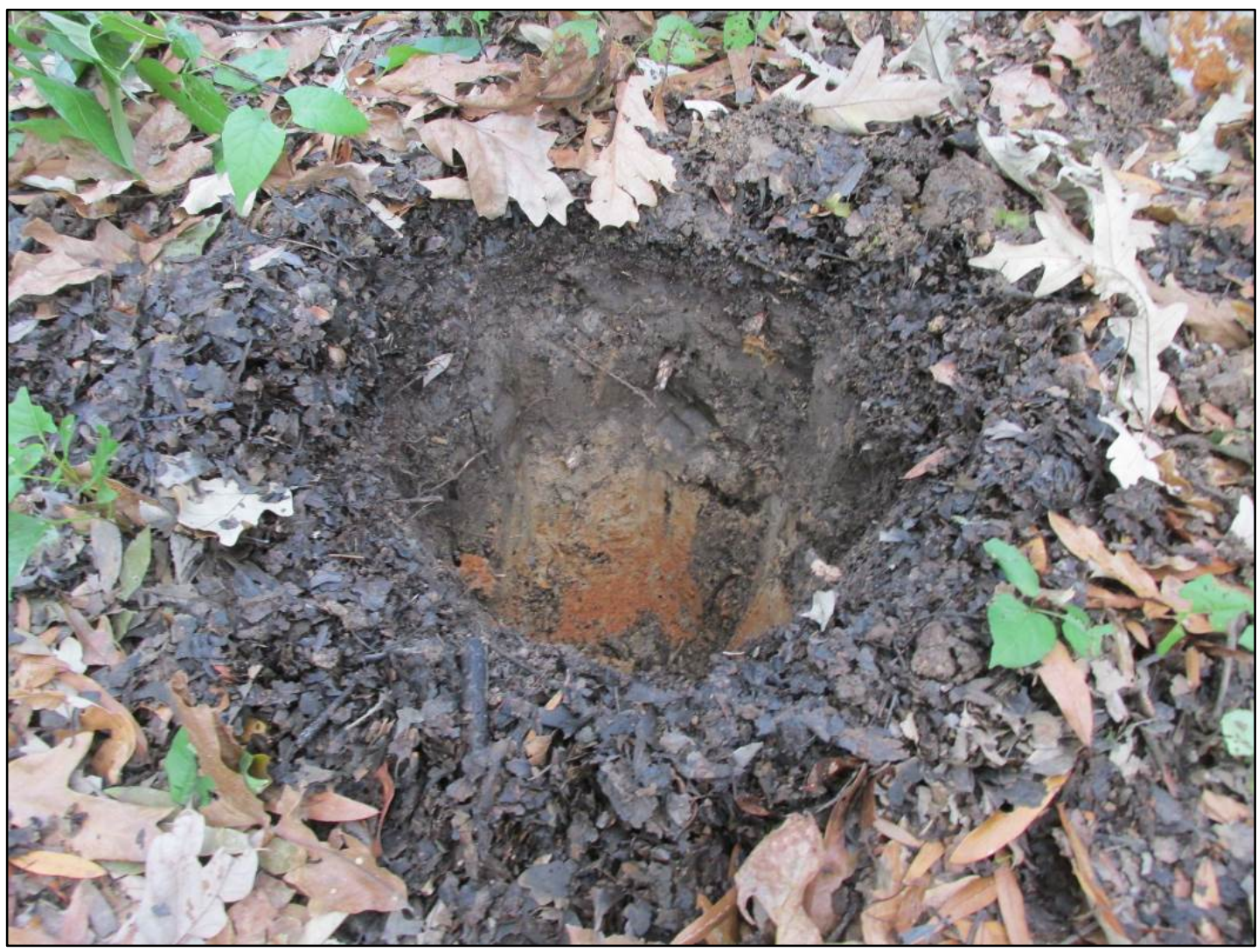

Figure 5.18. Typical soil profile at site 41BW77. 


\section{Site 41CS16}

Stephenson recorded site 41CS16 Figure Redacted (originally identified as 41-20D5-11) (Figure 5.19) on a large, sandy ridge overlooking Webster Creek in the fall of 1949. Based on the site's relative small size (1-2 ac) and paucity of artifacts, he (Stephenson 1950:9) characterized the site as a small camp area that may have been occupied seasonally or by a small contingent of people from a larger village. Artifacts include a small collection of pottery sherds and lithic debitage. No further work was recommended, but Stephenson noted that the site was above the 10-year frequency pool level (TARL 1949b) of $242 \mathrm{ft}$ amsl.

On October 25, 2015, SEARCH archaeologists relocated the large, sandy ridge occupied by site 41CS16. The ridge is approximately 30 to 35 feet higher than the pool level at Wright Patman Lake (224.25 ft amsl on October 25, 2015). The landform trends northeast to

Figure 5.19. Location of site 41CS16. southwest and overlooks Webster Creek, consistent with Stephenson's previous assessment, but is not indicated on US Geological Survey (USGS) Quadrangle maps or within elevation data provided by the US Department of Agriculture (USDA). The site location as listed on the TARL site form and within the USACE Fort Worth Wright Patman Lake GIS database is plotted along the northwestern edge of the ridge and should be moved approximately $50 \mathrm{~m}$ southeast to orient the site to the ridgetop. SEARCH archaeologists determined that the site is at an elevation that is outside of the area of potential effect for the Ultimate Rule Curve at Wright Patman Lake. As a result, the site was not assessed during this project, and site 41CS110 was chosen from the Contingency List. The NRHP status of site 41 CS16 remains undetermined.

\section{SITE 41 CS48}

Briggs and Malone recorded site 41CS48 (Figure 5.20) in February 1970. The site was located at an elevation between 221.5 and $225 \mathrm{ft}$ amsl on a long, low island covered with willow clumps. A midden was reportedly identified on the south side of the island (TARL 1970d). The artifact 
Figure 5.20. Location of site $41 \mathrm{CS} 48$.

assemblage was relatively robust, consisting of a large collection of lithic debitage and debris $(n=91)$ and pottery sherds $(n=51)$.

The site boundary as plotted in the USACE Fort Worth Wright Patman Lake GIS database consists of two discontiguous loci associated with artifact areas and midden identified by Briggs and Malone. On November 4, 2015, SEARCH archaeologists visited site 41CS48 and encountered a landform restricted by rising water. The pool level $(226.15 \mathrm{ft}$ amsl) had inundated much of the island, leaving a small corridor of high ground linking the two loci. In general, the island contains a few larger species of hardwoods in a sparse canopy with a moderately dense understory of small brush, vines, and greenbriar (Figure 5.21).

Fieldwork at site 41CS48 consisted of 16 shovel tests excavated in the northern locus, three shovel tests in the south locus, and one judgmental shovel test excavated between the two loci (Figure 5.22). All shovel tests yielded no artifacts. A typical shovel test exhibited dark grayishbrown (10YR 4/2) humic, silty sand from 0 to $3 \mathrm{cmbs}$, light yellowish-brown (10YR 6/4) wet, compact clay mottled with strong brown (7.5YR 5/6) wet compact clay from 3 to $35 \mathrm{cmbs}$ (Figure 5.23). No additional ground disturbances were observed. In addition, a pedestrian survey was conducted northeast of the northern locus, across an area covering $2,500 \mathrm{~m}^{2}$. No artifacts were observed during the pedestrian survey. 


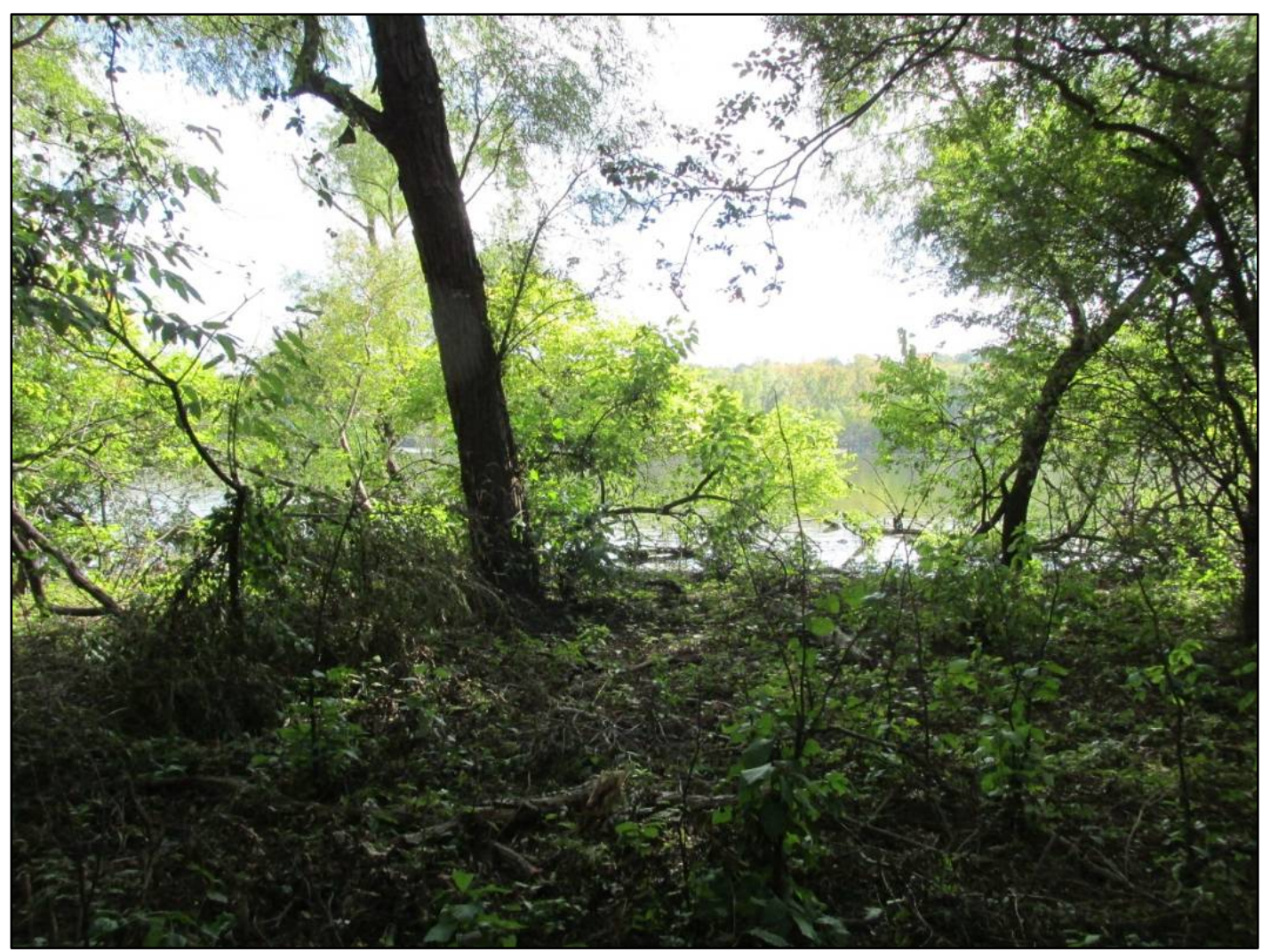

Figure 5.21. Typical vegetation at site 41CS48 from ST 3 facing south.

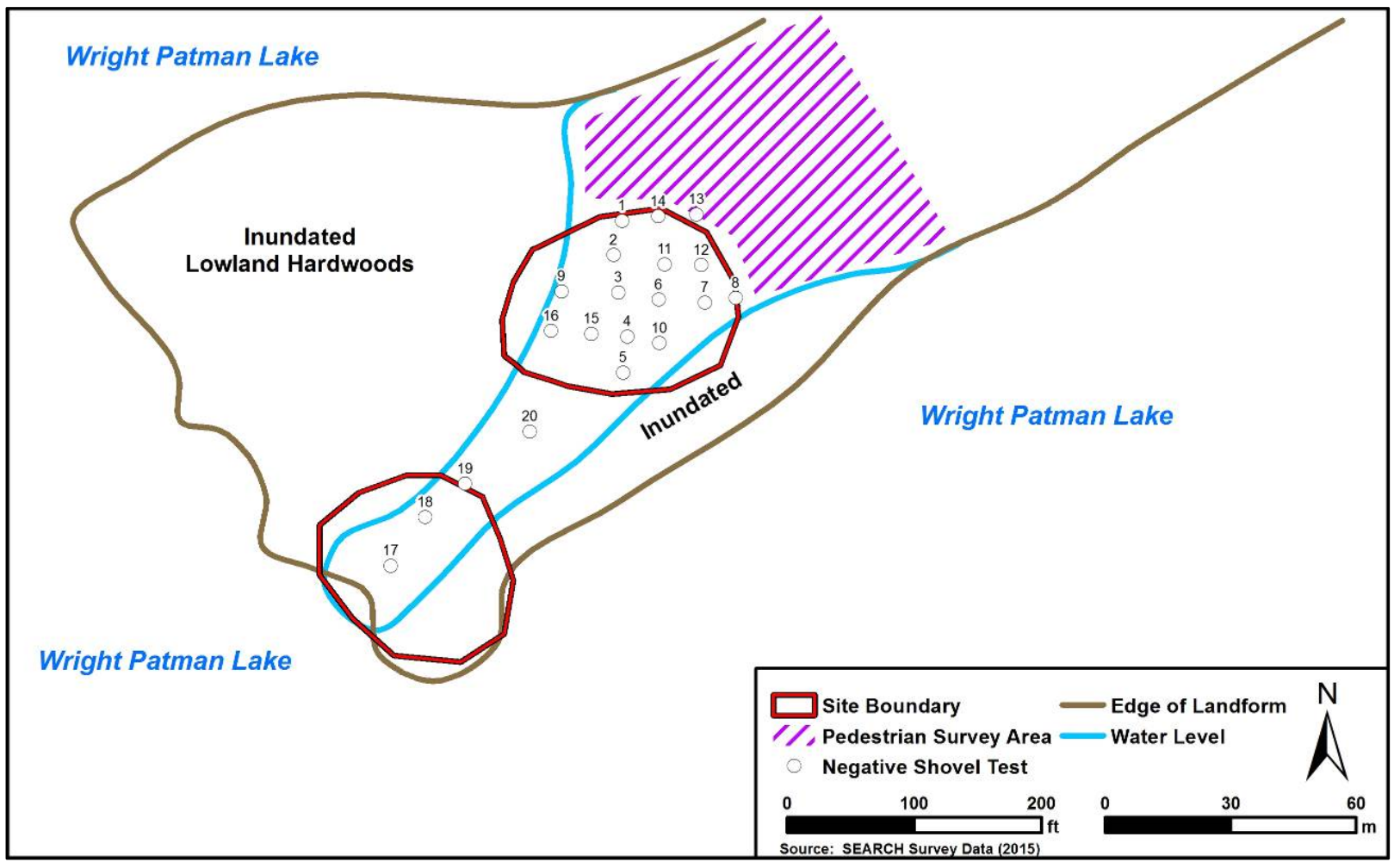

Figure 5.22. SEARCH 2015 fieldwork plan map for site 41CS48. 


\section{Recommendation}

In November 2015, a portion of site 41 CS48 was inundated by the rising pool level at Wright Patman Lake. A central, restricted corridor of high ground was tested to determine if intact cultural deposits existed within and adjacent to the defined boundary. No artifacts were encountered during pedestrian survey and subsurface testing. These areas do not appear to contribute to the overall NRHP eligibility of the site. Nevertheless, as only a portion of the site could be tested, SEARCH recommends that the

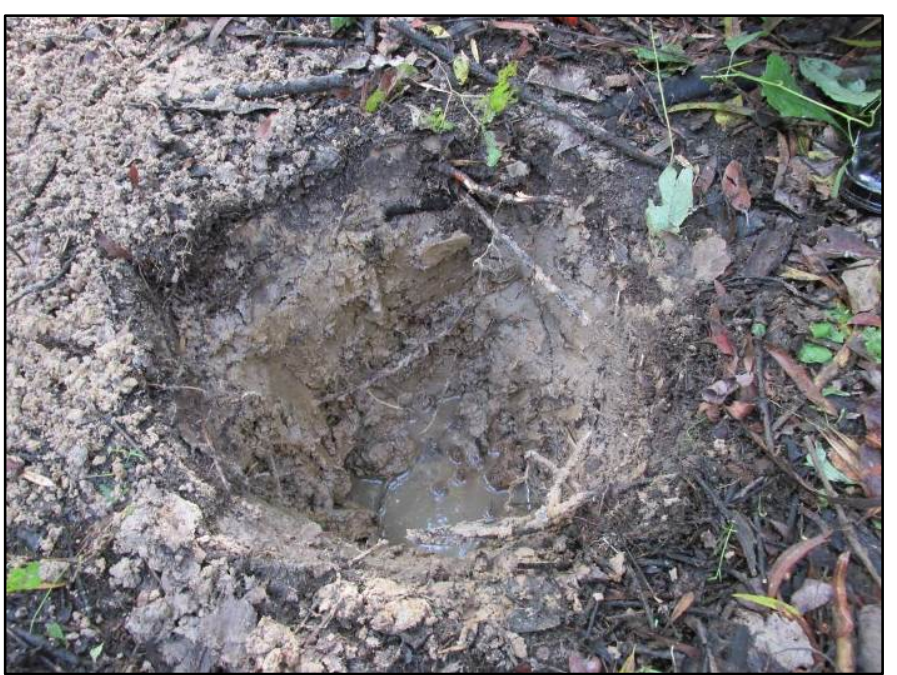

Figure 5.23. Typical soil profile at site 41CS48. NRHP status of site $41 \mathrm{CS} 48$ remain undetermined until such time as the submerged deposits can be evaluated.

\section{SITE 41CS55}

Briggs and Malone recorded site 41CS55 (Figure 5.24) in February 1970. The site was located at an elevation between 221 and $223 \mathrm{ft}$ amsl on a low, eroding ridgetop within Wright Patman Figure Redacted

Figure 5.24. Location of site 41CS55. 
Lake (TARL 1970e). The artifact assemblage included a small quantity of lithic debitage and a relatively robust collection of Native American pottery sherds.

SEARCH archaeologists visited site 41CS55 on November 3 and 4, 2015, when pool elevations were between 225.87 and $226.15 \mathrm{ft}$ amsl. The site boundary as presented in the USACE Fort Worth Wright Patman Lake GIS database covers 16,495 $\mathrm{m}^{2}$ (4.08 ac); however, a large portion of the area is inundated. A low island/sand bar remains, approximately 20 to $30 \mathrm{~m}$ wide and $230 \mathrm{~m}$ long. Vegetation is composed of young hardwoods with a light understory of greenbriar and wax myrtle (Figure 5.25). The overall landform is relatively flat with the south end of the island slightly higher than the north end.

During the initial reconnaissance at site 41CS55, SEARCH archaeologists determined that the plotted site location as listed on the TARL site form and within the USACE Fort Worth Wright Patman Lake GIS database was partially inundated by the current lake level (226.15 ft amsl). As a result, investigations focused on pedestrian survey and judgmental shovel testing across the limited portion of the site that remained exposed.

The pedestrian survey consisted of a complete walkover of the entire island. Ground visibility ranged from near 0 percent in the southern half of the island to 50 percent in the northern half of the island. Along the western and northern periphery of the island numerous artifacts were observed along the water's edge. A concentration of surface artifacts $(n=301)$ was also observed and collected between ST 10 and ST 11. These artifacts along with all artifacts

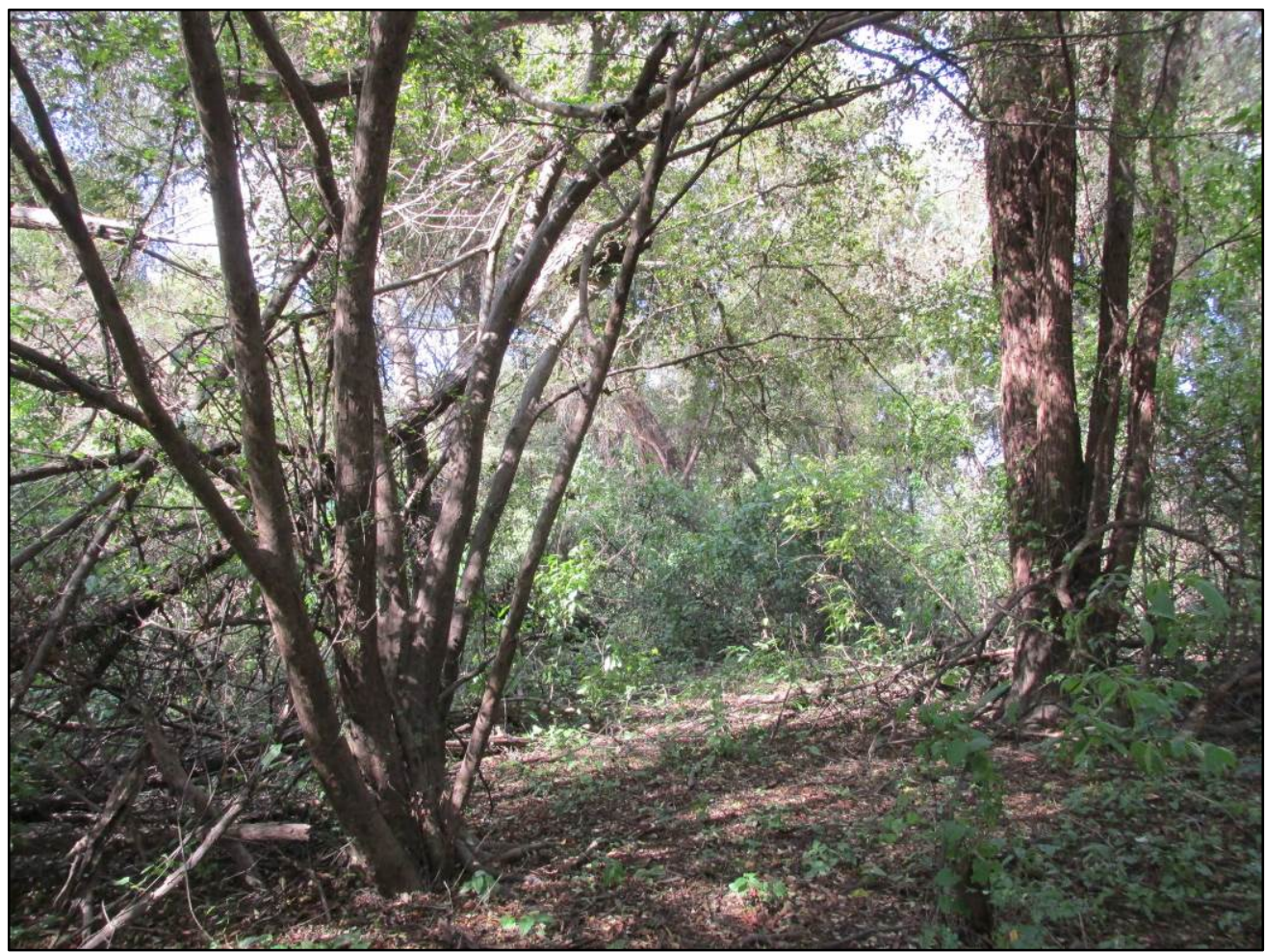

Figure 5.25. Typical vegetation at site $41 \mathrm{CS} 55$. 
collected from site 41CS55 are listed by provenience in Table 5.4. Select artifacts recovered from site 41CS55 are presented in Figures 5.26-5.29

Subsurface testing (Figure 5.30) included the excavation of 27 shovel tests, of which 13 were positive for cultural material, and five $50-x-50-\mathrm{cm}$ tests units, all of which produced artifacts (see Table 5.4). A typical soil profile displayed brown (10YR 4/3) loamy sand from 0 to $10 \mathrm{cmbs}$ and mottled light brownish-gray (10YR 6/2) and dark yellowish-brown (10YR 3/6) fine sandy clay from 10 to $35 \mathrm{cmbs}$ (Figure 5.31).

The distribution of artifacts from shovel tests revealed two areas of concentration. The first area is located near the northern tip of the island and includes STs 1, 2, 3, and 4. The artifact assemblage in this area consists almost exclusively of flake debitage. Additional artifacts include a small assortment of Native American pottery sherds, petrified wood, and a single seed. The second area occurs within the central portion of the site and includes ST 10 and ST 11 along with a concentration of surface scatters between the shovel tests. The artifact assemblage includes a large quantity of both Native American pottery sherds and lithic debris.

Table 5.4. Artifact Inventory for Site 41CS55.

\begin{tabular}{|c|c|c|c|c|c|}
\hline Provenience & $\begin{array}{l}\text { Depth } \\
\text { (cmbs) }\end{array}$ & Description & Count & $\begin{array}{l}\text { Weight } \\
\text { (g) }\end{array}$ & Comments \\
\hline $\mathrm{CP} 1$ & Surface & Flake, Thinning; Late & 1 & 0.16 & Chert, > 1/4", complete \\
\hline CP 1 & Surface & Flake, Thinning; Late & 1 & 0.16 & Chert, > 1/4", proximal \\
\hline CP 1 & Surface & Flake, Thinning & 1 & 1.18 & Chert, $>1 / 2 "$, complete \\
\hline $\mathrm{CP} 1$ & Surface & Flake, Thinning & 1 & 0.7 & Chert, $>1 / 2^{\prime \prime}$, complete \\
\hline $\mathrm{CP} 1$ & Surface & Flake, Thinning & 3 & 2.68 & Chert, > 1/2", complete \\
\hline $\mathrm{CP} 1$ & Surface & Flake, Thinning & 3 & 1.08 & Chert, $>1 / 2^{\prime \prime}$, proximal \\
\hline $\mathrm{CP} 1$ & Surface & Flake, Thinning & 2 & 1.69 & Chert, > 1/2", medial-distal \\
\hline $\mathrm{CP} 1$ & Surface & Flake, Thinning & 2 & 2.08 & Chert, > 1/2", non-orientable \\
\hline $\mathrm{CP} 1$ & Surface & Flake, Early Reduction & 1 & 1.01 & Chert, $>1 / 2$ ", complete \\
\hline CP 1 & Surface & Shatter, Angular & 1 & 2.87 & Chert, $>1 / 2 "$, complete \\
\hline CP 1 & Surface & Flake, Utilized & 1 & 1.52 & Chert, > 1/2", Medial- Distal \\
\hline CP 1 & Surface & $\begin{array}{l}\text { Aboriginal ceramic, } \\
\text { engraved }\end{array}$ & 4 & 19.16 & Body, grog/bone temper \\
\hline $\mathrm{CP} 1$ & Surface & $\begin{array}{l}\text { Aboriginal ceramic, } \\
\text { engraved }\end{array}$ & 2 & 6.83 & Body, grog/clay temper \\
\hline CP 1 & Surface & Aboriginal ceramic, plain & 1 & 3.3 & Heavy Grog, grog/clay temper \\
\hline CP 1 & Surface & $\begin{array}{l}\text { Aboriginal ceramic, } \\
\text { engraved }\end{array}$ & 2 & 10.42 & Body, Grit/grog temper \\
\hline $\mathrm{CP} 1$ & Surface & $\begin{array}{l}\text { Aboriginal ceramic, } \\
\text { engraved }\end{array}$ & 1 & 4.53 & Rim, grog/clay temper \\
\hline $\mathrm{CP} 1$ & Surface & $\begin{array}{l}\text { Aboriginal ceramic, } \\
\text { engraved }\end{array}$ & 1 & 1.17 & Body, grog/clay temper \\
\hline $\mathrm{CP} 2$ & Surface & $\begin{array}{l}\text { Aboriginal ceramic, } \\
\text { applique on body }\end{array}$ & 1 & 5.34 & Body, grog/clay temper, Decorated \\
\hline CP 3 & Surface & Flake, Thinning; Late & 2 & 0.89 & Chert, $>1 / 2$ ", complete \\
\hline CP 3 & Surface & Flake, Thinning; Late & 4 & 1.46 & Chert, $>1 / 2 "$, complete \\
\hline $\mathrm{CP} 3$ & Surface & Flake, Thinning; Late & 2 & 0.67 & Chert, $>1 / 2 "$, medial-distal \\
\hline $\mathrm{CP} 3$ & Surface & Flake, Thinning & 2 & 0.82 & Chert, > 1/2", complete \\
\hline
\end{tabular}


Table 5.4. Artifact Inventory for Site 41CS55.

\begin{tabular}{|c|c|c|c|c|c|}
\hline Provenience & $\begin{array}{l}\text { Depth } \\
\text { (cmbs) }\end{array}$ & Description & Count & $\begin{array}{l}\text { Weight } \\
\text { (g) }\end{array}$ & Comments \\
\hline $\mathrm{CP} 3$ & Surface & Flake, Thinning & 3 & 3.34 & Chert, > 1/2", complete \\
\hline CP 3 & Surface & Flake, Thinning & 4 & 4.66 & Chert, $>1 / 2^{\prime \prime}$, complete \\
\hline CP 3 & Surface & Flake, Thinning & 3 & 3.31 & Chert, > 1/2", complete \\
\hline CP 3 & Surface & Flake, Thinning & 1 & 0.65 & Chert, $>1 / 2^{\prime \prime}$, proximal \\
\hline CP 3 & Surface & Flake, Thinning & 1 & 0.44 & Chert, > 1/2", proximal \\
\hline CP 3 & Surface & Flake, Thinning & 8 & 4.94 & Chert, > 1/2", proximal \\
\hline $\mathrm{CP} 3$ & Surface & Flake, Thinning & 3 & 2.24 & Chert, $>1 / 2^{\prime \prime}$, proximal \\
\hline $\mathrm{CP} 3$ & Surface & Flake, Thinning & 1 & 0.31 & Chert, $>1 / 2^{\prime \prime}$, medial-distal \\
\hline CP 3 & Surface & Flake, Thinning & 1 & 1.06 & Chert, > 1/2", non-orientable \\
\hline CP 3 & Surface & Flake, Early Reduction & 1 & 0.66 & Chert, > 1/2", complete \\
\hline CP 3 & Surface & Flake, Early Reduction & 3 & 3.29 & Chert, >1/2", complete \\
\hline CP 3 & Surface & Flake, Early Reduction & 1 & 2.07 & Chert, > 1/2", complete \\
\hline CP 3 & Surface & Flake, Early Reduction & 2 & 3.1 & Chert, >1/2", complete \\
\hline CP 3 & Surface & Flake, Early Reduction & 1 & 1.74 & Chert, >1/2", complete \\
\hline CP 3 & Surface & Flake, Early Reduction & 4 & 6.88 & Chert, >1/2", complete \\
\hline CP 3 & Surface & Flake, Early Reduction & 1 & 0.9 & Chert, > 1/2", proximal \\
\hline $\mathrm{CP} 3$ & Surface & Flake, Early Reduction & 1 & 1.12 & Chert, $>1 / 2^{\prime \prime}$, proximal \\
\hline CP 3 & Surface & Flake, Early Reduction & 1 & 0.71 & Chert, > 1/2", proximal \\
\hline CP 3 & Surface & Flake, Early Reduction & 2 & 2.99 & Chert, $>1 / 2^{\prime \prime}$, proximal \\
\hline CP 3 & Surface & Flake, Early Reduction & 1 & 0.51 & Chert, > 1/2", proximal \\
\hline CP 3 & Surface & Flake, Early Reduction & 1 & 2.19 & Chert, $>1 / 2^{\prime \prime}$, medial-distal \\
\hline CP 3 & Surface & Flake, Early Reduction & 1 & 1 & Chert, > 1/2", medial-distal \\
\hline CP 3 & Surface & Flake, Early Reduction & 1 & 4.18 & Chert, $>1 / 2^{\prime \prime}$, non-orientable \\
\hline CP 3 & Surface & Shatter, Angular & 3 & 4.68 & Chert, $>1 / 2^{\prime \prime}$, non-orientable \\
\hline $\mathrm{CP} 3$ & Surface & Shatter, Thermal & 3 & 8.88 & Chert, $>1 / 2 "$, non-orientable \\
\hline CP 3 & Surface & Possible cultural lithic & 1 & 1 & Quartzite/sandstone \\
\hline CP 3 & Surface & Possible cultural lithic & 2 & 3.67 & Other \\
\hline $\mathrm{CP} 3$ & Surface & Flake, Thinning & 1 & 0.75 & Petrified wood, $>1 / 2^{\prime \prime}$, medial-distal \\
\hline CP 3 & Surface & Flake, Thinning; Late & 3 & 0.58 & Chert, $>1 / 4^{\prime \prime}$, complete \\
\hline CP 3 & Surface & Flake, Thinning; Late & 3 & 0.47 & Chert, $>1 / 4^{\prime \prime}$, complete \\
\hline CP 3 & Surface & Flake, Thinning; Late & 1 & 0.15 & Chert, > 1/4", proximal \\
\hline CP 3 & Surface & Flake, Thinning; Late & 1 & 0.34 & Chert, > 1/4", proximal \\
\hline CP 3 & Surface & Flake, Thinning; Late & 2 & 0.38 & Chert, $>1 / 4^{\prime \prime}$, proximal \\
\hline $\mathrm{CP} 3$ & Surface & Flake, Thinning; Late & 1 & 0.13 & Chert, >1/4", medial-distal \\
\hline CP 3 & Surface & Flake, Thinning; Late & 1 & 0.14 & Chert, $>1 / 4^{\prime \prime}$, medial-distal \\
\hline CP 3 & Surface & Flake, Thinning & 1 & 0.40 & Chert, > 1/4", proximal \\
\hline CP 3 & Surface & Flake, Thinning & 2 & 0.96 & Chert, >1/4", medial-distal \\
\hline $\mathrm{CP} 3$ & Surface & Aboriginal ceramic, plain & 2 & 6.18 & Body, grog/clay temper \\
\hline $\mathrm{CP} 3$ & Surface & $\begin{array}{l}\text { Aboriginal ceramic, } \\
\text { punctate }\end{array}$ & 5 & 22.2 & Body, grog/clay temper \\
\hline CP 3 & Surface & Aboriginal ceramic, plain & 1 & 8.08 & Body, grog/bone temper \\
\hline $\mathrm{CP} 3$ & Surface & $\begin{array}{l}\text { Aboriginal ceramic, } \\
\text { brushed }\end{array}$ & 1 & 10.8 & Body, grog/clay temper, Heavy grog \\
\hline $\mathrm{CP} 3$ & Surface & Aboriginal ceramic, plain & 2 & 7.3 & $\begin{array}{l}\text { Body, grog/clay temper, Mended } \\
\text { sherds }\end{array}$ \\
\hline $\mathrm{CP} 3$ & Surface & $\begin{array}{l}\text { Aboriginal ceramic, } \\
\text { engraved }\end{array}$ & 1 & 16.13 & Body, grog/clay temper, Heavy grog \\
\hline
\end{tabular}


Table 5.4. Artifact Inventory for Site 41CS55.

\begin{tabular}{|c|c|c|c|c|c|}
\hline Provenience & $\begin{array}{l}\text { Depth } \\
\text { (cmbs) }\end{array}$ & Description & Count & $\begin{array}{l}\text { Weight } \\
\text { (g) }\end{array}$ & Comments \\
\hline CP 3 & Surface & $\begin{array}{l}\text { Aboriginal ceramic, } \\
\text { applique on body }\end{array}$ & 1 & 5.45 & Body, grog/clay temper, possible node \\
\hline CP 3 & Surface & $\begin{array}{l}\text { Aboriginal ceramic, } \\
\text { brushed }\end{array}$ & 1 & 13.28 & Body, grog/clay temper \\
\hline CP 4 & Surface & Flake, core reduction & 2 & 3.26 & Chert, > 1", complete \\
\hline $\mathrm{CP} 4$ & Surface & Flake, core reduction & 1 & 1.83 & Chert, > 1", medial-distal \\
\hline CP 4 & Surface & Flake, core reduction & 2 & 1.93 & Chert, $>1 / 2^{\prime \prime}$, complete \\
\hline CP 4 & Surface & Flake, core reduction & 2 & 1.88 & Chert, > 1/2", proximal \\
\hline CP 4 & Surface & Flake, Early Reduction & 1 & 3.18 & Chert, > 1", complete \\
\hline CP 4 & Surface & Flake, Early Reduction & 1 & 1.41 & Chert, > 1", complete \\
\hline $\mathrm{CP} 4$ & Surface & Flake, Early Reduction & 1 & 0.12 & Chert, > 1/4", complete \\
\hline $\mathrm{CP} 4$ & Surface & Flake, Early Reduction & 3 & 2.89 & Chert, > 1/2", complete \\
\hline CP 4 & Surface & Flake, Early Reduction & 1 & 0.74 & Chert, > 1/2", proximal \\
\hline $\mathrm{CP} 4$ & Surface & Flake, Early Reduction & 1 & 1.13 & Chert, $>1 / 2 "$, medial-distal \\
\hline CP 4 & Surface & Flake, Early Reduction & 8 & 8.9 & Chert, $>1 / 2^{\prime \prime}$, complete \\
\hline CP 4 & Surface & Flake, Early Reduction & 3 & 2.6 & Chert, $>1 / 2 "$, medial-distal \\
\hline CP 4 & Surface & Flake, Thinning & 10 & 7.8 & Chert, $>1 / 2^{\prime \prime}$, complete \\
\hline $\mathrm{CP} 4$ & Surface & Flake, Thinning & 8 & 4.78 & Chert, > 1/2", proximal \\
\hline $\mathrm{CP} 4$ & Surface & Flake, Thinning & 4 & 1.68 & Chert, > 1/2", medial-distal \\
\hline $\mathrm{CP} 4$ & Surface & Flake, Thinning & 2 & 0.97 & Chert, > 1/2", proximal \\
\hline $\mathrm{CP} 4$ & Surface & Flake, Thinning & 1 & 0.18 & Chert, > 1/2", medial-distal \\
\hline CP 4 & Surface & Flake, Thinning & 1 & 0.57 & Chert, > 1/4", complete \\
\hline CP 4 & Surface & Flake, Thinning & 1 & 0.16 & Chert, $>1 / 4^{\prime \prime}$, medial-distal \\
\hline CP 4 & Surface & Flake, Thinning; Late & 1 & 0.15 & Chert, $>1 / 4^{\prime \prime}$, complete \\
\hline $\mathrm{CP} 4$ & Surface & Flake; Thinning; Late & 1 & 0.1 & Chert, > 1/4", proximal \\
\hline $\mathrm{CP} 4$ & Surface & Flake; Thinning; Late & 3 & 0.53 & Chert, $>1 / 4^{\prime \prime}$, medial-distal \\
\hline $\mathrm{CP} 4$ & Surface & Flake; Thinning; Late & 2 & 0.32 & Chert, > 1/4", complete \\
\hline CP 4 & Surface & Flake; Thinning; Late & 1 & 0.25 & Chert, $>1 / 2^{\prime \prime}$, complete \\
\hline CP 4 & Surface & Flake; Utilized & 1 & 3.46 & Chert, $>1$ ", Use-wear on long edge \\
\hline CP 4 & Surface & Flake, Thinning; Late & 1 & 3.77 & Quartzite, > 1/2", complete \\
\hline CP 4 & Surface & Aboriginal ceramic, plain & 4 & 36.62 & Body, grog/clay temper \\
\hline CP 4 & Surface & $\begin{array}{l}\text { Aboriginal ceramic, } \\
\text { punctate }\end{array}$ & 1 & 5.99 & Body, grog/clay temper \\
\hline CP 4 & Surface & $\begin{array}{l}\text { Aboriginal ceramic, } \\
\text { brushed }\end{array}$ & 1 & 9.1 & Base, grog/clay temper \\
\hline $\mathrm{CP} 4$ & Surface & Aboriginal ceramic, plain & 1 & 6.97 & Body, grog/clay temper \\
\hline CP 4 & Surface & $\begin{array}{l}\text { Aboriginal ceramic, } \\
\text { engraved }\end{array}$ & 1 & 2.73 & Rim, grog/clay temper \\
\hline CP 4 & Surface & Aboriginal ceramic, plain & 5 & 20.56 & Body, grog/clay temper, heavy grog \\
\hline CP 5 & Surface & Aboriginal ceramic, plain & 2 & 12.40 & Body, grog/clay temper \\
\hline CP 5 & Surface & Flake, Thinning; Late & 3 & 0.27 & Chert, $>1 / 8^{\prime \prime}$, complete \\
\hline CP 5 & Surface & Flake, Thinning; Late & 9 & 1.89 & Chert, > 1/4", complete \\
\hline CP 5 & Surface & Flake, Thinning; Late & 4 & 1.04 & Chert, > 1/4", complete \\
\hline CP 5 & Surface & Flake, Thinning; Late & 2 & 0.29 & Chert, $>1 / 4^{\prime \prime}$, complete \\
\hline CP 5 & Surface & Flake, Thinning; Late & 3 & 1.43 & Chert, $>1 / 2^{\prime \prime}$, complete \\
\hline CP 5 & Surface & Flake, Thinning; Late & 1 & 0.06 & Chert, > 1/8", proximal \\
\hline CP 5 & Surface & Flake, Thinning; Late & 8 & 1.93 & Chert, > 1/4", proximal \\
\hline CP 5 & Surface & Flake, Thinning; Late & 1 & 0.10 & Chert, > 1/4", proximal \\
\hline
\end{tabular}


Table 5.4. Artifact Inventory for Site 41CS55.

\begin{tabular}{|c|c|c|c|c|c|}
\hline Provenience & $\begin{array}{c}\text { Depth } \\
\text { (cmbs) }\end{array}$ & Description & Count & $\begin{array}{c}\text { Weight } \\
\text { (g) }\end{array}$ & Comments \\
\hline CP 5 & Surface & Flake, Thinning; Late & 1 & 0.54 & Chert, > 1/2", proximal \\
\hline CP 5 & Surface & Flake, Thinning; Late & 1 & 0.06 & Chert, $>1 / 8^{\prime \prime}$, medial-distal \\
\hline CP 5 & Surface & Flake, Thinning; Late & 8 & 1.64 & Chert, $>1 / 4 "$, medial-distal \\
\hline CP 5 & Surface & Flake, Thinning; Late & 1 & 0.26 & Chert, > 1/4", medial-distal \\
\hline CP 5 & Surface & Flake, Thinning; Late & 1 & 0.3 & Chert, $>1 / 2^{\prime \prime}$, medial-distal \\
\hline CP 5 & Surface & Flake, Retouch & 3 & 0.12 & Chert, > 1/8", complete \\
\hline CP 5 & Surface & Flake, Thinning & 1 & 0.63 & Chert, > 1/4", complete \\
\hline CP 5 & Surface & Flake, Thinning & 7 & 6.35 & Chert, $>1 / 2^{\prime \prime}$, complete \\
\hline CP 5 & Surface & Flake, Thinning & 4 & 5.6 & Chert, > 1/2", complete \\
\hline CP 5 & Surface & Flake, Thinning & 2 & 2.12 & Chert, $>1 / 2 "$, complete \\
\hline CP 5 & Surface & Flake, Thinning & 1 & 0.37 & Chert, > 1/4", proximal \\
\hline CP 5 & Surface & Flake, Thinning & 1 & 0.46 & Chert, > 1/4", proximal \\
\hline CP 5 & Surface & Flake, Thinning & 2 & 0.75 & Chert, > 1/4", proximal \\
\hline CP 5 & Surface & Flake, Thinning & 1 & 1.22 & Chert, > 1/2", proximal \\
\hline CP 5 & Surface & Flake, Thinning & 1 & 0.33 & Chert, $>1 / 4^{\prime \prime}$, medial-distal \\
\hline CP 5 & Surface & Flake, Thinning & 4 & 3.75 & Chert, $>1 / 2 "$, medial-distal \\
\hline CP 5 & Surface & Fire cracked rock & 1 & 2.93 & Quartzite \\
\hline CP 5 & Surface & Flake, Early Reduction & 3 & 4.07 & Chert, $>1 / 2^{\prime \prime}$, complete \\
\hline CP 5 & Surface & Flake, Early Reduction & 1 & 1.2 & Chert, > 1/2", proximal \\
\hline CP 5 & Surface & Flake, Early Reduction & 3 & 1.98 & Chert, $>1 / 2^{\prime \prime}$, medial-distal \\
\hline CP 5 & Surface & Flake, Core Reduction & 1 & 0.97 & Chert, > 1/4", medial-distal \\
\hline CP 5 & Surface & Flake, Core Reduction & 1 & 3.53 & Chert, $>1 / 2^{\prime \prime}$, medial-distal \\
\hline CP 5 & Surface & Flake, Core Reduction & 2 & 7.47 & Chert, $>1 / 2^{\prime \prime}$, complete \\
\hline CP 5 & Surface & Shatter, Angular & 3 & 1.15 & Chert \\
\hline CP 5 & Surface & Shatter, Angular & 2 & 3.45 & Quartz \\
\hline CP 5 & Surface & UID Aboriginal Ceramic & 2 & 0.82 & $<1 / 2$ in, grog/clay temper \\
\hline CP 5 & Surface & Shell, UID & 1 & 0.19 & Very Worn \\
\hline CP 5 & Surface & Wood & 1 & 0.04 & Non-cultural \\
\hline CP 5 & Surface & Unmodified stone & 8 & 9.4 & Sandstone, Chert, Quartz \\
\hline \multicolumn{3}{|c|}{ Surface Collection Point Subtotal } & 301 & 451.63 & \\
\hline ST 1 & $0-10$ & Flake, thinning; late & 11 & 1.73 & Chert, > 1/4", complete \\
\hline ST 1 & $0-10$ & Flake, thinning; late & 1 & 0.11 & Chert, $>1 / 4^{\prime \prime}$, proximal \\
\hline ST 1 & $0-10$ & Flake, thinning; late & 3 & 1.01 & Chert, $>1 / 4 "$, medial-distal \\
\hline ST 1 & $0-10$ & Flake, thinning; late & 2 & 0.62 & Chert, $>1 / 2^{\prime \prime}$, complete \\
\hline ST 1 & $0-10$ & Flake, thinning; late & 3 & 0.74 & Chert, > 1/2", proximal \\
\hline ST 1 & $0-10$ & Flake, thinning & 1 & 1.96 & Chert, > 1/2", non-orientable \\
\hline ST 1 & $0-10$ & Flake, thinning & 1 & 0.24 & Chert, $>1 / 4 "$, medial-distal \\
\hline ST 1 & $0-10$ & Shatter, angular & 2 & 0.51 & Chert, > 1/4", non-orientable \\
\hline ST 1 & $10-20$ & Flake, thinning; late & 1 & 0.09 & Chert, > 1/4", proximal \\
\hline ST 1 & $10-20$ & Flake, thinning; late & 1 & 0.24 & Chert, $>1 / 4^{\prime \prime}$, medial-distal \\
\hline ST 1 & $10-20$ & Flake, thinning & 4 & 2.11 & Chert, > 1/2", medial-distal \\
\hline ST 2 & $0-10$ & Flake, thinning & 1 & 0.50 & Chert, $>1 / 2^{\prime \prime}$, complete \\
\hline ST 2 & $0-10$ & Flake, thinning; late & 1 & 0.09 & Chert, > 1/4", medial-distal \\
\hline ST 3 & $5-15$ & Flake, thinning; late & 4 & 0.59 & Chert, $>1 / 4 "$, medial-distal \\
\hline ST 3 & $5-15$ & Flake, thinning; late & 1 & 0.16 & Chert, > 1/4", proximal \\
\hline ST 3 & $5-15$ & Flake, thinning; late & 8 & 2.00 & Chert, > 1/4", complete \\
\hline ST 3 & $5-15$ & Flake, thinning; late & 3 & 0.18 & Chert, $>1 / 8^{\prime \prime}$, complete \\
\hline
\end{tabular}


Table 5.4. Artifact Inventory for Site 41CS55.

\begin{tabular}{|c|c|c|c|c|c|}
\hline Provenience & $\begin{array}{l}\text { Depth } \\
\text { (cmbs) }\end{array}$ & Description & Count & $\begin{array}{l}\text { Weight } \\
\text { (g) }\end{array}$ & Comments \\
\hline ST 3 & $5-15$ & Flake, thinning; late & 1 & 0.57 & Chert, $>1 / 2^{\prime \prime}$, complete \\
\hline ST 3 & $5-15$ & Flake, thinning; late & 1 & 0.09 & Chert, > 1/4", non-orientable \\
\hline ST 3 & $5-15$ & Flake, thinning & 1 & 0.91 & Chert, > 1/2", medial-distal \\
\hline ST 3 & $5-15$ & Flake, thinning & 1 & 0.57 & Chert, > 1/4", proximal \\
\hline ST 3 & $5-15$ & Flake, early reduction & 1 & 0.20 & Chert, > 1/4", non-orientable \\
\hline ST 3 & $5-15$ & Shatter, angular & 4 & 3.58 & Chert \\
\hline ST 3 & $5-15$ & Possible cultural lithic & 1 & 0.74 & Petrified wood \\
\hline ST 3 & $5-15$ & Seed, other & 1 & 0.27 & Non-burned \\
\hline ST 3 & $15-35$ & Flake, thinning; late & 3 & 0.41 & Chert, $>1 / 4^{\prime \prime}$, complete \\
\hline ST 3 & $15-35$ & Flake, thinning; late & 3 & 0.26 & Chert, > 1/4", proximal \\
\hline ST 3 & $15-35$ & Flake, thinning; late & 2 & 0.23 & Chert, $>1 / 4^{\prime \prime}$, medial-distal \\
\hline ST 3 & $15-35$ & Flake, thinning & 2 & 0.45 & Chert, > 1/4", proximal \\
\hline ST 3 & $15-35$ & Flake, thinning & 1 & 0.33 & Chert, $>1 / 4^{\prime \prime}$, medial-distal \\
\hline ST 3 & $15-35$ & Flake, thinning & 4 & 0.91 & Chert, > 1/4", non-orientable \\
\hline ST 3 & $15-35$ & Flake, thinning & 1 & 0.32 & Chert, $>1 / 2 "$, medial-distal \\
\hline ST 3 & $15-35$ & Flake, thinning & 2 & 1.26 & Chert, > 1/2", non-orientable \\
\hline ST 3 & $15-35$ & Shatter, angular & 4 & 7.53 & Chert, non-orientable \\
\hline ST 3 & $15-35$ & Possible cultural lithic & 1 & 2.61 & Petrified wood \\
\hline ST 3 & $15-35$ & Possible cultural lithic & 1 & 1.27 & Quartzite, sandstone \\
\hline ST 3 & $15-35$ & Possible cultural lithic & 2 & 1.36 & Other \\
\hline ST 3 & $15-35$ & Aboriginal ceramic, plain & 2 & 5.94 & Grog/clay temper, body \\
\hline ST 4 & $0-15$ & Flake, thinning; late & 1 & 0.10 & Chert, > 1/4", complete \\
\hline ST 4 & $0-15$ & Flake, thinning; late & 1 & 0.05 & Chert, > 1/4", proximal \\
\hline ST 4 & $0-15$ & Flake, thinning; late & 2 & 0.28 & Chert, $>1 / 4^{\prime \prime}$, medial-distal \\
\hline ST 4 & $0-15$ & Flake, thinning; late & 1 & 0.75 & Chert, > 1/2", proximal \\
\hline ST 4 & $0-15$ & Flake, thinning & 1 & 0.26 & Chert, > 1/4", complete \\
\hline ST 4 & $0-15$ & Flake, thinning & 1 & 0.42 & Chert, > 1/4", proximal \\
\hline ST 4 & $0-15$ & Flake, thinning & 1 & 0.31 & Chert, > 1/2", non-orientable \\
\hline ST 4 & $0-15$ & Shatter, angular & 1 & 0.24 & Chert \\
\hline ST 4 & $0-15$ & Shatter, thermal & 1 & 0.11 & Chert \\
\hline ST 4 & $15-35$ & Flake, thinning & 1 & 0.11 & Chert, $>1 / 2^{\prime \prime}$, complete \\
\hline ST 4 & $15-35$ & Flake, thinning & 1 & 0.04 & Chert, > 1/4", complete \\
\hline ST 4 & $15-35$ & Flake, thinning; late & 1 & 0.09 & Chert, > 1/4", complete \\
\hline ST 4 & $15-35$ & Flake, thinning; late & 1 & 0.02 & Chert, $>1 / 4^{\prime \prime}$, proximal \\
\hline ST 4 & $15-35$ & Aboriginal ceramic, plain & 1 & 2.94 & Grog/clay temper, body \\
\hline ST 4 & $15-35$ & $\begin{array}{l}\text { Aboriginal ceramic, } \\
\text { engraved }\end{array}$ & 1 & 3.87 & Grog/clay temper, body \\
\hline ST 6 & $0-20$ & Flake, thinning; late & 1 & 0.29 & Chert, $>1 / 2^{\prime \prime}$, medial-distal \\
\hline ST 6 & $0-20$ & Flake, thinning & 1 & 0.60 & Chert, > 1/2", non-orientable \\
\hline ST 6 & $0-20$ & Tested cobble & 1 & 76.07 & Chert \\
\hline ST 6 & $0-20$ & Aboriginal ceramic, plain & 1 & 8.12 & Grog/clay temper, body \\
\hline ST 6 & $0-20$ & $\begin{array}{l}\text { Aboriginal ceramic, } \\
\text { incised }\end{array}$ & 1 & 5.76 & Grog/clay temper, body \\
\hline ST 7 & $0-10$ & Flake, thinning & 1 & 0.56 & Chert, > 1/2", proximal \\
\hline ST 8 & Surface & Aboriginal ceramic, plain & 1 & 3.96 & Grog/clay temper, body \\
\hline ST 8 & Surface & $\begin{array}{l}\text { Aboriginal ceramic, } \\
\text { engraved }\end{array}$ & 1 & 7.08 & Grog/clay temper, body \\
\hline
\end{tabular}


Table 5.4. Artifact Inventory for Site 41CS55.

\begin{tabular}{|c|c|c|c|c|c|}
\hline Provenience & $\begin{array}{l}\text { Depth } \\
\text { (cmbs) }\end{array}$ & Description & Count & $\begin{array}{l}\text { Weight } \\
\text { (g) }\end{array}$ & Comments \\
\hline ST 10 & Surface & $\begin{array}{l}\text { Aboriginal ceramic, } \\
\text { punctate }\end{array}$ & 2 & 9.29 & $\begin{array}{l}\text { Grog/clay temper, body, tool } \\
\text { punctated }\end{array}$ \\
\hline ST 10 & Surface & Aboriginal ceramic, plain & 19 & 80.97 & Grog/clay temper, body \\
\hline ST 10 & Surface & $\begin{array}{l}\text { Aboriginal ceramic, UID } \\
\text { decorated }\end{array}$ & 1 & 10.98 & $\begin{array}{l}\text { Grog/clay temper, body, possible } \\
\text { check stamped }\end{array}$ \\
\hline ST 10 & Surface & Aboriginal ceramic, plain & 2 & 10.82 & Grog/clay temper, straight rim \\
\hline ST 10 & Surface & Aboriginal ceramic, plain & 1 & 1.17 & Grog/clay temper, everted rim \\
\hline ST 10 & Surface & $\begin{array}{l}\text { Aboriginal ceramic, } \\
\text { engraved }\end{array}$ & 1 & 5.86 & Grog/clay temper, everted rim \\
\hline ST 10 & $0-10$ & Flake, thinning; late & 2 & 0.06 & Chert, $<1 / 4^{\prime \prime}$, complete \\
\hline ST 10 & $0-10$ & Flake, thinning; late & 1 & 0.12 & Chert, $>1 / 4^{\prime \prime}$, complete \\
\hline ST 10 & $0-10$ & Flake, thinning; late & 2 & 0.57 & Chert, > 1/4", proximal \\
\hline ST 10 & $0-10$ & Flake, thinning; late & 1 & 0.13 & Chert, > 1/4", medial-distal \\
\hline ST 10 & $0-10$ & Flake, thinning; late & 1 & 0.14 & Chert, > 1/4", non-orientable \\
\hline ST 10 & $0-10$ & Flake, thinning; late & 2 & 0.68 & Chert, $>1 / 2^{\prime \prime}$, complete \\
\hline ST 10 & $0-10$ & Flake, thinning & 1 & 0.32 & Chert, $>1 / 4^{\prime \prime}$, proximal \\
\hline ST 10 & $0-10$ & Flake, thinning & 1 & 0.76 & Chert, $>1 / 2^{\prime \prime}$, complete \\
\hline ST 10 & $0-10$ & Flake, thinning & 2 & 1.26 & Chert, $>1 / 2^{\prime \prime}$, proximal \\
\hline ST 10 & $0-10$ & Flake, thinning & 1 & 0.62 & Chert, $>1 / 2^{\prime \prime}$, medial-distal \\
\hline ST 10 & $0-10$ & Shatter, thermal & 1 & 0.28 & Chert, > 1/4", non-orientable \\
\hline ST 10 & $0-10$ & Possible cultural lithic & 1 & 0.45 & Quartzite, sandstone \\
\hline ST 11 & Surface & Aboriginal ceramic, plain & 2 & 3.81 & Grog/clay temper, body \\
\hline ST 11 & Surface & $\begin{array}{l}\text { Aboriginal ceramic, } \\
\text { engraved }\end{array}$ & 1 & 3.75 & Grog/clay temper, body \\
\hline ST 11 & $0-10$ & Flake, thinning; late & 3 & 0.94 & Chert, >1/4", complete \\
\hline ST 11 & $0-10$ & Flake, thinning; late & 2 & 0.19 & Chert, $>1 / 4^{\prime \prime}$, proximal \\
\hline ST 11 & $0-10$ & Flake, thinning; late & 2 & 0.38 & Chert, > 1/4", non-orientable \\
\hline ST 11 & $0-10$ & Flake, thinning & 8 & 6.61 & Chert, $>1 / 2^{\prime \prime}$, complete \\
\hline ST 11 & $0-10$ & Flake, thinning & 1 & 0.24 & Chert, $>1 / 2^{\prime \prime}$, proximal \\
\hline ST 11 & $0-10$ & Flake, early reduction & 2 & 3.57 & Chert, $>1 / 2^{\prime \prime}$, complete \\
\hline ST 11 & $0-10$ & Aboriginal ceramic, plain & 3 & 21.39 & Grog/clay temper, body \\
\hline ST 11 & $0-10$ & $\begin{array}{l}\text { Aboriginal ceramic, } \\
\text { engraved }\end{array}$ & 1 & 5.31 & Grog/clay temper, body \\
\hline ST 11 & $0-10$ & $\begin{array}{l}\text { Aboriginal ceramic, } \\
\text { engraved }\end{array}$ & 1 & 9.27 & Grog/clay temper, straight rim \\
\hline ST 11 & $10-15$ & Flake, thinning & 2 & 0.30 & Chert, $>1 / 4^{\prime \prime}$, medial-distal \\
\hline ST 11 & $10-15$ & Flake, thinning & 1 & 0.28 & Chert, $>1 / 4^{\prime \prime}$, complete \\
\hline ST 11 & $10-15$ & Flake, early reduction & 1 & 3.18 & Chert, $>1 / 2^{\prime \prime}$, complete \\
\hline ST 11 & $10-15$ & $\begin{array}{l}\text { Aboriginal ceramic, } \\
\text { engraved }\end{array}$ & 1 & 4.38 & $\begin{array}{l}\text { Grog/clay tempered, tapered, flared } \\
\text { rim }\end{array}$ \\
\hline ST 11 & $10-15$ & Aboriginal ceramic, plain & 1 & 2.66 & Grog/clay tempered, body \\
\hline ST 12 & Surface & Aboriginal ceramic, plain & 1 & 2.02 & Grog/clay tempered, straight rim \\
\hline ST 12 & Surface & Aboriginal ceramic, plain & 4 & 13.99 & Grog/clay tempered, body \\
\hline ST 12 & Surface & Aboriginal ceramic, plain & 1 & 21.62 & Grog/bone tempered, body \\
\hline ST 12 & Surface & $\begin{array}{l}\text { Aboriginal ceramic, } \\
\text { applique on body }\end{array}$ & 1 & 5.31 & Grog/clay tempered, body \\
\hline ST 12 & Surface & Unmodified stone & 1 & 21.28 & Non-cultural \\
\hline ST 12 & Surface & Fire cracked rock & 1 & 37.48 & \\
\hline
\end{tabular}


Table 5.4. Artifact Inventory for Site 41CS55.

\begin{tabular}{|c|c|c|c|c|c|}
\hline Provenience & $\begin{array}{l}\text { Depth } \\
\text { (cmbs) }\end{array}$ & Description & Count & $\begin{array}{c}\text { Weight } \\
\text { (g) }\end{array}$ & Comments \\
\hline ST 12 & Surface & Flake, thinning & 4 & 5.57 & Chert, $>1 / 2^{\prime \prime}$, complete \\
\hline ST 12 & Surface & Flake, thinning & 1 & 1.02 & Chert, $>1 / 2^{\prime \prime}$, proximal \\
\hline ST 12 & Surface & Blazed, utilized flake & 1 & 1.89 & Chert, > 1/2" \\
\hline ST 13 & $10-20$ & Flake, thinning; late & 1 & 0.21 & Chert, $>1 / 4^{\prime \prime}$, proximal \\
\hline ST 13 & $10-20$ & Flake, thinning; late & 1 & 0.16 & Chert, >1/4", medial-distal \\
\hline ST 13 & $10-20$ & Flake, thinning; late & 1 & 0.37 & Chert, $>1 / 2^{\prime \prime}$, complete \\
\hline ST 13 & $10-20$ & Flake, thinning & 1 & 0.38 & Chert, $>1 / 4^{\prime \prime}$, proximal \\
\hline ST 13 & $10-20$ & Flake, thinning & 1 & 0.64 & Chert, $>1 / 4 "$, non-orientae \\
\hline ST 13 & $20-30$ & Flake, early reduction & 2 & 4.61 & Chert, > 1/2", complete \\
\hline ST 13 & $20-30$ & Shatter, angular & 1 & 0.88 & Chert, > 1/2", non-orientable \\
\hline ST 14 & $0-10$ & Animal bone & 1 & 0.56 & \\
\hline ST 14 & $10-20$ & Flake, early reduction & 1 & 1.08 & Chert, > 1/2", proximal \\
\hline ST 26 & $0-10$ & Flake, thinning & 1 & 0.59 & $\begin{array}{l}\text { Coastal plain chert, heat treated, }> \\
1 / 2^{\prime \prime}, \text { proximal }\end{array}$ \\
\hline ST 26 & $0-10$ & Flake, early reduction & 1 & 0.71 & Chert, $>1 / 2^{\prime \prime}$ complete \\
\hline ST 27 & $0-10$ & Flake, Thinning; Late & 1 & 0.26 & Chert, > 1/4", proximal \\
\hline ST 27 & $0-10$ & Flake, Thinning; Late & 1 & 0.25 & Chert, > 1/4", medial-distal \\
\hline \multicolumn{3}{|c|}{ Shovel Test Subtotal } & 214 & 466.10 & \\
\hline TU 1 & $10-20$ & Flake, Thinning; Late & 1 & 0.11 & Chert, > 1/4", complete \\
\hline TU 1 & $10-20$ & Flake, Thinning; Late & 1 & 0.02 & Chert, > 1/4", complete \\
\hline TU 1 & $10-20$ & Flake, Thinning; Late & 1 & 0.10 & Chert, $>1 / 4^{\prime \prime}$, proximal \\
\hline TU 1 & $10-20$ & Flake, Thinning; Late & 1 & 0.09 & Chert, > 1/4", complete \\
\hline TU 1 & $10-20$ & Flake, Thinning; Late & 3 & 0.97 & Chert, > 1/4", proximal \\
\hline TU 1 & $10-20$ & Flake, Thinning; Late & 2 & 0.24 & Chert, >1/4", medial-distal \\
\hline TU 1 & $10-20$ & Flake, Thinning; Late & 1 & 0.3 & Chert, > 1/4", non-orientable \\
\hline TU 1 & $10-20$ & Flake, Thinning; Late & 1 & 0.45 & Chert, > 1/2", complete \\
\hline TU 1 & $10-20$ & Flake, Thinning & 2 & 0.66 & Chert, $>1 / 2^{\prime \prime}$, proximal \\
\hline TU 1 & $10-20$ & Flake, Thinning & 1 & 0.53 & Chert, $>1 / 2^{\prime \prime}$, medial-distal \\
\hline TU 1 & $10-20$ & Flake, Thinning & 1 & 1.29 & Chert, $>1 / 2^{\prime \prime}$, complete \\
\hline TU 1 & $10-20$ & Flake, Early Reduction & 1 & 0.6 & Chert, > 1/2", complete \\
\hline TU 1 & $10-20$ & Shatter, Angular & 2 & 2.49 & Chert, > 1/2" \\
\hline TU 1 & $10-20$ & Potlid & 1 & 0.08 & Chert, > 1/4" \\
\hline TU 1 & $10-20$ & Possible cultural lithic & 1 & 0.39 & \\
\hline TU 1 & $10-20$ & Possible cultural lithic & 4 & 22.3 & Other \\
\hline TU 1 & $10-20$ & Possible cultural lithic & 7 & 5.1 & Other \\
\hline TU 1 & $20-30$ & Flake, Thinning & 1 & 0.66 & Chert, > 1/4", complete \\
\hline TU 1 & $30-40$ & Shatter, Angular & 1 & 1.56 & Chert, > 1/4", non-orientable \\
\hline TU 2 & $12-25$ & Flake, Thinning; Late & 1 & 0.36 & Chert, $>1 / 4^{\prime \prime}$, complete \\
\hline TU 2 & $12-25$ & Flake, Thinning; Late & 2 & 0.23 & Chert, > 1/4", complete \\
\hline TU 2 & $12-25$ & Flake, Thinning; Late & 1 & 0.09 & Chert, $>1 / 4^{\prime \prime}$, proximal \\
\hline TU 2 & $12-25$ & Flake, Thinning; Late & 3 & 0.4 & Chert, >1/4", medial-distal \\
\hline TU 2 & $12-25$ & Flake, Thinning & 1 & 0.47 & Chert, > 1/2", complete \\
\hline TU 2 & $12-25$ & Flake, Thinning & 1 & 0.68 & Chert, > 1/2", medial-distal \\
\hline TU 2 & $12-25$ & Flake, Thinning & 3 & 1.14 & Chert, > 1/4", medial-distal \\
\hline TU 2 & $12-25$ & Aboriginal ceramic, plain & 4 & 13.96 & Body, Grog/clay temper \\
\hline TU 2 & $12-25$ & Animal bone & 1 & 0.26 & \\
\hline TU 2 & $12-25$ & Seed, other & 1 & 0.51 & \\
\hline
\end{tabular}


Table 5.4. Artifact Inventory for Site 41CS55.

\begin{tabular}{|c|c|c|c|c|c|}
\hline Provenience & $\begin{array}{l}\text { Depth } \\
\text { (cmbs) }\end{array}$ & Description & Count & $\begin{array}{c}\text { Weight } \\
\text { (g) }\end{array}$ & Comments \\
\hline TU 2 & $12-25$ & Possible cultural lithic & 1 & 2.37 & Other \\
\hline TU 3 & Surface & Aboriginal ceramic; Late & 2 & 2.68 & Body, Grog/clay temper \\
\hline TU 3 & Surface & UID Aboriginal ceramic & 1 & 0.25 & $<1 / 2$ in \\
\hline TU 3 & $10-20$ & Flake, Thinning; Late & 1 & 0.36 & Chert, > 1/2", complete \\
\hline TU 3 & $10-20$ & Flake, Thinning & 2 & 1.36 & Chert, $>1 / 2^{\prime \prime}$, complete \\
\hline TU 3 & $10-20$ & Flake, Thinning & 1 & 0.84 & Chert, $>1 / 2^{\prime \prime}$, complete \\
\hline TU 3 & $10-20$ & Flake, Thinning & 1 & 0.99 & Chert, $>1 / 2^{\prime \prime}$, medial-distal \\
\hline TU 3 & $10-20$ & Flake, Thinning & 1 & 1.36 & Chert, $>1 / 2^{\prime \prime}$, medial-distal \\
\hline TU 3 & $10-20$ & Flake, Thinning & 3 & 2.42 & Chert, > 1/2", complete \\
\hline TU 3 & $10-20$ & Flake, Thinning & 2 & 0.68 & Chert, $>1 / 2^{\prime \prime}$, proximal \\
\hline TU 3 & $10-20$ & Flake, Thinning & 2 & 0.93 & Chert, >1/2", medial-distal \\
\hline TU 3 & $10-20$ & Flake, Early Reduction & 1 & 3.09 & Chert, $>1 "$, complete \\
\hline TU 3 & $10-20$ & Flake, Thinning; Late & 3 & 0.55 & Chert, > 1/4", complete \\
\hline TU 3 & $10-20$ & Flake, Thinning; Late & 1 & 0.14 & Chert, $>1 / 4^{\prime \prime}$, complete \\
\hline TU 3 & $10-20$ & Flake, Thinning; Late & 7 & 0.76 & Chert, $>1 / 4^{\prime \prime}$, complete \\
\hline TU 3 & $10-20$ & Flake, Thinning; Late & 1 & 0.19 & Chert, $>1 / 4^{\prime \prime}$, proximal \\
\hline TU 3 & $10-20$ & Flake, Thinning; Late & 1 & 0.23 & Chert, $>1 / 4^{\prime \prime}$, proximal \\
\hline TU 3 & $10-20$ & Flake, Thinning; Late & 1 & 0.21 & Chert, > 1/4", proximal \\
\hline TU 3 & $10-20$ & Flake, Thinning; Late & 4 & 0.52 & Chert, > 1/4", proximal \\
\hline TU 3 & $10-20$ & Flake, Thinning; Late & 2 & 0.54 & Chert, > 1/4", medial-distal \\
\hline TU 3 & $10-20$ & Flake, Thinning; Late & 6 & 0.84 & Chert, > 1/4", non-orientable \\
\hline TU 3 & $10-20$ & Flake, Thinning & 1 & 0.55 & Chert, > 1/4", medial-distal \\
\hline TU 3 & $10-20$ & Shatter, Angular & 6 & 4.07 & non-orientable \\
\hline TU 3 & $10-20$ & Shatter, Thermal & 2 & 2.83 & non-orientable \\
\hline TU 3 & $10-20$ & $\begin{array}{l}\text { Aboriginal ceramic, } \\
\text { engraved }\end{array}$ & 9 & 41.56 & Body, Grog/bone temper \\
\hline TU 3 & $10-20$ & $\begin{array}{l}\text { Aboriginal ceramic, } \\
\text { incised }\end{array}$ & 1 & 2.66 & Rim, Grog/clay temper, lip notched \\
\hline TU 3 & $10-20$ & $\begin{array}{l}\text { Aboriginal ceramic, } \\
\text { engraved }\end{array}$ & 1 & 2.78 & Rim, Grog/clay temper \\
\hline TU 3 & $10-20$ & Aboriginal ceramic, plain & 1 & 2.17 & Body, Grog/bone temper \\
\hline TU 3 & $10-20$ & $\begin{array}{l}\text { Aboriginal ceramic, } \\
\text { engraved }\end{array}$ & 1 & 5.03 & Body, Grog/clay temper \\
\hline TU 3 & $20-30$ & Flake, Thinning; Late & 1 & 0.25 & Chert, > 1/4", proximal \\
\hline TU 3 & $20-30$ & Flake, Thinning; Late & 2 & 0.51 & Chert, $>1 / 4^{\prime \prime}$, complete \\
\hline TU 3 & $20-30$ & Flake, Thinning; Late & 2 & 0.66 & Chert, $>1 / 4^{\prime \prime}$, complete \\
\hline TU 3 & $20-30$ & Flake, Thinning & 1 & 0.7 & Chert, $>1 / 2^{\prime \prime}$, complete \\
\hline TU 3 & $20-30$ & Flake, Early Reduction & 1 & 0.88 & Chert, $>1 / 2^{\prime \prime}$, complete \\
\hline TU 3 & $20-30$ & Flake, Early Reduction & 1 & 0.97 & Chert, $>1 / 4^{\prime \prime}$, complete \\
\hline TU 3 & $40-50$ & $\begin{array}{l}\text { Bifacial chopping/cutting } \\
\text { tool }\end{array}$ & 1 & 34.08 & Bifacial flaking and retouch \\
\hline TU 3 & $40-50$ & Flake, Thinning: Late & 1 & 0.15 & Chert, > 1/4", complete \\
\hline TU 3 & $40-50$ & Flake, Thinning & 1 & 1.25 & Chert, $>1 / 2^{\prime \prime}$, complete \\
\hline TU 3 & $40-50$ & Flake, Thinning & 1 & 2.65 & Chert, $>1 / 2^{\prime \prime}$, complete \\
\hline TU 3 & $40-50$ & Flake, core reduction & 1 & 1.91 & Chert, > 1/2", complete \\
\hline TU 3 & $50-60$ & Flake, Early Reduction & 1 & 5.68 & Chert, > 1", medial-distal \\
\hline TU 4 & Surface & Flake, Thinning; Late & 2 & 0.26 & Chert, $>1 / 4^{\prime \prime}$, complete \\
\hline TU 4 & Surface & Flake, Thinning; Late & 3 & 0.47 & Chert, > 1/4", proximal \\
\hline
\end{tabular}


Table 5.4. Artifact Inventory for Site 41CS55.

\begin{tabular}{|c|c|c|c|c|c|}
\hline Provenience & $\begin{array}{l}\text { Depth } \\
\text { (cmbs) }\end{array}$ & Description & Count & $\begin{array}{l}\text { Weight } \\
\text { (g) }\end{array}$ & Comments \\
\hline TU 4 & Surface & Flake, Thinning; Late & 1 & 0.19 & Chert, $>1 / 4^{\prime \prime}$, medial-distal \\
\hline TU 4 & Surface & Flake, Thinning & 1 & 1.3 & Chert, $>1 / 2^{\prime \prime}$, medial-distal \\
\hline TU 4 & Surface & Flake, Early Reduction & 1 & 0.93 & Chert, > 1/2", complete \\
\hline TU 4 & Surface & Flake, Early Reduction & 1 & 1.88 & Chert, > 1/2", proximal \\
\hline TU 4 & Surface & Shatter, Thermal & 2 & 4.61 & Chert \\
\hline TU 4 & Surface & Unmodified stone & 1 & 0.88 & Other \\
\hline TU 4 & Surface & Aboriginal ceramic, plain & 9 & 25.84 & Body, Grog/clay temper \\
\hline TU 4 & Surface & Aboriginal ceramic, plain & 7 & 29.57 & Body, Grog/clay temper \\
\hline TU 4 & Surface & Aboriginal ceramic, plain & 1 & 6.69 & Rim, Grog/clay temper \\
\hline TU 4 & Surface & $\begin{array}{l}\text { Aboriginal ceramic, } \\
\text { applique on body }\end{array}$ & 1 & 11.69 & Body, Grog/clay temper \\
\hline TU 4 & Surface & $\begin{array}{l}\text { Aboriginal ceramic, } \\
\text { engraved }\end{array}$ & 1 & 4.36 & Body, Grog/clay temper \\
\hline TU 4 & Surface & UID Aboriginal ceramic & 7 & 2.98 & Grog/clay temper, $<1 / 2$ in \\
\hline TU 4 & Surface & Aboriginal ceramic, plain & 3 & 3.79 & Body, Grog/clay temper \\
\hline TU 4 & $10-15$ & Flake, Thinning; Late & 2 & 0.26 & Chert, $>1 / 4^{\prime \prime}$, medial-distal \\
\hline TU 4 & $10-15$ & Flake, Thinning; Late & 4 & 0.32 & Chert, > 1/4", complete \\
\hline TU 4 & $10-15$ & Flake; Thinning; Late & 2 & 0.22 & Chert, $>1 / 4^{\prime \prime}$, medial-distal \\
\hline TU 4 & $10-15$ & Flake, Thinning; Late & 2 & 0.04 & Chert, > 1/4", non-orientable \\
\hline TU 4 & $10-15$ & Flake; Thinning; Late & 1 & 0.1 & Chert, $>1 / 4^{\prime \prime}$, medial-distal \\
\hline TU 4 & $10-15$ & Flake, Thinning; Late & 1 & 0.36 & Chert, $>1 / 4^{\prime \prime}$, medial-distal \\
\hline TU 4 & $10-15$ & Flake, Thinning; Late & 2 & 0.56 & Chert, > 1/4", complete \\
\hline TU 4 & $10-15$ & Flake, Thinning; Late & 1 & 0.23 & Chert, > 1/4", non-orientable \\
\hline TU 4 & $10-15$ & Flake, Thinning & 1 & 0.48 & Chert, $>1 / 2^{\prime \prime}$, complete \\
\hline TU 4 & $10-15$ & Flake, Thinning & 1 & 0.55 & Chert, $>1 / 2^{\prime \prime}$, complete \\
\hline TU 4 & $10-15$ & Flake, Thinning & 1 & 0.28 & Chert, > 1/2", proximal \\
\hline TU 4 & $10-15$ & Flake, Thinning & 1 & 0.63 & Chert, $>1 / 2^{\prime \prime}$, medial-distal \\
\hline TU 4 & $10-15$ & Flake, Thinning & 3 & 1.76 & Chert, $>1 / 2^{\prime \prime}$, complete \\
\hline TU 4 & $10-15$ & Flake, Thinning & 2 & 0.67 & Chert, > 1/2", proximal \\
\hline TU 4 & $10-15$ & Flake, Thinning & 2 & 1.13 & Chert, > 1/2", medial-distal \\
\hline TU 4 & $10-15$ & Flake, Early Reduction & 1 & 1.47 & Chert, > 1/2", complete \\
\hline TU 4 & $10-15$ & Shatter, Angular & 7 & 3.68 & Chert, non-orientable \\
\hline TU 4 & $10-15$ & Shatter, Thermal & 2 & 2.15 & Chert, non-orientable \\
\hline TU 4 & $10-15$ & Unmodified stone & 1 & 0.11 & other \\
\hline TU 4 & $10-15$ & $\begin{array}{l}\text { Aboriginal ceramic, } \\
\text { incised }\end{array}$ & 5 & 15.79 & Body, Grog/clay temper \\
\hline TU 4 & $10-15$ & Aboriginal ceramic, plain & 5 & 2.26 & Body, Grog/clay temper \\
\hline TU 4 & $10-15$ & Aboriginal ceramic, plain & 1 & 2.3 & Body, Grog/clay temper \\
\hline TU 4 & $10-15$ & Aboriginal ceramic, plain & 1 & 2.39 & Body, Grit/grog temper \\
\hline TU 4 & $10-15$ & $\begin{array}{l}\text { Aboriginal ceramic, } \\
\text { incised }\end{array}$ & 1 & 2.52 & Rim, Grog/clay temper \\
\hline TU 4 & $10-15$ & Animal bone & 2 & 1.48 & Carapace/plastron \\
\hline TU 4 & $15-30$ & Flake, Unspecified & 1 & 0.14 & Chert, $>1 / 4^{\prime \prime}$, complete \\
\hline TU 4 & $15-30$ & Flake, Early Reduction & 1 & 1.12 & Chert, $>1 / 2 "$, complete \\
\hline TU 4 & $15-30$ & Flake, Thinning; Late & 3 & 0.48 & Chert, $>1 / 4^{\prime \prime}$, complete \\
\hline TU 4 & $15-30$ & Flake, Thinning; Late & 1 & 0.03 & Chert, $>1 / 8^{\prime \prime}$, complete \\
\hline TU 4 & $30-40$ & Flake, Thinning & 1 & 0.33 & Chert, > 1/2", complete \\
\hline TU 4 & $30-40$ & Shatter, Angular & 4 & 13.15 & Chert, non-orientable \\
\hline
\end{tabular}


Table 5.4. Artifact Inventory for Site 41CS55.

\begin{tabular}{|c|c|c|c|c|c|}
\hline Provenience & $\begin{array}{l}\text { Depth } \\
\text { (cmbs) }\end{array}$ & Description & Count & $\begin{array}{l}\text { Weight } \\
\text { (g) }\end{array}$ & Comments \\
\hline TU 4 & $30-40$ & Charcoal & 1 & 0.06 & \\
\hline TU 4 & $20-40$ & Flake, Early Reduction & 1 & 1.95 & Chert, $>1 / 2^{\prime \prime}$, complete \\
\hline TU 4 & $20-40$ & Shatter, Angular & 1 & 2.94 & Chert, > 1/2", non-orientable \\
\hline TU 4 & $40-50$ & Flake, Thinning & 1 & 0.94 & Chert, $>1 / 2^{\prime \prime}$, complete \\
\hline TU 4 & $40-50$ & Flake, Thinning & 1 & 0.44 & Chert, >1/4", proximal \\
\hline TU 4 & $50-60$ & Flake, Thinning; Late & 1 & 0.06 & Chert, $>1 / 8^{\prime \prime}$, complete \\
\hline TU 4 & $50-60$ & Flake, Thinning; Late & 2 & 0.41 & Chert, > 1/4", complete \\
\hline TU 4 & $50-60$ & Flake, Thinning & 1 & 1.26 & Chert, $>1 / 2^{\prime \prime}$, complete \\
\hline TU 4 & $50-60$ & Flake, Early Reduction & 1 & 3.38 & Chert, > 1/2", complete \\
\hline TU 4 & $50-60$ & Flake, Unspecified & 1 & 0.38 & Quartzite/sandstone, > 1/4" \\
\hline TU 4 & $50-60$ & $\begin{array}{l}\text { Aboriginal ceramic, } \\
\text { engraved }\end{array}$ & 1 & 9.08 & Body, Grog/clay temper \\
\hline TU 4 & $50-60$ & PPK Preform, Early Stage & 1 & 12.03 & \\
\hline TU 5 & $9-20$ & Flake, Thinning; Late & 1 & 0.25 & Chert, > 1/4", proximal \\
\hline TU 5 & $9-20$ & Flake, Thinning; Late & 3 & 0.48 & Chert, $>1 / 4^{\prime \prime}$, medial-distal \\
\hline TU 5 & $9-20$ & Flake, Thinning & 1 & 1.04 & Chert, $>1 / 2^{\prime \prime}$, complete \\
\hline TU 5 & $9-20$ & Flake, Thinning & 1 & 0.80 & Chert, >1/2", medial-distal \\
\hline TU 5 & $9-20$ & Flake, Thinning & 1 & 0.91 & Chert, $>1 / 2^{\prime \prime}$, complete \\
\hline TU 5 & $9-20$ & Flake, Thinning & 1 & 1.16 & Chert, >1/2", proximal \\
\hline TU 5 & $9-20$ & Biface fragment & 1 & 1 & Chert, > 1/2", non-orientable \\
\hline TU 5 & $9-20$ & Aboriginal ceramic, plain & 4 & 10.06 & Body, Grog/clay temper \\
\hline TU 5 & $9-20$ & Aboriginal ceramic, plain & 1 & 1.95 & Body, Grog/ bone temper \\
\hline TU 5 & $20-30$ & Flake, Thinning; Late & 1 & 0.95 & Chert, $>1 / 2^{\prime \prime}$, proximal \\
\hline TU 5 & $20-30$ & Flake, Thinning; Late & 1 & 0.29 & Chert, $>1 / 2^{\prime \prime}$, complete \\
\hline TU 5 & $20-30$ & Flake, Thinning; Late & 1 & 0.55 & Chert, >1/2", complete \\
\hline TU 5 & $20-30$ & Flake, Thinning & 1 & 1 & Chert, > 1/2", complete \\
\hline TU 5 & $20-30$ & Flake, Thinning; Late & 1 & 0.42 & Chert, > 1/4", proximal \\
\hline TU 5 & $20-30$ & Flake, Thinning & 1 & 0.30 & Chert, $>1 / 4^{\prime \prime}$, medial-distal \\
\hline TU 5 & $20-30$ & Flake, Core Reduction & 1 & 1.45 & Chert, $>1 / 2^{\prime \prime}$, complete \\
\hline TU 5 & $20-30$ & Flake, Utilized & 1 & 17.49 & Chert, $>1 "$, Ventral \\
\hline TU 5 & $30-40$ & Flake, Early Reduction & 1 & 2.23 & Chert, >1/2", complete \\
\hline TU 5 & $30-40$ & PPK fragment & 1 & 6.5 & Reutilized as a drill, stem snapped \\
\hline TU 5 & $40-51$ & Flake, Thinning & 1 & 0.56 & Chert, > 1/2", complete \\
\hline TU 5 & $40-51$ & Flake, Thinning & 1 & 1.19 & Chert, $>1 / 2^{\prime \prime}$, complete \\
\hline TU 5 & $40-51$ & Flake, Thinning & 1 & 0.76 & Chert, > 1/2", complete \\
\hline TU 5 & $40-51$ & Flake, Utilized & 1 & 20.35 & Novaculite, $>1^{\prime \prime}$, proximal, Uniface \\
\hline TU 5 & $40-51$ & Shatter, Angular & 1 & 4.81 & Novaculite, $>1 / 2^{\prime \prime}$, non-orientable \\
\hline TU 5 & $50-60$ & Flake, Thinning; Late & 1 & 0.34 & Chert, > 1/2", proximal \\
\hline TU 5 & $50-60$ & Flake, Thinning; Late & 1 & 0.32 & Chert, $>1 / 4^{\prime \prime}$, medial-distal \\
\hline TU 5 & $50-60$ & Flake, Core Reduction & 1 & 7.95 & Chert, $>1^{\prime \prime}$, complete \\
\hline TU 5 & $50-60$ & Unmodified stone & 1 & 3.1 & Sandstone \\
\hline \multicolumn{3}{|c|}{ Test Unit Subtotal } & 280 & 462.26 & \\
\hline \multicolumn{3}{|c|}{ Site Total } & 795 & 1379.99 & \\
\hline
\end{tabular}




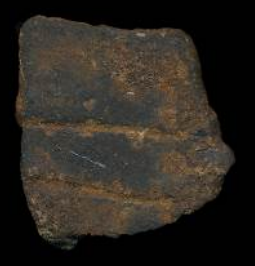

Engraved Aboriginal Ceramic Grog Temper

ST 4, Stratum I, 15-30 cmbs FS 89.07

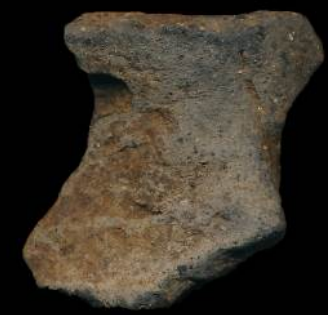

Engraved Aboriginal Ceramic Grog Temper

ST 10, Stratum I, 0-10 cmbs FS 94.06

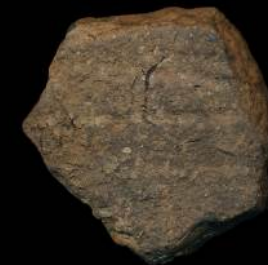

Engraved Aboriginal Ceramic Grog Temper

ST 11, Stratum I, 0-10 cmbs FS 96.13
Incised Aboriginal Ceramic Grog Temper

ST 6 , Strata $1 / I I, 0-20 \mathrm{cmbs}$ FS 90.05

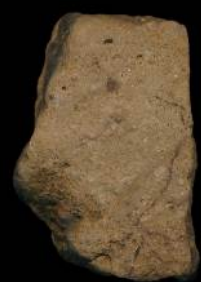

Engraved Aboriginal Ceramic Grog Temper

ST 11, Surface FS 95.01

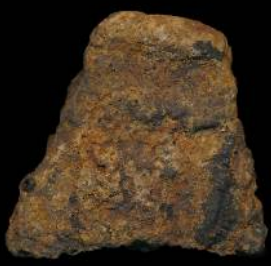

Engraved Aboriginal Ceramic Grog Temper, Rim

ST 11, Stratum II, 10-15 cmbs FS 97.04

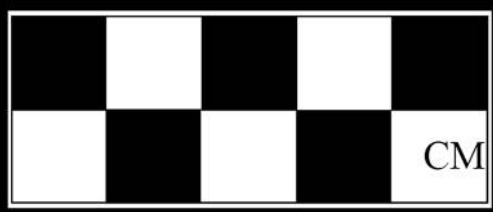

Punctated Aboriginal Ceramic Grog Temper

ST 10, Stratum I, 0-10 cmbs FS 94.01

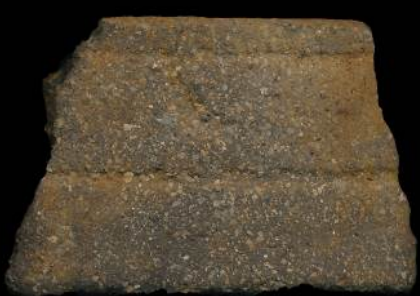

Engraved Aboriginal Ceramic Grog Temper, Rim

ST 11, Stratum I, 0-10 cmbs FS 96.12

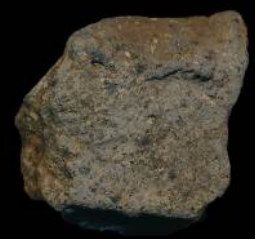

Appliqued Aboriginal Ceramic Grog Temper

ST 12, Surface FS 98.04

Figure 5.26. Select Native American pottery sherds collected from site 41CS55 (1 of 3). 


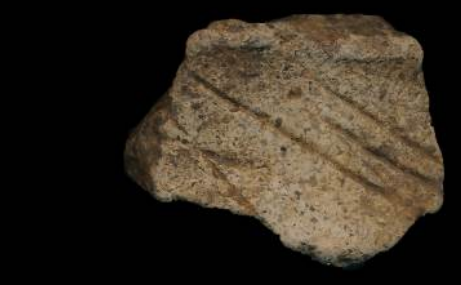

Engraved Aboriginal Ceramic

Grit and Grog Temper

Transect 1, Surface

FS 104.15

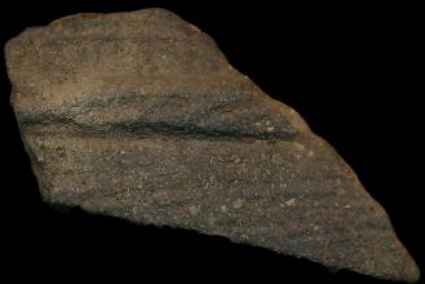

Appliqued Aboriginal Ceramic Grog Temper Transect 2, Surface FS 105.01

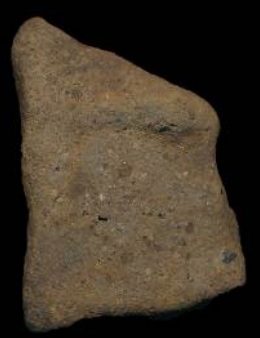

Appliqued Aboriginal Ceramic Grog Temper

Transect 3, Surface FS 106.48

\section{Engraved Aboriginal Ceramic Grog Temper, Rim Transect 1, Surface}

FS 104.16

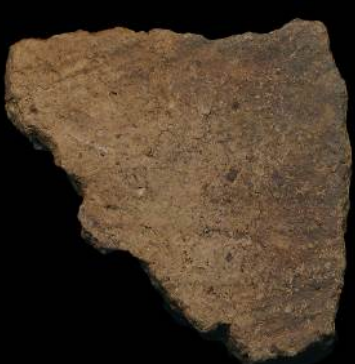

Brushed Aboriginal Ceramic Grog Temper Transect 3, Surface FS 106.45

Punc

Punctated Aboriginal Ceramic Grog Temper Transect 4, Surface

FS 107.28

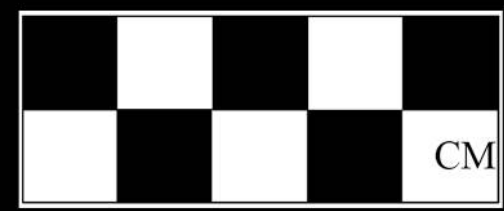

Engraved Aboriginal Ceramic Grog Temper

Transect 1, Surface FS 104.17

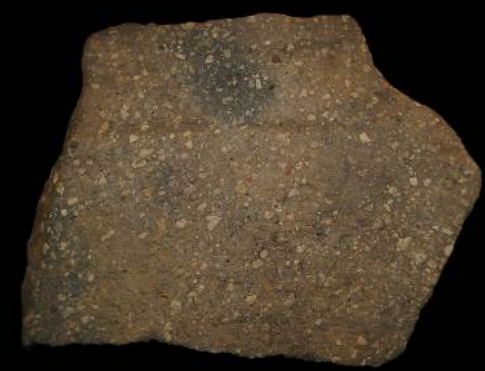

Engraved Aboriginal Ceramic Grog Temper Transect 3, Surface FS 106.47

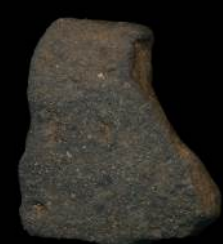

Engraved Aboriginal Ceramic Grog Temper, Rim Transect 5 , Surface FS 107.31

Figure 5.27. Select Native American pottery sherds collected from site 41CS55 (2 of 3). 


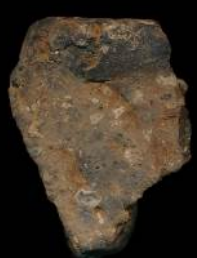

Incised Aboriginal Ceramic Grog Temper, Rim

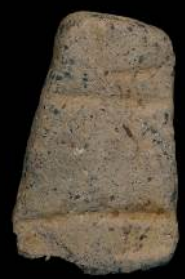

Engraved Aboriginal Ceramic Grog Temper, Rim

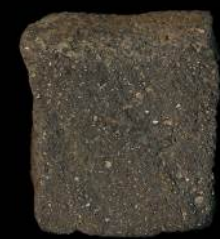

Engraved Aboriginal Ceramic Grog Temper

TU 3, Stratum I, 10-20 cmbd TU 3, Stratum I, 10-20 cmbd TU 3, Stratum 1, 10-20 cmbd FS 115.23

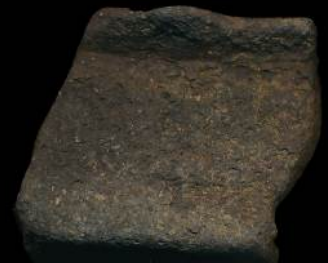

Plain Aboriginal Ceramic Grog Temper, Rim TU 4, Surface FS 119.11
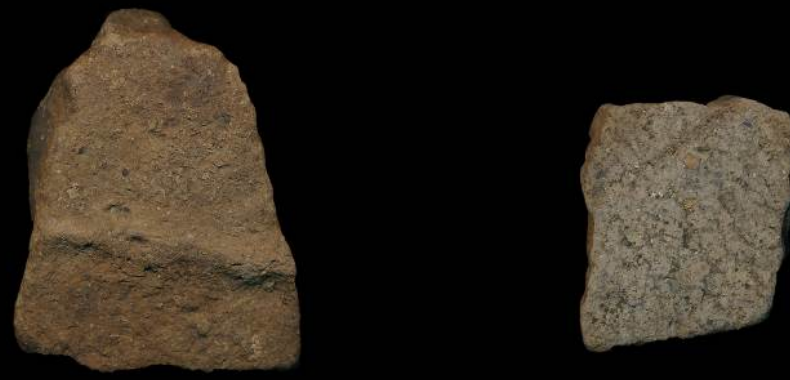

Appliqued Aboriginal Ceramic

\section{Grog Temper}

TU 4, Surface FS 119.12
Engraved Aboriginal Ceramic Grog Temper TU 4, Surface FS 119.13

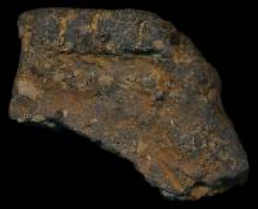

Incised Aboriginal Ceramic

Grog Temper, Rim

TU 4, Stratum I, 10-15 cmbd

FS 120.24

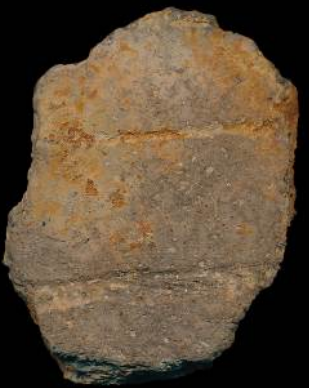

Engraved Aboriginal Ceramic Grog Temper

TU 4, Stratum III, 50-60 cmbd FS 125.06

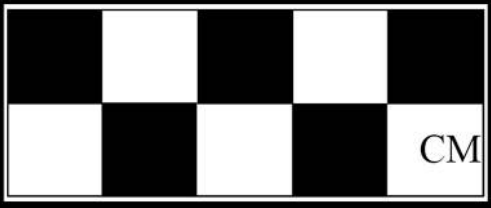

Figure 5.28. Select Native American pottery sherds collected from site 41CS55 (3 of 3). 


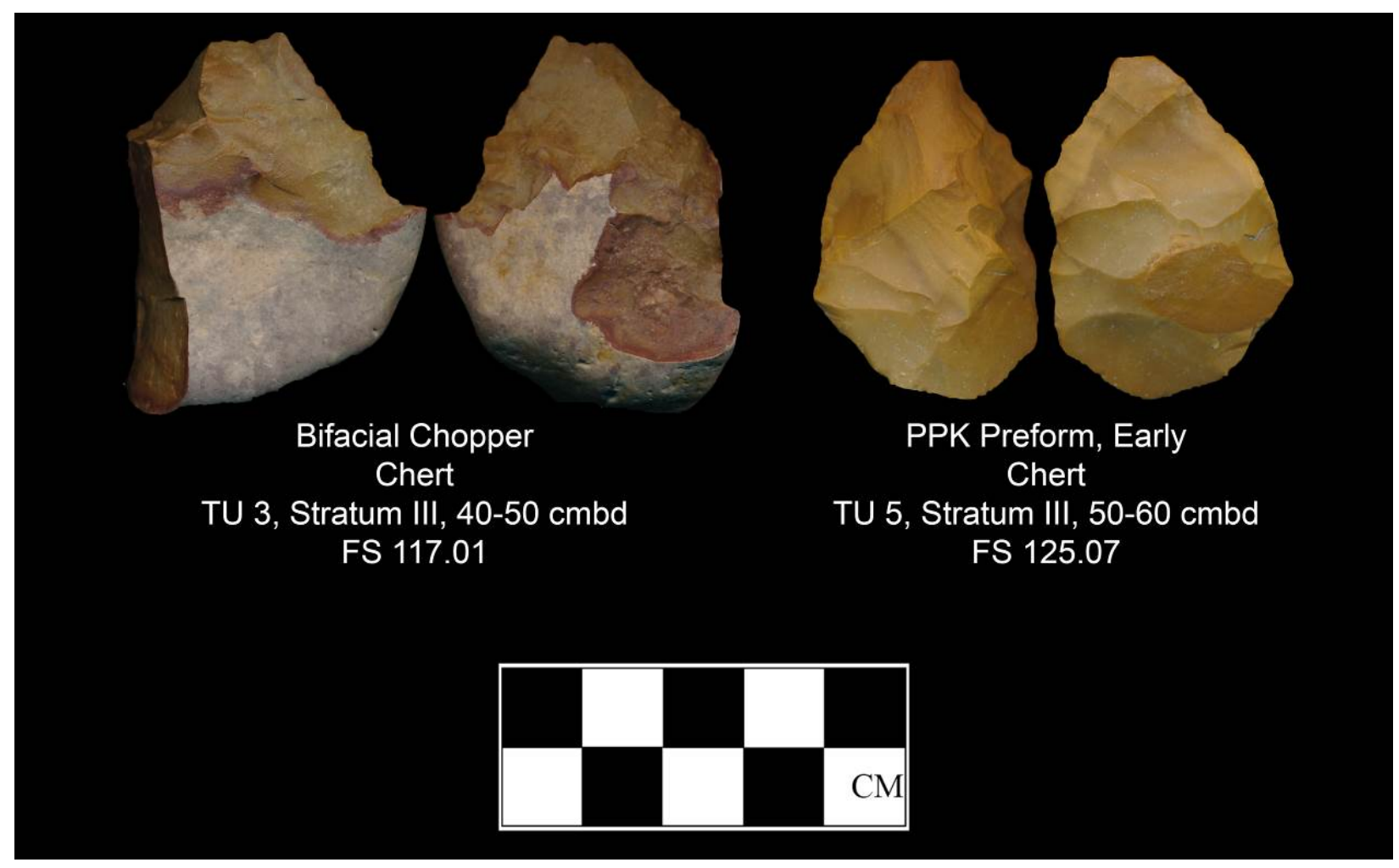

Figure 5.29. Select lithic artifacts collected from site 41CS55. 


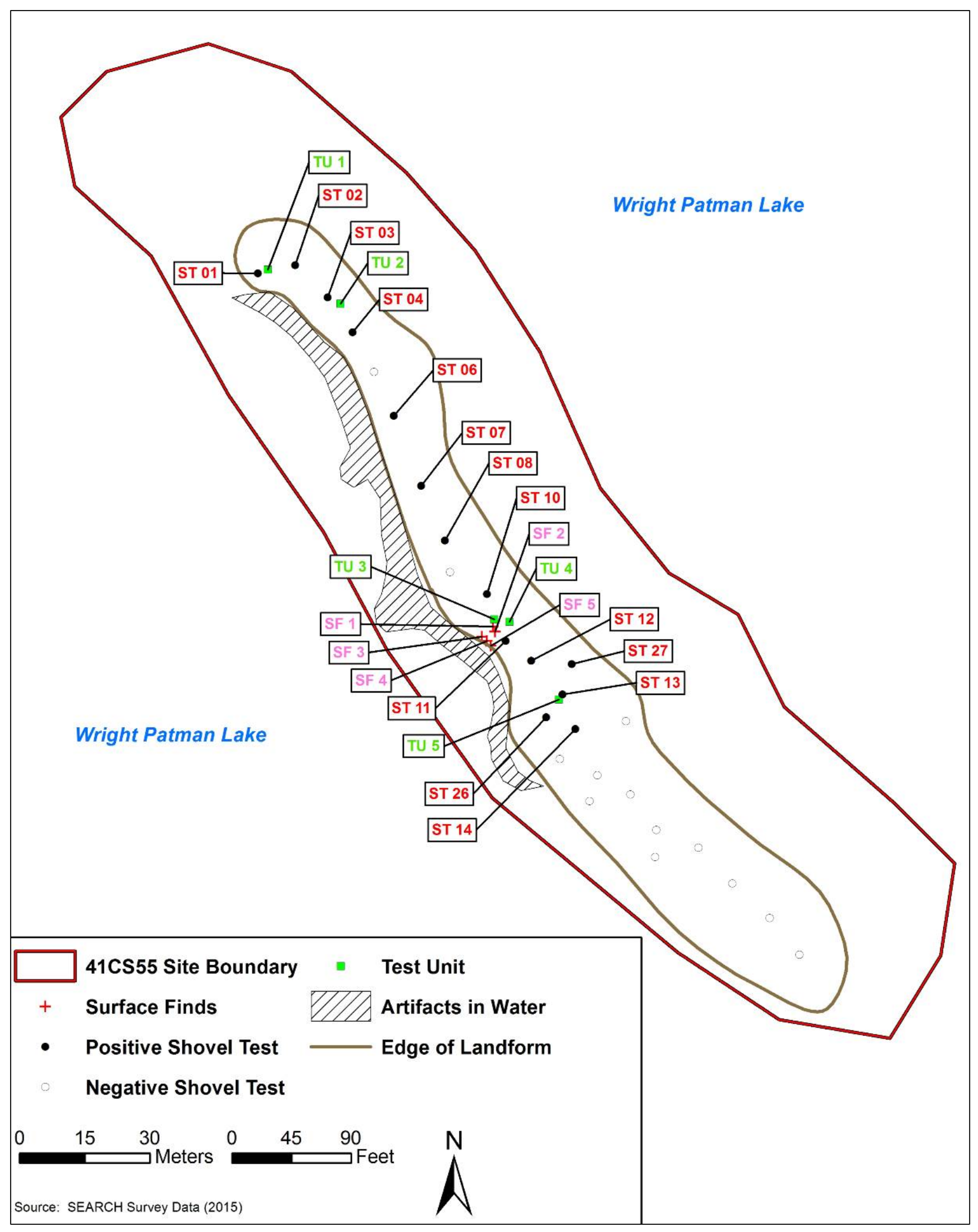

Figure 5.30. SEARCH 2015 fieldwork plan map for site 41CS55. 


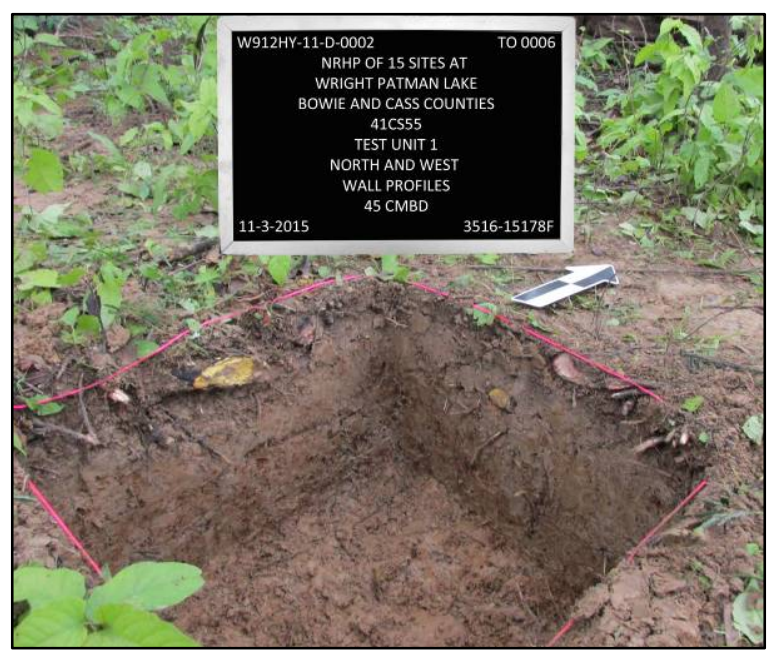

Figure 5.31. Typical soil profile at site 41CS55.

Based on the distribution of surface and subsurface artifacts, TU 1 and TU 2 were placed within the northern artifact locus, while TU 3 and TU 4 were placed in the central artifact locus. All test units produced artifact assemblages similar on composition to artifacts collected from shovel tests within each locus (see Table 5.4). Test Units 1 and 2 artifacts were dominated by lithic debitage and debris, while artifacts from TU 3 and TU 4 included a mixture of Native American pottery sherds and lithic debris. Test Unit 5 was excavated along the southern extent of the sitewide artifact distribution and produced a small number of Native American pottery sherds and lithic debitage.

\section{Recommendation}

Site 41CS55 is a large Native American site on a low sandbar/island surrounded by Wright Patman Lake. The large quantity of lithic debitage along with grog-tempered pottery sherds, lithic tools, and faunal and botanical remains suggest that site 41CS55 was a sizable Caddo occupation overlooking the Sulphur River prior to the inundation of the lake. The discernible concentrations of artifacts in the northern and central portions of the site suggest differential use of space, a typical hallmark of larger occupations such as villages or hamlets. The artifact assemblage, examined in tandem with absolute dating methods (radiocarbon or thermoluminescence), has the potential to offer insight into the daily lifestyle of Native American inhabitants of the site. It is the recommendation of SEARCH that additional work be performed to evaluate the NRHP status of site 41CS55 and mitigate adverse effects of the proposed pool rise for meeting the Ultimate Rule Curve. 


\section{SITE 41CS58}

Briggs and Malone recorded site 41CS58 (Figure 5.32) in February 1970. They identified the site at an elevation between 222 and $223 \mathrm{ft}$ amsl on a low, willow-covered peninsula that projects into Wright Patman Lake. Originally, this landform was likely a terrace along the Sulphur River. The artifact assemblage collected by Briggs and Malone (1970:Figure 14, Table 2; Figure 15, Table $3 A)$ includes a large number of lithic artifacts, primarily secondary and tertiary flakes, along with a limited quantity of Native American pottery sherds.

SEARCH archaeologists visited site 41CS58 on November 4, 2015. The pool elevation measured $226.15 \mathrm{ft}$ amsl. The site boundary as presented in the USACE Fort Worth Wright Patman Lake GIS database covers $1,015 \mathrm{~m}^{2}(0.25 \mathrm{ac})$ within Wright Patman Lake (see Figure 5.32).

During the initial reconnaissance at site 41CS58, SEARCH archaeologists determined that the plotted location as listed on the TARL site form (TARL 1970f) and within the USACE Fort Worth Wright Patman Lake GIS database was completely submerged (Figure 5.33), resulting in no fieldwork at the site. As a result, the site was not assessed during this project and site 41CS117 was chosen from the Contingency List. The NRHP status of site $41 \mathrm{CS} 58$ remains undetermined.

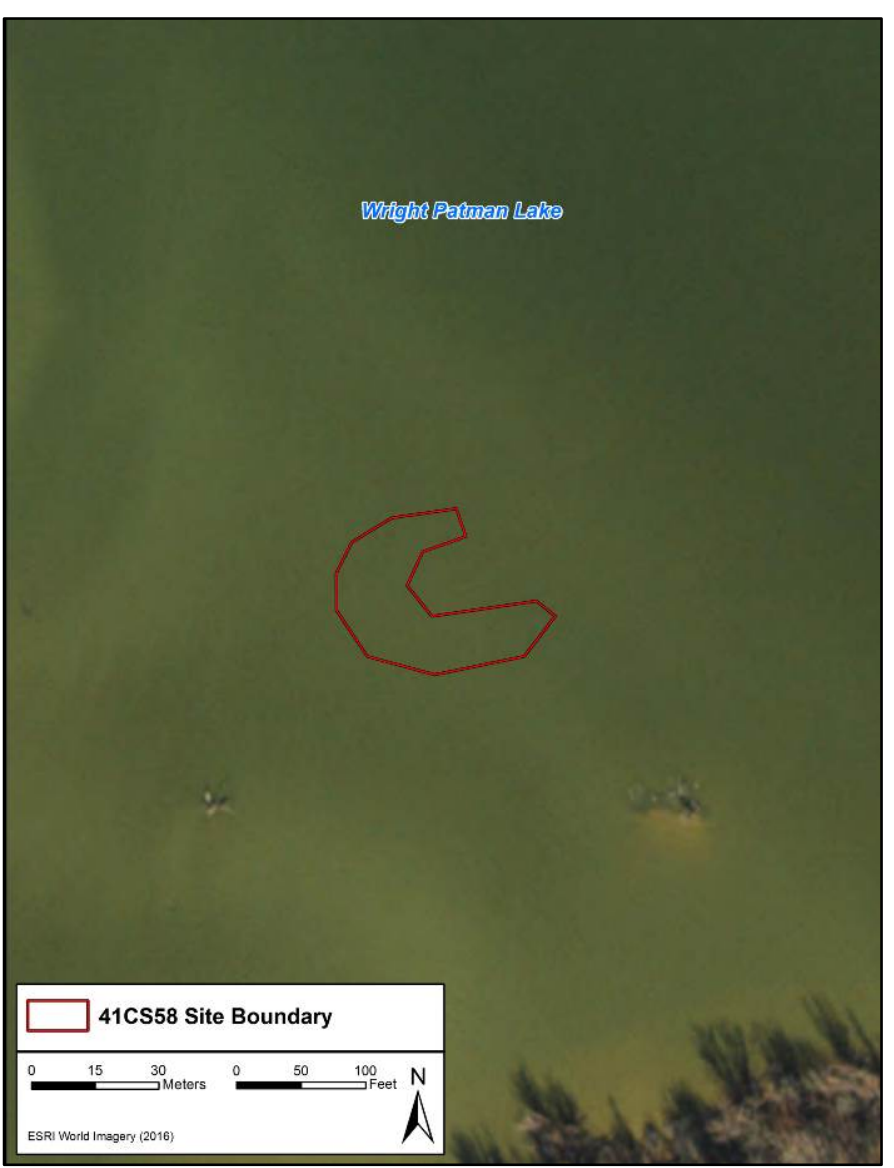

Figure 5.32. Location of site 41CS58.

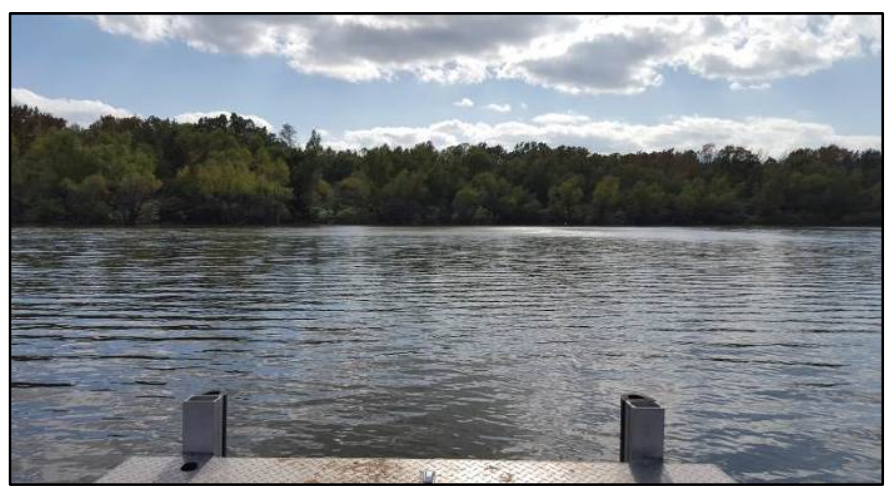

Figure. 5.33. Photo from the plotted location of site 41CS58, facing south. 


\section{SITE 41 CS73}

Briggs and Malone recorded site $41 \mathrm{CS73}$ (Figure 5.34) in February 1970. They identified the site at an elevation between 222 and $225 \mathrm{ft}$ amsl on a long, sandy beach adjacent to an unnamed tributary of Jackson Creek (TARL 1970g). The artifact assemblage includes a small collection of lithic debitage debris, composed of eight secondary flakes, nine tertiary flakes, one core, and one heavy biface (Briggs and Malone 1970:Figure 15, Table 3A).

In October 2015, SEARCH archaeologists returned to site 41CS73 to evaluate its NRHP status in support of the proposed pool level rise to meet the Ultimate Rule Curve at Wright Patman Lake. The site boundary as presented in the USACE Fort Worth Wright Patman Lake GIS database covers $2,080 \mathrm{~m}^{2}(0.51 \mathrm{ac})$ along a low terrace edge on the south side of an unnamed tributary of Jackson Creek. Vegetation consists of a mixture of hardwoods and pines with a relatively open understory on the upper terrace and bottomland scrub along the northwestern periphery of the site (Figures $\mathbf{5 . 3 5}$ and 5.36).

Ground surface visibility ranged between 20 and 50 percent and was typically predicated on the amount of associated leaf litter. A pedestrian survey was conducted along transects spaced 5 $\mathrm{m}$ apart, beginning from the southern site boundary and extending 30 to $35 \mathrm{~m}$ north and west. No artifacts were identified during the pedestrian survey.

Figure Redacted

Figure 5.34. Location of site 41CS73. 


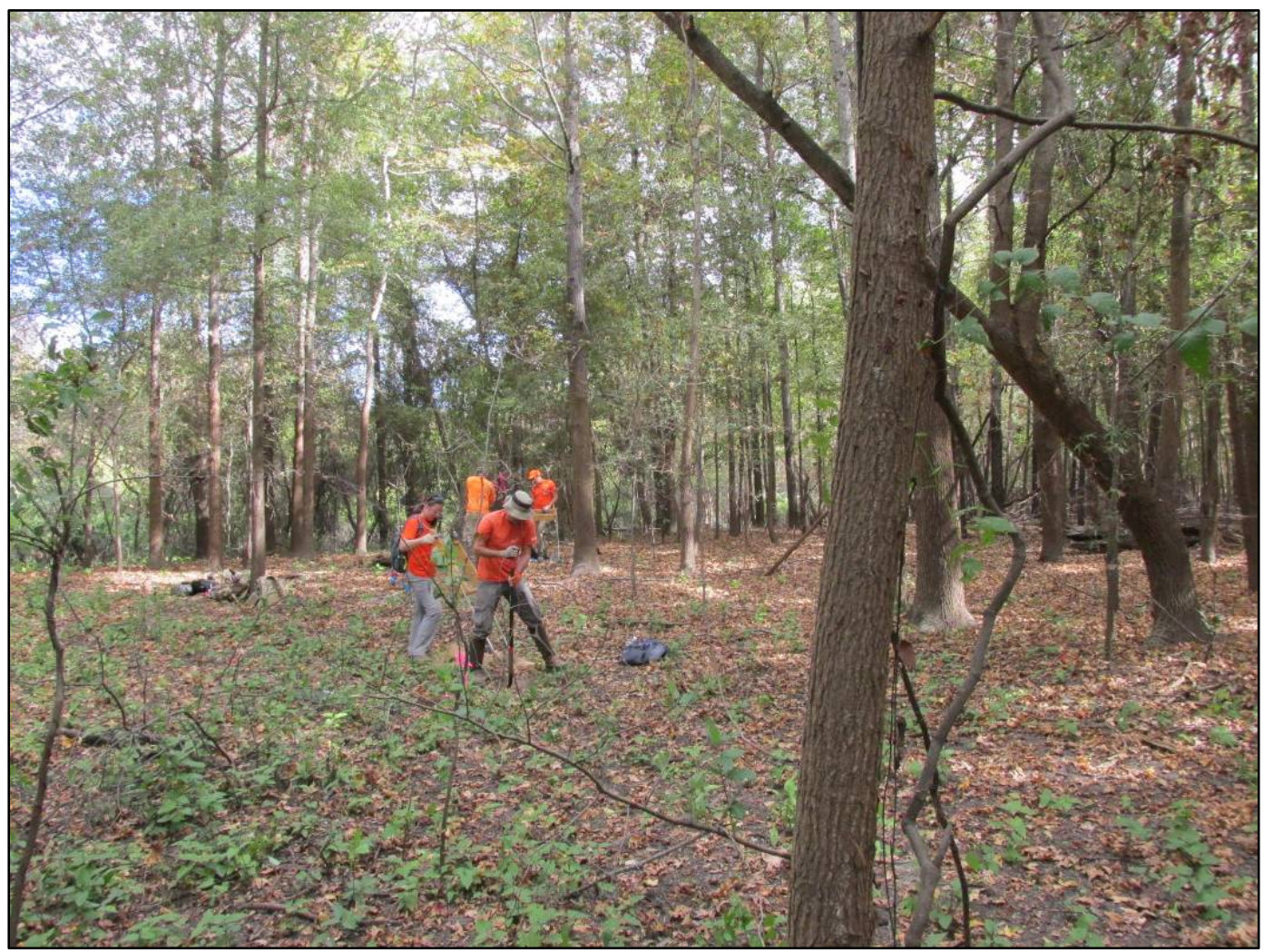

Figure 5.35. Typical upland vegetation at site 41CS73, facing northeast.

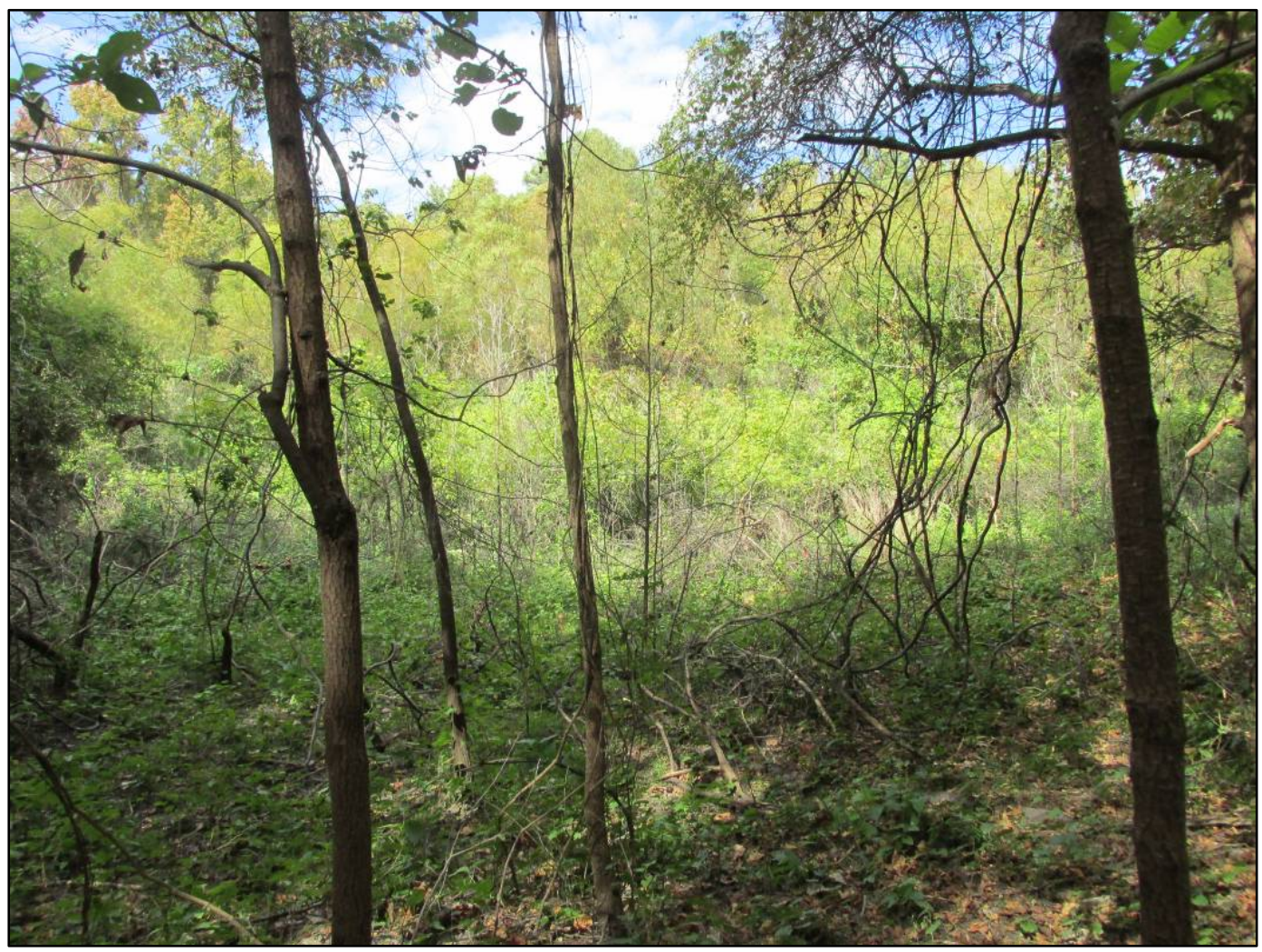

Figure 5.36. Lowland/wetland vegetation along the northwest periphery of site 41CS73, facing northwest. 


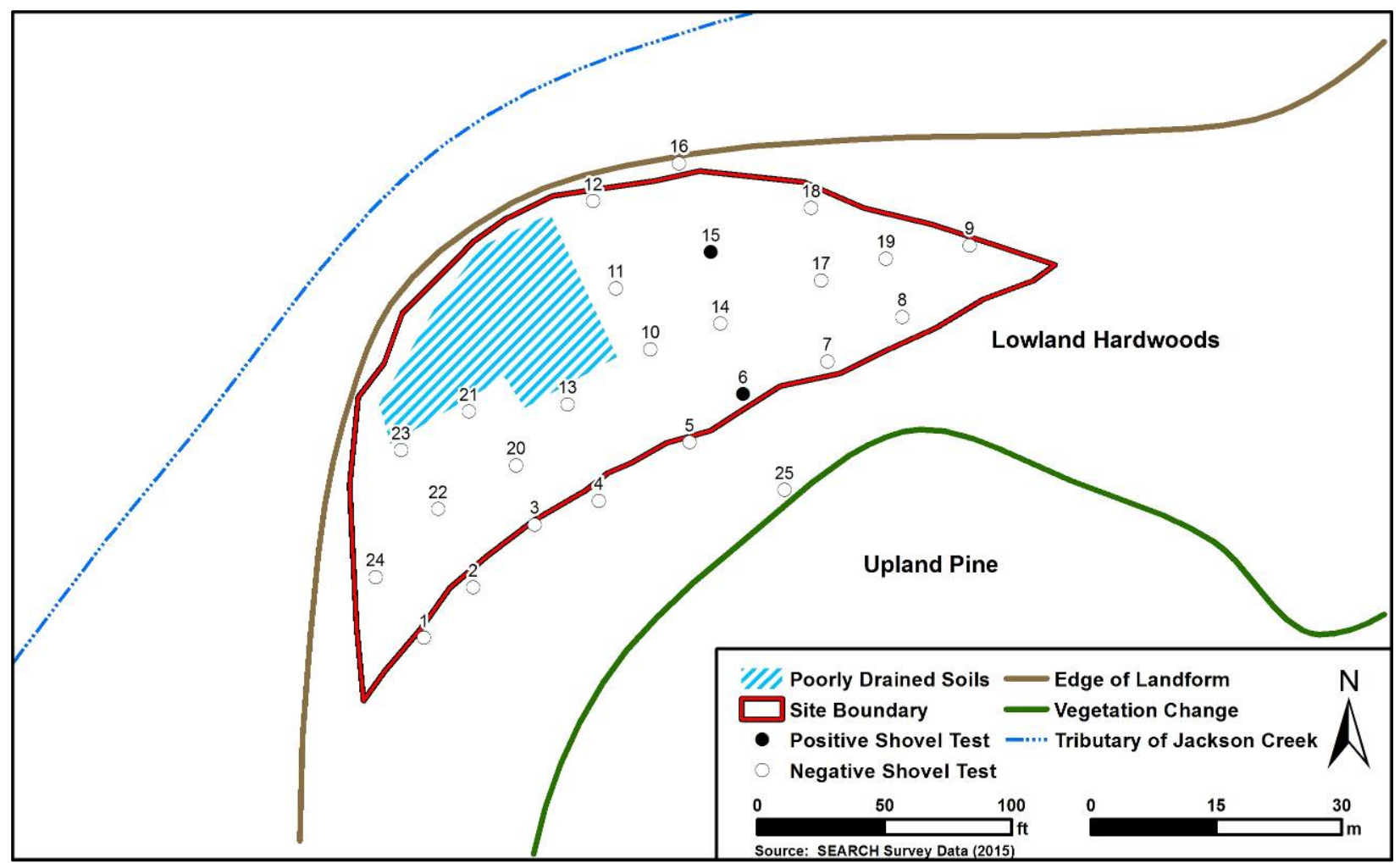

Figure 5.37. SEARCH 2015 fieldwork plan map for site 41CS73.

Subsurface testing included the excavation of 25 shovel tests, of which two (ST 6 and ST 15) were positive for cultural material (Figure 5.37). Shovel Test 6 yielded one chert late thinning flake from approximately $60 \mathrm{cmbs}$, while ST 15 produced a single chert unspecified flake between 30 and $40 \mathrm{cmbs}$. Due to the low artifact density, no test units were excavated at site 41CS73. A typical soil profile displayed gray (10YR 6/1) to light gray (10YR 7/1) fine sand from 0 to $10 \mathrm{cmbs}$, very pale brown (10YR 7/4) sandy loam from 10 to $35 \mathrm{cmbs}$, and strong brown (7.5YR 5/6) clayey sand from 35 to $65 \mathrm{cmbs}$ (Figure 5.38).

\section{Recommendation}

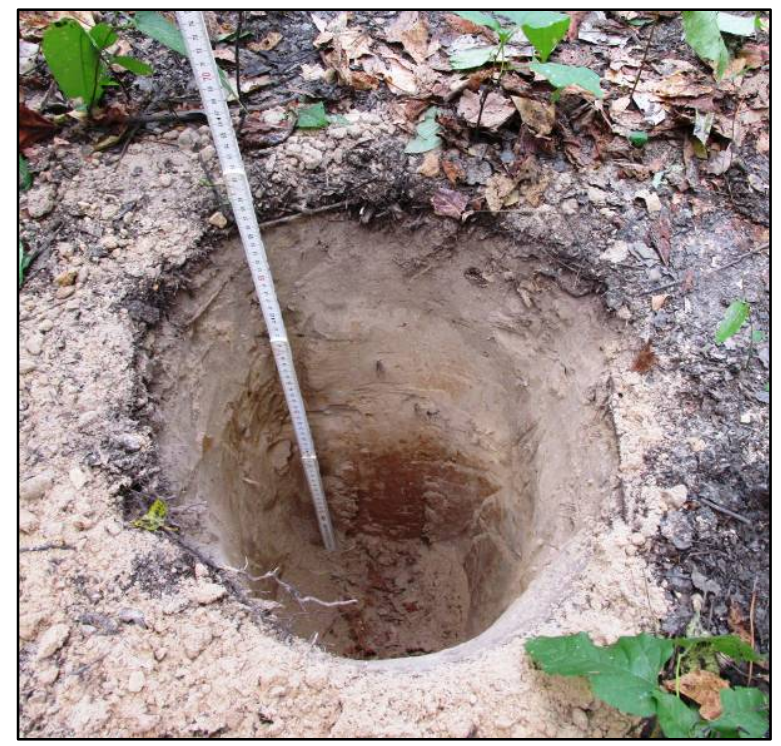

Figure 5.38. Typical soil profile at site 41CS73.

In October 2015, SEARCH archaeologists conducted pedestrian survey and subsurface testing across site 41CS73. The artifacts are consistent with previous cultural material collected by Briggs and Malone in 1970 and the site is characterized as a low-density lithic scatter. Based on the limited number of artifacts, 41CS73 was likely a small campsite or resource extraction point, perhaps used as a seasonal or limited-activity locus, developed to exploit multiple ecological 
niches along Jackson Creek. Based on the results of previous and current fieldwork, it is the opinion of SEARCH that site 41CS73 does not meet the Secretary of the Interior's criteria for listing in the NRHP and no further work is recommended.

\section{SITE 41 CS76}

Briggs and Malone recorded site 41CS76 (Figure 5.39) in February 1970. They identified the site at an elevation between 222 and $228 \mathrm{ft}$ amsl on a sandy beach along the western bank at the mouth of Armstrong Creek (TARL 1970h). Artifacts consist of two pottery sherds and a relatively robust lithic assemblage composed of flake debitage, unifacial tools, and miscellaneous chunks (Briggs and Malone 1970:Figure 14, Table 2; Figure 15, Table 3B).

SEARCH archaeologists visited site 41CS76 on November 6, 2015. The pool elevation measured $226.50 \mathrm{ft}$ amsl. The site boundary as presented in the USACE Fort Worth Wright Patman Lake GIS database covers $781 \mathrm{~m}^{2}(0.19 \mathrm{ac})$ along the western bank at the mouth of Armstrong Creek. The terrain consists of a scoured and eroded beach line and terrace toe fronting Wright Patman Lake backed by a broad, flat upland terrace. The beach is typically covered in short, scrubby grasses and smaller saplings (Figure 5.40), while the upland terrace supports mixed hardwoods and pine with a relatively open understory of small saplings and low grasses (Figure 5.41).

During the initial reconnaissance at site 41CS76, SEARCH archaeologists determined that the plotted site location as listed on the TARL site form and within the USACE Fort Worth Wright Patman Lake GIS database was largely submerged. As a result, nearly all of the archaeological investigation occurred across the uplands adjacent to the site's western and southern boundary.

\section{Figure Redacted}

Figure 5.39. Location of site $41 \mathrm{CS76}$. 


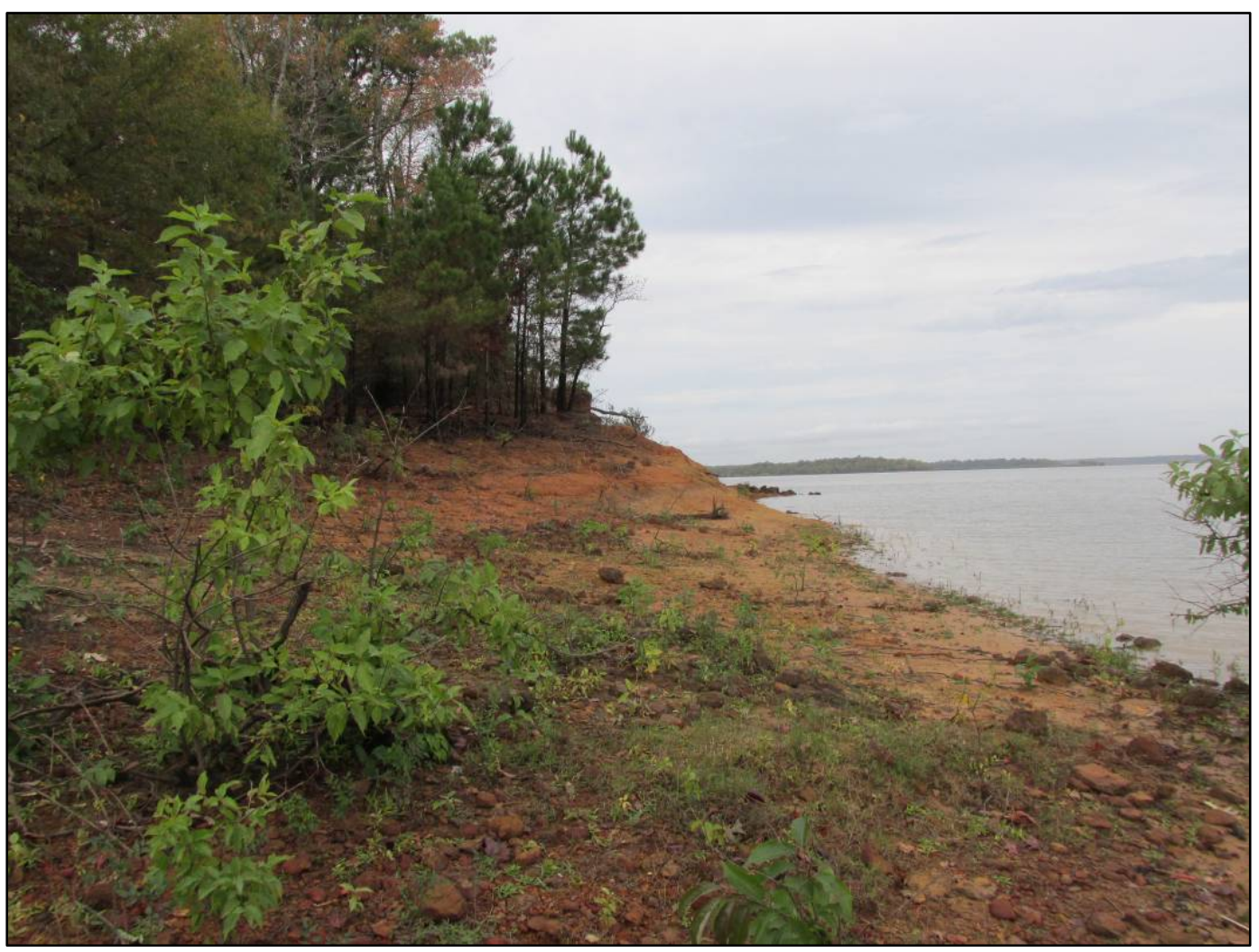

Figure 5.40. Typical vegetation along the shoreline at site 41CS76, facing northwest.

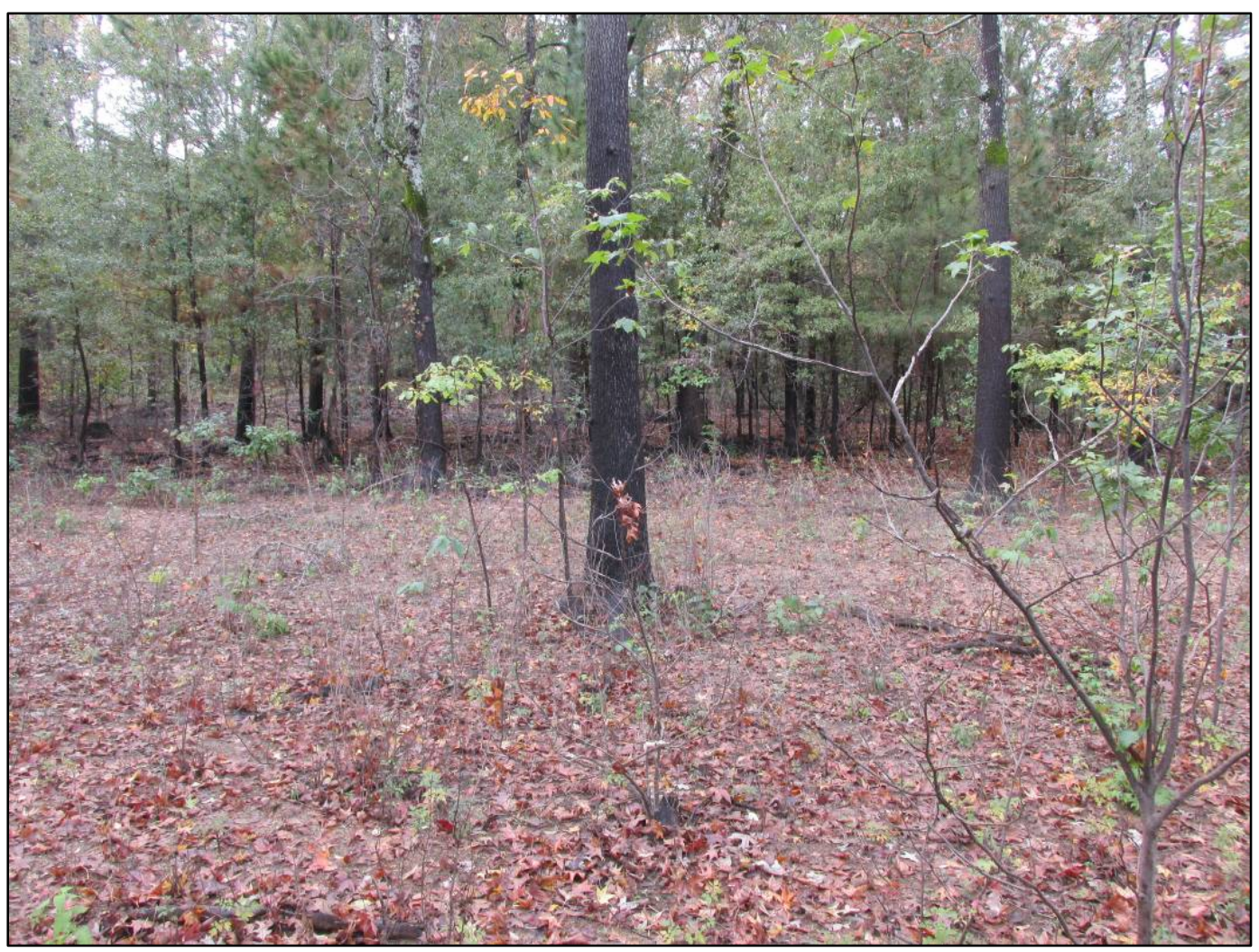

Figure 5.41. Typical vegetation along uplands west of site 41CS76, facing southwest. 


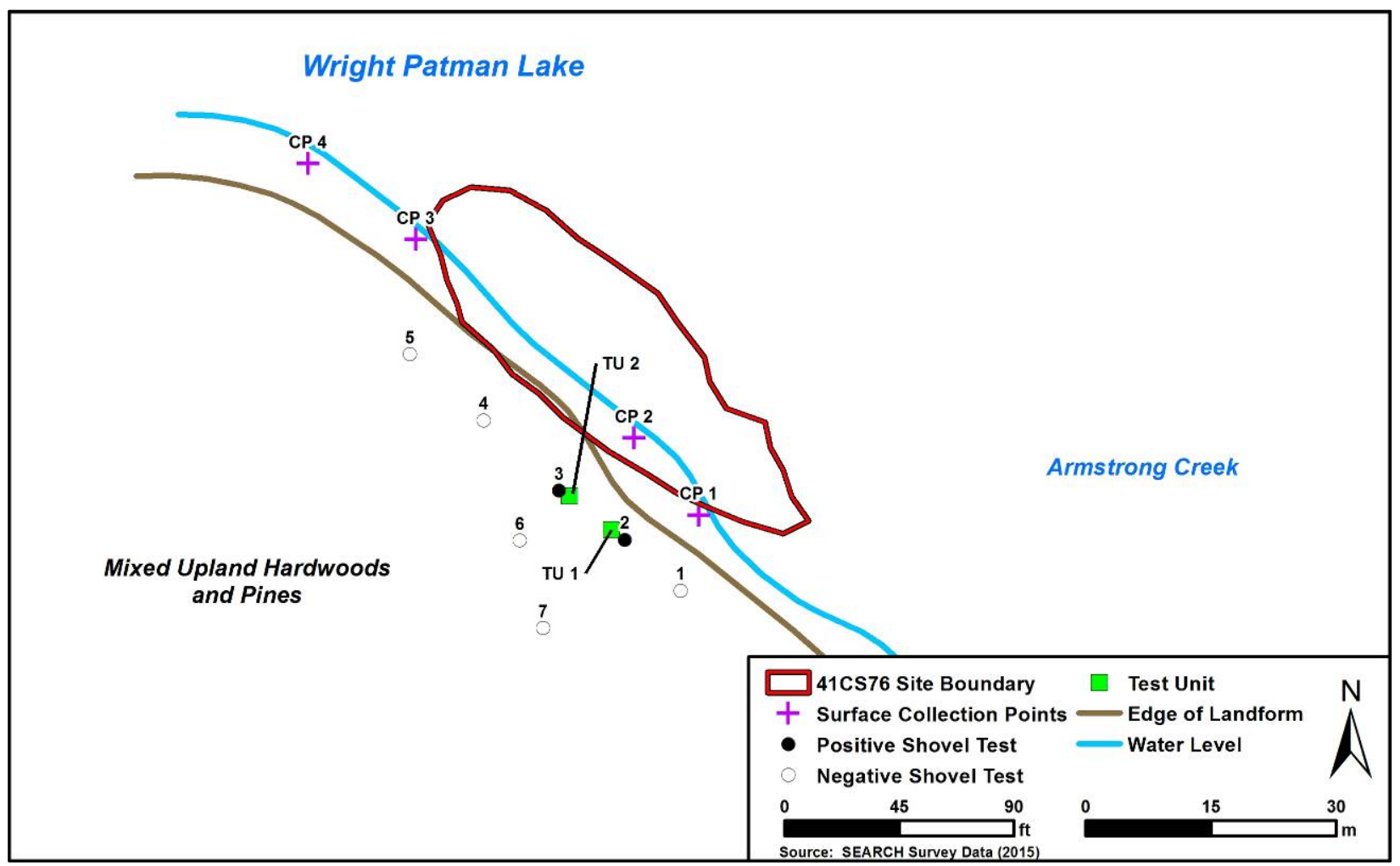

Figure 5.42. SEARCH 2015 fieldwork plan map for site 41CS76.

Ground surface visibility ranged between 20 and 100 percent with better visibility occurring near the waterline. A pedestrian survey was conducted along transects that measured the length of the site and spaced $5 \mathrm{~m}$ apart, beginning at the water line and extending 20 to $30 \mathrm{~m}$ south and west. Five artifacts were collected from four surface locations.

Subsurface testing included the excavation of seven shovel tests, of which two (ST 2 and 3) were positive for cultural material $(n=5)$, and two $50-x-50-\mathrm{cm}$ test units, both of which produced artifacts $(n=23)$ (Figure $\mathbf{5 . 4 2}$ ). A typical soil

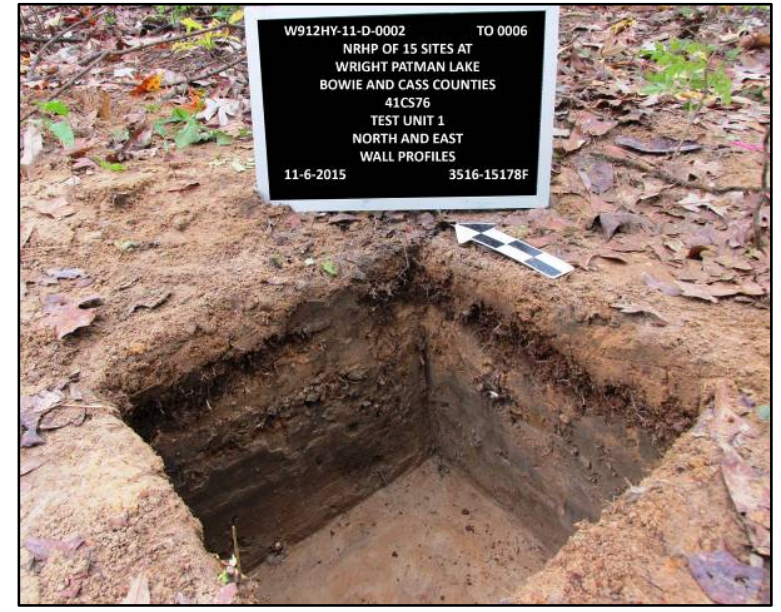

Figure 5.43. Typical soil profile at site 41CS76. profile displayed dark reddish-brown (5YR 3/4) coarse loose sand from 0 to $10 \mathrm{cmbs}$, yellowishred (5YR 5/6) medium sand from 10 to $20 \mathrm{cmbs}$, and reddish-brown (5YR 4/4) sandy, clay loam from 20 to $50 \mathrm{cmbs}$ (Figure 5.43). Table 5.5 presents all artifacts recovered by SEARCH archaeologists from site 41CS76. 
Table 5.5. Artifact Inventory for Site 41CS76.

\begin{tabular}{|c|c|c|c|c|c|}
\hline Provenience & $\begin{array}{l}\text { Depth } \\
\text { (cmbs) }\end{array}$ & Description & Count & $\begin{array}{c}\text { Weight } \\
\text { (g) }\end{array}$ & Comments \\
\hline CP 1 & Surface & Flake, late thinning & 1 & 0.18 & Chert, $>1 / 4^{\prime \prime}$, medial-distal \\
\hline $\mathrm{CP} 2$ & Surface & Flake, thinning & 1 & 1.22 & Chert, > 1/2", complete \\
\hline CP 2 & Surface & Flake, late thinning & 1 & 0.22 & Chert, > 1/4", complete \\
\hline CP 3 & Surface & Plain pottery sherd & 1 & 12.02 & Body, grog temper \\
\hline CP 4 & Surface & Tested cobble & 1 & 24.44 & Chert \\
\hline \multicolumn{3}{|c|}{ Surface Collection Point Subtotal } & 5 & 38.08 & \\
\hline ST 2 & $0-10$ & Flake, thinning & 1 & 1.45 & Chert, > 1/2", proximal \\
\hline ST 2 & $0-10$ & Flake, late thinning & 1 & 0.09 & Chert, > 1/4", non-orientable \\
\hline ST 2 & $0-10$ & Shatter, angular & 1 & 7.60 & Chert, > 1" \\
\hline ST 3 & $15-30$ & Flake, late thinning & 1 & 0.60 & Chert, > 1/2", complete \\
\hline ST 3 & $15-30$ & Flake, late thinning & 1 & 0.12 & Chert, $>1 / 4^{\prime \prime}$, proximal \\
\hline \multicolumn{3}{|c|}{ Shovel Test Subtotal } & 5 & 9.86 & \\
\hline TU 1 & $0-10$ & Flake, thinning & 9 & 5.52 & Chert \\
\hline TU 1 & $0-10$ & Flake, late thinning & 2 & 0.27 & Chert \\
\hline TU 1 & $10-20$ & Flake, early reduction & 2 & 1.98 & Chert \\
\hline TU 1 & $10-20$ & Flake, late thinning & 1 & 0.31 & Chert \\
\hline TU 1 & $20-30$ & Flake, early reduction & 1 & 0.36 & Chert \\
\hline TU 1 & $30-40$ & Flake, thinning & 3 & 1.64 & Chert \\
\hline TU 1 & $30-40$ & Flake, late thinning & 2 & 0.13 & Chert \\
\hline TU 1 & $40-50$ & Flake, thinning & 1 & 1.24 & Chert \\
\hline TU 1 & $40-50$ & Flake, late thinning & 1 & 0.24 & Chert \\
\hline TU 2 & $0-10$ & Flake, late thinning & 1 & 0.17 & Chert \\
\hline \multicolumn{3}{|c|}{ Test Unit Subtotal } & 23 & 11.86 & \\
\hline \multicolumn{3}{|c|}{ Site Total } & 33 & 59.80 & \\
\hline
\end{tabular}

\section{Recommendation}

In November 2015, a relatively large portion of site 41CS76 was inundated by the rising pool level at Wright Patman Lake. Exposed portions of the site and the adjacent uplands were tested to determine if intact cultural deposits existed within and adjacent to the defined site boundary. The artifact assemblage collected in the vicinity of site 41CS76 is a relatively small, diffuse scatter of lithic debitage located on a low beach strand and adjacent upland terrace along the western boundary of the site. As only a portion of the site could be tested, SEARCH recommends that the NRHP status of site 41 CS76 remain undetermined until such time as the submerged deposits can be evaluated. Furthermore, the extent of the site boundary should be addressed during supplemental archaeological testing. 


\section{SITE 41 CS78}

Briggs and Malone recorded site 41CS78 (Figure 5.44) in February 1970. The site was located at an elevation between 220 and $225 \mathrm{ft}$ amsl on low, flat peninsula near the inlet to Hams Creek. The site was partially submerged as artifacts were identified within the water surrounding the site (TARL 1970i). Artifacts include a large collection of lithic debitage, tools, and miscellaneous chunks along with a limited quantity of Native American pottery sherds.

In 1995, Geo-Marine, Inc., visited site 41CS78 as part of a cultural resources inventory for timber-harvesting parcels at Wright Patman Lake (Cliff et al. 1996). Geo-Marine archaeologists conducted a pedestrian survey and excavated 10 shovel tests within the site boundary, identifying a large number of lithics and pottery sherds across the surface, but only collecting two artifacts from subsurface contexts. Cliff et al. (1996:47) noted that the site had been severely eroded, but suggested that the site retained research potential based on the presence of subsurface archaeological deposits. As a result, they recommended that the site's NRHP status remain undetermined until further work could complete the evaluation process.

SEARCH archaeologists returned to site 41 CS78 on November 6, 2015. At that time, the pool level at Wright Patman Lake measured $226.50 \mathrm{ft}$ amsl. The site boundary as presented in the USACE Fort Worth Wright Patman Lake GIS database covers $9,520 \mathrm{~m}^{2}(2.35 \mathrm{ac})$ across a low terrace on the south shore of Wright Patman Lake. The site, as plotted, is inundated;

\section{Figure Redacted}

Figure 5.44. Location of site 41CS78. 


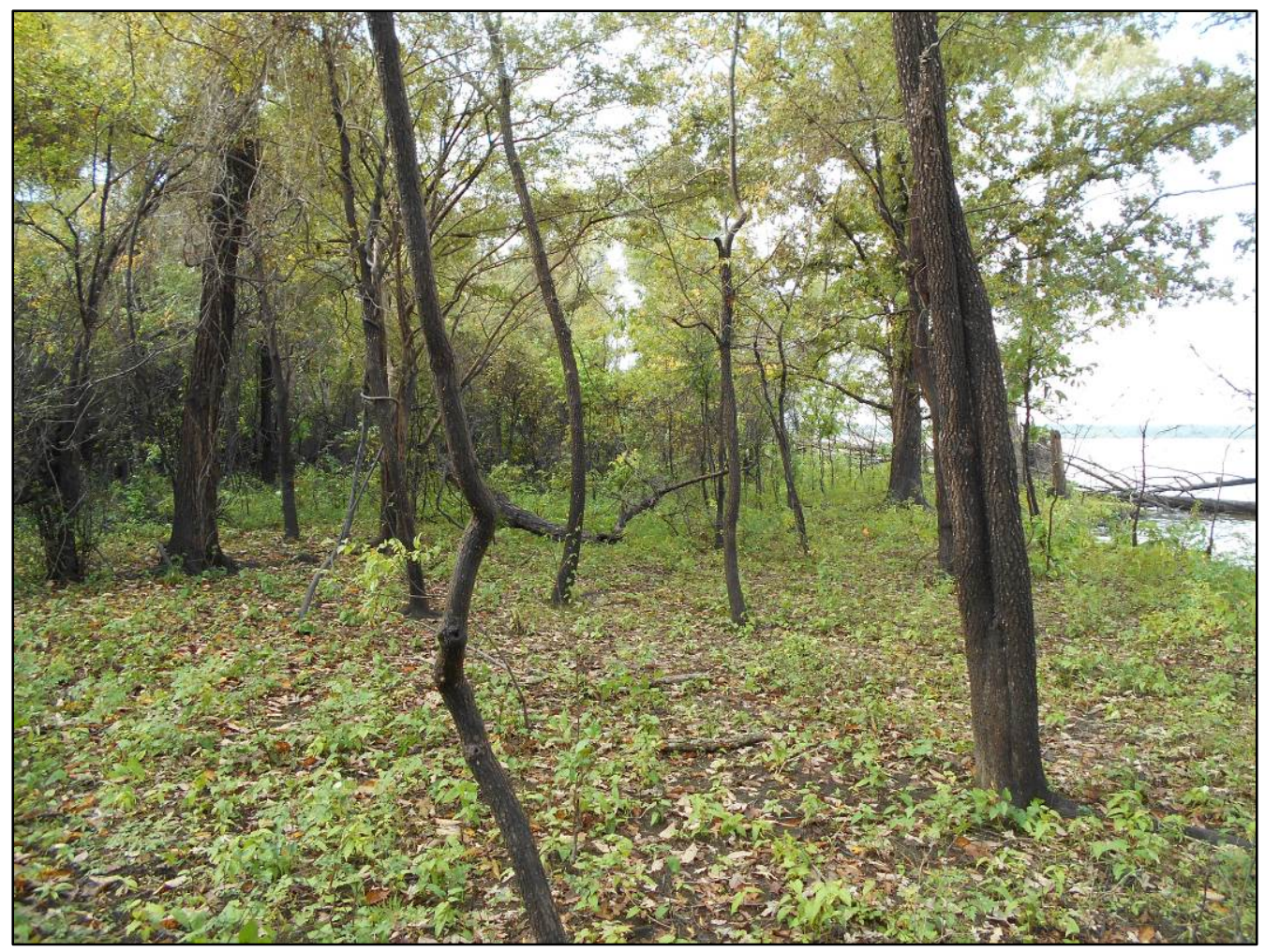

Figure 5.45. Typical vegetation at site 41CS78.

vegetation across the uplands south of the site support a mixture of hardwoods with a moderately dense understory of saplings, vines, and smaller shrubs (Figure 5.45).

During the initial reconnaissance at site 41CS78, SEARCH archaeologists determined that the plotted site location as provided in the USACE Fort Worth Wright Patman Lake GIS database was completely submerged by the current lake level $(226.50 \mathrm{ft}$ amsl). As a result, investigations focused on pedestrian survey and subsurface testing across exposed shorelines and the low terrace south of the site boundary.

The pedestrian survey consisted of a complete walkover of the upland south of the site for a distance equal to the length and width of the plotted site boundary. Ground visibility was between 0 and 10 percent, precluding a systematic transect approach. Furthermore, lake levels completely inundated the exposed shoreline. Nevertheless, three areas with surface artifacts were identified at the western and eastern ends of the survey area. These artifacts are summarized by provenience in Table 5.6.

Subsurface testing included the excavation of 47 shovel tests, of which 11 were positive for cultural material, and four 50-x-50-cm test units, of which three produced artifacts (Figure 5.46, see Table 5.6). A typical soil profile displayed very dark brown (10YR 2/2) fine sand from 0 to $10 \mathrm{cmbs}$, brown (10YR 4/3) fine sand from 10 to $15 \mathrm{cmbs}$, mottled brown (10YR 5/4), yellowishbrown (10YR 4/4) and dark reddish-brown (5YR 3/3) sandy clay loam from 15 to $40 \mathrm{cmbs}$ (Figure 5.47). 
Table 5.6. Artifact Inventory for Site 41CS78.

\begin{tabular}{|c|c|c|c|c|c|}
\hline Provenience & $\begin{array}{l}\text { Depth } \\
\text { (cmbs) }\end{array}$ & Description & Count & $\begin{array}{l}\text { Weight } \\
\text { (g) }\end{array}$ & Comments \\
\hline CP 1 & Surface & Flake, core reduction & 1 & 13.44 & Chert, > 1", complete \\
\hline CP 1 & Surface & Flake, early reduction & 2 & 12.18 & Chert, >1", complete \\
\hline $\mathrm{CP} 1$ & Surface & Flake, early reduction & 1 & 1.26 & Chert, > 1/2", proximal \\
\hline CP 1 & Surface & Flake, early reduction & 1 & 2.33 & Chert, $>1 / 2^{\prime \prime}$, complete \\
\hline CP 1 & Surface & Flake, early reduction & 1 & 5.84 & Quartzite, $>1 "$, complete \\
\hline CP 1 & Surface & Flake, thinning & 2 & 2.50 & Chert, $>1^{\prime \prime}$, complete \\
\hline CP 1 & Surface & Flake, thinning & 2 & 0.87 & Chert, > 1/2", complete \\
\hline $\mathrm{CP} 1$ & Surface & Shatter, angular & 1 & 38.18 & Chert, > 1", proximal \\
\hline CP 1 & Surface & Core & 1 & 16.66 & Chert \\
\hline CP 1 & Surface & PPK preform, early stage & 1 & 72.41 & Chert, complete bifacially worked \\
\hline CP 1 & Surface & Sandstone, ferruginous & 1 & 8.51 & React to magnet \\
\hline CP 1 & Surface & Sandstone, unmodified & 1 & 4.81 & \\
\hline CP 1 & Surface & Possible cultural mat-lithic & 1 & 1.09 & Heavily worn \\
\hline CP 1 & Surface & $\begin{array}{l}\text { Aboriginal ceramic, } \\
\text { burnished }\end{array}$ & 1 & 10.30 & Grog/clay temper, body \\
\hline $\mathrm{CP} 2$ & Surface & Flake, pressure & 1 & 0.14 & Chert, $>1 / 4^{\prime \prime}$, complete \\
\hline $\mathrm{CP} 2$ & Surface & Flake, thinning; late & 5 & 0.81 & Chert, $>1 / 4^{\prime \prime}$, complete \\
\hline $\mathrm{CP} 2$ & Surface & Flake, thinning; late & 2 & 0.24 & Chert, > 1/4", proximal \\
\hline $\mathrm{CP} 2$ & Surface & Flake, thinning; late & 1 & 0.42 & Chert, $>1 / 2^{\prime \prime}$, complete \\
\hline $\mathrm{CP} 2$ & Surface & Flake, thinning & 1 & 2.00 & Chert, > 1/2", proximal \\
\hline $\mathrm{CP} 2$ & Surface & Flake, thinning & 2 & 1.33 & Chert, $>1 / 2^{\prime \prime}$, complete \\
\hline CP 2 & Surface & Flake, thinning & 1 & 0.59 & $\begin{array}{l}\text { Heat treated chert, }>1 / 2^{\prime \prime} \text {, non- } \\
\text { orientable }\end{array}$ \\
\hline $\mathrm{CP} 2$ & Surface & Flake, thinning & 1 & 0.73 & Heat treated chert, $>1 / 2^{\prime \prime}$, complete \\
\hline $\mathrm{CP} 2$ & Surface & Flake, early reduction & 1 & 0.29 & Chert, $>1 / 4^{\prime \prime}$, complete \\
\hline $\mathrm{CP} 3$ & Surface & Flake, thinning & 6 & 5.49 & Chert, $>1 / 2^{\prime \prime}$, complete \\
\hline $\mathrm{CP} 3$ & Surface & Flake, thinning & 1 & 0.32 & Chert, $>1 / 4^{\prime \prime}$, complete \\
\hline $\mathrm{CP} 3$ & Surface & Flake, thinning & 4 & 2.44 & Chert, > 1/2", proximal \\
\hline $\mathrm{CP} 3$ & Surface & Flake, thinning & 1 & 0.35 & Chert, $>1 / 4^{\prime \prime}$, medial-distal \\
\hline $\mathrm{CP} 3$ & Surface & Flake, thinning; late & 2 & 0.75 & Chert, $>1 / 2^{\prime \prime}$, complete \\
\hline $\mathrm{CP} 3$ & Surface & Flake, thinning; late & 2 & 0.48 & Chert, $>1 / 4^{\prime \prime}$, complete \\
\hline $\mathrm{CP} 3$ & Surface & Fire cracked rock & 1 & 113.56 & Chert, > 1/2" \\
\hline \multicolumn{3}{|c|}{ Surface Collection Point Subtotal } & 49 & 320.32 & \\
\hline
\end{tabular}

\begin{tabular}{|c|c|l|r|r|l|}
\hline ST 3 & 15 & Flake, early reduction & 1 & 3.00 & Chert, $>1 / 2^{\prime \prime}$, complete \\
\hline ST 5 & $0-10$ & Flake, thinning & 1 & 0.35 & Chert, $>1 / 2^{\prime \prime}$, complete \\
\hline ST 5 & $0-10$ & Flake, thinning & 1 & 0.13 & Chert, $>1 / 2^{\prime \prime}$, medial-distal \\
\hline ST 5 & $0-10$ & Flake, thinning & 2 & 0.43 & Chert, $>1 / 4^{\prime \prime}$, proximal \\
\hline ST 5 & $0-10$ & Flake, thinning; late & 2 & 0.11 & Chert, $>1 / 4^{\prime \prime}$, complete \\
\hline ST 5 & $0-10$ & Flake, thinning; late & 1 & 0.02 & Chert, $>1 / 4^{\prime \prime}$, medial-distal \\
\hline ST 7 & 30 & Flake, thinning & 1 & 0.62 & Chert, $>1 / 2^{\prime \prime}$, complete \\
\hline ST 10 & $0-10$ & Flake, fragment & 1 & 0.48 & Chert, $>1 / 4^{\prime \prime}$, non-orientable \\
\hline ST 10 & $0-10$ & Flake, thinning & 1 & 0.54 & Chert, $>1 / 4^{\prime \prime}$, complete \\
\hline ST 10 & $0-10$ & Flake, thinning; late & 3 & 0.45 & Chert, $>1 / 4^{\prime \prime}$, complete \\
\hline ST 10 & $0-10$ & Flake, thinning; late & 2 & 0.10 & Chert, $>1 / 8^{\prime \prime}$, complete \\
\hline ST 25 & $10-20$ & Flake, thinning; late & 1 & 0.14 & Chert, $>1 / 4^{\prime \prime}$, medial-distal \\
\hline
\end{tabular}


Table 5.6. Artifact Inventory for Site 41CS78.

\begin{tabular}{|c|c|c|c|c|c|}
\hline Provenience & $\begin{array}{l}\text { Depth } \\
\text { (cmbs) }\end{array}$ & Description & Count & $\begin{array}{l}\text { Weight } \\
\text { (g) }\end{array}$ & Comments \\
\hline ST 30 & $10-20$ & Animal bone & 2 & 0.42 & Possible armadillo scoot \\
\hline ST 32 & $0-10$ & Flake, thinning & 1 & 0.34 & Quartzite, $>1 / 4^{\prime \prime}$, proximal \\
\hline ST 32 & $0-10$ & Flake, thinning; late & 2 & 0.26 & Chert, > 1/4", complete \\
\hline ST 34 & $10-20$ & Flake, thinning & 1 & 0.56 & Chert, $>1 / 2^{\prime \prime}$, complete \\
\hline ST 34 & $10-20$ & Flake, thinning; late & 1 & 0.26 & Chert, $>1 / 2^{\prime \prime}$, complete \\
\hline ST 34 & $10-20$ & Flake, thinning; late & 1 & 0.11 & Chert, $>1 / 4^{\prime \prime}$, proximal \\
\hline ST 40 & $20-35$ & Flake, early reduction & 1 & 0.27 & Chert, $>1 / 2^{\prime \prime}$, complete \\
\hline ST 41 & 35 & Core & 1 & 79.15 & Chert cobble with two flakes removed \\
\hline ST 45 & 20 & Flake, thinning & 1 & 0.31 & Chert, > 1/4", proximal \\
\hline \multicolumn{3}{|c|}{ Shovel Test Subtotal } & 28 & 88.05 & \\
\hline TU 2 & $10-20$ & Flake thinning. late & 4 & 0.19 & Chert $>1 / 8^{\prime \prime}$ complete \\
\hline TU 2 & $10-20$ & Flake, thinning; late & 21 & 3.46 & Chert, > 1/4", complete \\
\hline TU 2 & $10-20$ & Flake, thinning; late & 6 & 3.12 & Chert, $>1 / 2 "$, complete \\
\hline TU 2 & $10-20$ & Flake, thinning; late & 3 & 0.68 & Chert, $>1 / 4^{\prime \prime}$, proximal \\
\hline TU 2 & $10-20$ & Flake, thinning; late & 5 & 0.31 & Chert, $>1 / 8^{\prime \prime}$, medial-distal \\
\hline TU 2 & $10-20$ & Flake, thinning; late & 7 & 1.19 & Chert, $>1 / 4^{\prime \prime}$, medial-distal \\
\hline TU 2 & $10-20$ & Flake, thinning & 1 & 0.33 & Chert, > 1/4", proximal \\
\hline TU 2 & $10-20$ & Flake, thinning & 5 & 4.22 & Chert, $>1 / 2^{\prime \prime}$, complete \\
\hline TU 2 & $10-20$ & Flake, thinning & 1 & 2.15 & Chert, $>1 / 2^{\prime \prime}$, non-orientable \\
\hline TU 2 & $10-20$ & Flake, thinning & 1 & 0.92 & Chert, $>1 / 2^{\prime \prime}$, medial-distal \\
\hline TU 2 & $10-20$ & Flake, early reduction & 1 & 0.68 & Chert, $>1 / 2^{\prime \prime}$, complete \\
\hline TU 2 & $10-20$ & Flake, early reduction & 1 & 0.51 & Chert, $>1 / 4^{\prime \prime}$, complete \\
\hline TU 2 & $10-20$ & Flake, early reduction & 1 & 1.52 & Chert, > $1 / 2^{\prime \prime}$, non-orientable \\
\hline TU 2 & $10-20$ & Flake, core reduction & 1 & 0.78 & Chert, $>1 / 2 "$, complete \\
\hline TU 2 & $10-20$ & Flake, pressure & 1 & 0.11 & Chert, >1/4", complete \\
\hline TU 2 & $10-20$ & Shatter, angular & 4 & 1.22 & Chert \\
\hline TU 2 & $10-20$ & Shatter, angular & 1 & 0.79 & Quartzite \\
\hline TU 2 & $10-20$ & Cortex fragment & 1 & 0.06 & Chert \\
\hline TU 2 & $10-20$ & Unmodified stone & 2 & 0.23 & Chert \\
\hline TU 2 & $20-30$ & Flake, thinning & 2 & 0.80 & Chert, > 1/2", complete \\
\hline TU 2 & $20-30$ & Flake, thinning & 1 & 0.28 & Chert, $>1 / 4^{\prime \prime}$, medial-distal \\
\hline TU 2 & $20-30$ & Flake, thinning & 1 & 0.12 & Chert, $>1 / 4^{\prime \prime}$, non-orientable \\
\hline TU 2 & $20-30$ & Flake, thinning; late & 4 & 0.40 & Chert, > 1/4", complete \\
\hline TU 2 & $20-30$ & Flake, thinning; late & 3 & 0.13 & Chert, > 1/2", complete \\
\hline TU 2 & $20-30$ & Flake, thinning; late & 1 & 0.01 & Chert, $>1 / 2^{\prime \prime}$, proximal \\
\hline TU 2 & $20-30$ & Flake, thinning; late & 6 & 0.45 & Chert, $<1 / 4^{\prime \prime}$, medial-distal \\
\hline TU 2 & $20-30$ & Flake, thinning; late & 1 & 0.19 & Chert, $>1 / 4^{\prime \prime}$, medial-distal \\
\hline TU 2 & $20-30$ & Flake, thinning; late & 1 & 0.10 & Chert, $>1 / 2^{\prime \prime}$, medial-distal \\
\hline TU 2 & $20-30$ & Shatter, angular & 2 & 0.72 & Chert \\
\hline TU 2 & $20-30$ & Burned earth & 1 & 0.26 & Fired clay \\
\hline TU 2 & $20-30$ & Red ochre & 1 & 0.25 & \\
\hline TU 3 & $15-20$ & Flake, thinning; late & 1 & 0.36 & Chert, >1/2", complete \\
\hline TU 3 & $15-20$ & Flake, thinning; late & 1 & 0.05 & Chert, > 1/2", proximal \\
\hline TU 3 & $15-20$ & Flake, thinning & 2 & 1.16 & Chert, > 1/2", complete \\
\hline
\end{tabular}


Table 5.6. Artifact Inventory for Site 41CS78.

\begin{tabular}{|c|c|c|c|c|c|}
\hline Provenience & $\begin{array}{l}\text { Depth } \\
\text { (cmbs) }\end{array}$ & Description & Count & $\begin{array}{c}\text { Weight } \\
\text { (g) }\end{array}$ & Comments \\
\hline TU 3 & $15-20$ & Animal bone & 1 & 0.08 & Possible armadillo scoot \\
\hline TU 3 & $20-30$ & Flake, thinning; late & 1 & 0.08 & Chert, > 1/4", proximal \\
\hline TU 3 & $30-40$ & Flake, thinning & 1 & 1.40 & Chert, > 1/2", complete \\
\hline TU 3 & $30-40$ & Flake, thinning & 1 & 0.78 & Chert, > 1/2", medial-distal \\
\hline TU 3 & $30-40$ & Flake, thinning; late & 1 & 0.54 & Chert, $>1 / 2^{\prime \prime}$, complete \\
\hline TU 3 & $40-50$ & Flake, thinning & 1 & 0.51 & Chert, > 1/2", complete \\
\hline TU 3 & $40-50$ & Flake, thinning & 1 & 0.32 & Chert, > 1/2", medial-distal \\
\hline TU 3 & $40-50$ & Flake, thinning; late & 1 & 0.19 & Chert, > 1/4", complete \\
\hline TU 4 & $10-20$ & Flake, thinning; late & 1 & 0.27 & Chert, > 1/4", proximal \\
\hline TU 4 & $10-20$ & Flake, thinning & 1 & 0.23 & Chert, > 1/4", proximal \\
\hline TU 4 & $20-30$ & Flake, early reduction & 1 & 0.95 & Chert, > 1", proximal \\
\hline TU 4 & $20-30$ & Flake, thinning & 3 & 1.46 & Chert, > 1/2", complete \\
\hline TU 4 & $20-30$ & Flake, thinning & 1 & 0.37 & Quartzite, > 1/2", complete \\
\hline TU 4 & $20-30$ & Flake, thinning & 1 & 0.23 & Chert, > 1/4", proximal \\
\hline TU 4 & $20-30$ & Flake, thinning; late & 2 & 0.25 & Chert, > 1/4", medial-distal \\
\hline TU 4 & $30-40$ & Flake, thinning & 1 & 0.43 & Chert, > 1/4", complete \\
\hline TU 4 & $30-40$ & Flake, thinning & 3 & 1.32 & Chert, > 1/2", complete \\
\hline \multicolumn{3}{|c|}{ Test Unit Subtotal } & 117 & 37.16 & \\
\hline \multicolumn{3}{|c|}{ Site Total } & 194 & 445.53 & \\
\hline
\end{tabular}

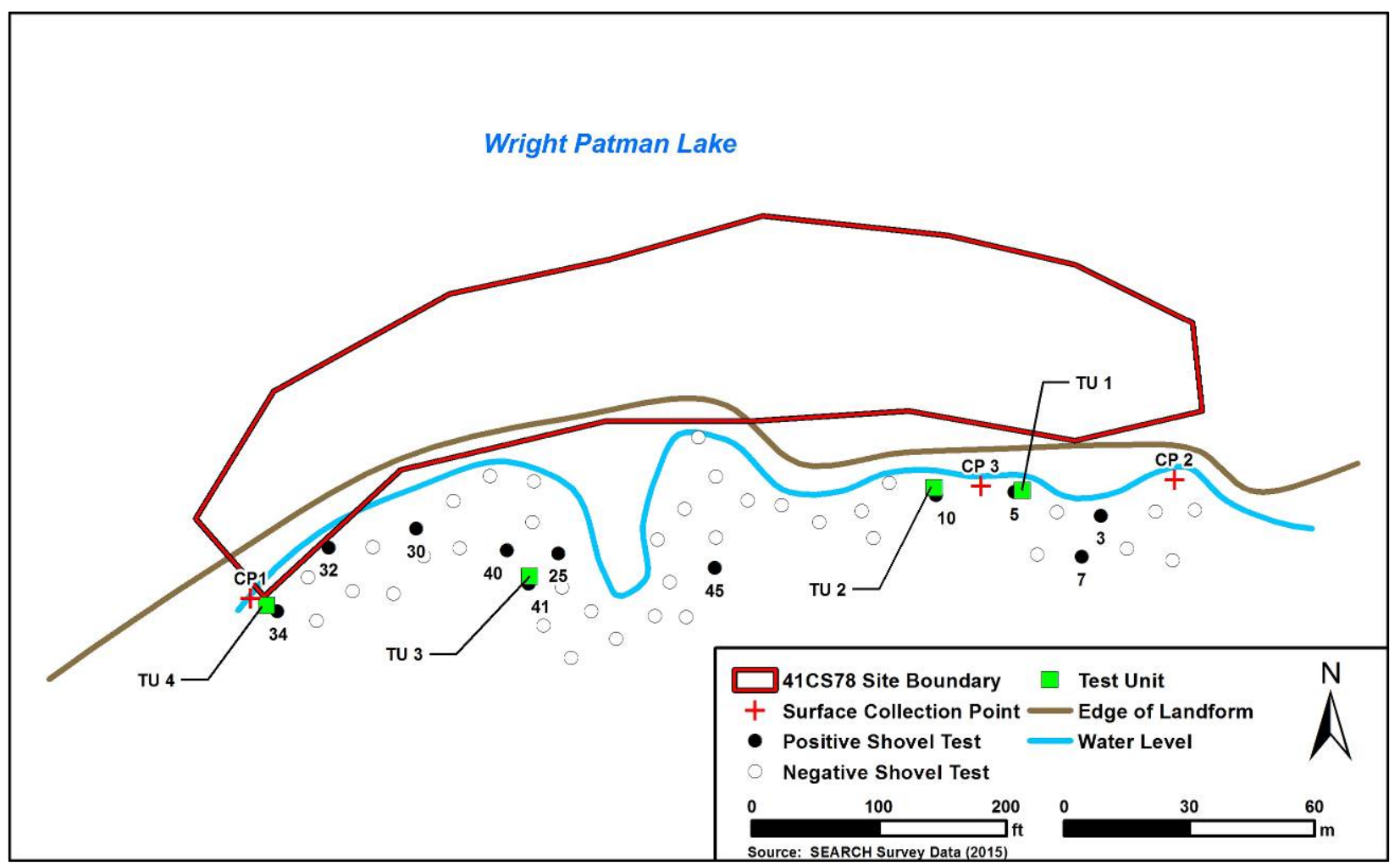

Figure 5.46. SEARCH 2015 fieldwork plan map for site 41CS78. 
The distribution of artifacts from shovel tests is relatively diffuse across a broad area with two small clusters in the eastern and western portions of the site. The eastern cluster with ST 5 and ST 10 yielded a small concentration of lithic debitage $(n=14)$. As a result, TU 1 and TU 2 were placed in this area to examine the vertical nature of the archaeological deposits. Test Unit 1 produced no artifacts; however, TU 2 yielded a large collection of lithic debitage $(n=90)$ consistent with artifact classes recovered from ST 5 and ST 10 . The western cluster is a low-density scatter of lithic debitage $(n=3)$ collected from ST 25 , ST 40 , and ST 41. Test Unit 3 was excavated near ST 41 and yielded only six thinning flakes, five late thinning flakes, and one animal bone fragment. Test Unit 4 was excavated near the western extent of the site. Like TU 3, Test Unit 4 produced a small assemblage of flake debitage $(n=14)$.

\section{Recommendation}

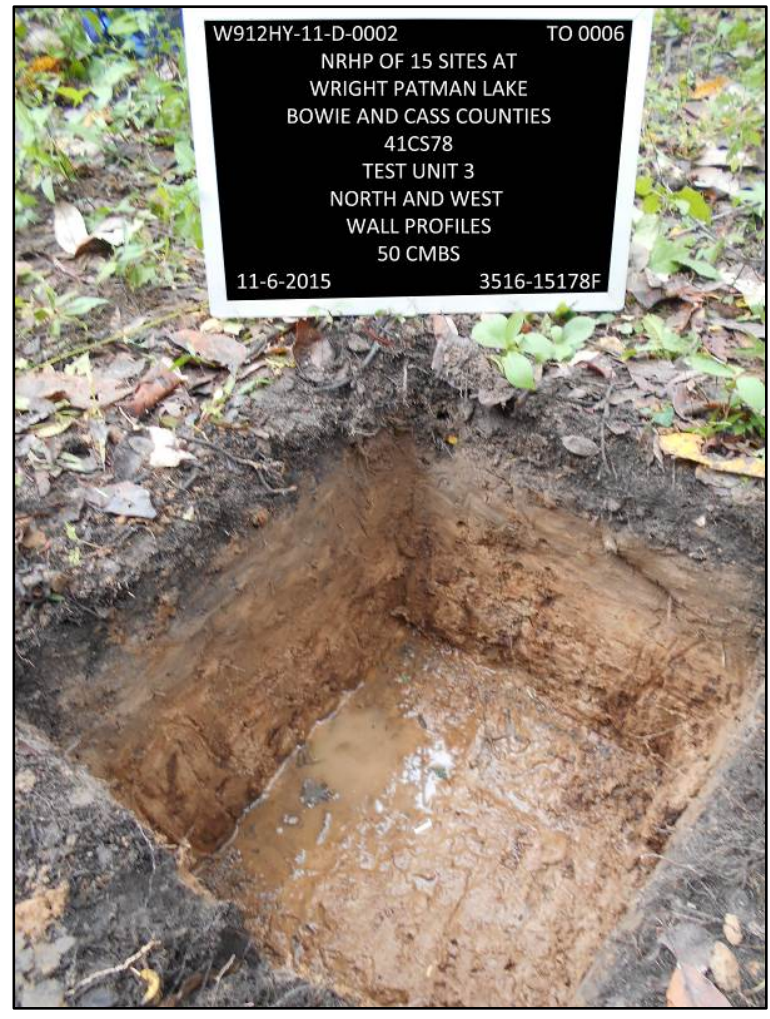

Figure 5.47. Typical soil profile at site 41 CS78.

Site 41CS78 is a large Native American site on a low a low terrace on the south shore of Wright Patman Lake. The artifact assemblage includes a relatively large collection of lithic debitage with a smaller quantity of formal lithic tools, fire-cracked rock, Native American pottery sherds, and faunal remains. The discernible concentrations of artifacts in the eastern and western portions of the site suggest differential use of space, and in this case, the homogeneity of both assemblages may represent a series of smaller occupations along the landform edge. The artifact assemblage, examined in tandem with absolute dating methods (radiocarbon or thermoluminescence), has the potential to offer insight into the lithic economy of Native American inhabitants of the site. It is the recommendation of SEARCH that additional work be performed to evaluate the NRHP status of site 41CS78 and mitigate adverse effects of the proposed pool rise for meeting the Ultimate Rule Curve. 


\section{SITE 41 CS79}

Briggs and Malone recorded site 41CS79 (Figure 5.48) in February 1970. They identified the site at an elevation between 222 and 225 $\mathrm{ft}$ amsl on a heavily eroded bank on the southern shore of Wright Patman Lake and noted several areas of charcoal-darkened soil, but suggested it may have been the result of modern stump burning or general burn-off of the area (TARL 1970j). Artifacts consist of a small collection of lithic debitage and tools that include flakes, small cores, and a bifacial tool (Briggs and Malone 1970:Figure 14, Table 2; TARL 1970j).

On October 22, 2015, SEARCH archaeologists returned to site 41C579. The pool elevation measured $224.19 \mathrm{ft}$ amsl. The site boundary as presented in the USACE Fort Worth Wright Patman Lake GIS database covers $411 \mathrm{~m}^{2}$ $(0.10 \mathrm{ac})$ across an eroding beach

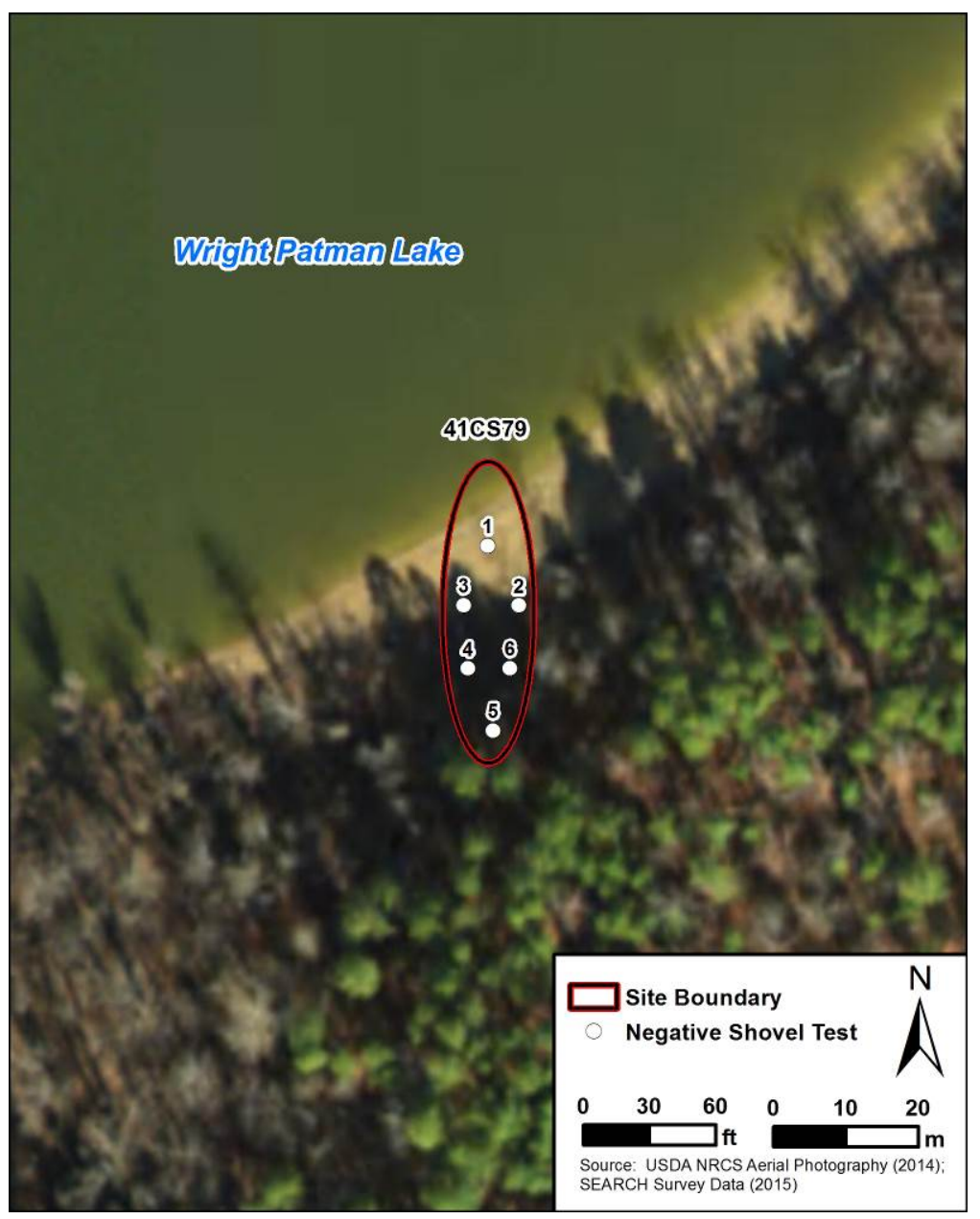

Figure 5.48. Location map and SEARCH 2015 fieldwork plan map for site 41CS79.

strand in the northern portion of the site and low terrace in the central and southern portions of the site. The beach is devoid of vegetation, while the terrace contains a mixture of hardwoods and pines with a scrubby understory of small saplings, low bushes, and grasses (Figure 5.49).

Ground surface visibility ranged between 30 and 100 percent with better visibility occurring near the waterline. A pedestrian survey was conducted along transects spaced $5 \mathrm{~m}$ apart and oriented perpendicular to the long axis of the site across the exposed shoreline and parallel to the site's long axis along the terrace. No artifacts were identified during the pedestrian survey.

Subsurface testing included the excavation of six shovel tests, none of which produced artifacts. As a result, no test units were excavated at site 41CS79. A typical soil profile displayed very pale brown (10YR 7/4) sandy clay from 0 to $10 \mathrm{cmbs}$ and moist, very compact reddish-yellow 


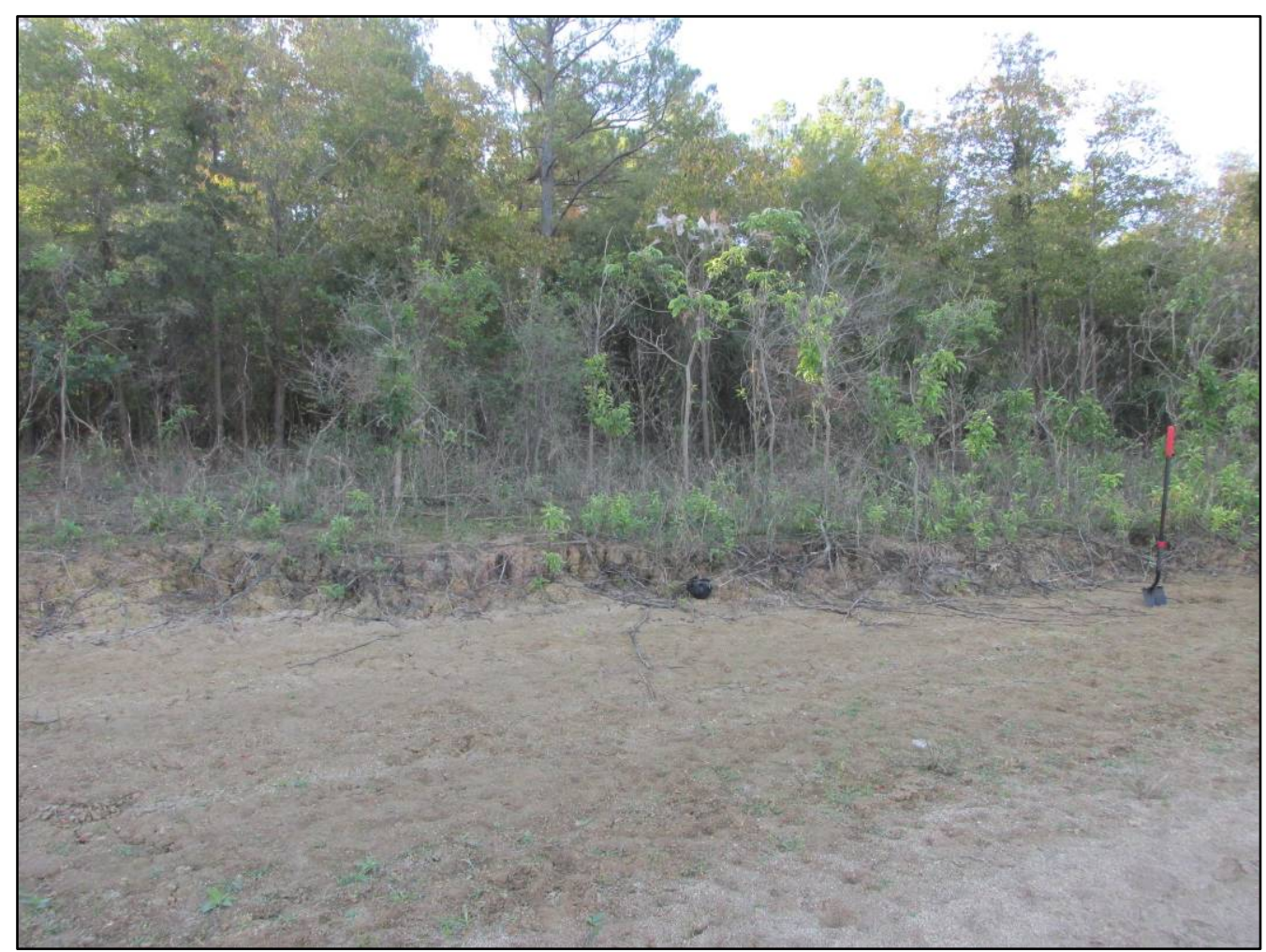

Figure 5.49. Typical vegetation at site 41CS79.

(5YR 6/6) clay mottled with very compact light gray (5YR 7/1) clay from 10 to $25 \mathrm{cmbs}$ (Figure 5.50). Water inundation begins in the clay layer as shallow as $10 \mathrm{cmbs}$ and increases with depth.

\section{Recommendation}

In October 2015, SEARCH archaeologists conducted pedestrian survey and subsurface testing across site 41CS79; however, no artifacts were identified. The absence of artifacts is likely attributed to numerous years of erosion of archaeological deposits-a condition noted by Briggs and Malone in 1970. Based on the limited nature of the previously recovered artifact assemblage, site 41CS79 was likely a small-scale

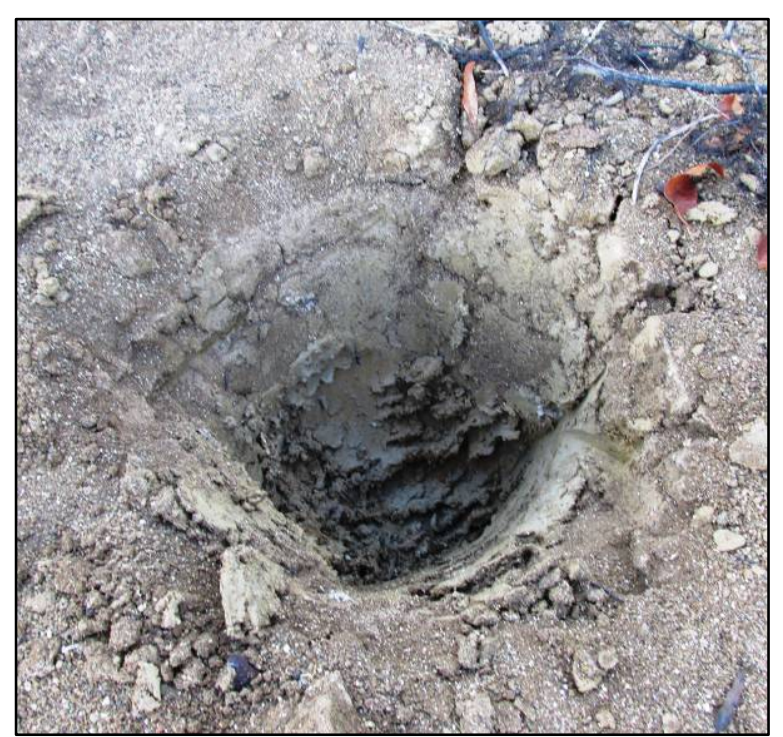

Figure 5.50. Typical soil profile at site 41CS79. habitation or resource extraction point, perhaps used as a seasonal or limited-activity locus, developed to exploit multiple ecological niches in the region. Based on the results of previous and current fieldwork, it is the opinion of SEARCH that site 41CS79 does not meet the Secretary of the Interior's criteria for listing in the NRHP and no further work is recommended. 


\section{SITE 41CS108}

Briggs and Malone recorded site 41CS108 (Figure 5.51) in February 1970. They identified the site at an elevation between 225 and 226 $\mathrm{ft}$ amsl on a small point that projects into Wright Patman Lake (TARL 1970I). Artifacts consist of a small collection of lithic debitage (Briggs and Malone 1970:Figure 14, Table 2; TARL 1970I).

During the initial reconnaissance at site 41CS108, SEARCH archaeologists determined that the plotted site location as listed on the TARL site form and within the USACE Fort Worth Wright Patman Lake GIS database was almost entirely submerged by the current lake level (226.70 ft amsl). As a result, nearly all of the archaeological investigation occurred across the uplands adjacent to the site's northern boundary (see Figure 5.51).

On November 9, 2015, SEARCH

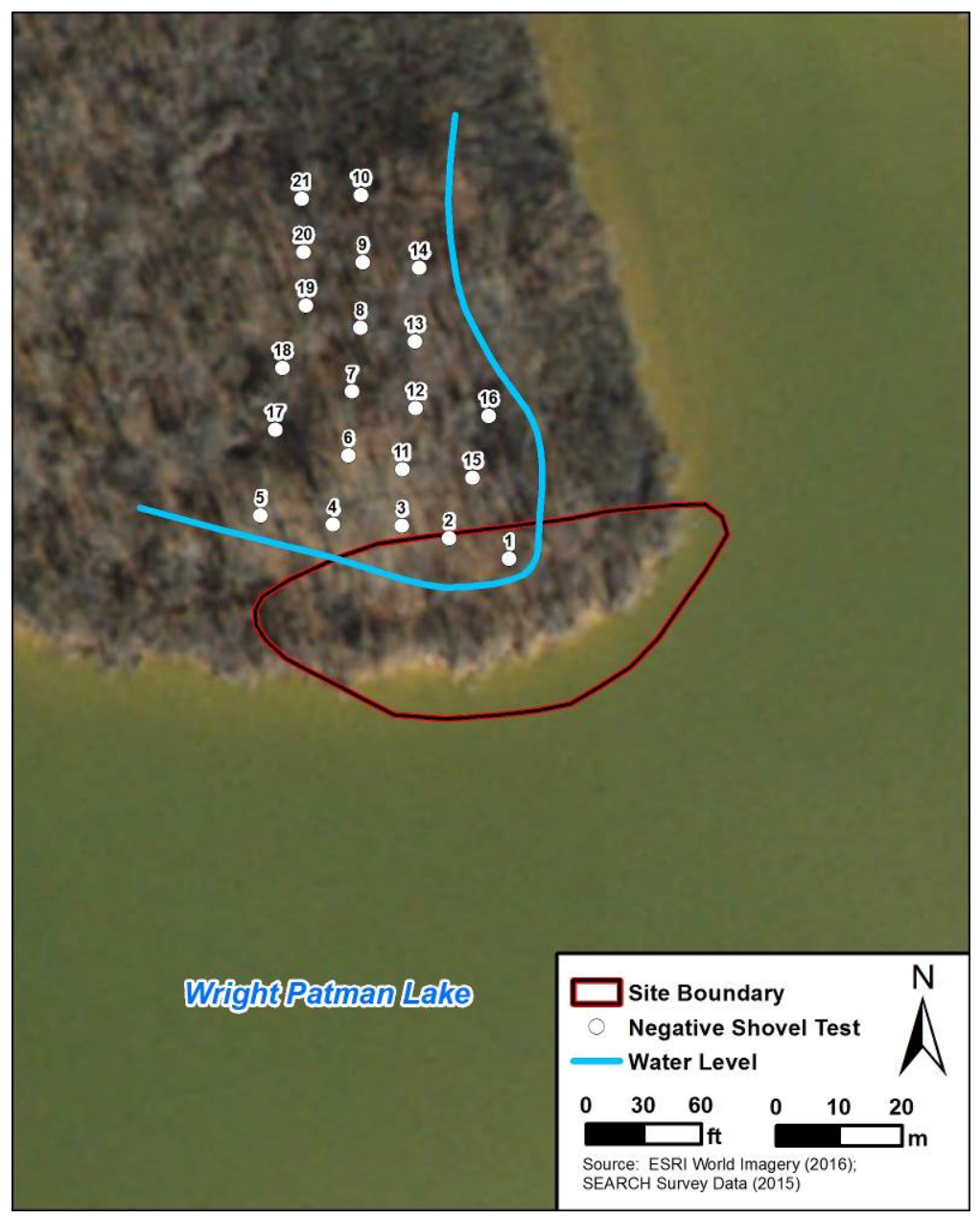

Figure 5.51. Location map and SEARCH 2015 fieldwork plan map for site 41CS108.

archaeologists returned to site 41CS108 to evaluate its NRHP status in support of the proposed pool level rise to meet the Ultimate Rule Curve at Wright Patman Lake. The site boundary as presented in the USACE Fort Worth Wright Patman Lake GIS database covers $1,713 \mathrm{~m}^{2}(0.42 \mathrm{ac})$ along the edge of a low terrace. Vegetation consists of a mixture of hardwoods with a relatively open understory of smaller saplings and scrub brush throughout and north of the site boundary (Figure 5.52).

Ground surface visibility ranged between 10 and 20 percent and was typically predicated on the amount of associated leaf litter. A pedestrian survey was conducted along transects that measured the length of the site and spaced $5 \mathrm{~m}$ apart, beginning at the water's edge and extending $50 \mathrm{~m}$ north. No exposed beach, scarps, or benches were observed. No artifacts were identified during the pedestrian survey. 


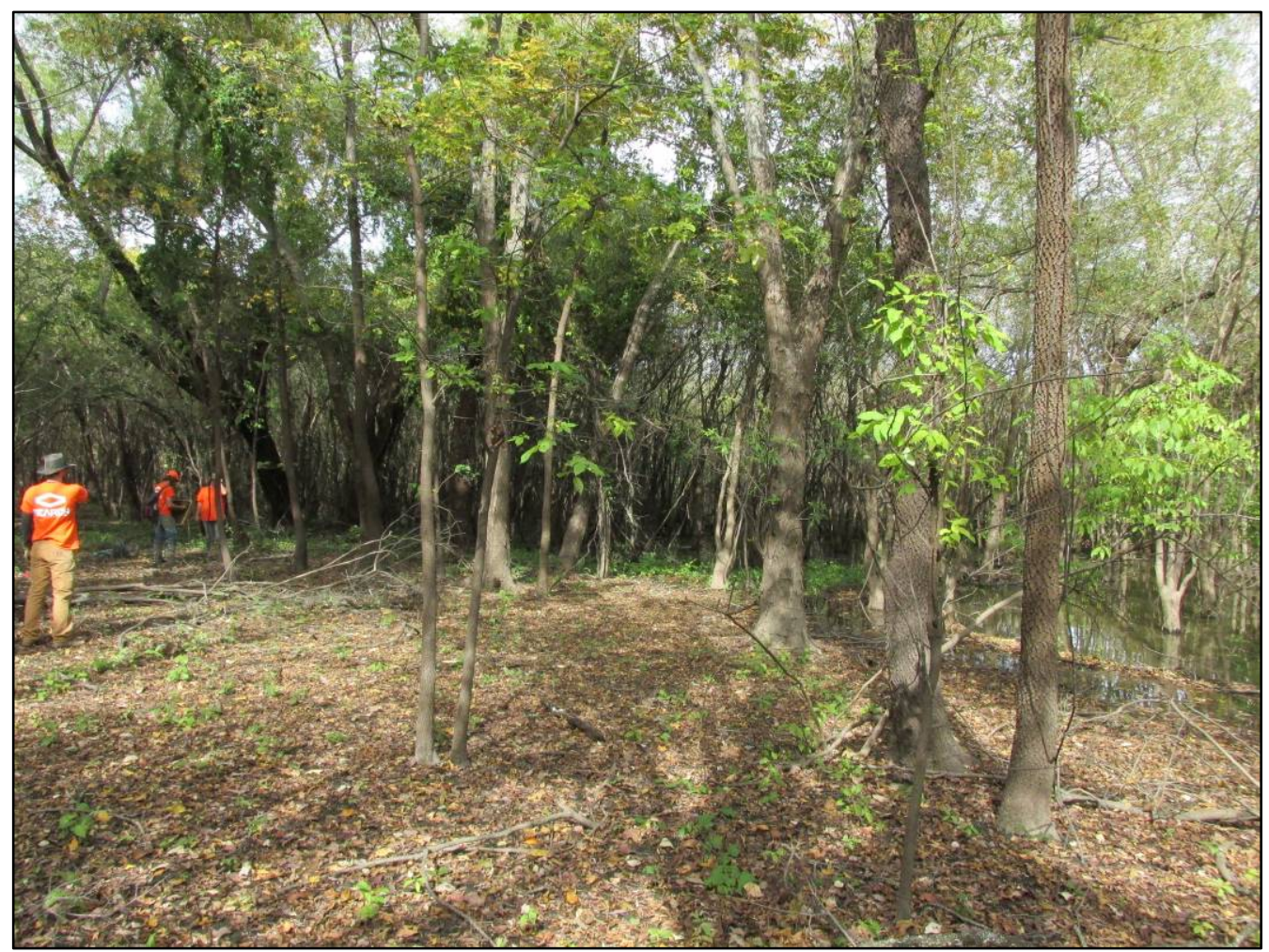

Figure 5.52. Typical vegetation north of site 41CS108, facing east.

Subsurface testing included the excavation of 21 shovel tests, none of which produced artifacts. As a result, no test units were excavated at site 41CS108. A typical soil profile displayed very dark grayish-brown (10YR 3/2) wet silty loam from 0 to $10 \mathrm{cmbs}$, dark yellowish-brown (10YR 4/6) wet clay from 10 to $25 \mathrm{cmbs}$, and yellowishred (5YR 5/6) wet clay from 25 to $35 \mathrm{cmbs}$ (Figure 5.53).

\section{Recommendation}

In November 2015, nearly all of site 41CS108 was inundated by rising lake levels at Wright Patman Lake. Exposed portions of the site and the adjacent uplands were tested to determine if intact cultural deposits existed within and

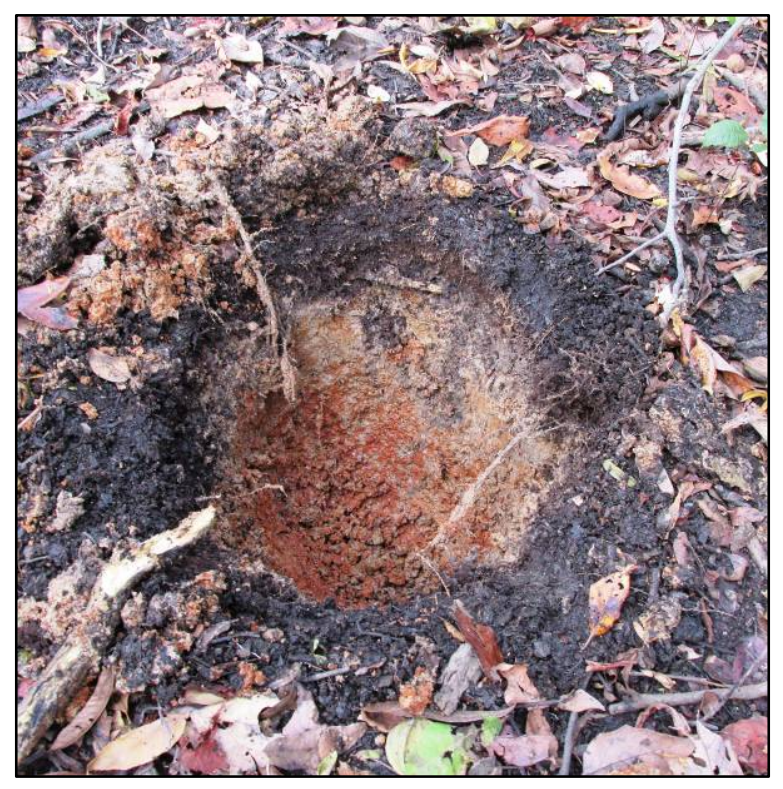

Figure 5.53. Typical soil profile at site $41 \mathrm{CS} 108$.

adjacent to the defined boundary. No artifacts were identified during pedestrian survey and subsurface testing. As only a small portion of the site could be tested, SEARCH recommends that the NRHP status of site 41CS108 remain undetermined until such time as the submerged deposits can be evaluated. 


\section{SITE 41CS122}

Site 41CS122 (Figure 5.54) was recorded in 1974 based on information obtained from local informant Mr. Larry Head (TARL 1974a). The site was located on the tip of the northwestern peninsula of Bells Island. No formal collection of artifacts and no description of the archaeological deposits were recorded on the site form.

In November 2015, SEARCH archaeologists visited site 41CS122 in an effort to evaluate its NRHP status in support of the proposed pool level rise to meet the Ultimate Rule Curve at Wright Patman Lake. The site boundary as presented in the USACE Fort Worth Wright Patman Lake GIS database covers $1,216 \mathrm{~m}^{2}(0.30 \mathrm{ac})$ across an eroding beach strand in the northern and western portions of the site and low terrace in the southeastern portion of the site (see Figure 5.54). The beach, when exposed, is devoid of vegetation, while the terrace contains a mixture of low scrub near the edge of the site (Figure 5.55). Vegetation increases in maturity and size within the interior portion of the terrace.

During the initial reconnaissance at site 41CS122, SEARCH archaeologists determined that the plotted site location as listed on the TARL site form and within the USACE Fort Worth Wright Patman Lake GIS database was largely submerged by the current lake level. As a result, nearly all of the archaeological investigation occurred across the uplands adjacent to the site's southeastern boundary (Figure 5.56).

\section{Figure Redacted}

Figure 5.54. Location of site 41CS122. 


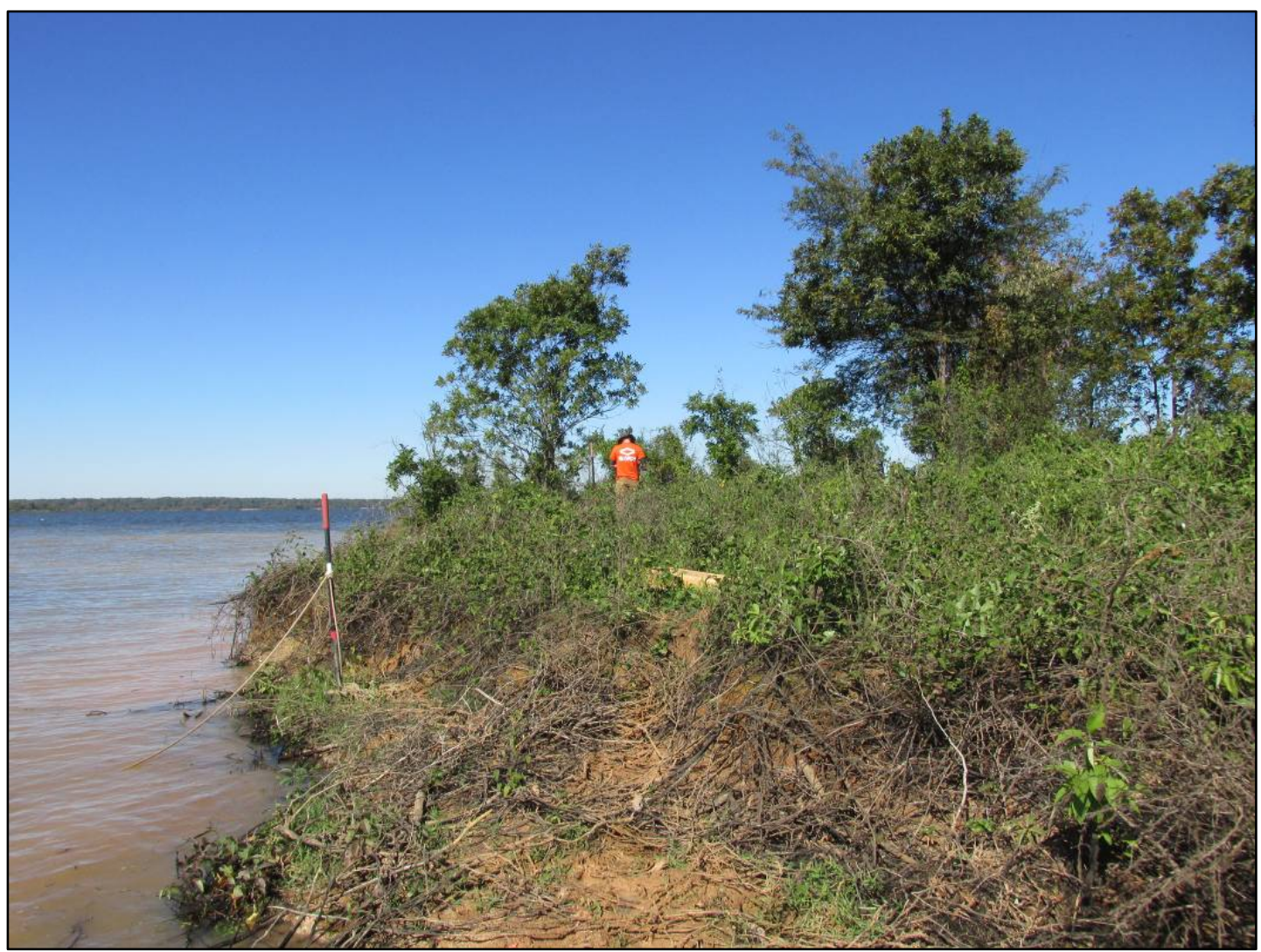

Figure 5.55. Typical vegetation at site 41CS122.

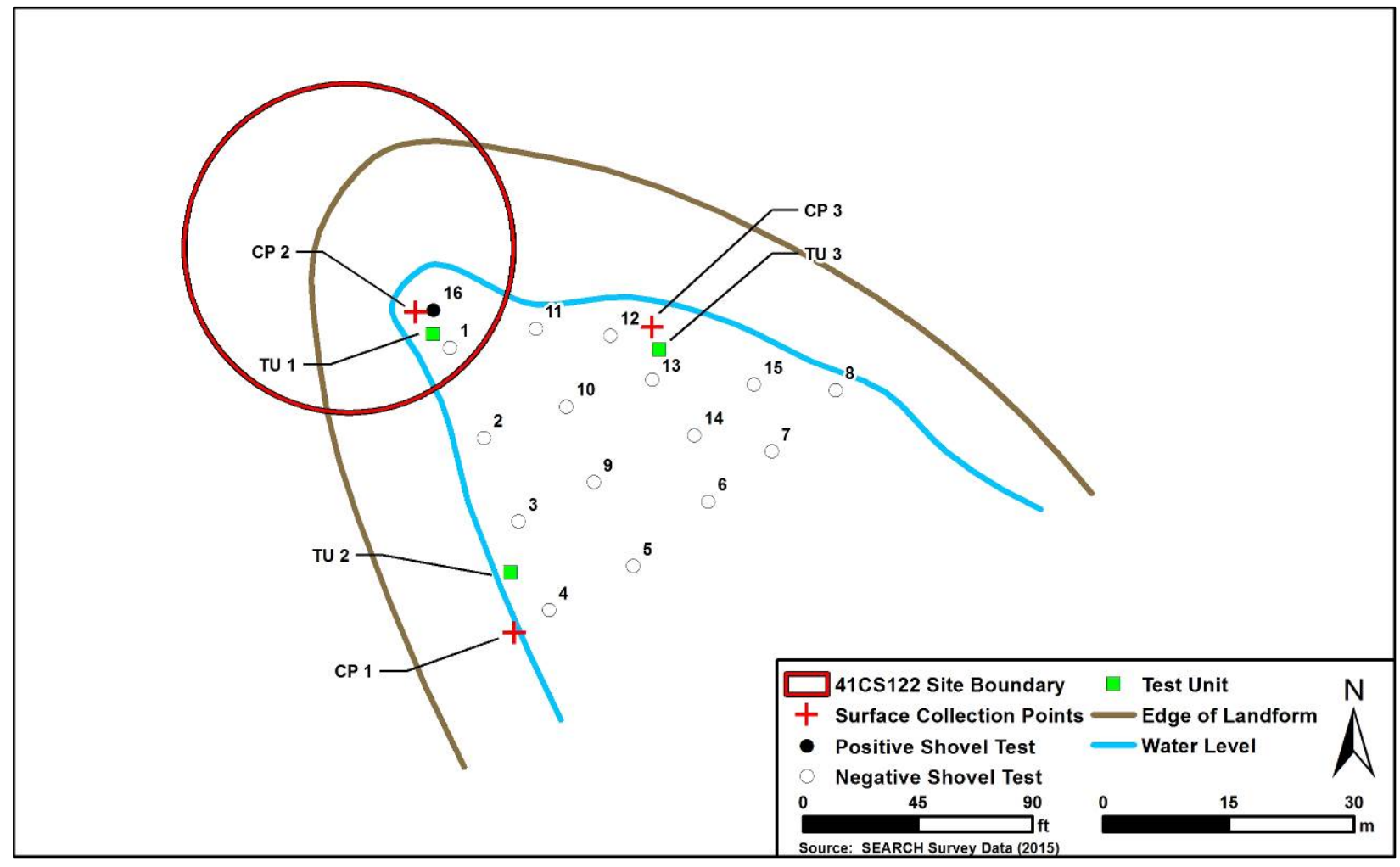

Figure 5.56. SEARCH 2015 fieldwork plan map for site 41CS122. 
The dense undergrowth across the terrace and the absence of an exposed shoreline limited the extent of the pedestrian survey, which was restricted to the edge of the wave-cut bench and the area immediately surrounding each shovel test. Nevertheless, three areas produced 14 artifacts from the surface around the northern periphery of the terrace (see Figure 5.56).

Subsurface testing included the excavation of 167 shovel tests, of which one was positive for cultural material, and three $50-x-50-\mathrm{cm}$ test units, of which only one produced artifacts (see

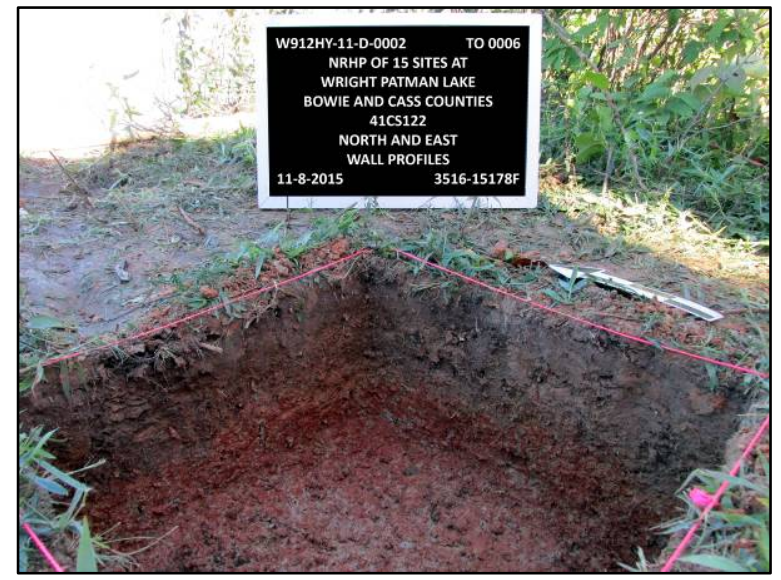

Figure 5.57. Typical soil profile at site 41CS122.

Figure 5.56). A typical soil profile displayed dark brown (10YR 3/3) silty clay loam from 0 to 7 cmbs, dark yellowish-brown (10YR 4/6) slightly loose silty clay from 7 to $17 \mathrm{cmbs}$, and mottled yellowish-red (5YR 4/6) and light gray (10YR 7/1) clay from 17 to $30 \mathrm{cmbs}$ (Figure 5.57). Table $\mathbf{5 . 7}$ presents a summary of all artifacts collected from site 41CS122. Select artifacts from site 41CS122 are presented in Figure 5.58.

Table 5.7. Artifact Inventory for Site 41CS122.

\begin{tabular}{|c|c|c|c|c|c|}
\hline Provenience & $\begin{array}{l}\text { Depth } \\
\text { (cmbs) }\end{array}$ & Description & Count & $\begin{array}{l}\text { Weight } \\
\text { (g) }\end{array}$ & Comments \\
\hline CP 1 & Surface & Flake, Early Reduction & 1 & 1.82 & Chert, > 1/2" \\
\hline CP 1 & Surface & Shatter, Thermal & 1 & 15.27 & Chert, non-orientable \\
\hline $\mathrm{CP} 2$ & Surface & Flake, Thinning; Late & 1 & 0.58 & Chert, > 1/2", complete \\
\hline CP 2 & Surface & Flake, Thinning; Late & 2 & 1.11 & Chert, $>1 / 2^{\prime \prime}$, proximal \\
\hline $\mathrm{CP} 2$ & Surface & Flake, Thinning; Late & 2 & 1.0 & Chert,> 1/2", medial-distal \\
\hline CP 2 & Surface & Flake, Thinning; Late & 1 & 0.3 & Chert, >1/4", medial-distal \\
\hline $\mathrm{CP} 2$ & Surface & Flake, Blade & 1 & 0.67 & Chert, > 1/2", proximal \\
\hline CP 2 & Surface & PPK, stemmed & 1 & 8.01 & Chert, Gary Type \\
\hline CP 3 & Surface & Flake, Thinning; Late & 1 & 0.38 & Chert, > 1/4", proximal \\
\hline CP 3 & Surface & Flake, Thinning & 1 & 1.94 & Chert, > 1/2", complete \\
\hline CP 3 & Surface & Flake, Early Reduction & 1 & 7.69 & Chert, > 1", medial-distal \\
\hline $\mathrm{CP} 3$ & Surface & $\begin{array}{l}\text { Aboriginal ceramic, Red } \\
\text { filmed, body }\end{array}$ & 1 & 20.96 & $\begin{array}{l}\text { Body, Grog/clay temper, black painted } \\
\text { linear design }\end{array}$ \\
\hline \multicolumn{3}{|c|}{ Surface Collection Point Subtotal } & 14 & 59.73 & \\
\hline ST 16 & $0-10$ & Flake, Thinning; Late & 1 & 0.2 & Chert, > 1/4" \\
\hline ST 16 & $0-10$ & Flake, core reduction & 1 & 7.01 & Chert, > 1", complete \\
\hline ST 16 & $10-20$ & $\begin{array}{l}\text { Possible cultural material- } \\
\text { lithic }\end{array}$ & 1 & 1.32 & Petrified wood \\
\hline ST 16 & $10-20$ & Flake, core reduction & 1 & 5.29 & Chert, > 1/2", non-orientable \\
\hline ST 16 & $10-20$ & Flake, core reduction & 1 & 8.89 & Quartzite/sandstone, $>1$ ", complete \\
\hline ST 16 & $20-30$ & $\begin{array}{l}\text { Possible cultural material- } \\
\text { lithic }\end{array}$ & 1 & 1.26 & Petrified wood \\
\hline \multicolumn{3}{|c|}{ Shovel Test Subtotal } & 6 & 23.97 & \\
\hline TU 1 & $10-20$ & Flake, thinning & 1 & 0.87 & Chert, > 1/2", complete \\
\hline
\end{tabular}


Table 5.7. Artifact Inventory for Site 41CS122.

\begin{tabular}{|c|c|c|c|c|c|}
\hline Provenience & $\begin{array}{l}\text { Depth } \\
\text { (cmbs) }\end{array}$ & Description & Count & $\begin{array}{l}\text { Weight } \\
\text { (g) }\end{array}$ & Comments \\
\hline TU 1 & $0-10$ & Flake, retouch & 1 & 0.03 & Chert, $>1 / 8^{\prime \prime}$, complete \\
\hline TU 1 & $10-20$ & Flake, retouch & 1 & 0.04 & Chert, $>1 / 8^{\prime \prime}$, proximal \\
\hline TU 1 & $10-20$ & Flake, Thinning & 1 & 0.93 & Chert, > 1/2", complete \\
\hline TU 1 & $10-20$ & Flake, Thinning & 2 & 1.53 & Chert, $>1 / 2^{\prime \prime}$, complete \\
\hline TU 1 & $10-20$ & Flake, Early Reduction & 1 & 3.34 & Chert, $>1 / 2^{\prime \prime}$, proximal \\
\hline TU 1 & $10-20$ & Fire cracked rock & 1 & 62.63 & Other \\
\hline TU 1 & $40-50$ & Unmodified stone & 1 & 0.63 & Petrified wood \\
\hline \multicolumn{3}{|c|}{ Test Unit Subtotal } & 9 & 70 & \\
\hline \multicolumn{3}{|c|}{ Site Total } & 29 & 153.70 & \\
\hline
\end{tabular}

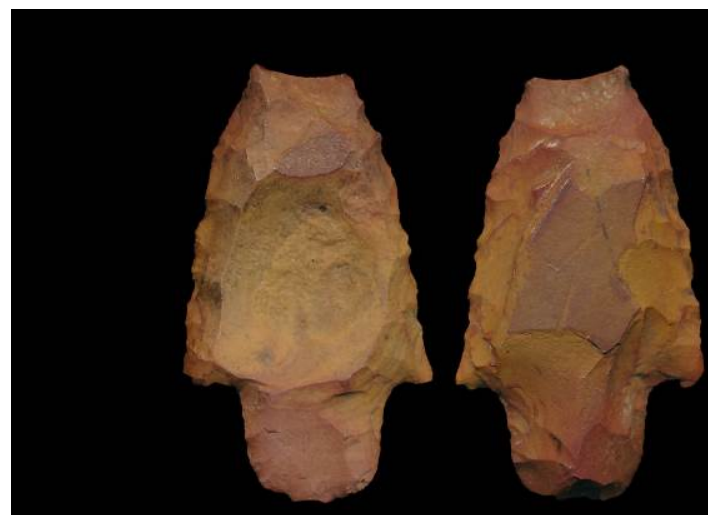

Gary Type PPK

Chert

CP 2, Surface

FS 132.06
Red Filmed Aboriginal Ceramic Grog Tempered CP 3, Surface FS 133.04

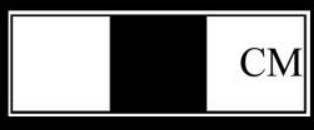

Figure 5.58. Select artifacts collected from site 41CS122.

\section{Recommendation}

In November 2015, a relatively large portion of site 41CS122 was inundated by rising lake levels at Wright Patman Lake. Exposed portions of the site and the adjacent uplands were tested to determine if intact cultural deposits existed within and adjacent to the defined boundary. The artifact assemblage collected in the vicinity of site 41CS122 is a relative diffuse scatter of lithic debitage in the southeastern portion of the site and across the adjacent low terrace (see Figure 41). The areas within the site boundary and across adjacent uplands that were subjected to pedestrian survey and subsurface testing and the associated artifact assemblage are not considered significant and do not contribute to the NRHP eligibility of site 41CS122. As only a portion of the site could be tested, SEARCH recommends that the NRHP status of site 41CS122 remain undetermined until such time as the submerged deposits can be evaluated. 


\section{SITE 41CS123}

Site 41CS123 (Figure 5.59) was recorded in 1974 based on information obtained from local informant Mr. Larry Head (TARL 1974b). The site was located on the western shore of the northeastern peninsula of Bells Island. No formal collection of artifacts and no description of the archaeological deposits were recorded on the site form.

In November 2015, SEARCH archaeologists visited site 41CS123 in an effort to evaluate its NRHP status in support of the proposed pool level rise to meet the Ultimate Rule Curve at Wright Patman Lake. The site boundary as presented in the USACE Fort Worth Wright Patman Lake GIS database covers $1,586 \mathrm{~m}^{2}(0.39 \mathrm{ac})$ across an eroding beach strand and a low terrace further inland (see Figure 5.59). The beach, when exposed, is devoid of vegetation, while the terrace contains a mixture of low scrub and immature hardwoods (Figures $\mathbf{5 . 6 0}$ and 5.61). During the initial reconnaissance at site 41CS123, SEARCH archaeologists determined that the plotted site location as listed on the TARL site form and within the USACE Fort Worth Wright Patman Lake GIS database was largely submerged by the current lake level (226.65 ft amsl). As a result, nearly all of the archaeological investigation occurred across the beach strand and low terrace adjacent to the site's eastern boundary.

Ground surface visibility ranged between 10 and 50 percent with better visibility occurring near the waterline. The dense undergrowth across the terrace and the absence of an exposed

\section{Figure Redacted}

Figure 5.59. Location of site 41CS123. 


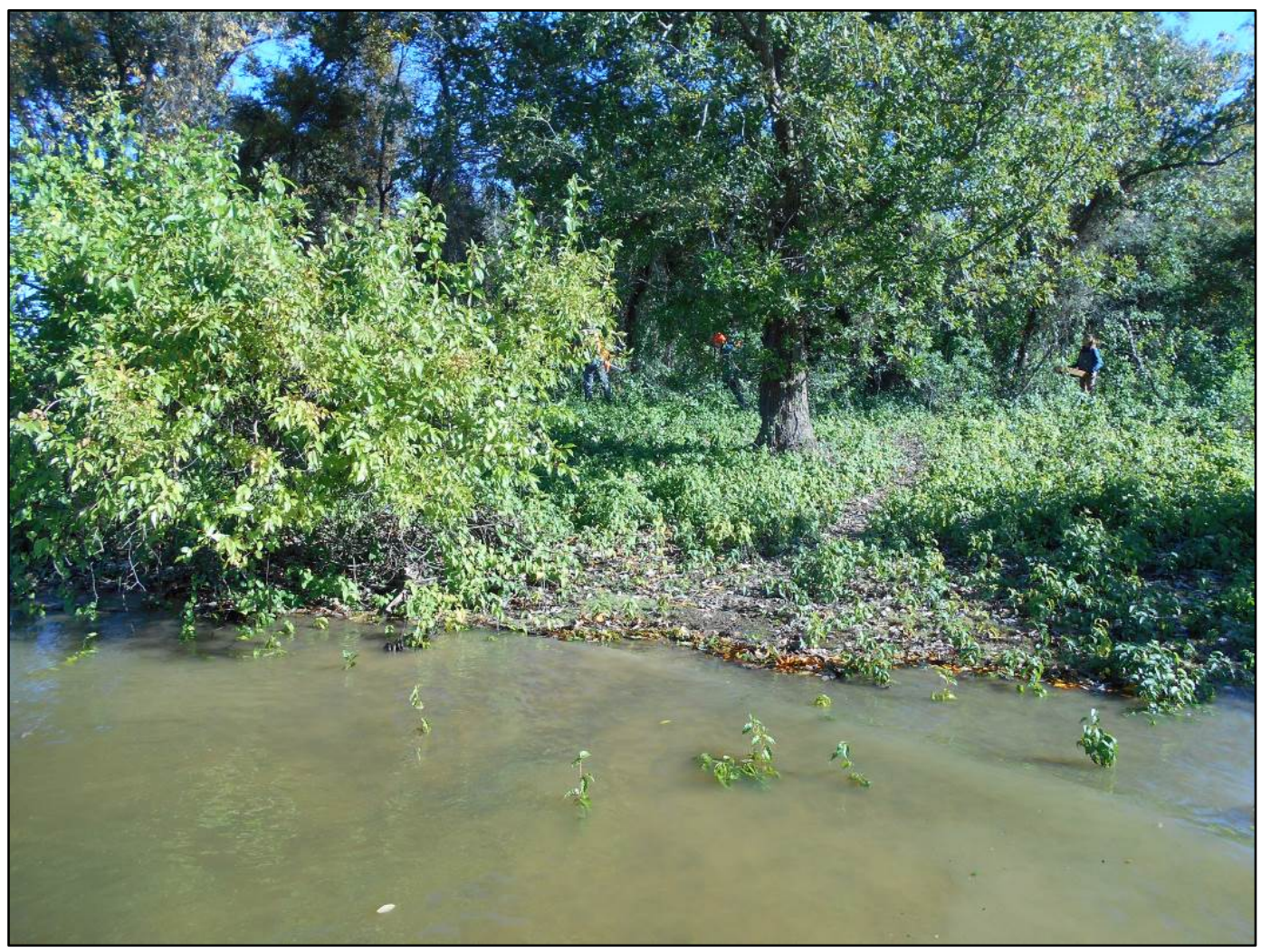

Figure 5.60. Typical vegetation on the inland areas east of site 41CS123.

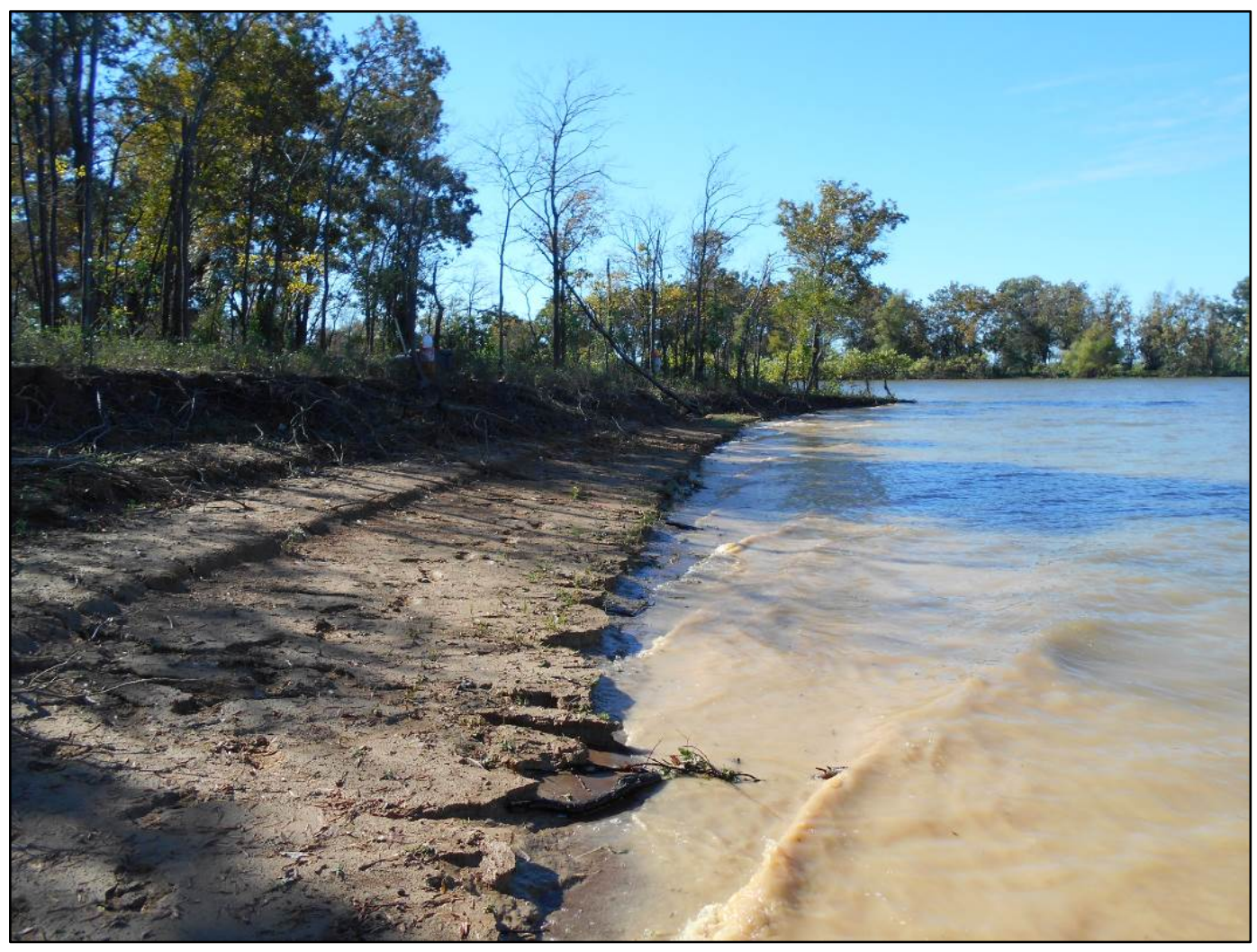

Figure 5.61. Exposed beach along the north portion of site 41CS123, facing southwest. 
shoreline limited the extent of the pedestrian survey, which was restricted to the edge of the wave-cut bench and the area immediately surrounding each shovel test. The pedestrian survey was conducted along transects that measured the length of the site and spaced $5 \mathrm{~m}$ apart, beginning at the water line and extending 20 to $30 \mathrm{~m}$ east. Artifacts (Table 5.8) were identified in the water and four collection points were taken as a sample of submerged cultural deposits.

Table 5.8. Artifact Inventory for Site 41CS123.

\begin{tabular}{|c|c|c|c|c|c|}
\hline Provenience & $\begin{array}{l}\text { Depth } \\
\text { (cmbs) }\end{array}$ & Description & Count & $\begin{array}{l}\text { Weight } \\
\text { (g) }\end{array}$ & Comments \\
\hline CP 1 & Surface & Flake, Thinning & 2 & 1.07 & Chert, $>1 / 2 "$, Proximal \\
\hline CP 1 & Surface & Flake, Early Reduction & 1 & 1.66 & Chert, > 1/2", Proximal \\
\hline CP 1 & Surface & Flake, Thinning & 1 & 1.04 & Chert, > 1/2", Complete \\
\hline $\mathrm{CP} 2$ & Surface & Flake, Thinning; Late & 1 & 0.67 & Chert, > 1/2", Complete \\
\hline $\mathrm{CP} 2$ & Surface & Flake Thinning & 2 & 3.93 & Chert, $>1 / 2 "$, Complete \\
\hline $\mathrm{CP} 2$ & Surface & Flake Thinning & 1 & 1.17 & Quartzite, > 1/2", Proximal \\
\hline $\mathrm{CP} 2$ & Surface & Flake Thinning & 2 & 1.61 & Chert, > 1/2", Medial-Distal \\
\hline $\mathrm{CP} 2$ & Surface & Flake, Early Reduction & 1 & 1.2 & Chert, > 1/2", Medial-Distal \\
\hline CP 2 & Surface & Flake, Core Reduction & 1 & 1.85 & Chert, > 1/2", Medial-Distal \\
\hline $\mathrm{CP} 2$ & Surface & Flake, Thinning; Late & 1 & 0.13 & Chert, > 1/4", Complete \\
\hline $\mathrm{CP} 2$ & Surface & Flake, Thinning & 1 & 0.47 & Chert, > 1/4", Medial-Distal \\
\hline $\mathrm{CP} 2$ & Surface & Flake, Thinning & 1 & 0.39 & Chert, $>1 / 4^{\prime \prime}$, Proximal \\
\hline $\mathrm{CP} 2$ & Surface & Flake, Early Reduction & 1 & 0.45 & Chert, > 1/4" \\
\hline CP 2 & Surface & $\begin{array}{l}\text { Bifacial chopping/cutting } \\
\text { tool }\end{array}$ & 1 & 40.37 & Quartzite, bifacial flaked broken cobble \\
\hline CP 3 & Surface & Flake, Thinning; Late & 2 & 0.39 & Chert, > 1/4", Proximal \\
\hline CP 3 & Surface & Flake, Thinning & 1 & 0.75 & Chert, > 1/2", Medial-Distal \\
\hline CP 3 & Surface & Flake, Thinning & 1 & 0.34 & Chert, > 1/2", Complete \\
\hline CP 3 & Surface & Flake, Thinning & 1 & 0.87 & Chert, $>1 / 2 "$, Complete \\
\hline CP 3 & Surface & Flake, Thinning & 1 & 0.97 & Chert, $>1 / 2^{\prime \prime}$, Complete \\
\hline CP 3 & Surface & Flake, Thinning & 2 & 1.64 & Chert, $>1 / 2 "$, Complete \\
\hline CP 3 & Surface & Flake, Thinning & 1 & 1.06 & Chert, > 1/2", Proximal \\
\hline CP 3 & Surface & Flake, Thinning & 2 & 0.88 & Chert, $>1 / 2^{\prime \prime}$, Proximal \\
\hline CP 3 & Surface & Flake, Thinning & 3 & 1.94 & Chert, > 1/2", Proximal \\
\hline CP 3 & Surface & Flake, Thinning & 1 & 0.64 & Chert, > 1/2", Medial-Distal \\
\hline CP 3 & Surface & Flake, Thinning & 1 & 1.94 & Chert, > 1/2", Complete, blade flake \\
\hline CP 3 & Surface & Flake, Early Reduction & 1 & 1.41 & Chert, > 1/2", Complete \\
\hline CP 3 & Surface & Flake, Thinning; Late & 1 & 0.3 & Chert, > 1/4", Complete \\
\hline CP 4 & Surface & Flake, Thinning; Late & 1 & 0.38 & Chert, $>1 / 4 "$, Complete \\
\hline CP 4 & Surface & Flake, Early Reduction & 1 & 3.51 & Chert, > 1/2", Complete \\
\hline CP 4 & Surface & Flake, Early Reduction & 1 & 3.40 & Chert, > 1/2", Medial-Distal \\
\hline \multicolumn{3}{|c|}{ Surface Collection Point Subtotal } & 38 & 76.43 & \\
\hline TU 1 & $9-14$ & Flake, Thinning; Late & 1 & 0.32 & Chert, > 1/4", Complete \\
\hline TU 1 & $9-14$ & Flake, Thinning; Late & 1 & 0.35 & Chert, > 1/4", Medial-Distal \\
\hline \multicolumn{3}{|c|}{ Test Unit Subtotal } & 2 & 0.67 & \\
\hline \multicolumn{3}{|c|}{ Site Total } & 40 & 77.10 & \\
\hline
\end{tabular}




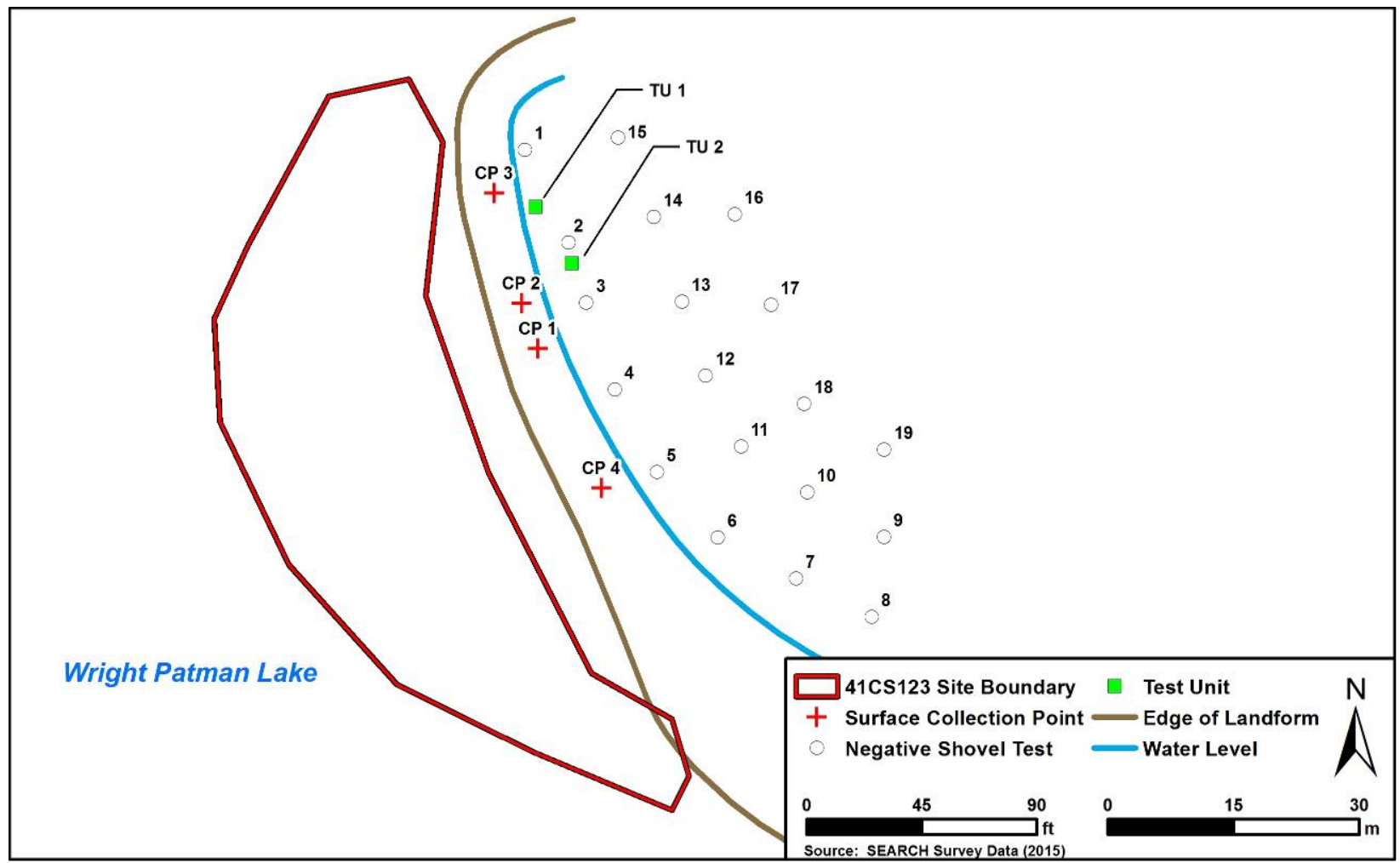

Figure 5.62. SEARCH 2015 fieldwork plan map for site 41CS123.

Subsurface testing included the excavation of 19 shovel tests (Figure 5.62), none of which produced artifacts. Two test units were excavated as close to collection points with the highest concentrations of artifacts. Only Test Unit 1 yielded artifacts: two pieces of lithic debitage from between 9 and 14 cmbs) (see Table 5.8). A typical profile displayed dark brown sandy clay from 0 to $5 \mathrm{cmbs}$, mottled grayish-brown mottled with strong brown compact clay from 5 to $35 \mathrm{cmbs}$, and strong brown or reddish brown clay $35+$ cmbs (Figure 5.63).

\section{Recommendation}

In November 2015, practically all of site

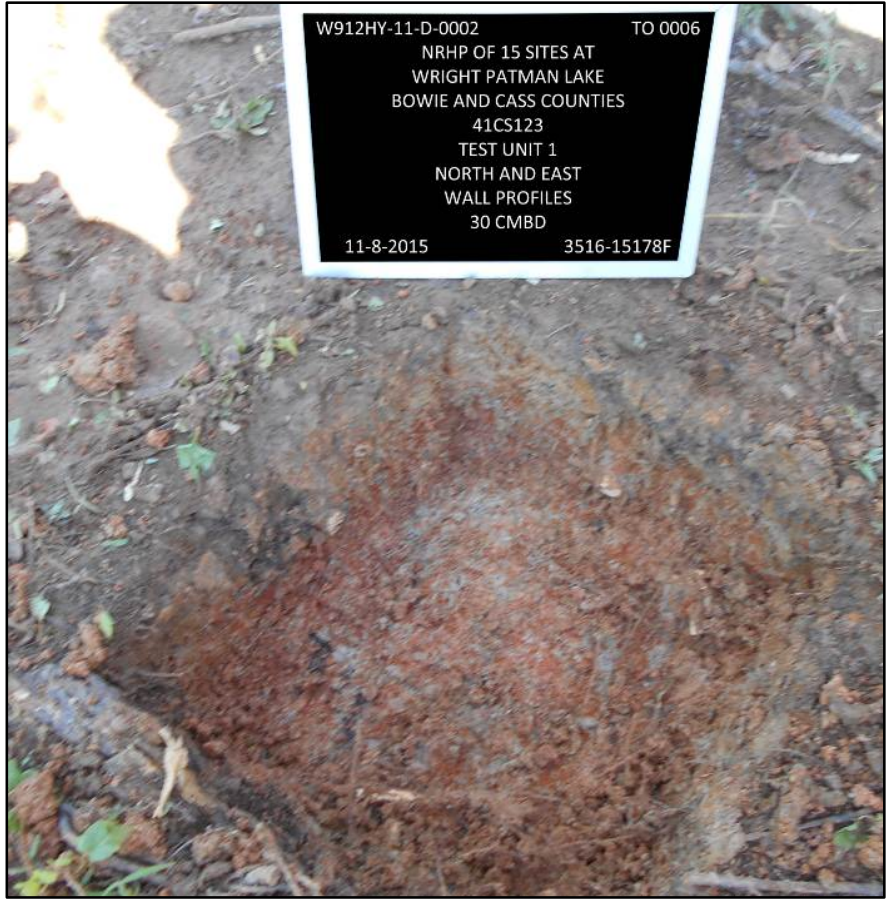

Figure 5.63. Typical soil profile at site 41CS123.

41 CS123 was inundated by rising lake levels at Wright Patman Lake. Exposed portions of the site and the adjacent uplands were tested to determine if intact cultural deposits existed within 
and adjacent to the defined boundary. Artifacts were recovered in four locations within the shallow water. Only two artifacts were identified from subsurface context in TU 1 . As the majority of site $41 \mathrm{CS} 123$ is submerged, SEARCH recommends that the NRHP status of site $41 \mathrm{CS} 123$ remain undetermined until such a time the submerged deposits can be evaluated.

\section{SITE 41CS95/96}

Briggs and Malone recorded both sites in February 1970. Because of the close proximity of these sites, both were combined into a single resource, although each is still listed separately in the TARL database. Both sites are located at elevations between 222 and $224 \mathrm{ft}$ amsl and occur along the edge of a low terrace peninsula protruding northward into Wright Patman Lake. Artifacts include plain and incised pottery, lithic debitage, and a scraper fragment.

The site boundary as presented in the USACE Fort Worth Wright Patman Lake GIS database covers $1,587 \mathrm{~m}^{2}(0.39 \mathrm{ac})$ within Wright Patman Lake (Figure 5.64). SEARCH archaeologists visited the site on November 5, 2016 (pool elevation $226.50 \mathrm{ft}$ amsl) and determined that the plotted location as listed on the TARL site form (TARL 1970k) and within the USACE Fort Worth Wright Patman Lake GIS database was completely submerged (Figure 5.65), resulting in no fieldwork at the site. Site 41CS118 was chosen from the Contingency List for evaluation. The NRHP status of site 41CS95/96 remains undetermined.

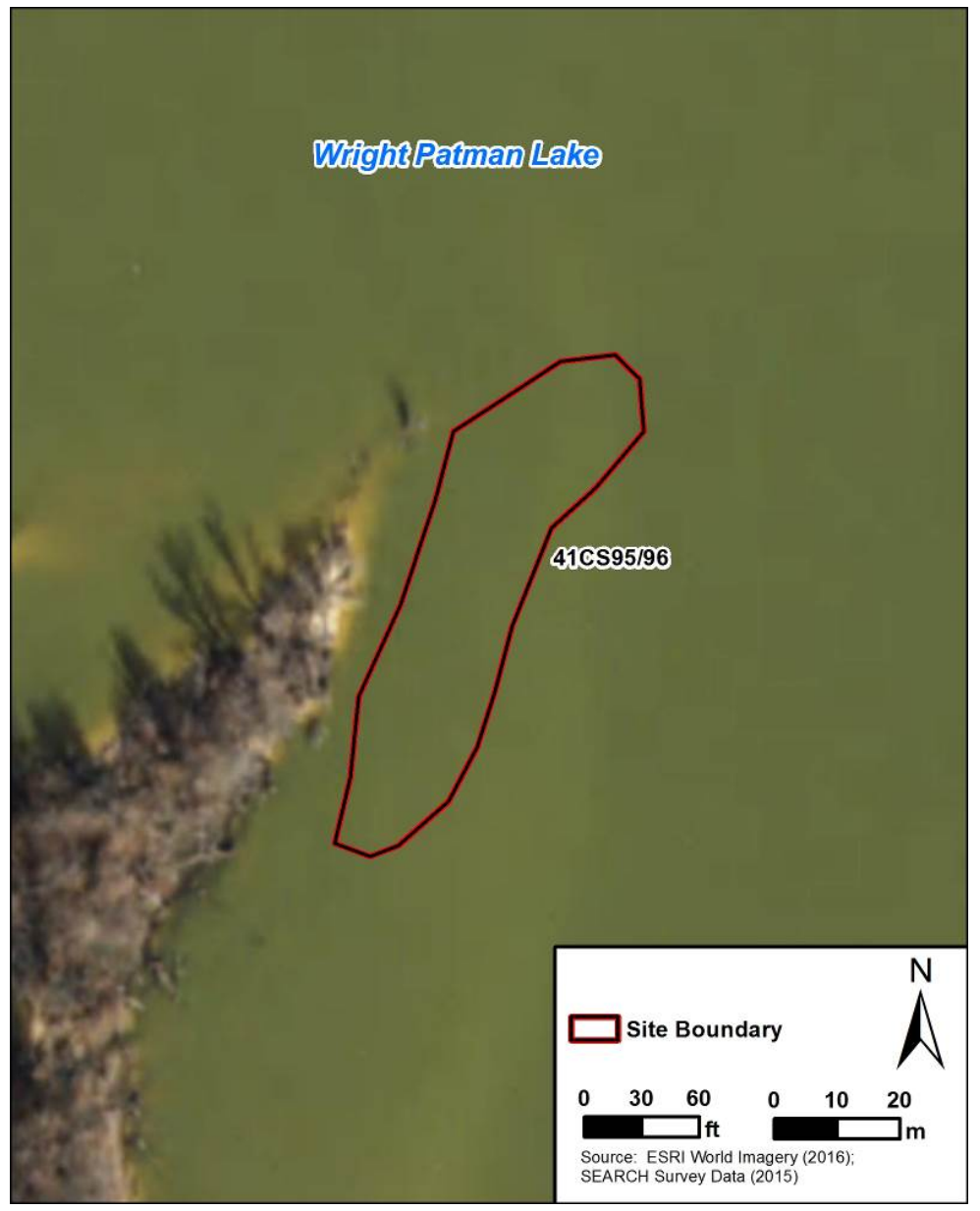

Figure 5.64. Location of site 41CS95/96.

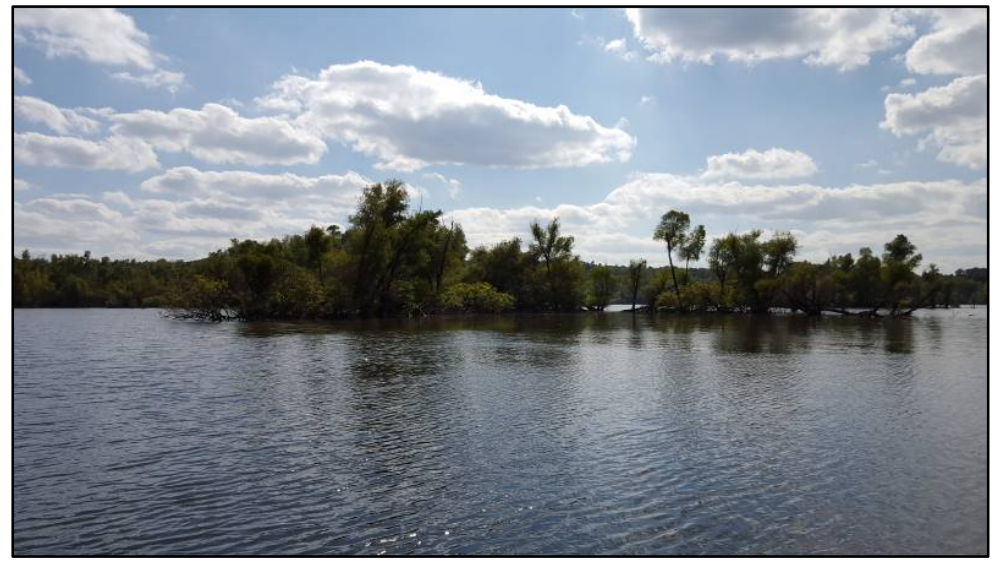

Figure 5.65. Photo south of plotted location of site 41CS95/96, facing north. 


\section{SITE 41CS109}

Briggs and Malone recorded site 41CS109 (Figure 5.66) in February 1970. They identified the site at an elevation between 226 and $230 \mathrm{ft}$ amsl along the edge of a slough and streamlet drainage. The site form (TARL 1970c) denotes large amounts of lithic debitage were eroding to the north south and east. An unspecified number of lithic debitage was recovered, in addition to at least one biface, retouched flakes, and a core.

On October 26, 2015, SEARCH archaeologists returned to site 41CS109. The site boundary as presented in the USACE Fort Worth Wright Patman Lake GIS database covers approximately $2,016 \mathrm{~m}^{2}(0.50 \mathrm{ac})$ along a low terrace adjacent to Wright Patman Lake. Vegetation is composed of young hardwood trees with very little understory of saplings and grass (Figures $\mathbf{5 . 6 7}$ and 5.68).

During the initial site reconnaissance, SEARCH archaeologists determined that the plotted site location as listed on the THC site file and within the USACE Fort Worth Wright Patman Lake GIS database was partially submerged by the current lake level (224.86 ft amsl). Ground visibility was near 90 percent with better visibility near the waterline. A pedestrian survey was conducted across the entire site including an exposed beach on the eastern portion of the site (see Figure 5.68). Seventeen collection points of artifacts were recovered and are summarized in Table 5.9. Select artifacts collected from site 41CS109 are presented in Figures $\mathbf{5 . 6 9}$ and 5.70 .

\section{Figure Redacted}

Figure 5.66. Location of site 41CS109. 


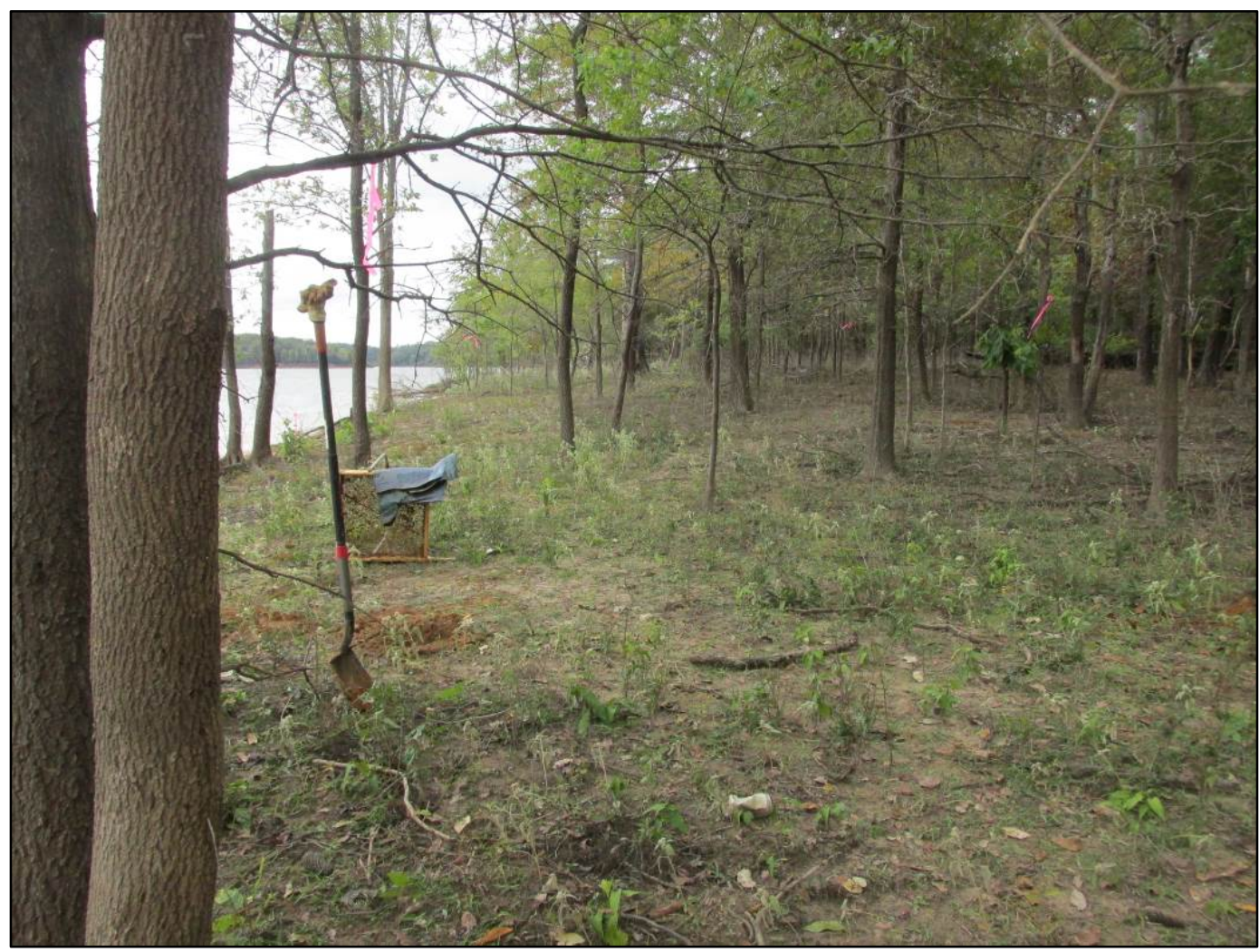

Figure 5.67. Typical vegetation at site 41CS109.

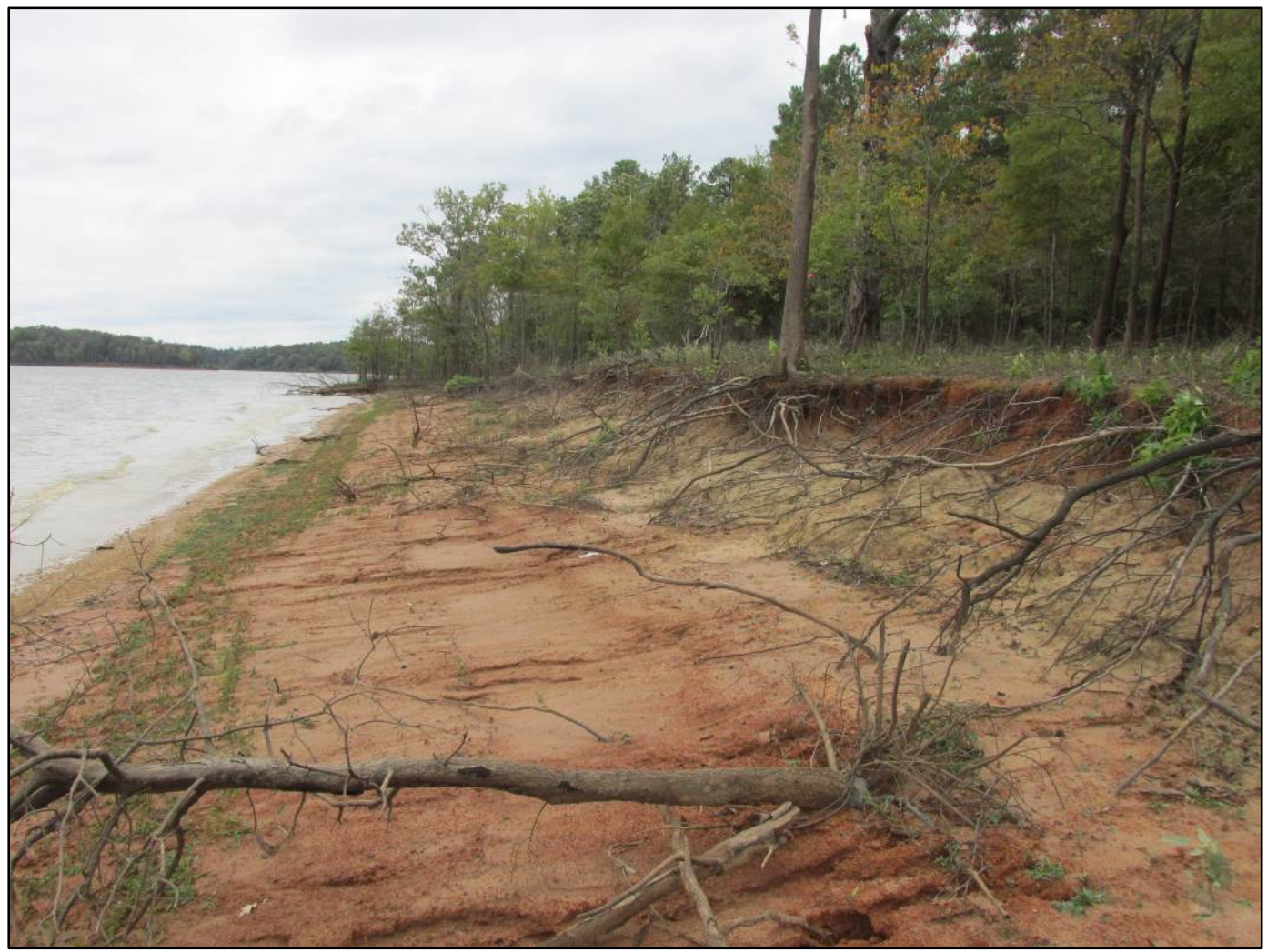

Figure 5.68. Bench and exposed beach along the east portion of site 41CS109. 
Table 5.9. Artifact Inventory for Site 41CS109.

\begin{tabular}{|c|c|c|c|c|c|}
\hline Provenience & $\begin{array}{l}\text { Depth } \\
\text { (cmbs) }\end{array}$ & Description & Count & $\begin{array}{l}\text { Weight } \\
\text { (g) }\end{array}$ & Comments \\
\hline $\mathrm{CP} 1$ & Surface & Flake, core reduction & 1 & 1.95 & Chert, $>1 / 2^{\prime \prime}$, complete \\
\hline CP 1 & Surface & Flake, early reduction & 1 & 5.54 & Chert, $>1 / 2^{\prime \prime}$, medial distal \\
\hline $\mathrm{CP} 1$ & Surface & Shatter, angular & 1 & 2.36 & Chert, \\
\hline $\mathrm{CP} 2$ & Surface & Flake, thinning & 3 & 3.84 & Chert, $>1 / 2^{\prime \prime}$, complete \\
\hline $\mathrm{CP} 2$ & Surface & Flake, thinning & 2 & 3.17 & Chert, $>1 / 2^{\prime \prime}$, proximal \\
\hline $\mathrm{CP} 2$ & Surface & Possible cultural lithic & 1 & 1.55 & \\
\hline $\mathrm{CP} 2$ & Surface & Tested pebble & 1 & 7.26 & Chert \\
\hline $\mathrm{CP} 3$ & Surface & Flake, thinning & 1 & 1.93 & Petrified wood, $>1 / 2^{\prime \prime}$, complete \\
\hline $\mathrm{CP} 3$ & Surface & Flake, thinning & 1 & 5.01 & Chert, $>1^{\prime \prime}$, non-orientable \\
\hline $\mathrm{CP} 3$ & Surface & Flake, thinning & 1 & 4.91 & Quartzite, $>1 "$, complete \\
\hline $\mathrm{CP} 3$ & Surface & PPK, straight stemmed & 1 & 5.61 & Quartzite, stem only \\
\hline $\mathrm{CP} 4$ & Surface & Flake, thinning & 2 & 2.14 & Chert, $>1 / 2^{\prime \prime}$, medial-distal \\
\hline $\mathrm{CP} 4$ & Surface & PPK, straight stemmed & 1 & 6.74 & $\begin{array}{l}\text { White chert, Kent type, long stem, } \\
\text { snapped. W-25.10mm T-8.00mm }\end{array}$ \\
\hline $\mathrm{CP} 4$ & Surface & PPK, contracting stemmed & 1 & 5.97 & $\begin{array}{l}\text { Maroon chert, Gary type, L-39.45mm, } \\
\text { W-26.25mm, T-7.30mm }\end{array}$ \\
\hline $\mathrm{CP} 4$ & Surface & Sandstone conglomerate & 1 & 44.16 & Naturally occurring \\
\hline CP 5 & Surface & Flake, thinning & 1 & 0.72 & Chert, $>1 / 2^{\prime \prime}$, complete \\
\hline $\mathrm{CP} 6$ & Surface & Flake, thinning & 1 & 2.23 & Quartzite, $>1 / 2^{\prime \prime}$, medial-distal \\
\hline CP 6 & Surface & Fire cracked rock & 1 & 28.40 & Chert \\
\hline $\mathrm{CP} 7$ & Surface & Flake, thinning & 1 & 2.53 & Chert, $>1 / 2^{\prime \prime}$, medial-distal \\
\hline $\mathrm{CP} 7$ & Surface & Shatter, thermal & 1 & 2.78 & Chert, > 1/2", non-orientable \\
\hline CP 8 & Surface & Flake, thinning & 1 & 1.84 & Chert, $>1 / 2^{\prime \prime}$, complete \\
\hline CP 8 & Surface & Flake, thinning & 1 & 1.10 & Chert, > 1/2", non-orientable \\
\hline $\mathrm{CP} 8$ & Surface & Flake, thinning; late & 3 & 1.65 & Chert, $>1 / 2^{\prime \prime}$, complete \\
\hline $\mathrm{CP} 8$ & Surface & Flake, thinning; late & 2 & 1.68 & Chert, $>1 / 2^{\prime \prime}$, medial-distal \\
\hline $\mathrm{CP} 8$ & Surface & Flake, thinning; late & 1 & 0.10 & Chert, $>1 / 4^{\prime \prime}$, complete \\
\hline CP 8 & Surface & Shatter, angular & 1 & 0.91 & Chert, $>1 / 4^{\prime \prime}$, non-orientable \\
\hline $\mathrm{CP} 9$ & Surface & Flake, core reduction & 3 & 8.93 & Chert, > 1", complete \\
\hline CP 9 & Surface & Flake, core reduction & 1 & 1.33 & Chert, $>1 / 2^{\prime \prime}$, proximal \\
\hline CP 9 & Surface & Flake, core reduction & 1 & 3.03 & Chert, $>1 "$, proximal \\
\hline $\mathrm{CP} 9$ & Surface & Flake, early reduction & 1 & 3.49 & Chert, $>1^{\prime \prime}$, complete \\
\hline CP 9 & Surface & Flake, thinning & 1 & 1.48 & Chert, $>1 / 2^{\prime \prime}$, complete \\
\hline CP 9 & Surface & Flake, thinning & 1 & 1.77 & Chert, >1", complete \\
\hline $\mathrm{CP} 9$ & Surface & Flake, thinning & 1 & 0.46 & Chert, $>1 / 2^{\prime \prime}$, proximal \\
\hline CP 9 & Surface & Possible cultural lithic & 1 & 1.38 & Petrified wood, possible core reduction \\
\hline $\mathrm{CP} 9$ & Surface & PPK fragment & 1 & 3.01 & Chert, probable long rounded stem \\
\hline $\mathrm{CP} 10$ & Surface & Flake, core reduction & 1 & 1.37 & Chert, $>1 / 2^{\prime \prime}$, complete \\
\hline CP 10 & Surface & Flake, thinning & 2 & 2.57 & Chert, > 1/2",complete \\
\hline CP 10 & Surface & PPK, contracting stemmed & 1 & 5.18 & Chert, Gary type, stem \& partial body \\
\hline $\mathrm{CP} 10$ & Surface & PPK, preform & 1 & 8.62 & Chert \\
\hline CP 10 & Surface & Fire cracked rock & 2 & 23.40 & Chert \\
\hline CP 11 & Surface & Uid, scapper & 1 & 12.28 & $\begin{array}{l}\text { Chert, L-33.32mm, W-26.58mm, T- } \\
11.84 \mathrm{~mm}\end{array}$ \\
\hline $\mathrm{CP} 11$ & Surface & Possible cultural lithic & 1 & 10.45 & Possibly non-cultural \\
\hline CP 12 & Surface & Flake, early reduction & 1 & 5.81 & Chert, >1", complete \\
\hline
\end{tabular}


Table 5.9. Artifact Inventory for Site 41CS109.

\begin{tabular}{|c|c|c|c|c|c|}
\hline Provenience & $\begin{array}{l}\text { Depth } \\
\text { (cmbs) }\end{array}$ & Description & Count & $\begin{array}{l}\text { Weight } \\
\text { (g) }\end{array}$ & Comments \\
\hline CP 12 & Surface & Flake, thinning & 2 & 3.83 & Chert, $>1 / 2^{\prime \prime}$ medial-distal \\
\hline CP 12 & Surface & Flake, thinning & 1 & 0.75 & Chert, > 1/2", proximal \\
\hline CP 13 & Surface & Flake, early reduction & 3 & 8.83 & Chert, > 1/2", complete \\
\hline CP 13 & Surface & Flake, thinning & 4 & 6.99 & Chert, $>1 / 2^{\prime \prime}$, complete \\
\hline CP 13 & Surface & Flake, thinning; late & 1 & 0.39 & Chert, $>1 / 4^{\prime \prime}$, complete \\
\hline CP 13 & Surface & Shatter, angular & 1 & 2.10 & Chert, > 1/2" \\
\hline CP 14 & Surface & PPK, contracting stemmed & 1 & 12.71 & $\begin{array}{l}\text { Chert, Gary type, no tip, L- } 45.08 \mathrm{~mm} \text {, } \\
\text { W-36.82mm, T-9.91mm }\end{array}$ \\
\hline CP 14 & Surface & Flake, thinning; late & 1 & 0.08 & Chert, $>1 / 4^{\prime \prime}$, complete \\
\hline CP 14 & Surface & Flake, early reduction & 1 & 4.15 & Chert, $>1^{\prime \prime}$, complete \\
\hline CP 14 & Surface & Flake, early reduction & 1 & 3.68 & Chert, > 1/2", complete \\
\hline CP 14 & Surface & Flake, thinning & 2 & 2.91 & Chert, $>1 / 2^{\prime \prime}$, complete \\
\hline CP 14 & Surface & Flake, thinning & 1 & 0.57 & Chert, $>1 \mathrm{~cm}$, proximal \\
\hline CP 14 & Surface & Flake, thinning & 1 & 2.85 & Chert, $>1 / 2^{\prime \prime}$, non-orientable \\
\hline CP 14 & Surface & Flake, thinning & 1 & 1.49 & Quartzite, >1/2", complete \\
\hline CP 14 & Surface & Flake, core reduction & 1 & 2.87 & Quartzite, $>1 / 2^{\prime \prime}$, complete \\
\hline CP 15 & Surface & Flake, early reduction & 1 & 5.71 & Chert, > 1", proximal \\
\hline CP 15 & Surface & Flake, thinning & 1 & 0.88 & Chert, $>1 / 2^{\prime \prime}$, complete \\
\hline CP 16 & Surface & Flake, early reduction & 3 & 9.69 & Chert, >1", complete \\
\hline CP 16 & Surface & Flake, early reduction & 1 & 2.15 & Chert, $>1 / 2^{\prime \prime}$, complete \\
\hline CP 16 & Surface & Shatter, thermal & 1 & 2.94 & Chert, $>1 / 2^{\prime \prime}$, non-orientable \\
\hline CP 17 & Surface & PPK preform, early stage & 1 & 30.93 & Chert \\
\hline CP 17 & Surface & Flake, early reduction & 1 & 3.98 & Chert, >1", complete \\
\hline CP 17 & Surface & Flake, thinning & 1 & 1.23 & Chert, $>1 / 2^{\prime \prime}$, proximal \\
\hline CP 17 & Surface & Flake, thinning & 2 & 3.58 & Chert, $>1 / 2^{\prime \prime}$, medial-distal \\
\hline \multicolumn{3}{|c|}{ Surface Collection Point Subtotal } & 88 & 355.93 & \\
\hline ST 4 & $20-30$ & Flake, core reduction & 1 & 1.73 & Chert, > 1/2", proximal \\
\hline ST 9 & Surface & Flake, thinning & 1 & 0.60 & Chert, $>1 / 2^{\prime \prime}$, proximal \\
\hline ST 9 & Surface & Flake, thinning & 1 & 0.69 & Chert, $>1 / 2^{\prime \prime}$, medial-distal \\
\hline ST 9 & Surface & Flake, thinning & 1 & 1.38 & Chert, $>1 / 2^{\prime \prime}$, complete \\
\hline ST 9 & Surface & Flake, early reduction & 1 & 1.97 & Chert, $>1 / 2^{\prime \prime}$, proximal \\
\hline ST 9 & Surface & Biface, fragment & 1 & 1.61 & Chert, 2 broken edges \\
\hline ST 9 & Surface & Shatter, thermal & 1 & 6.87 & Chert \\
\hline ST 10 & Surface & Fire cracked rock & 1 & 221.21 & \\
\hline \multicolumn{3}{|c|}{ Shovel Test Subtotal } & 8 & 236.06 & \\
\hline \multicolumn{3}{|c|}{ Site Total } & 96 & 591.99 & \\
\hline
\end{tabular}

Subsurface testing included the excavation of 12 shovel tests (Figure 5.71), of which one (ST 4) produced artifacts. The shovel test yielded a single chert core reduction flake between 20 and $30 \mathrm{cmbs}$. As a result, no test units were excavated at site 41CS109. A typical soil profile displayed very dark gray (10YR 3/1) sandy loam from 0 to $20 \mathrm{cmbs}$, yellowish-brown (10YR 5/6) 


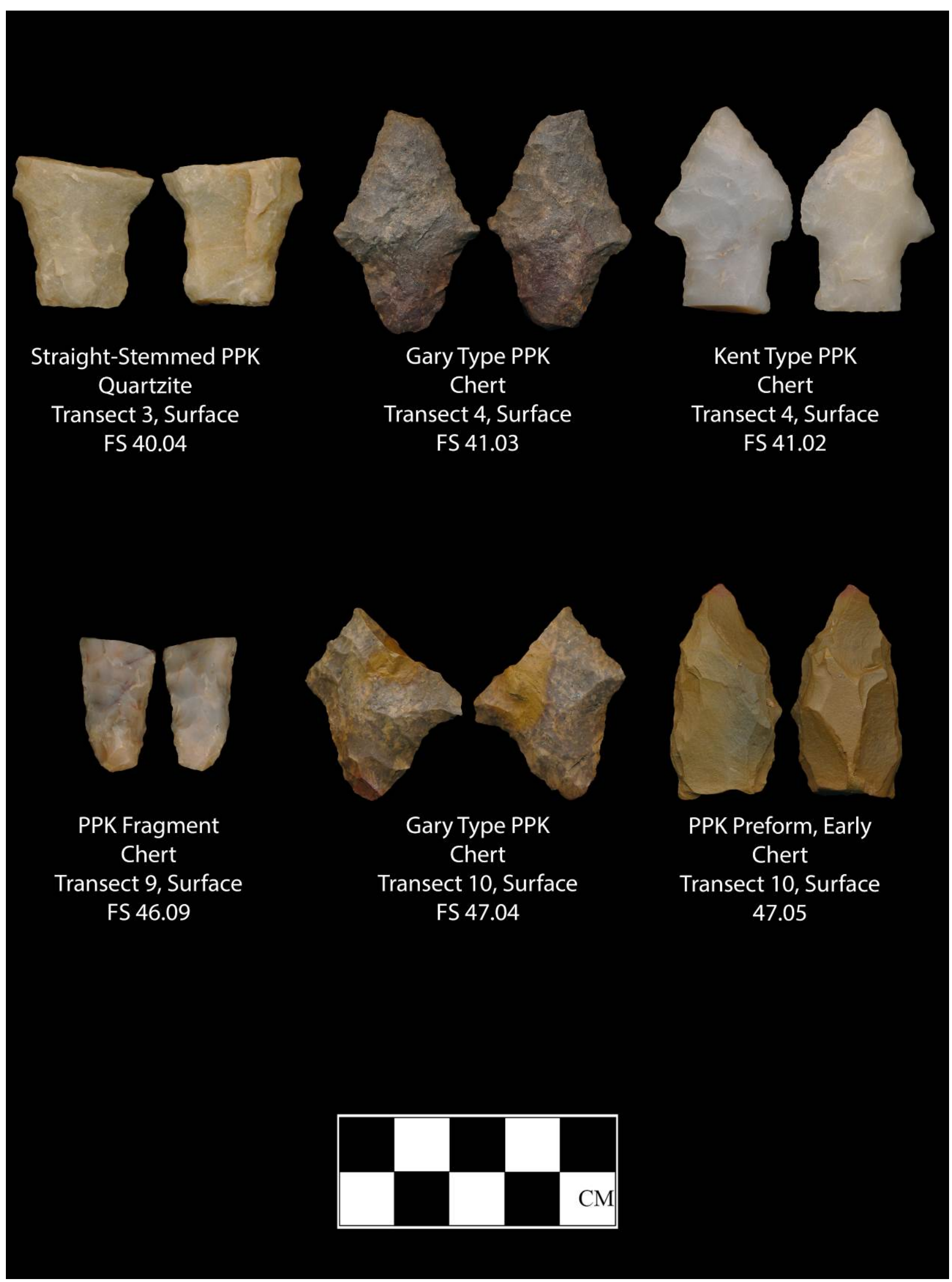

Figure 5.69. Select artifacts collected from site 41CS109 (1 of 2). 


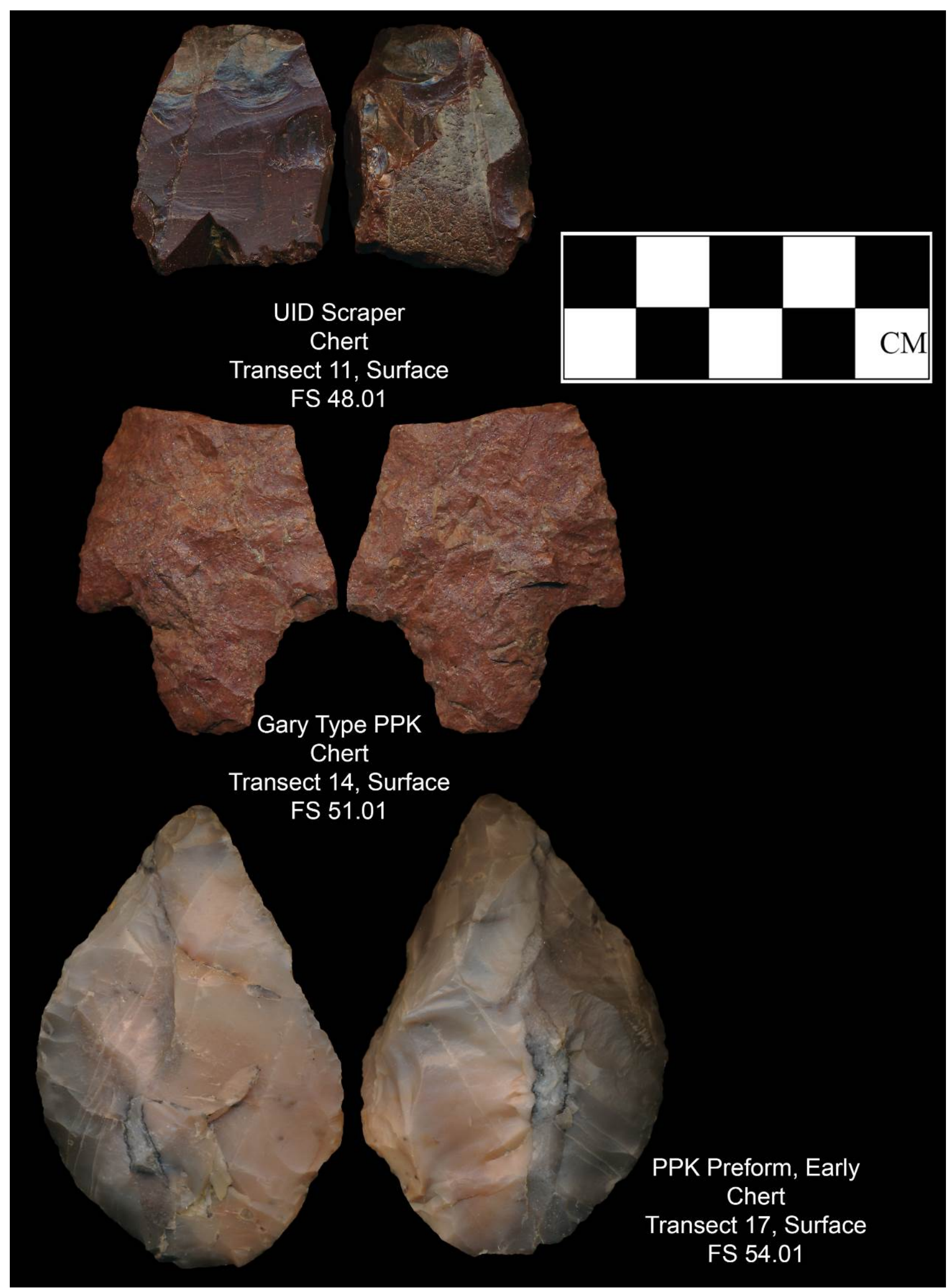

Figure 5.70. Select artifacts collected from site 41CS109 (2 of 2). 


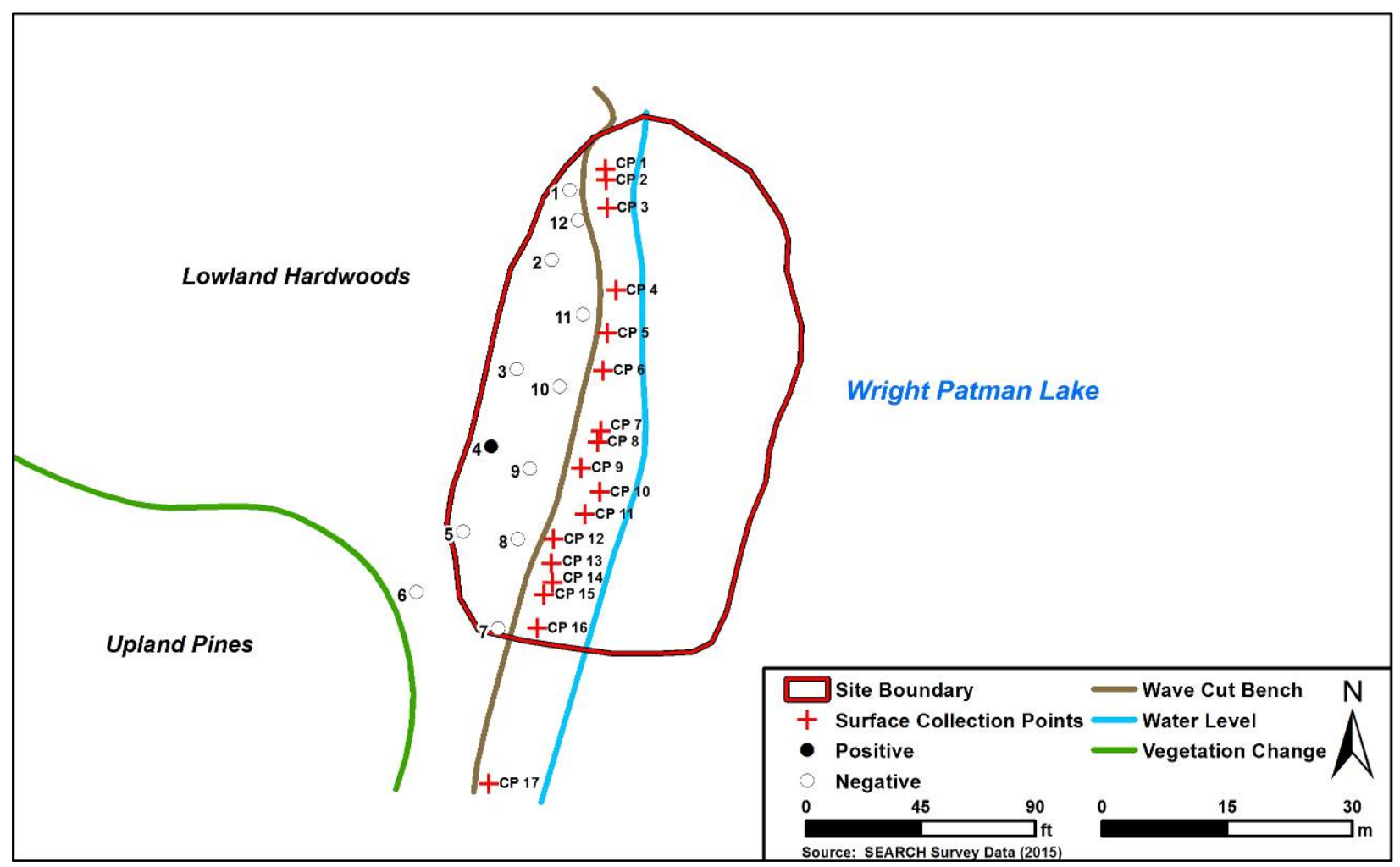

Figure 5.71. SEARCH 2015 fieldwork plan map for site 41CS109.

loamy clay from 20 to $35 \mathrm{cmbs}$, and strong brown (7.5YR 5/6) clay from 35 to $55+\mathrm{cmbs}$ (Figure 5.72).

\section{Recommendation}

In November 2015, a relatively large portion of site 41CS109 was inundated by rising lake levels at Wright Patman Lake. Exposed portions of the site and the adjacent uplands were tested to determine if intact cultural deposits existed within and adjacent to the defined boundary. One flake was

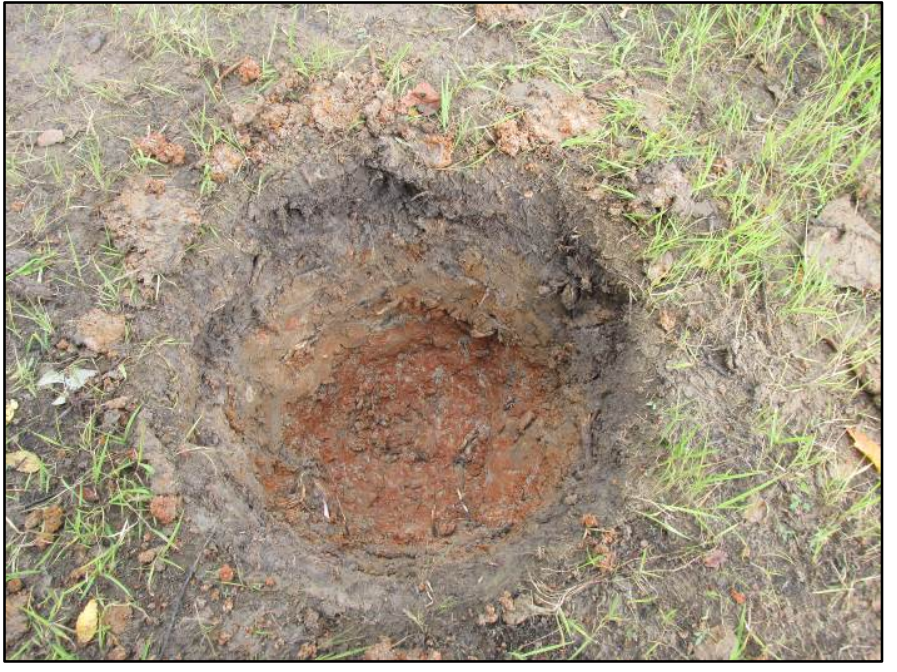

Figure 5.72. Typical soil profile at 41CS109. recovered from subsurface context. The remaining large collection of debitage and lithic tools were encountered on the surface and mostly along the exposed beach. The assemblage is dominated by lithic artifacts that include a large amount of lithic debitage along with formal and expedient tools. The Kent and Gary projectile points indicate a potential Middle Archaic to Early Woodland cultural affiliation for the site. The artifact assemblage, examined in tandem with absolute dating methods (radiocarbon or thermoluminescence), has the potential to offer insight into the lithic economy 
of Native American inhabitants of the site. It is the recommendation of SEARCH that additional work be performed to evaluate the NRHP status of site 41CS109 and mitigate adverse effects of the proposed pool rise for meeting the Ultimate Rule Curve.

\section{SITE 41CS110}

Briggs and Malone recorded site 41CS110 (Figure 5.73) in February 1970. The site was located at an elevation of $222 \mathrm{ft}$ amls on small points that extend into Wright Patman Lake. Artifacts including Native American ceramics, biface fragments, lithic flakes, and at least one point were recovered. A significant portion of the site may be located below the water (TARL 1970n).

SEARCH archaeologists returned to site $41 \mathrm{CS} 110$ on October 26, 2015. At that time, the pool elevation measured $224.86 \mathrm{ft}$ amsl. The site boundary as presented in the USACE Fort Worth Wright Patman Lake GIS database covers $2,804 \mathrm{~m}^{2}(0.69 \mathrm{ac})$ along a low terrace adjacent to Wright Patman Lake. In general, the vegetation is composed of immature hardwoods (oaks, persimmon) with a sparse understory of saplings and grass (Figure 5.74 and 5.75).

During the initial site reconnaissance, SEARCH archaeologists determined that the plotted site location as listed on the THC site file and within the USACE Fort Worth Wright Patman Lake GIS database was partially submerged on the eastern side by the current lake level. Ground visibility was about 85 percent with better visibility near the waterline. A pedestrian survey was conducted across the entire site including an exposed beach on the eastern portion of the site. No artifacts were encountered along the terrace; however, 11 artifacts were collected from the

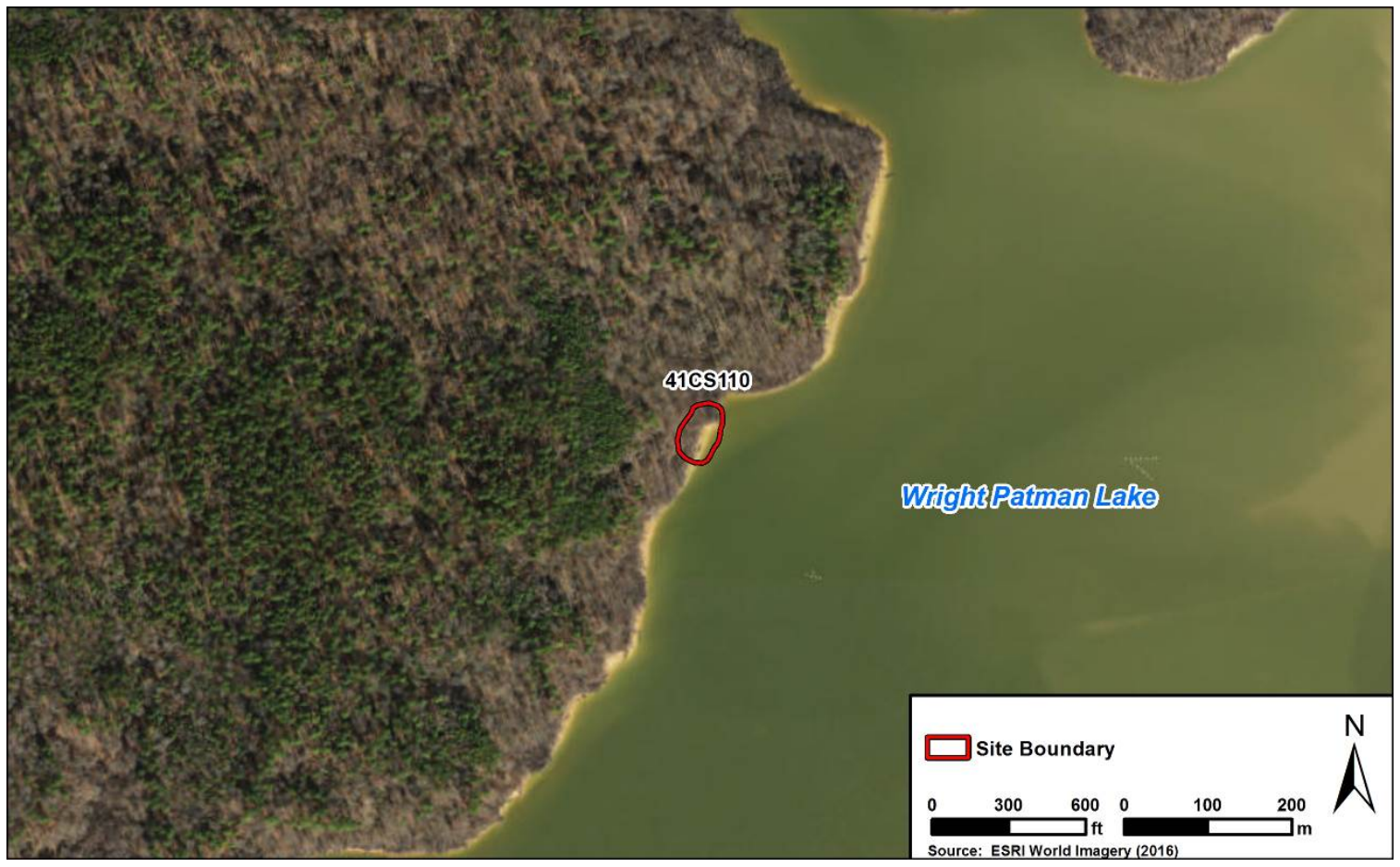

Figure 5.73. Location of site 41CS110. 


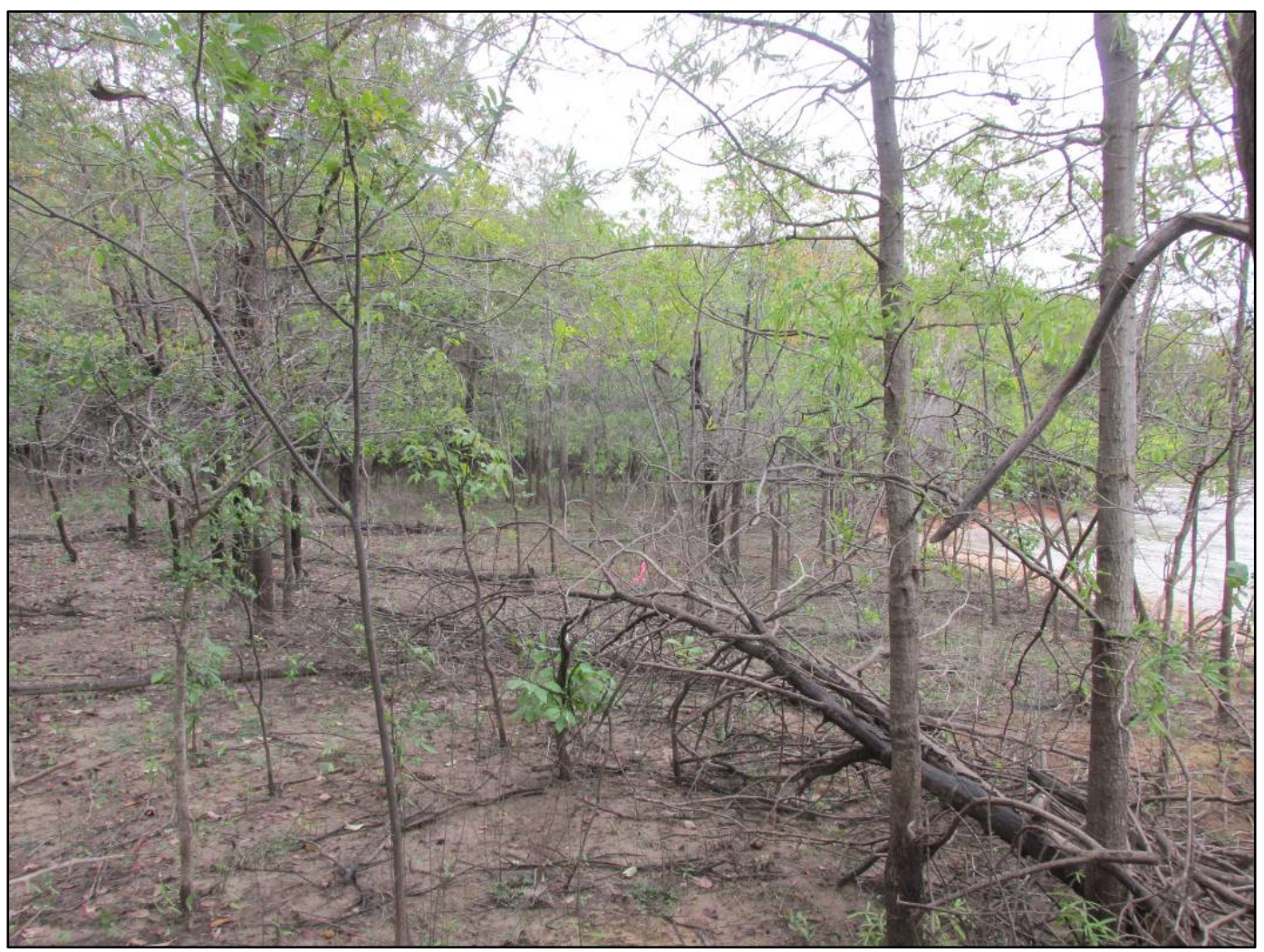

Figure 5.74. Typical vegetation at site 41CS110.

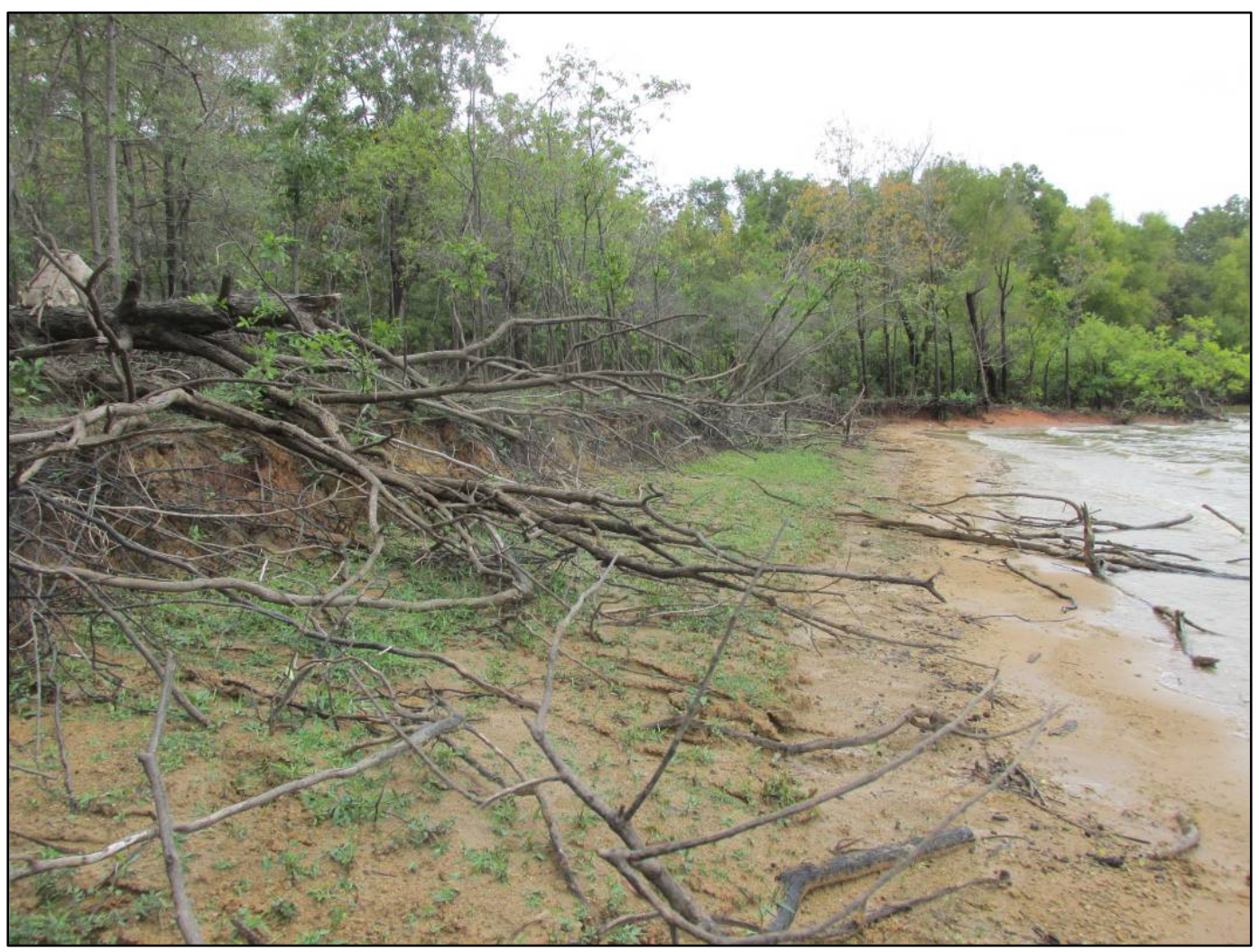

Figure 5.75. The exposed shoreline and bench at site 41CS110. 
exposed beach. These items include three chert core reduction flakes, six chert early reduction flakes, one chert thinning flake, and one piece of angular chert shatter.

Subsurface testing included the excavation of 12 shovel tests (Figure 5.76), none of which produced artifacts. As a result, no test units were excavated at site 41CS110. A typical soil profile displayed light grayish-brown (10YR 6/2) or pale brown (10YR 6/3) mottled with reddish brown (5YR 5/4) clay loam occurring from 0 to $10 \mathrm{cmbs}$ and reddish brown (5YR 6/2) mottled with strong brown (7.5YR 5/6) compact clay occurring from 10 to $30+\mathrm{cmbs}$ (Figure 5.77). No artifacts were recovered from shovel tests at site 41CS110.

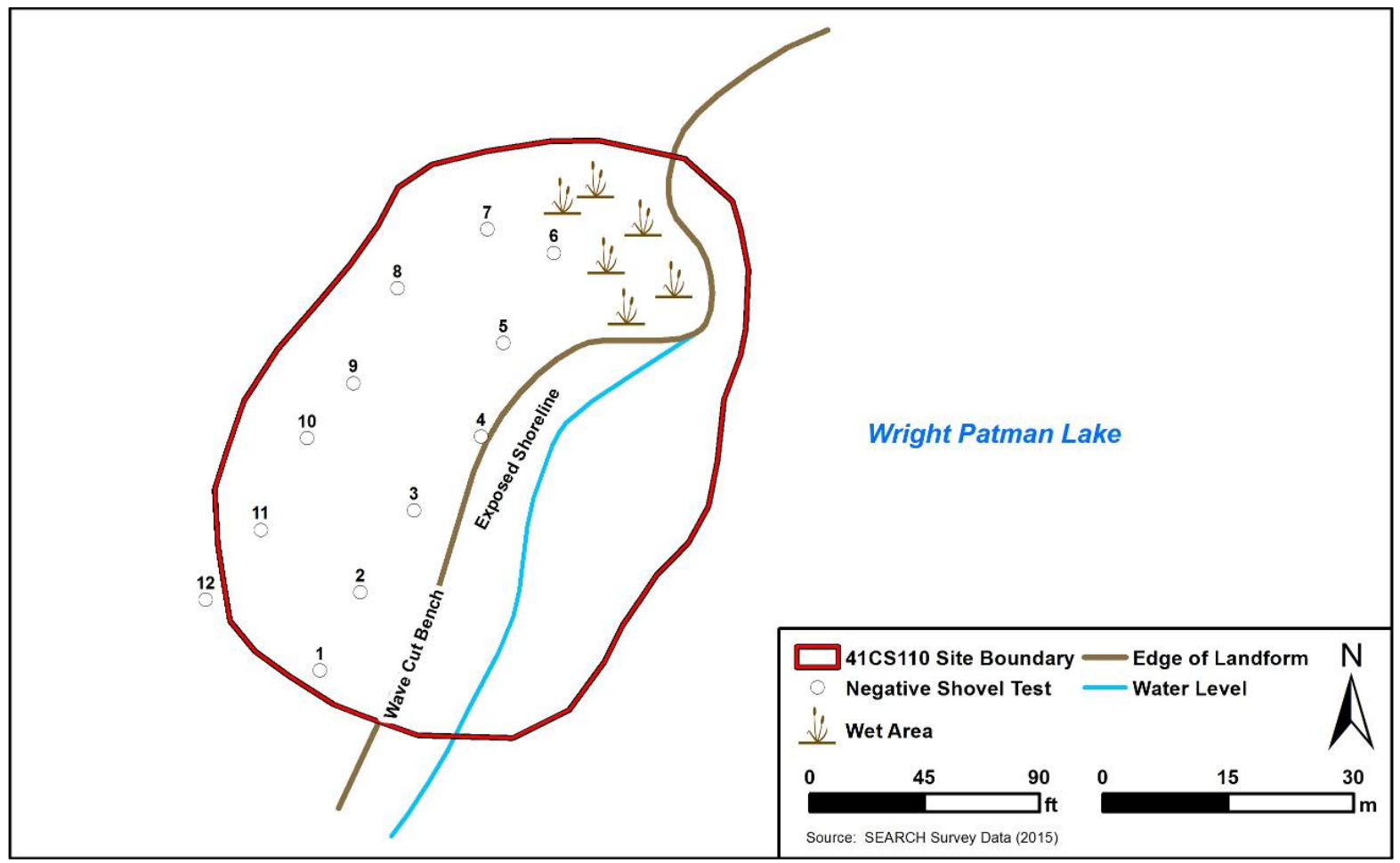

Figure 5.76. SEARH 2015 fieldwork plan map for site 41CS110.

\section{Recommendation}

In November 2015, a significant portion of site 41CS110 was inundated by rising lake levels at Wright Patman Lake. Exposed portions of the site were tested to determine if intact cultural deposits existed within and adjacent to the defined boundary. No artifacts were identified during subsurface testing and only 11 artifacts, entirely lithic debitage, were encountered during the pedestrian survey. Based on the small and limited artifact

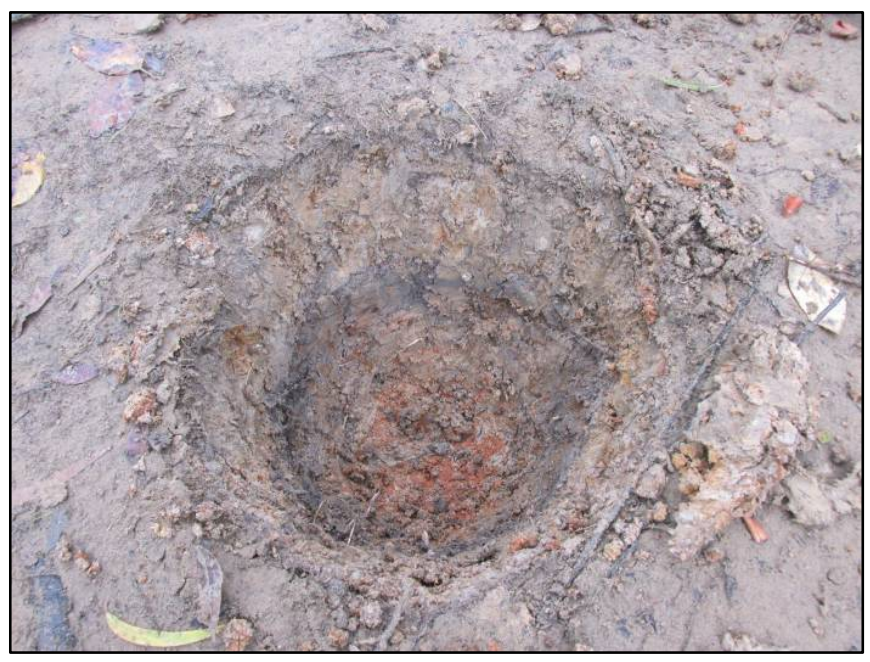

Figure 5.77. Typical soil profile at site 41CS110. 
assemblage identified at site 41CS110, it is the opinion of SEARCH that the tested portion of the site does not contribute to its NRHP eligibility. However, as a portion of the site remains submerged and untested, SEARCH recommends that the NRHP status of site 41SC110 remain undetermined until such time as the submerged deposits can be evaluated.

\section{SITE 41CS117}

Briggs and Malone recorded site 41CS117 (Figure 5.78) in March 1970. They identified the site at an elevation of $225 \mathrm{ft}$ amsl in a swampy area near an inlet into Old Jackson Creek and adjacent to Wright Patman Lake. The site form (TARL 1970o) denotes that this site is typically located underwater, but it may once have been rather dry. Artifacts collected from this site include an unspecified number of Native American lithic flakes and at least one projectile point.

SEARCH archaeologists returned to site 41CS117 on November 9, 2015. During that time, the pool elevation measured $226.70 \mathrm{ft}$ amsl. The site boundary as presented in the USACE Fort Worth Wright Patman Lake GIS database covers 2,081 $\mathrm{m}^{2}(0.51 \mathrm{ac})$ along a low terrace edge adjacent to Wright Patman Lake. Vegetation is composed of an open canopy of mostly hardwoods (oaks, persimmon) with an understory of low saplings, grass, and greenbriar (Figures 5.79 and 5.80).

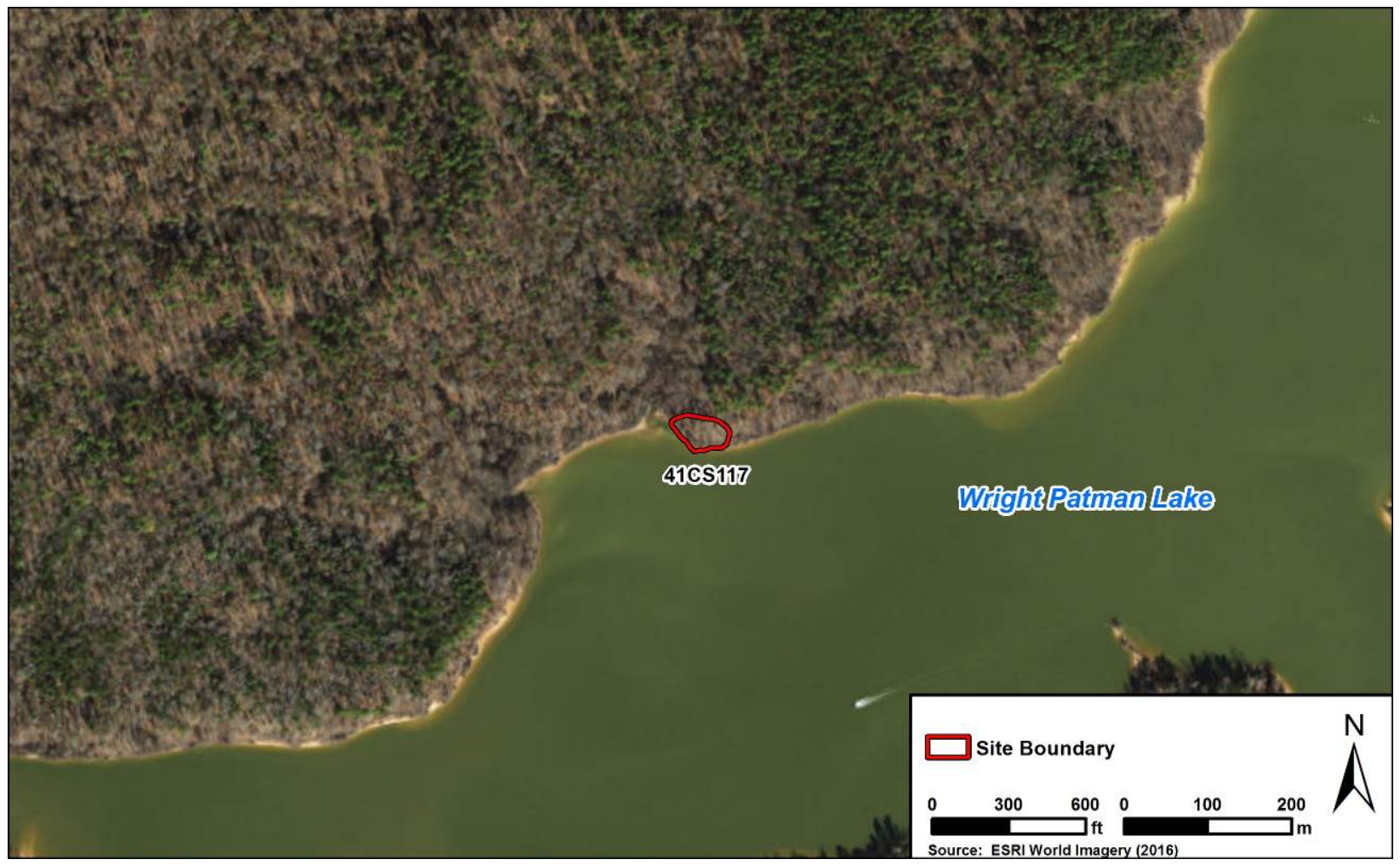

Figure 5.78. Location of site 41CS117. 


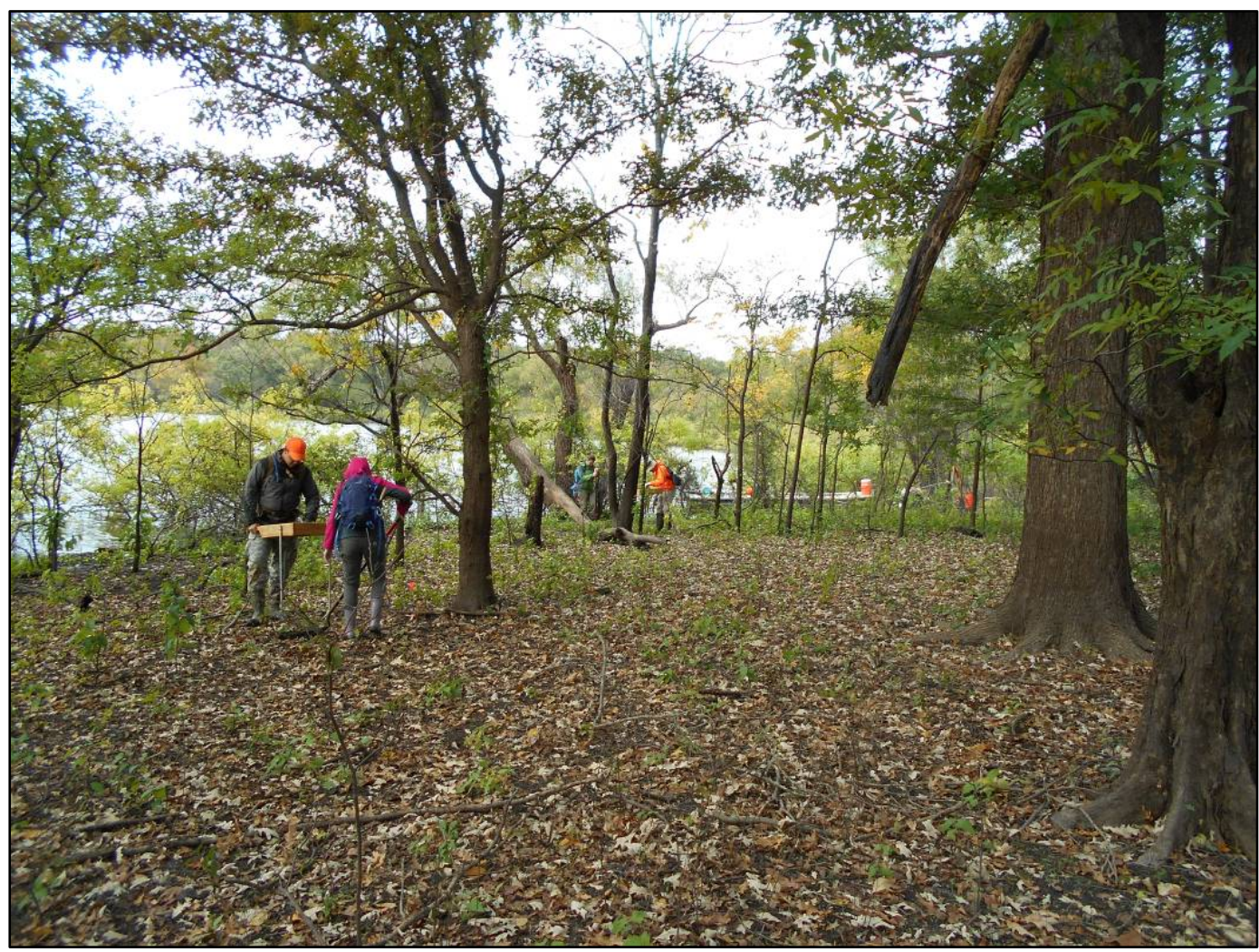

Figure 5.79. Typical vegetation at site $41 \mathrm{CS} 117$.

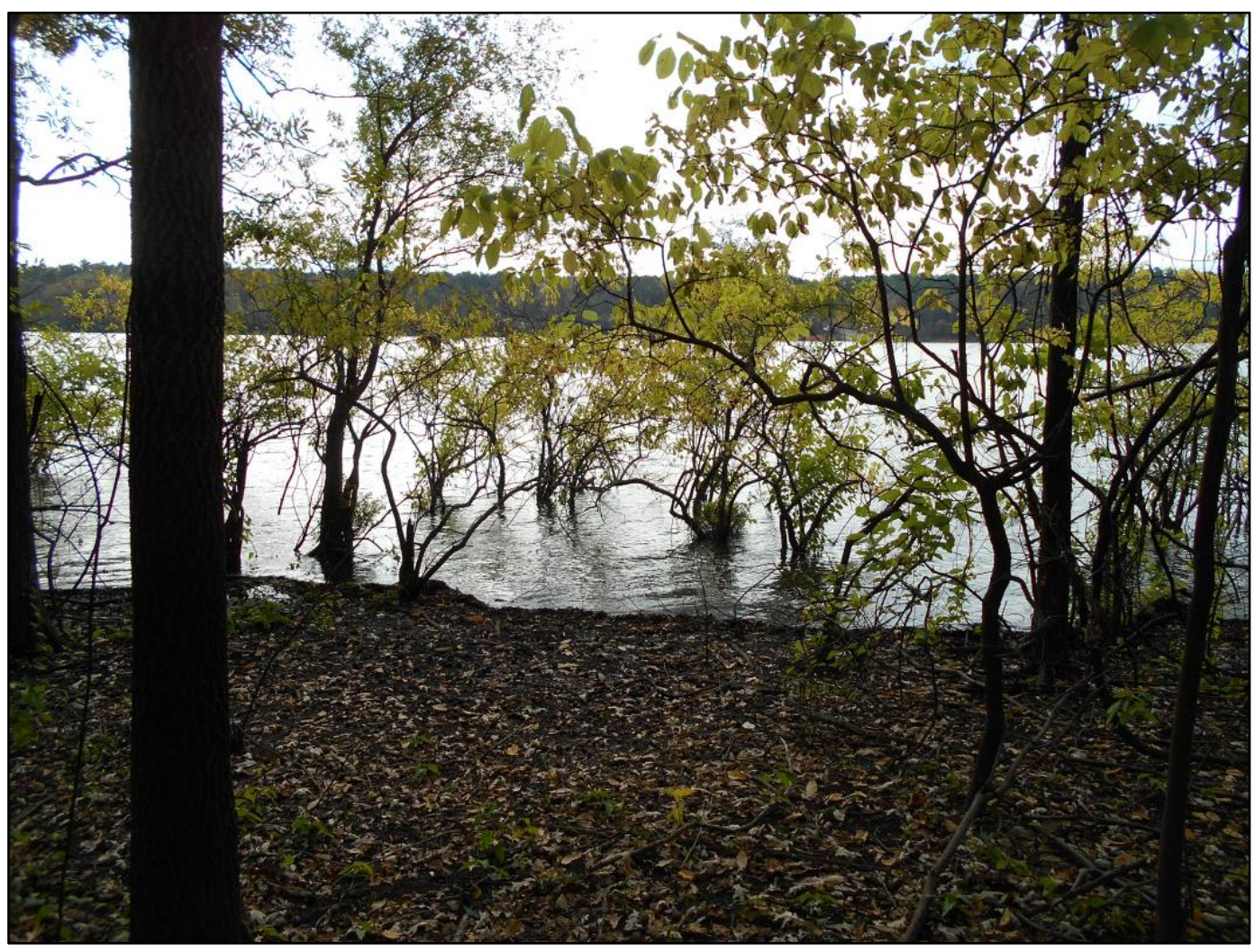

Figure 5.80. Submerged trees and lack of exposed beach along the south portion of site $41 \mathrm{CS} 117$. 
During the initial site reconnaissance, SEARCH archaeologists determined that the plotted site location as listed on the THC site file and within the USACE Fort Worth Wright Patman Lake GIS database was partially submerged by the current lake level. Nearly all of the archaeological investigation occurred within the site boundary; however, artifacts found within shovel tests along the northern periphery of the site extended fieldwork outside of the boundary.

Ground visibility was about 50 percent with better visibility occurring near the waterline. A pedestrian survey was conducted along transects that measured the length of the site and spaced $5 \mathrm{~m}$ apart, beginning at the water line and extending $40 \mathrm{~m}$ north. No exposed beach, scarps, or benches were observed (see Figure 5.80). No artifacts were observed during the pedestrian survey.

Subsurface testing included the excavation of 18 shovel tests, of which two produced artifacts (Figure 5.81). A typical soil profile displayed very dark gray (10YR 3/1) to dark yellowish-brown (10YR 3/4) silty loam from 0 to $10 \mathrm{~cm}$, a mottled $20-\mathrm{cm}$ thick zone of the Stratum I soils mixed with varying amounts of red (5YR 4/6) and strong brown (7.5YR 5/6) clay, and a compact, sticky red (5YR 4/6) clay from 30 to $35 \mathrm{cmbs}$ (Figure 5.82). Artifacts collected from shovel tests include one chert early reduction recovered at $15 \mathrm{cmbs}$ from ST 6 and one chert thinning flake recovered between 40 and $50 \mathrm{cmbs}$ from ST 13.

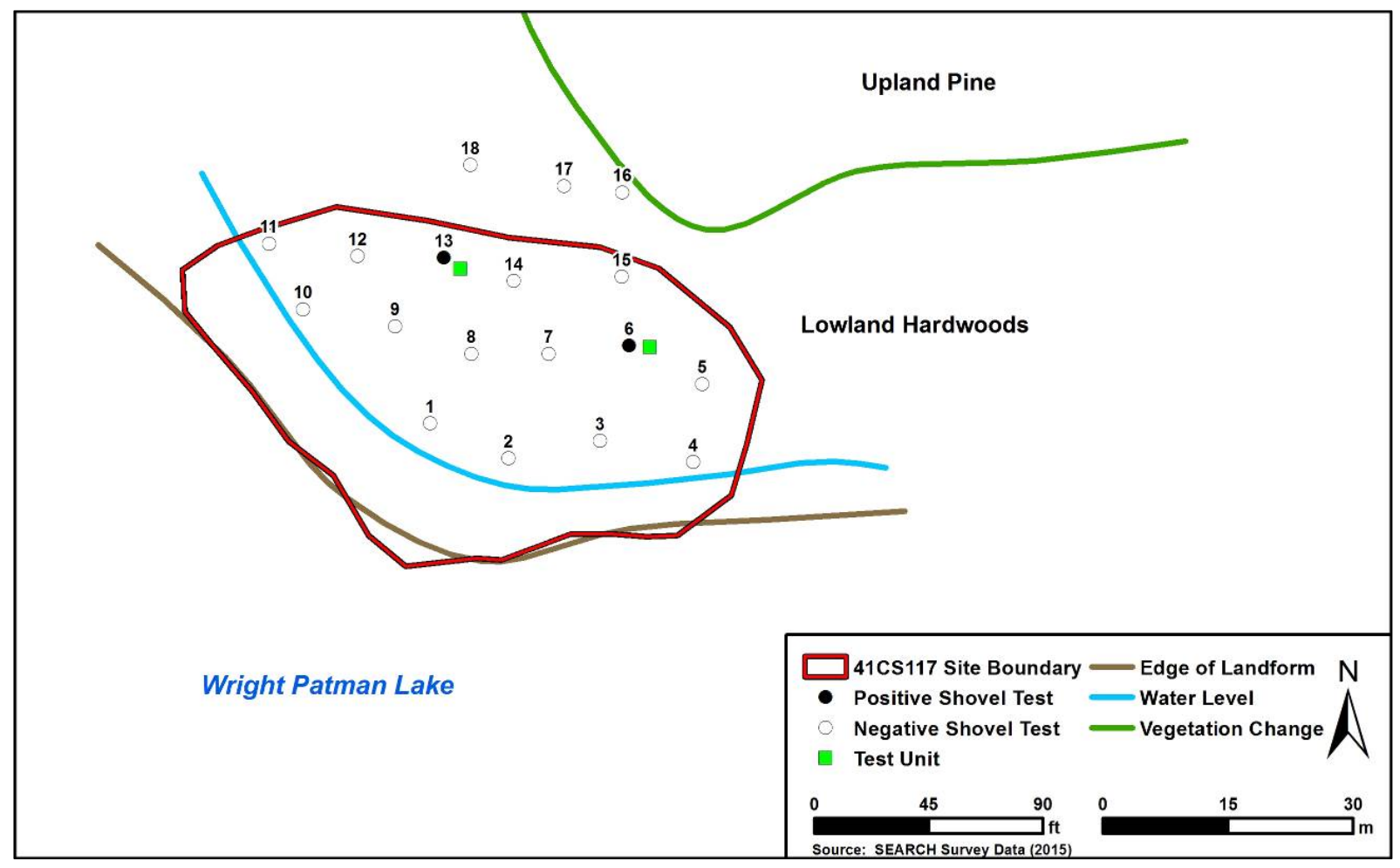

Figure 5.81. SEARCH 2015 fieldwork plan map for site 41CS117.

As a result of the shovel testing, two $50 \times 50 \mathrm{~cm}$ test units were excavated in close proximity to both shovel tests. Test Unit 1, placed adjacent to ST 13, was excavated in four arbitrary levels 
to a depth of $40 \mathrm{cmbs}$. No artifacts were recovered from TU 1. Test Unit 2, placed adjacent to ST 6, was excavated in four arbitrary levels to a depth of 40 cmbs. No artifacts were recovered from TU 2. No further testing occurred at site 41CS117.

\section{Recommendation}

In November 2015, a small portion of site 41CS117 was inundated by rising lake levels at Wright Patman Lake. The majority of the site was tested to determine if intact cultural deposits existed within the defined boundary. No artifacts were identified during the pedestrian survey. Subsurface testing yielded two artifacts-one chert early reduction flake from ST 6 and one chert thinning flake from ST 13. Test units placed in close proximity to these shovel tests encountered no additional artifacts. Based on the small and limited artifact assemblage identified at site 41CS117, it is the opinion of

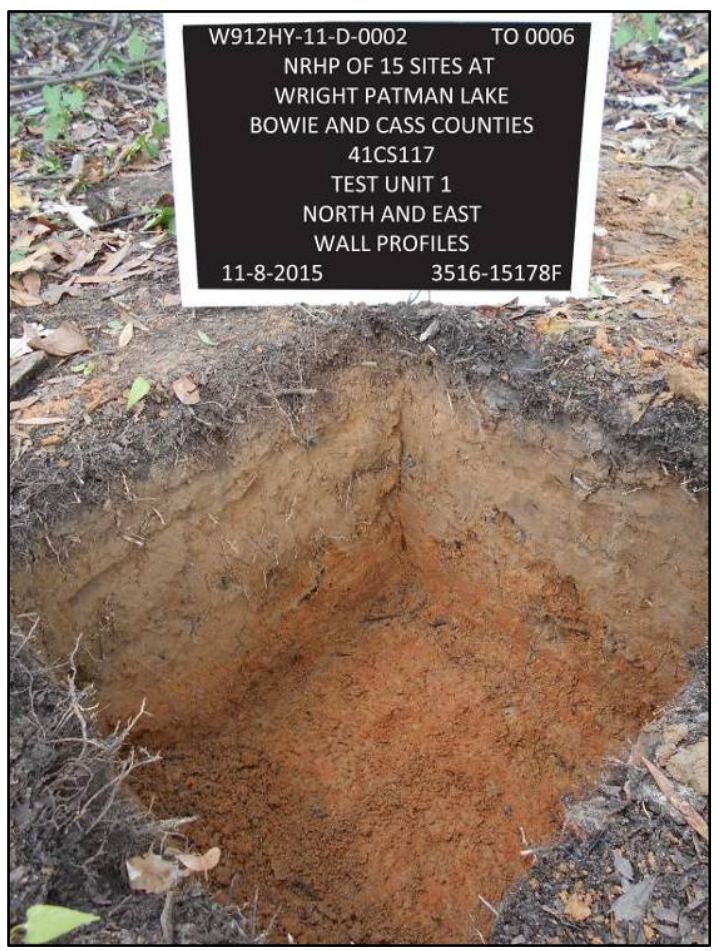

Figure 5.82. Typical soil profile from site 41CS117. SEARCH that the tested portion of the site does not contribute to its NRHP eligibility. However, as a portion of the site remains submerged and untested, SEARCH recommends that the NRHP status of site 41SC117 remain undetermined until such time as the submerged deposits can be evaluated. 


\section{SITE 41CS118}

Briggs and Malone recorded site 41CS118 (Figure 5.83) in 1970. They identified the site at an elevation of $222 \mathrm{ft}$ amsl on a gentle slope adjacent to Wright Patman Lake. The site form (TARL 1970p) denotes that the site is a Native American lithic scatter submerged during the summer, and is located only two feet above the water level during the remainder of the year. An unspecified number of lithic flakes were recovered, although the site file indicates that "large quantities" were collected. It is possible that the site is larger than currently recorded and that only the margins have been excavated.

On November 8, 2015, SEARCH archaeologists returned to site 41CS118. The pool elevation measured $226.65 \mathrm{ft}$ amsl. The site boundary as presented in the USACE Fort Worth Wright Patman Lake GIS database covers $1,587 \mathrm{~m}^{2}$

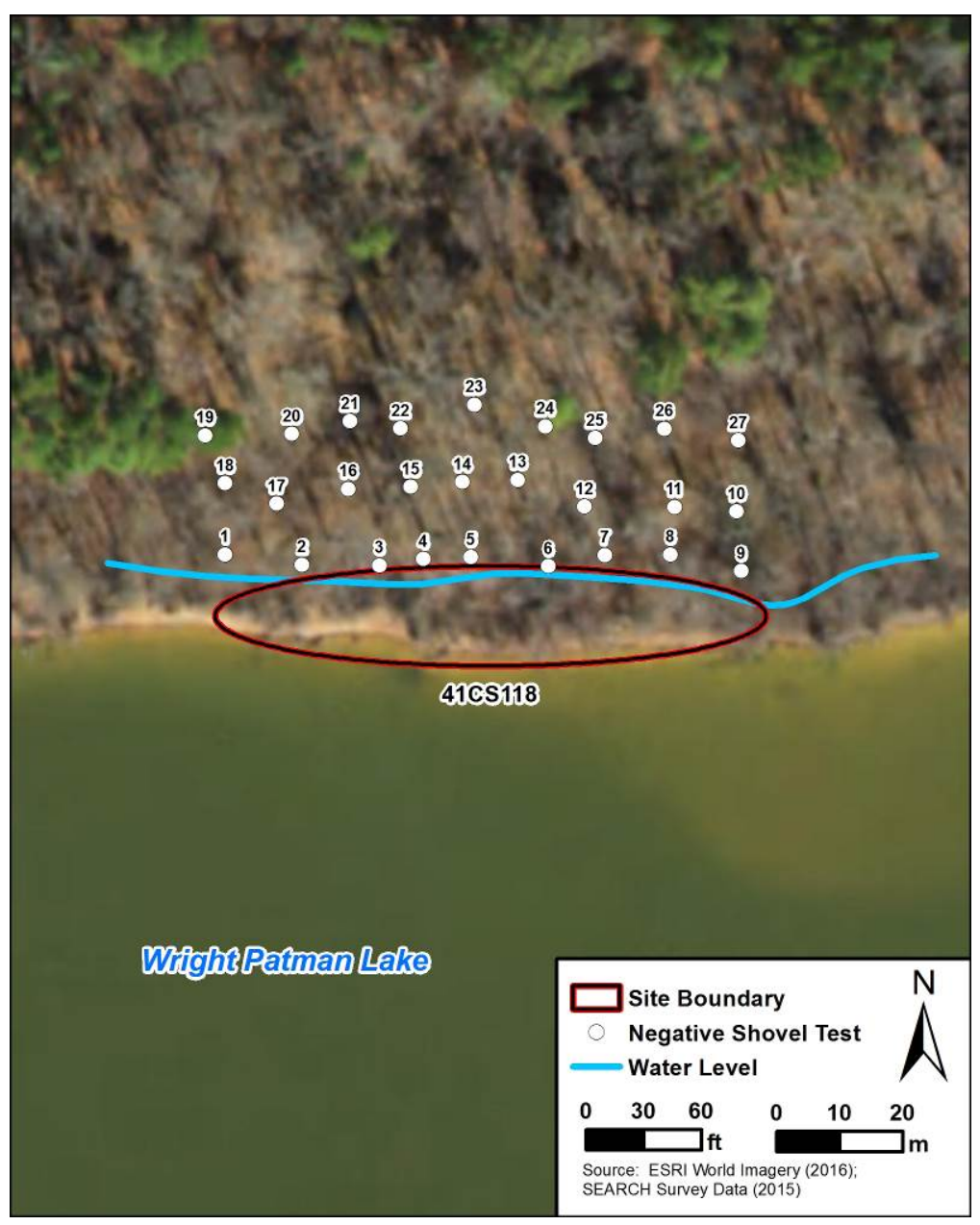

Figure 5.83. Location and SEARCH 2015 fieldwork plan map for site 41 CS118.

(0.39 ac) along a low terrace adjacent to Wright Patman Lake. In general, the vegetation is composed of mostly hardwoods (oaks, persimmon) with an understory of low saplings, grass, and greenbriar (Figures 5.84 and 5.85).

During the initial site reconnaissance at site 41SC118, SEARCH archaeologists determined that the plotted site location as listed on the THC site file and within the USACE Fort Worth Wright Patman Lake GIS database was largely submerged by the current lake level ( $226.65 \mathrm{ft}$ amsl). As a result, nearly all of the archaeological investigation occurred across the uplands adjacent to the site's northern boundary (see Figure 5.83).

Ground visibility was about 30 percent with better visibility occurring near the waterline. A pedestrian survey was conducted along transects that measured the length of the site and spaced $5 \mathrm{~m}$ apart, beginning at the water line and extending $30 \mathrm{~m}$ north of the site boundary. 


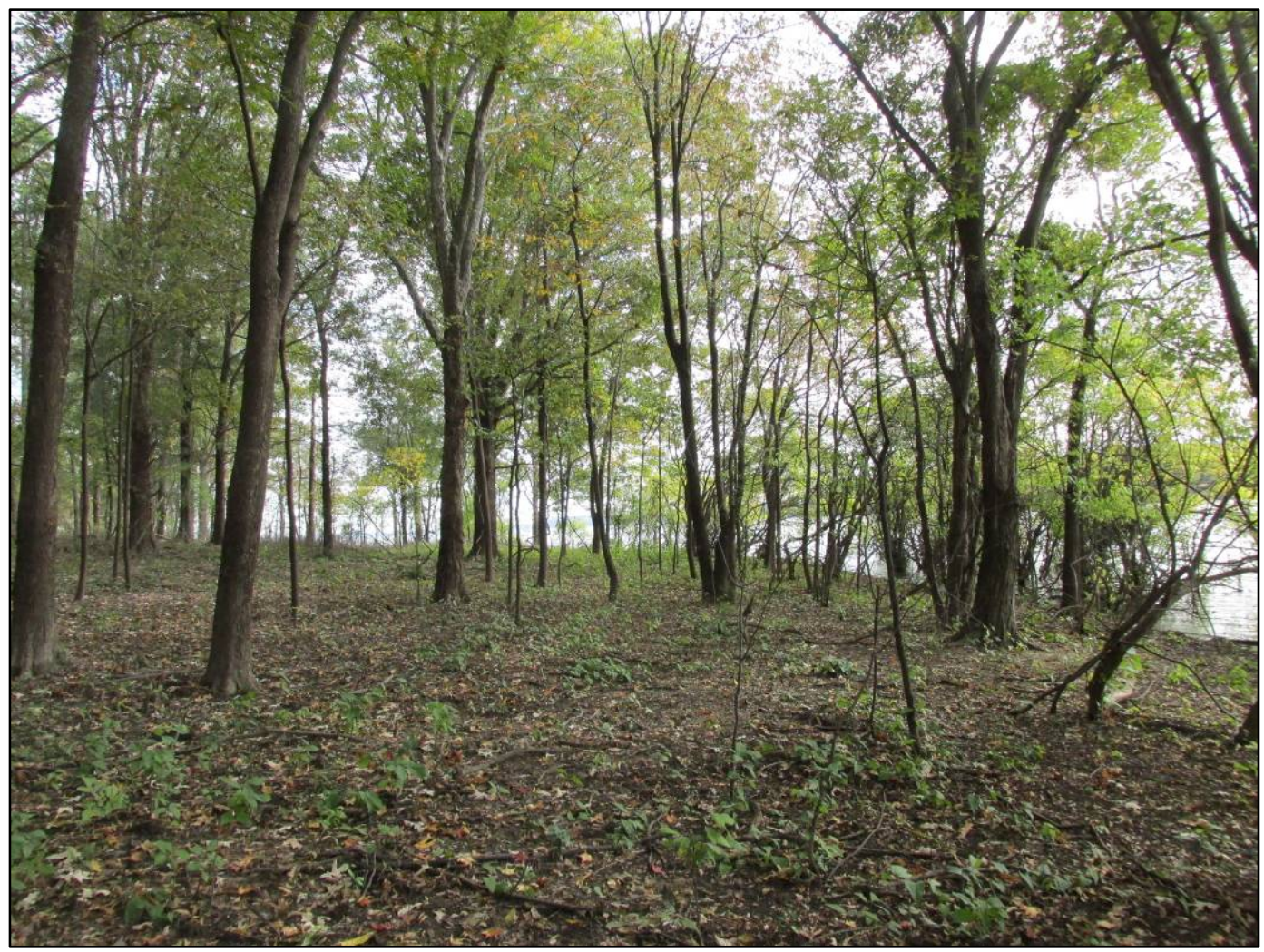

Figure 5.84. Typical vegetation immediately north of site 41CS118.

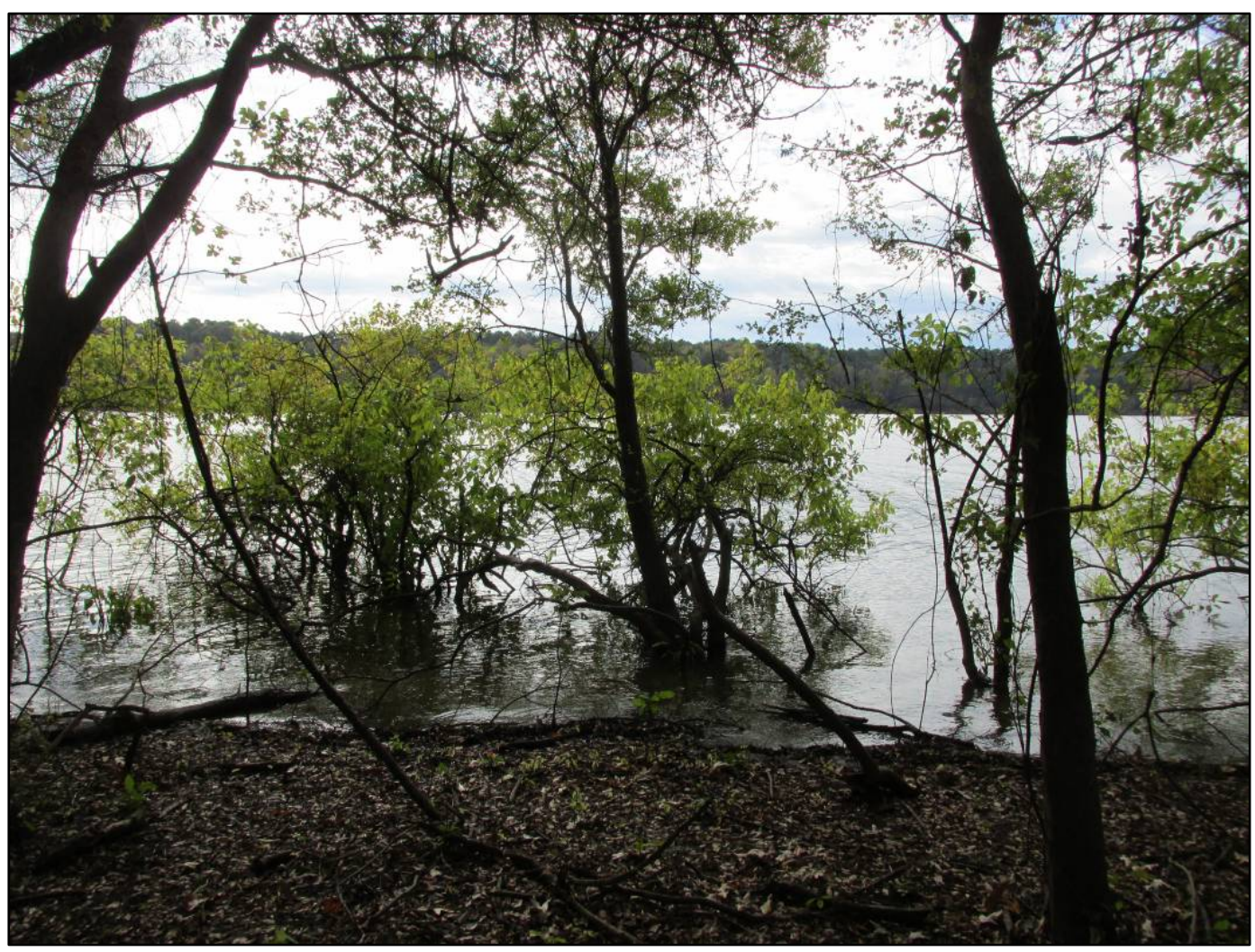

Figure 5.85. Submerged trees and lack of exposed beach along the northern edge of site $41 \mathrm{CS} 118$. 
No exposed beach, scarps, or benches were observed (see Figure 5.85). No artifacts were recovered during the pedestrian survey.

Subsurface testing included the excavation of 27 shovel tests, none of which produced artifacts. As a result, no test units were excavated at site 41CS118. A typical profile displayed very dark gray (10YR 3/1) to dark yellowishbrown (10YR 3/4) silty loam from 0 to 10 cmbs, a mottled $20-\mathrm{cm}$ thick zone of the Stratum I soils mixed with varying amounts of red (5YR 4/6) and strong

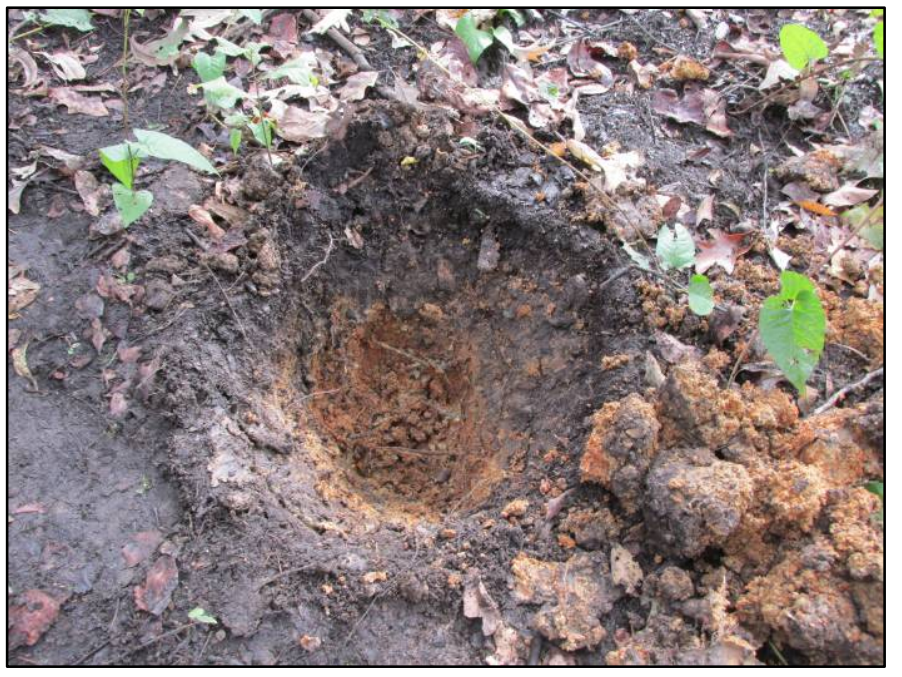

Figure 5.86. Typical shovel test profile at site 41CS118. brown (7.5YR 5/6) clay, and a sticky red (5YR 4/6) clay from 30 to $35+\mathrm{cmbs}$ (Figure 5.86).

\section{Recommendation}

In November 2015, nearly all of site 41CS118 was inundated by rising lake levels at Wright Patman Lake. Exposed portions of the site and adjacent uplands were tested to determine if intact cultural deposits existed within and adjacent to the defined boundary. No artifacts were identified during pedestrian survey and subsurface testing. As only a small portion of the site could be tested, SEARCH recommends that NRHP status of site 41CS118 remain undetermined until such time as the submerged deposits can be evaluated. 


\section{CHAPTER 6 CONCLUSIONS}

Between 19 October and 11 November 2015, SEARCH conducted NRHP eligibility determinations at previously recorded archaeological sites at Wright Patman Lake in Bowie and Cass counties, Texas. This project was conducted under Contract W912HY-11-D-0002, Task Order 0006 between the USACE, Fort Worth District, and SEARCH.

The USACE, Fort Worth District, is proposing to raise and operate the current pool level at Wright Patman Lake to $228.64 \mathrm{ft}$ amsl, thereby meeting the Ultimate Rule Curve for the provision of water to the local area. The purpose of this project was to provide systematic testing through pedestrian survey and the excavation of shovel tests and $50-x-50-\mathrm{cm}$ test units at a minimum of 15 previously recorded archaeological sites within the areas of potential effect of the Ultimate Rule Curve. The goal of this project was to determine if these unassessed (NRHP-eligibility undetermined) archaeological resources were ineligible for listing in the NRHP, required additional testing to determine NRHP status, or could not be evaluated because of inundation or inability to relocate the resource.

During fieldwork, SEARCH archaeologists visited 20 archaeological sites (see Table 1.1). Four sites (41BW42, 41CS55, 41CS78, and 41CS109) are recommended eligible for listing in the NRHP, while two sites (41CS73 and 41CS79) do not meet the Secretary of the Interior's criteria for listing in the NRHP and no further work is recommended. Twelve (41BW69, 41BW77, 41CS48, 41CS58, 41CS76, 41CS95/96, 41CS108, 41CS110, 41CS117, 41CS118, 41CS122, and 41CS123) of the remaining 14 sites could not be full evaluated based on complete or partial inundation by current and rising pool levels at Wright Patman Lake. As a result, the NRHP status of these sites remains undetermined. The remaining two sites (41BW26 and 41CS16) were not evaluated as it was determined based on elevation that these resources are outside of the proposed Ultimate Rule Curve Area of Potential Effect. 


\section{This PAge INTENTIONALLY Left BLANK}




\section{REFERENCES CITED}

Ahler, Stanley A.

1986 The Knife River Flint Quarries: Excavations at Site 32DU508. State Historical Society of North Dakota, North Dakota Heritage Center, Bismarck

Anderson, David G.

1996 Approaches to Modeling Regional Settlement in the Archaic Period Southeast. In Archaeology of the Mid-Holocene Southeast, edited by K. E. Sassaman and D. G.Anderson, pp.157-176. University Press of Florida, Gainesville.

Andrefsky, William, Jr.

2005 Lithics: Macroscopic Approaches to Analysis. Cambridge Manuals in Archaeology. Cambridge University Press, New York.

Austin, Robert J.

1999 Technological characterization of lithic waste-flake assemblages: multivariate analysis of experimental and archaeological data. Lithic Technology 24 (1): 53-68.

Austin, Stephen P.

2005 Integrated Cultural Resources Management Plan for Wright Patman Lake, Texas 20052009. Produced by US Army Corps of Engineers, Fort Worth District, Piney Woods Regional Office, Jefferson.

Ball, Donald B.

1997 Types, Headstamps, and Chronology of Winchester Shotgun Shells, 1877-1973. Ohio Valley Historical Archaeology 12:130-140.

Barber, Edwin A.

2001 Marks of American Potters. Blackburn Press, Caldwell, NJ.

Barnes, Virgil E.

1979 Geologic Atlas of Texas, Texarkana Sheet, Elias H. Sellards Memorial Edition. Bureau of Economic Geology - the University of Texas, Austin.

Bartley, Ernest R.

1953 The Tidelands Oil Controversy: A Legal and Historical Analysis. University of Texas Press, Austin.

Bense, Judith A.

1994 Archaeology of the Southeastern United States: Paleoindian to World War I. Academic Press, San Diego. 
Briggs, Alton K., and James M. Malone

1970 An Archeological Survey of the Texarkana Reservoir Enlargement Area - Report of the First Season. Archeological Survey Report Number 7. Texas Historical Survey Committee and Texas Water Development Board, Austin.

Campbell, Randolph B.

1989 An Empire for Slavery: The Peculiar Institution in Texas, 1821-1865. Louisiana State University Press, Baton Rouge.

Chipman, Donald E. and Harriet Denise Joseph

2010 Spanish Texas, 1519-1821. University of Texas Press, Austin.

Cliff, Maynard B., Steven M. Hunt, Darryl Pleasant, Rebecca Procter, H. Blaine Ensor

1996 Cultural Resources Survey of 600 Acres at Wright Patman Lake, Bowie and Cass Counties, Texas. Report submitted to the United States Army Corps of Engineers, Fort Worth District, Texas.

Collins, Michael B., and C. Britt Bousman

1993 Quaternary Environments and Archaeology in Northeast Texas. In Archaeology in the Eastern Planning Region, Texas: A Planning Document, edited by N. A. Kenmotsu and T. K. Perttula, pp. 49-68. Cultural Resources Management Report 3. Department of Antiquities Protection, Texas Historical Commission, Austin.

Delcourt, Hazel R., and Paul A. Delcourt

1981 Vegetation Maps for Eastern North America: 40,000 BP to the Present. In Geobotany II, edited by Robert C. Romans, pp. 123-165. Plenum Publishing Corp., New York.

1985 Quaternary Palynology and Vegetational History of the Southeastern United States. In Pollen Records of Late-Quaternary North American Sediments, edited by V. Bryant, Jr., and R. G. Holloway, pp. 1-37. American Association of Stratigraphic Palynologists Foundation, Dallas.

Dockall, John E. and Ross C. Fields

2006 Reconnaissance Survey to Assess the Impacts on Archaeological Resources of the Proposed Conservation Pool Level Raise at Wright Patman Lake, Bowie and Cass Counties, Texas. Report submitted to the United States Army Corps of Engineers, Fort Worth District, Texas.

Ferring, C. Reid

1995 Middle Holocene Environments, Geology, and Archaeology in the Southern Plains. In Archaeological Geology of the Archaic Period in North America, edited by E. A. Bettis, pp. 21-35. Geological Society of America, Boulder, Colorado. 
Fields, Ross C. and Steve A. Tomka

1993 Hunter-Gatherer Mobility in Northeast Texas. In Archaeology in the Eastern Planning Region, Texas: A Planning Document, edited by N.A. Kenmotsu and T.K. Perttula, pp. 69-97. Cultural Resource Management Report 3. Texas Historical Commission, Department of Antiquities Protection, Austin.

Flint, Richard and Shirley Cushing Flint (editors)

2012 The Coronado Expedition from the Distance of 460 Years. University of New Mexico Press, Albuquerque.

Godden, Geoffrey A.

1991 Encyclopedia of British Pottery and Porcelain Marks. Barrie and Jenkins, London.

Griffith, Glenn E., Sandra A. Bryce, James M. Omernik, Jeffrey A. Comstock, Anne C. Rogers, Bill Harrison, Stephen L. Hatch, and David Bezanson

2004 Ecoregions of Texas (color poster with map, descriptive text, and photographs): Reston, Virginia, U.S. Geological Survey (map scale 1:2,500,000). Electronic document, http:// www.epa.gov/wed/pages/ecoregions/tx_eco.htm, accessed December 22, 2014.

Hall, Andrew W.

2014 Civil War Blockade Running on the Texas Coast. The History Press, Charleston.

Harper, Cecil Jr.

2010a Bowie County. Handbook of Texas Online. Electronic document, http://www.tshaonline.org, accessed February 9, 2016.

2010b Cass County. Handbook of Texas Online. Electronic document, http://www.tshaonline.org, accessed February 9, 2016.

Jones, Olive and Catherine Sullivan

1989 The Parks Canada Glass Glossary of the Description of Containers, Tableware, Flat Glass, and Closures. National Historic Parks and Sites, Canadian Park Service, Environment Canada: Studies in Archaeology, Architecture, and History.

Kenmotsu, Nancy A., and Timothy K. Perttula (editors)

1993 Archaeology in the Eastern Planning Region, Texas: A Planning Document. Cultural Resources Management Report 3. Texas Historical Commission, Department of Antiquities Protection, Austin.

Kowalsky, Arnold A. and Dorothy E. Kowalsky

1999 Encyclopedia of Marks on American, English, and European Earthenware, Ironstone, and Stoneware. Shiffer Publishing, Ltd., Atglen, PA. 
Maril, Robert Lee

1995 The Bay Shrimpers of Texas: Rural Fishermen in a Global Economy. University Press of Kansas, Lawrence.

Martin, Robert L.

1969 The City Moves West: Economic and Industrial Growth in Central West Texas. University of Texas Press, Austin.

Miller, George L.

1980 Classification and Economic Scaling of 19th Century Ceramics - 1770-1881. Historical Archaeology 14:1-40.

Moneyhon, Carl H.

2004 Texas after the Civil War: The Struggle of Reconstruction. Texas A\&M University Press, College Station.

Neuman, Robert W.

1970 Archaeological and Historical Assessment of the Red River Valley Basin in Louisiana. In Archaeological and Historical Resources of the Red River Basin, edited by H. Davis, pp. 124. Research Series No. 1. Arkansas Archaeological Survey, Fayetteville.

1984 An Introduction to Louisiana Archaeology. Louisiana State University, Baton Rouge.

Perttula, Timothy $\mathrm{K}$.

1988 Cultural Setting. In Test Excavations at Sites 41BW182 and 41BW183, Red River Army Depot, Bowie County, Texas, edited by M. B. Cliff and D. E. Peter, pp. 11-25. RRAD/LSAAP Archeological Technical Series, Report of Investigations No. 1. Geo-Marine, Inc., Plano, Texas.

1993a The Development of Agriculture in Northeast Texas before A.D. 1600. In Archaeology in the Eastern Planning Region, Texas: A Planning Document, edited by N. A. Kenmotsu and T. K. Perttula, pp. 121-146. Cultural Resources Management Report 3. Department of Antiquities Protection, Texas Historical Commission, Austin.

1993b Effects of European Contact on Native and immigrant Indians in Northeast Texas. In Archaeology in the Eastern Planning Region, Texas: A Planning Document, edited by N. A. Kenmotsu and T. K. Perttula, pp. 147-187. Cultural Resources Management Report 3. Department of Antiquities Protection, Texas Historical Commission, Austin.

2004 The Prehistoric and Caddoan Archaeology of the Northeastern Texas Pineywoods. In The Prehistory of Texas, edited by T. K. Perttula, pp. 370-407. Texas A\&M University Press, College Station.

Perttula, Timothy K., and Nancy Adele Kenmotsu

1993 Introduction. In Archaeology in the Eastern Planning Region, Texas: A Planning Document, edited by N. A. Kenmotsu and T. K. Perttula, pp. 35-48. Cultural Resources Management Report 3. Department of Antiquities Protection, Texas Historical Commission, Austin. 
Perttula, Timothy K., Ross C. Fields, James E. Corbin, and Nancy A. Kenmotsu

1993 The Emergence of Sedentism in Northeast Texas, ca. 500 B.C. to A.D. 1000. In Archaeology in the Eastern Planning Region, Texas: A Planning Document, edited by N. A. Kenmotsu and T. K. Perttula, pp 97-120. Cultural Resource Management Report 3 Texas Historical Commission, Department of Antiquities Protection, Austin.

Peter, D. E., and D. H. Jurney

1988 Environmental Background. In Late Holocene Prehistory of the Mountain Creek Drainage, edited by D. E. Peter and D. E Mc Gregor, pp. 5-26. Joe Pool Lake Archaeological Project Volume I. Archaeology Research Program, Southern Methodist University, Dallas.

Reitz, E. J., and E. S. Wing

1999 Zooarchaeology. Cambridge University Press, Cambridge.

Rohling, E. J., M. Fenton, F. J. Jorissen, P. Bertrand, G. Ganssen, and J. P. Caulet

1998 Magnitudes of sea-level lowstands of the past 500,000 years. Nature 394:162-165.

Smith, David Paul

1992 Frontier Defense in the Civil War: Texas' Rangers and Rebels. Texas A\&M University Press, College Station.

South, Stanley

1977 Method and Theory in Historical Archaeology. Academic Press, San Diego.

Stephenson, Robert L.

1950 Archeological Survey of Texarkana Reservoir, Bowie and Cass Counties, Texas. River Basin Surveys, Smithsonian Institute. Washington, DC.

Story, Dee Ann

1990 Cultural History of the Native Americans. In the Archaeology and Bioarchaeology of the Gulf Coastal Plain, Volume 2, edited by D. A. Story, J. A. Guy, B. A. Burnett, M. D. Freeman, J. C. Rose, D. G. Steele, B. W. Olive, and K. J. Reinhard, pp 163-366. Research Series No. 38. Arkansas Archaeological Survey, Fayetteville

Sullivan, Alan P. and Rozen, Kenneth C.

1985 Debitage analysis and archaeological interpretation. American Antiquity 50 (4): 755779.

Texas Archaeological Research Laboratory (TARL)

1949a Site 41BW26 archaeological site form. On file at the University of Texas, Texas Archaeological Research Laboratory, Austin.

1949b Site 41CS16 archaeological site form. On file at the University of Texas, Texas Archaeological Research Laboratory, Austin. 
1970a Site 41BW42 archaeological site form. On file at the University of Texas, Texas Archaeological Research Laboratory, Austin.

1970b Site 41BW69 archaeological site form. On file at the University of Texas, Texas Archaeological Research Laboratory, Austin.

1970c Site 41BW77 archaeological site form. On file at the University of Texas, Texas Archaeological Research Laboratory, Austin.

1970d Site 41CS48 archaeological site form. On file at the University of Texas, Texas Archaeological Research Laboratory, Austin.

1970e Site 41CS55 archaeological site form. On file at the University of Texas, Texas Archaeological Research Laboratory, Austin.

1970 Site 41CS58 archaeological site form. On file at the University of Texas, Texas Archaeological Research Laboratory, Austin.

1970g Site 41CS73 archaeological site form. On file at the University of Texas, Texas Archaeological Research Laboratory, Austin.

1970h Site 41CS76 archaeological site form. On file at the University of Texas, Texas Archaeological Research Laboratory, Austin.

1970i Site 41CS78 archaeological site form. On file at the University of Texas, Texas Archaeological Research Laboratory, Austin.

1970j Site 41CS79 archaeological site form. On file at the University of Texas, Texas Archaeological Research Laboratory, Austin.

1970k Site 41CS95/96 archaeological site form. On file at the University of Texas, Texas Archaeological Research Laboratory, Austin.

1970I Site 41CS108 archaeological site form. On file at the University of Texas, Texas Archaeological Research Laboratory, Austin.

1970m Site 41CS109 archaeological site form. On file at the University of Texas, Texas Archaeological Research Laboratory, Austin.

1970n Site 41CS110 archaeological site form. On file at the University of Texas, Texas Archaeological Research Laboratory, Austin.

1970o Site 41CS117 archaeological site form. On file at the University of Texas, Texas Archaeological Research Laboratory, Austin.

1970p Site 41CS118 archaeological site form. On file at the University of Texas, Texas Archaeological Research Laboratory, Austin.

1974a Site 41CS122 archaeological site form. On file at the University of Texas, Texas Archaeological Research Laboratory, Austin.

1974b Site 41CS123 archaeological site form. On file at the University of Texas, Texas Archaeological Research Laboratory, Austin.

Thurmond, J. Peter

1990 Archaeology of the Cypress Creek Drainage Basin, Northeastern Texas and Northwestern Louisiana. Studies in Archaeology Series 5. Texas Archaeological Research Laboratory, University of Texas, Austin. 
Trierweiler, W. Nicholas and Richard S. Jones

2005 A Cultural Resource Inventory of 1,414 Acres at Lake Wright Patman and Lake $O^{\prime}$ the Pines, Bowie, Upshur, and Marion Counties, Texas. Prepared by Ecological Communications Corporation, Austin. Submitted to US Army Corps of Engineers, Fort Worth District.

US Army Corps of Engineers (USACE)

2016 History of Wright Patman Lake. Electronic document, http://www.swf-wc.usace.army. mil/wrightpatman/Information/History.asp, accessed January 15, 2016.

Waters, Michael R., Steven L. Forman, Thomas A. Jennings, Lee C. Nordt, Steven G. Driese, Joshua M. Feinberg, Joshua L. Keene, Jessi Halligan, Anna Lindquist, James Pierson, Charles T. Hallmark, Michael B. Collins, and James E. Wiederhold

2011 The Buttermilk Creek Complex and the Origins of Clovis at the Debra L. Friedkin Site, Texas. Science 331:1599-1603.

Weddle, Robert S.

1985 Spanish Sea: The Gulf of Mexico in North American Discovery, 1500-1685. Texas A\&M University Press, Austin.

1991 The French Thorn: Rival Explorers in the Spanish Sea, 1682-1762. Texas A\&M University Press, College Station, Texas.

2000 Spanish Sea: The Gulf of Mexico in North American Discovery, 1500-1685. Texas A\&M University Press, College Station, Texas.

Wyckoff, Don G.

1974 The Caddoan Cultural Area: An Archaeological Perspective. In Caddoan Indians I, edited by D. A. Horr, pp.25-279. Garland Publishing, New York

White, Wm. David, Steven M. Hunt, and Maynard B. Cliff

1995 Cultural resources Survey of 1,290 Acres at Wright Patman Lake, Bowie and Cass Counties, Texas. Report submitted to the United States Corps of Engineers, Fort Worth District, Texas. 


\section{This PAge InTENTIONALLY LEFT BLANK}


APPENDIX A:

ARTIFACT INVENTORY 



\begin{tabular}{|c|c|c|c|c|c|c|c|c|c|c|c|c|}
\hline $\begin{array}{c}\text { Site } \\
\#\end{array}$ & $\begin{array}{c}\text { FS } \\
\#\end{array}$ & LS\# & $\begin{array}{c}\text { Catalog } \\
\#\end{array}$ & Prov. & $\begin{array}{c}\text { Strat } \\
\text { a }\end{array}$ & $\begin{array}{c}\text { Leve } \\
1\end{array}$ & Depth & Description & Count & $\begin{array}{c}\text { Weight } \\
\text { (g) }\end{array}$ & $\begin{array}{c}\text { Date } \\
\text { Excavated }\end{array}$ & Exc/Rec \\
\hline 41BW42 & 1 & 1 & 1.01 & TR 1 & & & Surface & Flake, Early Reduction, chert; $>1 / 2 "$, Complete & 1 & 1.55 & $10 / 20 / 2015$ & $\mathrm{MH}$ \\
\hline 41BW42 & 1 & 1 & 1.02 & TR 1 & & & Surface & Flake, Early Reduction, chert; $>1 / 2 "$, Complete & 1 & 1.19 & $10 / 20 / 2015$ & $\mathrm{MH}$ \\
\hline 41BW42 & 1 & 1 & 1.03 & TR 1 & & & Surface & Flake, Early Reduction, chert; >1/4", Complete & 1 & 0.18 & $10 / 20 / 2015$ & $\mathrm{MH}$ \\
\hline 41BW42 & 1 & 1 & 1.04 & TR 1 & & & Surface & Flake, Early Reduction, basalt; >1", Complete & 1 & 23.55 & $10 / 20 / 2015$ & $\mathrm{MH}$ \\
\hline 41BW42 & 1 & 1 & 1.05 & TR 1 & & & Surface & Flake, Thinning, chert; >1", Complete & 1 & 2.35 & $10 / 20 / 2015$ & $\mathrm{MH}$ \\
\hline 41BW42 & 1 & 1 & 1.06 & TR 1 & & & Surface & Flake, Thinning, chert; $>1 / 2 "$, Proximal & 1 & 2.08 & $10 / 20 / 2015$ & $\mathrm{MH}$ \\
\hline 41BW42 & 1 & 1 & 1.07 & TR 1 & & & Surface & $\begin{array}{l}\text { Flake, Early Reduction, chert; >1/2", Medial- } \\
\text { Distal }\end{array}$ & 1 & 1.80 & $10 / 20 / 2015$ & $\mathrm{MH}$ \\
\hline 41BW42 & 1 & 1 & 1.08 & TR 1 & & & Surface & Flake, Thinning; Late, chert; $>1 / 2 "$, Complete & 2 & 0.77 & $10 / 20 / 2015$ & $\mathrm{MH}$ \\
\hline 41BW42 & 1 & 1 & 1.09 & TR 1 & & & Surface & Fire cracked rock, other & 2 & 111.52 & $10 / 20 / 2015$ & $\mathrm{MH}$ \\
\hline 41BW42 & 1 & 1 & 1.10 & TR 1 & & & Surface & Fire cracked rock, quartzite & 2 & 21.42 & $10 / 20 / 2015$ & $\mathrm{MH}$ \\
\hline 41BW42 & 1 & 1 & 1.11 & TR 1 & & & Surface & Flake, Thinning; Late, chert; >1/2", Medial-Distal & 1 & 0.68 & $10 / 20 / 2015$ & $\mathrm{MH}$ \\
\hline 41BW42 & 2 & 2 & 2.01 & TR 2 & & & Surface & Flake, Thinning; Late, chert; >1/4", Complete & 1 & 0.09 & $10 / 20 / 2015$ & MRM \\
\hline 41BW42 & 2 & 2 & 2.02 & TR 2 & & & Surface & Flake, Thinning, chert; $>1 / 2 "$ ", Proximal & 1 & 0.91 & $10 / 20 / 2015$ & MRM \\
\hline 41BW42 & 2 & 2 & 2.03 & TR 2 & & & Surface & Fire cracked rock & 1 & 0.97 & $10 / 20 / 2015$ & MRM \\
\hline 41BW42 & 3 & 3 & 3.01 & TR 3 & & & Surface & Shatter, Thermal, chert & 1 & 8.09 & $10 / 20 / 2015$ & $\mathrm{CS} / \mathrm{MH}$ \\
\hline 41BW42 & 3 & 3 & 3.02 & TR 3 & & & Surface & Shatter, Thermal, chert & 1 & 2.19 & $10 / 20 / 2015$ & $\mathrm{CS} / \mathrm{MH}$ \\
\hline 41BW42 & 3 & 3 & 3.03 & TR 3 & & & Surface & Flake, Thinning, chert; >1/2", Proximal & 1 & 1.30 & $10 / 20 / 2015$ & $\mathrm{CS} / \mathrm{MH}$ \\
\hline 41BW42 & 3 & 3 & 3.04 & TR 3 & & & Surface & Flake, Thinning; Late, chert; >1/4", Complete & 1 & 0.17 & $10 / 20 / 2015$ & $\mathrm{CS} / \mathrm{MH}$ \\
\hline 41BW42 & 4 & 4 & 4.01 & TR 4 & & & Surface & $\begin{array}{l}\text { Flake, core reduction, quartzite; >2", Proximal; } \\
\text { heat treated }\end{array}$ & 1 & 36.80 & $10 / 20 / 2015$ & MMM \\
\hline 41BW42 & 4 & 4 & 4.02 & TR 4 & & & Surface & Shatter, Angular, chert; heat treated & 1 & 2.51 & $10 / 20 / 2015$ & MMM \\
\hline 41BW42 & 4 & 4 & 4.03 & TR 4 & & & Surface & $\begin{array}{l}\text { Aboriginal ceramic, plain, grog/clay temper; } \\
\text { body; sherds mend }\end{array}$ & 2 & 12.12 & $10 / 20 / 2015$ & MMM \\
\hline 41BW42 & 5 & 5 & 5.01 & TR 5 & & & Surface & Unmodified stone; non-cultural & 3 & 77.93 & $10 / 20 / 2015$ & MO \\
\hline 41BW42 & 5 & 5 & 5.02 & TR 5 & & & Surface & Tested cobble, chert & 1 & 51.14 & $10 / 20 / 2015$ & MO \\
\hline 41BW42 & 7 & 6 & 6.01 & TR 7 & & & Surface & Whiteware, flatware, base & 1 & 2.17 & $10 / 20 / 2015$ & MMM \\
\hline 41BW42 & 8 & 7 & 7.01 & TR 8 & & & Surface & Fire cracked rock & 1 & 343.73 & $10 / 20 / 2015$ & $\mathrm{CS} / \mathrm{MH}$ \\
\hline
\end{tabular}




\begin{tabular}{|c|c|c|c|c|c|c|c|c|c|c|c|c|}
\hline $\begin{array}{c}\text { Site } \\
\#\end{array}$ & $\begin{array}{l}\text { FS } \\
\#\end{array}$ & LS\# & $\begin{array}{c}\text { Catalog } \\
\#\end{array}$ & Prov. & $\begin{array}{c}\text { Strat } \\
\text { a }\end{array}$ & $\begin{array}{c}\text { Leve } \\
1\end{array}$ & Depth & Description & Count & $\begin{array}{l}\text { Weight } \\
\text { (g) }\end{array}$ & $\begin{array}{c}\text { Date } \\
\text { Excavated }\end{array}$ & Exc/Rec \\
\hline 41BW42 & 8 & 7 & 7.02 & TR 8 & & & Surface & Possible cultural material-lithic, petrified wood & 1 & 39.97 & $10 / 20 / 2015$ & $\mathrm{CS} / \mathrm{MH}$ \\
\hline 41BW42 & 10 & 8 & 8.01 & ST 1 & 1 & & $5-10 \mathrm{cmbs}$ & Flake, Thinning, chert; $>1 / 2 "$, Complete & 1 & 1.02 & $10 / 20 / 2015$ & $\mathrm{AD} / \mathrm{BH}$ \\
\hline 41BW42 & 11 & 9 & 9.01 & ST 1 & & & Surface & Flake, Early Reduction, other; $>1 "$, Complete & 1 & 13.50 & $10 / 20 / 2015$ & $\mathrm{AD} / \mathrm{BH}$ \\
\hline 41BW42 & 11 & 9 & 9.02 & ST 1 & & & Surface & Fire cracked rock & 4 & 43.61 & $10 / 20 / 2015$ & $\mathrm{AD} / \mathrm{BH}$ \\
\hline 41BW42 & 12 & 10 & 10.01 & ST 2 & & & Surface & Flake, Thinning, chert; >1/2", Complete & 1 & 1.14 & $10 / 20 / 2015$ & $\mathrm{MRM} / \mathrm{MH}$ \\
\hline 41BW42 & 12 & 10 & 10.02 & ST 2 & & & Surface & Flake, Thinning, chert; $>1 / 2 "$, Proximal & 1 & 1.30 & $10 / 20 / 2015$ & $\mathrm{MRM} / \mathrm{MH}$ \\
\hline 41BW42 & 12 & 10 & 10.03 & ST 2 & & & Surface & Flake, Thinning; Late, chert; $>1 / 4 "$, Proximal & 1 & 0.09 & $10 / 20 / 2015$ & $\mathrm{MRM} / \mathrm{MH}$ \\
\hline 41BW42 & 13 & 11 & 11.01 & ST 2 & 1 & & $0-10 \mathrm{cmbs}$ & Refined earthenware, transfer printed, green & 1 & 4.04 & $10 / 20 / 2015$ & $\mathrm{MRM} / \mathrm{MH}$ \\
\hline 41BW42 & 14 & 12 & 12.01 & ST 2 & II & & $10-20 \mathrm{cmbs}$ & $\begin{array}{l}\text { Miscellaneous Glass }>1 / 2 " \text {, soda green, soda } \\
\text { green; flat }\end{array}$ & 1 & 0.32 & $10 / 20 / 2015$ & $\mathrm{MRM} / \mathrm{MH}$ \\
\hline 41BW42 & 14 & 12 & 12.02 & ST 2 & II & & $10-20 \mathrm{cmbs}$ & Animal bone & 1 & 0.36 & $10 / 20 / 2015$ & $\mathrm{MRM} / \mathrm{MH}$ \\
\hline 41BW42 & 15 & 13 & 13.01 & ST 3 & I & & $0-20 \mathrm{cmbs}$ & Flake, Thinning, chert; $>1 / 2 "$, Proximal & 1 & 0.91 & $10 / 20 / 2015$ & $\mathrm{MO} / \mathrm{MMM}$ \\
\hline 41BW42 & 15 & 13 & 13.02 & ST 3 & 1 & & $0-20 \mathrm{cmbs}$ & Shatter, Angular, chert, heat treated & 1 & 1.80 & $10 / 20 / 2015$ & $\mathrm{MO} / \mathrm{MMM}$ \\
\hline 41BW42 & 16 & 14 & 14.01 & ST 4 & I & & $5-10 \mathrm{cmbs}$ & Shatter, Angular, chert, heat treated & 1 & 0.87 & $10 / 20 / 2015$ & $\mathrm{AD} / \mathrm{BH}$ \\
\hline 41BW42 & 17 & 15 & 15.01 & ST 5 & II & & $10-20 \mathrm{cmbs}$ & $\begin{array}{l}\text { Flake, Thinning; Late, chert, heat treated; >1/4", } \\
\text { Proximal }\end{array}$ & 1 & 0.41 & $10 / 20 / 2015$ & $\mathrm{MRM} / \mathrm{MH}$ \\
\hline 41BW42 & 17 & 15 & 15.02 & ST 5 & II & & $10-20 \mathrm{cmbs}$ & $\begin{array}{l}\text { Flake, Thinning; Late, chert, heat treated; >1/4", } \\
\text { Medial-Distal }\end{array}$ & 1 & 0.17 & $10 / 20 / 2015$ & $\mathrm{MRM} / \mathrm{MH}$ \\
\hline 41BW42 & 18 & 16 & 16.01 & ST 6 & 1 & & $0-20 \mathrm{cmbs}$ & Animal bone & 1 & 0.81 & $10 / 20 / 2015$ & $\mathrm{MMM} / \mathrm{MO}$ \\
\hline 41BW42 & 19 & 17 & 17.01 & ST 7 & 1 & & $0-30 \mathrm{cmbs}$ & Shatter, Angular, chert & 1 & 1.22 & $10 / 20 / 2015$ & $\mathrm{MMM} / \mathrm{MO}$ \\
\hline 41BW42 & 19 & 17 & 17.02 & ST 7 & 1 & & $0-30 \mathrm{cmbs}$ & Flake, Thinning, chert; >1/4", Complete & 1 & 0.23 & $10 / 20 / 2015$ & $\mathrm{MMM} / \mathrm{MO}$ \\
\hline 41BW42 & 19 & 17 & 17.03 & ST 7 & 1 & & $0-30 \mathrm{cmbs}$ & Flake, Thinning; Late, chert; >1/4", Complete & 1 & 0.10 & $10 / 20 / 2015$ & $\mathrm{MMM} / \mathrm{MO}$ \\
\hline 41BW42 & 19 & 17 & 17.04 & ST 7 & 1 & & $0-30 \mathrm{cmbs}$ & Flake, Thinning; Late, chert; $<1 / 4 "$ ", Proximal & 1 & 0.02 & $10 / 20 / 2015$ & $\mathrm{MMM} / \mathrm{MO}$ \\
\hline 41BW42 & 19 & 17 & 17.05 & ST 7 & 1 & & $0-30 \mathrm{cmbs}$ & PPK, Straight stemmed, chert; fragment & 1 & 2.61 & $10 / 20 / 2015$ & $\mathrm{MMM} / \mathrm{MO}$ \\
\hline 41BW42 & 20 & 18 & 18.01 & ST 8 & 1 & & $0-10 \mathrm{cmbs}$ & Flake, Thinning; Late, chert; $>1 / 4 "$ ", Complete & 1 & 0.18 & $10 / 20 / 2015$ & $\mathrm{MRM} / \mathrm{MH}$ \\
\hline 41BW42 & 20 & 18 & 18.02 & ST 8 & 1 & & $0-10 \mathrm{cmbs}$ & Flake, Thinning; Late, chert; $>1 / 4 "$, Complete & 1 & 0.27 & $10 / 20 / 2015$ & $\mathrm{MRM} / \mathrm{MH}$ \\
\hline 41BW42 & 20 & 18 & 18.03 & ST 8 & 1 & & $0-10 \mathrm{cmbs}$ & Flake, Thinning; Late, chert; >1/2", Complete & 1 & 0.35 & $10 / 20 / 2015$ & $\mathrm{MRM} / \mathrm{MH}$ \\
\hline 41BW42 & 20 & 18 & 18.04 & ST 8 & 1 & & $0-10 \mathrm{cmbs}$ & Flake, Thinning, chert; $>1 / 2 "$ ", Non-orientable & 1 & 2.58 & $10 / 20 / 2015$ & $\mathrm{MRM} / \mathrm{MH}$ \\
\hline
\end{tabular}




\begin{tabular}{|c|c|c|c|c|c|c|c|c|c|c|c|c|}
\hline $\begin{array}{c}\text { Site } \\
\#\end{array}$ & $\begin{array}{l}\text { FS } \\
\#\end{array}$ & LS\# & $\begin{array}{c}\text { Catalog } \\
\#\end{array}$ & Prov. & $\begin{array}{c}\text { Strat } \\
\text { a }\end{array}$ & $\begin{array}{c}\text { Leve } \\
1\end{array}$ & Depth & Description & Count & $\begin{array}{l}\text { Weight } \\
\text { (g) }\end{array}$ & $\begin{array}{c}\text { Date } \\
\text { Excavated }\end{array}$ & Exc/Rec \\
\hline 41BW42 & 20 & 18 & 18.05 & ST 8 & I & & $0-10 \mathrm{cmbs}$ & Bottle glass, clear & 1 & 0.71 & $10 / 20 / 2015$ & $\mathrm{MRM} / \mathrm{MH}$ \\
\hline 41BW42 & 21 & 19 & 19.01 & ST 8 & II & & $10-20 \mathrm{cmbs}$ & Flake, Thinning, chert; >1/2", Complete & 1 & 0.63 & $10 / 20 / 2015$ & $\mathrm{MRM} / \mathrm{MH}$ \\
\hline 41BW42 & 21 & 19 & 19.02 & ST 8 & II & & $10-20 \mathrm{cmbs}$ & Possible cultural material-lithic, petrified wood & 1 & 7.10 & $10 / 20 / 2015$ & $\mathrm{MRM} / \mathrm{MH}$ \\
\hline 41BW42 & 22 & 20 & 20.01 & ST 10 & 1 & & $0-10 \mathrm{cmbs}$ & Flake, Thinning, chert; $>1 / 2 "$, Complete & 1 & 0.53 & $10 / 20 / 2015$ & $\mathrm{AD} / \mathrm{BH}$ \\
\hline 41BW42 & 22 & 20 & 20.02 & ST 10 & I & & $0-10 \mathrm{cmbs}$ & Fire cracked rock, chert & 1 & 23.79 & $10 / 20 / 2015$ & $\mathrm{AD} / \mathrm{BH}$ \\
\hline 41BW42 & 22 & 20 & 20.03 & ST 10 & I & & $0-10 \mathrm{cmbs}$ & Animal bone, otolith & 1 & 0.52 & $10 / 20 / 2015$ & $\mathrm{AD} / \mathrm{BH}$ \\
\hline 41BW42 & 23 & 21 & 21.01 & ST 11 & 1 & & $0-10 \mathrm{cmbs}$ & Flake, Thinning, chert; >1/4", Complete & 1 & 0.48 & $10 / 20 / 2015$ & $\mathrm{MMM} / \mathrm{MO}$ \\
\hline 41BW42 & 24 & 22 & 22.01 & ST 12 & & & Surface & $\begin{array}{l}\text { Bottle base, machine made, soda green; Dr. P } \\
\text { base; faded: "OZ"; base: "L", " } 974 " \text { "', "4"" }\end{array}$ & 3 & 50.91 & $10 / 21 / 2015$ & $\mathrm{MRM} / \mathrm{MH}$ \\
\hline 41BW42 & 24 & 22 & 22.02 & ST 12 & & & Surface & $\begin{array}{l}\text { Bottle glass, Applied color label, soda green; Dr. } \\
\text { Pepper bottle; lettering: "FL OZ" }\end{array}$ & 1 & 7.68 & $10 / 21 / 2015$ & $\mathrm{MRM} / \mathrm{MH}$ \\
\hline 41BW42 & 24 & 22 & 22.03 & ST 12 & & & Surface & $\begin{array}{l}\text { Other glass vessel, clear, clear; salt dish lid } \\
\text { fragment? }\end{array}$ & 1 & 94.37 & $10 / 21 / 2015$ & $\mathrm{MRM} / \mathrm{MH}$ \\
\hline 41BW42 & 24 & 22 & 22.04 & ST 12 & & & Surface & Flat glass, amber & 1 & 55.02 & $10 / 21 / 2015$ & $\mathrm{MRM} / \mathrm{MH}$ \\
\hline 41BW42 & 25 & 23 & 23.01 & ST 12 & I & & $0-10 \mathrm{cmbs}$ & $\begin{array}{l}\text { Flake, Thinning; Late, quartzite; }>1 / 4 " \text {, } \\
\text { Complete }\end{array}$ & 1 & 0.10 & $10 / 21 / 2015$ & $\mathrm{MRM} / \mathrm{MH}$ \\
\hline 41BW42 & 25 & 23 & 23.02 & ST 12 & I & & $0-10 \mathrm{cmbs}$ & Flake, Thinning, chert; $>1 / 2 "$, Complete & 2 & 1.52 & $10 / 21 / 2015$ & $\mathrm{MRM} / \mathrm{MH}$ \\
\hline 41BW42 & 25 & 23 & 23.03 & ST 12 & I & & $0-10 \mathrm{cmbs}$ & Flake, Thinning; Late, chert; >1/4", Complete & 1 & 0.15 & $10 / 21 / 2015$ & $\mathrm{MRM} / \mathrm{MH}$ \\
\hline 41BW42 & 25 & 23 & 23.04 & ST 12 & I & & $0-10 \mathrm{cmbs}$ & Bottle glass, clear & 1 & 1.15 & $10 / 21 / 2015$ & $\mathrm{MRM} / \mathrm{MH}$ \\
\hline 41BW42 & 25 & 23 & 23.05 & ST 12 & I & & $0-10 \mathrm{cmbs}$ & $\begin{array}{l}\text { Bottle glass, Applied color label, soda green; Dr } \\
\text { Pepper label }\end{array}$ & 1 & 3.45 & $10 / 21 / 2015$ & $\mathrm{MRM} / \mathrm{MH}$ \\
\hline 41BW42 & 25 & 23 & 23.06 & ST 12 & I & & $0-10 \mathrm{cmbs}$ & Whiteware, flatware, base & 1 & 0.54 & $10 / 21 / 2015$ & $\mathrm{MRM} / \mathrm{MH}$ \\
\hline 41BW42 & 25 & 23 & 23.07 & ST 12 & 1 & & $0-10 \mathrm{cmbs}$ & Uid lead & 1 & 2.26 & $10 / 21 / 2015$ & $\mathrm{MRM} / \mathrm{MH}$ \\
\hline 41BW42 & 26 & 24 & 24.01 & ST 12 & II & & $10-20 \mathrm{cmbs}$ & Shatter, Angular, chert; heat treated & 1 & 2.10 & $10 / 21 / 2015$ & $\mathrm{MRM} / \mathrm{MH}$ \\
\hline 41BW42 & 26 & 24 & 24.02 & ST 12 & II & & $10-20 \mathrm{cmbs}$ & $\begin{array}{l}\text { Flake, Early Reduction, chert; }>1 / 2 " \text {, Proximal; } \\
\text { heat treated }\end{array}$ & 1 & 1.71 & $10 / 21 / 2015$ & $\mathrm{MRM} / \mathrm{MH}$ \\
\hline 41BW42 & 26 & 24 & 24.03 & ST 12 & II & & $10-20 \mathrm{cmbs}$ & Shatter, Angular, chert & 1 & 0.22 & $10 / 21 / 2015$ & $\mathrm{MRM} / \mathrm{MH}$ \\
\hline 41BW42 & 26 & 24 & 24.04 & ST 12 & II & & $10-20 \mathrm{cmbs}$ & $\begin{array}{l}\text { Bottle glass, soda green; neck; more Dr. Pepper } \\
\text { bottle? }\end{array}$ & 1 & 0.93 & $10 / 21 / 2015$ & $\mathrm{MRM} / \mathrm{MH}$ \\
\hline
\end{tabular}




\begin{tabular}{|c|c|c|c|c|c|c|c|c|c|c|c|c|}
\hline $\begin{array}{c}\text { Site } \\
\#\end{array}$ & $\begin{array}{l}\text { FS } \\
\#\end{array}$ & LS\# & $\begin{array}{c}\text { Catalog } \\
\#\end{array}$ & Prov. & $\begin{array}{c}\text { Strat } \\
\text { a }\end{array}$ & $\begin{array}{c}\text { Leve } \\
1\end{array}$ & Depth & Description & Count & $\begin{array}{l}\text { Weight } \\
\text { (g) }\end{array}$ & $\begin{array}{c}\text { Date } \\
\text { Excavated }\end{array}$ & Exc/Rec \\
\hline 41BW42 & 26 & 24 & 24.05 & ST 12 & II & & $10-20 \mathrm{cmbs}$ & Eyelet/rivet/grommet, brass; "DOT" twice & 1 & 0.58 & $10 / 21 / 2015$ & $\mathrm{MRM} / \mathrm{MH}$ \\
\hline 41BW42 & 27 & 25 & 25.01 & ST 12 & II & & $20-30 \mathrm{cmbs}$ & Flake, Thinning; Late, quartzite; $>1 / 4 "$ ", Proximal & 1 & 0.41 & $10 / 21 / 2015$ & $\mathrm{MRM} / \mathrm{MH}$ \\
\hline 41BW42 & 28 & 26 & 26.01 & ST 14 & I & & $0-10 \mathrm{cmbs}$ & Shatter, Angular, chert, heat treated; potlids & 1 & 1.16 & $10 / 21 / 2015$ & $\mathrm{MO} / \mathrm{MMM}$ \\
\hline 41BW42 & 29 & 27 & 27.01 & ST 14 & II & & $10-20 \mathrm{cmbs}$ & Flake, Thinning, chert; >1/2", Complete & 1 & 1.22 & $10 / 21 / 2015$ & $\mathrm{MO} / \mathrm{MRM}$ \\
\hline 41BW42 & 29 & 27 & 27.02 & ST 14 & II & & $10-20 \mathrm{cmbs}$ & Flake, Thinning, chert; >1/2", Complete & 1 & 1.15 & $10 / 21 / 2015$ & $\mathrm{MO} / \mathrm{MRM}$ \\
\hline 41BW42 & 30 & 28 & 28.01 & ST 17 & II & & $10-20 \mathrm{cmbs}$ & Flake, Thinning; Late, chert; $>1 / 4 "$, Complete & 1 & 0.16 & $10 / 21 / 2015$ & $\mathrm{MRM} / \mathrm{MH}$ \\
\hline 41BW42 & 30 & 28 & 28.02 & ST 17 & II & & $10-20 \mathrm{cmbs}$ & Flake, Thinning; Late, chert; >1/4", Medial-Distal & 1 & 0.15 & $10 / 21 / 2015$ & $\mathrm{MRM} / \mathrm{MH}$ \\
\hline 41BW42 & 31 & 29 & 29.01 & ST 17 & II & & $20-30 \mathrm{cmbs}$ & Flake, Thinning; Late, chert; >1/2", Medial-Distal & 1 & 0.43 & $10 / 21 / 2015$ & $\mathrm{MRM} / \mathrm{MH}$ \\
\hline 41BW42 & 32 & 30 & 30.01 & ST J2 & I & & $0-5 \mathrm{cmbs}$ & Flake, retouch, chert; $>1 / 8$, Proximal & 1 & 0.05 & $10 / 21 / 2015$ & $\mathrm{AD} / \mathrm{CS}$ \\
\hline 41BW42 & 33 & 31 & 31.01 & ST J3 & 1 & & $0-10 \mathrm{cmbs}$ & Flake, Thinning; Late, chert; $>1 / 2 "$, Complete & 1 & 0.24 & $10 / 21 / 2015$ & $A D / C S$ \\
\hline 41BW42 & 33 & 31 & 31.02 & ST J3 & I & & $0-10 \mathrm{cmbs}$ & Flake tool, Unifacial flake; informal & 1 & 94.99 & $10 / 21 / 2015$ & $A D / C S$ \\
\hline 41BW42 & 1 & 32 & 32.01 & TU 1 & I & 1 & $7-20 \mathrm{cmbd}$ & Flake, Early Reduction, chert; $>1 / 2 "$, Complete & 1 & 0.95 & $10 / 21 / 2015$ & $\mathrm{MRM} / \mathrm{MH}$ \\
\hline 41BW42 & 1 & 32 & 32.02 & TU 1 & I & 1 & $7-20 \mathrm{cmbd}$ & Flake, Early Reduction, chert; $>1 / 2 "$, Complete & 1 & 1.10 & $10 / 21 / 2015$ & $\mathrm{MRM} / \mathrm{MH}$ \\
\hline 41BW42 & 1 & 32 & 32.03 & TU 1 & I & 1 & $7-20 \mathrm{cmbd}$ & Flake, Thinning, chert; >1/4", Complete & 1 & 0.41 & $10 / 21 / 2015$ & $\mathrm{MRM} / \mathrm{MH}$ \\
\hline 41BW42 & 1 & 32 & 32.04 & TU 1 & I & 1 & $7-20 \mathrm{cmbd}$ & Flake, Thinning, chert; >1/2", Complete & 1 & 0.60 & $10 / 21 / 2015$ & $\mathrm{MRM} / \mathrm{MH}$ \\
\hline 41BW42 & 1 & 32 & 32.05 & TU 1 & I & 1 & $7-20 \mathrm{cmbd}$ & Flake, Thinning, chert; >1/2", Complete & 1 & 0.58 & $10 / 21 / 2015$ & $\mathrm{MRM} / \mathrm{MH}$ \\
\hline 41BW42 & 1 & 32 & 32.06 & TU 1 & 1 & 1 & $7-20 \mathrm{cmbd}$ & Flake, Thinning, chert; >1/2", Proximal & 1 & 0.68 & $10 / 21 / 2015$ & $\mathrm{MRM} / \mathrm{MH}$ \\
\hline 41BW42 & 1 & 32 & 32.07 & TU 1 & I & 1 & $7-20 \mathrm{cmbd}$ & Flake, Thinning, chert; >1/4", Medial-Distal & 1 & 0.36 & $10 / 21 / 2015$ & $\mathrm{MRM} / \mathrm{MH}$ \\
\hline 41BW42 & 1 & 32 & 32.08 & TU 1 & I & 1 & $7-20 \mathrm{cmbd}$ & Flake, Thinning; Late, chert; >1/4", Complete & 2 & 0.44 & $10 / 21 / 2015$ & $\mathrm{MRM} / \mathrm{MH}$ \\
\hline 41BW42 & 1 & 32 & 32.09 & TU 1 & I & 1 & $7-20 \mathrm{cmbd}$ & Flake, Thinning; Late, chert; >1/4", Medial-Distal & 2 & 0.49 & $10 / 21 / 2015$ & $\mathrm{MRM} / \mathrm{MH}$ \\
\hline 41BW42 & 1 & 32 & 32.10 & TU 1 & 1 & 1 & $7-20 \mathrm{cmbd}$ & Flake, Thinning; Late, chert; >1/4", Proximal & 3 & 0.59 & $10 / 21 / 2015$ & $\mathrm{MRM} / \mathrm{MH}$ \\
\hline 41BW42 & 1 & 32 & 32.11 & TU 1 & 1 & 1 & $7-20 \mathrm{cmbd}$ & Flake, Thinning; Late, chert; $<1 / 4 "$ " Medial-Distal & 1 & 0.06 & $10 / 21 / 2015$ & $\mathrm{MRM} / \mathrm{MH}$ \\
\hline 41BW42 & 1 & 33 & 33.01 & TU 2 & I & 1 & $0-10 \mathrm{cmbd}$ & Flake, Thinning; Late, chert; >1/2", Complete & 1 & 0.39 & $10 / 21 / 2015$ & \\
\hline 41BW42 & 1 & 33 & 33.02 & TU 2 & I & 1 & $0-10 \mathrm{cmbd}$ & Shatter, Angular, chert & 1 & 0.34 & $10 / 21 / 2015$ & \\
\hline 41BW42 & 1 & 34 & 34.01 & TU 3 & 1 & 1 & $0-10 \mathrm{cmbd}$ & Flake, Thinning, quartzite; $>1 / 2 "$ ", Complete & 1 & 1.26 & $10 / 21 / 2015$ & $\mathrm{AD} / \mathrm{CS}$ \\
\hline 41BW42 & 1 & 34 & 34.02 & TU 3 & 1 & 1 & $0-10 \mathrm{cmbd}$ & Flake, Thinning, quartzite; >1/2", Medial-Distal & 1 & 0.65 & $10 / 21 / 2015$ & $A D / C S$ \\
\hline 41BW42 & 1 & 34 & 34.03 & TU 3 & 1 & 1 & $0-10 \mathrm{cmbd}$ & Flake, Thinning; Late, chert; >1/4", Complete & 2 & 0.44 & $10 / 21 / 2015$ & $\mathrm{AD} / \mathrm{CS}$ \\
\hline 41BW42 & 1 & 34 & 34.04 & TU 3 & I & 1 & $0-10 \mathrm{cmbd}$ & Potlid, chert & 1 & 0.83 & $10 / 21 / 2015$ & $A D / C S$ \\
\hline
\end{tabular}




\begin{tabular}{|c|c|c|c|c|c|c|c|c|c|c|c|c|}
\hline $\begin{array}{c}\text { Site } \\
\#\end{array}$ & $\begin{array}{l}\text { FS } \\
\# \\
\end{array}$ & LS\# & $\begin{array}{c}\text { Catalog } \\
\# \\
\end{array}$ & Prov. & $\begin{array}{c}\text { Strat } \\
\text { a }\end{array}$ & $\begin{array}{c}\text { Leve } \\
\text { I }\end{array}$ & Depth & Description & Count & $\begin{array}{c}\text { Weight } \\
\text { (g) }\end{array}$ & $\begin{array}{c}\text { Date } \\
\text { Excavated }\end{array}$ & Exc/Rec \\
\hline 41BW42 & 1 & 34 & 34.05 & TU 3 & 1 & 1 & $0-10 \mathrm{cmbd}$ & Flake, Thinning; Late, chert; >1/2", Complete & 2 & 0.60 & $10 / 21 / 2015$ & $\mathrm{AD} / \mathrm{CS}$ \\
\hline 41BW42 & 1 & 34 & 34.06 & TU 3 & 1 & 1 & $0-10 \mathrm{cmbd}$ & Flake, Thinning, chert; >1/4", Proximal & 1 & 0.27 & $10 / 21 / 2015$ & $\mathrm{AD} / \mathrm{CS}$ \\
\hline 41BW42 & 1 & 34 & 34.07 & TU 3 & 1 & 1 & $0-10 \mathrm{cmbd}$ & Flake, Thinning, chert; $>1 / 2 "$, Proximal & 1 & 0.37 & $10 / 21 / 2015$ & $A D / C S$ \\
\hline 41BW42 & 1 & 34 & 34.08 & TU 3 & 1 & 1 & $0-10 \mathrm{cmbd}$ & Flake, Thinning, chert; >1/2", Medial-Distal & 1 & 0.59 & $10 / 21 / 2015$ & $A D / C S$ \\
\hline 41BW42 & 1 & 34 & 34.09 & TU 3 & I & 1 & $0-10 \mathrm{cmbd}$ & Flake, Thinning; Late, chert; >1/4", Proximal & 1 & 0.08 & $10 / 21 / 2015$ & $A D / C S$ \\
\hline 41BW42 & 1 & 34 & 34.10 & TU 3 & 1 & 1 & $0-10 \mathrm{cmbd}$ & Shatter, Thermal, chert & 2 & 0.42 & $10 / 21 / 2015$ & $A D / C S$ \\
\hline 41BW42 & 1 & 34 & 34.11 & TU 3 & 1 & 1 & $0-10 \mathrm{cmbd}$ & Tested cobble, chert, heat treated & 1 & 54.03 & $10 / 21 / 2015$ & $A D / C S$ \\
\hline 41BW42 & 1 & 34 & 34.12 & TU 3 & 1 & 1 & $0-10 \mathrm{cmbd}$ & $\begin{array}{l}\text { Uniface, fragment, chert, heat treated; utilized } \\
\text { shatter fragment }\end{array}$ & 1 & 5.22 & $10 / 21 / 2015$ & $A D / C S$ \\
\hline 41BW42 & 1 & 34 & 34.13 & TU 3 & I & 1 & $0-10 \mathrm{cmbd}$ & Fire cracked rock & 1 & 7.75 & $10 / 21 / 2015$ & $A D / C S$ \\
\hline 41BW42 & 1 & 34 & 34.14 & TU 3 & 1 & 1 & $0-10 \mathrm{cmbd}$ & Animal bone, otolith & 5 & 2.97 & $10 / 21 / 2015$ & $\mathrm{AD} / \mathrm{CS}$ \\
\hline 41BW42 & 1 & 34 & 34.15 & TU 3 & 1 & 1 & $0-10 \mathrm{cmbd}$ & $\begin{array}{l}\text { Bottle glass, amber; included metallic tag; } \\
\text { fragments mend }\end{array}$ & 5 & 6.67 & $10 / 21 / 2015$ & $A D / C S$ \\
\hline 41BW42 & 1 & 34 & 34.16 & TU 3 & 1 & 1 & $0-10 \mathrm{cmbd}$ & $\begin{array}{l}\text { Bottle glass, amethyst; seam on one piece, lip } \\
\text { on another }\end{array}$ & 5 & 7.55 & $10 / 21 / 2015$ & $A D / C S$ \\
\hline 41BW42 & 1 & 34 & 34.17 & TU 3 & 1 & 1 & $0-10 \mathrm{cmbd}$ & Shotgun shell, "WINCHESTER REPEATER NO 20" & 1 & 3.25 & $10 / 21 / 2015$ & $\mathrm{AD} / \mathrm{CS}$ \\
\hline 41BW69 & 1 & 158 & 158.01 & ST 24 & I & $1 / 2$ & $0-20 \mathrm{cmbs}$ & Flake, Thinning; Late, chert; >1/4", Medial-Distal & 1 & 0.26 & $11 / 10 / 2015$ & $\mathrm{SF} / \mathrm{RT}$ \\
\hline 41BW69 & 1 & 158 & 158.02 & ST 24 & I & $1 / 2$ & $0-20 \mathrm{cmbs}$ & Flake, Early Reduction, chert; $>1 / 2 "$, Complete & 1 & 1.53 & $11 / 10 / 2015$ & $\mathrm{SF} / \mathrm{RT}$ \\
\hline 41BW69 & 2 & 159 & 159.01 & ST 40 & II & & $5-20 \mathrm{cmbs}$ & Flake, Thinning, chert; >1/2", Complete & 1 & 0.83 & $11 / 10 / 2015$ & $\mathrm{SF} / \mathrm{RT}$ \\
\hline 41BW69 & 3 & 160 & 160.01 & ST 42 & II & & $50-60 \mathrm{cmbs}$ & Flake, Thinning, chert; $>1 / 2 "$, Complete & 1 & 1.26 & $11 / 10 / 2015$ & $\mathrm{SF} / \mathrm{RT}$ \\
\hline 41BW69 & 3 & 160 & 160.02 & ST 42 & II & & $50-60 \mathrm{cmbs}$ & Flake, core reduction, chert; $>1 "$, Complete & 1 & 8.03 & $11 / 10 / 2015$ & $\mathrm{SF} / \mathrm{RT}$ \\
\hline 41BW69 & 1 & 161 & 161.01 & TU 2 & I & 1 & $15-20 \mathrm{cmbd}$ & Flake, Thinning; Late, chert; $>1 / 4 "$, Complete & 1 & 0.24 & $11 / 10 / 2015$ & $E A / A D$ \\
\hline 41BW69 & 1 & 162 & 162.01 & TU 3 & II & 1 & $20-30 \mathrm{cmbd}$ & Flake, Thinning; Late, chert; $>1 / 2 "$, Complete & 2 & 0.77 & $11 / 10 / 2015$ & \\
\hline 41BW69 & 2 & 163 & 163.01 & TU 3 & II & 2 & $30-40 \mathrm{cmbd}$ & Flake, Thinning; Late, chert; >1/4", Complete & 1 & 0.11 & $11 / 10 / 2015$ & \\
\hline 41BW69 & 2 & 163 & 163.02 & TU 3 & II & 2 & $30-40 \mathrm{cmbd}$ & Flake, Thinning; Late, chert; >1/4", Complete & 1 & 0.15 & $11 / 10 / 2015$ & \\
\hline $41 \mathrm{CS} 109$ & 1 & 37 & 37.01 & ST 4 & II & & $20-30 \mathrm{cmbs}$ & Flake, core reduction, chert; >1/2", Proximal & 1 & 1.73 & $10 / 26 / 2015$ & $\mathrm{BH}$ \\
\hline 41CS109 & 2 & 38 & 38.01 & $\mathrm{CP} 1$ & & & Surface & $\begin{array}{l}\text { Flake, core reduction, quartzite; }>1 / 2 " \text {, } \\
\text { Complete }\end{array}$ & 1 & 1.95 & $10 / 26 / 2015$ & $\mathrm{BH}$ \\
\hline
\end{tabular}




\begin{tabular}{|c|c|c|c|c|c|c|c|c|c|c|c|c|}
\hline $\begin{array}{c}\text { Site } \\
\#\end{array}$ & $\begin{array}{c}\text { FS } \\
\#\end{array}$ & LS\# & $\begin{array}{c}\text { Catalog } \\
\#\end{array}$ & Prov. & $\begin{array}{c}\text { Strat } \\
\text { a }\end{array}$ & $\begin{array}{c}\text { Leve } \\
1\end{array}$ & Depth & Description & Count & $\begin{array}{l}\text { Weight } \\
\text { (g) }\end{array}$ & $\begin{array}{c}\text { Date } \\
\text { Excavated }\end{array}$ & Exc/Rec \\
\hline $41 \mathrm{CS} 109$ & 2 & 38 & 38.02 & $\mathrm{CP} 1$ & & & Surface & $\begin{array}{l}\text { Flake, Early Reduction, chert; }>1 / 2 " \text {, Medial- } \\
\text { Distal }\end{array}$ & 1 & 5.54 & $10 / 26 / 2015$ & $\mathrm{BH}$ \\
\hline 41CS109 & 2 & 38 & 38.03 & $\mathrm{CP} 1$ & & & Surface & Shatter, Angular, chert & 1 & 2.36 & $10 / 26 / 2015$ & $\mathrm{BH}$ \\
\hline 41CS109 & 3 & 39 & 39.01 & $\mathrm{CP} 2$ & & & Surface & Flake, Thinning, chert; $>1 / 2 "$, Complete & 1 & 1.91 & $10 / 26 / 2015$ & $\mathrm{BH}$ \\
\hline $41 \mathrm{CS} 109$ & 3 & 39 & 39.02 & $\mathrm{CP} 2$ & & & Surface & Flake, Thinning, chert; $>1 / 2 "$, Proximal & 1 & 2.28 & $10 / 26 / 2015$ & $\mathrm{BH}$ \\
\hline 41CS109 & 3 & 39 & 39.03 & $\mathrm{CP} 2$ & & & Surface & Flake, Thinning, chert; $>1 / 2 "$, Proximal & 1 & 0.89 & $10 / 26 / 2015$ & $\mathrm{BH}$ \\
\hline 41CS109 & 3 & 39 & 39.04 & $\mathrm{CP} 2$ & & & Surface & Flake, Thinning, chert; $>1 / 2 "$, Complete & 2 & 1.93 & $10 / 26 / 2015$ & $\mathrm{BH}$ \\
\hline $41 C S 109$ & 3 & 39 & 39.05 & $\mathrm{CP} 2$ & & & Surface & Possible cultural material-lithic, other & 1 & 1.55 & $10 / 26 / 2015$ & $\mathrm{BH}$ \\
\hline 41CS109 & 3 & 39 & 39.06 & $\mathrm{CP} 2$ & & & Surface & Tested pebble, chert & 1 & 7.26 & $10 / 26 / 2015$ & $\mathrm{BH}$ \\
\hline 41CS109 & 4 & 40 & 40.01 & $\mathrm{CP} 3$ & & & Surface & $\begin{array}{l}\text { Flake, Thinning, petrified wood; >1/2", } \\
\text { Complete }\end{array}$ & 1 & 1.93 & $10 / 26 / 2015$ & $\mathrm{BH}$ \\
\hline 41CS109 & 4 & 40 & 40.02 & $\mathrm{CP} 3$ & & & Surface & Flake, Thinning, chert; >1", Non-orientable & 1 & 5.01 & $10 / 26 / 2015$ & $\mathrm{BH}$ \\
\hline 41CS109 & 4 & 40 & 40.03 & $\mathrm{CP} 3$ & & & Surface & Flake, Thinning, quartzite; $>1 "$ ", Complete & 1 & 4.91 & $10 / 26 / 2015$ & $\mathrm{BH}$ \\
\hline $41 \mathrm{CS} 109$ & 4 & 40 & 40.04 & $\mathrm{CP} 3$ & & & Surface & PPK, Straight stemmed, quartzite & 1 & 5.61 & $10 / 26 / 2015$ & $\mathrm{BH}$ \\
\hline $41 C S 109$ & 5 & 41 & 41.01 & $\mathrm{CP} 4$ & & & Surface & Flake, Thinning, chert; >1/2", Medial-Distal & 2 & 2.14 & $10 / 26 / 2015$ & MMM \\
\hline 41CS109 & 5 & 41 & 41.02 & $\mathrm{CP} 4$ & & & Surface & $\begin{array}{l}\text { PPK, Straight stemmed, chert; Kent type; white } \\
\text { chert; long stem, snapped; W- } 25.10 \text { mm; T-8.00 } \\
\text { mm }\end{array}$ & 1 & 6.74 & $10 / 26 / 2015$ & MMM \\
\hline $41 \mathrm{CS} 109$ & 5 & 41 & 41.03 & $\mathrm{CP} 4$ & & & Surface & $\begin{array}{l}\text { PPK, Contracting stemmed, chert; Gary type; } \\
\text { gray/maroon chert; L-39.45; W- } 26.25 \text { mm; T- } \\
7.30 \mathrm{~mm}\end{array}$ & 1 & 5.97 & $10 / 26 / 2015$ & MMM \\
\hline 41CS109 & 5 & 41 & 41.04 & $\mathrm{CP} 4$ & & & Surface & $\begin{array}{l}\text { Sandstone conglomerate, naturally occuring, } \\
\text { sandstone }\end{array}$ & 1 & 44.16 & $10 / 26 / 2015$ & MMM \\
\hline 41CS109 & 6 & 42 & 42.01 & CP 5 & & & Surface & Flake, Thinning, chert; >1/2", Complete & 1 & 0.72 & $10 / 26 / 2015$ & $A D$ \\
\hline $41 \mathrm{CS} 109$ & 7 & 43 & 43.01 & $\mathrm{CP} 6$ & & & Surface & Flake, Thinning, quartzite; >1/2", Medial-Distal & 1 & 2.23 & $10 / 26 / 2015$ & MRM \\
\hline $41 C S 109$ & 7 & 43 & 43.02 & $\mathrm{CP} 6$ & & & Surface & Fire cracked rock, chert & 1 & 28.40 & $10 / 26 / 2015$ & MRM \\
\hline $41 \mathrm{CS} 109$ & 8 & 44 & 44.01 & $\mathrm{CP} 7$ & & & Surface & Flake, Thinning, chert; >1/2", Medial-Distal & 1 & 2.53 & $10 / 26 / 2015$ & $\mathrm{MH}$ \\
\hline $41 C S 109$ & 8 & 44 & 44.02 & $\mathrm{CP} 7$ & & & Surface & Shatter, Thermal, chert & 1 & 2.78 & $10 / 26 / 2015$ & $\mathrm{MH}$ \\
\hline
\end{tabular}




\begin{tabular}{|c|c|c|c|c|c|c|c|c|c|c|c|c|}
\hline $\begin{array}{c}\text { Site } \\
\#\end{array}$ & $\begin{array}{l}\text { FS } \\
\#\end{array}$ & LS\# & $\begin{array}{c}\text { Catalog } \\
\#\end{array}$ & Prov. & $\begin{array}{c}\text { Strat } \\
\text { a }\end{array}$ & $\begin{array}{c}\text { Leve } \\
1\end{array}$ & Depth & Description & Count & $\begin{array}{l}\text { Weight } \\
\text { (g) }\end{array}$ & $\begin{array}{c}\text { Date } \\
\text { Excavated }\end{array}$ & Exc/Rec \\
\hline 41CS109 & 9 & 45 & 45.01 & $\mathrm{CP} 8$ & & & Surface & Flake, Thinning, chert; $>1 / 2 "$, Complete & 1 & 1.84 & $10 / 26 / 2015$ & CS \\
\hline $41 \mathrm{CS} 109$ & 9 & 45 & 45.02 & CP 8 & & & Surface & Flake, Thinning; Late, chert; >1/2", Complete & 3 & 1.65 & $10 / 26 / 2015$ & CS \\
\hline $41 \mathrm{CS} 109$ & 9 & 45 & 45.03 & CP 8 & & & Surface & Flake, Thinning; Late, chert; >1/2", Medial-Distal & 2 & 1.68 & $10 / 26 / 2015$ & CS \\
\hline $41 \mathrm{CS} 109$ & 9 & 45 & 45.04 & CP 8 & & & Surface & Flake, Thinning, chert; $>1 / 2 "$ ", Non-orientable & 1 & 1.10 & $10 / 26 / 2015$ & CS \\
\hline $41 \mathrm{CS} 109$ & 9 & 45 & 45.05 & CP 8 & & & Surface & Flake, Thinning; Late, chert; >1/4", Complete & 1 & 0.10 & $10 / 26 / 2015$ & CS \\
\hline $41 \mathrm{CS} 109$ & 9 & 45 & 45.06 & CP 8 & & & Surface & Shatter, Angular, chert & 1 & 0.91 & $10 / 26 / 2015$ & CS \\
\hline $41 \mathrm{CS} 109$ & 10 & 46 & 46.01 & CP 9 & & & Surface & Flake, core reduction, chert; $>1 "$ ", Complete & 3 & 8.93 & $10 / 26 / 2015$ & CS \\
\hline $41 \mathrm{CS} 109$ & 10 & 46 & 46.02 & CP 9 & & & Surface & Flake, core reduction, chert; >1/2", Proximal & 1 & 1.33 & $10 / 26 / 2015$ & CS \\
\hline $41 \mathrm{CS} 109$ & 10 & 46 & 46.03 & CP 9 & & & Surface & Flake, Early Reduction, chert; >1", Complete & 1 & 3.49 & $10 / 26 / 2015$ & CS \\
\hline $41 \mathrm{CS} 109$ & 10 & 46 & 46.04 & CP 9 & & & Surface & Flake, core reduction, chert; $>1 "$, Proximal & 1 & 3.03 & $10 / 26 / 2015$ & CS \\
\hline 41CS109 & 10 & 46 & 46.05 & $\mathrm{CP} 9$ & & & Surface & Flake, Thinning, chert; $>1 / 2 "$ ", Complete & 1 & 1.48 & $10 / 26 / 2015$ & CS \\
\hline $41 \mathrm{CS} 109$ & 10 & 46 & 46.06 & CP 9 & & & Surface & Flake, Thinning, chert; >1", Complete & 1 & 1.77 & $10 / 26 / 2015$ & CS \\
\hline $41 \mathrm{CS} 109$ & 10 & 46 & 46.07 & CP 9 & & & Surface & Flake, Thinning, chert; $>1 / 2 "$ ", Proximal & 1 & 0.46 & $10 / 26 / 2015$ & CS \\
\hline $41 \mathrm{CS} 109$ & 10 & 46 & 46.08 & CP 9 & & & Surface & Possible cultural material-lithic, petrified wood & 1 & 1.38 & $10 / 26 / 2015$ & CS \\
\hline 41CS109 & 10 & 46 & 46.09 & CP 9 & & & Surface & PPK fragment, chert & 1 & 3.01 & $10 / 26 / 2015$ & CS \\
\hline 41CS109 & 11 & 47 & 47.01 & $\mathrm{CP} 10$ & & & Surface & Flake, core reduction, chert; $>1 / 2 "$, Complete & 1 & 1.37 & $10 / 26 / 2015$ & CS \\
\hline $41 \mathrm{CS} 109$ & 11 & 47 & 47.02 & $\mathrm{CP} 10$ & & & Surface & Flake, Thinning, chert; >1/2", Complete & 1 & 1.89 & $10 / 26 / 2015$ & CS \\
\hline 41CS109 & 11 & 47 & 47.03 & $\mathrm{CP} 10$ & & & Surface & Flake, Thinning, chert; $>1 / 2 "$ ", Complete & 1 & 0.68 & $10 / 26 / 2015$ & CS \\
\hline $41 \mathrm{CS} 109$ & 11 & 47 & 47.04 & $\mathrm{CP} 10$ & & & Surface & $\begin{array}{l}\text { PPK, Contracting stemmed, chert; Gary type; } \\
\text { stem and partial body fragment only }\end{array}$ & 1 & 5.18 & $10 / 26 / 2015$ & CS \\
\hline $41 \mathrm{CS} 109$ & 11 & 47 & 47.05 & CP 10 & & & Surface & PPK Preform, Early stage, chert & 1 & 8.62 & $10 / 26 / 2015$ & CS \\
\hline 41CS109 & 11 & 47 & 47.06 & $\mathrm{CP} 10$ & & & Surface & Fire cracked rock, chert & 2 & 23.40 & $10 / 26 / 2015$ & CS \\
\hline $41 \mathrm{CS} 109$ & 12 & 48 & 48.01 & CP 11 & & & Surface & $\begin{array}{l}\text { Scraper, UID, chert; L-33.23mm, W-26.58mm, T- } \\
11.84 \mathrm{~mm} ; 0-25 \% \text { cortex }\end{array}$ & 1 & 12.28 & $10 / 26 / 2015$ & $\mathrm{BH}$ \\
\hline $41 \mathrm{CS} 109$ & 12 & 48 & 48.02 & $\mathrm{CP} 11$ & & & Surface & Possible cultural material-lithic, other & 1 & 10.45 & $10 / 26 / 2015$ & $\mathrm{BH}$ \\
\hline $41 \mathrm{CS} 109$ & 13 & 49 & 49.01 & $\mathrm{CP} 12$ & & & Surface & Flake, Early Reduction, chert; >1", Complete & 1 & 5.81 & $10 / 26 / 2015$ & $\mathrm{BH}$ \\
\hline 41CS109 & 13 & 49 & 49.02 & CP 12 & & & Surface & Flake, Thinning, chert; >1/2", Medial-Distal & 1 & 2.95 & $10 / 26 / 2015$ & $\mathrm{BH}$ \\
\hline $41 \mathrm{CS} 109$ & 13 & 49 & 49.03 & $\mathrm{CP} 12$ & & & Surface & Flake, Thinning, chert; $>1 / 2 "$ ", Proximal & 1 & 0.75 & $10 / 26 / 2015$ & $\mathrm{BH}$ \\
\hline
\end{tabular}




\begin{tabular}{|c|c|c|c|c|c|c|c|c|c|c|c|c|}
\hline $\begin{array}{c}\text { Site } \\
\#\end{array}$ & $\begin{array}{l}\text { FS } \\
\#\end{array}$ & LS\# & $\begin{array}{c}\text { Catalog } \\
\#\end{array}$ & Prov. & $\begin{array}{c}\text { Strat } \\
\text { a }\end{array}$ & $\begin{array}{c}\text { Leve } \\
1\end{array}$ & Depth & Description & Count & $\begin{array}{l}\text { Weight } \\
\text { (g) }\end{array}$ & $\begin{array}{c}\text { Date } \\
\text { Excavated }\end{array}$ & Exc/Rec \\
\hline 41CS109 & 13 & 49 & 49.04 & CP 12 & & & Surface & Flake, Thinning, chert; >1/2", Medial-Distal & 1 & 0.88 & $10 / 26 / 2015$ & $\mathrm{BH}$ \\
\hline 41CS109 & 14 & 50 & 50.01 & CP 13 & & & Surface & Flake, Early Reduction, chert; >1/2", Complete & 1 & 3.29 & $10 / 26 / 2015$ & $\mathrm{BH}$ \\
\hline 41CS109 & 14 & 50 & 50.02 & CP 13 & & & Surface & Flake, Early Reduction, chert; >1/2", Complete & 2 & 5.54 & $10 / 26 / 2015$ & $\mathrm{BH}$ \\
\hline 41CS109 & 14 & 50 & 50.03 & CP 13 & & & Surface & Flake, Thinning, chert; >1/2", Complete & 1 & 1.68 & $10 / 26 / 2015$ & $\mathrm{BH}$ \\
\hline 41CS109 & 14 & 50 & 50.04 & CP 13 & & & Surface & Flake, Thinning, chert; $>1 / 2 "$, Complete & 3 & 5.31 & $10 / 26 / 2015$ & $\mathrm{BH}$ \\
\hline 41CS109 & 14 & 50 & 50.05 & CP 13 & & & Surface & Flake, Thinning; Late, chert; $>1 / 4 "$, Complete & 1 & 0.39 & $10 / 26 / 2015$ & $\mathrm{BH}$ \\
\hline $41 \mathrm{CS} 109$ & 14 & 50 & 50.06 & CP 13 & & & Surface & Shatter, Angular, chert & 1 & 2.10 & $10 / 26 / 2015$ & $\mathrm{BH}$ \\
\hline $41 C S 109$ & 15 & 51 & 51.01 & CP 14 & & & Surface & $\begin{array}{l}\text { PPK, Contracting stemmed, chert; Gary type, } \\
60 \% \text { of body and stem only, no tip; L- } 45.08 \mathrm{~mm} \text {, } \\
\text { W-36.82mm, T-9.91mm }\end{array}$ & 1 & 12.71 & $10 / 25 / 2015$ & $\mathrm{CS}$ \\
\hline 41CS109 & 15 & 51 & 51.02 & CP 14 & & & Surface & Flake, Thinning; Late, chert; $>1 / 4 "$ ", Complete & 1 & 0.08 & $10 / 25 / 2015$ & CS \\
\hline 41CS109 & 15 & 51 & 51.03 & CP 14 & & & Surface & Flake, Early Reduction, chert; $>1 "$ ", Complete & 1 & 4.15 & $10 / 25 / 2015$ & CS \\
\hline $41 C S 109$ & 15 & 51 & 51.04 & CP 14 & & & Surface & Flake, Early Reduction, chert; $>1 / 2 "$ ", Complete & 1 & 3.68 & $10 / 25 / 2015$ & CS \\
\hline 41CS109 & 15 & 51 & 51.05 & CP 14 & & & Surface & Flake, Thinning, chert; >1/2", Complete & 2 & 2.91 & $10 / 25 / 2015$ & CS \\
\hline $41 \mathrm{CS} 109$ & 15 & 51 & 51.06 & CP 14 & & & Surface & Flake, Thinning, chert; $>1 / 2 "$, Non-orientable & 1 & 0.57 & $10 / 25 / 2015$ & CS \\
\hline 41CS109 & 15 & 51 & 51.07 & CP 14 & & & Surface & Flake, Thinning, chert; >1", Proximal & 1 & 2.85 & $10 / 25 / 2015$ & CS \\
\hline $41 C S 109$ & 15 & 51 & 51.08 & CP 14 & & & Surface & Flake, Thinning, quartzite; >1/2", Complete & 1 & 1.49 & $10 / 25 / 2015$ & CS \\
\hline $41 \mathrm{CS} 109$ & 15 & 51 & 51.09 & CP 14 & & & Surface & $\begin{array}{l}\text { Flake, core reduction, quartzite; }>1 / 2 " \text {, } \\
\text { Complete }\end{array}$ & 1 & 2.87 & $10 / 25 / 2015$ & CS \\
\hline $41 \mathrm{CS} 109$ & 16 & 52 & 52.01 & $\mathrm{CP} 15$ & & & Surface & Flake, Early Reduction, chert; $>1 "$ ", Proximal & 1 & 5.71 & $10 / 25 / 2015$ & $\mathrm{MH}$ \\
\hline $41 \mathrm{CS} 109$ & 16 & 52 & 52.02 & CP 15 & & & Surface & Flake, Thinning, chert; >1/2", Complete & 1 & 0.88 & $10 / 25 / 2015$ & $\mathrm{MH}$ \\
\hline $41 \mathrm{CS} 109$ & 17 & 53 & 53.01 & CP 16 & & & Surface & Flake, Early Reduction, chert; >1", Complete & 1 & 3.18 & $10 / 25 / 2015$ & $\mathrm{BH}$ \\
\hline $41 C S 109$ & 17 & 53 & 53.02 & CP 16 & & & Surface & Flake, Early Reduction, chert; >1", Complete & 2 & 6.51 & $10 / 25 / 2015$ & $\mathrm{BH}$ \\
\hline $41 \mathrm{CS} 109$ & 17 & 53 & 53.03 & CP 16 & & & Surface & Flake, Early Reduction, chert; $>1 / 2 "$ ", Complete & 1 & 2.15 & $10 / 25 / 2015$ & $\mathrm{BH}$ \\
\hline $41 \mathrm{CS} 109$ & 17 & 53 & 53.04 & CP 16 & & & Surface & Shatter, Thermal, chert & 1 & 2.94 & $10 / 25 / 2015$ & $\mathrm{BH}$ \\
\hline $41 \mathrm{CS} 109$ & 18 & 54 & 54.01 & CP 17 & & & Surface & PPK Preform, Early stage, chert; heat treated & 1 & 30.93 & $10 / 25 / 2015$ & $A D$ \\
\hline $41 \mathrm{CS} 109$ & 18 & 54 & 54.02 & CP 17 & & & Surface & Flake, Early Reduction, chert; >1", Complete & 1 & 3.98 & $10 / 25 / 2015$ & $A D$ \\
\hline 41CS109 & 18 & 54 & 54.03 & CP 17 & & & Surface & Flake, Thinning, chert; $>1 / 2 "$, Proximal & 1 & 1.23 & $10 / 25 / 2015$ & $A D$ \\
\hline
\end{tabular}




\begin{tabular}{|c|c|c|c|c|c|c|c|c|c|c|c|c|}
\hline $\begin{array}{c}\text { Site } \\
\#\end{array}$ & $\begin{array}{l}\text { FS } \\
\#\end{array}$ & LS\# & $\begin{array}{c}\text { Catalog } \\
\#\end{array}$ & Prov. & $\begin{array}{c}\text { Strat } \\
\text { a }\end{array}$ & $\begin{array}{c}\text { Leve } \\
1\end{array}$ & Depth & Description & Count & $\begin{array}{c}\text { Weight } \\
\text { (g) }\end{array}$ & $\begin{array}{c}\text { Date } \\
\text { Excavated }\end{array}$ & Exc/Rec \\
\hline $41 \mathrm{CS} 109$ & 18 & 54 & 54.04 & CP 17 & & & Surface & Flake, Thinning, chert; >1/2", Medial-Distal & 2 & 3.58 & $10 / 25 / 2015$ & $A D$ \\
\hline 41CS109 & 19 & 55 & 55.01 & ST 9 & & & Surface & Flake, Thinning, chert; $>1 / 2 "$, Proximal & 1 & 0.60 & $10 / 25 / 2015$ & $\mathrm{AD} / \mathrm{BH}$ \\
\hline 41CS109 & 19 & 55 & 55.02 & ST 9 & & & Surface & Flake, Thinning, chert; >1/2", Medial-Distal & 1 & 0.69 & $10 / 25 / 2015$ & $\mathrm{AD} / \mathrm{BH}$ \\
\hline 41CS109 & 19 & 55 & 55.03 & ST 9 & & & Surface & Flake, Thinning, chert; $>1 / 2 "$, Complete & 1 & 1.38 & $10 / 25 / 2015$ & $\mathrm{AD} / \mathrm{BH}$ \\
\hline 41CS109 & 19 & 55 & 55.04 & ST 9 & & & Surface & Flake, Early Reduction, chert; >1/2", Proximal & 1 & 1.97 & $10 / 25 / 2015$ & $\mathrm{AD} / \mathrm{BH}$ \\
\hline $41 \mathrm{CS} 109$ & 19 & 55 & 55.05 & ST 9 & & & Surface & Biface fragment, miscellaneous, chert & 1 & 1.61 & $10 / 25 / 2015$ & $\mathrm{AD} / \mathrm{BH}$ \\
\hline 41CS109 & 19 & 55 & 55.06 & ST 9 & & & Surface & $\begin{array}{l}\text { Shatter, Thermal, chert; potlid on exterior, } \\
\text { spalled and fragmented }\end{array}$ & 1 & 6.87 & $10 / 25 / 2015$ & $\mathrm{AD} / \mathrm{BH}$ \\
\hline 41CS109 & 20 & 56 & 56.01 & ST 10 & & & Surface & Fire cracked rock & 1 & 221.21 & $10 / 25 / 2015$ & $\mathrm{MO} / \mathrm{MMM}$ \\
\hline $41 \mathrm{CS} 110$ & 1 & 57 & 57.01 & TR 1 & & & Surface & Flake, core reduction, chert; $>1 "$ ", Complete & 1 & 3.08 & $10 / 26 / 2015$ & MMM \\
\hline $41 \mathrm{CS} 110$ & 2 & 58 & 58.01 & TR 2 & & & Surface & Shatter, Angular, chert & 1 & 18.96 & $10 / 26 / 2015$ & $A D$ \\
\hline $41 \mathrm{CS} 110$ & 2 & 58 & 58.02 & TR 2 & & & Surface & Flake, core reduction, chert; >1", Complete & 1 & 2.62 & $10 / 26 / 2015$ & $A D$ \\
\hline $41 \mathrm{CS} 110$ & 2 & 58 & 58.03 & TR 2 & & & Surface & Flake, core reduction, chert; >1/2", Proximal & 1 & 0.76 & $10 / 26 / 2015$ & $A D$ \\
\hline $41 \mathrm{CS} 110$ & 2 & 58 & 58.04 & TR 2 & & & Surface & Flake, Early Reduction, chert; >1", Complete & 2 & 6.44 & $10 / 26 / 2015$ & $A D$ \\
\hline $41 \mathrm{CS} 110$ & 2 & 58 & 58.05 & TR 2 & & & Surface & Flake, Early Reduction, chert; $>1 / 2 "$, Complete & 3 & 2.68 & $10 / 26 / 2015$ & $A D$ \\
\hline $41 \mathrm{CS} 110$ & 2 & 58 & 58.06 & TR 2 & & & Surface & Flake, Thinning, chert; $>1 / 2 "$, Complete & 1 & 0.72 & $10 / 26 / 2015$ & $A D$ \\
\hline $41 \mathrm{CS} 110$ & 3 & 59 & 59.01 & TR 3 & & & Surface & Flake, Early Reduction, chert; $>1 / 2 "$, Proximal & 1 & 4.58 & $10 / 26 / 2015$ & MO \\
\hline $41 \operatorname{CS} 117$ & 1 & 156 & 156.01 & ST 6 & II & 1 & $15 \mathrm{cmbs}$ & Flake, Early Reduction, chert; >1/4", Complete & 1 & 0.36 & $11 / 9 / 2015$ & $\mathrm{EA} / \mathrm{SF}$ \\
\hline $41 \mathrm{CS} 117$ & 2 & 157 & 157.01 & ST 13 & III & 4 & $40-50 \mathrm{cmbs}$ & Flake, Thinning, chert; $>1 / 2 "$, Complete & 1 & 0.44 & $11 / 9 / 2015$ & $\mathrm{EA} / \mathrm{SF}$ \\
\hline $41 \mathrm{CS} 122$ & 1 & 131 & 131.01 & $\mathrm{CP} 1$ & & & Surface & Flake, Early Reduction, chert; >1/2", Complete & 1 & 1.82 & $11 / 8 / 2015$ & MRM \\
\hline $41 \mathrm{CS} 122$ & 1 & 131 & 131.02 & $\mathrm{CP} 1$ & & & Surface & Shatter, Thermal, chert & 1 & 15.27 & $11 / 8 / 2015$ & MRM \\
\hline $41 \mathrm{CS} 122$ & 2 & 132 & 132.01 & $\mathrm{CP} 2$ & & & Surface & Flake, Thinning; Late, chert; >1/2", Complete & 1 & 0.58 & $11 / 8 / 2015$ & JTS/JMS \\
\hline $41 \mathrm{CS} 122$ & 2 & 132 & 132.02 & $\mathrm{CP} 2$ & & & Surface & Flake, Thinning; Late, chert; >1/2", Proximal & 2 & 1.11 & $11 / 8 / 2015$ & JTS/JMS \\
\hline $41 \mathrm{CS} 122$ & 2 & 132 & 132.03 & $\mathrm{CP} 2$ & & & Surface & Flake, Thinning; Late, chert; >1/2", Medial-Distal & 2 & 1.00 & $11 / 8 / 2015$ & JTS/JMS \\
\hline $41 \mathrm{CS} 122$ & 2 & 132 & 132.04 & $\mathrm{CP} 2$ & & & Surface & Flake, Thinning; Late, chert; >1/4", Medial-Distal & 1 & 0.30 & $11 / 8 / 2015$ & JTS/JMS \\
\hline $41 \mathrm{CS} 122$ & 2 & 132 & 132.05 & $\mathrm{CP} 2$ & & & Surface & Flake, blade, chert; $>1 / 2 "$ ", Proximal & 1 & 0.67 & $11 / 8 / 2015$ & JTS/JMS \\
\hline
\end{tabular}




\begin{tabular}{|c|c|c|c|c|c|c|c|c|c|c|c|c|}
\hline $\begin{array}{c}\text { Site } \\
\#\end{array}$ & $\begin{array}{c}\text { FS } \\
\#\end{array}$ & LS\# & $\begin{array}{c}\text { Catalog } \\
\#\end{array}$ & Prov. & $\begin{array}{c}\text { Strat } \\
\text { a }\end{array}$ & $\begin{array}{c}\text { Leve } \\
1\end{array}$ & Depth & Description & Count & $\begin{array}{c}\text { Weight } \\
\text { (g) }\end{array}$ & $\begin{array}{c}\text { Date } \\
\text { Excavated }\end{array}$ & Exc/Rec \\
\hline $41 \mathrm{CS} 122$ & 2 & 132 & 132.06 & $\mathrm{CP} 2$ & & & Surface & $\begin{array}{l}\text { PPK, Straight stemmed, chert; Gary type; tip } \\
\text { snapped off; cortex on one side, potlid-type } \\
\text { exclusion on the other; poor quality material }\end{array}$ & 1 & 8.01 & $11 / 8 / 2015$ & JTS/JMS \\
\hline $41 \mathrm{CS} 122$ & 3 & 133 & 133.01 & $\mathrm{CP} 3$ & & & Surface & Flake, Thinning; Late, chert; >1/4", Proximal & 1 & 0.38 & $11 / 8 / 2015$ & JTS/JMS \\
\hline $41 \mathrm{CS} 122$ & 3 & 133 & 133.02 & $\mathrm{CP} 3$ & & & Surface & Flake, Thinning, chert; $>1 / 2 "$, Complete & 1 & 1.94 & $11 / 8 / 2015$ & JTS/JMS \\
\hline $41 \mathrm{CS} 122$ & 3 & 133 & 133.03 & $\mathrm{CP} 3$ & & & Surface & Flake, Early Reduction, chert; >1", Medial-Distal & 1 & 7.69 & $11 / 8 / 2015$ & JTS/JMS \\
\hline $41 \mathrm{CS} 122$ & 3 & 133 & 133.04 & $\mathrm{CP} 3$ & & & Surface & $\begin{array}{l}\text { Aboriginal ceramic, red filmed, body, grog/clay } \\
\text { temper; body; red filmed, black painted linear } \\
\text { design }\end{array}$ & 1 & 20.96 & $11 / 8 / 2015$ & JTS/JMS \\
\hline $41 \mathrm{CS} 122$ & 4 & 134 & 134.01 & ST 16 & 1 & 1 & $0-10 \mathrm{cmbs}$ & Flake, Thinning; Late, chert; $>1 / 4 "$, Complete & 1 & 0.20 & $11 / 8 / 2015$ & JTS/JMS \\
\hline $41 \mathrm{CS} 122$ & 4 & 134 & 134.02 & ST 16 & 1 & 1 & $0-10 \mathrm{cmbs}$ & Flake, core reduction, chert; $>1 "$ ", Complete & 1 & 7.01 & $11 / 8 / 2015$ & JTS/JMS \\
\hline $41 \mathrm{CS} 122$ & 5 & 135 & 135.01 & ST 16 & II & 1 & $10-20 \mathrm{cmbs}$ & Possible cultural material-lithic, petrified wood & 1 & 1.32 & $11 / 8 / 2015$ & JTS/JMS \\
\hline $41 \mathrm{CS} 122$ & 5 & 135 & 135.02 & ST 16 & II & 1 & $10-20 \mathrm{cmbs}$ & $\begin{array}{l}\text { Flake, core reduction, chert; }>1 / 2 " \text {, Non- } \\
\text { orientable }\end{array}$ & 1 & 5.29 & $11 / 8 / 2015$ & JTS/JMS \\
\hline $41 \mathrm{CS} 122$ & 5 & 135 & 135.03 & ST 16 & II & 1 & $10-20 \mathrm{cmbs}$ & $\begin{array}{l}\text { Flake, core reduction, quartzite/sandstone; }>1 " \text {, } \\
\text { Complete }\end{array}$ & 1 & 8.89 & $11 / 8 / 2015$ & JTS/JMS \\
\hline $41 \mathrm{CS} 122$ & 6 & 136 & 136.01 & ST 16 & II & 2 & $20-30 \mathrm{cmbs}$ & Possible cultural material-lithic, petrified wood & 1 & 1.26 & $11 / 8 / 2015$ & JTS/JMS \\
\hline $41 \mathrm{CS} 122$ & 1 & 137 & 137.01 & TU 1 & 1 & 1 & $10-20 \mathrm{cmbd}$ & Flake, Thinning, chert; >1/2", Complete & 1 & 0.87 & $11 / 8 / 2015$ & JTS/JMS \\
\hline $41 \mathrm{CS} 122$ & 1 & 137 & 137.02 & TU 1 & I & 1 & $10-20 \mathrm{cmbd}$ & Flake, retouch, chert; $>1 / 8$, Complete & 1 & 0.03 & $11 / 8 / 2015$ & JTS/JMS \\
\hline $41 \mathrm{CS} 122$ & 1 & 137 & 137.03 & TU 1 & 1 & 1 & $10-20 \mathrm{cmbd}$ & Flake, retouch, chert; $>1 / 8$, Proximal & 1 & 0.04 & $11 / 8 / 2015$ & JTS/JMS \\
\hline $41 \mathrm{CS} 122$ & 2 & 138 & 138.01 & TU 1 & 1 & 2 & $10-20 \mathrm{cmbd}$ & Flake, Thinning, chert; >1/2", Complete & 1 & 0.93 & $11 / 8 / 2015$ & JTS/JMS \\
\hline $41 \mathrm{CS} 122$ & 2 & 138 & 138.02 & TU 1 & I & 2 & $10-20 \mathrm{cmbd}$ & Flake, Thinning, chert; $>1 / 2 "$, Complete & 2 & 1.53 & $11 / 8 / 2015$ & JTS/JMS \\
\hline $41 \mathrm{CS} 122$ & 2 & 138 & 138.03 & TU 1 & 1 & 2 & $10-20 \mathrm{cmbd}$ & Flake, Early Reduction, chert; $>1 / 2 "$ ", Proximal & 1 & 3.34 & $11 / 8 / 2015$ & JTS/JMS \\
\hline $41 \mathrm{CS} 122$ & 2 & 138 & 138.04 & TU 1 & I & 2 & $10-20 \mathrm{cmbd}$ & Fire cracked rock, other & 1 & 62.63 & $11 / 8 / 2015$ & JTS/JMS \\
\hline $41 \mathrm{CS} 122$ & 2 & 138 & 138.05 & TU 1 & I & 2 & $10-20 \mathrm{cmbd}$ & Unmodified stone, petrified wood & 1 & 0.63 & $11 / 8 / 2015$ & JTS/JMS \\
\hline $41 \mathrm{CS} 123$ & 1 & 151 & 151.01 & $\mathrm{CP} 1$ & & & Surface & Flake, Thinning, chert; >1/2", Proximal & 2 & 1.07 & $11 / 8 / 2015$ & \\
\hline $41 \mathrm{CS} 123$ & 1 & 151 & 151.02 & $\mathrm{CP} 1$ & & & Surface & Flake, Early Reduction, chert; $>1 / 2 "$ ", Proximal & 1 & 1.66 & $11 / 8 / 2015$ & \\
\hline $41 \mathrm{CS} 123$ & 1 & 151 & 151.03 & $\mathrm{CP} 1$ & & & Surface & Flake, Thinning, chert; >1/2", Complete & 1 & 1.04 & $11 / 8 / 2015$ & \\
\hline
\end{tabular}




\begin{tabular}{|c|c|c|c|c|c|c|c|c|c|c|c|c|}
\hline $\begin{array}{c}\text { Site } \\
\#\end{array}$ & $\begin{array}{c}\text { FS } \\
\#\end{array}$ & LS\# & $\begin{array}{c}\text { Catalog } \\
\#\end{array}$ & Prov. & $\begin{array}{c}\text { Strat } \\
\text { a }\end{array}$ & $\begin{array}{c}\text { Leve } \\
1\end{array}$ & Depth & Description & Count & $\begin{array}{l}\text { Weight } \\
\text { (g) }\end{array}$ & $\begin{array}{c}\text { Date } \\
\text { Excavated }\end{array}$ & Exc/Rec \\
\hline $41 \mathrm{CS} 123$ & 2 & 152 & 152.01 & $\mathrm{CP} 2$ & & & Surface & Flake, Thinning; Late, chert; >1/2", Complete & 1 & 0.67 & $11 / 8 / 2015$ & SPF \\
\hline $41 \mathrm{CS} 123$ & 2 & 152 & 152.02 & $\mathrm{CP} 2$ & & & Surface & Flake, Thinning, chert; $>1 / 2 "$, Complete & 2 & 3.93 & $11 / 8 / 2015$ & SPF \\
\hline $41 \mathrm{CS} 123$ & 2 & 152 & 152.03 & $\mathrm{CP} 2$ & & & Surface & Flake, Thinning, quartzite; $>1 / 2 "$, Proximal & 1 & 1.17 & $11 / 8 / 2015$ & SPF \\
\hline $41 \mathrm{CS} 123$ & 2 & 152 & 152.04 & $\mathrm{CP} 2$ & & & Surface & Flake, Thinning, chert; >1/2", Medial-Distal & 2 & 1.61 & $11 / 8 / 2015$ & SPF \\
\hline $41 \mathrm{CS} 123$ & 2 & 152 & 152.05 & $\mathrm{CP} 2$ & & & Surface & $\begin{array}{l}\text { Flake, Early Reduction, chert; >1/2", Medial- } \\
\text { Distal }\end{array}$ & 1 & 1.20 & $11 / 8 / 2015$ & SPF \\
\hline $41 \mathrm{CS} 123$ & 2 & 152 & 152.06 & $\mathrm{CP} 2$ & & & Surface & $\begin{array}{l}\text { Flake, core reduction, chert; >1/2", Medial- } \\
\text { Distal }\end{array}$ & 1 & 1.85 & $11 / 8 / 2015$ & SPF \\
\hline $41 \mathrm{CS} 123$ & 2 & 152 & 152.07 & $\mathrm{CP} 2$ & & & Surface & Flake, Thinning; Late, chert; $>1 / 4 "$, Complete & 1 & 0.13 & $11 / 8 / 2015$ & SPF \\
\hline $41 \mathrm{CS} 123$ & 2 & 152 & 152.08 & $\mathrm{CP} 2$ & & & Surface & Flake, Thinning, chert; >1/4", Medial-Distal & 1 & 0.47 & $11 / 8 / 2015$ & SPF \\
\hline $41 \mathrm{CS} 123$ & 2 & 152 & 152.09 & $\mathrm{CP} 2$ & & & Surface & Flake, Thinning, chert; >1/4", Proximal & 1 & 0.39 & $11 / 8 / 2015$ & SPF \\
\hline $41 \mathrm{CS} 123$ & 2 & 152 & 152.10 & $\mathrm{CP} 2$ & & & Surface & Flake, Early Reduction, chert; $>1 / 4 "$ ", unknown & 1 & 0.45 & $11 / 8 / 2015$ & SPF \\
\hline $41 \mathrm{CS} 123$ & 2 & 152 & 152.11 & $\mathrm{CP} 2$ & & & Surface & Bifacial chopping/cutting tool, quartzite & 1 & 40.37 & $11 / 8 / 2015$ & SPF \\
\hline $41 \mathrm{CS} 123$ & 3 & 153 & 153.01 & $\mathrm{CP} 3$ & & & Surface & Flake, Thinning; Late, chert; >1/4", Proximal & 2 & 0.39 & $11 / 8 / 2015$ & EA \\
\hline $41 \mathrm{CS} 123$ & 3 & 153 & 153.02 & $\mathrm{CP} 3$ & & & Surface & Flake, Thinning, chert; >1/2", Medial-Distal & 1 & 0.75 & $11 / 8 / 2015$ & EA \\
\hline $41 \mathrm{CS} 123$ & 3 & 153 & 153.03 & $\mathrm{CP} 3$ & & & Surface & Flake, Thinning, chert; $>1 / 2 "$, Complete & 1 & 0.34 & $11 / 8 / 2015$ & EA \\
\hline $41 \mathrm{CS} 123$ & 3 & 153 & 153.04 & $\mathrm{CP} 3$ & & & Surface & Flake, Thinning, chert; $>1 / 2 "$, Complete & 1 & 0.87 & $11 / 8 / 2015$ & EA \\
\hline $41 \mathrm{CS} 123$ & 3 & 153 & 153.05 & $\mathrm{CP} 3$ & & & Surface & Flake, Thinning, chert; $>1 / 2 "$, Complete & 1 & 0.97 & $11 / 8 / 2015$ & EA \\
\hline $41 \mathrm{CS} 123$ & 3 & 153 & 153.06 & $\mathrm{CP} 3$ & & & Surface & Flake, Thinning, chert; >1/2", Complete & 2 & 1.64 & $11 / 8 / 2015$ & EA \\
\hline $41 \mathrm{CS} 123$ & 3 & 153 & 153.07 & $\mathrm{CP} 3$ & & & Surface & Flake, Thinning, chert; $>1 / 2 "$, Proximal & 1 & 1.06 & $11 / 8 / 2015$ & EA \\
\hline $41 \mathrm{CS} 123$ & 3 & 153 & 153.08 & $\mathrm{CP} 3$ & & & Surface & Flake, Thinning, chert; $>1 / 2 "$, Proximal & 2 & 0.88 & $11 / 8 / 2015$ & EA \\
\hline $41 \mathrm{CS} 123$ & 3 & 153 & 153.09 & $\mathrm{CP} 3$ & & & Surface & Flake, Thinning, chert; >1/2", Proximal & 3 & 1.94 & $11 / 8 / 2015$ & EA \\
\hline $41 \mathrm{CS} 123$ & 3 & 153 & 153.10 & $\mathrm{CP} 3$ & & & Surface & Flake, Thinning, chert; >1/2", Medial-Distal & 1 & 0.64 & $11 / 8 / 2015$ & EA \\
\hline $41 \mathrm{CS} 123$ & 3 & 153 & 153.11 & $\mathrm{CP} 3$ & & & Surface & $\begin{array}{l}\text { Flake, Thinning, chert; >1", Complete; blade } \\
\text { flake }\end{array}$ & 1 & 1.94 & $11 / 8 / 2015$ & EA \\
\hline $41 \mathrm{CS} 123$ & 3 & 153 & 153.12 & $\mathrm{CP} 3$ & & & Surface & Flake, Early Reduction, chert; $>1 / 2 "$, Complete & 1 & 1.41 & $11 / 8 / 2015$ & EA \\
\hline $41 \mathrm{CS} 123$ & 3 & 153 & 153.13 & $\mathrm{CP} 3$ & & & Surface & Flake, Thinning; Late, chert; $>1 / 4 "$, Complete & 1 & 0.30 & $11 / 8 / 2015$ & EA \\
\hline $41 \mathrm{CS} 123$ & 4 & 154 & 154.01 & $\mathrm{CP} 4$ & & & Surface & Flake, Thinning; Late, chert; >1/4", Complete & 1 & 0.38 & $11 / 8 / 2015$ & \\
\hline $41 \mathrm{CS} 123$ & 4 & 154 & 154.02 & $\mathrm{CP} 4$ & & & Surface & Flake, Early Reduction, chert; $>1 / 2 "$ ", Complete & 1 & 3.51 & $11 / 8 / 2015$ & \\
\hline
\end{tabular}




\begin{tabular}{|c|c|c|c|c|c|c|c|c|c|c|c|c|}
\hline $\begin{array}{c}\text { Site } \\
\#\end{array}$ & $\begin{array}{c}\text { FS } \\
\#\end{array}$ & LS\# & $\begin{array}{c}\text { Catalog } \\
\#\end{array}$ & Prov. & $\begin{array}{c}\text { Strat } \\
\text { a }\end{array}$ & $\begin{array}{c}\text { Leve } \\
1\end{array}$ & Depth & Description & Count & $\begin{array}{l}\text { Weight } \\
\text { (g) }\end{array}$ & $\begin{array}{c}\text { Date } \\
\text { Excavated }\end{array}$ & Exc/Rec \\
\hline $41 \mathrm{CS} 123$ & 4 & 154 & 154.03 & $\mathrm{CP} 4$ & & & Surface & $\begin{array}{l}\text { Flake, Early Reduction, chert; >1/2", Medial- } \\
\text { Distal }\end{array}$ & 1 & 3.40 & $11 / 8 / 2015$ & \\
\hline $41 \mathrm{CS} 123$ & 1 & 155 & 155.01 & TU 1 & I & 1 & $9-14 \mathrm{cmbd}$ & Flake, Thinning; Late, chert; >1/4", Complete & 1 & 0.32 & $11 / 8 / 2015$ & $\mathrm{MO} / \mathrm{JF} / \mathrm{AE}$ \\
\hline $41 \mathrm{CS} 123$ & 1 & 155 & 155.02 & TU 1 & I & 1 & $9-14 \mathrm{cmbd}$ & Flake, Thinning; Late, chert; >1/4", Medial-Distal & 1 & 0.35 & $11 / 8 / 2015$ & $\mathrm{MO} / \mathrm{JF} / \mathrm{AE}$ \\
\hline $41 \mathrm{CS} 55$ & 1 & 83 & 83.01 & ST 1 & I & & $0-10 \mathrm{cmbs}$ & Flake, Thinning; Late, chert; >1/4", Complete & 1 & 0.19 & $11 / 3 / 2015$ & JTS, JMS \\
\hline $41 \mathrm{CS} 55$ & 1 & 83 & 83.02 & ST 1 & 1 & & $0-10 \mathrm{cmbs}$ & Flake, Thinning; Late, chert; >1/4", Complete & 1 & 0.16 & $11 / 3 / 2015$ & JTS, JMS \\
\hline $41 \mathrm{CS} 55$ & 1 & 83 & 83.03 & ST 1 & 1 & & $0-10 \mathrm{cmbs}$ & Flake, Thinning; Late, chert; >1/4", Complete & 1 & 0.14 & $11 / 3 / 2015$ & JTS, JMS \\
\hline $41 \mathrm{CS} 55$ & 1 & 83 & 83.04 & ST 1 & I & & $0-10 \mathrm{cmbs}$ & Flake, Thinning; Late, chert; $>1 / 4 "$ ", Complete & 8 & 1.24 & $11 / 3 / 2015$ & JTS, JMS \\
\hline $41 \mathrm{CS} 55$ & 1 & 83 & 83.05 & ST 1 & 1 & & $0-10 \mathrm{cmbs}$ & Flake, Thinning; Late, chert; >1/4", Proximal & 1 & 0.11 & $11 / 3 / 2015$ & JTS, JMS \\
\hline $41 \mathrm{CS} 55$ & 1 & 83 & 83.06 & ST 1 & 1 & & $0-10 \mathrm{cmbs}$ & Flake, Thinning; Late, chert; >1/4", Medial-Distal & 1 & 0.49 & $11 / 3 / 2015$ & JTS, JMS \\
\hline $41 \mathrm{CS} 55$ & 1 & 83 & 83.07 & ST 1 & I & & $0-10 \mathrm{cmbs}$ & Flake, Thinning; Late, chert; >1/4", Medial-Distal & 1 & 0.24 & $11 / 3 / 2015$ & JTS, JMS \\
\hline $41 \mathrm{CS} 55$ & 1 & 83 & 83.08 & ST 1 & I & & $0-10 \mathrm{cmbs}$ & Flake, Thinning; Late, chert; $>1 / 2 "$, Complete & 1 & 0.34 & $11 / 3 / 2015$ & JTS, JMS \\
\hline $41 \mathrm{CS} 55$ & 1 & 83 & 83.09 & ST 1 & 1 & & $0-10 \mathrm{cmbs}$ & Flake, Thinning; Late, chert; $>1 / 2 "$, Complete & 1 & 0.28 & $11 / 3 / 2015$ & JTS, JMS \\
\hline $41 \mathrm{CS} 55$ & 1 & 83 & 83.10 & ST 1 & I & & $0-10 \mathrm{cmbs}$ & Flake, Thinning; Late, chert; >1/2", Proximal & 1 & 0.30 & $11 / 3 / 2015$ & JTS, JMS \\
\hline $41 \mathrm{CS} 55$ & 1 & 83 & 83.11 & ST 1 & I & & $0-10 \mathrm{cmbs}$ & Flake, Thinning; Late, chert; $>1 / 2 "$, Proximal & 1 & 0.18 & $11 / 3 / 2015$ & JTS, JMS \\
\hline $41 \mathrm{CS} 55$ & 1 & 83 & 83.12 & ST 1 & I & & $0-10 \mathrm{cmbs}$ & Flake, Thinning; Late, chert; >1/2", Proximal & 1 & 0.26 & $11 / 3 / 2015$ & JTS, JMS \\
\hline $41 \mathrm{CS} 55$ & 1 & 83 & 83.13 & ST 1 & 1 & & $0-10 \mathrm{cmbs}$ & Flake, Thinning; Late, chert; >1/4", Medial-Distal & 1 & 0.28 & $11 / 3 / 2015$ & JTS, JMS \\
\hline $41 \mathrm{CS} 55$ & 1 & 83 & 83.14 & ST 1 & I & & $0-10 \mathrm{cmbs}$ & Flake, Thinning, chert; $>1 / 2 "$, Non-orientable & 1 & 1.96 & $11 / 3 / 2015$ & JTS, JMS \\
\hline $41 \mathrm{CS} 55$ & 1 & 83 & 83.15 & ST 1 & 1 & & $0-10 \mathrm{cmbs}$ & Flake, Thinning, chert; >1/4", Medial-Distal & 1 & 0.24 & $11 / 3 / 2015$ & JTS, JMS \\
\hline $41 \mathrm{CS} 55$ & 1 & 83 & 83.16 & ST 1 & I & & $0-10 \mathrm{cmbs}$ & Shatter, Angular, chert & 2 & 0.51 & $11 / 3 / 2015$ & JTS, JMS \\
\hline $41 \mathrm{CS} 55$ & 2 & 84 & 84.01 & ST 1 & II & & $10-20 \mathrm{cmbs}$ & Flake, Thinning; Late, chert; >1/4", Proximal & 1 & 0.09 & $11 / 3 / 2015$ & JTS, JMS \\
\hline $41 \mathrm{CS} 55$ & 2 & 84 & 84.02 & ST 1 & II & & $10-20 \mathrm{cmbs}$ & Flake, Thinning; Late, chert; >1/4", Medial-Distal & 1 & 0.24 & $11 / 3 / 2015$ & JTS, JMS \\
\hline $41 \mathrm{CS} 55$ & 2 & 84 & 84.03 & ST 1 & II & & $10-20 \mathrm{cmbs}$ & Flake, Thinning, chert; >1/2", Medial-Distal & 3 & 1.42 & $11 / 3 / 2015$ & JTS, JMS \\
\hline $41 \mathrm{CS} 55$ & 2 & 84 & 84.04 & ST 1 & II & & $10-20 \mathrm{cmbs}$ & Flake, Thinning, chert; >1/2", Medial-Distal & 1 & 0.69 & $11 / 3 / 2015$ & JTS, JMS \\
\hline $41 \mathrm{CS} 55$ & 3 & 85 & 85.01 & ST 2 & 1 & & $0-10 \mathrm{cmbs}$ & Flake, Thinning, chert; >1/2", Complete & 1 & 0.50 & $11 / 3 / 2015$ & MRM, SE \\
\hline $41 \mathrm{CS} 55$ & 3 & 85 & 85.02 & ST 2 & I & & $0-10 \mathrm{cmbs}$ & Flake, Thinning; Late, chert; >1/4", Medial-Distal & 1 & 0.09 & $11 / 3 / 2015$ & MRM, SE \\
\hline $41 \mathrm{CS} 55$ & 4 & 86 & 86.01 & ST 3 & II & & $5-15 \mathrm{cmbs}$ & Flake, Thinning; Late, chert; >1/4", Medial-Distal & 1 & 0.19 & $11 / 3 / 2015$ & $\mathrm{MO}, \mathrm{MMM}$ \\
\hline $41 \mathrm{CS} 55$ & 4 & 86 & 86.02 & ST 3 & II & & $5-15 \mathrm{cmbs}$ & Flake, Thinning; Late, chert; >1/4", Medial-Distal & 2 & 0.33 & $11 / 3 / 2015$ & $\mathrm{MO}, \mathrm{MMM}$ \\
\hline
\end{tabular}




\begin{tabular}{|c|c|c|c|c|c|c|c|c|c|c|c|c|}
\hline $\begin{array}{c}\text { Site } \\
\#\end{array}$ & $\begin{array}{c}\text { FS } \\
\#\end{array}$ & LS\# & $\begin{array}{c}\text { Catalog } \\
\#\end{array}$ & Prov. & $\begin{array}{c}\text { Strat } \\
\text { a }\end{array}$ & $\begin{array}{c}\text { Leve } \\
1\end{array}$ & Depth & Description & Count & $\begin{array}{l}\text { Weight } \\
\text { (g) }\end{array}$ & $\begin{array}{c}\text { Date } \\
\text { Excavated }\end{array}$ & Exc/Rec \\
\hline $41 \mathrm{CS} 55$ & 4 & 86 & 86.03 & ST 3 & II & & $5-15 \mathrm{cmbs}$ & Flake, Thinning; Late, chert; >1/4", Proximal & 1 & 0.16 & $11 / 3 / 2015$ & $\mathrm{MO}, \mathrm{MMM}$ \\
\hline $41 \mathrm{CS} 55$ & 4 & 86 & 86.04 & ST 3 & II & & $5-15 \mathrm{cmbs}$ & Flake, Thinning; Late, chert; $>1 / 4 "$, Complete & 1 & 0.44 & $11 / 3 / 2015$ & $\mathrm{MO}, \mathrm{MMM}$ \\
\hline $41 \mathrm{CS} 55$ & 4 & 86 & 86.05 & ST 3 & II & & $5-15 \mathrm{cmbs}$ & Flake, Thinning; Late, chert; $>1 / 8$, Complete & 3 & 0.18 & $11 / 3 / 2015$ & $\mathrm{MO}, \mathrm{MMM}$ \\
\hline $41 \mathrm{CS} 55$ & 4 & 86 & 86.06 & ST 3 & II & & $5-15 \mathrm{cmbs}$ & Flake, Thinning; Late, chert; >1/4", Complete & 4 & 1.02 & $11 / 3 / 2015$ & $\mathrm{MO}, \mathrm{MMM}$ \\
\hline $41 \mathrm{CS} 55$ & 4 & 86 & 86.07 & ST 3 & II & & $5-15 \mathrm{cmbs}$ & Flake, Thinning; Late, chert; $>1 / 2 "$ ", Complete & 1 & 0.57 & $11 / 3 / 2015$ & MO, MMM \\
\hline $41 \mathrm{CS} 55$ & 4 & 86 & 86.08 & ST 3 & II & & $5-15 \mathrm{cmbs}$ & Flake, Thinning, chert; >1/2", Medial-Distal & 1 & 0.91 & $11 / 3 / 2015$ & $\mathrm{MO}, \mathrm{MMM}$ \\
\hline $41 \mathrm{CS} 55$ & 4 & 86 & 86.09 & ST 3 & II & & $5-15 \mathrm{cmbs}$ & Flake, Thinning, chert; $>1 / 4 "$, Proximal & 1 & 0.57 & $11 / 3 / 2015$ & $\mathrm{MO}, \mathrm{MMM}$ \\
\hline $41 \mathrm{CS} 55$ & 4 & 86 & 86.10 & ST 3 & II & & $5-15 \mathrm{cmbs}$ & Flake, Thinning; Late, chert; >1/4", Complete & 3 & 0.54 & $11 / 3 / 2015$ & MO, MMM \\
\hline $41 \mathrm{CS} 55$ & 4 & 86 & 86.11 & ST 3 & II & & $5-15 \mathrm{cmbs}$ & $\begin{array}{l}\text { Flake, Thinning; Late, chert; >1/4", Non- } \\
\text { orientable }\end{array}$ & 1 & 0.09 & $11 / 3 / 2015$ & $\mathrm{MO}, \mathrm{MMM}$ \\
\hline $41 \mathrm{CS} 55$ & 4 & 86 & 86.12 & ST 3 & II & & $5-15 \mathrm{cmbs}$ & Flake, Thinning; Late, chert; >1/4", Medial-Distal & 1 & 0.07 & $11 / 3 / 2015$ & $\mathrm{MO}, \mathrm{MMM}$ \\
\hline $41 \mathrm{CS} 55$ & 4 & 86 & 86.13 & ST 3 & II & & $5-15 \mathrm{cmbs}$ & $\begin{array}{l}\text { Flake, Early Reduction, chert; }>1 / 4 " \text {, Non- } \\
\text { orientable }\end{array}$ & 1 & 0.20 & $11 / 3 / 2015$ & $\mathrm{MO}, \mathrm{MMM}$ \\
\hline $41 \mathrm{CS} 55$ & 4 & 86 & 86.14 & ST 3 & II & & $5-15 \mathrm{cmbs}$ & Shatter, Angular, chert & 4 & 3.58 & $11 / 3 / 2015$ & $\mathrm{MO}, \mathrm{MMM}$ \\
\hline $41 \mathrm{CS} 55$ & 4 & 86 & 86.15 & ST 3 & II & & $5-15 \mathrm{cmbs}$ & Possible cultural material-lithic, petrified wood & 1 & 0.74 & $11 / 3 / 2015$ & $\mathrm{MO}, \mathrm{MMM}$ \\
\hline $41 \mathrm{CS} 55$ & 4 & 86 & 86.16 & ST 3 & II & & $5-15 \mathrm{cmbs}$ & Seed, other; ungerminated seed; not burned & 1 & 0.27 & $11 / 3 / 2015$ & $\mathrm{MO}, \mathrm{MMM}$ \\
\hline $41 \mathrm{CS} 55$ & 5 & 87 & 87.01 & ST 3 & II & & $15-35 \mathrm{cmbs}$ & Flake, Thinning; Late, chert; >1/4", Complete & 1 & 0.20 & $11 / 3 / 2015$ & $\mathrm{MO}, \mathrm{MMM}$ \\
\hline $41 \mathrm{CS} 55$ & 5 & 87 & 87.02 & ST 3 & II & & $15-35 \mathrm{cmbs}$ & Flake, Thinning; Late, chert; >1/4", Complete & 2 & 0.21 & $11 / 3 / 2015$ & $\mathrm{MO}, \mathrm{MMM}$ \\
\hline $41 \mathrm{CS} 55$ & 5 & 87 & 87.03 & ST 3 & II & & $15-35 \mathrm{cmbs}$ & Flake, Thinning; Late, chert; >1/4", Proximal & 3 & 0.26 & $11 / 3 / 2015$ & $\mathrm{MO}, \mathrm{MMM}$ \\
\hline $41 \mathrm{CS} 55$ & 5 & 87 & 87.04 & ST 3 & II & & $15-35 \mathrm{cmbs}$ & Flake, Thinning; Late, chert; >1/4", Medial-Distal & 2 & 0.23 & $11 / 3 / 2015$ & MO, MMM \\
\hline $41 \mathrm{CS} 55$ & 5 & 87 & 87.05 & ST 3 & II & & $15-35 \mathrm{cmbs}$ & Flake, Thinning, chert; >1/4", Proximal & 2 & 0.45 & $11 / 3 / 2015$ & $\mathrm{MO}, \mathrm{MMM}$ \\
\hline $41 \mathrm{CS} 55$ & 5 & 87 & 87.06 & ST 3 & II & & $15-35 \mathrm{cmbs}$ & Flake, Thinning, chert; >1/4", Medial-Distal & 1 & 0.33 & $11 / 3 / 2015$ & MO, MMM \\
\hline $41 \mathrm{CS} 55$ & 5 & 87 & 87.07 & ST 3 & II & & $15-35 \mathrm{cmbs}$ & Flake, Thinning, chert; $>1 / 4 "$, Non-orientable & 1 & 0.15 & $11 / 3 / 2015$ & $\mathrm{MO}, \mathrm{MMM}$ \\
\hline $41 \mathrm{CS} 55$ & 5 & 87 & 87.08 & ST 3 & II & & $15-35 \mathrm{cmbs}$ & Flake, Thinning, chert; $>1 / 4 "$, Non-orientable & 1 & 0.27 & $11 / 3 / 2015$ & $\mathrm{MO}, \mathrm{MMM}$ \\
\hline $41 \mathrm{CS} 55$ & 5 & 87 & 87.09 & ST 3 & II & & $15-35 \mathrm{cmbs}$ & Flake, Thinning, chert; $>1 / 4 "$, Non-orientable & 2 & 0.49 & $11 / 3 / 2015$ & $\mathrm{MO}, \mathrm{MMM}$ \\
\hline $41 \mathrm{CS} 55$ & 5 & 87 & 87.10 & ST 3 & II & & $15-35 \mathrm{cmbs}$ & Flake, Thinning, chert; >1/2", Medial-Distal & 1 & 0.32 & $11 / 3 / 2015$ & $\mathrm{MO}, \mathrm{MMM}$ \\
\hline $41 \mathrm{CS} 55$ & 5 & 87 & 87.11 & ST 3 & II & & $15-35 \mathrm{cmbs}$ & Flake, Thinning, chert; $>1 / 2 "$, Non-orientable & 1 & 0.69 & $11 / 3 / 2015$ & $\mathrm{MO}, \mathrm{MMM}$ \\
\hline $41 \mathrm{CS} 55$ & 5 & 87 & 87.12 & ST 3 & II & & $15-35 \mathrm{cmbs}$ & Flake, Thinning, chert; $>1 / 2 "$, Non-orientable & 1 & 0.57 & $11 / 3 / 2015$ & $\mathrm{MO}, \mathrm{MMM}$ \\
\hline
\end{tabular}




\begin{tabular}{|c|c|c|c|c|c|c|c|c|c|c|c|c|}
\hline $\begin{array}{c}\text { Site } \\
\#\end{array}$ & $\begin{array}{c}\text { FS } \\
\#\end{array}$ & LS\# & $\begin{array}{c}\text { Catalog } \\
\#\end{array}$ & Prov. & $\begin{array}{c}\text { Strat } \\
\text { a }\end{array}$ & $\begin{array}{c}\text { Leve } \\
1\end{array}$ & Depth & Description & Count & $\begin{array}{c}\text { Weight } \\
\text { (g) }\end{array}$ & $\begin{array}{c}\text { Date } \\
\text { Excavated }\end{array}$ & Exc/Rec \\
\hline $41 \mathrm{CS} 55$ & 5 & 87 & 87.13 & ST 3 & II & & $15-35 \mathrm{cmbs}$ & Shatter, Angular, chert & 4 & 7.53 & $11 / 3 / 2015$ & MO, MMM \\
\hline $41 \mathrm{CS} 55$ & 5 & 87 & 87.14 & ST 3 & II & & $15-35 \mathrm{cmbs}$ & Possible cultural material-lithic, petrified wood & 1 & 2.61 & $11 / 3 / 2015$ & $\mathrm{MO}, \mathrm{MMM}$ \\
\hline $41 \mathrm{CS} 55$ & 5 & 87 & 87.15 & ST 3 & II & & $15-35 \mathrm{cmbs}$ & $\begin{array}{l}\text { Possible cultural material-lithic, } \\
\text { quartzite/sandstone }\end{array}$ & 1 & 1.27 & $11 / 3 / 2015$ & $\mathrm{MO}, \mathrm{MMM}$ \\
\hline $41 \mathrm{CS} 55$ & 5 & 87 & 87.16 & ST 3 & II & & $15-35 \mathrm{cmbs}$ & Possible cultural material-lithic, other & 2 & 1.36 & $11 / 3 / 2015$ & MO, MMM \\
\hline $41 \mathrm{CS} 55$ & 5 & 87 & 87.17 & ST 3 & II & & $15-35 \mathrm{cmbs}$ & $\begin{array}{l}\text { Aboriginal ceramic, plain, grog/clay temper; } \\
\text { body }\end{array}$ & 2 & 5.94 & $11 / 3 / 2015$ & $\mathrm{MO}, \mathrm{MMM}$ \\
\hline $41 \mathrm{CS} 55$ & 6 & 88 & 88.01 & ST 4 & I & & $0-15 \mathrm{cmbs}$ & Flake, Thinning; Late, chert; >1/4", Complete & 1 & 0.10 & $11 / 3 / 2015$ & EA, SPF \\
\hline $41 \mathrm{CS} 55$ & 6 & 88 & 88.02 & ST 4 & 1 & & $0-15 \mathrm{cmbs}$ & Flake, Thinning; Late, chert; >1/4", Proximal & 1 & 0.05 & $11 / 3 / 2015$ & EA, SPF \\
\hline $41 \mathrm{CS} 55$ & 6 & 88 & 88.03 & ST 4 & I & & $0-15 \mathrm{cmbs}$ & Flake, Thinning; Late, chert; >1/4", Medial-Distal & 2 & 0.28 & $11 / 3 / 2015$ & EA, SPF \\
\hline $41 \mathrm{CS} 55$ & 6 & 88 & 88.04 & ST 4 & I & & $0-15 \mathrm{cmbs}$ & Flake, Thinning; Late, chert; >1/2", Proximal & 1 & 0.75 & $11 / 3 / 2015$ & EA, SPF \\
\hline $41 \mathrm{CS} 55$ & 6 & 88 & 88.05 & ST 4 & 1 & & $0-15 \mathrm{cmbs}$ & Flake, Thinning, chert; $>1 / 4 "$, Complete & 1 & 0.26 & $11 / 3 / 2015$ & EA, SPF \\
\hline $41 \mathrm{CS} 55$ & 6 & 88 & 88.06 & ST 4 & I & & $0-15 \mathrm{cmbs}$ & Flake, Thinning, chert; >1/4", Proximal & 1 & 0.42 & $11 / 3 / 2015$ & EA, SPF \\
\hline $41 \mathrm{CS} 55$ & 6 & 88 & 88.07 & ST 4 & I & & $0-15 \mathrm{cmbs}$ & Flake, Thinning, chert; $>1 / 2 "$, Non-orientable & 1 & 0.31 & $11 / 3 / 2015$ & EA, SPF \\
\hline $41 \mathrm{CS} 55$ & 6 & 88 & 88.08 & ST 4 & 1 & & $0-15 \mathrm{cmbs}$ & Shatter, Angular, chert & 1 & 0.24 & $11 / 3 / 2015$ & EA, SPF \\
\hline $41 \mathrm{CS} 55$ & 6 & 88 & 88.09 & ST 4 & 1 & & $0-15 \mathrm{cmbs}$ & Shatter, Thermal, chert & 1 & 0.11 & $11 / 3 / 2015$ & $\mathrm{EA}, \mathrm{SPF}$ \\
\hline $41 \mathrm{CS} 55$ & 7 & 89 & 89.01 & ST 4 & 1 & & $15-30 \mathrm{cmbs}$ & Flake, Thinning, chert; >1/2", Complete & 1 & 0.11 & $11 / 3 / 2015$ & $\mathrm{EA} / \mathrm{SPF}$ \\
\hline $41 \mathrm{CS} 55$ & 7 & 89 & 89.02 & ST 4 & 1 & & $15-30 \mathrm{cmbs}$ & Flake, Thinning, chert; $>1 / 4 "$, Complete & 1 & 0.04 & $11 / 3 / 2015$ & EA/SPF \\
\hline $41 \mathrm{CS} 55$ & 7 & 89 & 89.04 & ST 4 & 1 & & $15-30 \mathrm{cmbs}$ & Flake, Thinning; Late, chert; $>1 / 4 "$, Complete & 1 & 0.09 & $11 / 3 / 2015$ & $\mathrm{EA} / \mathrm{SPF}$ \\
\hline $41 \mathrm{CS} 55$ & 7 & 89 & 89.05 & ST 4 & 1 & & $15-30 \mathrm{cmbs}$ & Flake, Thinning; Late, chert; >1/4", Proximal & 1 & 0.02 & $11 / 3 / 2015$ & EA/SPF \\
\hline $41 \mathrm{CS} 55$ & 7 & 89 & 89.06 & ST 4 & I & & $15-30 \mathrm{cmbs}$ & $\begin{array}{l}\text { Aboriginal ceramic, plain, grog/clay temper; } \\
\text { body; gray paste with buff exterior that is } \\
\text { coated with possible soot or black slip }\end{array}$ & 1 & 2.94 & $11 / 3 / 2015$ & $\mathrm{EA} / \mathrm{SPF}$ \\
\hline $41 \mathrm{CS} 55$ & 7 & 89 & 89.07 & ST 4 & 1 & & $15-30 \mathrm{cmbs}$ & $\begin{array}{l}\text { Aboriginal ceramic, engraved, grog/clay temper; } \\
\text { body; engraved with two near-parallel lines, all } \\
\text { black (reduced) interior and exterior }\end{array}$ & 1 & 3.87 & $11 / 3 / 2015$ & $\mathrm{EA} / \mathrm{SPF}$ \\
\hline $41 \mathrm{CS} 55$ & 8 & 90 & 90.01 & ST 6 & $1 / 11$ & & $0-20 \mathrm{cmbs}$ & Flake, Thinning; Late, chert; >1/2", Medial-Distal & 1 & 0.29 & $11 / 3 / 2015$ & $\mathrm{KP} / \mathrm{IM}$ \\
\hline $41 \mathrm{CS} 55$ & 8 & 90 & 90.02 & ST 6 & $1 / I I$ & & $0-20 \mathrm{cmbs}$ & Flake, Thinning, chert; >1/2", Non-orientable & 1 & 0.60 & $11 / 3 / 2015$ & $\mathrm{KP} / \mathrm{IM}$ \\
\hline
\end{tabular}




\begin{tabular}{|c|c|c|c|c|c|c|c|c|c|c|c|c|}
\hline $\begin{array}{c}\text { Site } \\
\#\end{array}$ & $\begin{array}{l}\text { FS } \\
\#\end{array}$ & LS\# & $\begin{array}{c}\text { Catalog } \\
\# \\
\end{array}$ & Prov. & $\begin{array}{c}\text { Strat } \\
\text { a }\end{array}$ & $\begin{array}{c}\text { Leve } \\
\text { I }\end{array}$ & Depth & Description & Count & $\begin{array}{c}\text { Weight } \\
\text { (g) }\end{array}$ & $\begin{array}{c}\text { Date } \\
\text { Excavated }\end{array}$ & Exc/Rec \\
\hline $41 \mathrm{CS} 55$ & 8 & 90 & 90.03 & ST 6 & I/II & & $0-20 \mathrm{cmbs}$ & Tested cobble, chert & 1 & 76.07 & $11 / 3 / 2015$ & $\mathrm{KP} / \mathrm{IM}$ \\
\hline $41 \mathrm{CS} 55$ & 8 & 90 & 90.04 & ST 6 & $1 / I I$ & & $0-20 \mathrm{cmbs}$ & $\begin{array}{l}\text { Aboriginal ceramic, plain, grog/clay temper; } \\
\text { body }\end{array}$ & 1 & 8.12 & $11 / 3 / 2015$ & $\mathrm{KP} / \mathrm{IM}$ \\
\hline $41 \mathrm{CS} 55$ & 8 & 90 & 90.05 & ST 6 & $I / I I$ & & $0-20 \mathrm{cmbs}$ & $\begin{array}{l}\text { Aboriginal ceramic, incised, grog/clay temper; } \\
\text { body }\end{array}$ & 1 & 5.76 & $11 / 3 / 2015$ & $\mathrm{KP} / \mathrm{IM}$ \\
\hline $41 \mathrm{CS} 55$ & 9 & 91 & 91.01 & ST 7 & I & & $0-10 \mathrm{cmbs}$ & Flake, Thinning, chert; $>1 / 2 "$, Proximal & 1 & 0.56 & $11 / 3 / 2015$ & $\mathrm{KP} / \mathrm{IM}$ \\
\hline $41 \mathrm{CS} 55$ & 10 & 92 & 92.01 & ST 8 & & & Surface & $\begin{array}{l}\text { Aboriginal ceramic, engraved, grog/clay temper; } \\
\text { body }\end{array}$ & 1 & 3.96 & $11 / 3 / 2015$ & JS \\
\hline $41 \mathrm{CS} 55$ & 10 & 92 & 92.02 & ST 8 & & & Surface & $\begin{array}{l}\text { Aboriginal ceramic, plain, grog/clay temper; } \\
\text { body }\end{array}$ & 1 & 7.08 & $11 / 3 / 2015$ & JS \\
\hline $41 \mathrm{CS} 55$ & 11 & 93 & 93.01 & ST 10 & 1 & & $0-10 \mathrm{cmbs}$ & Flake, Thinning; Late, chert; $<1 / 4 "$, Complete & 1 & 0.04 & $11 / 3 / 2015$ & $\mathrm{KP} / \mathrm{IM}$ \\
\hline $41 \mathrm{CS} 55$ & 11 & 93 & 93.02 & ST 10 & 1 & & $0-10 \mathrm{cmbs}$ & Flake, Thinning; Late, chert; $<1 / 4 "$ ", Complete & 1 & 0.02 & $11 / 3 / 2015$ & $\mathrm{KP} / \mathrm{IM}$ \\
\hline $41 \mathrm{CS} 55$ & 11 & 93 & 93.03 & ST 10 & I & & $0-10 \mathrm{cmbs}$ & Flake, Thinning; Late, chert; $>1 / 4 "$, Complete & 1 & 0.12 & $11 / 3 / 2015$ & $\mathrm{KP} / \mathrm{IM}$ \\
\hline $41 \mathrm{CS} 55$ & 11 & 93 & 93.04 & ST 10 & I & & $0-10 \mathrm{cmbs}$ & Flake, Thinning; Late, chert; >1/4", Proximal & 2 & 0.57 & $11 / 3 / 2015$ & $\mathrm{KP} / \mathrm{IM}$ \\
\hline $41 \mathrm{CS} 55$ & 11 & 93 & 93.05 & ST 10 & 1 & & $0-10 \mathrm{cmbs}$ & Flake, Thinning; Late, chert; >1/4", Medial-Distal & 1 & 0.13 & $11 / 3 / 2015$ & $\mathrm{KP} / \mathrm{IM}$ \\
\hline $41 \mathrm{CS} 55$ & 11 & 93 & 93.06 & ST 10 & 1 & & $0-10 \mathrm{cmbs}$ & $\begin{array}{l}\text { Flake, Thinning; Late, chert; >1/4", Non- } \\
\text { orientable }\end{array}$ & 1 & 0.14 & $11 / 3 / 2015$ & $\mathrm{KP} / \mathrm{IM}$ \\
\hline $41 \mathrm{CS} 55$ & 11 & 93 & 93.07 & ST 10 & I & & $0-10 \mathrm{cmbs}$ & Flake, Thinning; Late, chert; >1/2", Complete & 2 & 0.68 & $11 / 3 / 2015$ & $\mathrm{KP} / \mathrm{IM}$ \\
\hline $41 \mathrm{CS} 55$ & 11 & 93 & 93.08 & ST 10 & 1 & & $0-10 \mathrm{cmbs}$ & Flake, Thinning, chert; >1/4", Proximal & 1 & 0.32 & $11 / 3 / 2015$ & $\mathrm{KP} / \mathrm{IM}$ \\
\hline $41 \mathrm{CS} 55$ & 11 & 93 & 93.09 & ST 10 & I & & $0-10 \mathrm{cmbs}$ & Flake, Thinning, chert; $>1 / 2 "$, Complete & 1 & 0.76 & $11 / 3 / 2015$ & $\mathrm{KP} / \mathrm{IM}$ \\
\hline $41 \mathrm{CS} 55$ & 11 & 93 & 93.10 & ST 10 & 1 & & $0-10 \mathrm{cmbs}$ & Flake, Thinning, chert; >1/2", Proximal & 2 & 1.26 & $11 / 3 / 2015$ & $\mathrm{KP} / \mathrm{IM}$ \\
\hline $41 \mathrm{CS} 55$ & 11 & 93 & 93.11 & ST 10 & 1 & & $0-10 \mathrm{cmbs}$ & Flake, Thinning, chert; >1/2", Medial-Distal & 1 & 0.62 & $11 / 3 / 2015$ & $\mathrm{KP} / \mathrm{IM}$ \\
\hline $41 \mathrm{CS} 55$ & 11 & 93 & 93.12 & ST 10 & 1 & & $0-10 \mathrm{cmbs}$ & Shatter, Thermal, chert & 1 & 0.28 & $11 / 3 / 2015$ & $\mathrm{KP} / \mathrm{IM}$ \\
\hline $41 \mathrm{CS} 55$ & 11 & 93 & 93.13 & ST 10 & I & & $0-10 \mathrm{cmbs}$ & $\begin{array}{l}\text { Possible cultural material-lithic, } \\
\text { quartzite/sandstone }\end{array}$ & 1 & 0.45 & $11 / 3 / 2015$ & $\mathrm{KP} / \mathrm{IM}$ \\
\hline $41 \mathrm{CS} 55$ & 12 & 94 & 94.01 & ST 10 & & & Surface & $\begin{array}{l}\text { Aboriginal ceramic, punctate, grog/clay temper; } \\
\text { body; tool punctated; parallel, widely-spaced } \\
\text { decoration }\end{array}$ & 2 & 9.23 & $11 / 3 / 2015$ & $\mathrm{KP} / \mathrm{IM}$ \\
\hline
\end{tabular}




\begin{tabular}{|c|c|c|c|c|c|c|c|c|c|c|c|c|}
\hline $\begin{array}{c}\text { Site } \\
\#\end{array}$ & $\begin{array}{l}\text { FS } \\
\#\end{array}$ & LS\# & $\begin{array}{c}\text { Catalog } \\
\# \\
\end{array}$ & Prov. & $\begin{array}{c}\text { Strat } \\
\text { a }\end{array}$ & $\begin{array}{c}\text { Leve } \\
\text { I }\end{array}$ & Depth & Description & Count & $\begin{array}{c}\text { Weight } \\
\text { (g) }\end{array}$ & $\begin{array}{c}\text { Date } \\
\text { Excavated }\end{array}$ & Exc/Rec \\
\hline $41 \mathrm{CS} 55$ & 12 & 94 & 94.02 & ST 10 & & & Surface & $\begin{array}{l}\text { Aboriginal ceramic, plain, grog/clay temper; } \\
\text { body }\end{array}$ & 14 & 62.35 & $11 / 3 / 2015$ & $\mathrm{KP} / \mathrm{IM}$ \\
\hline $41 \mathrm{CS} 55$ & 12 & 94 & 94.03 & ST 10 & & & Surface & $\begin{array}{l}\text { Aboriginal ceramic, plain, grog/clay temper; } \\
\text { body }\end{array}$ & 5 & 18.62 & $11 / 3 / 2015$ & $\mathrm{KP} / \mathrm{IM}$ \\
\hline $41 \mathrm{CS} 55$ & 12 & 94 & 94.04 & ST 10 & & & Surface & $\begin{array}{l}\text { Aboriginal ceramic, uid decorated, grog/clay } \\
\text { temper; body; possible check stamping; surface } \\
\text { is eroded }\end{array}$ & 1 & 10.98 & $11 / 3 / 2015$ & $\mathrm{KP} / \mathrm{IM}$ \\
\hline $41 \mathrm{CS} 55$ & 12 & 94 & 94.05 & ST 10 & & & Surface & $\begin{array}{l}\text { Aboriginal ceramic, plain, grog/clay temper; } \\
\text { straight rim, round lip }\end{array}$ & 2 & 10.82 & $11 / 3 / 2015$ & $\mathrm{KP} / \mathrm{IM}$ \\
\hline $41 \mathrm{CS} 55$ & 12 & 94 & 94.06 & ST 10 & & & Surface & $\begin{array}{l}\text { Aboriginal ceramic, engraved, grog/clay temper; } \\
\text { everted rim; lip broken }\end{array}$ & 1 & 5.68 & $11 / 3 / 2015$ & $\mathrm{KP} / \mathrm{IM}$ \\
\hline $41 \mathrm{CS} 55$ & 12 & 94 & 94.07 & ST 10 & & & Surface & $\begin{array}{l}\text { Aboriginal ceramic, plain, grog/clay temper; } \\
\text { everted rim, tapered lip }\end{array}$ & 1 & 1.17 & $11 / 3 / 2015$ & $\mathrm{KP} / \mathrm{IM}$ \\
\hline $41 \mathrm{CS} 55$ & 13 & 95 & 95.01 & ST 11 & & & Surface & $\begin{array}{l}\text { Aboriginal ceramic, engraved, grog/clay temper; } \\
\text { body }\end{array}$ & 1 & 3.75 & $11 / 3 / 2015$ & $\mathrm{MRM} / \mathrm{SE}$ \\
\hline $41 \mathrm{CS} 55$ & 13 & 95 & 95.02 & ST 11 & & & Surface & $\begin{array}{l}\text { Aboriginal ceramic, plain, grog/clay temper; } \\
\text { body }\end{array}$ & 2 & 3.81 & $11 / 3 / 2015$ & $\mathrm{MRM} / \mathrm{SE}$ \\
\hline $41 \mathrm{CS} 55$ & 14 & 96 & 96.01 & ST 11 & 1 & & $0-10 \mathrm{cmbs}$ & Flake, Thinning; Late, chert; $>1 / 4 "$, Complete & 1 & 0.35 & $11 / 3 / 2015$ & $\mathrm{MRM} / \mathrm{SE}$ \\
\hline $41 \mathrm{CS} 55$ & 14 & 96 & 96.02 & ST 11 & 1 & & $0-10 \mathrm{cmbs}$ & Flake, Thinning; Late, chert; $>1 / 4 "$, Complete & 2 & 0.59 & $11 / 3 / 2015$ & $\mathrm{MRM} / \mathrm{SE}$ \\
\hline $41 \mathrm{CS} 55$ & 14 & 96 & 96.03 & ST 11 & 1 & & $0-10 \mathrm{cmbs}$ & Flake, Thinning; Late, chert; >1/4", Proximal & 2 & 0.19 & $11 / 3 / 2015$ & $\mathrm{MRM} / \mathrm{SE}$ \\
\hline $41 \mathrm{CS} 55$ & 14 & 96 & 96.04 & ST 11 & I & & $0-10 \mathrm{cmbs}$ & $\begin{array}{l}\text { Flake, Thinning; Late, chert; >1/4", Non- } \\
\text { orientable }\end{array}$ & 2 & 0.38 & $11 / 3 / 2015$ & $\mathrm{MRM} / \mathrm{SE}$ \\
\hline $41 \mathrm{CS} 55$ & 14 & 96 & 96.05 & ST 11 & I & & $0-10 \mathrm{cmbs}$ & Flake, Thinning, chert; >1/2", Complete & 2 & 1.27 & $11 / 3 / 2015$ & $\mathrm{MRM} / \mathrm{SE}$ \\
\hline $41 \mathrm{CS} 55$ & 14 & 96 & 96.06 & ST 11 & 1 & & $0-10 \mathrm{cmbs}$ & Flake, Thinning, chert; >1/2", Complete & 2 & 3.25 & $11 / 3 / 2015$ & $\mathrm{MRM} / \mathrm{SE}$ \\
\hline $41 \mathrm{CS} 55$ & 14 & 96 & 96.07 & ST 11 & 1 & & $0-10 \mathrm{cmbs}$ & Flake, Thinning, chert; >1/2", Complete & 4 & 2.09 & $11 / 3 / 2015$ & $\mathrm{MRM} / \mathrm{SE}$ \\
\hline $41 \mathrm{CS} 55$ & 14 & 96 & 96.08 & ST 11 & 1 & & $0-10 \mathrm{cmbs}$ & Flake, Thinning, chert; $>1 / 2 "$, Proximal & 1 & 0.24 & $11 / 3 / 2015$ & $\mathrm{MRM} / \mathrm{SE}$ \\
\hline $41 \mathrm{CS} 55$ & 14 & 96 & 96.09 & ST 11 & I & & $0-10 \mathrm{cmbs}$ & Flake, Early Reduction, chert; $>1 / 2 "$, Complete & 1 & 1.81 & $11 / 3 / 2015$ & $\mathrm{MRM} / \mathrm{SE}$ \\
\hline $41 \mathrm{CS} 55$ & 14 & 96 & 96.10 & ST 11 & 1 & & $0-10 \mathrm{cmbs}$ & Flake, Early Reduction, chert; $>1 / 2 "$, Complete & 1 & 1.76 & $11 / 3 / 2015$ & $\mathrm{MRM} / \mathrm{SE}$ \\
\hline
\end{tabular}




\begin{tabular}{|c|c|c|c|c|c|c|c|c|c|c|c|c|}
\hline $\begin{array}{c}\text { Site } \\
\#\end{array}$ & $\begin{array}{l}\text { FS } \\
\#\end{array}$ & LS\# & $\begin{array}{c}\text { Catalog } \\
\# \\
\end{array}$ & Prov. & $\begin{array}{c}\text { Strat } \\
\text { a }\end{array}$ & $\begin{array}{c}\text { Leve } \\
\text { I }\end{array}$ & Depth & Description & Count & $\begin{array}{c}\text { Weight } \\
\text { (g) }\end{array}$ & $\begin{array}{c}\text { Date } \\
\text { Excavated }\end{array}$ & Exc/Rec \\
\hline $41 \mathrm{CS} 55$ & 14 & 96 & 96.11 & ST 11 & 1 & & $0-10 \mathrm{cmbs}$ & $\begin{array}{l}\text { Aboriginal ceramic, plain, grog/clay temper; } \\
\text { body }\end{array}$ & 3 & 21.39 & $11 / 3 / 2015$ & $\mathrm{MRM} / \mathrm{SE}$ \\
\hline $41 \mathrm{CS} 55$ & 14 & 96 & 96.12 & ST 11 & 1 & & $0-10 \mathrm{cmbs}$ & $\begin{array}{l}\text { Aboriginal ceramic, engraved, grog/clay temper; } \\
\text { straight rim, tapered lip; two parallel lines, one } \\
\text { at rim and one below }\end{array}$ & 1 & 9.27 & $11 / 3 / 2015$ & $\mathrm{MRM} / \mathrm{SE}$ \\
\hline $41 \mathrm{CS} 55$ & 14 & 96 & 96.13 & ST 11 & 1 & & $0-10 \mathrm{cmbs}$ & $\begin{array}{l}\text { Aboriginal ceramic, engraved, grog/clay temper; } \\
\text { body }\end{array}$ & 1 & 5.31 & $11 / 3 / 2015$ & $\mathrm{MRM} / \mathrm{SE}$ \\
\hline $41 \mathrm{CS} 55$ & 15 & 97 & 97.01 & ST 11 & II & & $10-15 \mathrm{cmbs}$ & Flake, Thinning, chert; >1/4", Medial-Distal & 2 & 0.30 & $11 / 3 / 2015$ & $\mathrm{MRM} / \mathrm{SE}$ \\
\hline $41 \mathrm{CS} 55$ & 15 & 97 & 97.02 & ST 11 & II & & $10-15 \mathrm{cmbs}$ & Flake, Thinning, chert; $>1 / 4 "$, Complete & 1 & 0.28 & $11 / 3 / 2015$ & $\mathrm{MRM} / \mathrm{SE}$ \\
\hline $41 \mathrm{CS} 55$ & 15 & 97 & 97.03 & ST 11 & II & & $10-15 \mathrm{cmbs}$ & Flake, Early Reduction, chert; $>1 / 2 "$, Complete & 1 & 3.18 & $11 / 3 / 2015$ & $\mathrm{MRM} / \mathrm{SE}$ \\
\hline $41 \mathrm{CS} 55$ & 15 & 97 & 97.04 & ST 11 & II & & $10-15 \mathrm{cmbs}$ & $\begin{array}{l}\text { Aboriginal ceramic, engraved, grog/clay temper; } \\
\text { flared rim, tapered lip }\end{array}$ & 1 & 4.38 & $11 / 3 / 2015$ & $\mathrm{MRM} / \mathrm{SE}$ \\
\hline $41 \mathrm{CS} 55$ & 15 & 97 & 97.05 & ST 11 & II & & $10-15 \mathrm{cmbs}$ & $\begin{array}{l}\text { Aboriginal ceramic, plain, grog/clay temper; } \\
\text { body }\end{array}$ & 1 & 2.66 & $11 / 3 / 2015$ & $\mathrm{MRM} / \mathrm{SE}$ \\
\hline $41 \mathrm{CS} 55$ & 16 & 98 & 98.01 & ST 12 & & & Surface & $\begin{array}{l}\text { Aboriginal ceramic, plain, grog/clay temper; } \\
\text { straight rim, round lip }\end{array}$ & 1 & 2.02 & $11 / 3 / 2015$ & $\mathrm{RT} / \mathrm{AD}$ \\
\hline $41 \mathrm{CS} 55$ & 16 & 98 & 98.02 & ST 12 & & & Surface & Unmodified stone; non cultural & 1 & 21.28 & $11 / 3 / 2015$ & $\mathrm{RT} / \mathrm{AD}$ \\
\hline $41 \mathrm{CS} 55$ & 16 & 98 & 98.03 & ST 12 & & & Surface & $\begin{array}{l}\text { Aboriginal ceramic, plain, grog/clay temper; } \\
\text { body }\end{array}$ & 3 & 6.13 & $11 / 3 / 2015$ & $\mathrm{RT} / \mathrm{AD}$ \\
\hline $41 \mathrm{CS} 55$ & 16 & 98 & 98.04 & ST 12 & & & Surface & $\begin{array}{l}\text { Aboriginal ceramic, applique on body, grog/clay } \\
\text { temper; body }\end{array}$ & 1 & 5.31 & $11 / 3 / 2015$ & $\mathrm{RT} / \mathrm{AD}$ \\
\hline $41 \mathrm{CS} 55$ & 16 & 98 & 98.05 & ST 12 & & & Surface & $\begin{array}{l}\text { Aboriginal ceramic, plain, grog/bone temper; } \\
\text { body }\end{array}$ & 1 & 21.62 & $11 / 3 / 2015$ & $\mathrm{RT} / \mathrm{AD}$ \\
\hline $41 \mathrm{CS} 55$ & 16 & 98 & 98.06 & ST 12 & & & Surface & Fire cracked rock & 1 & 37.48 & $11 / 3 / 2015$ & $\mathrm{RT} / \mathrm{AD}$ \\
\hline $41 \mathrm{CS} 55$ & 16 & 98 & 98.07 & ST 12 & & & Surface & Flake, Thinning, chert; >1/2", Complete & 3 & 2.81 & $11 / 3 / 2015$ & RT/AD \\
\hline $41 \mathrm{CS} 55$ & 16 & 98 & 98.08 & ST 12 & & & Surface & Flake, Thinning, chert; $>1 / 2 "$, Complete & 1 & 2.76 & $11 / 3 / 2015$ & $\mathrm{RT} / \mathrm{AD}$ \\
\hline $41 \mathrm{CS} 55$ & 16 & 98 & 98.09 & ST 12 & & & Surface & Flake, Thinning, chert; >1/2", Proximal & 1 & 1.02 & $11 / 3 / 2015$ & $\mathrm{RT} / \mathrm{AD}$ \\
\hline $41 \mathrm{CS} 55$ & 16 & 98 & 98.10 & ST 12 & & & Surface & Blade, utilized, chert & 1 & 1.89 & $11 / 3 / 2015$ & $\mathrm{RT} / \mathrm{AD}$ \\
\hline
\end{tabular}




\begin{tabular}{|c|c|c|c|c|c|c|c|c|c|c|c|c|}
\hline $\begin{array}{c}\text { Site } \\
\#\end{array}$ & $\begin{array}{c}\text { FS } \\
\#\end{array}$ & LS\# & $\begin{array}{c}\text { Catalog } \\
\#\end{array}$ & Prov. & $\begin{array}{c}\text { Strat } \\
\text { a }\end{array}$ & $\begin{array}{c}\text { Leve } \\
1\end{array}$ & Depth & Description & Count & $\begin{array}{l}\text { Weight } \\
\text { (g) }\end{array}$ & $\begin{array}{c}\text { Date } \\
\text { Excavated }\end{array}$ & Exc/Rec \\
\hline $41 \mathrm{CS} 55$ & 16 & 98 & 98.11 & ST 12 & & & Surface & $\begin{array}{l}\text { Aboriginal ceramic, plain, grog/clay temper; } \\
\text { body }\end{array}$ & 1 & 7.86 & $11 / 3 / 2015$ & $\mathrm{RT} / \mathrm{AD}$ \\
\hline $41 \mathrm{CS} 55$ & 17 & 99 & 99.01 & ST 13 & II & & $10-20 \mathrm{cmbs}$ & Flake, Thinning; Late, chert; >1/4", Proximal & 1 & 0.21 & $11 / 3 / 2015$ & JTS/JMS \\
\hline $41 \mathrm{CS} 55$ & 17 & 99 & 99.02 & ST 13 & II & & $10-20 \mathrm{cmbs}$ & Flake, Thinning; Late, chert; >1/4", Medial-Distal & 1 & 0.16 & $11 / 3 / 2015$ & JTS/JMS \\
\hline $41 \mathrm{CS} 55$ & 17 & 99 & 99.03 & ST 13 & II & & $10-20 \mathrm{cmbs}$ & Flake, Thinning; Late, chert; >1/2", Complete & 1 & 0.37 & $11 / 3 / 2015$ & JTS/JMS \\
\hline $41 \mathrm{CS} 55$ & 17 & 99 & 99.04 & ST 13 & II & & $10-20 \mathrm{cmbs}$ & Flake, Thinning, chert; >1/4", Proximal & 1 & 0.38 & $11 / 3 / 2015$ & JTS/JMS \\
\hline $41 \mathrm{CS} 55$ & 17 & 99 & 99.05 & ST 13 & II & & $10-20 \mathrm{cmbs}$ & Shatter, Angular, chert & 1 & 0.64 & $11 / 3 / 2015$ & JTS/JMS \\
\hline $41 \mathrm{CS} 55$ & 18 & 100 & 100.01 & ST 13 & II & & $20-30 \mathrm{cmbs}$ & Flake, Early Reduction, chert; $>1 / 2 "$, Complete & 1 & 2.97 & $11 / 3 / 2015$ & JTS/JMS \\
\hline $41 \mathrm{CS} 55$ & 18 & 100 & 100.02 & ST 13 & II & & $20-30 \mathrm{cmbs}$ & Flake, Early Reduction, chert; >1/2", Complete & 1 & 1.64 & $11 / 3 / 2015$ & JTS/JMS \\
\hline $41 \mathrm{CS} 55$ & 18 & 100 & 100.03 & ST 13 & II & & $20-30 \mathrm{cmbs}$ & Shatter, Angular, chert & 1 & 0.88 & $11 / 3 / 2015$ & JTS/JMS \\
\hline $41 \mathrm{CS} 55$ & 19 & 101 & 101.01 & ST 14 & 1 & & $0-10 \mathrm{cmbs}$ & Animal bone & 1 & 0.56 & $11 / 3 / 2015$ & EA/SPF \\
\hline $41 \mathrm{CS} 55$ & 20 & 102 & 102.01 & ST 14 & II & & $10-20 \mathrm{cmbs}$ & Flake, Early Reduction, chert; $>1 / 2 "$ ", Proximal & 1 & 1.08 & $11 / 3 / 2015$ & EA/SPF \\
\hline $41 \mathrm{CS} 55$ & 21 & 103 & 103.01 & ST 26 & I & & $0-10 \mathrm{cmbs}$ & $\begin{array}{l}\text { Flake, Thinning, coastal plain chert, heat } \\
\text { treated; }>1 / 2 \text { ", Proximal }\end{array}$ & 1 & 0.59 & $11 / 3 / 2015$ & SE/MRM \\
\hline $41 \mathrm{CS} 55$ & 21 & 103 & 103.02 & ST 26 & 1 & & $0-10 \mathrm{cmbs}$ & Flake, Early Reduction, chert; >1/2", Complete & 1 & 0.71 & $11 / 3 / 2015$ & SE/MRM \\
\hline $41 \mathrm{CS} 55$ & 22 & 104 & 104.01 & $\mathrm{CP} 1$ & & & Surface & Flake, Thinning; Late, chert; >1/4", Complete & 1 & 0.16 & $11 / 3 / 2015$ & MMM \\
\hline $41 \mathrm{CS} 55$ & 22 & 104 & 104.02 & $\mathrm{CP} 1$ & & & Surface & Flake, Thinning; Late, chert; >1/4", Proximal & 1 & 0.16 & $11 / 3 / 2015$ & MMM \\
\hline $41 \mathrm{CS} 55$ & 22 & 104 & 104.03 & $\mathrm{CP} 1$ & & & Surface & Flake, Thinning, chert; $>1 / 2 "$, Complete & 1 & 1.18 & $11 / 3 / 2015$ & MMM \\
\hline $41 \mathrm{CS} 55$ & 22 & 104 & 104.04 & $\mathrm{CP} 1$ & & & Surface & Flake, Thinning, chert; >1/2", Complete & 1 & 0.70 & $11 / 3 / 2015$ & MMM \\
\hline $41 \mathrm{CS} 55$ & 22 & 104 & 104.05 & $\mathrm{CP} 1$ & & & Surface & Flake, Thinning, chert; $>1 / 2 "$, Complete & 3 & 2.68 & $11 / 3 / 2015$ & MMM \\
\hline $41 \mathrm{CS} 55$ & 22 & 104 & 104.06 & $\mathrm{CP} 1$ & & & Surface & Flake, Thinning, chert; >1/2", Proximal & 3 & 1.08 & $11 / 3 / 2015$ & MMM \\
\hline $41 \mathrm{CS} 55$ & 22 & 104 & 104.07 & $\mathrm{CP} 1$ & & & Surface & Flake, Thinning, chert; >1/2", Medial-Distal & 2 & 1.69 & $11 / 3 / 2015$ & MMM \\
\hline $41 \mathrm{CS} 55$ & 22 & 104 & 104.08 & $\mathrm{CP} 1$ & & & Surface & Flake, Thinning, chert; $>1 / 2 "$ ", Non-orientable & 2 & 2.08 & $11 / 3 / 2015$ & MMM \\
\hline $41 \mathrm{CS} 55$ & 22 & 104 & 104.09 & $\mathrm{CP} 1$ & & & Surface & Flake, Early Reduction, chert; >1/2", Complete & 1 & 1.01 & $11 / 3 / 2015$ & MMM \\
\hline $41 \mathrm{CS} 55$ & 22 & 104 & 104.10 & $\mathrm{CP} 1$ & & & Surface & Shatter, Angular, chert & 1 & 2.87 & $11 / 3 / 2015$ & MMM \\
\hline 41CS55 & 22 & 104 & 104.11 & $\mathrm{CP} 1$ & & & Surface & $\begin{array}{l}\text { Flake, Utilized, chert; >1/2", Medial-Distal; } \\
\text { perhaps flaked along one edge; fragment only }\end{array}$ & 1 & 1.52 & $11 / 3 / 2015$ & MMM \\
\hline
\end{tabular}




\begin{tabular}{|c|c|c|c|c|c|c|c|c|c|c|c|c|}
\hline $\begin{array}{c}\text { Site } \\
\#\end{array}$ & $\begin{array}{c}\text { FS } \\
\#\end{array}$ & LS\# & $\begin{array}{c}\text { Catalog } \\
\#\end{array}$ & Prov. & $\begin{array}{c}\text { Strat } \\
\text { a }\end{array}$ & $\begin{array}{c}\text { Leve } \\
1\end{array}$ & Depth & Description & Count & $\begin{array}{l}\text { Weight } \\
\text { (g) }\end{array}$ & $\begin{array}{c}\text { Date } \\
\text { Excavated }\end{array}$ & Exc/Rec \\
\hline $41 \mathrm{CS} 55$ & 22 & 104 & 104.12 & $\mathrm{CP} 1$ & & & Surface & $\begin{array}{l}\text { Aboriginal ceramic, engraved, grog/bone } \\
\text { temper; body }\end{array}$ & 4 & 19.16 & $11 / 3 / 2015$ & MMM \\
\hline $41 \mathrm{CS} 55$ & 22 & 104 & 104.13 & $\mathrm{CP} 1$ & & & Surface & $\begin{array}{l}\text { Aboriginal ceramic, engraved, grog/clay temper; } \\
\text { body }\end{array}$ & 2 & 6.83 & $11 / 3 / 2015$ & MMM \\
\hline $41 \mathrm{CS} 55$ & 22 & 104 & 104.14 & $\mathrm{CP} 1$ & & & Surface & $\begin{array}{l}\text { Aboriginal ceramic, plain, grog/clay temper; } \\
\text { body }\end{array}$ & 1 & 3.30 & $11 / 3 / 2015$ & MMM \\
\hline $41 \mathrm{CS} 55$ & 22 & 104 & 104.15 & $\mathrm{CP} 1$ & & & Surface & $\begin{array}{l}\text { Aboriginal ceramic, engraved, grit/grog temper; } \\
\text { body }\end{array}$ & 2 & 10.42 & $11 / 3 / 2015$ & MMM \\
\hline $41 \mathrm{CS} 55$ & 22 & 104 & 104.16 & $\mathrm{CP} 1$ & & & Surface & $\begin{array}{l}\text { Aboriginal ceramic, engraved, grog/clay temper; } \\
\text { everted rim, tapered lip; parallel, slightly curved } \\
\text { lines below rim and on body }\end{array}$ & 1 & 4.53 & $11 / 3 / 2015$ & MMM \\
\hline $41 \mathrm{CS} 55$ & 22 & 104 & 104.17 & $\mathrm{CP} 1$ & & & Surface & $\begin{array}{l}\text { Aboriginal ceramic, engraved, grog/clay temper; } \\
\text { body }\end{array}$ & 1 & 1.17 & $11 / 3 / 2015$ & MMM \\
\hline $41 \mathrm{CS} 55$ & 23 & 105 & 105.01 & $\mathrm{CP} 2$ & & & Surface & $\begin{array}{l}\text { Aboriginal ceramic, applique on body, grog/clay } \\
\text { temper; body; one raised band with parallel, } \\
\text { diagonal ticking; brushed surface above and } \\
\text { below applique }\end{array}$ & 1 & 5.34 & $11 / 3 / 2015$ & MMM \\
\hline $41 \mathrm{CS} 55$ & 24 & 106 & 106.01 & $\mathrm{CP} 3$ & & & Surface & Flake, Thinning; Late, chert; >1/2", Complete & 2 & 0.89 & $11 / 3 / 2015$ & MO \\
\hline $41 \mathrm{CS} 55$ & 24 & 106 & 106.02 & $\mathrm{CP} 3$ & & & Surface & Flake, Thinning; Late, chert; $>1 / 2 "$ ", Complete & 4 & 1.46 & $11 / 3 / 2015$ & MO \\
\hline $41 \mathrm{CS} 55$ & 24 & 106 & 106.03 & $\mathrm{CP} 3$ & & & Surface & Flake, Thinning; Late, chert; $>1 / 2 "$, Medial-Distal & 2 & 0.67 & $11 / 3 / 2015$ & MO \\
\hline $41 \mathrm{CS} 55$ & 24 & 106 & 106.04 & $\mathrm{CP} 3$ & & & Surface & Flake, Thinning, chert; $>1 / 2 "$, Complete & 2 & 0.82 & $11 / 3 / 2015$ & MO \\
\hline $41 \mathrm{CS} 55$ & 24 & 106 & 106.05 & $\mathrm{CP} 3$ & & & Surface & Flake, Thinning, chert; $>1 / 2 "$, Complete & 3 & 3.34 & $11 / 3 / 2015$ & MO \\
\hline $41 \mathrm{CS} 55$ & 24 & 106 & 106.06 & $\mathrm{CP} 3$ & & & Surface & Flake, Thinning, chert; $>1 / 2 "$, Complete & 4 & 4.66 & $11 / 3 / 2015$ & MO \\
\hline $41 \mathrm{CS} 55$ & 24 & 106 & 106.07 & $\mathrm{CP} 3$ & & & Surface & Flake, Thinning, chert; >1/2", Complete & 3 & 3.31 & $11 / 3 / 2015$ & MO \\
\hline $41 \mathrm{CS} 55$ & 24 & 106 & 106.08 & $\mathrm{CP} 3$ & & & Surface & Flake, Thinning, chert; $>1 / 2 "$, Proximal & 1 & 0.65 & $11 / 3 / 2015$ & MO \\
\hline $41 \mathrm{CS} 55$ & 24 & 106 & 106.09 & $\mathrm{CP} 3$ & & & Surface & Flake, Thinning, chert; >1/2", Proximal & 1 & 0.44 & $11 / 3 / 2015$ & MO \\
\hline $41 \mathrm{CS} 55$ & 24 & 106 & 106.10 & $\mathrm{CP} 3$ & & & Surface & Flake, Thinning, chert; $>1 / 2 "$, Proximal & 8 & 4.94 & $11 / 3 / 2015$ & MO \\
\hline $41 \mathrm{CS} 55$ & 24 & 106 & 106.11 & $\mathrm{CP} 3$ & & & Surface & Flake, Thinning, chert; $>1 / 2 "$, Proximal & 3 & 2.24 & $11 / 3 / 2015$ & MO \\
\hline $41 \mathrm{CS} 55$ & 24 & 106 & 106.12 & $\mathrm{CP} 3$ & & & Surface & Flake, Thinning, chert; >1/2", Medial-Distal & 1 & 0.31 & $11 / 3 / 2015$ & MO \\
\hline
\end{tabular}




\begin{tabular}{|c|c|c|c|c|c|c|c|c|c|c|c|c|}
\hline $\begin{array}{c}\text { Site } \\
\#\end{array}$ & $\begin{array}{l}\text { FS } \\
\#\end{array}$ & LS\# & $\begin{array}{c}\text { Catalog } \\
\#\end{array}$ & Prov. & $\begin{array}{c}\text { Strat } \\
\text { a }\end{array}$ & $\begin{array}{c}\text { Leve } \\
1\end{array}$ & Depth & Description & Count & $\begin{array}{c}\text { Weight } \\
\text { (g) }\end{array}$ & $\begin{array}{c}\text { Date } \\
\text { Excavated }\end{array}$ & Exc/Rec \\
\hline $41 \mathrm{CS} 55$ & 24 & 106 & 106.13 & $\mathrm{CP} 3$ & & & Surface & Flake, Thinning, chert; $>1 / 2 "$, Non-orientable & 1 & 1.06 & $11 / 3 / 2015$ & MO \\
\hline $41 \mathrm{CS} 55$ & 24 & 106 & 106.14 & $\mathrm{CP} 3$ & & & Surface & Flake, Early Reduction, chert; >1/2", Complete & 1 & 0.66 & $11 / 3 / 2015$ & MO \\
\hline $41 \mathrm{CS} 55$ & 24 & 106 & 106.15 & $\mathrm{CP} 3$ & & & Surface & Flake, Early Reduction, chert; >1/2", Complete & 3 & 3.29 & $11 / 3 / 2015$ & MO \\
\hline $41 \mathrm{CS} 55$ & 24 & 106 & 106.16 & $\mathrm{CP} 3$ & & & Surface & Flake, Early Reduction, chert; >1/2", Complete & 1 & 2.07 & $11 / 3 / 2015$ & MO \\
\hline $41 \mathrm{CS} 55$ & 24 & 106 & 106.17 & $\mathrm{CP} 3$ & & & Surface & Flake, Early Reduction, chert; >1/2", Complete & 2 & 3.10 & $11 / 3 / 2015$ & MO \\
\hline $41 \mathrm{CS} 55$ & 24 & 106 & 106.18 & $\mathrm{CP} 3$ & & & Surface & Flake, Early Reduction, chert; >1/2", Complete & 1 & 1.74 & $11 / 3 / 2015$ & MO \\
\hline $41 \mathrm{CS} 55$ & 24 & 106 & 106.19 & $\mathrm{CP} 3$ & & & Surface & Flake, Early Reduction, chert; >1/2", Complete & 4 & 6.88 & $11 / 3 / 2015$ & MO \\
\hline $41 \mathrm{CS} 55$ & 24 & 106 & 106.20 & $\mathrm{CP} 3$ & & & Surface & Flake, Early Reduction, chert; >1/2", Proximal & 1 & 0.90 & $11 / 3 / 2015$ & MO \\
\hline 41CS55 & 24 & 106 & 106.21 & $\mathrm{CP} 3$ & & & Surface & Flake, Early Reduction, chert; $>1 / 2 "$, Proximal & 1 & 1.12 & $11 / 3 / 2015$ & MO \\
\hline $41 \mathrm{CS} 55$ & 24 & 106 & 106.22 & $\mathrm{CP} 3$ & & & Surface & Flake, Early Reduction, chert; >1/2", Proximal & 1 & 0.71 & $11 / 3 / 2015$ & MO \\
\hline $41 \mathrm{CS} 55$ & 24 & 106 & 106.23 & $\mathrm{CP} 3$ & & & Surface & Flake, Early Reduction, chert; $>1 / 2 "$, Proximal & 2 & 2.99 & $11 / 3 / 2015$ & MO \\
\hline $41 \mathrm{CS} 55$ & 24 & 106 & 106.24 & $\mathrm{CP} 3$ & & & Surface & Flake, Early Reduction, chert; $>1 / 2 "$, Proximal & 1 & 0.51 & $11 / 3 / 2015$ & MO \\
\hline $41 \mathrm{CS} 55$ & 24 & 106 & 106.25 & $\mathrm{CP} 3$ & & & Surface & $\begin{array}{l}\text { Flake, Early Reduction, chert; >1/2", Medial- } \\
\text { Distal }\end{array}$ & 1 & 2.19 & $11 / 3 / 2015$ & MO \\
\hline $41 \mathrm{CS} 55$ & 24 & 106 & 106.26 & $\mathrm{CP} 3$ & & & Surface & $\begin{array}{l}\text { Flake, Early Reduction, chert; >1/2", Medial- } \\
\text { Distal }\end{array}$ & 1 & 1.00 & $11 / 3 / 2015$ & MO \\
\hline $41 \mathrm{CS} 55$ & 24 & 106 & 106.27 & $\mathrm{CP} 3$ & & & Surface & $\begin{array}{l}\text { Flake, Early Reduction, chert; >1/2", Non- } \\
\text { orientable }\end{array}$ & 1 & 4.18 & $11 / 3 / 2015$ & MO \\
\hline $41 \mathrm{CS} 55$ & 24 & 106 & 106.28 & $\mathrm{CP} 3$ & & & Surface & Shatter, Angular, chert & 3 & 4.68 & $11 / 3 / 2015$ & MO \\
\hline $41 \mathrm{CS} 55$ & 24 & 106 & 106.29 & $\mathrm{CP} 3$ & & & Surface & Shatter, Thermal, chert & 3 & 8.88 & $11 / 3 / 2015$ & MO \\
\hline $41 \mathrm{CS} 55$ & 24 & 106 & 106.30 & $\mathrm{CP} 3$ & & & Surface & $\begin{array}{l}\text { Possible cultural material-lithic, } \\
\text { quartzite/sandstone }\end{array}$ & 1 & 1.00 & $11 / 3 / 2015$ & MO \\
\hline $41 \mathrm{CS} 55$ & 24 & 106 & 106.31 & $\mathrm{CP} 3$ & & & Surface & Possible cultural material-lithic, other & 2 & 3.67 & $11 / 3 / 2015$ & MO \\
\hline $41 \mathrm{CS} 55$ & 24 & 106 & 106.32 & $\mathrm{CP} 3$ & & & Surface & $\begin{array}{l}\text { Flake, Thinning, petrified wood; >1/2", Medial- } \\
\text { Distal }\end{array}$ & 1 & 0.75 & $11 / 3 / 2015$ & MO \\
\hline $41 \mathrm{CS} 55$ & 24 & 106 & 106.33 & $\mathrm{CP} 3$ & & & Surface & Flake, Thinning; Late, chert; >1/4", Complete & 3 & 0.58 & $11 / 3 / 2015$ & MO \\
\hline $41 \mathrm{CS} 55$ & 24 & 106 & 106.34 & $\mathrm{CP} 3$ & & & Surface & Flake, Thinning; Late, chert; $>1 / 4 "$, Complete & 3 & 0.47 & $11 / 3 / 2015$ & MO \\
\hline $41 \mathrm{CS} 55$ & 24 & 106 & 106.35 & $\mathrm{CP} 3$ & & & Surface & Flake, Thinning; Late, chert; >1/4", Proximal & 1 & 0.15 & $11 / 3 / 2015$ & $\mathrm{MO}$ \\
\hline
\end{tabular}




\begin{tabular}{|c|c|c|c|c|c|c|c|c|c|c|c|c|}
\hline $\begin{array}{c}\text { Site } \\
\#\end{array}$ & $\begin{array}{l}\text { FS } \\
\#\end{array}$ & LS\# & $\begin{array}{c}\text { Catalog } \\
\# \\
\end{array}$ & Prov. & $\begin{array}{c}\text { Strat } \\
\text { a }\end{array}$ & $\begin{array}{c}\text { Leve } \\
\text { I }\end{array}$ & Depth & Description & Count & $\begin{array}{c}\text { Weight } \\
\text { (g) }\end{array}$ & $\begin{array}{c}\text { Date } \\
\text { Excavated }\end{array}$ & Exc/Rec \\
\hline $41 \mathrm{CS} 55$ & 24 & 106 & 106.36 & $\mathrm{CP} 3$ & & & Surface & Flake, Thinning; Late, chert; >1/4", Proximal & 1 & 0.34 & $11 / 3 / 2015$ & MO \\
\hline $41 \mathrm{CS} 55$ & 24 & 106 & 106.37 & $\mathrm{CP} 3$ & & & Surface & Flake, Thinning; Late, chert; >1/4", Proximal & 2 & 0.38 & $11 / 3 / 2015$ & MO \\
\hline $41 \mathrm{CS} 55$ & 24 & 106 & 106.38 & $\mathrm{CP} 3$ & & & Surface & Flake, Thinning; Late, chert; >1/4", Medial-Distal & 1 & 0.13 & $11 / 3 / 2015$ & MO \\
\hline $41 \mathrm{CS} 55$ & 24 & 106 & 106.39 & $\mathrm{CP} 3$ & & & Surface & Flake, Thinning; Late, chert; >1/4", Medial-Distal & 1 & 0.14 & $11 / 3 / 2015$ & $\mathrm{MO}$ \\
\hline $41 \mathrm{CS} 55$ & 24 & 106 & 106.40 & $\mathrm{CP} 3$ & & & Surface & Flake, Thinning, chert; >1/4", Proximal & 1 & 0.40 & $11 / 3 / 2015$ & $\mathrm{MO}$ \\
\hline $41 \mathrm{CS} 55$ & 24 & 106 & 106.41 & $\mathrm{CP} 3$ & & & Surface & Flake, Thinning, chert; >1/4", Medial-Distal & 2 & 0.96 & $11 / 3 / 2015$ & MO \\
\hline $41 \mathrm{CS} 55$ & 24 & 106 & 106.42 & $\mathrm{CP} 3$ & & & Surface & $\begin{array}{l}\text { Aboriginal ceramic, plain, grog/clay temper; } \\
\text { body; sherds mend, fresh break }\end{array}$ & 2 & 6.18 & $11 / 3 / 2015$ & $\mathrm{MO}$ \\
\hline $41 \mathrm{CS} 55$ & 24 & 106 & 106.43 & $\mathrm{CP} 3$ & & & Surface & $\begin{array}{l}\text { Aboriginal ceramic, punctate, grog/clay temper; } \\
\text { body; tool punctated }\end{array}$ & 5 & 22.20 & $11 / 3 / 2015$ & $\mathrm{MO}$ \\
\hline $41 \mathrm{CS} 55$ & 24 & 106 & 106.44 & $\mathrm{CP} 3$ & & & Surface & $\begin{array}{l}\text { Aboriginal ceramic, plain, grog/bone temper; } \\
\text { body }\end{array}$ & 1 & 8.08 & $11 / 3 / 2015$ & $\mathrm{MO}$ \\
\hline $41 \mathrm{CS} 55$ & 24 & 106 & 106.45 & $\mathrm{CP} 3$ & & & Surface & $\begin{array}{l}\text { Aboriginal ceramic, brushed, grog/clay temper; } \\
\text { body }\end{array}$ & 1 & 10.80 & $11 / 3 / 2015$ & $\mathrm{MO}$ \\
\hline $41 \mathrm{CS} 55$ & 24 & 106 & 106.46 & $\mathrm{CP} 3$ & & & Surface & $\begin{array}{l}\text { Aboriginal ceramic, plain, grog/clay temper; } \\
\text { body; sherds mend }\end{array}$ & 2 & 7.30 & $11 / 3 / 2015$ & $\mathrm{MO}$ \\
\hline $41 \mathrm{CS} 55$ & 24 & 106 & 106.47 & $\mathrm{CP} 3$ & & & Surface & $\begin{array}{l}\text { Aboriginal ceramic, engraved, grog/clay temper; } \\
\text { body }\end{array}$ & 1 & 16.13 & $11 / 3 / 2015$ & $\mathrm{MO}$ \\
\hline $41 \mathrm{CS} 55$ & 24 & 106 & 106.48 & $\mathrm{CP} 3$ & & & Surface & $\begin{array}{l}\text { Aboriginal ceramic, applique on body, grog/clay } \\
\text { temper; body; possible node }\end{array}$ & 1 & 5.45 & $11 / 3 / 2015$ & $\mathrm{MO}$ \\
\hline $41 \mathrm{CS} 55$ & 24 & 106 & 106.49 & $\mathrm{CP} 3$ & & & Surface & $\begin{array}{l}\text { Aboriginal ceramic, brushed, grog/clay temper; } \\
\text { body }\end{array}$ & 1 & 13.28 & $11 / 3 / 2015$ & $\mathrm{MO}$ \\
\hline $41 \mathrm{CS} 55$ & 25 & 107 & 107.01 & $\mathrm{CP} 4$ & & & Surface & Flake, core reduction, chert; >1", Complete & 2 & 3.26 & $11 / 3 / 2015$ & MMM \\
\hline $41 \mathrm{CS} 55$ & 25 & 107 & 107.02 & $\mathrm{CP} 4$ & & & Surface & Flake, core reduction, chert; >1", Medial-Distal & 1 & 1.83 & $11 / 3 / 2015$ & MMM \\
\hline $41 \mathrm{CS} 55$ & 25 & 107 & 107.03 & $\mathrm{CP} 4$ & & & Surface & Flake, core reduction, chert; $>1 / 2 "$, Complete & 2 & 1.93 & $11 / 3 / 2015$ & MMM \\
\hline $41 \mathrm{CS} 55$ & 25 & 107 & 107.04 & $\mathrm{CP} 4$ & & & Surface & Flake, core reduction, chert; $>1 / 2 "$, Proximal & 2 & 1.88 & $11 / 3 / 2015$ & MMM \\
\hline $41 \mathrm{CS} 55$ & 25 & 107 & 107.05 & $\mathrm{CP} 4$ & & & Surface & Flake, Early Reduction, chert; >1", Complete & 1 & 3.18 & $11 / 3 / 2015$ & MMM \\
\hline $41 \mathrm{CS} 55$ & 25 & 107 & 107.06 & $\mathrm{CP} 4$ & & & Surface & Flake, Early Reduction, chert; >1", Complete & 1 & 1.41 & $11 / 3 / 2015$ & MMM \\
\hline
\end{tabular}




\begin{tabular}{|c|c|c|c|c|c|c|c|c|c|c|c|c|}
\hline $\begin{array}{c}\text { Site } \\
\#\end{array}$ & $\begin{array}{l}\text { FS } \\
\#\end{array}$ & LS\# & $\begin{array}{c}\text { Catalog } \\
\#\end{array}$ & Prov. & $\begin{array}{c}\text { Strat } \\
\text { a }\end{array}$ & $\begin{array}{c}\text { Leve } \\
1\end{array}$ & Depth & Description & Count & $\begin{array}{c}\text { Weight } \\
\text { (g) }\end{array}$ & $\begin{array}{c}\text { Date } \\
\text { Excavated }\end{array}$ & Exc/Rec \\
\hline $41 \mathrm{CS} 55$ & 25 & 107 & 107.07 & $\mathrm{CP} 4$ & & & Surface & Flake, Early Reduction, chert; $>1 / 4 "$, Complete & 1 & 0.12 & $11 / 3 / 2015$ & MMM \\
\hline $41 \mathrm{CS} 55$ & 25 & 107 & 107.08 & $\mathrm{CP} 4$ & & & Surface & Flake, Early Reduction, chert; $>1 / 2 "$ ", Complete & 3 & 2.89 & $11 / 3 / 2015$ & MMM \\
\hline $41 \mathrm{CS} 55$ & 25 & 107 & 107.09 & $\mathrm{CP} 4$ & & & Surface & Flake, Early Reduction, chert; $>1 / 2 "$, Proximal & 1 & 0.74 & $11 / 3 / 2015$ & MMM \\
\hline $41 \mathrm{CS} 55$ & 25 & 107 & 107.10 & $\mathrm{CP} 4$ & & & Surface & $\begin{array}{l}\text { Flake, Early Reduction, chert; >1/2", Medial- } \\
\text { Distal }\end{array}$ & 1 & 1.13 & $11 / 3 / 2015$ & MMM \\
\hline $41 \mathrm{CS} 55$ & 25 & 107 & 107.11 & $\mathrm{CP} 4$ & & & Surface & Flake, Early Reduction, chert; >1/2", Complete & 8 & 8.90 & $11 / 3 / 2015$ & MMM \\
\hline $41 \mathrm{CS} 55$ & 25 & 107 & 107.12 & $\mathrm{CP} 4$ & & & Surface & $\begin{array}{l}\text { Flake, Early Reduction, chert; >1/2", Medial- } \\
\text { Distal }\end{array}$ & 3 & 2.60 & $11 / 3 / 2015$ & MMM \\
\hline $41 \mathrm{CS} 55$ & 25 & 107 & 107.13 & $\mathrm{CP} 4$ & & & Surface & Flake, Thinning, chert; $>1 / 2 "$, Complete & 10 & 7.80 & $11 / 3 / 2015$ & MMM \\
\hline $41 \mathrm{CS} 55$ & 25 & 107 & 107.14 & $\mathrm{CP} 4$ & & & Surface & Flake, Thinning, chert; $>1 / 2 "$, Proximal & 8 & 4.78 & $11 / 3 / 2015$ & MMM \\
\hline $41 \mathrm{CS} 55$ & 25 & 107 & 107.15 & $\mathrm{CP} 4$ & & & Surface & Flake, Thinning, chert; >1/2", Medial-Distal & 4 & 1.68 & $11 / 3 / 2015$ & MMM \\
\hline $41 \mathrm{CS} 55$ & 25 & 107 & 107.16 & $\mathrm{CP} 4$ & & & Surface & Flake, Thinning, chert; $>1 / 2 "$, Proximal & 2 & 0.97 & $11 / 3 / 2015$ & MMM \\
\hline $41 \mathrm{CS} 55$ & 25 & 107 & 107.17 & $\mathrm{CP} 4$ & & & Surface & Flake, Thinning, chert; >1/2", Medial-Distal & 1 & 0.18 & $11 / 3 / 2015$ & MMM \\
\hline $41 \mathrm{CS} 55$ & 25 & 107 & 107.18 & $\mathrm{CP} 4$ & & & Surface & Flake, Thinning, chert; $>1 / 4 "$, Complete & 1 & 0.57 & $11 / 3 / 2015$ & MMM \\
\hline $41 \mathrm{CS} 55$ & 25 & 107 & 107.19 & $\mathrm{CP} 4$ & & & Surface & Flake, Thinning, chert; >1/4", Medial-Distal & 1 & 0.16 & $11 / 3 / 2015$ & MMM \\
\hline $41 \mathrm{CS} 55$ & 25 & 107 & 107.20 & $\mathrm{CP} 4$ & & & Surface & Flake, Thinning; Late, chert; >1/4", Complete & 1 & 0.15 & $11 / 3 / 2015$ & MMM \\
\hline $41 \mathrm{CS} 55$ & 25 & 107 & 107.21 & $\mathrm{CP} 4$ & & & Surface & Flake, Thinning; Late, chert; >1/4", Proximal & 1 & 0.10 & $11 / 3 / 2015$ & MMM \\
\hline $41 \mathrm{CS} 55$ & 25 & 107 & 107.22 & $\mathrm{CP} 4$ & & & Surface & Flake, Thinning; Late, chert; >1/4", Medial-Distal & 3 & 0.53 & $11 / 3 / 2015$ & MMM \\
\hline $41 \mathrm{CS} 55$ & 25 & 107 & 107.23 & $\mathrm{CP} 4$ & & & Surface & Flake, Thinning; Late, chert; $>1 / 4 "$ ", Complete & 2 & 0.32 & $11 / 3 / 2015$ & MMM \\
\hline $41 \mathrm{CS} 55$ & 25 & 107 & 107.24 & $\mathrm{CP} 4$ & & & Surface & Flake, Thinning; Late, chert; >1/2", Complete & 1 & 0.25 & $11 / 3 / 2015$ & MMM \\
\hline $41 \mathrm{CS} 55$ & 25 & 107 & 107.25 & $\mathrm{CP} 4$ & & & Surface & $\begin{array}{l}\text { Flake, Utilized, chert; }>1 " \text {, Complete; usewear } \\
\text { on long edge }\end{array}$ & 1 & 3.46 & $11 / 3 / 2015$ & MMM \\
\hline $41 \mathrm{CS} 55$ & 25 & 107 & 107.26 & $\mathrm{CP} 4$ & & & Surface & $\begin{array}{l}\text { Flake, Thinning; Late, quartzite; }>1 / 2 " \text {, } \\
\text { Complete }\end{array}$ & 1 & 3.77 & $11 / 3 / 2015$ & MMM \\
\hline $41 \mathrm{CS} 55$ & 25 & 107 & 107.27 & $\mathrm{CP} 4$ & & & Surface & $\begin{array}{l}\text { Aboriginal ceramic, plain, grog/clay temper; } \\
\text { body; also some fine sand in paste }\end{array}$ & 4 & 36.62 & $11 / 3 / 2015$ & MMM \\
\hline $41 \mathrm{CS} 55$ & 25 & 107 & 107.28 & $\mathrm{CP} 4$ & & & Surface & $\begin{array}{l}\text { Aboriginal ceramic, punctate, grog/clay temper; } \\
\text { body; surface eroded, tool punctated, also } \\
\text { some fine sand in paste }\end{array}$ & 1 & 5.99 & $11 / 3 / 2015$ & MMM \\
\hline
\end{tabular}




\begin{tabular}{|c|c|c|c|c|c|c|c|c|c|c|c|c|}
\hline $\begin{array}{c}\text { Site } \\
\# \\
\end{array}$ & $\begin{array}{l}\text { FS } \\
\#\end{array}$ & LS\# & $\begin{array}{c}\text { Catalog } \\
\#\end{array}$ & Prov. & $\begin{array}{c}\text { Strat } \\
\text { a }\end{array}$ & $\begin{array}{c}\text { Leve } \\
1\end{array}$ & Depth & Description & Count & $\begin{array}{l}\text { Weight } \\
\text { (g) }\end{array}$ & $\begin{array}{c}\text { Date } \\
\text { Excavated }\end{array}$ & Exc/Rec \\
\hline $41 \mathrm{CS} 55$ & 25 & 107 & 107.29 & CP 4 & & & Surface & $\begin{array}{l}\text { Aboriginal ceramic, brushed, grog/clay temper; } \\
\text { base; also small amount of grog; possible } \\
\text { shoulder or trend towards base }\end{array}$ & 1 & 9.10 & $11 / 3 / 2015$ & MMM \\
\hline $41 \mathrm{CS} 55$ & 25 & 107 & 107.30 & CP 4 & & & Surface & $\begin{array}{l}\text { Aboriginal ceramic, plain, grog/clay temper; } \\
\text { body; also some grog in paste }\end{array}$ & 1 & 6.97 & $11 / 3 / 2015$ & MMM \\
\hline $41 \mathrm{CS} 55$ & 25 & 107 & 107.31 & CP 4 & & & Surface & $\begin{array}{l}\text { Aboriginal ceramic, engraved, grog/clay temper; } \\
\text { everted rim, tapered lip; engraved parallel to } \\
\text { rim }\end{array}$ & 1 & 2.73 & $11 / 3 / 2015$ & MMM \\
\hline $41 \mathrm{CS} 55$ & 25 & 107 & 107.32 & $\mathrm{CP} 4$ & & & Surface & $\begin{array}{l}\text { Aboriginal ceramic, plain, grog/clay temper; } \\
\text { body }\end{array}$ & 5 & 20.56 & $11 / 3 / 2015$ & MMM \\
\hline $41 \mathrm{CS} 55$ & 26 & 108 & 108.01 & CP 5 & & & Surface & $\begin{array}{l}\text { Aboriginal ceramic, plain, grog/clay temper; } \\
\text { body }\end{array}$ & 2 & 12.40 & $11 / 3 / 2015$ & MMM \\
\hline $41 \mathrm{CS} 55$ & 26 & 108 & 108.02 & CP 5 & & & Surface & Flake, Thinning; Late, chert; $>1 / 8$, Complete & 3 & 0.27 & $11 / 3 / 2015$ & MMM \\
\hline $41 \mathrm{CS} 55$ & 26 & 108 & 108.03 & CP 5 & & & Surface & Flake, Thinning; Late, chert; >1/4", Complete & 9 & 1.89 & $11 / 3 / 2015$ & MMM \\
\hline 41CS55 & 26 & 108 & 108.04 & CP 5 & & & Surface & Flake, Thinning; Late, chert; $>1 / 4 "$ ", Complete & 4 & 1.04 & $11 / 3 / 2015$ & MMM \\
\hline $41 \mathrm{CS} 55$ & 26 & 108 & 108.05 & CP 5 & & & Surface & Flake, Thinning; Late, chert; >1/4", Complete & 2 & 0.29 & $11 / 3 / 2015$ & MMM \\
\hline $41 \mathrm{CS} 55$ & 26 & 108 & 108.06 & CP 5 & & & Surface & Flake, Thinning; Late, chert; >1/2", Complete & 3 & 1.43 & $11 / 3 / 2015$ & MMM \\
\hline $41 \mathrm{CS} 55$ & 26 & 108 & 108.07 & CP 5 & & & Surface & Flake, Thinning; Late, chert; >1/8, Proximal & 1 & 0.06 & $11 / 3 / 2015$ & MMM \\
\hline $41 \mathrm{CS} 55$ & 26 & 108 & 108.08 & CP 5 & & & Surface & Flake, Thinning; Late, chert; >1/4", Proximal & 8 & 1.93 & $11 / 3 / 2015$ & MMM \\
\hline 41CS55 & 26 & 108 & 108.09 & CP 5 & & & Surface & Flake, Thinning; Late, chert; >1/4", Proximal & 1 & 0.10 & $11 / 3 / 2015$ & MMM \\
\hline $41 \mathrm{CS} 55$ & 26 & 108 & 108.10 & CP 5 & & & Surface & Flake, Thinning; Late, chert; >1/2", Proximal & 1 & 0.54 & $11 / 3 / 2015$ & MMM \\
\hline $41 \mathrm{CS} 55$ & 26 & 108 & 108.11 & CP 5 & & & Surface & Flake, Thinning; Late, chert; >1/8, Medial-Distal & 1 & 0.06 & $11 / 3 / 2015$ & MMM \\
\hline 41CS55 & 26 & 108 & 108.12 & $\mathrm{CP} 5$ & & & Surface & Flake, Thinning; Late, chert; >1/4", Medial-Distal & 8 & 1.64 & $11 / 3 / 2015$ & MMM \\
\hline $41 \mathrm{CS} 55$ & 26 & 108 & 108.13 & CP 5 & & & Surface & Flake, Thinning; Late, chert; >1/4", Medial-Distal & 1 & 0.26 & $11 / 3 / 2015$ & MMM \\
\hline $41 \mathrm{CS} 55$ & 26 & 108 & 108.14 & CP 5 & & & Surface & Flake, Thinning; Late, chert; >1/2", Medial-Distal & 1 & 0.30 & $11 / 3 / 2015$ & MMM \\
\hline $41 \mathrm{CS} 55$ & 26 & 108 & 108.15 & CP 5 & & & Surface & Flake, retouch, chert; $>1 / 8$, Complete & 3 & 0.12 & $11 / 3 / 2015$ & MMM \\
\hline 41CS55 & 26 & 108 & 108.16 & CP 5 & & & Surface & Flake, Thinning, chert; $>1 / 4 "$ ", Complete & 1 & 0.63 & $11 / 3 / 2015$ & MMM \\
\hline $41 \mathrm{CS} 55$ & 26 & 108 & 108.17 & CP 5 & & & Surface & Flake, Thinning, chert; >1/2", Complete & 7 & 6.35 & $11 / 3 / 2015$ & MMM \\
\hline
\end{tabular}




\begin{tabular}{|c|c|c|c|c|c|c|c|c|c|c|c|c|}
\hline $\begin{array}{c}\text { Site } \\
\#\end{array}$ & $\begin{array}{l}\text { FS } \\
\#\end{array}$ & LS\# & $\begin{array}{c}\text { Catalog } \\
\#\end{array}$ & Prov. & $\begin{array}{c}\text { Strat } \\
\text { a }\end{array}$ & $\begin{array}{c}\text { Leve } \\
1\end{array}$ & Depth & Description & Count & $\begin{array}{l}\text { Weight } \\
\text { (g) }\end{array}$ & $\begin{array}{c}\text { Date } \\
\text { Excavated }\end{array}$ & Exc/Rec \\
\hline $41 \mathrm{CS} 55$ & 26 & 108 & 108.18 & $\mathrm{CP} 5$ & & & Surface & Flake, Thinning, chert; $>1 / 2 "$, Complete & 4 & 5.60 & $11 / 3 / 2015$ & MMM \\
\hline $41 \mathrm{CS} 55$ & 26 & 108 & 108.19 & CP 5 & & & Surface & Flake, Thinning, chert; $>1 / 2 "$, Complete & 2 & 2.12 & $11 / 3 / 2015$ & MMM \\
\hline $41 \mathrm{CS} 55$ & 26 & 108 & 108.20 & $\mathrm{CP} 5$ & & & Surface & Flake, Thinning, chert; $>1 / 4 "$, Proximal & 1 & 0.37 & $11 / 3 / 2015$ & MMM \\
\hline $41 \mathrm{CS} 55$ & 26 & 108 & 108.21 & $\mathrm{CP} 5$ & & & Surface & Flake, Thinning, chert; $>1 / 4 "$, Proximal & 1 & 0.46 & $11 / 3 / 2015$ & MMM \\
\hline $41 \mathrm{CS} 55$ & 26 & 108 & 108.22 & $\mathrm{CP} 5$ & & & Surface & Flake, Thinning, chert; $>1 / 4 "$, Proximal & 2 & 0.75 & $11 / 3 / 2015$ & MMM \\
\hline $41 \mathrm{CS} 55$ & 26 & 108 & 108.23 & $\mathrm{CP} 5$ & & & Surface & Flake, Thinning, chert; $>1 / 2 "$, Proximal & 1 & 1.22 & $11 / 3 / 2015$ & MMM \\
\hline $41 \mathrm{CS} 55$ & 26 & 108 & 108.24 & $\mathrm{CP} 5$ & & & Surface & Flake, Thinning, chert; >1/4", Medial-Distal & 1 & 0.33 & $11 / 3 / 2015$ & MMM \\
\hline $41 \mathrm{CS} 55$ & 26 & 108 & 108.25 & $\mathrm{CP} 5$ & & & Surface & Flake, Thinning, chert; >1/2", Medial-Distal & 4 & 3.75 & $11 / 3 / 2015$ & MMM \\
\hline $41 \mathrm{CS} 55$ & 26 & 108 & 108.26 & CP 5 & & & Surface & Fire cracked rock, quartzite & 1 & 2.93 & $11 / 3 / 2015$ & MMM \\
\hline $41 \mathrm{CS} 55$ & 26 & 108 & 108.27 & $\mathrm{CP} 5$ & & & Surface & Flake, Early Reduction, chert; $>1 / 2 "$, Complete & 3 & 4.07 & $11 / 3 / 2015$ & MMM \\
\hline $41 \mathrm{CS} 55$ & 26 & 108 & 108.28 & CP 5 & & & Surface & Flake, Early Reduction, chert; $>1 / 2 "$, Proximal & 1 & 1.20 & $11 / 3 / 2015$ & MMM \\
\hline $41 \mathrm{CS} 55$ & 26 & 108 & 108.29 & CP 5 & & & Surface & $\begin{array}{l}\text { Flake, Early Reduction, chert; >1/2", Medial- } \\
\text { Distal }\end{array}$ & 3 & 1.98 & $11 / 3 / 2015$ & MMM \\
\hline $41 \mathrm{CS} 55$ & 26 & 108 & 108.30 & $\mathrm{CP} 5$ & & & Surface & $\begin{array}{l}\text { Flake, core reduction, chert; >1/4", Medial- } \\
\text { Distal }\end{array}$ & 1 & 0.97 & $11 / 3 / 2015$ & MMM \\
\hline $41 \mathrm{CS} 55$ & 26 & 108 & 108.31 & CP 5 & & & Surface & $\begin{array}{l}\text { Flake, core reduction, chert; }>1 / 2 " \text {, Medial- } \\
\text { Distal }\end{array}$ & 1 & 3.53 & $11 / 3 / 2015$ & MMM \\
\hline $41 \mathrm{CS} 55$ & 26 & 108 & 108.32 & $\mathrm{CP} 5$ & & & Surface & Flake, core reduction, chert; $>1 / 2 "$, Complete & 2 & 7.47 & $11 / 3 / 2015$ & MMM \\
\hline $41 \mathrm{CS} 55$ & 26 & 108 & 108.33 & CP 5 & & & Surface & Shatter, Angular, chert & 3 & 1.15 & $11 / 3 / 2015$ & MMM \\
\hline $41 \mathrm{CS} 55$ & 26 & 108 & 108.34 & CP 5 & & & Surface & Shatter, Angular, quartz & 2 & 3.45 & $11 / 3 / 2015$ & MMM \\
\hline $41 \mathrm{CS} 55$ & 26 & 108 & 108.35 & $\mathrm{CP} 5$ & & & Surface & Uid aboriginal ceramic, less than $1 / 2$ inch & 2 & 0.82 & $11 / 3 / 2015$ & MMM \\
\hline $41 \mathrm{CS} 55$ & 26 & 108 & 108.36 & CP 5 & & & Surface & Lot number not used & & & $11 / 3 / 2015$ & MMM \\
\hline $41 \mathrm{CS} 55$ & 26 & 108 & 108.37 & $\mathrm{CP} 5$ & & & Surface & Shell, uid, very worn & 1 & 0.19 & $11 / 3 / 2015$ & MMM \\
\hline $41 \mathrm{CS} 55$ & 26 & 108 & 108.38 & CP 5 & & & Surface & Wood; non-cultural & 1 & 0.04 & $11 / 3 / 2015$ & MMM \\
\hline $41 \mathrm{CS} 55$ & 26 & 108 & 108.39 & $\mathrm{CP} 5$ & & & Surface & $\begin{array}{l}\text { Unmodified stone; sandstone, chert, quartz, } \\
\text { etc. }\end{array}$ & 8 & 9.40 & $11 / 3 / 2015$ & MMM \\
\hline $41 \mathrm{CS} 55$ & 27 & 109 & 109.01 & ST 27 & & & $0-10 \mathrm{cmbs}$ & Flake, Thinning; Late, chert; >1/4", Proximal & 1 & 0.26 & $11 / 3 / 2015$ & $\mathrm{EA} / \mathrm{SPF}$ \\
\hline $41 \mathrm{CS} 55$ & 27 & 109 & 109.02 & ST 27 & & & $0-10 \mathrm{cmbs}$ & Flake, Thinning; Late, chert; >1/4", Medial-Distal & 1 & 0.25 & $11 / 3 / 2015$ & $\mathrm{EA} / \mathrm{SPF}$ \\
\hline $41 \mathrm{CS} 55$ & 1 & 110 & 110.01 & TU 1 & I & 1 & $10-20 \mathrm{cmbd}$ & Flake, Thinning; Late, chert; >1/4", Complete & 1 & 0.11 & $11 / 3 / 2015$ & $\mathrm{IM} / \mathrm{KP}$ \\
\hline $41 \mathrm{CS} 55$ & 1 & 110 & 110.02 & TU 1 & 1 & 1 & $10-20 \mathrm{cmbd}$ & Flake, Thinning; Late, chert; >1/4", Complete & 1 & 0.02 & $11 / 3 / 2015$ & $\mathrm{IM} / \mathrm{KP}$ \\
\hline
\end{tabular}




\begin{tabular}{|c|c|c|c|c|c|c|c|c|c|c|c|c|}
\hline $\begin{array}{c}\text { Site } \\
\#\end{array}$ & $\begin{array}{c}\text { FS } \\
\#\end{array}$ & LS\# & $\begin{array}{c}\text { Catalog } \\
\#\end{array}$ & Prov. & $\begin{array}{c}\text { Strat } \\
\text { a }\end{array}$ & $\begin{array}{c}\text { Leve } \\
1\end{array}$ & Depth & Description & Count & $\begin{array}{l}\text { Weight } \\
\text { (g) }\end{array}$ & $\begin{array}{c}\text { Date } \\
\text { Excavated }\end{array}$ & Exc/Rec \\
\hline $41 \mathrm{CS} 55$ & 1 & 110 & 110.03 & TU 1 & I & 1 & $10-20 \mathrm{cmbd}$ & Flake, Thinning; Late, chert; >1/4", Proximal & 1 & 0.10 & $11 / 3 / 2015$ & $\mathrm{IM} / \mathrm{KP}$ \\
\hline $41 \mathrm{CS} 55$ & 1 & 110 & 110.04 & TU 1 & 1 & 1 & $10-20 \mathrm{cmbd}$ & Flake, Thinning; Late, chert; $>1 / 4 "$, Complete & 1 & 0.09 & $11 / 3 / 2015$ & $\mathrm{IM} / \mathrm{KP}$ \\
\hline $41 \mathrm{CS} 55$ & 1 & 110 & 110.05 & TU 1 & 1 & 1 & $10-20 \mathrm{cmbd}$ & Flake, Thinning; Late, chert; >1/4", Proximal & 3 & 0.97 & $11 / 3 / 2015$ & $\mathrm{IM} / \mathrm{KP}$ \\
\hline $41 \mathrm{CS} 55$ & 1 & 110 & 110.06 & TU 1 & I & 1 & $10-20 \mathrm{cmbd}$ & Flake, Thinning; Late, chert; >1/4", Medial-Distal & 2 & 0.24 & $11 / 3 / 2015$ & $\mathrm{IM} / \mathrm{KP}$ \\
\hline $41 \mathrm{CS} 55$ & 1 & 110 & 110.07 & TU 1 & I & 1 & $10-20 \mathrm{cmbd}$ & $\begin{array}{l}\text { Flake, Thinning; Late, chert; >1/4", Non- } \\
\text { orientable }\end{array}$ & 1 & 0.30 & $11 / 3 / 2015$ & $\mathrm{IM} / \mathrm{KP}$ \\
\hline $41 \mathrm{CS} 55$ & 1 & 110 & 110.08 & TU 1 & 1 & 1 & $10-20 \mathrm{cmbd}$ & Flake, Thinning; Late, chert; $>1 / 2 "$ ", Complete & 1 & 0.45 & $11 / 3 / 2015$ & $\mathrm{IM} / \mathrm{KP}$ \\
\hline $41 \mathrm{CS} 55$ & 1 & 110 & 110.09 & TU 1 & I & 1 & $10-20 \mathrm{cmbd}$ & Flake, Thinning, chert; $>1 / 2 "$, Proximal & 2 & 0.66 & $11 / 3 / 2015$ & $\mathrm{IM} / \mathrm{KP}$ \\
\hline $41 \mathrm{CS} 55$ & 1 & 110 & 110.10 & TU 1 & 1 & 1 & $10-20 \mathrm{cmbd}$ & Flake, Thinning, chert; >1/2", Medial-Distal & 1 & 0.53 & $11 / 3 / 2015$ & $\mathrm{IM} / \mathrm{KP}$ \\
\hline $41 \mathrm{CS} 55$ & 1 & 110 & 110.11 & TU 1 & I & 1 & $10-20 \mathrm{cmbd}$ & Flake, Thinning, chert; $>1 / 2 "$, Complete & 1 & 1.29 & $11 / 3 / 2015$ & $\mathrm{IM} / \mathrm{KP}$ \\
\hline $41 \mathrm{CS} 55$ & 1 & 110 & 110.12 & TU 1 & 1 & 1 & $10-20 \mathrm{cmbd}$ & Flake, Early Reduction, chert; >1/2", Complete & 1 & 0.60 & $11 / 3 / 2015$ & $\mathrm{IM} / \mathrm{KP}$ \\
\hline $41 \mathrm{CS} 55$ & 1 & 110 & 110.13 & TU 1 & 1 & 1 & $10-20 \mathrm{cmbd}$ & Shatter, Angular, chert & 2 & 2.49 & $11 / 3 / 2015$ & $\mathrm{IM} / \mathrm{KP}$ \\
\hline $41 \mathrm{CS} 55$ & 1 & 110 & 110.14 & TU 1 & 1 & 1 & $10-20 \mathrm{cmbd}$ & Potlid, chert & 1 & 0.08 & $11 / 3 / 2015$ & $\mathrm{IM} / \mathrm{KP}$ \\
\hline $41 \mathrm{CS} 55$ & 1 & 110 & 110.15 & TU 1 & 1 & 1 & $10-20 \mathrm{cmbd}$ & Possible cultural material-lithic, chert & 1 & 0.39 & $11 / 3 / 2015$ & $\mathrm{IM} / \mathrm{KP}$ \\
\hline $41 \mathrm{CS} 55$ & 1 & 110 & 110.16 & TU 1 & I & 1 & $10-20 \mathrm{cmbd}$ & Possible cultural material-lithic, other & 4 & 22.30 & $11 / 3 / 2015$ & $\mathrm{IM} / \mathrm{KP}$ \\
\hline $41 \mathrm{CS} 55$ & 1 & 110 & 110.17 & TU 1 & I & 1 & $10-20 \mathrm{cmbd}$ & Possible cultural material-lithic, other & 7 & 5.10 & $11 / 3 / 2015$ & IM/KP \\
\hline $41 \mathrm{CS} 55$ & 2 & 111 & 111.01 & TU 1 & II & 1 & $20-30 \mathrm{cmbd}$ & Flake, Thinning, chert; >1/4", Complete & 1 & 0.66 & $11 / 3 / 2015$ & IM/KP \\
\hline $41 \mathrm{CS} 55$ & 3 & 112 & 112.01 & TU 1 & II & 2 & $30-40 \mathrm{cmbd}$ & Shatter, Angular, chert & 1 & 1.56 & $11 / 4 / 2015$ & MMM/SPP \\
\hline $41 \mathrm{CS} 55$ & 1 & 113 & 113.01 & TU 2 & I & 1 & $12-25 \mathrm{cmbd}$ & Flake, Thinning; Late, chert; >1/4", Complete & 1 & 0.36 & $11 / 3 / 2015$ & $\mathrm{BN} / \mathrm{CS}$ \\
\hline $41 \mathrm{CS} 55$ & 1 & 113 & 113.02 & TU 2 & I & 1 & $12-25 \mathrm{cmbd}$ & Flake, Thinning; Late, chert; $>1 / 4 "$ ", Complete & 2 & 0.23 & $11 / 3 / 2015$ & $\mathrm{BN} / \mathrm{CS}$ \\
\hline $41 \mathrm{CS} 55$ & 1 & 113 & 113.03 & TU 2 & 1 & 1 & $12-25 \mathrm{cmbd}$ & Flake, Thinning; Late, chert; >1/4", Proximal & 1 & 0.09 & $11 / 3 / 2015$ & $\mathrm{BN} / \mathrm{CS}$ \\
\hline $41 \mathrm{CS} 55$ & 1 & 113 & 113.04 & TU 2 & 1 & 1 & $12-25 \mathrm{cmbd}$ & Flake, Thinning; Late, chert; >1/4", Medial-Distal & 3 & 0.40 & $11 / 3 / 2015$ & $\mathrm{BN} / \mathrm{CS}$ \\
\hline $41 \mathrm{CS} 55$ & 1 & 113 & 113.05 & TU 2 & 1 & 1 & $12-25 \mathrm{cmbd}$ & Flake, Thinning, chert; >1/2", Complete & 1 & 0.47 & $11 / 3 / 2015$ & $\mathrm{BN} / \mathrm{CS}$ \\
\hline $41 \mathrm{CS} 55$ & 1 & 113 & 113.06 & TU 2 & 1 & 1 & $12-25 \mathrm{cmbd}$ & Flake, Thinning, chert; >1/2", Medial-Distal & 1 & 0.68 & $11 / 3 / 2015$ & $\mathrm{BN} / \mathrm{CS}$ \\
\hline $41 \mathrm{CS} 55$ & 1 & 113 & 113.07 & TU 2 & I & 1 & $12-25 \mathrm{cmbd}$ & Flake, Thinning, chert; >1/4", Medial-Distal & 3 & 1.14 & $11 / 3 / 2015$ & $\mathrm{BN} / \mathrm{CS}$ \\
\hline $41 \mathrm{CS} 55$ & 1 & 113 & 113.08 & TU 2 & 1 & 1 & $12-25 \mathrm{cmbd}$ & $\begin{array}{l}\text { Aboriginal ceramic, plain, grog/clay temper; } \\
\text { body }\end{array}$ & 4 & 13.96 & $11 / 3 / 2015$ & $\mathrm{BN} / \mathrm{CS}$ \\
\hline $41 \mathrm{CS} 55$ & 1 & 113 & 113.09 & TU 2 & 1 & 1 & $12-25 \mathrm{cmbd}$ & Animal bone & 1 & 0.26 & $11 / 3 / 2015$ & $\mathrm{BN} / \mathrm{CS}$ \\
\hline
\end{tabular}




\begin{tabular}{|c|c|c|c|c|c|c|c|c|c|c|c|c|}
\hline $\begin{array}{c}\text { Site } \\
\#\end{array}$ & $\begin{array}{c}\text { FS } \\
\#\end{array}$ & LS\# & $\begin{array}{c}\text { Catalog } \\
\#\end{array}$ & Prov. & $\begin{array}{c}\text { Strat } \\
\text { a }\end{array}$ & $\begin{array}{c}\text { Leve } \\
1\end{array}$ & Depth & Description & Count & $\begin{array}{c}\text { Weight } \\
\text { (g) }\end{array}$ & $\begin{array}{c}\text { Date } \\
\text { Excavated }\end{array}$ & Exc/Rec \\
\hline $41 \mathrm{CS} 55$ & 1 & 113 & 113.10 & TU 2 & I & 1 & $12-25 \mathrm{cmbd}$ & Seed, other & 1 & 0.51 & $11 / 3 / 2015$ & $\mathrm{BN} / \mathrm{CS}$ \\
\hline $41 \mathrm{CS} 55$ & 1 & 113 & 113.11 & TU 2 & I & 1 & $12-25 \mathrm{cmbd}$ & Possible cultural material-lithic, other & 1 & 2.37 & $11 / 3 / 2015$ & $\mathrm{BN} / \mathrm{CS}$ \\
\hline $41 \mathrm{CS} 55$ & 1 & 114 & 114.01 & TU 3 & & & Surface & $\begin{array}{l}\text { Aboriginal ceramic, plain, grog/clay temper; } \\
\text { body; sherds mend, possible shoulder }\end{array}$ & 2 & 2.68 & $11 / 3 / 2015$ & $\mathrm{JTS} / \mathrm{JMS}$ \\
\hline $41 \mathrm{CS} 55$ & 1 & 114 & 114.02 & TU 3 & & & Surface & Uid aboriginal ceramic, less than $1 / 2$ inch & 1 & 0.25 & $11 / 3 / 2015$ & JTS/JMS \\
\hline $41 \mathrm{CS} 55$ & 2 & 115 & 115.01 & TU 3 & I & 1 & $10-20 \mathrm{cmbd}$ & Flake, Thinning; Late, chert; $>1 / 2 "$, Complete & 1 & 0.36 & $11 / 3 / 2015$ & $\mathrm{JTS} / \mathrm{JMS}$ \\
\hline $41 \mathrm{CS} 55$ & 2 & 115 & 115.02 & TU 3 & 1 & 1 & $10-20 \mathrm{cmbd}$ & Flake, Thinning, chert; $>1 / 2 "$, Complete & 2 & 1.36 & $11 / 3 / 2015$ & JTS/JMS \\
\hline $41 \mathrm{CS} 55$ & 2 & 115 & 115.03 & TU 3 & I & 1 & $10-20 \mathrm{cmbd}$ & Flake, Thinning, chert; $>1 / 2 "$, Complete & 1 & 0.84 & $11 / 3 / 2015$ & JTS/JMS \\
\hline $41 \mathrm{CS} 55$ & 2 & 115 & 115.04 & TU 3 & 1 & 1 & $10-20 \mathrm{cmbd}$ & Flake, Thinning, chert; >1/2", Medial-Distal & 1 & 0.99 & $11 / 3 / 2015$ & JTS/JMS \\
\hline $41 \mathrm{CS} 55$ & 2 & 115 & 115.05 & TU 3 & 1 & 1 & $10-20 \mathrm{cmbd}$ & Flake, Thinning, chert; >1/2", Medial-Distal & 1 & 1.36 & $11 / 3 / 2015$ & JTS/JMS \\
\hline $41 \mathrm{CS} 55$ & 2 & 115 & 115.06 & TU 3 & I & 1 & $10-20 \mathrm{cmbd}$ & Flake, Thinning, chert; $>1 / 2 "$, Complete & 3 & 2.42 & $11 / 3 / 2015$ & $\mathrm{JTS} / \mathrm{JMS}$ \\
\hline $41 \mathrm{CS} 55$ & 2 & 115 & 115.07 & TU 3 & 1 & 1 & $10-20 \mathrm{cmbd}$ & Flake, Thinning, chert; >1/2", Proximal & 2 & 0.68 & $11 / 3 / 2015$ & JTS/JMS \\
\hline $41 \mathrm{CS} 55$ & 2 & 115 & 115.08 & TU 3 & 1 & 1 & $10-20 \mathrm{cmbd}$ & Flake, Thinning, chert; >1/2", Medial-Distal & 2 & 0.93 & $11 / 3 / 2015$ & JTS/JMS \\
\hline $41 \mathrm{CS} 55$ & 2 & 115 & 115.09 & TU 3 & 1 & 1 & $10-20 \mathrm{cmbd}$ & Flake, Early Reduction, chert; >1", Complete & 1 & 3.09 & $11 / 3 / 2015$ & JTS/JMS \\
\hline $41 \mathrm{CS} 55$ & 2 & 115 & 115.10 & TU 3 & I & 1 & $10-20 \mathrm{cmbd}$ & Flake, Thinning; Late, chert; >1/4", Complete & 3 & 0.55 & $11 / 3 / 2015$ & JTS/JMS \\
\hline $41 \mathrm{CS} 55$ & 2 & 115 & 115.11 & TU 3 & 1 & 1 & $10-20 \mathrm{cmbd}$ & Flake, Thinning; Late, chert; $>1 / 4 "$ ", Complete & 1 & 0.14 & $11 / 3 / 2015$ & $\mathrm{JTS} / \mathrm{JMS}$ \\
\hline $41 \mathrm{CS} 55$ & 2 & 115 & 115.12 & TU 3 & 1 & 1 & $10-20 \mathrm{cmbd}$ & Flake, Thinning; Late, chert; $>1 / 4 "$, Complete & 7 & 0.76 & $11 / 3 / 2015$ & $\mathrm{JTS} / \mathrm{JMS}$ \\
\hline $41 \mathrm{CS} 55$ & 2 & 115 & 115.13 & TU 3 & 1 & 1 & $10-20 \mathrm{cmbd}$ & Flake, Thinning; Late, chert; >1/4", Proximal & 1 & 0.19 & $11 / 3 / 2015$ & JTS/JMS \\
\hline $41 \mathrm{CS} 55$ & 2 & 115 & 115.14 & TU 3 & 1 & 1 & $10-20 \mathrm{cmbd}$ & Flake, Thinning; Late, chert; >1/4", Proximal & 1 & 0.23 & $11 / 3 / 2015$ & JTS/JMS \\
\hline $41 \mathrm{CS} 55$ & 2 & 115 & 115.15 & TU 3 & I & 1 & $10-20 \mathrm{cmbd}$ & Flake, Thinning; Late, chert; >1/4", Proximal & 1 & 0.21 & $11 / 3 / 2015$ & $\mathrm{JTS} / \mathrm{JMS}$ \\
\hline $41 \mathrm{CS} 55$ & 2 & 115 & 115.16 & TU 3 & 1 & 1 & $10-20 \mathrm{cmbd}$ & Flake, Thinning; Late, chert; >1/4", Proximal & 4 & 0.52 & $11 / 3 / 2015$ & JTS/JMS \\
\hline $41 \mathrm{CS} 55$ & 2 & 115 & 115.17 & TU 3 & I & 1 & $10-20 \mathrm{cmbd}$ & Flake, Thinning; Late, chert; >1/4", Medial-Distal & 2 & 0.54 & $11 / 3 / 2015$ & $\mathrm{JTS} / \mathrm{JMS}$ \\
\hline $41 \mathrm{CS} 55$ & 2 & 115 & 115.18 & TU 3 & 1 & 1 & $10-20 \mathrm{cmbd}$ & $\begin{array}{l}\text { Flake, Thinning; Late, chert; >1/4", Non- } \\
\text { orientable }\end{array}$ & 6 & 0.84 & $11 / 3 / 2015$ & $\mathrm{JTS} / \mathrm{JMS}$ \\
\hline $41 \mathrm{CS} 55$ & 2 & 115 & 115.19 & TU 3 & I & 1 & $10-20 \mathrm{cmbd}$ & Flake, Thinning, chert; >1/4", Medial-Distal & 1 & 0.55 & $11 / 3 / 2015$ & JTS/JMS \\
\hline $41 \mathrm{CS} 55$ & 2 & 115 & 115.20 & TU 3 & I & 1 & $10-20 \mathrm{cmbd}$ & Shatter, Angular, chert & 6 & 4.07 & $11 / 3 / 2015$ & $\mathrm{JTS} / \mathrm{JMS}$ \\
\hline $41 \mathrm{CS} 55$ & 2 & 115 & 115.21 & TU 3 & 1 & 1 & $10-20 \mathrm{cmbd}$ & Shatter, Thermal, chert & 2 & 2.83 & $11 / 3 / 2015$ & JTS/JMS \\
\hline
\end{tabular}




\begin{tabular}{|c|c|c|c|c|c|c|c|c|c|c|c|c|}
\hline $\begin{array}{c}\text { Site } \\
\#\end{array}$ & $\begin{array}{c}\text { FS } \\
\#\end{array}$ & LS\# & $\begin{array}{c}\text { Catalog } \\
\#\end{array}$ & Prov. & $\begin{array}{c}\text { Strat } \\
\text { a }\end{array}$ & $\begin{array}{c}\text { Leve } \\
1\end{array}$ & Depth & Description & Count & $\begin{array}{c}\text { Weight } \\
\text { (g) }\end{array}$ & $\begin{array}{c}\text { Date } \\
\text { Excavated }\end{array}$ & Exc/Rec \\
\hline $41 \mathrm{CS} 55$ & 2 & 115 & 115.22 & TU 3 & I & 1 & $10-20 \mathrm{cmbd}$ & $\begin{array}{l}\text { Aboriginal ceramic, engraved, grog/bone } \\
\text { temper; body }\end{array}$ & 9 & 41.56 & $11 / 3 / 2015$ & JTS/JMS \\
\hline $41 \mathrm{CS} 55$ & 2 & 115 & 115.23 & TU 3 & I & 1 & $10-20 \mathrm{cmbd}$ & $\begin{array}{l}\text { Aboriginal ceramic, incised, grog/clay temper; } \\
\text { flared rim, flattened lip; lip notched, possible } \\
\text { fold }\end{array}$ & 1 & 2.66 & $11 / 3 / 2015$ & JTS/JMS \\
\hline $41 \mathrm{CS} 55$ & 2 & 115 & 115.24 & TU 3 & I & 1 & $10-20 \mathrm{cmbd}$ & $\begin{array}{l}\text { Aboriginal ceramic, engraved, grog/clay temper; } \\
\text { flared rim, tapered lip; one slightly curving } \\
\text { incised line paralell to the rim---and double lines } \\
\text { connected with ticks below on body, lip- } \\
\text { notched }\end{array}$ & 1 & 2.78 & $11 / 3 / 2015$ & JTS/JMS \\
\hline $41 \mathrm{CS} 55$ & 2 & 115 & 115.25 & TU 3 & I & 1 & $10-20 \mathrm{cmbd}$ & $\begin{array}{l}\text { Aboriginal ceramic, plain, grog/bone temper; } \\
\text { body }\end{array}$ & 1 & 2.17 & $11 / 3 / 2015$ & JTS/JMS \\
\hline $41 \mathrm{CS} 55$ & 2 & 115 & 115.26 & TU 3 & I & 1 & $10-20 \mathrm{cmbd}$ & $\begin{array}{l}\text { Aboriginal ceramic, engraved, grog/clay temper; } \\
\text { body; probable shoulder with parallel incised } \\
\text { lines diagonal to the curve }\end{array}$ & 1 & 5.03 & $11 / 3 / 2015$ & JTS/JMS \\
\hline $41 \mathrm{CS} 55$ & 3 & 116 & 116.01 & TU 3 & II & 1 & $20-30 \mathrm{cmbd}$ & Flake, Thinning; Late, chert; >1/4", Proximal & 1 & 0.25 & $11 / 3 / 2015$ & JTS/JMS \\
\hline $41 \mathrm{CS} 55$ & 3 & 116 & 116.02 & TU 3 & II & 1 & $20-30 \mathrm{cmbd}$ & Flake, Thinning; Late, chert; >1/4", Complete & 2 & 0.51 & $11 / 3 / 2015$ & JTS/JMS \\
\hline $41 \mathrm{CS} 55$ & 3 & 116 & 116.03 & TU 3 & II & 1 & $20-30 \mathrm{cmbd}$ & Flake, Thinning; Late, chert; >1/4", Complete & 2 & 0.66 & $11 / 3 / 2015$ & JTS/JMS \\
\hline $41 \mathrm{CS} 55$ & 3 & 116 & 116.04 & TU 3 & II & 1 & $20-30 \mathrm{cmbd}$ & Flake, Thinning, chert; $>1 / 2 "$, Complete & 1 & 0.70 & $11 / 3 / 2015$ & JTS/JMS \\
\hline $41 \mathrm{CS} 55$ & 3 & 116 & 116.05 & TU 3 & II & 1 & $20-30 \mathrm{cmbd}$ & Flake, Early Reduction, chert; $>1 / 2 "$ ", Complete & 1 & 0.88 & $11 / 3 / 2015$ & JTS/JMS \\
\hline $41 \mathrm{CS} 55$ & 3 & 116 & 116.06 & TU 3 & II & 1 & $20-30 \mathrm{cmbd}$ & Flake, Early Reduction, chert; $>1 / 4 "$, Complete & 1 & 0.97 & $11 / 3 / 2015$ & JTS/JMS \\
\hline $41 \mathrm{CS} 55$ & 4 & 117 & 117.01 & TU 3 & III & 2 & $40-50 \mathrm{cmbd}$ & Bifacial chopping/cutting tool, chert & 1 & 34.08 & $11 / 4 / 2015$ & JTS/JMS \\
\hline $41 \mathrm{CS} 55$ & 4 & 117 & 117.02 & TU 3 & III & 2 & $40-50 \mathrm{cmbd}$ & Flake, Thinning; Late, chert; $>1 / 4 "$ ", Complete & 1 & 0.15 & $11 / 4 / 2015$ & JTS/JMS \\
\hline $41 \mathrm{CS} 55$ & 4 & 117 & 117.03 & TU 3 & III & 2 & $40-50 \mathrm{cmbd}$ & Flake, Thinning, chert; $>1 / 2 "$, Complete & 1 & 1.25 & $11 / 4 / 2015$ & JTS/JMS \\
\hline $41 \mathrm{CS} 55$ & 4 & 117 & 117.04 & TU 3 & III & 2 & $40-50 \mathrm{cmbd}$ & Flake, Thinning, chert; $>1 / 2 "$, Complete & 1 & 2.65 & $11 / 4 / 2015$ & JTS/JMS \\
\hline $41 \mathrm{CS} 55$ & 4 & 117 & 117.05 & TU 3 & III & 2 & $40-50 \mathrm{cmbd}$ & Flake, core reduction, chert; $>1 / 2 "$, Complete & 1 & 1.91 & $11 / 4 / 2015$ & JTS/JMS \\
\hline $41 \mathrm{CS} 55$ & 5 & 118 & 118.01 & TU 3 & III & 3 & $50-60 \mathrm{cmbd}$ & Flake, Early Reduction, chert; >1", Medial-Distal & 1 & 5.68 & $11 / 4 / 2015$ & JTS/JMS \\
\hline $41 \mathrm{CS} 55$ & 1 & 119 & 119.01 & TU 4 & & & Surface & Flake, Thinning; Late, chert; >1/4", Complete & 2 & 0.26 & $11 / 3 / 2015$ & SPF/EA \\
\hline $41 \mathrm{CS} 55$ & 1 & 119 & 119.02 & TU 4 & & & Surface & Flake, Thinning; Late, chert; >1/4", Proximal & 3 & 0.47 & $11 / 3 / 2015$ & SPF/EA \\
\hline
\end{tabular}




\begin{tabular}{|c|c|c|c|c|c|c|c|c|c|c|c|c|}
\hline $\begin{array}{c}\text { Site } \\
\#\end{array}$ & $\begin{array}{l}\text { FS } \\
\# \\
\end{array}$ & LS\# & $\begin{array}{c}\text { Catalog } \\
\# \\
\end{array}$ & Prov. & $\begin{array}{c}\text { Strat } \\
\text { a }\end{array}$ & $\begin{array}{c}\text { Leve } \\
\text { I }\end{array}$ & Depth & Description & Count & $\begin{array}{c}\text { Weight } \\
\text { (g) }\end{array}$ & $\begin{array}{c}\text { Date } \\
\text { Excavated }\end{array}$ & Exc/Rec \\
\hline $41 \mathrm{CS} 55$ & 1 & 119 & 119.03 & TU 4 & & & Surface & Flake, Thinning; Late, chert; >1/4", Medial-Distal & 1 & 0.19 & $11 / 3 / 2015$ & SPF/EA \\
\hline $41 \mathrm{CS} 55$ & 1 & 119 & 119.04 & TU 4 & & & Surface & Flake, Thinning, chert; >1/2", Medial-Distal & 1 & 1.30 & $11 / 3 / 2015$ & SPF/EA \\
\hline $41 \mathrm{CS} 55$ & 1 & 119 & 119.05 & TU 4 & & & Surface & Flake, Early Reduction, chert; >1/2", Complete & 1 & 0.93 & $11 / 3 / 2015$ & SPF/EA \\
\hline $41 \mathrm{CS} 55$ & 1 & 119 & 119.06 & TU 4 & & & Surface & Flake, Early Reduction, chert; >1/2", Proximal & 1 & 1.88 & $11 / 3 / 2015$ & SPF/EA \\
\hline $41 \mathrm{CS} 55$ & 1 & 119 & 119.07 & TU 4 & & & Surface & Shatter, Thermal, chert & 2 & 4.61 & $11 / 3 / 2015$ & SPF/EA \\
\hline $41 \mathrm{CS} 55$ & 1 & 119 & 119.08 & TU 4 & & & Surface & Unmodified stone, other & 1 & 0.88 & $11 / 3 / 2015$ & SPF/EA \\
\hline $41 \mathrm{CS} 55$ & 1 & 119 & 119.09 & TU 4 & & & Surface & $\begin{array}{l}\text { Aboriginal ceramic, plain, grog/clay temper; } \\
\text { body }\end{array}$ & 9 & 25.84 & $11 / 3 / 2015$ & SPF/EA \\
\hline $41 \mathrm{CS} 55$ & 1 & 119 & 119.10 & TU 4 & & & Surface & $\begin{array}{l}\text { Aboriginal ceramic, plain, grog/clay temper; } \\
\text { body; } 2 \text { sherds mend, heavy grog temper }\end{array}$ & 7 & 29.57 & $11 / 3 / 2015$ & SPF/EA \\
\hline $41 \mathrm{CS} 55$ & 1 & 119 & 119.11 & TU 4 & & & Surface & $\begin{array}{l}\text { Aboriginal ceramic, plain, grog/clay temper; } \\
\text { incurvate rim, tapered lip; carinated rim with } \\
\text { scalloped lip }\end{array}$ & 1 & 6.69 & $11 / 3 / 2015$ & SPF/EA \\
\hline $41 \mathrm{CS} 55$ & 1 & 119 & 119.12 & TU 4 & & & Surface & $\begin{array}{l}\text { Aboriginal ceramic, applique on body, grog/clay } \\
\text { temper; body }\end{array}$ & 1 & 11.69 & $11 / 3 / 2015$ & SPF/EA \\
\hline $41 \mathrm{CS} 55$ & 1 & 119 & 119.13 & TU 4 & & & Surface & $\begin{array}{l}\text { Aboriginal ceramic, engraved, grog/clay temper; } \\
\text { body }\end{array}$ & 1 & 4.36 & $11 / 3 / 2015$ & SPF/EA \\
\hline $41 \mathrm{CS} 55$ & 1 & 119 & 119.14 & TU 4 & & & Surface & Uid aboriginal ceramic, less than $1 / 2$ inch & 7 & 2.98 & $11 / 3 / 2015$ & SPF/EA \\
\hline $41 \mathrm{CS} 55$ & 1 & 119 & 119.15 & TU 4 & & & Surface & $\begin{array}{l}\text { Aboriginal ceramic, plain, grog/clay temper; } \\
\text { body; sherds mend }\end{array}$ & 3 & 3.79 & $11 / 3 / 2015$ & SPF/EA \\
\hline $41 \mathrm{CS} 55$ & 2 & 120 & 120.01 & TU 4 & 1 & 1 & $10-15 \mathrm{cmbd}$ & Flake, Thinning; Late, chert; >1/4", Medial-Distal & 2 & 0.26 & $11 / 3 / 2015$ & SPF/EA \\
\hline $41 \mathrm{CS} 55$ & 2 & 120 & 120.02 & TU 4 & 1 & 1 & $10-15 \mathrm{cmbd}$ & Flake, Thinning; Late, chert; $>1 / 4 "$, Complete & 4 & 0.32 & $11 / 3 / 2015$ & SPF/EA \\
\hline $41 \mathrm{CS} 55$ & 2 & 120 & 120.03 & TU 4 & I & 1 & $10-15 \mathrm{cmbd}$ & Flake, Thinning; Late, chert; >1/4", Medial-Distal & 2 & 0.22 & $11 / 3 / 2015$ & SPF/EA \\
\hline $41 \mathrm{CS} 55$ & 2 & 120 & 120.04 & TU 4 & 1 & 1 & $10-15 \mathrm{cmbd}$ & $\begin{array}{l}\text { Flake, Thinning; Late, chert; >1/4", Non- } \\
\text { orientable }\end{array}$ & 2 & 0.04 & $11 / 3 / 2015$ & SPF/EA \\
\hline $41 \mathrm{CS} 55$ & 2 & 120 & 120.05 & TU 4 & I & 1 & $10-15 \mathrm{cmbd}$ & Flake, Thinning; Late, chert; >1/4", Medial-Distal & 1 & 0.10 & $11 / 3 / 2015$ & SPF/EA \\
\hline $41 \mathrm{CS} 55$ & 2 & 120 & 120.06 & TU 4 & I & 1 & $10-15 \mathrm{cmbd}$ & Flake, Thinning; Late, chert; >1/4", Medial-Distal & 1 & 0.36 & $11 / 3 / 2015$ & SPF/EA \\
\hline $41 \mathrm{CS} 55$ & 2 & 120 & 120.07 & TU 4 & I & 1 & $10-15 \mathrm{cmbd}$ & Flake, Thinning; Late, chert; >1/4", Complete & 2 & 0.56 & $11 / 3 / 2015$ & SPF/EA \\
\hline
\end{tabular}




\begin{tabular}{|c|c|c|c|c|c|c|c|c|c|c|c|c|}
\hline $\begin{array}{c}\text { Site } \\
\#\end{array}$ & $\begin{array}{c}\text { FS } \\
\#\end{array}$ & LS\# & $\begin{array}{c}\text { Catalog } \\
\#\end{array}$ & Prov. & $\begin{array}{c}\text { Strat } \\
\text { a }\end{array}$ & $\begin{array}{c}\text { Leve } \\
1\end{array}$ & Depth & Description & Count & $\begin{array}{c}\text { Weight } \\
\text { (g) }\end{array}$ & $\begin{array}{c}\text { Date } \\
\text { Excavated }\end{array}$ & Exc/Rec \\
\hline $41 \mathrm{CS} 55$ & 2 & 120 & 120.08 & TU 4 & I & 1 & $10-15 \mathrm{cmbd}$ & $\begin{array}{l}\text { Flake, Thinning; Late, chert; >1/4", Non- } \\
\text { orientable }\end{array}$ & 1 & 0.23 & $11 / 3 / 2015$ & SPF/EA \\
\hline $41 \mathrm{CS} 55$ & 2 & 120 & 120.09 & TU 4 & I & 1 & $10-15 \mathrm{cmbd}$ & Flake, Thinning, chert; $>1 / 2 "$, Complete & 1 & 0.48 & $11 / 3 / 2015$ & SPF/EA \\
\hline $41 \mathrm{CS} 55$ & 2 & 120 & 120.10 & TU 4 & I & 1 & $10-15 \mathrm{cmbd}$ & Flake, Thinning, chert; $>1 / 2 "$, Complete & 1 & 0.55 & $11 / 3 / 2015$ & SPF/EA \\
\hline $41 \mathrm{CS} 55$ & 2 & 120 & 120.11 & TU 4 & I & 1 & $10-15 \mathrm{cmbd}$ & Flake, Thinning, chert; $>1 / 2 "$, Proximal & 1 & 0.28 & $11 / 3 / 2015$ & SPF/EA \\
\hline $41 \mathrm{CS} 55$ & 2 & 120 & 120.12 & TU 4 & I & 1 & $10-15 \mathrm{cmbd}$ & Flake, Thinning, chert; >1/2", Medial-Distal & 1 & 0.63 & $11 / 3 / 2015$ & SPF/EA \\
\hline $41 \mathrm{CS} 55$ & 2 & 120 & 120.13 & TU 4 & I & 1 & $10-15 \mathrm{cmbd}$ & Flake, Thinning, chert; $>1 / 2 "$, Complete & 3 & 1.76 & $11 / 3 / 2015$ & SPF/EA \\
\hline $41 \mathrm{CS} 55$ & 2 & 120 & 120.14 & TU 4 & I & 1 & $10-15 \mathrm{cmbd}$ & Flake, Thinning, chert; $>1 / 2 "$, Proximal & 2 & 0.67 & $11 / 3 / 2015$ & SPF/EA \\
\hline $41 \mathrm{CS} 55$ & 2 & 120 & 120.15 & TU 4 & 1 & 1 & $10-15 \mathrm{cmbd}$ & Flake, Thinning, chert; >1/2", Medial-Distal & 2 & 1.13 & $11 / 3 / 2015$ & SPF/EA \\
\hline $41 \mathrm{CS} 55$ & 2 & 120 & 120.16 & TU 4 & I & 1 & $10-15 \mathrm{cmbd}$ & Flake, Early Reduction, chert; $>1 / 2 "$, Complete & 1 & 1.47 & $11 / 3 / 2015$ & SPF/EA \\
\hline $41 \mathrm{CS} 55$ & 2 & 120 & 120.17 & TU 4 & I & 1 & $10-15 \mathrm{cmbd}$ & Shatter, Angular, chert & 7 & 3.68 & $11 / 3 / 2015$ & SPF/EA \\
\hline $41 \mathrm{CS} 55$ & 2 & 120 & 120.18 & TU 4 & I & 1 & $10-15 \mathrm{cmbd}$ & Shatter, Thermal, chert & 2 & 2.15 & $11 / 3 / 2015$ & SPF/EA \\
\hline $41 \mathrm{CS} 55$ & 2 & 120 & 120.19 & TU 4 & I & 1 & $10-15 \mathrm{cmbd}$ & Unmodified stone, other & 1 & 0.11 & $11 / 3 / 2015$ & SPF/EA \\
\hline $41 \mathrm{CS} 55$ & 2 & 120 & 120.20 & TU 4 & I & 1 & $10-15 \mathrm{cmbd}$ & $\begin{array}{l}\text { Aboriginal ceramic, incised, grog/clay temper; } \\
\text { body }\end{array}$ & 5 & 15.79 & $11 / 3 / 2015$ & SPF/EA \\
\hline $41 \mathrm{CS} 55$ & 2 & 120 & 120.21 & TU 4 & 1 & 1 & $10-15 \mathrm{cmbd}$ & $\begin{array}{l}\text { Aboriginal ceramic, plain, grog/clay temper; } \\
\text { body; sherds mend }\end{array}$ & 5 & 2.26 & $11 / 3 / 2015$ & SPF/EA \\
\hline $41 \mathrm{CS} 55$ & 2 & 120 & 120.22 & TU 4 & I & 1 & $10-15 \mathrm{cmbd}$ & $\begin{array}{l}\text { Aboriginal ceramic, plain, grog/bone temper; } \\
\text { body }\end{array}$ & 1 & 2.30 & $11 / 3 / 2015$ & SPF/EA \\
\hline $41 \mathrm{CS} 55$ & 2 & 120 & 120.23 & TU 4 & I & 1 & $10-15 \mathrm{cmbd}$ & $\begin{array}{l}\text { Aboriginal ceramic, plain, grit/grog temper; } \\
\text { body }\end{array}$ & 1 & 2.39 & $11 / 3 / 2015$ & SPF/EA \\
\hline $41 \mathrm{CS} 55$ & 2 & 120 & 120.24 & TU 4 & I & 1 & $10-15 \mathrm{cmbd}$ & $\begin{array}{l}\text { Aboriginal ceramic, incised, grog/clay temper; } \\
\text { everted rim, folded lip; lip-notched, vertical } \\
\text { incised decoration on rim }\end{array}$ & 1 & 2.52 & $11 / 3 / 2015$ & SPF/EA \\
\hline $41 \mathrm{CS} 55$ & 2 & 120 & 120.25 & TU 4 & I & 1 & $10-15 \mathrm{cmbd}$ & Animal bone; carapace/plastron & 2 & 1.48 & $11 / 3 / 2015$ & SPF/EA \\
\hline $41 \mathrm{CS} 55$ & 3 & 121 & 121.01 & TU 4 & II & & $15-30 \mathrm{cmbd}$ & Flake, Unspecified, chert; $>1 / 4 "$ ", Complete & 1 & 0.14 & $11 / 3 / 2015$ & SPF/EA \\
\hline $41 \mathrm{CS} 55$ & 3 & 121 & 121.02 & TU 4 & II & & $15-30 \mathrm{cmbd}$ & Flake, Early Reduction, chert; $>1 / 2 "$, Complete & 1 & 1.12 & $11 / 3 / 2015$ & SPF/EA \\
\hline $41 \mathrm{CS} 55$ & 3 & 121 & 121.03 & TU 4 & II & & $15-30 \mathrm{cmbd}$ & Flake, Thinning; Late, chert; >1/4", Complete & 3 & 0.48 & $11 / 3 / 2015$ & SPF/EA \\
\hline
\end{tabular}




\begin{tabular}{|c|c|c|c|c|c|c|c|c|c|c|c|c|}
\hline $\begin{array}{c}\text { Site } \\
\#\end{array}$ & $\begin{array}{c}\text { FS } \\
\#\end{array}$ & LS\# & $\begin{array}{c}\text { Catalog } \\
\#\end{array}$ & Prov. & $\begin{array}{c}\text { Strat } \\
\text { a }\end{array}$ & $\begin{array}{c}\text { Leve } \\
1\end{array}$ & Depth & Description & Count & $\begin{array}{l}\text { Weight } \\
\text { (g) }\end{array}$ & $\begin{array}{c}\text { Date } \\
\text { Excavated }\end{array}$ & Exc/Rec \\
\hline $41 \mathrm{CS} 55$ & 3 & 121 & 121.04 & TU 4 & II & & $15-30 \mathrm{cmbd}$ & Flake, Thinning; Late, chert; $>1 / 8$, Complete & 1 & 0.03 & $11 / 3 / 2015$ & SPF/EA \\
\hline $41 \mathrm{CS} 55$ & 4 & 122 & 122.01 & TU 4 & II & 1 & $30-40 \mathrm{cmbd}$ & Flake, Thinning, chert; $>1 / 2 "$, Complete & 1 & 0.33 & $11 / 4 / 2015$ & SPF/MMM \\
\hline $41 \mathrm{CS} 55$ & 4 & 122 & 122.02 & TU 4 & II & 1 & $30-40 \mathrm{cmbd}$ & Shatter, Angular, chert & 4 & 13.15 & $11 / 4 / 2015$ & SPF/MMM \\
\hline $41 \mathrm{CS} 55$ & 4 & 122 & 122.03 & TU 4 & II & 1 & $30-40 \mathrm{cmbd}$ & Charcoal & & 0.06 & $11 / 4 / 2015$ & SPF/MMM \\
\hline $41 \mathrm{CS} 55$ & 5 & 123 & 123.01 & TU 4 & II & $1 / 2$ & $20-40 \mathrm{cmbd}$ & Flake, Early Reduction, chert; $>1 / 2 "$, Complete & 1 & 1.95 & $11 / 4 / 2015$ & SPF/MMM \\
\hline $41 \mathrm{CS} 55$ & 5 & 123 & 123.02 & TU 4 & II & $1 / 2$ & $20-40 \mathrm{cmbd}$ & Shatter, Angular, chert & 1 & 2.94 & $11 / 4 / 2015$ & SPF/MMM \\
\hline $41 \mathrm{CS} 55$ & 6 & 124 & 124.01 & TU 4 & II & 3 & $40-50 \mathrm{cmbd}$ & Flake, Thinning, chert; >1/2", Complete & 1 & 0.94 & $11 / 4 / 2015$ & SPF/MMM \\
\hline $41 \mathrm{CS} 55$ & 6 & 124 & 124.02 & TU 4 & II & 3 & $40-50 \mathrm{cmbd}$ & Flake, Thinning, chert; $>1 / 4 "$, Proximal & 1 & 0.44 & $11 / 4 / 2015$ & SPF/MMM \\
\hline $41 \mathrm{CS} 55$ & 7 & 125 & 125.01 & TU 4 & III & 1 & $50-60 \mathrm{cmbd}$ & Flake, Thinning; Late, chert; >1/8, Complete & 1 & 0.06 & $11 / 4 / 2015$ & SPF/MMM \\
\hline $41 \mathrm{CS} 55$ & 7 & 125 & 125.02 & TU 4 & III & 1 & $50-60 \mathrm{cmbd}$ & Flake, Thinning; Late, chert; $>1 / 4 "$ ", Complete & 2 & 0.41 & $11 / 4 / 2015$ & SPF/MMM \\
\hline $41 \mathrm{CS} 55$ & 7 & 125 & 125.03 & TU 4 & III & 1 & $50-60 \mathrm{cmbd}$ & Flake, Thinning, chert; >1/2", Complete & 1 & 1.26 & $11 / 4 / 2015$ & SPF/MMM \\
\hline $41 \mathrm{CS} 55$ & 7 & 125 & 125.04 & TU 4 & III & 1 & $50-60 \mathrm{cmbd}$ & Flake, Early Reduction, chert; >1/2", Complete & 1 & 3.38 & $11 / 4 / 2015$ & SPF/MMM \\
\hline $41 \mathrm{CS} 55$ & 7 & 125 & 125.05 & TU 4 & III & 1 & $50-60 \mathrm{cmbd}$ & $\begin{array}{l}\text { Flake, Unspecified, quartzite/sandstone; >1/4", } \\
\text { unknown }\end{array}$ & 1 & 0.38 & $11 / 4 / 2015$ & SPF/MMM \\
\hline $41 \mathrm{CS} 55$ & 7 & 125 & 125.06 & TU 4 & III & 1 & $50-60 \mathrm{cmbd}$ & $\begin{array}{l}\text { Aboriginal ceramic, engraved, grog/clay temper; } \\
\text { body; possible paint or slip; parallel, widely- } \\
\text { spaced lines }\end{array}$ & 1 & 9.08 & $11 / 4 / 2015$ & SPF/MMM \\
\hline $41 \mathrm{CS} 55$ & 7 & 125 & 125.07 & TU 4 & III & 1 & $50-60 \mathrm{cmbd}$ & PPK Preform, Early stage, chert & 1 & 12.03 & $11 / 4 / 2015$ & SPF/MMM \\
\hline $41 \mathrm{CS} 55$ & 1 & 126 & 126.01 & TU 5 & $1 / 11$ & 1 & $9-20 \mathrm{cmbd}$ & Flake, Thinning; Late, chert; >1/4", Proximal & 1 & 0.25 & $11 / 3 / 2015$ & $\mathrm{MRM} / \mathrm{RT} / \mathrm{SE}$ \\
\hline $41 \mathrm{CS} 55$ & 1 & 126 & 126.02 & TU 5 & $1 / I I$ & 1 & $9-20 \mathrm{cmbd}$ & Flake, Thinning; Late, chert; >1/4", Medial-Distal & 3 & 0.48 & $11 / 3 / 2015$ & $\mathrm{MRM} / \mathrm{RT} / \mathrm{SE}$ \\
\hline $41 \mathrm{CS} 55$ & 1 & 126 & 126.03 & TU 5 & $1 / 11$ & 1 & $9-20 \mathrm{cmbd}$ & Flake, Thinning, chert; $>1 / 2 "$, Complete & 1 & 1.04 & $11 / 3 / 2015$ & $\mathrm{MRM} / \mathrm{RT} / \mathrm{SE}$ \\
\hline $41 \mathrm{CS} 55$ & 1 & 126 & 126.04 & TU 5 & $1 / 11$ & 1 & $9-20 \mathrm{cmbd}$ & Flake, Thinning, chert; >1/2", Medial-Distal & 1 & 0.80 & $11 / 3 / 2015$ & $\mathrm{MRM} / \mathrm{RT} / \mathrm{SE}$ \\
\hline $41 \mathrm{CS} 55$ & 1 & 126 & 126.05 & TU 5 & $1 / 11$ & 1 & $9-20 \mathrm{cmbd}$ & Flake, Thinning, chert; >1/2", Complete & 1 & 0.91 & $11 / 3 / 2015$ & MRM/RT/SE \\
\hline $41 \mathrm{CS} 55$ & 1 & 126 & 126.06 & TU 5 & $1 / 11$ & 1 & $9-20 \mathrm{cmbd}$ & Flake, Thinning, chert; >1/2", Proximal & 1 & 1.16 & $11 / 3 / 2015$ & $\mathrm{MRM} / \mathrm{RT} / \mathrm{SE}$ \\
\hline $41 \mathrm{CS} 55$ & 1 & 126 & 126.07 & TU 5 & $1 / 11$ & 1 & $9-20 \mathrm{cmbd}$ & Biface fragment, chert & 1 & 1.00 & $11 / 3 / 2015$ & $\mathrm{MRM} / \mathrm{RT} / \mathrm{SE}$ \\
\hline $41 \mathrm{CS} 55$ & 1 & 126 & 126.08 & TU 5 & $I / I I$ & 1 & $9-20 \mathrm{cmbd}$ & $\begin{array}{l}\text { Aboriginal ceramic, plain, grog/clay temper; } \\
\text { body }\end{array}$ & 4 & 10.06 & $11 / 3 / 2015$ & $\mathrm{MRM} / \mathrm{RT} / \mathrm{SE}$ \\
\hline
\end{tabular}




\begin{tabular}{|c|c|c|c|c|c|c|c|c|c|c|c|c|}
\hline $\begin{array}{c}\text { Site } \\
\#\end{array}$ & $\begin{array}{c}\text { FS } \\
\# \\
\end{array}$ & LS\# & $\begin{array}{c}\text { Catalog } \\
\quad \#\end{array}$ & Prov. & $\begin{array}{c}\text { Strat } \\
\text { a }\end{array}$ & $\begin{array}{c}\text { Leve } \\
\text { I }\end{array}$ & Depth & Description & Count & $\begin{array}{l}\text { Weight } \\
\text { (g) }\end{array}$ & $\begin{array}{c}\text { Date } \\
\text { Excavated }\end{array}$ & Exc/Rec \\
\hline $41 \mathrm{CS} 55$ & 1 & 126 & 126.09 & TU 5 & $1 / I 1$ & 1 & $9-20 \mathrm{cmbd}$ & $\begin{array}{l}\text { Aboriginal ceramic, plain, grog/bone temper; } \\
\text { body }\end{array}$ & 1 & 1.95 & $11 / 3 / 2015$ & $\mathrm{MRM} / \mathrm{RT} / \mathrm{SE}$ \\
\hline $41 \mathrm{CS} 55$ & 2 & 127 & 127.01 & TU 5 & II & 2 & $20-30 \mathrm{cmbd}$ & Flake, Thinning; Late, chert; >1/2", Proximal & 1 & 0.95 & $11 / 3 / 2015$ & $\mathrm{MRM} / \mathrm{RT} / \mathrm{SE}$ \\
\hline $41 \mathrm{CS} 55$ & 2 & 127 & 127.02 & TU 5 & II & 2 & $20-30 \mathrm{cmbd}$ & Flake, Thinning; Late, chert; >1/2", Complete & 1 & 0.29 & $11 / 3 / 2015$ & $\mathrm{MRM} / \mathrm{RT} / \mathrm{SE}$ \\
\hline $41 \mathrm{CS} 55$ & 2 & 127 & 127.03 & TU 5 & II & 2 & $20-30 \mathrm{cmbd}$ & Flake, Thinning; Late, chert; >1/2", Complete & 1 & 0.55 & $11 / 3 / 2015$ & $\mathrm{MRM} / \mathrm{RT} / \mathrm{SE}$ \\
\hline $41 \mathrm{CS} 55$ & 2 & 127 & 127.04 & TU 5 & II & 2 & $20-30 \mathrm{cmbd}$ & Flake, Thinning, chert; $>1 / 2 "$, Complete & 1 & 1.00 & $11 / 3 / 2015$ & $\mathrm{MRM} / \mathrm{RT} / \mathrm{SE}$ \\
\hline $41 \mathrm{CS} 55$ & 2 & 127 & 127.05 & TU 5 & II & 2 & $20-30 \mathrm{cmbd}$ & Flake, Thinning; Late, chert; >1/4", Proximal & 1 & 0.42 & $11 / 3 / 2015$ & $\mathrm{MRM} / \mathrm{RT} / \mathrm{SE}$ \\
\hline $41 \mathrm{CS} 55$ & 2 & 127 & 127.06 & TU 5 & II & 2 & $20-30 \mathrm{cmbd}$ & Flake, Thinning, chert; >1/4", Medial-Distal & 1 & 0.30 & $11 / 3 / 2015$ & $\mathrm{MRM} / \mathrm{RT} / \mathrm{SE}$ \\
\hline $41 \mathrm{CS} 55$ & 2 & 127 & 127.07 & TU 5 & II & 2 & $20-30 \mathrm{cmbd}$ & Flake, core reduction, chert; >1/2", Complete & 1 & 1.45 & $11 / 3 / 2015$ & MRM/RT/SE \\
\hline $41 \mathrm{CS} 55$ & 2 & 127 & 127.08 & TU 5 & II & 2 & $20-30 \mathrm{cmbd}$ & $\begin{array}{l}\text { Flake, Utilized, chert; }>1 " \text {, Complete; some } \\
\text { usewear visible on the ventral side }\end{array}$ & 1 & 17.49 & $11 / 3 / 2015$ & $\mathrm{MRM} / \mathrm{RT} / \mathrm{SE}$ \\
\hline $41 \mathrm{CS} 55$ & 3 & 128 & 128.01 & TU 5 & II & 3 & $30-40 \mathrm{cmbd}$ & Flake, Early Reduction, chert; >1/2", Complete & 1 & 2.23 & $11 / 3 / 2015$ & $\mathrm{MRM} / \mathrm{RT} / \mathrm{SE}$ \\
\hline $41 \mathrm{CS} 55$ & 3 & 128 & 128.02 & TU 5 & II & 3 & $30-40 \mathrm{cmbd}$ & $\begin{array}{l}\text { PPK fragment, chert; stem snapped; appears } \\
\text { reutilized as a drill }\end{array}$ & 1 & 6.50 & $11 / 3 / 2015$ & $\mathrm{MRM} / \mathrm{RT} / \mathrm{SE}$ \\
\hline $41 \mathrm{CS} 55$ & 4 & 129 & 129.01 & TU 5 & II & 4 & $40-51 \mathrm{cmbd}$ & Flake, Thinning, chert; $>1 / 2 "$, Complete & 1 & 0.56 & $11 / 3 / 2015$ & $\mathrm{MRM} / \mathrm{RT} / \mathrm{SE}$ \\
\hline $41 \mathrm{CS} 55$ & 4 & 129 & 129.02 & TU 5 & II & 4 & $40-51 \mathrm{cmbd}$ & Flake, Thinning, chert; >1/2", Complete & 1 & 1.19 & $11 / 3 / 2015$ & $\mathrm{MRM} / \mathrm{RT} / \mathrm{SE}$ \\
\hline $41 \mathrm{CS} 55$ & 4 & 129 & 129.03 & TU 5 & II & 4 & $40-51 \mathrm{cmbd}$ & Flake, Thinning, chert; $>1 / 2 "$, Complete & 1 & 0.76 & $11 / 3 / 2015$ & $\mathrm{MRM} / \mathrm{RT} / \mathrm{SE}$ \\
\hline $41 \mathrm{CS} 55$ & 4 & 129 & 129.04 & TU 5 & II & 4 & $40-51 \mathrm{cmbd}$ & $\begin{array}{l}\text { Flake, Utilized, novaculite; unifacially worked } \\
\text { along one edge; }>1 " \text {, Proximal }\end{array}$ & 1 & 20.35 & $11 / 3 / 2015$ & $\mathrm{MRM} / \mathrm{RT} / \mathrm{SE}$ \\
\hline $41 \mathrm{CS} 55$ & 4 & 129 & 129.05 & TU 5 & II & 4 & $40-51 \mathrm{cmbd}$ & Shatter, Angular, novaculite & 1 & 4.81 & $11 / 3 / 2015$ & $\mathrm{MRM} / \mathrm{RT} / \mathrm{SE}$ \\
\hline $41 \mathrm{CS} 55$ & 5 & 130 & 130.01 & TU 5 & III & 1 & $50-60 \mathrm{cmbd}$ & Flake, Thinning; Late, chert; >1/2", Proximal & 1 & 0.34 & $11 / 4 / 2015$ & $\mathrm{MRM} / \mathrm{BN}$ \\
\hline $41 \mathrm{CS} 55$ & 5 & 130 & 130.02 & TU 5 & III & 1 & $50-60 \mathrm{cmbd}$ & Flake, Thinning; Late, chert; >1/4", Medial-Distal & 1 & 0.32 & $11 / 4 / 2015$ & $\mathrm{MRM} / \mathrm{BN}$ \\
\hline $41 \mathrm{CS} 55$ & 5 & 130 & 130.03 & TU 5 & III & 1 & $50-60 \mathrm{cmbd}$ & Flake, core reduction, chert; $>1 "$ ", Complete & 1 & 7.95 & $11 / 4 / 2015$ & MRM/BN \\
\hline $41 \mathrm{CS} 55$ & 5 & 130 & 130.04 & TU 5 & III & 1 & $50-60 \mathrm{cmbd}$ & Unmodified stone, sandstone & 1 & 3.10 & $11 / 4 / 2015$ & MRM/BN \\
\hline $41 \mathrm{CS} 73$ & 1 & 35 & 35.01 & ST 6 & II & & $\sim 60 \mathrm{cmbs}$ & Flake, Thinning; Late, chert; >1/2", Complete & 1 & 0.59 & $10 / 22 / 2015$ & $\mathrm{MRM} / \mathrm{MH}$ \\
\hline $41 \mathrm{CS} 73$ & 2 & 36 & 36.01 & ST 15 & II & & $30-40 \mathrm{cmbs}$ & Flake, Unspecified, chert; >1/2", unknown & 1 & 2.02 & $10 / 22 / 2015$ & MO/MRM \\
\hline $41 \mathrm{CS} 76$ & 1 & 139 & 139.01 & ST 2 & 1 & & $0-10 \mathrm{cmbs}$ & $\begin{array}{l}\text { Flake, Thinning; Late, chert; >1/4", Non- } \\
\text { orientable }\end{array}$ & 1 & 0.09 & $11 / 6 / 2015$ & $C S / A D$ \\
\hline
\end{tabular}




\begin{tabular}{|c|c|c|c|c|c|c|c|c|c|c|c|c|}
\hline $\begin{array}{c}\text { Site } \\
\#\end{array}$ & $\begin{array}{c}\text { FS } \\
\#\end{array}$ & LS\# & $\begin{array}{c}\text { Catalog } \\
\#\end{array}$ & Prov. & $\begin{array}{c}\text { Strat } \\
\text { a }\end{array}$ & $\begin{array}{c}\text { Leve } \\
1\end{array}$ & Depth & Description & Count & $\begin{array}{c}\text { Weight } \\
\text { (g) }\end{array}$ & $\begin{array}{c}\text { Date } \\
\text { Excavated }\end{array}$ & Exc/Rec \\
\hline $41 \mathrm{CS} 76$ & 1 & 139 & 139.02 & ST 2 & I & & $0-10 \mathrm{cmbs}$ & Flake, Thinning, chert; >1/2", Proximal & 1 & 1.45 & $11 / 6 / 2015$ & $C S / A D$ \\
\hline $41 \mathrm{CS} 76$ & 1 & 139 & 139.03 & ST 2 & I & & $0-10 \mathrm{cmbs}$ & Shatter, Angular, chert & 1 & 7.60 & $11 / 6 / 2015$ & $C S / A D$ \\
\hline $41 \mathrm{CS} 76$ & 2 & 140 & 140.01 & ST 3 & II & & $15-30 \mathrm{cmbs}$ & Flake, Thinning; Late, chert; $>1 / 2 "$, Complete & 1 & 0.60 & $11 / 6 / 2015$ & $A D / E A$ \\
\hline $41 \mathrm{CS} 76$ & 2 & 140 & 140.02 & ST 3 & II & & $15-30 \mathrm{cmbs}$ & Flake, Thinning; Late, chert; >1/4", Proximal & 1 & 0.12 & $11 / 6 / 2015$ & $A D / E A$ \\
\hline $41 \mathrm{CS} 76$ & 3 & 141 & 141.01 & $\mathrm{CP} 1$ & & & Surface & Flake, Thinning; Late, chert; >1/4", Medial-Distal & 1 & 0.18 & $11 / 6 / 2015$ & $A D / E A$ \\
\hline $41 \mathrm{CS} 76$ & 4 & 142 & 142.01 & $\mathrm{CP} 2$ & & & Surface & Flake, Thinning, chert; $>1 / 2 "$, Complete & 1 & 1.22 & $11 / 6 / 2015$ & $A D$ \\
\hline $41 \mathrm{CS} 76$ & 4 & 142 & 142.02 & $\mathrm{CP} 2$ & & & Surface & Flake, Thinning; Late, chert; >1/4", Complete & 1 & 0.22 & $11 / 6 / 2015$ & $A D$ \\
\hline $41 \mathrm{CS} 76$ & 5 & 143 & 143.01 & $\mathrm{CP} 3$ & & & Surface & $\begin{array}{l}\text { Aboriginal ceramic, plain, grog/clay temper; } \\
\text { body }\end{array}$ & 1 & 12.02 & $11 / 6 / 2015$ & $\mathrm{RT} / \mathrm{AD}$ \\
\hline $41 \mathrm{CS} 76$ & 6 & 144 & 144.01 & $\mathrm{CP} 4$ & & & Surface & Tested cobble, chert & 1 & 24.44 & $11 / 6 / 2015$ & $C S / A D$ \\
\hline $41 \mathrm{CS} 76$ & 1 & 145 & 145.01 & TU 2 & I & 1 & $11-21 \mathrm{cmbd}$ & Flake, Thinning; Late, chert; >1/4", Complete & 1 & 0.17 & $11 / 6 / 2015$ & EA \\
\hline $41 \mathrm{CS} 76$ & 1 & 146 & 146.01 & TU 1 & I & 1 & $11-21 \mathrm{cmbd}$ & Flake, Thinning; Late, chert; >1/4", Complete & 2 & 0.27 & $11 / 6 / 2015$ & KP \\
\hline $41 \mathrm{CS} 76$ & 1 & 146 & 146.02 & TU 1 & 1 & 1 & $11-21 \mathrm{cmbd}$ & Flake, Thinning, chert; $>1 / 2 "$, Complete & 2 & 1.28 & $11 / 6 / 2015$ & KP \\
\hline $41 \mathrm{CS} 76$ & 1 & 146 & 146.03 & TU 1 & I & 1 & $11-21 \mathrm{cmbd}$ & Flake, Thinning, chert; $>1 / 2 "$, Complete & 6 & 3.82 & $11 / 6 / 2015$ & KP \\
\hline $41 \mathrm{CS} 76$ & 1 & 146 & 146.04 & TU 1 & 1 & 1 & $11-21 \mathrm{cmbd}$ & Flake, Thinning, chert; >1/2", Medial-Distal & 1 & 0.42 & $11 / 6 / 2015$ & KP \\
\hline $41 \mathrm{CS} 76$ & 2 & 147 & 147.01 & TU 1 & II & 2 & $21-31 \mathrm{cmbd}$ & Flake, Thinning; Late, chert; $>1 / 2 "$ ", Complete & 1 & 0.31 & $11 / 6 / 2015$ & KP \\
\hline $41 \mathrm{CS} 76$ & 2 & 147 & 147.02 & TU 1 & II & 2 & $21-31 \mathrm{cmbd}$ & Flake, Early Reduction, chert; >1/2", Complete & 1 & 1.56 & $11 / 6 / 2015$ & KP \\
\hline $41 \mathrm{CS} 76$ & 2 & 147 & 147.03 & TU 1 & II & 2 & $21-31 \mathrm{cmbd}$ & Flake, Early Reduction, chert; $>1 / 2 "$, Complete & 1 & 0.42 & $11 / 6 / 2015$ & KP \\
\hline $41 \mathrm{CS76}$ & 3 & 148 & 148.01 & TU 1 & III & 3 & $31-41 \mathrm{cmbd}$ & Flake, Early Reduction, chert; $>1 / 2 "$, Complete & 1 & 0.36 & $11 / 6 / 2015$ & KP \\
\hline $41 \mathrm{CS} 76$ & 4 & 149 & 149.01 & TU 1 & III & 4 & $41-51 \mathrm{cmbd}$ & Flake, Thinning, chert; $>1 / 2 "$, Complete & 2 & 1.23 & $11 / 6 / 2015$ & KP \\
\hline $41 \mathrm{CS} 76$ & 4 & 149 & 149.02 & TU 1 & III & 4 & $41-51 \mathrm{cmbd}$ & Flake, Thinning, chert; $>1 / 4 "$, Complete & 1 & 0.41 & $11 / 6 / 2015$ & KP \\
\hline $41 \mathrm{CS76}$ & 4 & 149 & 149.03 & TU 1 & III & 4 & $41-51 \mathrm{cmbd}$ & Flake, Thinning; Late, chert; >1/4", Complete & 1 & 0.11 & $11 / 6 / 2015$ & $\mathrm{KP}$ \\
\hline $41 \mathrm{CS} 76$ & 4 & 149 & 149.04 & TU 1 & III & 4 & $41-51 \mathrm{cmbd}$ & Flake, Thinning; Late, chert; >1/4", Medial-Distal & 1 & 0.02 & $11 / 6 / 2015$ & KP \\
\hline $41 \mathrm{CS} 76$ & 5 & 150 & 150.01 & TU 1 & III & 5 & $51-61 \mathrm{cmbd}$ & Flake, Thinning; Late, chert; >1/4", Medial-Distal & 1 & 0.24 & $11 / 6 / 2015$ & KP \\
\hline $41 \mathrm{CS} 76$ & 5 & 150 & 150.02 & TU 1 & III & 5 & $51-61 \mathrm{cmbd}$ & Flake, Thinning, chert; $>1 / 2 "$, Complete & 1 & 1.24 & $11 / 6 / 2015$ & KP \\
\hline $41 \mathrm{CS} 78$ & 1 & 60 & 60.01 & ST 3 & II & & $15 \mathrm{cmbs}$ & Flake, Early Reduction, chert; $>1 / 2 "$, Complete & 1 & 3.00 & $11 / 6 / 2015$ & $\mathrm{SE} / \mathrm{KP}$ \\
\hline $41 \mathrm{CS78}$ & 2 & 61 & 61.01 & ST 5 & I & 1 & $0-10 \mathrm{cmbs}$ & Flake, Thinning, chert; >1/2", Complete & 1 & 0.35 & $11 / 6 / 2015$ & JTS/JMS \\
\hline $41 \mathrm{CS} 78$ & 2 & 61 & 61.02 & ST 5 & I & 1 & $0-10 \mathrm{cmbs}$ & Flake, Thinning, chert; >1/2", Medial-Distal & 1 & 0.13 & $11 / 6 / 2015$ & JTS/JMS \\
\hline
\end{tabular}




\begin{tabular}{|c|c|c|c|c|c|c|c|c|c|c|c|c|}
\hline $\begin{array}{c}\text { Site } \\
\#\end{array}$ & $\begin{array}{l}\text { FS } \\
\#\end{array}$ & LS\# & $\begin{array}{c}\text { Catalog } \\
\#\end{array}$ & Prov. & $\begin{array}{c}\text { Strat } \\
\text { a }\end{array}$ & $\begin{array}{c}\text { Leve } \\
1\end{array}$ & Depth & Description & Count & $\begin{array}{c}\text { Weight } \\
\text { (g) }\end{array}$ & $\begin{array}{c}\text { Date } \\
\text { Excavated }\end{array}$ & Exc/Rec \\
\hline $41 \mathrm{CS} 78$ & 2 & 61 & 61.03 & ST 5 & I & 1 & $0-10 \mathrm{cmbs}$ & Flake, Thinning, chert; $>1 / 4 "$, Proximal & 2 & 0.43 & $11 / 6 / 2015$ & JTS/JMS \\
\hline $41 \mathrm{CS} 78$ & 2 & 61 & 61.04 & ST 5 & I & 1 & $0-10 \mathrm{cmbs}$ & Flake, Thinning; Late, chert; $>1 / 4 "$, Complete & 2 & 0.11 & $11 / 6 / 2015$ & JTS/JMS \\
\hline $41 \mathrm{CS} 78$ & 2 & 61 & 61.05 & ST 5 & 1 & 1 & $0-10 \mathrm{cmbs}$ & Flake, Thinning; Late, chert; >1/4", Medial-Distal & 1 & 0.02 & $11 / 6 / 2015$ & JTS/JMS \\
\hline $41 \mathrm{CS} 78$ & 3 & 62 & 62.01 & ST 7 & II & 2 & $30 \mathrm{cmbs}$ & Flake, Thinning, chert; $>1 / 2 "$, Complete & 1 & 0.62 & $11 / 6 / 2015$ & $\mathrm{MM} / \mathrm{SPF}$ \\
\hline $41 \mathrm{CS} 78$ & 4 & 63 & 63.01 & ST 10 & I & & $0-10 \mathrm{cmbs}$ & Flake fragment, chert; >1/4", Non-orientable & 1 & 0.48 & $11 / 6 / 2015$ & $\mathrm{MMM} / \mathrm{IM}$ \\
\hline $41 \mathrm{CS} 78$ & 4 & 63 & 63.02 & ST 10 & 1 & & $0-10 \mathrm{cmbs}$ & Flake, Thinning, chert; $>1 / 4 "$, Complete & 1 & 0.54 & $11 / 6 / 2015$ & MMM/IM \\
\hline $41 \mathrm{CS} 78$ & 4 & 63 & 63.03 & ST 10 & I & & $0-10 \mathrm{cmbs}$ & Flake, Thinning; Late, chert; >1/4", Complete & 3 & 0.45 & $11 / 6 / 2015$ & $\mathrm{MMM} / \mathrm{IM}$ \\
\hline $41 \mathrm{CS} 78$ & 4 & 63 & 63.04 & ST 10 & I & & $0-10 \mathrm{cmbs}$ & Flake, Thinning; Late, chert; $>1 / 8$, Complete & 2 & 0.10 & $11 / 6 / 2015$ & $\mathrm{MMM} / \mathrm{IM}$ \\
\hline $41 \mathrm{CS} 78$ & 5 & 64 & 64.01 & ST 25 & $1 / I 1$ & 2 & $10-20 \mathrm{cmbs}$ & Flake, Thinning; Late, chert; >1/4", Medial-Distal & 1 & 0.14 & $11 / 6 / 2015$ & $\mathrm{MRM} / \mathrm{SF}$ \\
\hline $41 \mathrm{CS} 78$ & 6 & 65 & 65.01 & ST 30 & I & 2 & $10-20 \mathrm{cmbs}$ & Animal bone; possible armadillo scute & 2 & 0.42 & $11 / 6 / 2015$ & $\mathrm{JMS} / \mathrm{JTS}$ \\
\hline $41 \mathrm{CS} 78$ & 7 & 66 & 66.01 & ST 32 & I & & $0-10 \mathrm{cmbs}$ & Flake, Thinning, quartzite; $>1 / 4 "$, Proximal & 1 & 0.34 & $11 / 6 / 2015$ & $\mathrm{MMM} / \mathrm{IM}$ \\
\hline $41 \mathrm{CS} 78$ & 7 & 66 & 66.02 & ST 32 & 1 & & $0-10 \mathrm{cmbs}$ & Flake, Thinning; Late, chert; $>1 / 4 "$, Complete & 2 & 0.26 & $11 / 6 / 2015$ & $\mathrm{MMM} / \mathrm{IM}$ \\
\hline $41 \mathrm{CS} 78$ & 8 & 67 & 67.01 & ST 34 & I & & $10-20 \mathrm{cmbs}$ & Flake, Thinning, chert; $>1 / 2 "$, Complete & 1 & 0.56 & $11 / 6 / 2015$ & $\mathrm{JMS} / \mathrm{JTS}$ \\
\hline $41 \mathrm{CS} 78$ & 8 & 67 & 67.02 & ST 34 & I & & $10-20 \mathrm{cmbs}$ & Flake, Thinning; Late, chert; $>1 / 2 "$, Complete & 1 & 0.26 & $11 / 6 / 2015$ & JMS/JTS \\
\hline $41 \mathrm{CS} 78$ & 8 & 67 & 67.03 & ST 34 & I & & $10-20 \mathrm{cmbs}$ & Flake, Thinning; Late, chert; >1/4", Proximal & 1 & 0.11 & $11 / 6 / 2015$ & JMS/JTS \\
\hline $41 \mathrm{CS} 78$ & 9 & 68 & 68.01 & ST 40 & I & & $20-35 \mathrm{cmbs}$ & Flake, Early Reduction, chert; $>1 / 2 "$, Complete & 1 & 0.27 & $11 / 6 / 2015$ & JMS/JTS \\
\hline $41 \mathrm{CS} 78$ & 10 & 69 & 69.01 & ST 41 & III & & $35 \mathrm{cmbs}$ & Core, chert & 1 & 79.15 & $11 / 6 / 2015$ & $\mathrm{SE} / \mathrm{KP}$ \\
\hline $41 \mathrm{CS} 78$ & 11 & 70 & 70.01 & ST 45 & I & & $20 \mathrm{cmbs}$ & Flake, Thinning, chert; $>1 / 4 "$, Proximal & 1 & 0.31 & $11 / 6 / 2015$ & $\mathrm{MRM} / \mathrm{SPF}$ \\
\hline $41 \mathrm{CS} 78$ & 12 & 71 & 71.01 & $\mathrm{CP} 1$ & & & Surface & Flake, core reduction, chert; >1", Complete & 1 & 13.44 & $11 / 6 / 2015$ & MO \\
\hline $41 \mathrm{CS} 78$ & 12 & 71 & 71.02 & $\mathrm{CP} 1$ & & & Surface & Flake, Early Reduction, chert; >1", Complete & 2 & 12.18 & $11 / 6 / 2015$ & MO \\
\hline $41 \mathrm{CS} 78$ & 12 & 71 & 71.03 & $\mathrm{CP} 1$ & & & Surface & Flake, Early Reduction, chert; $>1 / 2 "$, Proximal & 1 & 1.26 & $11 / 6 / 2015$ & MO \\
\hline $41 \mathrm{CS} 78$ & 12 & 71 & 71.04 & $\mathrm{CP} 1$ & & & Surface & Flake, Early Reduction, chert; $>1 / 2 "$, Complete & 1 & 2.33 & $11 / 6 / 2015$ & MO \\
\hline $41 \mathrm{CS} 78$ & 12 & 71 & 71.05 & $\mathrm{CP} 1$ & & & Surface & Flake, Early Reduction, quartzite; $>1 "$ ", Complete & 1 & 5.84 & $11 / 6 / 2015$ & MO \\
\hline $41 \mathrm{CS} 78$ & 12 & 71 & 71.06 & $\mathrm{CP} 1$ & & & Surface & Flake, Thinning, chert; >1", Complete & 1 & 0.58 & $11 / 6 / 2015$ & MO \\
\hline $41 \mathrm{CS} 78$ & 12 & 71 & 71.07 & $\mathrm{CP} 1$ & & & Surface & Flake, Thinning, chert; >1", Complete & 1 & 1.92 & $11 / 6 / 2015$ & MO \\
\hline $41 \mathrm{CS} 78$ & 12 & 71 & 71.08 & $\mathrm{CP} 1$ & & & Surface & Flake, Thinning, chert; >1/2", Complete & 2 & 0.87 & $11 / 6 / 2015$ & MO \\
\hline $41 \mathrm{CS} 78$ & 12 & 71 & 71.09 & CP 1 & & & Surface & $\begin{array}{l}\text { Shatter, Angular, chert; large primary flake with } \\
\text { step fracture worked along one edge }\end{array}$ & 1 & 38.18 & $11 / 6 / 2015$ & MO \\
\hline
\end{tabular}




\begin{tabular}{|c|c|c|c|c|c|c|c|c|c|c|c|c|}
\hline $\begin{array}{c}\text { Site } \\
\#\end{array}$ & $\begin{array}{l}\text { FS } \\
\#\end{array}$ & LS\# & $\begin{array}{c}\text { Catalog } \\
\#\end{array}$ & Prov. & $\begin{array}{c}\text { Strat } \\
\text { a }\end{array}$ & $\begin{array}{c}\text { Leve } \\
1\end{array}$ & Depth & Description & Count & $\begin{array}{l}\text { Weight } \\
\text { (g) }\end{array}$ & $\begin{array}{c}\text { Date } \\
\text { Excavated }\end{array}$ & Exc/Rec \\
\hline $41 \mathrm{CS} 78$ & 12 & 71 & 71.10 & $\mathrm{CP} 1$ & & & Surface & Core, chert & 1 & 16.66 & $11 / 6 / 2015$ & MO \\
\hline $41 \mathrm{CS} 78$ & 12 & 71 & 71.11 & $\mathrm{CP} 1$ & & & Surface & $\begin{array}{l}\text { PPK Preform, Early stage, chert; complete } \\
\text { bifacially worked/shaped distal end, proximal } \\
\text { half covered with cortex }\end{array}$ & 1 & 72.41 & $11 / 6 / 2015$ & MO \\
\hline $41 \mathrm{CS} 78$ & 12 & 71 & 71.12 & $\mathrm{CP} 1$ & & & Surface & Sandstone, Ferruginous & 1 & 8.51 & $11 / 6 / 2015$ & MO \\
\hline $41 \mathrm{CS} 78$ & 12 & 71 & 71.13 & $\mathrm{CP} 1$ & & & Surface & Sandstone, unmodified & 1 & 4.81 & $11 / 6 / 2015$ & MO \\
\hline $41 \mathrm{CS} 78$ & 12 & 71 & 71.14 & $\mathrm{CP} 1$ & & & Surface & Possible cultural material-lithic & 1 & 1.09 & $11 / 6 / 2015$ & MO \\
\hline $41 \mathrm{CS} 78$ & 12 & 71 & 71.15 & $\mathrm{CP} 1$ & & & Surface & $\begin{array}{l}\text { Aboriginal ceramic, burnished, grog/clay } \\
\text { temper; body; possible engraving, possible } \\
\text { black film on exterior surface }\end{array}$ & 1 & 10.30 & $11 / 6 / 2015$ & MO \\
\hline $41 \mathrm{CS} 78$ & 13 & 72 & 72.01 & $\mathrm{CP} 2$ & & & Surface & Flake, pressure, chert; $>1 / 4 "$, Complete & 1 & 0.14 & $11 / 6 / 2015$ & MO \\
\hline $41 \mathrm{CS} 78$ & 13 & 72 & 72.02 & $\mathrm{CP} 2$ & & & Surface & Flake, Thinning; Late, chert; >1/4", Complete & 4 & 0.64 & $11 / 6 / 2015$ & MO \\
\hline $41 \mathrm{CS} 78$ & 13 & 72 & 72.03 & $\mathrm{CP} 2$ & & & Surface & Flake, Thinning; Late, chert; >1/4", Proximal & 2 & 0.24 & $11 / 6 / 2015$ & MO \\
\hline $41 \mathrm{CS} 78$ & 13 & 72 & 72.04 & $\mathrm{CP} 2$ & & & Surface & Flake, Thinning; Late, chert; >1/2", Complete & 1 & 0.42 & $11 / 6 / 2015$ & MO \\
\hline $41 \mathrm{CS} 78$ & 13 & 72 & 72.05 & $\mathrm{CP} 2$ & & & Surface & Flake, Thinning; Late, chert; >1/4", Complete & 1 & 0.17 & $11 / 6 / 2015$ & MO \\
\hline $41 \mathrm{CS} 78$ & 13 & 72 & 72.06 & $\mathrm{CP} 2$ & & & Surface & Flake, Thinning, chert; $>1 / 2 "$, Proximal & 1 & 2.00 & $11 / 6 / 2015$ & MO \\
\hline $41 \mathrm{CS} 78$ & 13 & 72 & 72.07 & $\mathrm{CP} 2$ & & & Surface & Flake, Thinning, chert; $>1 / 2 "$, Complete & 1 & 0.58 & $11 / 6 / 2015$ & MO \\
\hline $41 \mathrm{CS} 78$ & 13 & 72 & 72.08 & $\mathrm{CP} 2$ & & & Surface & Flake, Thinning, chert; >1/2", Complete & 1 & 0.75 & $11 / 6 / 2015$ & MO \\
\hline $41 \mathrm{CS} 78$ & 13 & 72 & 72.09 & $\mathrm{CP} 2$ & & & Surface & Flake, Early Reduction, chert; >1/4", Complete & 1 & 0.29 & $11 / 6 / 2015$ & MO \\
\hline $41 \mathrm{CS} 78$ & 13 & 72 & 72.10 & $\mathrm{CP} 2$ & & & Surface & $\begin{array}{l}\text { Flake, Thinning, chert, heat treated; }>1 / 2 " \text {, Non- } \\
\text { orientable }\end{array}$ & 1 & 0.59 & $11 / 6 / 2015$ & MO \\
\hline $41 \mathrm{CS} 78$ & 13 & 72 & 72.11 & $\mathrm{CP} 2$ & & & Surface & $\begin{array}{l}\text { Flake, Thinning, chert, heat treated; }>1 / 2 " \text {, } \\
\text { Complete }\end{array}$ & 1 & 0.73 & $11 / 6 / 2015$ & MO \\
\hline $41 \mathrm{CS} 78$ & 14 & 73 & 73.01 & CP3 & & & Surface & $\begin{array}{l}\text { Flake, Early Reduction, chert, heat treated; } \\
>1 / 2 " \text {, Complete }\end{array}$ & 1 & 1.13 & $11 / 6 / 2015$ & MO \\
\hline $41 \mathrm{CS} 78$ & 14 & 73 & 73.02 & CP3 & & & Surface & Flake, Unspecified, chert; >1/4", Complete & 1 & 0.30 & $11 / 6 / 2015$ & MO \\
\hline $41 \mathrm{CS} 78$ & 14 & 73 & 73.03 & CP3 & & & Surface & Flake, Thinning, chert; >1/2", Complete & 1 & 1.03 & $11 / 6 / 2015$ & MO \\
\hline $41 \mathrm{CS} 78$ & 14 & 73 & 73.04 & CP3 & & & Surface & Flake, Thinning, chert; >1/2", Complete & 1 & 0.34 & $11 / 6 / 2015$ & MO \\
\hline
\end{tabular}




\begin{tabular}{|c|c|c|c|c|c|c|c|c|c|c|c|c|}
\hline $\begin{array}{c}\text { Site } \\
\#\end{array}$ & $\begin{array}{l}\text { FS } \\
\#\end{array}$ & LS\# & $\begin{array}{c}\text { Catalog } \\
\#\end{array}$ & Prov. & $\begin{array}{c}\text { Strat } \\
\text { a }\end{array}$ & $\begin{array}{c}\text { Leve } \\
1\end{array}$ & Depth & Description & Count & $\begin{array}{c}\text { Weight } \\
\text { (g) }\end{array}$ & $\begin{array}{c}\text { Date } \\
\text { Excavated }\end{array}$ & Exc/Rec \\
\hline $41 \mathrm{CS} 78$ & 14 & 73 & 73.05 & $\mathrm{CP} 3$ & & & Surface & Flake, Early Reduction, chert; >1/2", Proximal & 1 & 0.44 & $11 / 6 / 2015$ & MO \\
\hline $41 \mathrm{CS} 78$ & 14 & 73 & 73.06 & $\mathrm{CP} 3$ & & & Surface & Flake, Thinning, chert; >1/4", Medial-Distal & 1 & 0.35 & $11 / 6 / 2015$ & MO \\
\hline $41 \mathrm{CS} 78$ & 14 & 73 & 73.07 & $\mathrm{CP3}$ & & & Surface & Flake, Thinning, chert; $>1 / 2 "$, Complete & 3 & 2.82 & $11 / 6 / 2015$ & MO \\
\hline $41 \mathrm{CS} 78$ & 14 & 73 & 73.08 & $\mathrm{CP} 3$ & & & Surface & Flake, Thinning; Late, chert; $>1 / 2 "$, Complete & 1 & 0.41 & $11 / 6 / 2015$ & MO \\
\hline $41 \mathrm{CS} 78$ & 14 & 73 & 73.09 & $\mathrm{CP} 3$ & & & Surface & Flake, Thinning, chert; $>1 / 2 "$, Proximal & 3 & 2.00 & $11 / 6 / 2015$ & MO \\
\hline $41 \mathrm{CS} 78$ & 14 & 73 & 73.10 & $\mathrm{CP} 3$ & & & Surface & $\begin{array}{l}\text { Flake, Thinning, chert, heat treated; >1/2", } \\
\text { Complete }\end{array}$ & 1 & 0.51 & $11 / 6 / 2015$ & MO \\
\hline $41 \mathrm{CS} 78$ & 14 & 73 & 73.11 & $\mathrm{CP3}$ & & & Surface & Flake, Thinning, chert; $>1 / 4 "$, Complete & 1 & 0.32 & $11 / 6 / 2015$ & MO \\
\hline $41 \mathrm{CS} 78$ & 14 & 73 & 73.12 & $\mathrm{CP} 3$ & & & Surface & Flake, Thinning; Late, chert; $>1 / 4 "$, Complete & 1 & 0.18 & $11 / 6 / 2015$ & MO \\
\hline $41 \mathrm{CS} 78$ & 14 & 73 & 73.13 & $\mathrm{CP3}$ & & & Surface & Fire cracked rock, chert & 1 & 113.56 & $11 / 6 / 2015$ & MO \\
\hline $41 \mathrm{CS} 78$ & 1 & 74 & 74.01 & TU 2 & I & 1 & $10-20 \mathrm{cmbd}$ & Flake, Thinning; Late, chert; $>1 / 8$, Complete & 4 & 0.19 & $11 / 6 / 2015$ & SF/IM/MRP \\
\hline $41 \mathrm{CS} 78$ & 1 & 74 & 74.02 & TU 2 & I & 1 & $10-20 \mathrm{cmbd}$ & Flake, Thinning; Late, chert; >1/4", Complete & 18 & 2.71 & $11 / 6 / 2015$ & $\mathrm{SF} / \mathrm{IM} / \mathrm{MRP}$ \\
\hline $41 \mathrm{CS} 78$ & 1 & 74 & 74.03 & TU 2 & 1 & 1 & $10-20 \mathrm{cmbd}$ & Flake, Thinning; Late, chert; $>1 / 2 "$, Complete & 5 & 2.72 & $11 / 6 / 2015$ & $\mathrm{SF} / \mathrm{IM} / \mathrm{MRP}$ \\
\hline $41 \mathrm{CS} 78$ & 1 & 74 & 74.04 & TU 2 & I & 1 & $10-20 \mathrm{cmbd}$ & Flake, Thinning; Late, chert; $>1 / 4 "$, Proximal & 3 & 0.68 & $11 / 6 / 2015$ & $\mathrm{SF} / \mathrm{IM} / \mathrm{MRP}$ \\
\hline $41 \mathrm{CS} 78$ & 1 & 74 & 74.05 & TU 2 & I & 1 & $10-20 \mathrm{cmbd}$ & Flake, Thinning; Late, chert; $>1 / 8$, Medial-Distal & 5 & 0.31 & $11 / 6 / 2015$ & $\mathrm{SF} / \mathrm{IM} / \mathrm{MRP}$ \\
\hline $41 \mathrm{CS} 78$ & 1 & 74 & 74.06 & TU 2 & I & 1 & $10-20 \mathrm{cmbd}$ & Flake, Thinning; Late, chert; >1/4", Medial-Distal & 4 & 0.37 & $11 / 6 / 2015$ & $\mathrm{SF} / \mathrm{IM} / \mathrm{MRP}$ \\
\hline $41 C S 78$ & 1 & 74 & 74.07 & TU 2 & 1 & 1 & $10-20 \mathrm{cmbd}$ & Flake, pressure, chert; $>1 / 4 "$, Complete & 1 & 0.11 & $11 / 6 / 2015$ & SF/IM/MRP \\
\hline $41 \mathrm{CS} 78$ & 1 & 74 & 74.08 & TU 2 & I & 1 & $10-20 \mathrm{cmbd}$ & Flake, Thinning, chert; $>1 / 4 "$, Proximal & 1 & 0.33 & $11 / 6 / 2015$ & SF/IM/MRP \\
\hline $41 \mathrm{CS} 78$ & 1 & 74 & 74.09 & TU 2 & I & 1 & $10-20 \mathrm{cmbd}$ & Flake, Thinning, chert; $>1 / 2 "$, Complete & 1 & 0.90 & $11 / 6 / 2015$ & $\mathrm{SF} / \mathrm{IM} / \mathrm{MRP}$ \\
\hline $41 \mathrm{CS} 78$ & 1 & 74 & 74.10 & TU 2 & 1 & 1 & $10-20 \mathrm{cmbd}$ & Flake, Thinning, chert; $>1 / 2 "$, Complete & 2 & 2.09 & $11 / 6 / 2015$ & $\mathrm{SF} / \mathrm{IM} / \mathrm{MRP}$ \\
\hline $41 \mathrm{CS} 78$ & 1 & 74 & 74.11 & TU 2 & I & 1 & $10-20 \mathrm{cmbd}$ & Flake, Thinning, chert; $>1 / 2 "$, Complete & 2 & 1.23 & $11 / 6 / 2015$ & $\mathrm{SF} / \mathrm{IM} / \mathrm{MRP}$ \\
\hline $41 \mathrm{CS78}$ & 1 & 74 & 74.12 & TU 2 & 1 & 1 & $10-20 \mathrm{cmbd}$ & Flake, Thinning, chert; $>1 / 2 "$, Non-orientable & 1 & 2.15 & $11 / 6 / 2015$ & $\mathrm{SF} / \mathrm{IM} / \mathrm{MRP}$ \\
\hline $41 \mathrm{CS} 78$ & 1 & 74 & 74.13 & TU 2 & I & 1 & $10-20 \mathrm{cmbd}$ & Flake, Thinning; Late, chert; >1/4", Complete & 3 & 0.75 & $11 / 6 / 2015$ & SF/IM/MRP \\
\hline $41 \mathrm{CS} 78$ & 1 & 74 & 74.14 & TU 2 & I & 1 & $10-20 \mathrm{cmbd}$ & Flake, Thinning; Late, chert; >1/4", Medial-Distal & 2 & 0.65 & $11 / 6 / 2015$ & $\mathrm{SF} / \mathrm{IM} / \mathrm{MRP}$ \\
\hline $41 \mathrm{CS} 78$ & 1 & 74 & 74.15 & TU 2 & I & 1 & $10-20 \mathrm{cmbd}$ & Flake, Thinning; Late, chert; $>1 / 2 "$, Complete & 1 & 0.40 & $11 / 6 / 2015$ & $\mathrm{SF} / \mathrm{IM} / \mathrm{MRP}$ \\
\hline $41 \mathrm{CS} 78$ & 1 & 74 & 74.16 & TU 2 & 1 & 1 & $10-20 \mathrm{cmbd}$ & Flake, Thinning; Late, chert; >1/4", Medial-Distal & 1 & 0.17 & $11 / 6 / 2015$ & SF/IM/MRP \\
\hline $41 \mathrm{CS78}$ & 1 & 74 & 74.17 & TU 2 & 1 & 1 & $10-20 \mathrm{cmbd}$ & Flake, Early Reduction, chert; $>1 / 2 "$, Complete & 1 & 0.68 & $11 / 6 / 2015$ & $\mathrm{SF} / \mathrm{IM} / \mathrm{MRP}$ \\
\hline $41 \mathrm{CS} 78$ & 1 & 74 & 74.18 & TU 2 & I & 1 & $10-20 \mathrm{cmbd}$ & Flake, Early Reduction, chert; $>1 / 4 "$ ", Complete & 1 & 0.51 & $11 / 6 / 2015$ & SF/IM/MRP \\
\hline
\end{tabular}




\begin{tabular}{|c|c|c|c|c|c|c|c|c|c|c|c|c|}
\hline $\begin{array}{c}\text { Site } \\
\#\end{array}$ & $\begin{array}{c}\text { FS } \\
\#\end{array}$ & LS\# & $\begin{array}{c}\text { Catalog } \\
\#\end{array}$ & Prov. & $\begin{array}{c}\text { Strat } \\
\text { a }\end{array}$ & $\begin{array}{c}\text { Leve } \\
1\end{array}$ & Depth & Description & Count & $\begin{array}{l}\text { Weight } \\
\text { (g) }\end{array}$ & $\begin{array}{c}\text { Date } \\
\text { Excavated }\end{array}$ & Exc/Rec \\
\hline $41 \mathrm{CS} 78$ & 1 & 74 & 74.19 & TU 2 & 1 & 1 & $10-20 \mathrm{cmbd}$ & Flake, core reduction, chert; $>1 / 2 "$, Complete & 1 & 0.78 & $11 / 6 / 2015$ & $\mathrm{SF} / \mathrm{IM} / \mathrm{MRP}$ \\
\hline $41 \mathrm{CS} 78$ & 1 & 74 & 74.20 & TU 2 & I & 1 & $10-20 \mathrm{cmbd}$ & Flake, Thinning, chert; >1/2", Medial-Distal & 1 & 0.92 & $11 / 6 / 2015$ & $\mathrm{SF} / \mathrm{IM} / \mathrm{MRP}$ \\
\hline $41 \mathrm{CS} 78$ & 1 & 74 & 74.21 & TU 2 & I & 1 & $10-20 \mathrm{cmbd}$ & $\begin{array}{l}\text { Flake, Early Reduction, chert; }>1 / 2 " \text {, Non- } \\
\text { orientable }\end{array}$ & 1 & 1.52 & $11 / 6 / 2015$ & $\mathrm{SF} / \mathrm{IM} / \mathrm{MRP}$ \\
\hline $41 \mathrm{CS} 78$ & 1 & 74 & 74.22 & TU 2 & I & 1 & $10-20 \mathrm{cmbd}$ & Shatter, Angular, chert & 4 & 1.22 & $11 / 6 / 2015$ & $\mathrm{SF} / \mathrm{IM} / \mathrm{MRP}$ \\
\hline $41 \mathrm{CS} 78$ & 1 & 74 & 74.23 & TU 2 & 1 & 1 & $10-20 \mathrm{cmbd}$ & Shatter, Angular, quartz & 1 & 0.79 & $11 / 6 / 2015$ & $\mathrm{SF} / \mathrm{IM} / \mathrm{MRP}$ \\
\hline $41 \mathrm{CS} 78$ & 1 & 74 & 74.24 & TU 2 & 1 & 1 & $10-20 \mathrm{cmbd}$ & Cortex fragment, chert & 1 & 0.06 & $11 / 6 / 2015$ & SF/IM/MRP \\
\hline $41 \mathrm{CS} 78$ & 1 & 74 & 74.25 & TU 2 & I & 1 & $10-20 \mathrm{cmbd}$ & $\begin{array}{l}\text { Unmodified stone, chert; probably water-worn } \\
\text { pebbles }\end{array}$ & 2 & 0.23 & $11 / 6 / 2015$ & SF/IM/MRP \\
\hline $41 \mathrm{CS} 78$ & 2 & 75 & 75.01 & TU 2 & II & 2 & $20-30 \mathrm{cmbd}$ & Flake, Thinning, chert; $>1 / 2 "$, Complete & 1 & 0.23 & $11 / 6 / 2015$ & $\mathrm{SF} / \mathrm{IM} / \mathrm{MRP}$ \\
\hline $41 \mathrm{CS} 78$ & 2 & 75 & 75.02 & TU 2 & ॥ & 2 & $20-30 \mathrm{cmbd}$ & Flake, Thinning, chert; $>1 / 2 "$, Complete & 1 & 0.57 & $11 / 6 / 2015$ & $\mathrm{SF} / \mathrm{IM} / \mathrm{MRP}$ \\
\hline $41 \mathrm{CS} 78$ & 2 & 75 & 75.03 & TU 2 & II & 2 & $20-30 \mathrm{cmbd}$ & Flake, Thinning, chert; >1/4", Medial-Distal & 1 & 0.28 & $11 / 6 / 2015$ & SF/IM/MRP \\
\hline $41 \mathrm{CS} 78$ & 2 & 75 & 75.04 & TU 2 & II & 2 & $20-30 \mathrm{cmbd}$ & Flake, Thinning, chert; >1/4", Non-orientable & 1 & 0.12 & $11 / 6 / 2015$ & $\mathrm{SF} / \mathrm{IM} / \mathrm{MRP}$ \\
\hline $41 \mathrm{CS} 78$ & 2 & 75 & 75.05 & TU 2 & II & 2 & $20-30 \mathrm{cmbd}$ & Flake, Thinning; Late, chert; $>1 / 4 "$, Complete & 4 & 0.40 & $11 / 6 / 2015$ & $\mathrm{SF} / \mathrm{IM} / \mathrm{MRP}$ \\
\hline $41 \mathrm{CS} 78$ & 2 & 75 & 75.06 & TU 2 & II & 2 & $20-30 \mathrm{cmbd}$ & Flake, Thinning; Late, chert; $>1 / 2 "$, Complete & 3 & 0.13 & $11 / 6 / 2015$ & $\mathrm{SF} / \mathrm{IM} / \mathrm{MRP}$ \\
\hline $41 \mathrm{CS} 78$ & 2 & 75 & 75.07 & TU 2 & II & 2 & $20-30 \mathrm{cmbd}$ & Flake, Thinning; Late, chert; >1/4", Proximal & 1 & 0.01 & $11 / 6 / 2015$ & $\mathrm{SF} / \mathrm{IM} / \mathrm{MRP}$ \\
\hline $41 \mathrm{CS} 78$ & 2 & 75 & 75.08 & TU 2 & II & 2 & $20-30 \mathrm{cmbd}$ & Flake, Thinning; Late, chert; $<1 / 4 "$, Medial-Distal & 6 & 0.45 & $11 / 6 / 2015$ & SF/IM/MRP \\
\hline $41 \mathrm{CS} 78$ & 2 & 75 & 75.09 & TU 2 & II & 2 & $20-30 \mathrm{cmbd}$ & Flake, Thinning; Late, chert; >1/4", Medial-Distal & 1 & 0.19 & $11 / 6 / 2015$ & SF/IM/MRP \\
\hline $41 \mathrm{CS} 78$ & 2 & 75 & 75.10 & TU 2 & II & 2 & $20-30 \mathrm{cmbd}$ & Flake, Thinning; Late, chert; >1/2", Medial-Distal & 1 & 0.10 & $11 / 6 / 2015$ & $\mathrm{SF} / \mathrm{IM} / \mathrm{MRP}$ \\
\hline $41 \mathrm{CS} 78$ & 2 & 75 & 75.11 & TU 2 & II & 2 & $20-30 \mathrm{cmbd}$ & Shatter, Angular, chert & 2 & 0.72 & $11 / 6 / 2015$ & $\mathrm{SF} / \mathrm{IM} / \mathrm{MRP}$ \\
\hline $41 \mathrm{CS} 78$ & 2 & 75 & 75.12 & TU 2 & II & 2 & $20-30 \mathrm{cmbd}$ & Burned earth/fired clay & 1 & 0.26 & $11 / 6 / 2015$ & $\mathrm{SF} / \mathrm{IM} / \mathrm{MRP}$ \\
\hline $41 \mathrm{CS} 78$ & 2 & 75 & 75.13 & TU 2 & II & 2 & $20-30 \mathrm{cmbd}$ & Red ochre & 1 & 0.25 & $11 / 6 / 2015$ & $\mathrm{SF} / \mathrm{IM} / \mathrm{MRP}$ \\
\hline $41 \mathrm{CS} 78$ & 1 & 76 & 76.01 & TU 3 & II & 1 & $15-20 \mathrm{cmbd}$ & Flake, Thinning; Late, chert; $>1 / 2 "$, Complete & 1 & 0.36 & $11 / 6 / 2015$ & $\mathrm{SE} / \mathrm{MO} / \mathrm{KP}$ \\
\hline $41 \mathrm{CS} 78$ & 1 & 76 & 76.02 & TU 3 & II & 1 & $15-20 \mathrm{cmbd}$ & Flake, Thinning, chert; >1/2", Complete & 1 & 0.66 & $11 / 6 / 2015$ & $\mathrm{SE} / \mathrm{MO} / \mathrm{KP}$ \\
\hline $41 \mathrm{CS78}$ & 1 & 76 & 76.03 & TU 3 & II & 1 & $15-20 \mathrm{cmbd}$ & Flake, Thinning, chert; $>1 / 2 "$, Complete & 1 & 0.50 & $11 / 6 / 2015$ & $\mathrm{SE} / \mathrm{MO} / \mathrm{KP}$ \\
\hline $41 \mathrm{CS} 78$ & 1 & 76 & 76.04 & TU 3 & II & 1 & $15-20 \mathrm{cmbd}$ & Flake, Thinning; Late, chert; >1/4", Proximal & 1 & 0.05 & $11 / 6 / 2015$ & $\mathrm{SE} / \mathrm{MO} / \mathrm{KP}$ \\
\hline $41 \mathrm{CS} 78$ & 1 & 76 & 76.05 & TU 3 & II & 1 & $15-20 \mathrm{cmbd}$ & Animal bone; probable armadillo scute & 1 & 0.08 & $11 / 6 / 2015$ & $\mathrm{SE} / \mathrm{MO} / \mathrm{KP}$ \\
\hline $41 \mathrm{CS} 78$ & 2 & 77 & 77.01 & TU 3 & III & 3 & $20-30 \mathrm{cmbd}$ & Flake, Thinning; Late, chert; >1/4", Proximal & 1 & 0.08 & $11 / 6 / 2015$ & $\mathrm{SE} / \mathrm{MO} / \mathrm{KP}$ \\
\hline
\end{tabular}




\begin{tabular}{|c|c|c|c|c|c|c|c|c|c|c|c|c|}
\hline $\begin{array}{c}\text { Site } \\
\#\end{array}$ & $\begin{array}{l}\text { FS } \\
\#\end{array}$ & LS\# & $\begin{array}{c}\text { Catalog } \\
\#\end{array}$ & Prov. & $\begin{array}{c}\text { Strat } \\
\text { a }\end{array}$ & $\begin{array}{c}\text { Leve } \\
1\end{array}$ & Depth & Description & Count & $\begin{array}{l}\text { Weight } \\
\text { (g) }\end{array}$ & $\begin{array}{c}\text { Date } \\
\text { Excavated }\end{array}$ & Exc/Rec \\
\hline $41 \mathrm{CS} 78$ & 3 & 78 & 78.01 & TU 3 & III & 3 & $30-40 \mathrm{cmbd}$ & Flake, Thinning, chert; $>1 / 2 "$, Complete & 1 & 1.40 & $11 / 6 / 2015$ & $\mathrm{SE} / \mathrm{MO} / \mathrm{KP}$ \\
\hline $41 \mathrm{CS} 78$ & 3 & 78 & 78.02 & TU 3 & III & 3 & $30-40 \mathrm{cmbd}$ & Flake, Thinning, chert; >1/2", Medial-Distal & 1 & 0.78 & $11 / 6 / 2015$ & $\mathrm{SE} / \mathrm{MO} / \mathrm{KP}$ \\
\hline $41 \mathrm{CS} 78$ & 3 & 78 & 78.03 & TU 3 & III & 3 & $30-40 \mathrm{cmbd}$ & Flake, Thinning; Late, chert; >1/2", Complete & 1 & 0.54 & $11 / 6 / 2015$ & $\mathrm{SE} / \mathrm{MO} / \mathrm{KP}$ \\
\hline $41 \mathrm{CS78}$ & 4 & 79 & 79.01 & TU 3 & III & 3 & $40-50 \mathrm{cmbd}$ & Flake, Thinning, chert; $>1 / 2 "$, Complete & 1 & 0.51 & $11 / 6 / 2015$ & $\mathrm{SE} / \mathrm{MO} / \mathrm{KP}$ \\
\hline $41 \mathrm{CS78}$ & 4 & 79 & 79.02 & TU 3 & III & 3 & $40-50 \mathrm{cmbd}$ & Flake, Thinning, chert; $>1 / 2 "$, Medial-Distal & 1 & 0.32 & $11 / 6 / 2015$ & $\mathrm{SE} / \mathrm{MO} / \mathrm{KP}$ \\
\hline $41 \mathrm{CS78}$ & 4 & 79 & 79.03 & TU 3 & III & 3 & $40-50 \mathrm{cmbd}$ & Flake, Thinning; Late, chert; $>1 / 4 "$, Complete & 1 & 0.19 & $11 / 6 / 2015$ & $\mathrm{SE} / \mathrm{MO} / \mathrm{KP}$ \\
\hline $41 \mathrm{CS78}$ & 1 & 80 & 80.01 & TU 4 & 1 & 1 & $10-20 \mathrm{cmbd}$ & Flake, Thinning; Late, chert; >1/4", Proximal & 1 & 0.27 & $11 / 6 / 2015$ & $\mathrm{MMH} / \mathrm{JTS} / \mathrm{JMS}$ \\
\hline $41 \mathrm{CS78}$ & 1 & 80 & 80.02 & TU 4 & 1 & 1 & $10-20 \mathrm{cmbd}$ & Flake, Thinning, chert; $>1 / 4 "$, Proximal & 1 & 0.23 & $11 / 6 / 2015$ & $\mathrm{MMH} / \mathrm{JTS} / \mathrm{JMS}$ \\
\hline $41 \mathrm{CS} 78$ & 2 & 81 & 81.01 & TU 4 & I & 2 & $20-30 \mathrm{cmbd}$ & Flake, Early Reduction, chert; >1", Proximal & 1 & 0.95 & $11 / 6 / 2015$ & $\mathrm{MMH} / \mathrm{JTS} / \mathrm{JMS}$ \\
\hline $41 \mathrm{CS} 78$ & 2 & 81 & 81.02 & TU 4 & 1 & 2 & $20-30 \mathrm{cmbd}$ & Flake, Thinning, chert; >1/2", Complete & 3 & 1.46 & $11 / 6 / 2015$ & $\mathrm{MMH} / \mathrm{JTS} / \mathrm{JMS}$ \\
\hline $41 \mathrm{CS} 78$ & 2 & 81 & 81.03 & TU 4 & I & 2 & $20-30 \mathrm{cmbd}$ & Flake, Thinning, quartzite; $>1 / 2 "$, Complete & 1 & 0.37 & $11 / 6 / 2015$ & $\mathrm{MMH} / \mathrm{JTS} / \mathrm{JMS}$ \\
\hline $41 \mathrm{CS78}$ & 2 & 81 & 81.04 & TU 4 & 1 & 2 & $20-30 \mathrm{cmbd}$ & Flake, Thinning, chert; >1/4", Proximal & 1 & 0.23 & $11 / 6 / 2015$ & $\mathrm{MMH} / \mathrm{JTS} / \mathrm{JMS}$ \\
\hline $41 \mathrm{CS} 78$ & 2 & 81 & 81.05 & TU 4 & I & 2 & $20-30 \mathrm{cmbd}$ & Flake, Thinning; Late, chert; >1/4", Medial-Distal & 2 & 0.25 & $11 / 6 / 2015$ & $\mathrm{MMH} / \mathrm{JTS} / \mathrm{JMS}$ \\
\hline $41 \mathrm{CS} 78$ & 3 & 82 & 82.01 & TU 4 & II & 1 & $30-40 \mathrm{cmbd}$ & Flake, Unspecified, chert; $>1 / 4 "$, Complete & 1 & 0.43 & $11 / 6 / 2015$ & $\mathrm{MMH} / \mathrm{JTS} / \mathrm{JMS}$ \\
\hline $41 \mathrm{CS} 78$ & 3 & 82 & 82.02 & TU 4 & II & 1 & $30-40 \mathrm{cmbd}$ & Flake, Thinning, chert; >1/2", Complete & 1 & 0.46 & $11 / 6 / 2015$ & $\mathrm{MMH} / \mathrm{JTS} / \mathrm{JMS}$ \\
\hline $41 \mathrm{CS78}$ & 3 & 82 & 82.03 & TU 4 & II & 1 & $30-40 \mathrm{cmbd}$ & Flake, Thinning, chert; $>1 / 2 "$, Complete & 1 & 0.42 & $11 / 6 / 2015$ & $\mathrm{MMH} / \mathrm{JTS} / \mathrm{JMS}$ \\
\hline $41 \mathrm{CS} 78$ & 3 & 82 & 82.04 & TU 4 & II & 1 & $30-40 \mathrm{cmbd}$ & Flake, Thinning, chert; $>1 / 2 "$, Complete & 1 & 0.44 & $11 / 6 / 2015$ & $\mathrm{MMH} / \mathrm{JTS} / \mathrm{JMS}$ \\
\hline
\end{tabular}


NATIONAL REGISTER OF HISTORIC PLACES (NRHP)

ELIGIBILITY DETERMINATIONS FOR PREVIOUSLY

RECORDED ARCHAEOLOGICAL SITES

AT WRIGHT PATMAN LAKE,

BOWIE AND CASS COUNTIES, TEXAS

US ARMY CORPS OF ENGINEERS,

FORTH WORTH DISTRICT

CONTRACT \#W912HY-11-D-0002,

TASK ORDER \#0006

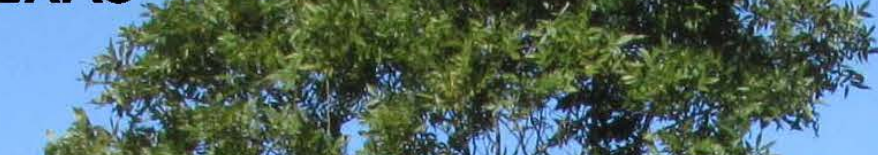

